\title{
Heide Willich
}

\section{Lev L. Kobylinskij-Ëllis: vom Symbolismus \\ zur ars sacra}

\section{Eine Studie über Leben und Werk}

Verlag Otto Sagner München · Berlin · Washington D.C.

Digitalisiert im Rahmen der Kooperation mit dem DFG-Projekt „Digi20“

der Bayerischen Staatsbibliothek, München. OCR-Bearbeitung und Erstellung des eBooks durch den Verlag Otto Sagner:

http://verlag.kubon-sagner.de

() bei Verlag Otto Sagner. Eine Verwertung oder Weitergabe der Texte und Abbildungen, insbesondere durch Vervielfältigung, ist ohne vorherige schriftliche Genehmigung des Verlages unzulässig. 


\title{
SLAVISTISCHE BEITRÄGE
}

\author{
Begründet von \\ Alois Schmaus \\ Herausgegeben von \\ Peter Rehder
}

Beirat:

Tilman Berger - Walter Breu - Johanna Renate Döring-Smimov

Wilfried Fiedler · Walter Koschmal · Ulrich Schweier · Miloš Sedmidubský $\cdot$ Klaus Steinke

BAND 341

VERLAG OTTO SAGNER

MÜNCHEN 1996 


\section{Heide Willich \\ Lev L. Kobylinskij-Ėllis: \\ Vom Symbolismus zur ars sacra}

Eine Studie über Leben und Werk

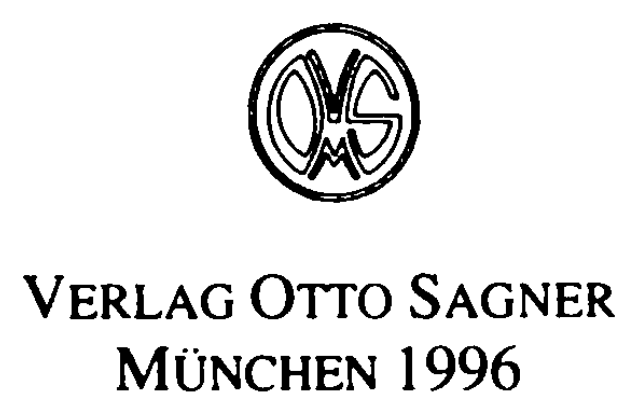


Bayerischo

8taatsbibliothok

München

ISBN 3-87690-651-2

(1) Verlag Otto Sagner, München 1996

Abteilung der Firma Kubon \& Sagner

D-80328 München

$97 P 87690$ 


\section{VORBEMERKUNG}

In der vorliegenden Arbeit erfolgt die Wiedergabe russischer Buch-, Zeitschriften-, Aufsatz- und Gedichttitel im fortlaufenden Text durchweg in kyrillischen Lettern, wo dies dem Original entspricht. Dadurch kann der Leser zwischen kyrillisch und lateinisch geschriebenen Titeln russischer Werke unterscheiden. Russische Titel werden bei ihrer ersten Nennung übersetzt. Russische Literaturangaben in Anmerkungen werden in der wissenschaftlichen Transliteration wiedergegeben (außer Quellenangaben von Materialien aus russischen Archiven), um ihr Wiederauffinden im alphabetischen Literaturverzeichnis und darüber hinaus in wissenschaftlichen Bibliographien zu erleichtern. Alle russischen Namen, auch Verlags- und Ortsnamen (falls letztere nicht in ihrer deutschen Form eingebürgen sind, wie z.B. Moskau), werden wissenschaftlich transliterier. Das gilt auch für Familiennamen deutscher Herkunft, wenn der Namensträger russischer Nationalität ist oder überwiegend auf Russisch publizient hat I.

Die "Bibliographie von Ėllis' Werken" strebt zwar nach Vollständigkeit und erfaBt auch seine wesentlichen Arbeiten. doch kann nicht ausgeschlossen werden, daß sich in jenen Zeitschriften. Sammelbänden und Almanachen, die seinerzeit in geringer Auflage erschienen und heute in den groBen Bibliotheken nicht greifbar sind, noch weitere kleine Publikationen dieses Autors finden lassen. Sie dürften allerdings kaum Anla $B$ geben. die wesentlichen Ergebnisse der vorliegenden Arbeit in Frage zu stellen.

Die aufgelisteten Archivmaterialien konnten - wenn nicht anders vermerkt - von der Verfasserin eingesehen und ausgewertet werden. Sie werden, wo nötig, knapp kommentiert.

Die weiteren Literaturangaben ("Literatur'erzeichnis") sind systematisch angeordnet und enthalten nur Werke, die für die vorliegende Arbeit ausgewertet wurden. Publikationen. auf die lediglich im Zusammenhang der Untersuchung von Detail- und Randproblemen verwiesen wird. sind nur in den Anmerkungen aufgeführ. Auf die Nennung von gängigen Lexika. Enzyklopädien und Wönterbüchem ist weitgehend verzichtet worden.

Das alphabetische "Namenregister" enthält bei jedem Eintrag die notwendigen Daten und Erläuterungen, die sich jedoch auf das Erkenntnisinteresse der vorliegenden Arbeit und nicht auf die objektive Bedeutung der genannten Person beziehen. Das erklän und rechtfertigt ausführlichere Angaben bei russischen Symbolisten und Persönlichkeiten, die dem Symbolismus nahestanden oder für ihn von Bedeutung waren. Namen allgemein bekannter Personen (z.B. Flauben, Goethe, Schiller, Shakespeare, Wagner etc.) sind nur mit Lebensdaten versehen. Kritiker, Übersetzer und Verfasser wissenschaftlicher Forschungsliteratur sind. von begründeten Ausnahmen abgesehen, nicht erfaßt.

Die "Ühersetzung der Zitate" im Anhang enthält alle zitierten Originaltexte und stammt. sofem keine Quellenangabe erfolgt, von der Verfasserin. Da diese Übertragungen lediglich als Verständnishilfe dienen sollen, ist auf möglichst genaue Wiedergabe Wert gelegt und von einer stilistischen Überarbeitung abgesehen worden.

1 Z.B. Metнep = Metner (und nicht. wie sich der deutsche Familienname schreibt: Medtner). C tenyн = Stepun (und nicht, wie häufig auf Deutsch. Steppun oder Steppuhn): jedoch der überwiegend deutsch publizierende Apryp Лrotep = Arthur Luther. 


\section{DANKSAGUNG}

Die vorliegende Arbeit wurde von der Neuphilologischen Fakultät der EberhardKarls-Universität Tübingen 1996 als Dissertation zur Erlangung des akademischen Grades eines Doktors der Philosophie (Dr.phil.) im Fach "Ostslavische Philologie" angenommen.

Ihr Entstehen geht auf eine Anregung von Wilfried Potthoff (damals Heidelberg) im Jahre 1987 zurück. Ich danke ihm sowie Horst-Jürgen Gerigk, beide haben meine Bewerbung beim DAAD unterstützt. so daB mir 1988/89 und 1990 Forschungsaufenthalte in Moskau zur Auswertung von unveröffentlichtem Archivmaterial gewährt wurden.

Aufrichtiger Dank gebühn meinem akademischen Lehrer Rolf-Dieter Kluge, der die Arbeit seit 1989 in Tübingen wissenschaftlich betreut hat, für viele anregende. mitunter kontroverse Diskussionen. fördemde Hilfestellungen und notwendige Kritik.

Allen, die mir bei der Abfassung meiner Dissentation geholfen haben, möchte ich an dieser Stelle meinen herzlichen Dank aussprechen:

Den Direktoren und Mitarbeitem zahlreicher Institute. Archive, Bibliotheken und Verlage in Rußland, Deutschland, der Schweiz. Italien. Österreich. den Niederlanden. den russischen wissenschaftlichen Betreuem während meiner Forschungsaufenthalte in Moskau und Petersburg, meinen Kollegen am Slavischen Seminar der Universität Tübingen, vielen Diskussionspartnem auf Konferenzen und Symposien, meinen Gutachtern und Prüfern sowie meinen Verwandten und Freunden. Michail Bezrodnyj. Uwe Densch, Lidija Kolobacva, Nikolaj Kotrelev, Michail Koz'menko, Aleksandr Lavrov, Ludolf Müller, Regine Nohejl, Daniela Rizzi, Heinz Setzer und Dietrich Wöm haben mich wiederholt hilfreich beraten und Einzelprobleme mit mir diskutien. Dirk Lederbogen hat mich immer wieder ermutigend unterstützt. Peter Rehder und der Verlag Otto Sagner haben es ermöglicht, meine Dissertation in der Reihe "Slavistische Beiträge" zu veröffentlichen. Meine Mutter Holdherta Willich hatte stets ein offenes Ohr und ein aufmuntemdes Wor für mich; sie hat mir einen großzügigen Druckkostenzuschub gewährt. 
INHALT

Seite:

VORBEMERKUNG

DANKSAGUNG 6

EINLEITUNG

1. Erkenntnisinteresse und Forschungsstand 9

2. Der russische Symbolismus - Versuch einer kurzen Charakteristik 11

I. DIE RUSSISCHE SCHAFFENSPERIODE - LEBEN UND WERK 25

1. Leben 25

A. Biographische Angaben 25

B. Ëllis und seine Zeitgenossen

2. Werk 45

A. Allgemeiner Überblick 45

B. Ëllis als Übersetzer 47

C. Ellis als Lyriker 51

D. Ellis als Theoretiker und Kritiker 71

a. Die Zeitschrift "Весы" 71

b. "Русскне символисты"

c. Die Zeitschrift "Труды и дни" 112

1) Zur Geschichte der Zeitschrift 112

2) Ellis und Rudolf Steiner 118

3) Elllis' Beiträge in "Труды и дни" 134

a) Arbeiten zum Thema Symbolismus 134

b) Ellis' Beschäftigung mit Richard Wagner 141

$\begin{array}{ll}\text { c) Ellis' Beschäftigung mit Dante } & 152 \\ & 158\end{array}$

E. Unveröffentlichte Materialien in Archiven (РГАЛИ und РО РГБ) und geplante Projekte 171

F. Zusammenfassung des 1 . Teils:

Ellis' Symbolismus- und Kunstauffassung 176

I1. DIE DEUTSCHSPRACHIGE SCHAFFENSPERIODE LEBEN UND WERK

1. Leben - Biographische Angaben 179

2. Werk 185

A. Allgemeiner Überblick 185

B. "Christliche Weisheit" (Intermediarius) 187

C. Ellis' Beschäftigung mit Vladimir Solov'ev 191

D. Monographie und Arbeiten über Vasilij Žukovskij 204

E. Monographie und Arbeiten über Aleksandr Puškin 212 
F. Sonstige Arbeiten $\quad 219$

a. Aufsätze über Nikolaj Gogol' 219

b. Beiträge zur russischen Kulturgeschichte 221

G. Zusammenfassung des II. Teils:

Éllis' Kunst- und Literaturauffassung in der Emigration 229

SCHLUSS

1. Bibliographie von Ėllis' Werken in chronologischer Reihenfolge 235

2. Materialien von/über Ėllis aus Moskauer Archiven

А. РГИА (Российский Государственный Исторический Архив Города Москвы)

В. РГАЛИИ (Российский Государственный Архив Литературы и Искусства)

С. РО РГБ (Рукописный отдел Российской Государственной Библиотеки)

3. Materialien von Ellis aus Archiven in Rom

A. Archiv von Dmitrij V. Ivanov

B. Bibliothek des Pontificium Collegium Russicum

4. Literaturverzeichnis

A. Werkausgaben

a. Russische Symbolisten; VI. Solov'ev 249

b. Nichtrussische Autoren

B. Bibliographien, Literaturgeschichten,

Nachschlage- und Sammelwerke

C. Sozio-ökonomischer, historischer, politischer, religions-, kultur- und geistesgeschichtlicher Hintergrund

D. (Russischer) Symbolismus (Modemismus): Gesamidarstellungen und Spezialuntersuchungen zu Theorie, Geschichte und ausgewählten Problemen

E. Literatur zu Ėllis (Leben, Werk. Wirken, Umkreis)

F. Verschiedenes

a. Primärtexte

b. Untersuchungen und Abhandlungen 


\section{EINLEITUNG;}

\section{Erkenntnisinteresse und Forschungsstand}

Эллис [... - ] переводчик Бодлера, один из самых страстных ранних снмволистов. разбросанный поэт. гениальный человек'

Die vorliegende Arbeit stellt den Versuch einer wissenschaftlich-kritischen Studie über Leben und Werk von Lev L'vovic Kobylinskij-Ëllis (1879-1947) dar, um dadurch eine Lücke in der Erforschung des russischen Symbolismus zu schließen².

Betrachtet man diese Stilformation, so wird man nämlich in erster Linie auf die Namen ihrer Hauptvertreter stoßen, wie Dmitrij Merežkovskij, Zinaida Gippius. Konstantin Bal'mont. Fedor Sologub, Valerij Brjusov, Vjačeslav Ivanov, Andrej Be lyj. Aleksandr Blok, und vielleicht auf Innokentij Annenskij und Aleksej Remizov. Wenn man sich jedoch eingehender mit dieser literarischen Strömung befaBt, wird schnell deutlich, daB es sich keineswegs um eine einheit liche, eindeutig bestimmbare Stilformation handelt, um ein geschlossenes künstlerisches System. Neben den genannten Hauptvertretern gibt es eine Vielzahl von Autoren, die (aus heutiger Sicht) sogenannten "poetae minores", die zur Zeit des russischen Symbolismus eine wichtige Rolle gespielt und einen beachtlichen Beitrag geleistet haben, aber heute weitgehend in Vergessenheit geraten und längst noch nicht alle umfassend erforscht und kritisch beurteilt worden sind. $\mathrm{Zu}$ ihnen gehört auch der eingangs charakterisiente Übersetzer, Dichter, Theoretiker und Kritiker des russischen Symbolismus: Ėllis, dem die vorliegende Untersuchung gewidmet ist ${ }^{3}$.

In der Memoirenliteratur aus der Zeit des russischen Symbolismus taucht Ėllis' Name wiederholt auf: es finden sich lebhafte Beschreibungen seines Wesens und Charakters, seiner Aktivitäten und "Auftritte". Kritische ÄuBerungen und Rezensionen zu Ellis' Werk fallen dagegen insgesamt eher negativ aus. Sein Primärwerk ist - mit Ausnahme seiner Baudelaire-Übersetzungen, des Abdrucks einiger seiner Gedichte in Anthologien ${ }^{4}$ und eines Nachdrucks sowie einer Neupublikation seiner "Русские символисты" ("Die russischen Symbolisten". Letchworth 1972 bzw. Tomsk 1996) nicht wieder aufgelegt worden, auch gibt es keine Gesamt- oder textkritische, kommentierte Ausgabe seiner Werke.

Was die Forschung zum russischen Symbolismus anbelangt. so wird zwar in einigen Literaturgeschichten. Nachschlagewerken und in fast allen umfassenden Gesamtdarstellungen dieser Stilformation mit wenigen Sätzen auf Ėllis und sein Werk bzw. auf einzelne seiner Arbeiten verwiesen 5 ; es gibt auch einige Teiluntersuchungen zu Einzelaspekten seines Euvres ${ }^{6}$, einige seiner Briefe und der Briefe an ihn sind an

I M. Cvetaeva: Plennyj duch. In: Dies.: Soxinenija v dvuch tomach. T. 2. Moskva 1984. S. 237.

2 Der Kürze halber wird im weiteren Verlauf der Arbeit einfach von Ėllis gesprochen werden.

${ }^{3}$ Andere weitgehend unerforschte russische Symbolisten sind z.B. Georgij Culkov. Aleksandr Dobroljubov. Vladimir Pjast. Nina Petrovskaja. Sergej Auslender u.a.

${ }^{4}$ Z.B. in: Russkij sonet XVIII-naCala XX veka. Moskva 1986; oder in: Russkaja poezija serebrjanogo veka. $1890-1917$. Moskva 1993.

${ }^{5}$ Etwa in der von W. Düwel und $\mathbf{H}$. Grasshoff herausgegebenen "Geschichte der russischen Literatur von den Anfangen bis 1917" (2. Band. Berlin 1986. S. 481), in W. Kasacks "Lexikon der russischen Literatur des 20. Jahrhunderts" (München ${ }^{2}$ 1992) und in den Gesamtdarstellungen des russischen Symbolismus von O. Maslenikov, J. West. R. Peterson. A. Pyman (vgl das Literaturverzeichnis im Anhangsteil der vorliegenden Arbeit).

${ }^{6}$ Einen ersten kurzen zusammenfassenden (̈̈berblick bietet die Arbeit von S.S. Grečšskin und A.V. Lavrov: Ëllis - poét-simvolist, teoretik i kritik |1900 - 1910-e gody] (In: XXV Gercenovskie ctenija [9]. Leningrad 1972. S. 59-62); weiter sind zahlreiche Aufsätze und die Belyj-Monographie von A. Lavrov 
verschiedenen Stellen publizient worden ${ }^{7}$, seine deutschsprachigen Werke werden ge legentlich in Arbeiten zur russischen Romantik ${ }^{8}$ und in der Vl. Solov'ev-Forschung rezipien, aber eine Gesamtdarstellung seines Lebens und Werks existien bisher nicht ${ }^{9}$.

In der vorliegenden Arbeit bemüht sich die Verfasserin, unter Zuhilfenahme der Memoirenliteratur, von Archivmaterialien (soweit sie zugänglich waren), des Primärwerks von Ellis und der oben erwähnten Teiluntersuchungen. Ëllis' Biographie möglichst vollständig zu erschließen ${ }^{10}$ und sein - heute kaum noch bekanntes - Werk vorzustellen. Diese Vorgehensweise bedingt eine Untergliederung der Arbeit in zwei Teile: in eine Moskauer und eine Emigrationsperiode, die jeweils in Leben und Werk aufgeteilt sind. Da Ellis nicht nur durch seine Veröffentlichungen, sondern mindestens ebenso einflußreich durch seine Persönlichkeit gewirkt hat (zumindest während der Moskauer Schaffensperiode und der Zeit seiner Begeisterung für R. Steiner und dessen Lehre). scheint diese Aufteilung sinnvoll. Der Schwerpunkt der vorliegenden Arbeit wird auf der Moskauer Periode liegen, das heißt, der erste Teil der Untersuchung wird der umfangmäBig größere sein. was einerseits durch die Materiallage und andererseits durch das Forschungsinteresse der Verfasserin bedingt ist. Ėllis' Primärwerk wird - da es nicht als bekannt vorausgesetzt werden kann und teilweise schwer zugänglich ist - nach Themen geglieden und soweit dabei möglich chronologisch in zusammengefaßter Form referien und charakterisien sowie einer Bewertung und kritischen Beureilung unterzogen 'I.

Sinnvoll und notwendig erscheint es, vor Beginn der eigentlichen Untersuchung kurz die zwei Hauptrichtungen innerhalb des russischen Symbolismus in ihrer Entwicklung aufzuzeigen und in ihrer Problematik - auch bezüglich der Symbolismusforschung - zu diskutieren. um im Verlauf der Arbeit Ellis' Werk im Kontext des russischen Symbolismus kritisch bewerten und beurteilen zu können. Aus diesem Grund wird ein literarhistorischer (und nicht ein texttheoretischer oder -kritischer) Ansatz gewählt

Die vorliegende Studie soll folgende Fragen beantworten: Ist Ellis zu recht in Vergessenheit geraten? Hat er durch sein Werk einen Beitrag zum russischen Symbolismus geleistet? War sein Werk damals von Bedeutung? Ist es heute lediglich als Zeit zeugnis von Interesse oder auch als Selbstzeugnis von Belang? Enthalten die Arbeiten seiner zweiten Schaffensperiode gewichtige. untersuchenswerte Innovationen?

zu nennen. aber auch Untersuchungen anderer Forscher (V. Pepitoni. L. Sproge. F. Poljakov, D. Rizzi etc.: W. Potthoff kommt in seinen Arteiten über Dante in RuBland und den russischen Symbolismus wiederholt auf Ellis zu sprechen: M. Ljunggren geht in seinen Monographien über Belyj und Metner auch auf Ëllis und dessen Werk ein: vgl. das "Literaturverzeichnis" der vorliegenden Arbeit, S. 256ff.).

7 7.B. in Literatumne Nasledstvo (die Bände zu Brjusov und Blok), in Werkausgaben Brjusovs. $M$. Cvetaevas (Neizdannye pis'ma), im Almanach "l.ica" (Nr. 5). in Europa (rientalis (14. 1995) etc.

${ }^{x}$ Z.B. in B. Zelinsky: Russische Romantik. Köln. Wien 1975.

9 Den Versuch einer (iesamtdarstellung bietet die Diplomarbeit Vera Pepitonis: "Ellis-Kobylinskij L.L.. preta simbolista" (Milano, 1987-1988), die sich überwiegend mit Ëllis' erster Lebensperiode als Moskauer Symbolist und mıt Ëllis als Dante-Übersetzer befabt. Sie ist nicht publizien worden, konnte jedoch von der Verfasserin der vorliegenden Arbeit an der Mailänder Universität eingesehen werden.

1" Dies führte vor allem in Ellis' zweiter Lebenshälfte, als er in der Emigration lebte. zu Problemen. da ich über diese Zeit kaum Materialien finden konnte.

11 Da es sich in der vorliegenden Studie um die erste Monographie über Ellis' l.eben und Werk handelt. die zugleich auch als Nachschlage werk zu Einzelaspekten und -themen in Ëllis' Werk gedacht ist. konnte - nicht zuletzt auch der Lesbarkeit wegen - auf gelegentliche Wiederholungen nicht verzichtet werden (ausschlieblich Querverweise, deren es zahlreiche gibt. würden die Lektüre nur einzelner Kapitel erheblich erschweren); aus diesem (irunde ist auch von einer zusammenfassenden Straffung der Darstellung von Ellis' Gesamtwerk abgesehen worden. 


\section{Der russische Symbolismus - Versuch einer kurzen Charakteristik}

Gegen Ende des 19. Jahrhunderts befand sich ganz Europa in einer Kultur- und Identitätskrise, die auch in RuBland große Ausmaße annahm. Neue Emungenschaften in Naturwissenschaft und Technik sowie Industrialisierung und Kapitalisierung der Wirtschaft ließen unter den Intellektuellen große Zweifel und Ablehnung gegenüber dem positivistischen Fortschrittsoptimismus aufkommen. Die zunehmende Institutionalisierung von Kunst und Kultur und die Einschränkung der künstlerischen Freiheit riefen überall in Europa eine Gegenreaktion hervor, die zu einer Umwertung aller traditionellen Normen und Werte der Kunst und Kultur führte und im Bereich der Literatur eine Strömung entstehen lieB, die als Modernismus, Symbolismus. Décadence. Ästhetizismus, Fin de Siècle, Neoromantik, Impressionismus oder - speziell in Rußland - auch als "Silbernes Zeitalter" ("Серебряный век") in die Literaturgeschichte eingegangen ist.

Aufgabe dieser Einleitung ist nun aber nicht eine Diskussion der terminologischen Unterschiede der einzelnen genannten Bezeichnungen dieser literarischen Strömung. die in der vorliegenden Arbeit, um begriffliche Unklarheiten und Verwirrungen zu vermeiden. allgemein als Symbolismus bezeichnet wird. Es soll vielmehr der Versuch einer kurzen Charakteristik der wesentlichen Kriterien der Stilformation ${ }^{1}$ des Symbolismus in RuBland unternommen werden, der eine wichtige Strömung innerhalb der Geschichte der russischen Literatur darstellt ${ }^{2}$.

Betrachtet man die russische Literatur in ihrer Entwicklung, so kann man im 19. Jahrhundert nicht mehr von einem eindeutigen Vorherrschen jeweils nur einer Stilformation sprechen. Während die Romantik zu Beginn des 19. Jahrhunderts den Klassizismus noch vollständig verdrängte. hat die sich seit den vierziger Jahren immer stärker durchsetzende realistische Stilformation die Romantik nie ganz ablösen können. auch wenn der Realismus zwischen den vierziger und achtziger Jahren des 19. Jahrhunderts das literarische Leben Rußlands dominierte ${ }^{3}$. Die Romantik dauerte an und fand in der Lyrik Tjutčevs. Fets. Majkovs und Polonskijs sowie auch in den Gedichten VI. Solov'evs einen neuen, späten Höhepunkt, der allerdings nicht mit ihrer ersten Blütezeit, dem sogenannten "Goldenen Zeitalter" ("Золотой век") konkurrieren konnte oder den Realismus in den Hintergrund zu drängen vermochte ${ }^{4}$.

1 Der Begriff "Stilformation" mag problematisch scheinen, ist aber als Bezeichnung für eine komplexe literarische Strömung. die auch kulturelle Phänomene im weitesten Sinne umfaBt, geläufig und begegnet z.B. wiederholt in Arbeiten von A. Flaker, R.-D. Kluge, R. Lauer u.a. Die Begriffe "Richtung" und "Schule" sind enger und nur auf literarisch-stilistische Kriterien fixien. der Begriff "Strömung" wird in einem weiteren Sinne verwendet und bezeichnet synchrone zusammenhängende Erscheinungen. die auch über den kulturellen Raum hinausgehen. Insoweit entspricht "Strömung" den nur chronologisch verwendeten Begriffen "Epoche" und "Periode".

2 W. Kasack (Lexikon der russischen Literatur des 20. Jahrhundents. a.a.O.. S. 1265) bezeichnet den Symbolismus als "erste und bedeutendste literarische Strömung der russischen Literatur des 20. Jahrhunderts".

${ }^{3} \mathrm{Vgl}$. hierzu auch R.-D. Kluge: Der russische Spätrealismus (1880-1920). Überblick - Bibliographie - Kommentar. Eine Arbeitshilfe für Studium und Lehre. Tübingen 1993, S. 5. 51.

+ VI. Solov'ev und andere Literaturtheoretiker zur Zeit der Jahrhunderiwende nannten dieses zweite. spate Aufblühen der russischen Romantik "Silbernes Zeitalter" ("Cеребpяный век"; vgl. hierzu auch S. 193 der vorliegenden Arbeit. Anm. 11); im 6. Band der Kratkaja Literatur naja Énciklopedija (Moskva 1971, S. 476) wird der Terminus "«серебряньий век» pусской поэзия" ("«Silbernes Zeitalter» der russischen Lyrik") im Zusammenhang mit Fet. Polonskij, Majkov und A. Żemćuźnikov verwendet. Seit der Zeit des Symbolismus. Akmeismus und Futurismus wurde dann jedoch der Begriff "Silbernes Zeitalter" auf die Lyrik und Literatur dieser Strömungen, vomehmlich auf den Symbolismus, angewandt. von der sowjetischen Literaturwissenschaft allerdings bis zum Ende der 80er Jahre vermieden 
Zu Beginn der neunziger Jahre des 19. Jahrhunderts begann sich dann in RuBland, einerseits als Gegenreaktion auf den Realismus und Positivismus in der Literatur und weltanschaulichen Diskussion. andererseits als Anknüpfung an die (späte) Romantik. die neue Stilformation des Symbolismus herauszubilden, als deren erste Manifeste und Programmschriften Nikolaj Minskijs Essayband "При свете совести" ("Im Lichte des Gewissens", 1890) und Dmitrij Merežkovskijs aus verschiedenen Vorträgen zusammengestellte Arbeit "O причинах упалька и о новых течениях современной русской литературы" ("Über die Gründe des Verfalls und über die neuen Strömungen der modemen russischen Literatur". 1893) bezeichnet werden können 5 .

Entscheidende Anstöße zur Herausbildung dieser neuen Stilformation in RuBland kamen aus Europa, in erster Linie aus Frankreich (vgl. das Manifest des französischen Symbolismus von Jean Moréas [1886], die Werke Baudelaires. Verlaines, Rimbauds, Mallarmés. Huysmans' etc.) und Belgien (Rodenbach. Maeterlinck. Verhaeren u.a..) ${ }^{6}$, aber auch die deutsche Klassik und Romantik (Goethe. Novalis, Hoffmann u.a.) und idealistische Philosophie (vor allem Schelling und die Brüder Schlegel) waren für die Entstehung des russischen Symbolismus wichtig. Als weitere europäische Vorbilder müssen Edgar A. Poe, die englischen Präraffaeliten (Dante Gabriel Rossetti, W. Hunt. J. Millais, W. Morris. J. Ruskin u.a.). Oscar Wilde, die Philosophen Schopenhauer, Nietzsche. Bergson und viele andere genannt werden; Ibsens Dramen sowie die antike griechische Tragödie gaben weitere schöpferische Impulse, und $R$. Wagners Konzeption des Gesamtkunstwerks war für die russischen Symbolisten von besonders großer Bedeutung?.

Aber auch die russische Literaturtradition war maBgeblich für die Entstehung der neuen literarischen Strömung?: Einerseits knüpften die Symbolisten, wie oben er-

(vgl. W. Kasack. Lexikon der russischen Literatur des 20 . Jahrhunderts, a.a.O., S. 1148f.); er begegnet haufig in Literaturgeschichten (V. Terras und R. Peterson 2.B nennen die Periode von den 1880 er/90er Jahren bis 1917 "'The Silver Age") sowie in Titeln von Anthologien und Monographien (z.B. C. and E: Proffer |Eds. |: The Silver Age of Russian Culture. An Anthology. Ann Artor/Mich. 1975; B.G. Rosenthal: D.S. Merezhkovsky and the Silver Age. The Hague 1975). Seit der Perestrojka ist dieser Terminus dann in die sowjetische br.w. nusstische Literaturwissenschaft eingegangen. viele Anthologien und Untersuchungen führen ihn in ihrem Titel (2.B.: Serebrjanyj vek. Memuary. Moskva 1990: Russkaja poezija Serehrjumogo veha. 1890-1917. Antologija. Moskva 1993: S. Bavin. I. Semibratova: Sud by poetov serebrjanogo veka. Moskva 1993: Serebrjanyj vek v Rossii. Izbrannye stranicy. Moskva 1993; Vospominanija o serebrjanom veke. Moskva 1993).

"Vgl. dazu auch das Kapitel "Der russische Symbolismus" in: A. Stender-Petersen: Geschichte der russischen Literatur. Teil II. München ${ }^{3}$ 1978. S. 501-539; hier bes. S. 508f.

${ }^{n} \mathrm{Vgl}$. G. Donchin: The influence of French Symbolism on Russian Poetry. The Hague 1958.

7 Die europaischen Einflüsse auf den russischen Symbolismus werden in den meisten Literaturgeschichten und Gesamtdarstellungen erwähnt und behandelt (vgl. Literaturverzeichnis im Anhang der vorliegenden Arteit) sowie auch in: J. Holthusen: Studien zur Ästhetik und Poetik des russischen Symbolismus. Göttingen 1957; und in: R.-D. Kluge: Westeuropa und RuBland im Weltbild Aleksandr Bloks. München 1967. Zu Nietzsche in RuBland und im russischen Symbolismus gibt es viele Untersuchungen, die größtenteils in der Arteit von M. Deppermann: Nietzsche in RuBland (in: Nietzsche Stu dien. 21. 1992. S. 211-253) genannt werden: (zu Nietzsche in RuBland vgl. auch die anderen im LiteraIurverzeichnis der vorliegenden Arbeit genannten Publikationen von M. Deppermann. E.W. Clowes, R.D. Kluge $|1982|$ und B.G. Rosenthal). Zu Schopenhaver in RuBland vgl. die Arbeiten von J. Baer und S. Macl aughlin (Literaturverzeichnis). Angaben zur Bedeutung der englischen Präraffaeliten für den russischen Symbolismus finden sich in W. Potthoff: Dante in RuBland. Heidelberg 1991. Auf die Wagner-Rezeption im russischen Symbolismus wird im Kapitel "Elllis' Beschäftigung mit R. Wagner" eingegangen.

${ }^{*} \mathrm{Vgl}$. hierzu auch A. Pyman: A Historry of Russian Symbolism. Cambridge 1994, S. 10-15. 
wähnt, an die Romantik an 9 . Im russischen Symbolismus wurde teilweise die theoretische Diskussion, die zur Zeit der Romantik in RuBland nicht stattgefunden hatte, nachgeholt und somit verspätet das theoretische Reflexionsniveau der westeuropäischen Romantik erreicht ${ }^{10}$. Andererseits stützten sich vor allem die sogenannten "jüngeren" russischen Symbolisten zunächst auf den Religionsphilosophen und Dichter Vladimir Solov'ev, den sie als "geistigen Vater" betrachteten. und auf seine Sophiologie mit Sophia als der mystischen Weltseele"l.

Diese verschiedenartigen Anstöße und Einflüsse lassen es nicht verwunderlich erscheinen, daB der russische Symbolismus keine einheitliche, eindeutig zu fassende Strömung ist, sondern eine vielfältige, weitverzweigte Bewegung. Dieses Problem wird in der Forschung erkannt und hervorgehoben. Oleg Maslenikov schreibt zum Beispiel: "[...] the term «symbolism» embraces a number of different connotations. because it describes not a single, homogeneous current, but rather several, parallel streams" 12. Aleksandar Flaker hebt gar hervor, daB "man in der Dichtergruppe, die unter diesem Namen [= Symbolismus] aufgetreten ist, weder von einer gemeinsamen Poetik noch von einer Stileinheit sprechen kann" 13. Ronald Peterson nennt den Symbolismus ein "multi-faceted movement"14. Diese Tatsache erschwert eine eindeutige Definition des russischen Symbolismus bzw. macht sie unmöglich und führ zu einer Vielzahl mitunter widersprüchlicher Bestimmungen, zu verschiedenen Gliederungsversuchen und unterschiedlichen Symbolismusmodellen 15 .

Es sollen nun die wesentlichen Entwicklungsstufen des russischen Symbolismus kurz charakterisien werden, die als Hintergrund für die folgenden Ausführungen und die Einordnung von Ëllis in den Kontext des russischen Symbolismus wichtig und maBgeblich sind ${ }^{16}$.

In den neunziger Jahren des letzten Jahrhunderts, als sich der russische Symbolismus herauszubilden begann. versuchten seine ersten Vertreter zunächst durch Provokation. Schock- und Skandalwirkung auf sich aufmerksam zu machen. So zum Bei-

${ }^{4}$ Hierauf weist 2.B. V. Terras (A History of Russian Literature. New Haven and London 1991. S. 391ff.) explizit hin. Vgl. hierzu auch Erik Egeberg: Romantizm i simvolizm. In: Russian Literature XXXVIII-II. 1995. S. 149-156.

10 $\mathrm{Vgl}$. hierzu auch V. Žirmunskij: Nemeckij romantizm i sovremennaja mistika [SPb. 1914]. der auf eine enge Vertindung zwischen deutscher Romantik und russischem Symbolismus verweist, sowie R.D. Kluge: We steuropa und RuBland.... a.a.O.. S. 66.

$11 \mathrm{Vgl}$. hierzu auch $\mathrm{W}$. Kasack: Lexikon der russischen Literatur des 20. Jahrhunderts, a.a.O., S. 1267. Der Nähe Solov'evs zum Symbolismus und seiner Bedeutung für die russischen Symbolisten sind mehrere Unter suchungen gewidmet (z.B.: R.J. Lager: Vladimir Soloviev - Symbolist poet. Washington 1970: A. Knigge: Die Lyrik VI. Solov'evs und ihre Nachwirkung bei A. Belyj und A. Blok. Amsterdam 1973).

12 O. Maslenikov: The Frenzied Poets. Berkeley and Los Angeles 1952. S. VIII.

13 A. Faker: Die slavischen Literaturen 1870-1900. In: Neues Handbuch der Literaturwissenschaft. Band 18. Wiesbaden 1976. S. 352.

Indem Flaker und andere Avantgardeforscher überhaupt die Einheitlichkeit des Symbolismus als fraglich darstellen. beziehen sie eine Position. die es yuasi nicht mehr rechtfertigt, vom Symbolismus als wichtiger eigenständiger Stilformation innerhalb der Entwicklung der russischen Literatur zu sprechen.

14 R.E. Peterson: A History of Russian Symbolism. Amsterdam. Philadelphia 1993, S. 1.

15 Einen guten Überblick über die Vielfalt der Symbolismusmodelle, die verschiedenen Entwicklungsphasen des russischen Symbolismus und seine unterschiedlichen Richtungen bietet die Darstellung von A.A. Hansen-Löve: Der russische Symbolismus. System und Entfaltung der poetischen Motive. 1. Band: Diabolischer Symbolismus. Wien 1989, S. 16-19. 29-38.

16 Auf einzelne Aspekte und Probleme innerhalb der Entwicklung des russischen Symbolismus wird im Verlauf der vorliegenden Untersuchung an entsprechend relevanten Stellen ausführlicher eingegangen werden. 
spiel Valerij Brjusov mit seinen drei kleinen Bändchen "Русские символисты" ("Russische Symbolisten", 1894/95). Brjusov als Initiator und Herausgeber dieser Bände verfaßte zugleich auch die meisten der darin abgedruckten Gedichte (Nachdichtungen französischer Lyrik und einige eigene Gedichte), die er aber unter Pseudonymen einer großen Anzahl fingierter Autoren publizierte, um dadurch den Symbolismus als eine bereits affirmierte, gesicherte Bewegung auszugeben. Einige wenige Gedichte stammen von Brjusovs Schulfreund Miropol'skij. Diese Bände stieBen bei der damaligen Literaturkritik auf Ablehnung. Die neue Stilformation wurde zunächst nicht oder mißverstanden und als ästhetischer Unsinn abgetan ${ }^{17}$. Brjusov erklärte sein Anliegen in verschiedenen kurzen Kommentaren, Vorworten und Artikeln über die neue Kunst des Symbolismus: Er sei bestrebt, eine Lyrik zu schaffen. die dem Leben gegenüber fremd ist; er wolle Stimmungen erzeugen, die das Leben überhaupt nicht kenne und überhaupt nicht zu geben vermöge ${ }^{18}$. Brjusov erlangte durch diese Bändchen bald skandalöse Berühmtheit, die nicht zuletzt durch sein einzeiliges Gedicht "O, закрой свои бледные ноги"19 mitbegründet wurde 20 .

Merežkovskij, der am Beginn des russischen Symbolismus stand und in der sozialkritischen Tendenzliteratur des Realismus einen Verfall der russischen Dichtung sah. forderte bzw. propagierte eine Wiedergebur der Kunst. Den Naturalismus wollte er durch einen religiösen Idealismus überwinden. In seiner erwähnten Programmschrift "О причинах упадка и о новых течениях современной русской литературы" führte er aus, da $B$ im Kunstwerk Erkenntnisse nicht direkt ausgesprochen werden sollen; ein Kunstwerk solle die Leser oder Hörer lediglich in die nötige Stimmung versetzen. damit sie das Göttliche, das sich der direkten Aussage entzieht, hinter den Erschei nungen erahnen können ${ }^{21}$. Es heißt bei Merežkovskij:

\footnotetext{
"Мысль изреченная есть лохь"22. В поэзия то. что не сказано и мерцает сквозь красоту символа. действует сильнее на серлие. чем то, что выражено словами. (имволизм делает самый стиль. самюе художественное веццество поззия олухотворенным. прозрачным. насквозь просвечивак)шим. как тонкие стенки алебастржвой амфоры. в которой зажжено пламя. 23
}

$17 \mathrm{Vgl}$. huerzu J. Holthusen: Studien zur Ästhetik und Poetik des russischen Symbolismus. a.a.O.. S. 55f. Auch VI. Solov'ev verspottete die "Русские символисты" und fügte seinen Rezensionen geistvolle Parodien auf den Stil symbolistischer Dichtungen bei (vgl. VI. Solovev: Russkie simvolisty. 1895. In: Ders.: Sobranie soxinenij. Tom VII. Brjussel' 1966. S. 159-170).

I 8 "[...] я надеюсь создать поззию, чуждую жизни. воплотить настроения. которые жизнь :ать не может" schreibt Brjusov über seinen geplanten Lyrikband "Me eum esse" (in: V. Brjusov: Subranie socinenij v 7-i tt. Tom I. Moskva 1973. S. 565). Vgl. auch Brjusovs Vorworte zu seinen "Русские символисты", sein Interview "Московские декаденты" ("Moskauer Décadents". in: V. Brjusov: Sredi stichov. 1894-1924. Moskva 1990, S. 35-46) sowie sein Gespräch mit dem Kortespondenten der Zeitung "Новости" ("Nachrichten": 18.11.1895) anläBlich seines Gedichts "Tворчеств)" ("Schopfung" [1895], in: V. Brjusov: Sobranie soxinenij. a.a.O., Bd. 1. S. 567f.). Ebenfalls hierzu vgl. R.-D. Kluge: Der nussische Symbolismus. Bibliographie - Kommentar - Texte. Fine Arbeitshilfe für Studium und Lehre. Tübingen ${ }^{3}$ 1992. S. 37 sowie R.-D. Kluges Vorlesung: "Symbolismus und Avant garde in der russischen Literatur". Universität Tübingen. WS 1992/93.

${ }^{19}$ Geschrieben am 3. Dezember 1894. publizient im 3. Band der "Русскис символисты" (1895).

${ }^{20} \mathrm{Vgl}$. hierzu auch W. Düwel. H. Grasshoff (Hrsg.): Geschichte der russischen Literatur von den Anfängen bis 1917. Band 2. a.a.O.. S. 466.

21 Vgl. R.-D. Kluge: Westeuropa und RuBland im Weltbild Aleksandr Bloks. a.a.().. S. 10 f.

22 Zitat aus F.I. TjutCevs Gedicht "Silentium!" (1830).

23 D. Merežkovskij: O pricinach upadka i o novych tecenijach sovremennoj nusskoj literatury. In Ders.: Izbrannye stati. Simvolizm. Gogol'. Lermontov. München 1972 (Reprint der Bände 10 und 15. S.-Peterburg/Mosk va 1911/1912), S. 249.

Zu Bedeutung und Prinzip der Transparenz (Iтp)зрачность) im russischen Symbolismus vgl. auch J. Striedter: Transparenz und Verfremdung. Zur Theorie des poetischen Bildes in der russischen Moder- 
Merežkovskijs Gedichtband "Символы" ("Symbole", 1892) ist ein frühes Beispiel dieser neuen Art von Dichtung.

Das Bestreben der ersten russischen Symbolisten war also, eine Erneuerung der Kunst zu bewirken, eine Kunst zu schaffen. die gänzlich frei von allen Regeln und Konventionen und nicht an bestimmte Inhalte gebunden war. Folglich kam es zur Erschließung und Gestaltung neuer Inhalte und Themen: Angeregt durch Baudelaire ("Les fleurs du mal") wurde eine Ästhetik des Ungewöhnlichen geschaffen; Themen wie Tod, Krankheit, das Abnorme, Künstliche, Unnatürliche, aber auch Technik und Industrie etc. fanden Eingang in die Literatur, jedoch auf ganz andere Weise als dies in den parallel verlaufenden realistischen Strömungen (Literatur des Narodničestvo, Naturalismus, Spätrealismus) der Fall war, gegen die sich zu behaupten der russische Symbolismus eifrig bemüht war.

Bei einem Kunstwerk ist jedoch nicht nur der Inhalt, sonderm auch die Form von Bedeutung; Kunst ist zugleich Können, das heiBt Beherrschung des Handwerks. Im russischen Symbolismus kommt es zusehends zu einer Perfektionierung des Handwerklichen und allmählich zu einer Verselbständigung der "Priemy". Die Auffassung vom literarischen Text als einem künstlichen Gebilde, als etwas nicht Natürlichem, spielt für das Verständnis der Kunst und des Kreativen im Symbolismus eine wichtige Rolle $^{24}$. Die formvollendeten Gedichte der russischen Symbolisten haben keine konkreten Themen und Gegenstände mehr zum Inhalt, sondern suggerieren vielmehr verschwommene, unklare Stimmungen, die sich nicht in einen Gesamtkontext einordnen lassen. Sie appellieren an das kreative BewuBtsein eines Lesers oder Rezipienten, der bereit ist, sich durch die evozienten Andeutungen zum Weiterdichten und Zuendestrukturieren des literarischen Kunstwerks anregen zu lassen. Die russischen Symbolisten sind nicht nur bestrebt, das Künstliche, Unnatürliche, Ungewöhnliche zu gestalten, eine Zuflucht in Traumwelten und künstliche Paradiese zu nehmen (vgl. die französischen Vorbilder), sondem versuchen, auch dasjenige zum Gegenstand ihrer Lyrik zu machen, was es sonst nicht gibt, in ihren lyrischen Werken die Erschaffung des Gedichts selber aus dem Nichts als intelligibles Phänomen zu gestalten ${ }^{25}$. Wenn jedoch der symbolistische Dichter etwas aus dem Nichts erschaffen kann. besitzt er dieselbe Fähigkeit wie Gott, der allmächtige Schöpfer. Diese theurgische Auffassung der Symbolisten ist gewissermaßen eine Vereinnahmung und Aneignung der Religion: Der symbolistische Künstler tritt an die Stelle Gottes, vollzieht einen Schöpfungsakt, der demjenigen Gottes gleicht. Er unterliegt keinen höheren Ordnungen, Mächten und Gesetzen mehr, sondem bestimmt sein eigenes Tun in absoluter Selbständigkeit und Freiheit 26.

Im russischen Symbolismus unterscheidet man zwei Generationen, die sogenannten "старшие" ("älteren") und die "младшие символисты" ("jüngeren Symbolisten"). Zur ersten Generation gehören als wesentliche Vertreter Merežkovskij. Gippius. Brjusov, Bal'mont, Sologub und Annenskij, die vorwiegend von der französischen Mo-

ne. In: W. Iser (Hrsg.): Immanente Ästhetik. München 1966, S. 263-296 sowie A. Hansen-Löve: Zum ästhetischen Programm des russischen Frühsymbolismus. In: Sprachkunst, XV (1984) 2, S. $306 f$.

${ }^{24}$ Die Künstlichkeit und Kreativität des russischen Symbolismus ist dem Kult des Volkstümlichen (наропность), der Volksverbundenheit in der russischen Literaturtradition entgegengestellt.

25 Frühe Beispiele hierfür sind V. Brjusovs Gedicht "Tворчество" (1895) oder Z. Gippius' "Песня" ("Lied". 1893), worin es heiBt: "[...] О. пусть будет то. чего не бывает. / Никогда не бывает [...] / Мне нужно то. чего нет на свете [...]". Auch die späteren Gedichte von Belyj und Blok lassen sich nicht mehr plausibel erklären.

$26 \mathrm{Vgl}$. hierzu auch A. Hansen-Löve: Kunst als Religion. In: Ders.: Der russische Symbolismus, a.a.O., S. 408-447. 
derne und dem europäischen Ästhetizismus des fin de siècle angeregt und beeinflußt wurden: später standen ihnen die Akmeisten nahe. Als Hauptvertreter der "jüngeren" Symbolisten gelten Vjač. Ivanov, Belyj und Blok. Sie waren eher germanophil ausgerichtet und sahen im Symbolismus nicht nur eine bestimmte literarische Strömung oder Schule, sondern eine neue Weltanschauung und Lebensauffassung. In ihrer Dichtung strebten sie eine Verbindung von Kunst und Leben an: Erst die Kunst, verstanden als etwas Kreatives, schafft das Leben (und nicht umgekehrt). Die Ansichten der "jüngeren" Symbolisten, vor allem Belyjs und Bloks, wurden zunächst maBgeblich von der mystisch-romantischen Philosophie Vl. Solov'evs sowie den Jenaer Romantikem beeinfluBt ${ }^{27}$. Mit dieser mystisch-romantischen Ausgangsposition brachen Belyj und Blok jedoch später radikal; besonders Blok geriet in verstärktem MaBe unter den Einfluß der Philosophie Nietzsches. Während Vjač. Ivanov seine religiöse Gesinnung bewahrte, wurde die ursprüngliche Religiosität vor allem bei Blok, aber auch bei Belyj, durch eine skeptische Einstellung abgelöst. wobei sie jedoch nicht ihre irrationalistische Haltung aufgaben ${ }^{28}$.

Diese Einteilung in zwei Symbolistengenerationen darf allerdings nicht verabsolutien werden. Merežkovskij beispielsweise stand den "jüngeren" Symbolisten nahe in seiner Auffassung vom "zeitlosen" Symbolismus. Für ihn war Symbolismus nicht nur eine künstlerische Technik, sondern zugleich eine Möglichkeit, eine Brücke von der Kunst zur Mystik und Religion zu schlagen. Durch das symbolistische Kunstwerk sollte eine mystische Beziehung zwischen Leben und Kunst hergestellt werden, eine Verbindung zwischen der realen und der mystischen Welt ${ }^{29}$.

Während sich der russische Symbolismus in der letzten Dekade des 19. Jahrhunderts überhaupt erst einmal einen Platz in der literarischen Szene RuBlands erobem mußte, wurde er zu Beginn dieses Jahrhundents allmählich zur vorherrschenden Stilformation, auch wenn er den Spätrealismus nicht völlig zu verdrängen vermochte. Die einzelnen Vertreter dieser neuen literarischen Strömung, die zunächst gemeinsam für eine Etablierung ihrer Richtung gekämpft und gegen alle realistischen Strömungen polemisiert hatten, begannen nun, sich untereinander anzugreifen, gegeneinander zu polemisieren und in Untergruppen zu zersplittern.

Eine wichtige Rolle spielten in diesem Zusammenhang die zahlreichen literarischen. (religiös)philosophischen und allgemein kulturell ausgerichteten Zirkel (кружки). Salons und Gesellschaften (общества), die sich teils in den Wohnungen der Symbolisten oder der an symbolistischer Kunst und Kultur Interessierten, teils in den symbolistischen Verlagshäusem zusammenfanden. Vorträge, Diskussionen. Lesungen. Konzerte etc., die sich zum Teil großer Resonanz in der Öfentlichkeit erfreuten und im Grunde die später von den Avantgardisten angestrebte Massenwirkung (zumindest

27 Das zeigt sich z.B. deutlich in Bloks "Стихи о Прекрасной Даме" ("Verse von der Schönen Dame". 1901/02 entstanden). die von den "Argonauten" (vgl. unten. S. 26-29 der vorliegenden Arbeit) geradezu vergötten wurden

Diese Einteilung des russischen Symbolismus in zwei Generationen begegnet überall in der Forschung. Eine gute Darstellung der unterschiedlichen Konzeptionen (mit Schwerpunkt auf der ersten Generation) bietet A. Hansen-Löve: Zum ästhetischen Programm des russischen Frühsymbolismus. a.a.O.. S. 293-329.

${ }^{28}$ Vgl. hierzu auch R.-D. Kluge: Westeuropa und Rubland im Weltbild A. Bloks, a.a.O.: Ders.: Zur Theorie des russischen Symbolismus - A. Blok und F. Nietzsche. Zum Stand der Diskussion. In: Literatur und Sprachentwicklung in Osteuropa im 20. Jahrhunden. (Hrsg.: E. Reißner). Berlin. 1982, S. 79-88. hier besonders S. 80f.

${ }^{29} \mathrm{Vgl}$. hierzu auch W. Potthoff: Dante in RuBland, a.a.O.. S. 390. 405. 
ansatzweise) vorwegnahmen, rückten diese Veranstaltungen ins Zentrum des geistigen und kulturellen Lebens RuBlands ${ }^{30}$.

Bedeutendste Publikationsorgane des russischen Symbolismus waren in der frühen Phase die Zeitschriften "Северный вестник" ("Der nördliche Bote", 1882-1898). "Мир искусства" ("Die Welt der Kunst", 1899-1904) und "Новый путь" ("Der neue Weg", 1903-1904); zum führenden Publikationsorgan der Blütezeit des russischen Symbolismus wurde die Zeitschrift "Весы" ("Die Waage", 1904-1909), daneben "Золотое руно" ("Das Goldene Vlies", 1906-1909); vom Ende des Symbolismus zeugen schlieBlich die Zeitschriften "Труды и дни" ("Werke und Tage", 1912-1916) und "Aполлон" ("Apollo", 1909-1917); letztere wurde später zum Sprachrohr der Akmeisten ${ }^{31}$. In diesen Zeitschriften wurden, ebenso wie in den erwähnten Zirkeln und Salons, die innersymbolistischen Polemiken diskutiert und ausgetragen, etwa der "Kampf" der Moskauer gegen die Petersburger Symbolisten um den "mystischen Anarchismus" (1906-1907) 32 und die große Symbolismusdebatte, die 1910 heftig entbrannte.

Diese letztgenannte große Kontroverse kam nicht unvorbereitet. Bereits 1904 hatte Belyj in seinem Aufsatz "Символизм как миропонимание" ("Symbolismus als Weltanschauung") ${ }^{33}$ ausgeführ, daB Symbolismus nicht nur eine rein literarische Strömung, sondem Weltanschauung, Lebensauffassung sei. 1908 publizierte Vjač. Ivanov die ausgearbeitete Fassung seines Vortrags "Две стихии в современном символизме" ("Zwei Elemente im zeitgenössischen Symbolismus") ${ }^{34}$, worin er zwei grundsätzlich verschiedene Richtungen innerhalb des Symbolismus unterscheidet: den "realistischen" ("реалистический") und den "idealistischen" ("идеалистический") Symbolismus. Während der "idealistische" Symbolismus das Künstliche (im Sinne von rein ästhetisch) gegenüber dem Natürlichen bevorzugt, nach Exotik strebt und die formale Meisterschaft und symbolistische Ästhetik überbewertet, verkörpert der "realistische" (oder auch "religiöse") Symbolismus das wahre Wesen symbolistischer Kunst. das das Ästhetische zugleich auf das Menschliche verpflichtet und in der Formel "a realibus ad realiora" beschlossen liegt. GemäB der Theorie vom "realistischen" Symbolismus weist das Symbol nicht nur auf das wahre transzendente Wesen der Dinge hin. sondem enthält dieses, ohne daß es zunächst erkannt wird. Das Symbol ist vieldeutig und beinhaltet den Mythos:

Символ только тогда истинный символ. когда он ненсчерпаем и беспределен в своем значении. когда он изрекает на своем сокровенном (иератическом н магическом) языхе намека и внушения нечто неизлаголемое. неалэкватное внешнему слову. Он многоли. мюоосмыслен и всегда темен в последней глубине. Он - органическое образование. как кристалл. Он даже некая монада. - и тем отличается от сложного и разложимого состава аллегорнн. прнтчи или сравнекия. Аллегория - учение; символ - ознаменование. Аллегория - иносказание: символ - указанне. Аллегория логически ограннчена и внутренне неполвижна: символ имеет лушу и внутреннее развитие. он живет и перерожлается. ${ }^{35}$

$30 \mathrm{Vgl}$. hierzu auch J. Scherrer: Die Petersburger religiös-philosophischen Vereinigungen. Berlin 1973.

"1 Der Titel der letzıgenannten Zeitschrift. "Аполлон", ging aus der Diskussion um das Apollinische und das Dionysische in der Kunst hervor und verweist auf das apollinische Prinzip der Klarheit und Genauigkeit. für das die Akmeisten plädierten, die das dionysische Prinzip des Symbolismus. alles Rauschhafte. Ekstatische. Verschwommene und Unbestimmte. ablehnten.

$32 \mathrm{Vgl}$. unten. S. 32f.. Anm. 54.

${ }^{33}$ Erstmals publizient in der Zeitschrift "Mир нскусства" (1904. Nr. 5. S. 173-196: auch abgedruckt in: A. Belyj: Simvolizm kak miroponimanie. Moskva 1994. S. 244-255).

34 In der Zeitschrift "Золотое руно" (1908. Nr. 3-4: auch abgedruckı in: Vjac. Ivanov: Sobranie socinenij. Tom 2. Brjussel" 1974, S. 537-565).

35 Vjač. Ivanov: Poèt i Cem' (1904). In: Ders.: Sobranie soxinenij. Tom 1. Brjussel' 1971, S. 713. 
Реалистический символизм идет путем символа к мифу; миф - уже содержится в символе. он имманентен ему; созерцание символа раскрывает в символе миф. ${ }^{36}$

Im Frühjahr 1910 kam es zum sogenannten "Symbolistenstreit". der dann überwiegend auf den Seiten der Zeitschrift "Аполлон" ausgetragen wurde 37: Vjač. Ivanov38, Blok $^{39}$ und auch Belyj ${ }^{40}$ forderten, daB der symbolistische Dichter zugleich Theurg. Priester und Prophet sein müsse. Symbolismus sei mehr als nur Kunst, als lediglich eine literarische Schule. Symbolismus sei Weltanschauung oder müsse zur Weltanschauung werden. Kunst müsse ins Leben überführt werden. Die Kunst bzw. Literatur müsse den Menschen der Vergangenheit verwandeln in einen "Gottmenschen" (VI. Solov'ev), einen "Übermenschen" (Nietzsche), oder einen "Künstlermenschen der Zukunft" (R. Wagner), der frei, unabhängig und selbstbewuBt lebe. Brjusov dagegen vertrat die These ${ }^{41}$, daB Dichter vor allem Dichter sein sollten und Symbolismus immer nur Kunst sein wollte und war. Die Kunst sei autonom. Man solle ihr endlich Freiheit geben und sie nicht weltanschaulich vereinnahmen. Für Brjusov ist und bleibt der Symbolismus ein historisches Phänomen. eine literarische Schule:

\begin{abstract}
«Символизм». как жромантизм». - определенное историческое явление. связанное с определенњыми датами и именами. Возникшее. как литературная школа. в конще XIX века. во Франции (не без английского влияния), хсимволистское» движение нашло последователей во всех литературах Евроты, оплодотворило своими илеями друтие искусства. и не могло не отразиться на миросозерцания эпохи. Но все же оно всегда развивалось исключительно в области искусства. [...]

Символизм есть метю) искусства. осознанный в той школе. которая получнла название «символическойж. 42
\end{abstract}

Zu Beginn der zweiten Dekade des 20. Jahrhunderts begannen sich - hervorgehend aus dem Symbolismus - verschiedene, meist recht kurzlebige Bewegungen herauszubilden, die sich überwiegend gegen den Symbolismus gruppierten (z.B. Akmeismus. Futurismus. Imaginismus, Suprematismus, Expressionismus. Biokosmismus.

36 Vjac. Ivanov: Dve stichii v sovremennom simvolizme (1908). In: Ders.: Sobranie soxinenij. Tom 2. a.a.O., S. 554.

Vgl. hierzu auch: F. Stepun: Mystische Weltschau. München 1964. S. 221-232: G. Langer: Kunst Wissenschaft - Utopie. Frankfun/M. 1990. S. 100-106: R.-D. Kluge: Vjaceslav Ivanovs Beitrag zu einer symbolistischen Theorie der Literatur und Kunst als Schlüssel zum Verständnis seiner Aufsätze über Aleksandr Skrjabin. In: W. Potthoff (Hrsg.): Vjaceslav Ivanov. Russischer Dichter - europäischer Kulturphilosoph. Heidelberg 1993, S. 241 If.

Der "idealistische" Symbolismus entspricht in etwa der Konzeption der "älteren" Symbolisten, der "realistische" dem der "jüngeren"

37 Die in der Zeitschrift publizierten Beiträge waren gröbtenteils zuvor als Vorträge gehalten und lebhaft und kontrovers diskutiert worden.

38 In seinem Aufsatz "Заветы символизма" ("Die Vermächtnisse des Symbolismus". Аnоллон. Nr. 8. 1910, S. 5-20).

39 In seinem Beitrag "О современном состояния русского символизма" ("Über die gegenwartige Lage des russischen Symbolismus". Аполлон, Nr. 8, 1910. S. 21-30).

41" In seiner Antwort auf Brjusovs Beitrag ("Венок или венеи" - "Kranz oder Krone/Dichterkranz". Аполлон, Nr. 11, 1910, im Chronik-Teil (Хроника) S. 1-4).

41 In seinem Aufsatz. "O «речи рабской". в зашиту поэзия" ("Über die «sklavische Sprache», zur Verteidigung der Dichtkunst", Аполлон. Nr. 9, 1910, S. 31-34).

42 Ebd.. S. $32 f$.

Zum "Symbolistenstreit" vgl. auch R.-D. Kluge: Westeuropa und RuBland..., a.a.O., S. 74-77: Ders.: Der russische Symbolismus, a.a.O.. S. 53-55: W. Potthoff: Dante in RuBland, a.a.O.. S. 21 f.: R. Peterson: A History of Russian Symbolism. a.a.O.. S. 150-152: A. Pyman: A History of Russian Symbolism., a.a.O.. S. 331-336. 
Emotionalismus, Konstruktivismus, die Gruppe "Obériu") ${ }^{43}$. Der Symbolismus als relativ geschlossene Richtung oder Schule in der russischen Literatur war ungefähr zwischen 1912 und 1914 beendet, trat nicht mehr in Form von Manifesten und theoretischen Abhandlungen hervor oder polemisierte gegen andere literarische Gruppierungen. In einzelnen Vertretem lebte er jedoch weiter als überzeitliches oder zeitloses Kunstprinzip, so z.B. bei Vjač. Ivanov, Blok und Belyj und es ist schwer zu bestimmen, auf welches Jahr sein Ende fältt. Belyj bezeichnet sich selbst noch Ende der zwanziger Jahre als Symbolisten ${ }^{44}$.

Die literarhistorischen Forschungspositionen zum (russischen) Symbolismus sind polarisien, wobei beide Positionen ihre Berechtigung haben. Es lassen sich nämlich zwei Argumentationsmuster unterscheiden je nachdem. worauf der Schwerpunkt gelegt wird. Einerseits können die im Symbolismus gewiß noch vorhandenen traditionellen Züge und Verfahrensweisen in den Mittelpunkt der Betrachtung gestellt werden und folglich diese Stilformation als SchluBphase der aristotelisch-mimetischen Ästhetik und Poetik gesehen werden; andererseits kann man den Symbolismus vor allem nach seinen wichtigen und wesentlichen Neuerungen befragen und folglich als progressive Tendenz in der Kunst und Literatur betrachten.

Venreter der ersten, traditionellen Position thematisieren für den russischen Kontext vor allem eine Kontinuität zwischen Romantik und Symbolismus und erkennen im Symbolismus als Stilerscheinung den Höhepunkt und AbschluB der aristotelischen oder mimetischen Kunst- und Literaturperiode ${ }^{45}$. Es handle sich hier um eine Vervollkommnung und Raffinierung der traditionellen künstlerischen Verfahren, um diffizile Sensibilisienung des literarischen Ausdrucks, um ein l'art pour l'art, eine elitäre, hermetische, gesellschaftsferne Kunst des Selbstzwecks. Gesellschaftliche und lebens-

43 Vgl. R.-D. Kluge: Der russische Symbolismus, a.a.O.. S. 85-87.

$44 \mathrm{Vgl}$. A. Belyj: Poxemu ja stal simvolistom i pocemu ja ne perestal im byt' vo vsech fazach moego idejnogo i chudozestvennogo razvitija, 1928 geschrieben als "Tagebuch bzw. Autobiographie ... für mich selbst und für einige Freunde" (A. Belyj: Ich, ein Symbolist. Eine Selbstbiographie. Frankfurt/M 1987. S 13).

45 Eine deran pauschale Einbeziehung der Romantik in die aristotelisch-mimetische Ästhetik und Poetik mag auf einzelne Romantiker zutreffen, ist insgesamt jedoch schon fraglich und bedenklich. Umso mehr trifft das auf den Symbolismus zu. Die Offenheit des Symbols ist bereits bei Kant angelegt und findet sich in Goethes Symbolbegriff wieder, auf den sich die russischen Symbolisten berufen: "Die Symbolik verwandelt die Erscheinung in Idee, die ldee in ein Bild, und so. dab die Idee im Bild immer unendlich wirksam und unerreichbar bleibt und, selbst in allen Sprachen ausgesprochen. doch unaussprechlich bliebe." (J.W. Goethe: Maximen und Reflexionen. Frankfur/M. 1980. S. 192.) Vgl. zu die sem Problem H. Friedrich (Die Struktur der modernen Lyrik. Von der Mitte des 19. bis zur Mitte des 20. Jahrhunderts. Erweiterte Neuausgabe. Reinbek 1992), der darauf verweist, daB wichtige Charakteristika modemen Dichtens bereits in der Romantik zu finden sind. $\mathrm{Vgl}$. hierzu ebenfalls: M.H. Abrams: The Mirror and the Lamp. New York 1953: Mario Praz: Liebe. Tod und Teufel. Die schwarze Romantik. München 1963.

Die Verfasserin ist sich bewuBt, daB sie hier ein ungeklärtes, kontroverses Gebiet der Romantikforschung berühn. Es würde jedoch den Rahmen der vorliegenden Studie über Ėllis' Leben und Werk sprengen, wenn hier ein Exkurs über die problematische Romantikdiskussion eingefuigt würde (wie sie etwa im 2. Band von "Poetik und Hermeneutik". 1966, erfolgt oder in der Abeit von W. Preisendanz: Zur Poetik der deutschen Romantik 1: Die Abkehr vom Grundsatz der Naturnachahmung (in: Die deutsche Romantik. Poetik. Formen und Motive. Hrsg. v. H. Steffen. Göttingen ${ }^{2} 1970$, S. 54-74] sowie auch im 1994 in Stuttgant (Kröner-Verlag) erschienenen "Romantik-Handbuch). Auch kann diese Diskussion nicht einfach auf russische Verhältnisse übertragen werden. zumal es in der russischen Romantik keine Theoriediskussion gegeben hat. die sich mit derjenigen in der westeuropäischen und vor allem in der deutschen Romantik vergleichen ließe. Die russische Romantik gründet doch insgesamt eher auf einem geschlossenen, ganzheitlichen Weltbild, was ihre pauschale Einbeziehung in die aristotelisch-mimetische Ästhetik und Poetik in diesem Einieitungskapitel rechtfertigt. 
wirkliche Themen würden abgelehnt zugunsten einer irrationalistischen. philosophischen und religiös-mystischen Stimmungsgestaltung. Die realitätsferne, esoterische und ganz traditionelle Poetik des russischen Symbolismus zeichne sich durch Melodiosität. Musikalität und weitere raffinierte künstlerische Verfahren aus; die Korre spondenzen der Dinge näherten den symbolistischen Text der Musik. Das Symbol als zentrales künstlerisches Verfahren im Symbolismus sei ein sinnliches Scheinen innerer geistiger Vollkommenheit und Totalität ${ }^{46}$.

Als repräsentativ für diese Symbolismusposition können die folgenden Definitionen von Wellek (für den Symbolismus allgemein) sowie von Potthoff und Terras (für den russischen Symbolismus) angeführt werden:

Der Begriff [Symbolismus] eignet sich meiner Ansicht nach gut als allgemeine Bezeichnung für die Literatur aller westlichen Länder, die auf den Niedergang des Realismus und Naturalismus im neunzehnten Jahrhundert folgte und dem Aufstieg der neuen avantgardistischen Bewegungen vorterging: Futurismus. Expressionismus, Surrealismus. Existenzialismus und was immer sonst noch. ${ }^{49}$

Wellek sieht im Symbolismus eine Kontinuität zur Romantik ${ }^{48}$; zugleich gäbe es aber auch einen Unterschied zwischen Romantik und Symbolismus:

Das MiBtrauen gegen die Inspiration, die Feindschaft gegen die Natur sind die entscheidenden Punkte, die den Symbolismus von der Romantik trennen. ${ }^{49}$

Potthoff bestimmt den russischen Symbolismus folgendermaßen:

Die Entwicklung des russischen Symbolismus zeigt früh eine inn charakterisierende subtile Mi schung von Elementen europäischen KrisenbewuBtseins des Fin de Siecle, eines russischen Kulturstreits. neuer Mythenbildung. eines verbreiteten Panästhetizismus, neuidealistischer Konzeptionen. ${ }^{50}$

Im Symbolismus lassen sich ähnliche Motive feststellen, wie sie aus Romantik. Spätromantik und Skeptizismus bekannt sind. |... Innerliterarisch zeigt sich eine Wiederaufnahme idealistischer Ansätze in der Auscinandersetzung mit den Brudem Schlegel und Schelling $\$ !$.

Bei Terras heißt es:

Symbolism [... | The Russian movement was. like the French, a resurgence of idealism and aestheticism. Realism and positivism had enjoyed a long period of dominance in Russia before symbolism arose as a neo-romantic reaction. ${ }_{2}$

In seiner "History of Russian Literature" zeigt Terras zahlreiche Parallelen zwischen Romantik und Symbolismus auf:

In many ways symbolism repeated the development of romanticism. In a reaction to the apparent failure of the preceding age to satisfy the spiritual needs of the educated classes, it returned to an

4h $\mathrm{Vgl}$. hierzu auch die Ausführungen von R.-D. Kluge in der Vorlesung "Symbolismus und Avantgarde in der russischen Literatur" (Universität Tübingen. WS 1992/93).

Diese Auffassung des Symbolismus vertreten z.B. A. Stender-Petersen und A. Flaker. Sie findet sich auch in neueren Darstellungen dieser Stilformation, beispielsweise in W. Düwel, H. Grasshoff (Hrsg.): Geschichte der russischen Literatur. Band 2, a.a.O., S. 464-467: Victor Terras: A History of Russian Literature, a.a.O., S. 391-405.

47 R. Wellek: Das Wort und der Begriff "Symbolismus" in der Literaturgeschichte. In: Ders.: Grenzziehungen. Beiträge zur Literaturkritik. Stuttgart, Berlin, Köln. Mainz 1972. S. 64.

48 Ebd., S. 79.

${ }^{49}$ Ebd.. S. 80.

51) W. Pothoff: Dante in RuBland. a.a.O., S. 15.

51 Ebd., S. 24.

52 V. Terras: Handbook of Russian Literature. New Haven - London 1985, S. 460. 
idealist worldview, renewing the search for absolute values and for a religious sensibility. Then. having driven such idealism to an extreme, some symbolists. like some romantics, would negate in through some form of romantic irony or veer into mysticism. escapism, or unchecked fantasy. The political experience of some Russian symbolists also paralleled that of the romantics: they started as near revolutionaries and eventually found themselves in the ranks of conservative opponents of the Soviet regime. 53

In seinen weiteren Ausführungen weist Terras auf zahlreiche romantische Themen innerhalb des Symbolismus hin, nennt Brjusovs Kunsttheorie eklektisch ${ }^{54}$, Belyjs ästhe tische Positionen seien "rediscoveries of familiar romantic clichés" gewesen 55 und miBt der Stilformation des Symbolismus insgesamt kaum eigenständige Bedeutung bei.

Dieser traditionellen Symbolismusforschung läßt sich eine Neubewertung des russischen Symbolismus in der Forschung der letzten Jahre gegenüberstellen, die diese Stilformation vor allem nach ihren Innovationen befragt und deutlich von einer auf Harmonie und Religiosität festgelegten Romantik sowie der gesamten aristotelischen oder mimetischen Kunst- und Literaturauffassung abgrenzt. Kunst und Literatur im Symbolismus vermitteln dem Leser bzw. Rezipienten nicht harmonische Befriedigung, "interesseloses Wohlgefallen" (Kant) im nachvollziehenden GenuB ${ }^{56}$, sondern stellen ganz andere Forderungen an ihn. Die Wirklichkeit als Stoffvorlage wird aufgegeben; Dissonanz. das HäBliche, Unschöne, Primitive und die Destruktion der tradierten Gesetze finden Eingang in die Kunst ${ }^{57}$. Der Versuch eines neuen kreativen Sehens führt allmählich zur Preisgabe der Gegenständlichkeit und schlieBlich zum Wagnis einer ungegenständlichen Kunst. So verstanden stellt der Symbolismus bereits den Anfang der "historischen Avantgarde" dar und einen Bruch mit der mimetischen oder aristotelischen Kunsttradition.

Diese Auffassung widerspricht zugleich der Meinung anerkannter Avantgardeforscher (zum Beispiel Peter Bürger, Aleksandar Flaker und Igor' Smirnov), für die in Übereinstimmung mit der traditionellen Symbolismusauffassung - der Symbolismus als Impressionismus oder Ästhetizismus das Ende der aristotelischen (oder mimetischen) Periode der europäischen Literaturen und antiken Kunst markien. wovon sich die gegenstandslose, freie und experimentelle Kunst der Avantgarde fundamental unterscheide. Die genannten Forscher übersehen, daB die entscheidenden Neuerungen und künstlerischen Verfahren der historischen Avantgarde bereits im Symbolismus angelegt sind, die "Avantgarde übernimmt und radikalisiert symbolistische künstlerische Verfahren, versucht diese in gesellschaftliche und politische Praxis zu überführen [...]"58. Die Verbindung zwischen Symbolismus und Avantgarde läBt sich nicht so radikal leugnen, wie dies zum Beispiel die Futuristen in ihrem Manifest "Пощечина общественному вкусу" ("Eine Ohrfeige dem öffentlichen Geschmack". 1912) tun. Darauf weist etwa Osip Mandel'štam in seinem Aufsatzband "O

53 V. Terras: A History of Russian Literature, a.a.O., S. 391.

$\$ 4$ Ebd., S. 399

.55 Ebd.. S. 401.

$56 \mathrm{Vgl}$. R.-D. Kluge: Symbolismus und Avantgarde in der russischen Literatur. In: Obdobje simbolizma v slovenskom jeziku, književnosti in kulturi. Prvi del. Ljubljana 1983. S. 234.

$57 \mathrm{Vgl}$. hierzu auch Hugo Friedrich: Die Struktur der modemen Lyrik. a.a.O.

58 R.-D. Kluge: Symbolismus und Avantgarde in der russischen Literatur, a.a.O.. S. 237: weitere Ausführungen zu diesem Thema: R.-D. Kluge: Simvolizm i avangard v russkoj literature - perelom ili preemstvennost'? In: Litteraria humanitas Il. Genologické studie. Brno 1993, S. 151-160, hier be sonders S. 151. 157: eine ergänzte und erweiterte Fassung dieser Arbeit mit demselben Titel ist publizient in: Literatumyj avangard. Osobennosti razvitija. Moskva 1993, S. 53-69: M. Deppermann: Niezsche in RuBland, a.a.O., S. $228 f$. 
поэзии" ("Über die Dichtkunst") hin: "Но вся современная русская поэзия вышла из родового символического лона. У читателя короткая память - он этого не хочет знать. $" 59$

Vor allem die kulturkritische Philosophie Nietzsches mit seinem Appell zur Umwertung aller tradienten Werte war für viele russischen Symbolisten maßgeblich. Nietzsche versteht Mimesis als Abhängigkeit von der Realität, ja sogar als Unterwerfung unter die realen Verhältnisse. Menschliches Denken und Handeln müsse sich von dem falschen Glauben befreien, daß es eine überirdische Macht, einen Gott gebe, dem man durch die Kunst diene und der sich im vollendeten Kunstwerk zeige oder offenbare. Alle tradierten Werte seien abzuschaffen und radikal umzubewerten. Nur der Mensch allein sei Ursache, Kraft. Sinn und Ziel seines Lebens. Er sei auf keine äußerliche Wirklichkeit angewiesen, von keinen transzendenten Kräften abhängig. Er müsse seinen Blick von Gott und dem Tod abwenden und ganz auf sich selbst, auf sein Leben richten. In der Kunst dürfe kein fremdes Nachahmen, Abbilden, Veredeln der Wirklichkeit stattfinden, sondem es müsse kühn und phantasievoll in spielerischer, schöpferischer Lust etwas ganz Neues geschaffen werden. und sei es auch noch so verrückt, unverständlich, unbekannt oder unbegreifbar. Das schöpferische, kreative Vermögen sei absolut frei, entstehe aus der hemmungslosen Hingabe an das Leben, an die Sinnlichkeit, an Rausch und Orgiasmus als kreatürlicher vitaler Seinserfahrung ${ }^{60}$.

Aus Nietzsches Denken ergibt sich, daB Kunst bzw. Literatur in jeder Beziehung frei ist und das Unbekannte. Unverständliche wagen, auf das Überraschende, Einmalige und Spontane setzen soll. Genau das taten die ersten russischen Symbolisten in ihren Werken und schufen etwas radikal Neues. Brjusovs Bändchen "Русские символисты" hatten seinerzeit mindestens eine ebenso große Schock- und Provokationswirkung wie später die gelben Jacken der Futuristen!

Zwei fundamentale Neuerungen im Symbolismus müssen hervorgehoben werden und grenzen ihn von der traditionellen Kunstauffassung ab:

Das Symbol als zentrales künstlerisches Verfahren im Symbolismus steht - im Gegensatz zum traditionell verstandenen romantischen Symbol - nicht mehr für bestimmte, sonst unzugängliche, transzendente Vorgänge und Wesenheiten, sondern ist ein offenes, unvollständiges Gebilde, ein Signal, das im Leser bzw. Rezipienten bestimmte Vorstellungen, Anschauungen und Assoziationen hervorruft, Leseanweisungen erteilt. Es ist nicht abgeschlossen, sondern kreativ, hat ProzeBcharakter und ereignet sich in einer Interaktion von Textanweisung und Rezeptionsvorgang ${ }^{61}$.

Ein symbolistischer Text ist fragmentarisch, unvollständig und funktionient anders als ein traditioneller, vollendeter, harmonisch gestalteter literarischer Text. Der Leser eines solchen symbolistischen Textes wird aufgerufen zur Mitarbeit und Mitgestaltung am Text. wird in den kreativen SchaffensprozeB involviert. Das offene, prozessuale symbolistische Kunstwerk braucht den Leser und funktioniert erst im Wechselspiel $z$ wischen Autor, Text und Rezipienten. Der Leser eines symbolistischen Textes muB bereit sein, auf Signale zu reagieren, sich Stimmungen und Empfindungen suggerie ren zu lassen, sich das assoziative Reich der Kunst "aufschlieBen"62 und die intellektuelle Anstrengung der Mitarbeit am Text leisten. Andrej Belyj spricht in diesem

59 O. Mandel ऊtam: Sobranie soxinenij v cetyrech tomach. Tom 2. Moskva 1991, S. 230.

61) Vgl. hierzu R.-D. Kluge: Westeuropa und RuBland im Weltbild A. Bloks. a.a.O.. S. 84-104: Ders.: Zur Theorie des russischen Symbolismus - A. Blok und F. Nietzsche, a.a.O.. S. 79-88; Ders.: Simvolizm i avangard... In: Literaturnyj avangard. a.a.O.. S. $55 \mathrm{f}$.

$61 \mathrm{Vgl}$. hierzu auch die zitierte Symboldefinition von Vjac. Ivanov. S. 17 der vorliegenden Arbeit.

$62 \mathrm{Vgl}$. V. Brjusovs programmatischen Aufsatz "Ключи тайн" ("Schlüssel der Geheimnisse". publiziert in der ersten Nummer der Zeitschrift "Becы" |1904|: ebenfalls in: V. Brjusov: Sobranie soxinenij v 7-i tt. Tom 6, a.a.O., S. 78-93). 
Zusammenhang von "преображение личности" ("Verwandlung der Persönlichkeit"), A. Blok (in Anlehnung an R. Wagner) vom "человек-артист будущего" ("Künstlermenschen der Zukunft")63.

In diesem Zusammenhang ist vor allem Brjusovs Forderung der bedingungslosen Freiheit für Kunst bzw. Literatur wichtig. Der symbolistische Dichter teilt sich selbst unbeschränkte schöpferische Vollmacht oder Allmacht $\mathrm{zu}^{64}$. Brjusov und andere symbolistische Dichter schufen formvollendete Gedichte mit einem Inhalt, der sich dem Verstehen entzieht. Die Harmonie von Form und Inhalt wird also in der symbolistischen Lyrik zerstör. In der Dissonanz, im Widersprüchlichen liegt ihr kreativer Reiz $^{65}$. Besonders für frühsymbolistische Texte (Bal'mont, Brjusov) ist das Unklare, Verschwommene, Vage kennzeichnend, ein irrealer Schwebezustand, der sich als Ahnung oder Andeutung ereignet, geheime Korrespondenzen der Dinge erregt und in eine unbestimmte Zukunft verweist. Später nahmen jedoch vor allem Merežkovskij und Ivanov die totale schöpferische Freiheit des symbolistischen Ansatzes wieder zurück. Kunst wird bei ihnen, ähnlich wie in der harmonisch verstandenen Romantik. zur Transmission des Übersinnlichen, zur Mystik und zur Offenbarung. Im Selbstverständnis des russischen Symbolismus kommt es zu einer Identifizierung von symbolistisch und symbolisch, wenn Dichten, in Anlehnung an A.W. Schlegel, als "ewiges Symbolisieren" aufgefaBt wird66.

In ihren formvollendeten Gedichten sind die russischen Symbolisten einerseits wohl die größten und perfektesten Meister des poetischen Handwerks; andererseits beginnt jedoch gerade im Symbolismus die Zersetzung bzw. Destruktion des syllabotonischen Verssystems, und es findet ein allmählicher Übergang (über den "Dol'nik") zum akzentuierenden System statt, das von den Avantgardisten aufgegriffen. radikalisiert und vollendet wird. Beispiele hierfür bieten frühe Gedichte Belyjs (z.B. in seinem Lyrikband "Золото в лазури" - "Gold im Azur", 190467, auch einige frühe, später umgearbeitete Gedichte, etwa "Поэт [Бальмонту]" - "Der Dichter [an Bal'mont]" oder "Тело" - "Der Körper", beide 1903/1929) und Bloks (zum Beispiel der Zyklus "Снежная маска" - "Die Schneemaske", 1907), die Majakovskijs Technik des akzentuierenden Verses mit Reimassonanzen vorausnehmen. Entsprechend werden Belyj und Blok von den Avantgardeforschem (neben I. Annenskij) als Vorläufer der russischen Avantgarde bezeichnet. ${ }^{68}$

$63 \mathrm{Vgl}$. M. Deppermann: A. Belyjs ästhetische Theorie des schöpferischen BewuBtseins. Symbolisierung und Krise der Kultur um die Jahrhundertwende. München 1982. Zu den Ausführungen über das Innovatorische im Symbolismus vgl. die Arbeiten von R.-D. Kluge ("Der russische Symbolismus". "Wie funktionient ein symbolistisches Gedicht?", "Zur Theorie des russischen Symbolismus". "Symbolismus und Avantgarde in der russi schen Literatur". "Simvolizm i avangard v russkoj literature - perelom ili preemstvennost'?" sowie die Vorlesung "Symbolismus und Avantgarde in der russischen Literatur", Universität Tübingen. WS 1992/93).

$64 \mathrm{Vgl}$. Brjusovs Aufsatz "Свяиенная жертва" ("Das heilige Opfer", in: Becы. Nr. 1, 1905: auch abgedruckt in: V. Brjusov: Sobranie soxinenij v 7-i tt. Tom 6, a.a.O., S. 94-99).

$65 \mathrm{Vgl}$. hierzu auch H. Friedrich: Die Struktur der modernen Lyrik, a.a.O., hier besonders S. 15-19.

$66 \mathrm{Vgl}$. W. Potthoff: Zum Begriff des "überzeitlichen Symbolismus". In: Obdobje simbolizma v slovenskem jeziku, knjižzennosti in kulturi. Dnugi del. Ljubljana 1983, S. 185-196, hier bes. S. 190.

67 Vgl. hierzu auch A. Lavrov: Andrej Belyj v 1900-e gody. Moskva 1995, S. 154.

68 Z.B. von A. Flaker: Die slavischen Literaturen zur Zeit des Modernismus. Das Auftreten der Avantgarde und des Expressionismus. In: Neues Handbuch der Literaturwissenschaft. Band 19. Wiesbaden 1976, S. 410-412; Ders.: Zur Charakterisienung der russischen Avantgarde als Stilformation. In: K. Barck, D. Schlenstedt, W. Thierse (Hrsg.): Künstlerische Avantgarde. Berlin (O) 1979. S. $61,73 f ., 95 f$. 



\section{DIE RUSSISCHE SCHAFFENSPERIODE - LEBEN UND WERK}

\section{Leben}

\section{A. Biographische Angaben}

Lev L'vovič Kobylinskij-Ëllis wurde am 2. August 1879 als zweiter der drei unehe lichen Söhne des berühmten russischen Pädagogen Lev Ivanovič Polivanov in Moskau geboren. Die Mutter dieser drei Söhne war vermutlich Varvara Petrovna Kobylinskaja!. Über Ėllis' Kindheit ist so gut wie nichts bekannt, nur daB er und seine beiden Brüder Il'ja L'vovič (geb. 1876) und Sergej L'vovič (geb. 1882) in Moskau das 7. Gymnasium besuchten, dort das Abitur ablegten und anschlieBend an der Moskauer Universität studierten: Ëllis an der Juristischen Fakultät (von 1897 bis 1903), Il'ja und Sergej an der Historisch-Philologischen ${ }^{2}$. Ellis' Studium wurde zweimal unterbrochen: Im März 1899 nahm er an Studentenunruhen teil und wurde deshalb, nach dem 3. Semester, von der Universität verwiesen. Im Juli 1899 wurde er wieder aufgenommen und hörte nochmals die Vorlesungen des 3. Semesters. In diesem Jahr fand eine Annäherung zwischen ihm und Maksimilian Vološin statt; letzterer studierte damals ebenfalls an der Juristischen Fakultät ${ }^{3}$. Anfang April 1900 wurde Ellis emeut relegiert. da er seine Studiengebuihren nicht bezahlt hatte. Ende April 1900 zahlte er und durfte weiterstudieren. Im Sommer 1903 bekam er sein Diplom 1. Grades ausgehändigt.

Während seines Jurastudiums bis etwa $1902 / 03$ befaBte sich Ėllis mit Ökonomie und der Lehre von Marx. Er war Anhänger des "theoretischen Marxismus"4. 1902 beendete er sein eigentliches Studium und begann unter der Betreuung von Professor 1. Ozerov an einer Dissertation über den bedeutenden russischen Finanz- und Wirtschaftsminister Kankrin zu arbeiten. 1903 brach er aber plötzlich seine wissenschaftlichen Studien ab und widmete sich fortan ausschlieBlich Literatur und Dichtung. Er nannte sich selbst einen "Symbolisten" und "ehemaligen Marxisten"5. Besonders beschäftigte er sich nun mit Baudelaire und Dante ${ }^{6}$. Ellis' Jugendansichten sind in seinen Briefen mit dem Titel "Критика радикальной идеи" ("Kritik der radikalen Idee") ${ }^{7}$ an seinen Mitstudenten Vasilij Grejner ${ }^{8}$ enthalten. Sein oberflächlicher Radi-

1 Zur Mutter der drei Brüder Kobylinskij finden sich in den Universitätsunterlagen im PГИA (Russischen historischen Staatsarchiv, Moskau) nur sehr vage, ungenaue Auskünfte, während der Vater dont überhaupt nicht erwähnt wird (PГMA. \$. 418. on. 311, eд.xp. 444, 445 und $\Phi .418$, on. 314. eд.xp. 377). A. Belyj spricht in seinen Memoiren von einer Varvara Petrovna (vgl. A. Belyj: Nacalo veka. Moskva 1990, S. 49f.). Aussagen darüber, daB L.l. Polivanov Ėllis' Vater war, finden sich bei M. Cvetaeva: Plennyj duch, a.a.O.. S. 237, bei A. Cretaeva: Vospominanija. Moskva 1984. S. 258; bei A. Belyj: Na rubeze dvuch stoletij. Moskva 1989, S. 204, 502; bei Petr Zajcev: Moskovskie vstreci (in: V.M. Piskunov (Hrsg.): Vospominanija ob A. Belom. Moskva 1995. S. 369) und bei M. Ljunggren: The Dream of Rebirth. A Study of Andrey Bely's Novel "Peterburg". Stockholm/Sweden 1982, S. 66.

2 Davon zeugen die Universitätsunterlagen im PГИA. Ф. 418. on. 311, eд.xp. 444, 445 und Ф. 418. on. 314. eд.xp. 377.

3 Vgl. den Kommentar von A. Lavrov in A. Belyj: Nacalo veka. a.a.O.. S. 578, sowie: Literaturnoe nasledstvo. Valerij Brjusov i ego korrespondenty. Kniga 2-aja. Moskva 1994, S. 376.

4 Vgl. S.S. Grežłkin, A.V. Lavrov: Ėllis-poet-simvolist, teoretik i kritik, a.a.O., S. 60.

5 Vgl. A. Belyj: Načalo veka, a.a.O., S. 41: "|...] уже с 1903 года он (= Ellis) себя назьпал не

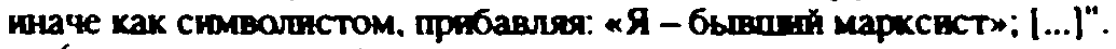

6 Vgl. ebd.. S. 40ff.

7 РГАЛИ (Russisches Staatsarchiv für Literatur und Kunst), Ф. 575. on. 1. ед.শp. 18.

8 Zu Grejner: PГИA. Ф. 418, on. 311, ea.xp. 232. 
kalismus in den Jahren der ersten russischen Revolution kann auf sie zurückgeführt werden 9 .

Ende 1901 oder zu Beginn des Jahres 1902 wurde Ëllis durch Sergej Solov'ev mit Andrej Belyj bekannt ${ }^{10}$. Er wohnte damals zusammen mit seiner Mutter und seinem jüngeren Bruder in einem Zimmer eines Hauses in Tušino am Ufer der Moskva ${ }^{\prime \prime}$. Belyj berichtet in seinen Memoiren 12 von häufigen Streitereien zwischen Ëllis und seinen Angehörigen. Er beschreibt Varvara Petrovna als ebenso leidenschaftlich, mager und blaß wie ihren Sohn. Im Frühjahr 1902 war Belyj oft mit Ėllis zusammen. die beiden enthusiastischen jungen Männer freundeten sich an, bald war Ëllis häufiger Gast im Hause Bugaev. Belyjs Vater, der bekannte Mathematikprofessor Bugaev, schätzte Ėllis unter Belyjs Freunden am meisten ${ }^{13}$.

In der Folgezeit überwarf sich Ėllis vollständig mit seiner Mutter und seinem Bruder und zog (vermutlich Ende 1904 oder 1905) in ein möblientes Zimmer des Gast hauses "Don" (Ecke Arbat/Smolenskij rynok)14.

1902/03 gründete Ėllis zusammen mit Andrej Belyj den Kreis der "Argonauten" 15. In diesem Kreis trafen sich von etwa 1903 bis 1906 junge Moskauer Symbolisten, die bestrebt waren, das geistige Leben umzugestalten, und eine apokalyptische Weltanschauung entwickelten. Ellis, den Belyj als "душою кружка - толкачом-агитатором, пропагандистом" bezeichnet ${ }^{16}$, verstand den griechischen Mythos von der Suche der Hellenen nach dem Goldenen Vlies als Symbol für die Suche nach einer geistigen Emeuenung RuBlands ${ }^{17}$. Belyj formuliert das Anliegen der "Argonauten" in einem Brief an Ėmilij K. Metner ${ }^{18}$ folgendermaßen:

[...] цель экзотерическая - изучение литературы, посвящ<енной> Шопенгауеру и Ницие. а также их самых; цель эзотернческая - путешествне сквозь Нишие в належле отыскать золотое руно [...] Эмилий Карловкч - чувствуете Вы, что звучнт в этом сочетаний слов. пронзнесенном в XX столетия русскимн студентами - аргонавты скеозь Ницие за золотькм румом!! [...] аля лрутих зто упльпание за черту горнзонта.

${ }^{9}$ Vgl. S.S. Grecißkin. A.V. Lavrov: Éllis - poet-simvolist, teoretik i kritik. a.a.O., S. 60.

I1"I.aut A. Lavrov lernten Eillis und Belyj sich im November 1901 kennen: eine Annäherung zwischen ihnen fand im Frühjahr 1902 statt. (Vgl. hierzu: A.V. Lavrov: Andrej Belyj. Chronologiceskaja kanva żizni i tvořestva. In: A. Belyj. Problemy tvorcestva. Moskva 1988. S. 776.)

$11 \mathrm{Vgl}$. S.I. Taneev: Dnevniki v trech knigach 1894-1909. Kniga 3. Moskva 1985. S. 183.

12 A. Belyj: Nacalo veka, a.a.O.. S. 40ff.

$13 \mathrm{Vgl}$. A. Belyj: Na rubeże dvuch stoletij. a.a.O., S. 60. Zu Belyjs Vater vgl. A. Lavrov: A. Belyj v 1900-e gody, a.a.O.. S. 22.

14 Vgl. A. Belyj: Nacalo veka. a.a.O., S. 55: M. Cvetaeva: Plennyj duch, a.a.O.. S. 237; A. Cretaeva: Vospominanija. a.a.O., S. 258.

is Laut A. Lavrov (A. Belyj. Chronologıceskaja kanva zizni i tvorcestva, a.a.O.. S. 778) fand die eigentliche Gründung dieses Kreises erst im Oktober 1903 statt.

Die "Argonauten" sind in der griechischen Mythologie die Helden, die unter Jasons Führung auf dem Schiff Argo nach Kolchis am Schwarzen Meer fuhren, um das Goldene Vlies nach Griechenland zu holen. Dieses Bild der Argonauten, die auf dem Schiff Argo nach dem Goldenen Vlies suchten, hatte symbolische Bedeutung für die geistigen Bestrebungen der "jüngeren" Symbolisten. Das Goldene Vlies. "Золотое руно", war zugleich der Name der erwähnten, aufwendig gestalteten symbolistischen Zeitschrift (1906-1909) und eines Verlags in St. Petersburg. Zum "Argonautenkreis" vgl. A.V. Lavrov: Mifotvortestvo "Argonavtov". In: Mif - Fol'klor-Literatura. Leningrad 1978, S. 137-170: Ders.: A. Bely and the Argonauts' Mythmaking. In: I. Papemo. J.D. Grossman (Hrsg.): Creating Life. Stanford. Calif. 1994. S. 83-121 sowie Ders.: A. Belyj v 1900-e gody, a.a.O.. S. 103-148.

I6 A. Belyj: Vospominanija o A.A. Bloke. München 1969, S. 64.

17 Vgl. W. Kasack: Lexikon der nussischen Literatur des 20. Jahrhunderts. a.a.O., S. 294: A.V. Lavrov: Mifotvor'estvo "Argonavtov", a.a.O., S. 140.

I8 Zu E.K. Metner vgl. M. Ljunggren: The Russian Mephisto. A Study of the Life and Work of Emilii Mediner. Stockholm 1994. 
которое я хочу предпрннять. будет казаться гибелью. но пусть знают и то. что в то время когда парус утонет за горнзонтом для взора береговьх жителей. он все еще продолжает бороться с волнами. пльвя ... $\mathrm{k}$ неведомому богу ... ${ }^{19}$

Diese metaphernreiche Sprache Belyjs und die von ihm verwendeten Bilder sind typisch für die sogenannten "jüngeren" Symbolisten, die sich im "Argonautenkreis" zusammenfanden und die Realwelt, den Alltag zu überwinden und zu durchbrechen suchten.

Als wichtige verbindende Motive bei der Bildung der "Argonautengemeinschaft" können gelten: das Wahrnehmen des "Endes des Jahrhunderts" und das Gefühl der "Grenze", hinter der sich "alles Neue" eröffnen werde und die es zu überwinden gelte $^{20}$. Der stilisierte Mittelalterkult der englischen Präraffaeliten beeinfluBte den "Argonautenkreis" maBgeblich21.

"Жизнетворчество", also "Leben erschaffen", wurde als Hauptaufgabe der "Argonauten" proklamiert. Dadurch erwuchs in ihrem Kreis das kollektive Bestreben zur Mythologisierung des alltäglichen Daseins, der menschlichen Beziehungen, des künstlerischen Schaffens ${ }^{22}$. Kunst (дар писать) und Leben (дар жить) waren faktisch gleichwertig23.

Der Alltag bot den "Argonauten", die sich als praktische Symbolisten, als "Theurgen" verstanden, reiches Material für die Schaffung ihrer Mythen. Das Leben stellte sich ihnen dar als Text, der voller Zeichen. Andeutungen und Allegorien ist und ein tiefes Erfassen und Verstehen erforder ${ }^{24}$. Sie hatten ständig Schreckerlebnisse "сначала мистические, потом психические и, наконец, реальные"25. Das heißt. zum Beispiel ein Spaziergang von einem Ende Moskaus zum anderen, der sich entschieden durch nichts AuBergewöhnliches auszeichnete, erhielt einen sakralen Sinn und kündete von mystischen Bedrohungen und Versuchungen ${ }^{26}$. Aleksej Petrovskij erlebte auf einem Abendspaziergang durch Moskau den Mond beispielsweise folgendermaßen:

Более отвратительного животното. чем хакое я вилел на небе в 7 часов вечера 25 aвr[уста]. я ннхогда не внлал [...] Громалная. мутная. как промасленны лист бумаги. зелено-желтая (я изиегаю более точных зиитетов. хоторые вертятся у меня в голове. чтобы ... "гусей не раздразнить") луна поднималась на ужас земнородным. предвещия, по меньшей мере. какую-нибудь из казней египетских. чуму и т.п. [...] Атмосфера. ляпхая. удуш-

19 Brief vom 26. März 1903, PO PTБ (Handschriftenabieilung der Russischen Staatsbibliothek). $\Phi$ 167. карт. 1. eд.xp. 12; zitien nach A.V. Lavrov: Mifotvor¿estvo "Argonavtov", a.a.O., S. 141.

20 Vgl. A.V. Lavrov: Mifotvortestvo "Argonavtov", a.a.O., S. 137.

21 Darauf weist z.B. W. Potthoff: Dante in RuBland, a.a.O.. wiedertholt hin.

Die Fin de siezcle-Stimmung der Präraffaeliten ist deutlich gegen den Positivismus gerichtet: Die Zukunft wird als etwas Unbekanntes. Bedrohliches. Nichtverstehbares aufgefaBt, als ein grobes bevor stehendes Ereignis. Fin de siècle-Stimmung kann - so gesehen - als strukturelle Entsprechung zum mittelalterichen Chiliasmusverstanden werden.

22 Vgl. A.V. Lavrov: Mifotvortestvo "Argonavtov", a.a.O., S.137.

23 Hierfür ist Ėllis mit Sicherheit ein gutes Beispiel, der durch seinen Lebensstil als Symbolist unter seinen Zeitgenossen eine bedeutend größere Rolle spielte, als es sein hinterlassenes literarisches Werk der Nachwelt vermittelnkann.

$24 \mathrm{Vgl}$. A.V. Lavrov: Mifotvortestvo "Argonavtov", a.a.O.. S. 145.

Allerdings haben die "Argonauten" selbst sich nicht derantiger semiotischer Termini bedient. (Diese Terminologie hat A. Lavrov von Z. Minc übernommen. vgl. A. Lavrov: A. Belyj v 1900-e gody, a.a.O.. S. 107. Anm. 117.)

25 So schreibt A. Belyj in der ersten Maihälfte 1904 in einem Brief an E.K. Metner (zitient nach A.V. Lavrov: Mifotvorcestvo "Argonavtov", a.a.O.. S. 146).

26 Das ist besonders stark bei Ėllis und auch bei Belyj ausgeprägt und wird ausfuihrlich in Belyjs Memoiren beschrieben. 
ливая. была насыщена злокачественным туманом и лряннымн испарениями Цветного бульвара. Желто-шарфаннъ й закат довершал картину. Мне нужно было пройти на Сретенку, и я ясно почувствовал. что несдобровать; - и действительно захворал бессоннцей и проч.; $[\ldots]^{27}$

Übergangserscheinungen in der Natur, etwa Sonnenauf- und -untergang, wurden also als Zeichen für globale Veränderungen im Weltschicksal betrachtet. Aber nicht nur in den Naturphänomenen erkannten die Argonauten die Konturen ihres Mythos, sondem auch in den wesentlichen Episoden des Neuen Testaments, vor allem in der Apokalypse ${ }^{28}$.

Der Tod bedeutete für die "Argonauten" nicht etwas Schreckliches, wurde nicht als Ende erlebt, sondern als Vordussetzung für die Auferstehung, als Überschreiten der Horizontlinie zur "Argonauten-Sonne" 29.

Die "Argonauten" suchten nach Formen der Überwindung des Alltags. Eine Möglichkeit des Durchbrechens der Realwelt waren beispielsweise Harlekinaden. Das erklän viele Narreteien, Possen, Eskapaden und sonstige Absonderlichkeiten der Moskauer Symbolisten, an denen Ellis und auch Belyj regen Anteil hatten ${ }^{30}$.

Bloks frühe Lyrik wurde von den "Argonauten" tief verehrt, und er selbst stand ihnen anfangs recht nahe. Belyjs Frühwerk, seine "Sinfonien" 31 und theoretischen Schriften, sind Produkt der "Argonautenphase" 32.

Die "Argonautentreffen" fanden ab April 1903 sonntags bei Belyj in dessen Wohnung statt, und es ging dort meist recht turbulent und lebhaft $\mathrm{zu}$, wozu die Brüder Kobylinskij (Ëllis und Sergej) mit ihren hitzigen Gemütem und ihrem aufbrausenden Temperament nicht unmaBgeblich beitrugen ${ }^{33}$. Neben Belyj und den Brüdem Kobylinskij nahmen an den "Argonautentreffen" Sergej Solov'ev, Michail Ertel', Pavel Batjuškov, Vasilij Vladimirov, Nina Petrovskaja, Vladimir Nilender, Konstantin Bal'mont, Valerij Brjusov, Jurgis Baltrušajtis, Maksimilian Vološin, Sergej I. Taneev, Nikolaj Metner, Pavel Astrov, Vjačeslav Ivanov (wenn er in Moskau

27 So A.S. Petrovskij am 27.8.1903 in einem Brief an A. Belyj (zitiert nach A.V. Lavrov: Mifotvorčestvo "Argonavtov". a.a.O.. S. 146).

${ }^{28} \mathrm{Vgl}$. A.V. Lavrov: Mifotvořestvo "Argonavtov", a.a.O.. S.147: Ders.: A. Belyj v 1900-e gody. a.a.O.. S. 120.

29 Vgl. A.V. Lavrov: Mifotvortestvo "Argonavtov". a.a.O..S. 162. Die Suche nach dem Goldenen Vlies wird mit dem Streben zur Sonne verglichen. (Siehe hierzu auch A. Belyjs Gedicht "Золотre руно" in: Ders.: Zoloto v lazuri. Moskva 1904. S. 8f.) Die "Argonauten" träumten davon. mit ihrem Sonnenschiff "Argo" zur Sonne zu fliegen (vgl. A.V. Lavrov: Mifotvortestvo "Argonavtov", a.a.O., S. 143ff.). Zum Sonnenmythos der "Argonauten" vgl. auch A. Lavrov: A. Belyj v 1900-e gody, a.a.O., S. 115-118. Ein besonders beliebter Aufenthaltson für die "Argonauten" waren die Gräber auf dem Friedhof des Neujungfrauenklosters (Новодевичий Монастырь) in Moskau (vgl. ebd., S. I36f.).

${ }^{30} \mathrm{Vgl}$. hierzu auch A. Lavrov: A. Belyj v 1900-e gody, a.a.O. S. 137-140.

31 Bei Belyjs "Sinfonien" handelt es sich um lyrisch gestimmte Dichtungen, in denen der Gattungscharakter aufgelöst ist und der Versuch einer Verschmelzung von Dichtung und Musik unternommen wird. Sie bestehen gröBtenteils aus thythmischer Prosa. enthalten aber auch Gedichte. Vgl. hierzu auch A. Kovac: Andrej Belyj: The Symphonies (1899-1908). Frankfur/M. u.a. 1976.

$32 \mathrm{Vgl}$. A.V. Lavrov: Mifotvorcestvo "Argonavtov", a.a.O., S. 151. Belyjs Frühwerk wird ausführlich in A. Lavrovs Monographie "A. Belyj v 1900-e gody" charakterisien und analysien.

${ }^{33} \mathrm{Vgl}$. dazu A. Belyj: Nacalo veka, a.a.O..S. 258ff.

Ellis' Bruder Sergej befaBte sich mit Philosophie, vor allem mit R.H. Lotze. über den er eine Arbeit schrieb (vgl. A. Belyj: Nacalo veka, a.a.O., S. 294), aber 2.B. auch mit Schopenhauer (vgl. seinen Beitrag "UZenie Šopengauera o prekrasnom" in: Svobodnaja sovest' II. Moskva 1906. S. 245-267). Belyj beschreibt ihn als "очень болтливый философ. умекинй заговарнвать собеседника до смерти" (A. Belyj: Vospominanija o Bloke, a.a.O.. S. 104). 
weilte) und viele andere, heute gänzlich vergessene und unbekannte literatur- und kulturbegeisterte Zeitgenossen teil ${ }^{34}$.

Ellis befaBte sich damals intensiv mit Dante, Nietzsche und dem belgischen und französischen Symbolismus, vor allem mit Ch. Baudelaire. Durch seine Übersetzungen aus der neueren französischen und belgischen Literatur (bereits ab 1903 und in verstärktem Maße 1904) wirkte er als Mittler des französischen und belgischen Symbolismus nach RuBland.

Ab 1903 begann er, aktiv am literarischen und kulturellen Leben Moskaus teilzunehmen. Neben dem "Argonautenkreis" organisierte er ab 1904 literarisch-kulturelle Abende, die gewöhnlich mittwochs in der Wohnung Pavel Astrovs stattfanden (die sogenannten "астровские среды") und allmählich die "Argonautentreffen" bei Belyj ablösten 35 . Dort hielt er u.a. zwei Vorträge über Dante 36 . Außerdem war er, wohl auch ab 1904, häufiger Gast bei Sergej Taneev, der den Symbolisten nahestand und oft an ihren Dichterlesungen teilnahm. Taneev veranstaltete in seinem Hause regelmäBig literarisch-musikalische Abende (meist dienstags, die sogenannten "вторники"), an denen Ėllis zusammen mit Belyj, Batjuškov, Ėrtel' und S. Solov'ev häufig teilnahm und dort seine Gedichte und neuesten Gedichtübersetzungen vortrug 37 . An einem dieser Abende schrieb Taneev spontan eine Romanze zu Ėllis' Übersetzung aus L. Stecchetti "Koгда, кружась, осенние листы" ("Wenn, kreisend, die Herbstblätter", publizien im 2. Teil von Ėllis' Werk "Иммортели" ["Die Unsterblichen"]). Die anwesende Sängerin Marija Dejša-Sionickaja beschreibt die Entstehung dieser Romanze in ihren Memoiren:

\begin{abstract}
Это было во вторних 15-го февраля 1905 r. Мы по обыхновению музыцировали. Говорнли. межлу прочим. о разных романсах с удобным и неудобным текстом. Кобылински Эллис сказал. что у него есть хороинй текст для романса и продекламировал нам "Когда. кружась. осеннне листы". Сергею Ивановнчу понравнлись эти стихи. Он нашел их легкимн. звучными н сказал. что на тахие стихн можно быстро напнсать музьку. Мы шутя спроскли. можно ли написать в несколько часов. он нам ответил: "Не часов. а мннут. Хотите, я сделако это сейчас же. не более как в 40-50 мкнут?". Нас это странно зантте ресовало. и мы обеирли сейчас же спеть романс, как только Танеев его напишет. Сергей Иванович ушел в свкн спально и минут через 25-30 прннес нам романс. ${ }^{38}$
\end{abstract}

Einige Jahre später, vom 5.-17. August 1908, schrieb Taneev zehn weitere Romanzen auf Gedichtübersetzungen von Ėllis aus dem Band "Иммортели" (für eine Singstimme mit Klavierbegleitung), die im Januar bzw. Februar 1909 aufgeführt wurden.

Die anfängliche Begeisterung der "Argonauten". die auf eine Umgestaltung der Welt hofften und zunächst freudig an die Verwirklichung ihrer theurgischen Sehnsüchte und Bestrebungen glaubten, wurde jedoch bald durch die unausweichlichen Realia des Alltags enttäuscht ${ }^{39}$. Einen guten Eindruck über die Stimmung, in der sich Ellis zu jener Zeit befand, gibt sein "Tagebuch", das er im Sommer 1905 schrieb. als er mit seiner Mutter und seinem Bruder Sergej in Alupka auf der Krim (in der Nähe

34 Vgl. A. Belyj: Nacalo veka, a.a.O.. S. $293 f$.

35 Vgl. A. Lavrov: A. Belyj v 1900 -e gody, a.a.O.. S. 127.

$36 \mathrm{Vgl}$. A. Belyj: Im Zeichen der Morgenröte. Erinnerungen an A. Blok. Basel, 1974, S. 158: A. Belyj: Nacalo veka. a.a.O.. S. 392-398: A. Lavrov: Mifotvorcestvo "Argonavtov", a.a.O., S. 149f.: Ders.: A. Belyj v 1900 - gody, a.a.O.. S. 127.

37 Vgl. hierzu S.I. Taneev: Dnevniki v trech knigach. 1894-1909. Moskva 1981-1985 und S.I. Taneev: Materialy i dokumenty. Tom 1: Perepiska i vospominanija. Moskva 1952.

38 M. Dejša-Sionickaja: Vospominanija o Sergee Ivanoviðe Taneeve. In: S. Taneev: Materialy i dokumenty, a.a.O..S. 330.

39 Vgl. hierzu auch A. Lavrov: Mifotvortestvo "Argonavtov", a.a.O., S. 154. 
von Jalta) auf einer Datscha lebte ${ }^{40}$. Ellis befand sich in diesem Sommer in einer Krisenstimmung. die wohl - zusätzlich zur Enttäuschung über die Nichtrealisierbarkeit der "Argonauten"-ldeale - vor allem durch eine unglückliche Liebesgeschichte mit einer gewissen "N..." hervorgerufen worden war (bereits seine zweite unglückliche Liebe, wie er schreibt). Auch später wurden seine Hoffnungen auf eine Familie immer wieder enttäuscht; die ideale Frau und Mutter für seine Kinder, die inm vorschwebte, fand er nicht. In seinen Briefen an Marija I. Sizova betont er jedoch, daB er in einigen Frauen das Idealbild einer "geistigen Schwester" und beinahe eines Engels gefunden habe, so z.B. auch in ihr ${ }^{41}$.

Die recht wirr und konfus anmutenden Tagebuchaufzeichnungen lassen Ëllis als einsames, entwurzeltes Individuum erscheinen, das die bestehende gesellschaftliche Ordnung und ihre Vertreter als unerträglich banal ablehnt, ihr gleichzeitig aber keine positiven Ideale entgegenstellen kann und sich krank, verzweifelt, dem Wahnsinn nahe fühlt. Ein exemplarisches Textbeispiel mag genügen, um Ėllis' Stil und die Darstellungsart in seinem "Tagebuch" vorzuführen:

Боже! Дай мне терпения переносить банальность разговоров и не сойти с ума раньше cpoka.

Всспоминания прщшлых бед. ужасов. падений. оскорблений и душевных пыток - мой вамтир. боль ...

Но и в этом есть доля блага. ибо в этом заключается несомненное доказательство иной реальнсти. царства мечты.

Моя болезнь - болезнь вюхоражения. но это лалеко не значит. что это - вображенная болезнь.

Кто. хоть раз. взглянул из өремени в вечность, не вернется назад. он или всё. или ничто. либо побепил хаос. либо потиб навсегла!42

Ėllis empfindet das ganze Jahr 1905 als Qual und beklagt den unwiederbringlichen Verlust seiner Kindheit, die für ihn ein Märchen gewesen sei ${ }^{43}$. Neben Reflexionen über verschiedene Arten der Liebe äußent er in seinem "Tagebuch" vor allem Gedanken über große Gestalten der Weltliteratur (Dante, Shakespeare, Milton, Byron. Wilde, Baudelaire. Maupassant. Flauben u.a.), in deren Werken er, auBer bei Dante. jedoch nur Negation und Pessimismus findet. Die auBere Welt in ihrer Unvollkommenheit kann ihm keine Befriedigung bieten, obwohl er sich verpflichtet fühlt, sie zu lieben: "Я люблю мир, ибо он отблеск вечного. Я не люблю его, ибо он отблеск вечного", heiBt es in seinem "Tagebuch" 44 . Das Durchscheinen des Ewigen befriedigt. enttäuscht jedoch zugleich. weil es nur Abbild. Spiegelung, aber nicht das Ewi-

40 РО РГБ. Ф. 167. карт. 10. ед.xp. 16.

41 РГАЛИ. Ф. 575. on. 1. ед.xp. 20 und 44

Die Beziehung zwischen Marija I. Sizova und Ėllis bzw. die An. wie Ėllis diese stilisierend charakterisien, erinnen stark an das Mythenschaffen der "Argonauten": man denke etwa an den Kult um Bloks Frau Ljubov' Dmitrievna im "Argonautenkreis" (vgl. hierzu auch die bekannte Fotografie von 1904 |z.B. in: A. Belyj: Meżu dvuch revoljucij. Moskva 1990. nach S. 224|: Belyj und S. Solovev sizen an einem Tisch, auf dem eine Bibel liegt und je ein Foto von L.D. Blok und VI. Solov'ev stehen (vgl. auch A. Lavrov: A. Belyj v 1900-e gody, a.a.O.. S. 196|) sowie an Belyjs my stisches Vertültnis zu Margarita K. Morozova. die er als Symbol erkannt zu haben meinte und für seine "Geistesschwester" ("сестра в духе") hielt. Er schrieb ihr Briefe, die er mit "Baw psnaps" ("Ihr Ritter") unterschrieb, ohne dab er die Morozova persönlich kannte oder diese wubte, wer der Autor dieser Briefe war. (Vgl. A. Lavrov: Mifotvortestvo "Argonavtov". a.a.O.. S. 158f., 164ff. sowie Ders.: A. Belyj v 1900-e gody. a.a.O.. S. 66f., 83f., 123f., 133, 141-143.)

42 РО РГБ. Ф. 167. карт. 10. eд.xp. 16. Blatt 20 u. Rückseite.

43 Ell is vertritt hier die romantische Auffassung von der Kindheit als naivem Zustand der Reinheit und Geborgenheit.

${ }^{44}$ Ebd.. Rückseite Blatt 8. 
ge selbst in seiner Wesenhaftigkeit ist ${ }^{45}$. Ėllis' Versuche, hinter die Grenzen des Realen zu gelangen, Eingang in übersinnliche, transzendente Welten zu finden, in denen er eine Überwindung der Banalität des Alltags sucht, schlagen jedoch fehl. Es wird deutlich, daB er sich, wenn auch unbewuBt, nicht von der Methode der positivistischen Beweisführung lösen kann, die sein Jura- und Wirtschaftsstudium geprägt hatte. Das zeigt sich - sowohl in seinen Aufzeichnungen und Briefen als auch in seinen Werken - in seinem Hang zur Kategorisierung und seiner Vorliebe für Schemata. In seinem "Tagebuch" findet sich bereits die wesentliche Formel, die Ellis' ganzes Leben bestimmt und seinen Fanatismus, seine Neigung zu Extremen erklärt: "всё или ничеro" ${ }^{46}$. Vergebens sucht er nach unbestreitbaren Wahrheiten, festen Normen und Werten einer metaphysischen Ewigkeit.

Die innere Zerrissenheit und der Dualismus, die deutlich aus Ėllis' Zeilen sprechen, sind zugleich kennzeichnend für die übersensible Wahmehmungsgabe vieler Symbolisten; somit stellt dieses "Tagebuch" ein wichtiges Zeitzeugnis dar. Bereits hier deutet sich allerdings der Konflikt zwischen den Ansichten des im Grunde starren, festgefahrenen Dogmatikers Ėllis und der Dynamik, Kreativität und Offenheit des Symbolismus an, der fortan Ėllis' Leben und Werk beherrschen wird und ihn konsequenterweise zum Bruch mit dem Symbolismus und allen modemistischen literarischen und geistesgeschichtlichen Strömungen führen muB.

Ab 1906 widmete sich Ėllis verstärkt literarischen Aktivitäten. Neben seinen Übersetzungen begann er, eigene Gedichte sowie Rezensionen und Aufsätze zu schreiben. AuBerdem organisierte er die zwei literarisch-philosophischen Sammelbände "Свободная совесть" ("Freies Gewissen"), die das Produkt der "Argonautentreffen" im Zirkel bei Pavel Astrov sind; allerdings wurden sie kein allzu großer Erfolg und zeugen gewissermaßen vom Ende der "Argonautenphase"47.

1906/1907 kam es zu einer Annäherung zwischen Valerij Brjusov und Ėllis im "(ббщество свобопной зстетики" ("Gesellschaft für freie Ästhetik") 48 , an dem beide aktiv teilnahmen und Vorträge hielten. Ëllis las dort seine neuesten Gedichte vor,

45 Der Terminus "ororeck" ("Abglanz"). der auch bei anderen Symbolisten vorkommt (2.B. bei Be lyj: vgl. A. Lavrov: A. Belyj v 1900-e gody, a.a.O., S. 121) geht auf Vl. Solov'ev zurück. vgl. dessen Gedicht: "Мильй друт, иль ты не вилиш. / Что все видимое нами - / Только отблеск. только тени / Oт не зримого очами? [...]" (in: VI. Solov'ev: Ctenija o Bogocelovecestve. Stati. Stichotvorenija i poema. 12 "Trech razgovorov". Sankt-Peterburg 1994, S. 390): zu diesem Terminus und seiner Bedeutung im russischen Symbolismus vgl. A. Hansen-Löve: Der russische Symbolismus, a.a.O.. S. 253267.

46 PО РГБ. Ф. 167. карт. 10. en.xp. 16. Rückseite Blatt 13.

$47 \mathrm{Vgl}$. hierzu A. Bloks Rezensionen der beiden Sammelbände "Свобопная coвects". abgedruckt in A. Blok: Sobranie soxinenij v vos'mi tomach. Tom 5. Moskva-Leningrad 1962, S.606-611 und 629633. A. Belyj spricht in seinen Memoiren vom "тупейшнй. ничтожнейший сборник «Свободная cosectb" (Nacalo veka, a.a.O.. S. 509).

Die von Ellis geplanten Sammelbande "Argo" (1906) blieben ein unrealisientes Projekt (vgl. hierzu A.V. Lavrov: Mifotvoréestvo "Argonavtov", a.a.O., S. 150 sowie Ders.: A. Belyj v 1900-e gody, a.a.O., S. 127f.).

48 Das "О6щество свободно̆ эстетики" existiene von 1906/1907 bis 1917 (laut A. Lavrov [Brjusov i Éllis. In: Brjusovskie čtenija 1973 goda. Erevan 1976. S. 222] wurde es im Herbst 1906 ge gründet: L.O. Pastemak [Zapisi raznych let. Moskva 1975, S. 226] und der Kommentar in N.K. Metner: Pis'ma (Moskva 1973, S. 99, 118 | nennen 1907 als Gründungsjahr) und veranstaltete Kunstausstellungen. Konzerte. Dichterlesungen und Vorträge über Kunst. Musik und Literatur, an denen neben Ëllis. Brjusov, Belyj, Bal'mont. Vjac. Ivanov, Vološin u.a. auch die den Symbolisten nahestehenden Vertueter der Kunst. Musik und Philosophie teilnahmen (2.B. L.O. Pasternak, der die Anwesenden während der Veranstaltungen skizzierte, N.K. Metner u.a.). 
hielt Vorträge über Baudelaire, den französischen und belgischen Symbolismus ${ }^{49}$. hörte Skrjabin (wohl 1909), der ihn sehr beeindruckte, und nahm eifrig an den Debatten um das Wesen des Symbolismus teil. Unter anderem hielt er dort am 25. Fe bruar 1909 seinen Vortrag "Итоги символизма" ("Bilanz des Symbolismus") ${ }^{50}$ und erlebte im März 1910 die Debatte um Vjač. Ivanovs "Доклад о символизме" ("Vortrag über den Symbolismus") mit, der den sogenannten "Symbolistenstreit" einleitete $^{51}$, wobei er sich zusammen mit Belyj gegen Brjusov wandte und auf die Seite Ivanovs stellte.

Wohl motivien durch die Ereignisse und Folgen der Revolution von 1905, begann sich Ëllis auch sozial zu engagieren ${ }^{52}$ und veranstaltete, teils gemeinsam mit Brjusov, in den folgenden Jahren Kurse für Arbeiter, so z.B. am 19. Mai 1907 zusammen mit Brjusov einen Baudelaire-Abend zugunsten der Arbeitslosen, auf dem heftige Streitgespräche über Sozialismus und Proletariat geführt wurden.

In den Jahren 1907 bis 1909 arbeitete Ellis mit Belyj und Brjusov an der symbolistischen Zeitschrift "Bесы" 53 mit. Er schrieb zahlreiche Rezensionen und Aufsät ze; auch einige seiner Gedichte wurden hier publiziert. 1907-1908 beteiligte er sich als Mitarbeiter der "Becы" aktiv an der Polemik gegen die Petersburger Symbolisten und vor allem gegen den von Georgij Čulkov entwickelten "mystischen Anarchismus"54, verteidigte den (wie er ihn nannte) "klassischen", "reinen" Symbolismus und

49 Aufzeichnungen dazu finden sich im РГАЛИ und im РО РГБ.

50 Abgedruckt in: Becbl. Nr. 7. 1909; entspricht in etwa dem ersten Kapitel von "Русские символисты".

51 Abgedruckt wurde dieser Vortrag Ivanovs in der Zeitschrift "Аполлон" unter dem Titel "Заветы символизма" (vgl. hierzu auch oben, Einleitung der vorliegenden Arteit, S. 18. Anm. 38).

52 Belyj und andere (ehemalige) "Argonauten" hegten ebenfalls revolutionäre Sympathien und wur den aktiv (vgl. auch A. Lavrov: A. Belyj v 1900-e gody, a.a.O.. S. 186f.).

53 "Весы" war eine literarische und kritisch-bibliographische Monatszeitschrift, die von 1904-1909 im Verlag "Skorpion" erschien und als die wohl führende Zeitschrift anfangs der russischen Symbolisten überhaupt und später der Moskauer Symbolisten bezeichnet werden kann. Der verantwortliche Redakteur und Herausgeber dieser Zeitschrift war Sergej A. Poljakov. (Ausführlicher hierzu vgl. unten. das Kapitel "Die Zeitschrift « Becson" der verliegenden Arbeit, S. 71f.)

$\$ 4$ Der "mystische Anarchismus" ("мнстический анархизм") wurde ab 1905 von Georgij Culkov entwickelt und muB als Versuch seiner Bemühungen gelten. den Symbolismus mit politischem Radikalismus in Einklang zu bringen. Er beruft sich vor allem auf Michail Bakunin. Petr Kropotkin und die anarchistischen Bestrebungen in RuBland ab 1905 sowie auf die Bewegung der "SR-y" (= Sozialrevolutionäre), die sich 1900 als politische Gruppierung des Narodnicestvo etabliente und sich letztendlich auf die terronstischen Bewegungen "Наролная воля" ("Volksfreiheit") und "Земля и воля" ("Land und Freiheit") zurückführen läßt. Die "mystischen Anarchisten" standen den Sozialdemokraten nahe und waren bestrebt, die aktuellen sozialpolitischen Probleme der Gegenwan zu lösen. Nach der ersten Russischen Revolution 1905 waren auch innerhalb der Symbolistenkreise Stimmen laut geworden, die sich gegen das Prinzip der "autonomen Kunst". wie es vor allem von Brjusov in der Zeitschrift "Весы" vertreten wurde, richteten. Die Forderungen, sich den aktuellen gesellschafulichen Problemen zu stellen, wurden immer eindringlicher. Die physische. reale Welt und ihre soziale Struktur waren in der vorliegenden Form nicht annehmbar für die "mystischen Anarchisten". Der "mystische Anarchismus" kann in diesem Zusammenhang gemeinsam mit Vjac. Ivanovs "Co6ophoctb"-Bestrebungen (Gemeinsamkeitserfahrung (einer universalen christlichen Glaubensgemeinschafi]) und Bloks Suche nach Wegen zur Volksverbundenheit als Gegenreaktion gegen die individualistischen Elemente im Symbolismus und gegen den Ästhetizismus aufgefaBt werden.

Seine Ideen und Überlegungen publizierte Culkov in seinem Bändchen "О мистическом анархизме" ("Über den mystischen Anarchismus". SPb.. 1906: erste Entwürfe zum "mystischen Anarchismus" hatte er bereits 1905 in der Zeitschrift "Bompосы жизни" |"Fragen des Lebens"). Nr. 5 und 7, publiziert), zu dem Vjac. Ivanov ein Vorwort schrieb: "Идея неприятия мнра и мнстическия анархизм" ("Die Idee der Nichtannehmbarkeit der Welt und der mystische Anarchismus"; vgl. V. Ivanov: Sobranie soxinenij. Tom III. Brjussel' 1979. S. 79-90; ausführlicher Kommentar zu Ivanovs Beziehung zum und den Ideen des "mystischen Anarchismus": ebd.. S. 707-733). Das Organ der "mystischen Anarchisten" 
verehrte Brjusov als allein maBgeblichen Führer dieser Stilformation, indem er seiner symbolistischen Ästhetik und seinem radikalen Individualismus huldigte.

Ellis besuchte auch andere literarische und philosophische Zirkel und Kreise, die den Symbolisten nahestanden, etwa den Salon von Lidija Tamburer, wo er (wohl 1908 oder 1909) Marina und Anastasija Cvetaeva kennenlemte, sowie das sogenannte "Maison du Lied"55.

Seit 1909/1910 stand Ėllis zusammen mit Ėmilij Metner und Belyj an der Spitze des Verlags "Musaget" 56 und nahm don aktiv an verschiedenen Arbeitskreisen teil bzw. leitete diese 57 .

1909 zog er sich von journalistischen Aktivitäten zurück und beschäftigte sich eingehend mit der Entwicklung des westeuropäischen und russischen Symbolismus, woraus sein recht umfassendes Werk "Русские символисты" hervorgegangen ist. 1912 , 1913 und 1914 veröffentlichte er Aufsätze in der Zeitschrift "Труды и дни"58. Еr

waren die drei Almanache "Факелы" ("Die Fackeln"), die Culkov in den Jahren 1906-1908 herausgab. Im Teil "Объявленяя" ("Bekanntmachungen") in der Zeitschrift "Bесы" (Nr. 5, 1906) wird das Anliegen der "mystischen Anarchisten" folgendermaBen formulien: "Мы полагаем смысл исторического процесса в искании человечеством последней свободы. Мы приветствуем социалистическое движение. стремящееся разрушит старый экономический порядок. но социализм не является лля нас единственной целью и последней формой общественности. Свободная мысль и своболное творчество поэтов и художников. мудрецов н пророков - вот свет на пути человечества. Мы боремся за освобождение личности оr цепей моральной. философской и религиозной догматики и не примиряемся с поверхностным миросозерцанием, которое пьтается ограннчить сферу душевных переживаний. Мы поднимаем наш факел во имя утверждения личности и во имя своболного союза людей. основанното на любви к будущему преображенному миру. В этом смысле мы анархисты". (Zitient nach: Vl. Orlov: Puti i sud'by. Literaturnye oxerki. Leningrad 1971. S. 564.)

Der "mystische Anarchismus" Culkovs fand wenig Anhänger und wurde vor allem von den Moskauer Symbolisten heftig kritisient und verspottet. Brjusov, Belyj. Ellis u.a. polemisierten eifrig gegen ihn auf den Seiten von "Becbi" (seit Mai 1906 bis Ende 1908). Die Abwertung, die der "mystische Anarchismus" von seiten seiner Gegner erfuhr, ist jedoch nicht gerechtfertigt, zumal er teilweise Vjac. Ivanovs "Coxopucts"-Konzeption ent spricht.

Zum "mystischen Anarchismus" vgl. auch: V.N. Orlov: Puti i sud'by. Literatumye ocerki. Leningrad 1971. S. 562-572; K.M. Azadovskij. D.E. Maksimov: Brjusov i "Vesy" (k istorii izdanija). In: Literatumoe Nasledstvo. Valerij Brjusov. Moskva 1976. S. 257-324, hier bes. S. 284-286, 320; R.E. Peterson: A History of Russian Symbolism, a.a.O.. S. 97-102: A. Pyman: A History of Russian Symbolism, a.a.O.. S. 278-284; A. Lavrov: A. Belyj v 1900-e gody, a.a.O., S. 218-228.

55 Das "Maison du Lied" ("Дом Песни") wurde 1908 von Pierre d'Alheim (Petr d'Al'gejm) und seiner Frau, der Sängerin M.A. Olenina-d'Al'gejm, in Moskau gegründet mit dem Ziel, klassische und zeitgenössische Kammer-Vokalmusik zu propagieren. Neben Sängern und Musikern traten hier aber auch viele Symbolisten mit Vorträgen und Lesungen auf (vgl.: Literaturnoe Nasledstvo. Valerij Brjusov, a.a.O., S. 417. 517f.; Vol'fing (Ë.K. Metner]: Modernizm i muzyka. Moskva 1912, S. 161-189; R. Barlett: Wagner and Russia. Cambridge 1995, S. 166f.).

Die Verfasserin konnte keine Belege darüber finden. ob Ëllis jemals in Petersburg war und dort z.B. den literarisch-philosophischen Zirkel in Vjac. Ivanovs "Turm" ("6ашня") besucht hat.

56 Der von Metner. Ėllis und Belyj gegründete Verlag "Musaget" (= der Musenführer. Beiname des (Gottes Apollo) existiente von 1910-1917. Neben Metner als Hauptredakteur gelten Ellis und Belyj als die engsten Mitarbeiter in den ersten Existenzjahren des Verlags. Nachdem die Zeitschrift "Becы" 1909 ihr Erscheinen eingestellt hatte. wurde der Verlag "Musaget" schnell zu einem neuen Zentrum der Moskauer Symbolisten, in dem ein reges kulturelles Leben erblühte (Arbeitskreise, praktische Kurse u.a.). (Für genauere Ausführungen über den "Musaget"-Verlag vgl. unten. das Kapitel "Die Zeitschrift "Труды и дним" der vorliegenden Arbeit. S. 112f.)

57 Vgl. hierzu auch die Briefe S. Bobrovs an A. Belyj (in: Lica. 1, 1992. S. 113-169) sowie M. Ljunggren: The Russian Mephisto, a.a.O.. S. 43.46.

58 Die Zeitschrifi "Tруды и дки" erschien 1912-1914 und 1916 im Verlag "Musaget" unter Ė.K. Metners Redaktion. (Ausfuhrlicher hierzu vgl. unten, das Kapitel "Die Zeitschrift “Tруды и дниж" der vorliegenden Arbeit. S. 112-117.) 
wandte sich nunmehr, nicht zuletzt von E. K. Metner angeregt und beeinflußt. Goethe, Richard Wagner und der deutschen Literatur und Kultur zu.

Etwa um 1909 begannen sich Belyj und Ėllis für Theosophie zu interessieren. Ėllis besuchte regelmäBig die theosophischen Zirkel der Kleopatra Petrovna Christoforova, zusammen mit Belyj traf er sich mit Anna Rudol'fovna Minclova, die sie mit den Vorträgen und Schriften Rudolf Steiners bekanntmachte ${ }^{59}$.

1911 geriet er als erster russischer Symbolist intensiv und aktiv unter den EinfluB der anthroposophischen Lehren Rudolf Steiners, für die er sich mit dem ihm eigenen leidenschaftlichen Eifer zu begeistem begann ${ }^{60}$. Da Ëllis bereits im Herbst 1911 nach Deutschland reiste und nie wieder nach RuBland zurückgekehr ist, enden hier seine Tätigkeiten und sein Wirken als aktiver Moskauer Symbolist.

59 Vgl. A. Belyj: Im Zeichen der Morgenröte, a.a.O.. S. 503, 507. 517.

60 Der Periode von Ėllis' intensiver Begeisterung für Steiner und die Anthroposophie ist im Verlauf der Arbeit ein Unterkapitel gewidmet (vgl. unten. S. 118-134). 


\section{B. Ellis und seine Zeitgenossen}

Während seiner symbolistischen Schaffensperiode von 1902 bis 1911 schienen Éllis' ganze Erscheinung, sein Auftreten und seine Lebensweise geradezu gelebter Symbolismus zu sein. Victor Fedjuschin weist darauf hin, wenn er Ëllis einen russischen Dichter, Kritiker und Philosophen nennt. "dessen Leben selbst unzweifelhaft als ein bedeutendes und ungewöhnliches Kunstwerk erscheint, bedeutender und ungewöhnlicher als alles, was er uns an Schriften hinterlassen hat."l Deshalb soll an dieser Stelle näher auf Ėllis' Charakter, Wirken und Leben als Moskauer Symbolist eingegangen werden - und zwar aus der Perspektive seiner Mitmenschen. Gleichzeitig soll das Verhältnis von Ėllis zu einigen seiner literarischen Mitstreiter charakterisiert werden.

Allgemein wird Ellis von seinen Zeitgenossen als ein schwieriger, fanatischer und unpraktischer Mensch beschrieben. leidenschaftlich. leicht aufbrausend, klein, hager. blaB. kahlköpfig. mit schwarzem Bar, grünen Augen und blutroten Lippen. A. Belyj gibt in seinen Memoiren eine anschauliche Schilderung, wie er Ėllis zum ersten Mal im Theater erblickte:

Смотрю: между публикой мелькает белое. как гипсовая маска. лицо студента. орамленное черной. как вороново крыло. боролкой; он прикал подбородок к высокому синему воротнику, нытяя в сюртуки белою лысинкой; вдрут мимолетом стрельнули в нас неестественным блеском зеленые его фосфорические глаза: из узких разрезов: а красные губы застыли рассклабленно как-то; $[\ldots]^{2}$

Ellis muß eine ungewöhnliche Redegabe und ein großes schauspielerisches Talent besessen haben. das ihn hervorragend Leute imitieren lieB. Der Publizist. Philosoph und Sozialdemokrat Nikolaj Valentinov schilder diese Eigenschaften von Ëllis sehr lebendig in seinen Memoiren über seine Zeit im Kreise der Moskauer Symbolisten:

\footnotetext{
Эллис незабываем и. как и А. Белый. неповторим. Этот странный человек [...]. превра тивинй нољ в день. а денъ в ночъ. живший в комнате всегда темной с опушенными шторами и свечами перел портретом Бодлзра. а потом бюстом Данте. фбладал темпераментом бешеного агитатора. создавал необычайные мифы. вымысли. был творцом всяких паропий и изумительньм мимом. [...]

У него был огромный дар увлекать аудиторию. привлекать ее внимание к тому или нњому вотросу. но отнюдь не было исключено, что в середнне лекция Эллнс вдрут не заявит: "Ну вас всех к чорту. мне надоело говорить". и уйлет. ${ }^{3}$

Эллис обладал способностью заражать. магнетизировать люлей. Его пародия на то. как танцукот вальс большевик. меньшевик. эсэр. кадет, юнкер. паж. еврей. армянкн. были столь выразительны. так комичны. что зрители налрывались со смеху. Самого его смекицися я никогда не видеs. 4
}

1 V.B. Fedjuschin: RuBlands Sehnsucht nach Spiritualität. Theosophie, Anthroposophie, Rudolf Steiner und die Russen. Eine geistige Wanderschaft. Schaffhausen 1988, S. 175.

2 A. Belyj: Nacalo veka. a.a.O.. S. 44

Leider gibt es nur sehr wenige Fotografien oder Bilder von Ëllis; die Verfasserin hat lediglich zwei Aufnahmen gefunden, eine von Ëllis als Student (im РГИА. Ф.418. on. 311. ед.xp. 445) und eine von Eillis als junger Mann (in: A.Saakjanc: Marina Cvetaeva. Stranicy Żizni i tvořestva |1910-1922|. Moskva 1986: dieselbe Aufnahme findet sich auch in: A. Belyj: Meždu dvuch revoljucij, a.a.O., nach S. 224, sowie in: V.B. Fedjuschin: RuBlands Sehnsucht nach Spiritualität, a.a.O.. S. 178) und eine Skizze von Leonid Pasternak (in: L.O. Pastemak: Zapisi raznych let.Moskva. 1975. S. 132).

${ }^{3}$ N. Valentinov: Dva goda s simvolistami. Stanford (California) 1969. S. 151. Valentinov hatte Ėllis 1906 kennengelemt und war vor allem 1907 und 1908 häufig mit ihm zusammen.

4 Ebd.. S. 152.

Valentinov beschreibt femer Éllis' auBergewöhnliche Fähigkeit, andere Personen nicht nur nachzuahmen. sondem sich geradezu in sie zu verwandeln (vgl. ebd.. S. 153). 
Extreme Kehrtwendungen in Ėllis' Leben waren durchaus nichts Ungewöhnliches. Sein aufbrausender, leidenschaftlicher Charakter, seine Gabe, sich spontan für eine Sache zu begeistem oder diese radikal abzulehnen, prägten seine Beziehungen, Kontakte und sein Werk. Aufgrund dieser Eigenschaften waren die meisten Bekanntschaften und Freundschaften zwischen ihm und seinen Zeitgenossen nur von kurzer Dauer.

Wohl die am längsten währende Freundschaft bestand zwischen Ëllis und Andrej Belyj (ab 1902), obwohl sie natürlich auch einige Krisen durchmachte, ehe sie 1913 endgültig zerbrach5. Die Zeit von 1913 bis 1916 bezeichnet Belyj als Epoche der Feindschaft $\mathrm{z}$ wischen ihm auf der einen und Ėllis und E.K. Metner auf der anderen Seite. Ab 1916 seien dann nicht einmal mehr Gerüchte über Ëllis zu Belyj gedrungen6.

In seinen Erinnerungen an A. Blok beschreibt Belyj Ëllis' Entwicklung folgendermaßen:

[...] я знал. что неистовый Эллис может умереть за то именно. что сейчас представлялось ему идеалом: увы: идеалы - менялись: сначала - ученый марксист. агитатор; поклонник Стеккети - потом: в 1901 году проповедывающий профессора Озерова: в 1902 - 1907 годах - бодлернанец. в 1908 - брюссианец: в 1909 - "дантист"; в 1910 - искатель пути посвяцения; в 1911 - 1913 годах - штейнернст; в 1915 - 1916 верный поклоннк Ло̆̆олы $[\ldots]^{7}$

Einen Charakterzug habe Ėllis jedoch stets bewahrt: den des Schauspielers, des Mimikers; er sei ein Charlie Chaplin gewesen noch vor dessen Zeit ${ }^{8}$.

[...] он никогда не бьц тем. чем казался себе и нам; был он лииь мимом; его талант интерфермровал искрами гениальности: [.... ${ }^{9}$

Кобылинский был образован. имел дар слова и дар актера: итрать ту или иную роль: н верить прн этом. что раль - убежление: $(\text {... })^{10}$

Sein ganzes Talent habe Ellis "auf der Zungenspitze getragen", wohingegen seine Werke eher talentlos seien "I.

Folglich ist Belyj der Ansicht, daB Ëllis seinen Beruf verfehlt habe, indem er Übersetzer und Dichter anstatt Schauspieler geworden sei:

5 Im Februar 1908 z.B. erlebte diese Freundschaft eine Krise: Belyj machte Ëllis heftige Vorwürfe. $\mathrm{daB}$ er sich mit Brjusov gegen inn verbünde. (Vgl. Belyjs Brief an Ellis. publizien mit Vorwon und Kommentar in: Lica. Biograficeskij al'manach, 5. Moskva 1994. S. 386-398.)

6 Vgl. A. Belyj: Nacalo veka. a.a.O.. S. 44, 46. Zum Verhälinis Belyj-Ëllis vgl. auberdem: A. Belyj: Na rubeže dvuch stoletij, a.a.O.: Ders.: Meżdu dvuch revoljucij. a.a.O.: Ders.: Vospominanija o Bloke, a.a.O. (deutsche Übersetzung: Im Zeichen der Morgenröle. Erinnerungen an A. Blok, a.a.O.): Ders.: Vospominanija o Stejnere. Paris 1982 (deutsche Übersetzung: Verwandeln des Lebens. Erinnerungen an Rudolf Steiner. Basel ${ }^{3}$ 1990).

7 A. Belyj: Vospominanija o Bloke, a.a.O., S. 108f. An anderer Stelle beschreibt er Ėllis kurz und treffend als "зкономист - пессимист - бодлернст - брносовец - лантист - оккультист - иттей нерист - католик" (A. Belyj: Načalo veka. a.a.O.. S. 4lf.).

A. Belyj: Nacalo veka. a.a.O., S. 42.

${ }^{9}$ Ebd.

10 Ebd., S. 41.

11 "Все талантливое в себе отдавал он кончику языка: бездарное - кончику пера." (Ebd., S. 64). Ähnlich wie von Belyj wird Ėllis auch von Asja Turgeneva beschrieben (vgl. A. Turgeneva: Andrej Belyj i Rudol'f Štejner. In: V.M. Piskunov (Hrsg.): Vospominanija ob A. Belom, a.a.O.. S. 194). 
[...] он был бы великим артистом. а стал - плохим переводчиком. бездарным поэтом и посредственным публицистом и экс-ом (экс-символист. экс-марксист и т.д.); [...] $]^{12}$

Устраивал скандал за скандалом; очередной скандал кончался истерикой: истерика принимала такие формы. что мы говорили:

- "Тут ему и конец!"

Но "труп" Кобылинского восставал к новой жизненной фазе $[\ldots]^{13}$

Die Beziehung zwischen Ėllis und Aleksandr Blok beschreibt Lavrov in seinen Vorbemerkungen zu Ėllis' Briefen an Blok'4. Am 11. Januar 1904 begegneten sich Blok und Ėllis zum ersten Mal persönlich, als ersterer nach Moskau kam und an einem der "Argonautentreffen" teilnahm. Blok fand keinen Gefallen an Ėllis!

\begin{abstract}
Эллис. бледыы. с кровавыми. как у вампира. губами. [.. ] с лицом. налезаюиим. обдаюиям слюною собеседниха - мучил А.А. [= Блок]. и нервически передергивался плечами. покручивал усик: и - сыпал свои арабески из слов; всем хотелось сидеть в тишине. при несенной с могил. а тут - нате-же: со страстнок) сухостью. неутоляемой. фанатической. Эллис ташил за собою А.А. через образы Данте, через химеры соборов к ... Бодлеру. который А.А. был так чужд; [...] я видел - А.А. зеленеет в словесных потоках: несносна ему эта взвинченность Эллиса. на пружинах схоластики: [...] так помнится: лысое. мертвеннсе лицо. зелень глас и кровавые влажные губы; за ними откинутый. изнемогаюший Блок. под потоками парадоксов. давно каменеюший; загар лучезарный потух в серожелтые тени худого такого лица. а лрожашие губы просили о помоци "Освободите скорее меня от сухой этой бурн!"[...]

После Блок говорил: "Нет. вы знаете. нет: я Льва Львовича [= Эллиса]. все-тақи. выносить не могу. нет уж. нет!" 15
\end{abstract}

Eine emeute Begegnung zwischen Blok und Ėllis fand im August 1906 statt ${ }^{16}$, als Ëllis in seiner Eigenschaft als Belyjs Sekundant Blok eine Aufforderung zum Duell brachte. Es kam zu einem intensiven Gespräch zwischen Blok, seiner Frau und Ellis und in der Folge zu freundschaftlichen Beziehungen. Das Duell zwischen Belyj und Blok fand nicht statt ${ }^{17}$. Ende 1906/Anfang 1907 plante Ėllis die Herausgabe eines Almanachs "Vox Coelestis", wofür Blok ihm Gedichte schickte 18. Von Januar bis Anfang April 1907 standen Ëllis und Blok in freundschaftlichem Briefwechsel, der dann jedoch jäh von Ėllis abgebrochen wurde, als Blok G. Culkov gegen Ëllis' heftige Angriffe verteidigte ${ }^{19}$.

Überhaupt teilten Culkov und sein "mystischer Anarchismus" die Symbolisten Moskaus und Petersburgs in zwei kontroverse Lager. 1908 finden wir scharfe. kriti-

12 Ebd.. S. 42.

13 Ebd.. S. 45.

An dieser Stelle soll noch einmal an die Provokations- und Schockwirkung erinnert werden. die die ersten Symbolisten in RuBland am Ende des 19. Jahrhunderts hervorriefen. (Man denke zum Beispiel an Brjusovs Bändchen "Русские символисты". 1894/95, sowie an die ersten "gegenstandslosen" Ge dichte, etwa Brjusovs (jedicht "Творчество", 1895.) Dem entspricht Ellis' Auftreten und seine Lebensweise in der ersten Dekade des 20. Jahrhundens. nicht aber sein Werk. Im Gegensatz zu Brjusov hat Ellis aber nicht bewuBt provoziert und schockien. doch verhielt er sich nicht den Normen der Gesellschaft entsprechend. was zu häufigen "Skandalen" führe.

14 Pis'ma Ellisa k Bloku (1907). Vstupitel'naja stat'ja. publikacija ikommentarii A.V. Lavrova. In: Literatumoe Nasledstvo. Aleksandr Blok. Tom 92. kniga 2. Moskva 1981, S. 273-291.

is A. Belyj: Vospominanija o Bloke. a.a.O.. S. 107-109.

If Zur Datienung vgl. A. Lavrov: A. Belyj. Chronologičeskaja kanva Žizni i tvorčestva. a.a.O.. S. 780.

17 Vgl. hierzu auch A. Lavrov: A. Belyj v 1900-e gody. a.a.O.. S. 199f.

$1 \times$ Dieser Almanach ist jedoch nie erschienen.

19 Seinen letzten Brief an Blok. Anfang April 1907, beendet Ėllis mit den folgenden Worten: "Ilрощайте навсегда и бесповоротно." (Abgednuckt in: Literatumoe Nasledstvo. Tom 92. kniga 2. Moskva 1981, S. 290f.) 
sche Aufsätze Bloks über Ėllis und noch schärfere Äußerungen von Ėllis über Blok ${ }^{20}$. 1910 fand eine An Versöhnung statt: Bloks Vortrag "О современном состоянии русского символизма", der in der Zeitschrift "Anоллон"21 abgedruckt wurde, begeisterte Ellis. Er widmete daraufhin Blok sein Gedicht "Resignation"22. Seit Herbst 1911 lebte Ellis ständig im Ausland; von dort hat er keine Kontakte zu Blok unterhalten.

Den Unterschied zwischen Ellis und Blok charakterisient Lavrov sehr treffend: Bei Ëllis fehle völlig die Bewegung, die Entwicklung. Die Objekte seiner Verehrung wechselten zwar ständig. aber in sich bleibe Ëllis fest, mache keine Entwicklung durch. Dagegen werde das geistige Leben Bloks ganz von der "Idee des Weges", das heiBt der Entwicklung, bestimmt ${ }^{23}$.

Auch das Verhältnis zwischen Ėllis und Valerij Brjusov spiegelt deutlich Ėllis' unsteten Charakter wider ${ }^{24}$ :

Bei der ersten Begegnung zwischen den Brüdern Kobylinskij (Ëllis und sein Bruder Sergej) und Brjusov auf einem der ersten "Argonautentreffen" bei Belyj im April $1903 \mathrm{kam}$ es gleich zu einem heftigen Streit. Ellis wollte Brjusov sogar verprügeln. AnläBlich dieses Vorfalls schrieb Brjusov Belyj einen Entschuldigungsbrief:

Я очень извиняюсь перед вами и особенно перед Александрой Дмитриевной $I=$ Belyjs Mutter] за мон излишне злобные слова братьям Кобылинским. Но правда и то. что эти братья (хотя вы нх н любите и цените) одня из самых пустых. вздорных и несносных болтунов в Москве. 25

In den folgenden Jahren äußerte sich Brjusov negativ über Ėllis' Gedichte und Übersetzungen. Auch Ëllis war nicht gut auf Brjusov zu sprechen. Ende 1906/Anfang 1907 fand dann eine Wende in der Beziehung zwischen Brjusov und Ellis statt. Beide wirkten im "Общество свободной эстетики" mit, und von 1907 bis 1909 wurde Ėllis neben Belyj einer der engsten und engagientesten Mitarbeiter Brjusovs bei der Herausgabe der Zeitschrift "Becы". Diese Annäherung zwischen Brjusov und Ëllis und ihre Zusammenarbeit in "Bесы" fand zur Zeit des Höhepunkts der Polemik um den sogenannten "mystischen Anarchismus" von Čulkov statt. Für Ëllis und auch für $\mathrm{Be}$ lyj wurde Brjusov in dieser Zeit zum Hauptvertreter und "Führer" des russischen Symbolismus. Doch bereits ab Herbst 1908 traten Schwierigkeiten bei der gemeinsamen Herausgabe der "Bесы" auf, und schlieBlich lieB sich die Unvereinbarkeit der unterschiedlichen Symbolismusauffassungen von Brjusov, Ëllis und Belyj nicht mehr leugnen.

2" Z.B. Bloks Rezension von Ėllis' Verhaeren-Übersetzung ("Mонастырь" - "Das Kloster") in der Zeitschrift "О6разование" ("Bildung". Nr. 7, 1908, S. 74-76) und Ėllis' ÄuBerungen über Bloks "Балаганчик" ("Die Schaubude") in seinem Aufsatz "Что такое театр?" ("Was ist Theater?", in: Vesy. Nir. 4. 1908, S. 85-91).

$21 \mathrm{Vgl}$. oben. S. 17 und S. 18, Anm. 39, sowie unten. S. 72, Anm. 6

22 "Resignation. A. Блоку". In: Ëllis: Argo. Moskva 1914. S. 50f.

${ }^{23} \mathrm{Vgl}$. Literatumoe Nasledstvo. Tom 2. kniga 2. Moskva 1981, S. 279. Das entspricht D.E. Mak simovs Ausführungen über Blok (vgl. hierzu R.-D. Kluge: Zur Theorie des nussischen Symbolismus, a.a.O., S. 85f.; Ders.: Wie funktionient ein symbolistisches Gedicht? a.a.O., S. 272).

In einem Gespräch im Juni 1989 sagte mir Lavrov zu diesem Thema, Ėllis sei seiner Meinung nach еіп "кумиротвореu по природе" ("naturgemäBer Götzenbilderschaffer") gewesen und habe überall Ixoppelgänger seiner Ideale gesehen (z.B. Marx, Baudelaire, Brjusov, Steiner): dadurch könne man seine wechselnden Begeisterungen erklären.

$24 \mathrm{Vgl}$. A.V. Lavrov: Brjusov i Ėllis, a.a.O., S. 217-236.

25 Literaturnoe Nasledstvo. Tom 85. Valerij Brjusov. Moskva 1976, S. 357. Dieses "Argonautentreffen" beschreibt auch A. Belyj in seinen Memoiren (Nacalo veka, a.a.O., S. 257-263). 
Nachdem "Весы" 1909 eingestellt worden war, trennten sich Brjusovs und Ėllis' Wege. Brjusov ging zur Zeitschrift "Pусская мысль" ("Der russische Gedanke")26, Ėllis und Belyj gründeten zusammen mit $\dot{E} . K$. Metner den Verlag "Musaget" und fanden dort einen neuen Wirkungsbereich. Noch extremer wurde die Kluft, als Éllis 1911 Steiner-Anhänger wurde. Nach 1911 haben sich die beiden nicht mehr getroffen.

Diese Diskrepanz bzw. die unterschiedliche Kunstauffassung und Weltanschauung von Ėllis und Brjusov hat letzterer 1914 sehr treffend in einem Gedicht mit dem Titel "Эллису" ("An Ellis") ausgedrückt, das hier abschließend zu diesem Thema zitiert sei:

\section{эллису}

Нет! к озаренной сияннмм бездне

Серцие мое не зови!

Годы идут, а мечте все любезней

Грешные песни любви.

Белые рьпари... сень Палестињы...

Вечная Роза и крест...

Ах. поцелуй заменяет единый

Мне всех небесных невест!

Ax! за мгновенье под свечей сиренью

С милой - навек я отдам

Слинком привычных к нездешнему пенью

Оньх мистических Дам.

Их не умею прославить я в песне...

Серде! опять славословь.

С. годамн все умиленней, чудесней.

Вечно земную любовь! 27

In diesem Gedicht hat Brjusov deutlich das Hauptmotiv der Divergenzen und Meinungsverschiedenheiten, die sich ab 1908/1909 und verstärkt ab 1910 nach dem Ende von "Весы" zwischen ihm und Ëllis herausbildeten, formuliert und ausgedrückt. Die Richtung. die Ėllis in seiner Lyrik eingeschlagen hat, bzw. den gesamten dogmatischreligiösen Symbolismus von Ellis, lehnt Brjusov entschieden ab. Dieses Gedicht spiegelt jedoch nicht nur Brjusovs Haltung gegenüber der mystisch-religiösen Thematik in Ëllis' Gedichten wider, sondern überhaupt seine Ablehnung des gesamten weltanschaulich-religiösen Zweiges des russischen Symbolismus, wie ihn auch Belyj. Blok und Ivanov (jeder auf seine Weise) vertraten ${ }^{28}$. Somit stellt Brjusovs Gedicht eine Art Fortsetzung oder vielleicht gar den Endpunkt des sogenannten "Symbolistenstreits" dar, der $1910 \mathrm{im}$ "Аполлон" ausgetragen wurde.

26 "Русская мысль" war eine wissenschaftliche, literarische und politische Zeitschrifi, die von 1880 bis 1918 monatlich in Moskau erschien. Ab 1910 übernahm Brjusov die Leitung des Literaturteils von "Русская мысль". Da diese Zeitschrift die Oktoberrevolution negativ aufgenommen hatte, wurde sie 1918 von der sowjetischen Regierung verboten. In den zwanziger und dreißiger Jahren dieses Jahrhunderts wurde "Русская мысль" von P.B. Struve im Ausland herausgegeben (Sofia. Prag. Paris. Belgrad).

27 In: V. Brjusov: Sobranie soxinenij v semi tomach. Tom 3, Moskva 1974, S. 332.

28 Die unterschiedliche Symbolismusauffassung von Brjusov und den sogenannten "jüngeren" Symbolisten wird z.B. sehr anschaulich von N. Valentinov charakterisien (in: Dva goda s simvolistami. a.a.O., S. 143-146). 
Ėmilij Karlovič Metner und Ėllis verbanden ab etwa 1905/1906 freundschaftliche Beziehungen. Als Metner 1907 und 1909 länger in Deutschland weilte 29 , entwickelte sich ein intensiver Briefwechsel zwischen Ellis und ihm. Bereits in diesen Jahren begannen Metner, Ellis und Belyj Pläne zu schmieden, die 1909/1910 zur Gründung von "Musaget" führen. In den Jahren 1911 und 1912, als sich zuerst Ëllis und danach auch Belyj intensiv für Rudolf Steiner und dessen Lehre zu begeistern begannen und nach Deutschland reisten. kam es zu einer Entfremdung zwischen Ellis und Metner; letzterer konnte Ėllis' fanatische Steinerverehrung nicht verstehen. Dennoch setzten sie ihren Briefwechsel fort, dem viele interessante Informationen über Ėllis und Steiner sowie Ėllis' Anthroposophiebegeisterung und spätere Abkehr von Steiners Lehre entnommen werden können. Eine emeute (briefliche) Annäherung fand dann 1913 statt, als Ėllis sich von Steiner und der Anthroposophie lossagte. Noch 1917 unterstützte Ėllis Metner brieflich gegen Belyj ${ }^{30}$.

$\mathrm{Zu}$ einem endgültigen Bruch zwischen Ėllis und Metner kam es wohl Anfang der zwanziger Jahre, nachdem Metner seit 1914 zusehends unter den EinfluB C.G. Jungs geraten war, dessen Patient und Freund er war und aus dessen Werken er Teile ins Russische übersetzte (diese Übersetzungen befinden sich im PO РГБ); er fühlte sich stark zu Jungs Tiefenpsychologie hingezogen. Ėllis hielt diesen EinfluB Jungs auf Metner für äuBerst gefährlich und wandte sich ganz von Metner $a^{3}{ }^{31}$.

Mit den Schwestem Marina und Anastasija Cvetaeva verband Ėllis in den Jahren 1908/1909 eine enge Freundschaft. Sie besuchten Ëllis in seinem möblienten Zimmer im Gasthaus "Don", wo sie zum ersten Mal A. Belyj sahen 32; öfter noch weilte Ėllis bei ihnen zu Hause und las ihnen seine Gedichte vor, erzählte ihnen Märchen und Geschichten. Damit hat Ëllis maBgeblich auf die Phantasie der beiden Schwestern eingewirkt und Marina zu ersten eigenen schöpferischen Versuchen ermutigt. Zu einer Erschütterung dieser Freundschaft kam es im Herbst/Winter 1909, als Vladimir

$29 \mathrm{Vgl.} \mathrm{M.} \mathrm{Ljunggren:} \mathrm{The} \mathrm{Russian} \mathrm{Mephisto,} \mathrm{a.a.O.,} \mathrm{S.} \mathrm{25-37.}$

30 РГБ: $\$$. 167. карт. 14. eд.xp. 68f. Metner hatte 1914 eine Abhandlung über Steiners - wie er meinte - falsches Goetheverständnis geschrieben. auf die Belyj 1917 mit einem Werk zu Steiners Verteidigung reagierte. ( $\mathrm{Vgl}$. hierzu auch unten. S. I79f.)

3 'Hiervon zeugen Ellis' (leider) undatiente Briefe an Vjac. Ivanov, die wohl Ende der 20er/Anfang der 30er Jahre geschrieben wurden und sich im Archiv von Dmitrij V. Ivanov in Rom befinden. In diesen Briefen äubern sich Ëllis folgendermaben über sein Verhältnis zu Metner:"Дело в том. это между моей $\partial y x$. личностьк) н его [= Метнер] ннкогда никахото разрыва не было. но был разрыв мехоу его собственной мичн(х тьк) и его внешной обхмочкой, пощпавшей элементарно-магнетическому внушенню (suggestion!) через Д|окто]ра Юнга. весьма опасной. турко-арабской магин. Внешнее (бщение удержать было de facto тогда невозможно. помочь то же. Если Э.К. [= Метнер] преодолел это опасное влияние. нбо сам Д|окто]р Кнт (очень скоро после моего внешнего удаления от Э.К.) пережил катастрофу и едва ли способен к прежней передаче магического тока (последние работы Д|окто]ра Юнга маловажны философски и неопасны. Он стал дюжинным психологом. Hanpotкв. Prof.Dr. Freud все еще смердит и отравляет), то наше внешнее общенне легко может восстановнться." In einem anderen Brief heibt es: "[...] я отрнцаю самълй факт разрыва моего с Э.К.. его духом. душой. подлинной личностью и его путем. ПІроизошел разрыв не межлу моей личностью и личностью Э.К.. но разрыв между его личностью и его внешней оболочкой. путем сехсуальной магия и даже психо-аналитич[еской] метољы внушения (даже механической - во время сна в общей комнате) r. Юнта." Die Freundschafi und das teilweise recht problematische Vertältnis zwischen Metner und Jung ist ausführlich von M. Ljunggren untersucht worden (vgl. M. Ljunggren: The Russian Mephisto. a.a.O., S. 86-160).

32 Vgl. M. Cvetaeva: Plennyj duch. a.a.O., S. 237f.: A. Cvetaeva: Vospominanija. a.a.O., S. 306. 
Nilender Ėllis' Heiratsantrag Marina Cvetaeva überbrachte, die ihn allerdings nicht annahm ${ }^{33}$.

In ihrem "Вечерний альбом" ("Abendalbum") finden sich einige Gedichte, die Marina Cvetaeva an Ëllis, ihren "Zauberer" ("Чародей"), wie sie ihn nannte, gerichtet hat ${ }^{34}$. Das folgende Gedicht gibt eine besonders treffende Beschreibung von Ellis' Erscheinung und Charakter:

\section{ЧАРОДЕЮ}

Рот как кровь, а глаза зелекы.

И ульбка кзмученно-злая...

$O$. не скроешв. теперь поняла $x$ :

Ты возлобленњпи бледнй Лушы.

Над тобон и днем не слабели

В дальнем детстве сказанья ночей.

Oттого ты с рожденя - ничей.

Оттого ты любил - с кольбели.

О, как многих любил ты. позт:

Темнооких. светло-белокурых.

И намменньх, и нежных, и хмурых.

В них вселяя своћ собственнњ бред.

Но забвение. ах. на груди ли?

Есть ли чары в земных голосах?

Исчезая, как дым в небесах.

Уходили они. уходили.

Вечный гость на чужом 6ерегу.

Ты замучен серебраным рогом...

О. я знако о маногом. о многом.

Но откуда - сказать не могу.

Ortoro тебе искры бокала

И пурман наслажления блещњы:

Ты возлкблснњ Дй Девы-Луны.

Ты кз тех. что Луна прнласкала. ${ }^{35}$

Insgesamt schätzte Marina Cvetaeva Ëllis als Mensch und Dichter sehr ${ }^{36}$.

Auch Anastasija Cretaeva zeichnet in ihren "Erinnerungen" ein genaues Bild von Ellis:

[...] вошел Лев Льович Элинс.

Худо̆. в черном скортуке. [...] "доктор", маг из средневекового романа.

Жил Эллис в бедности. без определенного заработка. от стихов к статье, делал переводы, не имел быта. Комната в номерах "Дон" на Смоленском рынке и хождение днем - по редакцихм. вечером - по домам друзей. где его встречали радостно. как желанного гостя, слушали последние стихн и вместе с ним уносились в дебрн мечтаний и споров о роли символизма. романтизма. Часто голодиы.̆. непрактичный. он обладал едхим умом и блестяцей речью. заворачнваюией самых разнородых людей. И был у него еще

33 Vgl. A. Cvetaeva: Vospominanija, a.a.O., S. 314-316; Maria Razumovsky: Marina Zwetajewa. Eine Biographie. Frankfurn 1989, S. 59f.

${ }^{34}$ M. Cvetaeva: Vecemij al'bom. Detstvo. Ljubov'. Tol'ko teni. In: M.Cvetaeva: Stichotvorenija i poemy $v$ pjati tomach. Tom 1: Stichotvorenija 1908-1916. New York 1980. Direkt an Ellis gerichtet sind die Gedichte "Чародею" ("An den Zauberer"). "Бывшему чародею" ("An den ehemaligen Zau berer") und "Ounnka" ("Der Fehler").

35 M. Cvetaeva: Vecemij albom, a.a.O., S. $28 f$.

36 Vgl. M. Cvetaeva: Plennyj duch, a.a.O., S. 237. 
один талант. которым он покорял людей не менее. чем певучим стихом: талант изображения всего, о чем он говорил. - более: талавт превращения. перевоплощения такой силы и такой мгновенности. которая не под стать и самому искусному актеру, всегда связанному прннудтельностью роли данного часа, несвободон выбора.

Эллис. в своей полюой матернальной неустроенности. был насмешлив. неблагодарен до самого мозга костей. надменен к тому, у кого ел. повелителен к тому. от кого зависел. ${ }^{37}$

Die Malerin Margarita Vološina. die den Symbolisten nahestand, geht in ihren Memoiren auch auf Ëllis ein, dem sie in Moskau in Kreisen um den Verlag "Musaget" begegnet war und den sie dann später, 1911, in Karlsruhe, auf seinem Weg zu Rudolf Steiner, wiedertraf. In ihrer Charakteristik von Ëllis sind der ganze Extremismus und Fanatismus seines Wesens sehr treffend beschrieben:

Er [Ëllis] war zuerst Marxist und bereit. jeden umzubringen. der nicht seine Überzeugung teilte. Dann wurde er ein glühender Verehrer von Dante und der mittelalterlichen Geistigkeit. Er wohnte in einem verkommenen Hotel "Don" auf dem schmutzigen Smolenskij-Marktplatz, und sein Traum war, auf diesem Platz einen gotischen Dom zu errichten. Sein Freund Niländer. der mit ihm das Zimmer teilte, träumte einen anderen Traum. Er lebte in der Welt des orphischen Griechenland und übersetzte damals die Bruchstücke Heraklits. des Dunklen. Beide hatten nie Geld und führen ein chaotisches Leben. Ellis besab eine unheimliche Fähigkeit. Menschen nachzuahmen. aber immer ins Groteske. Karikaturhafte. Seine plötzliche Bekehrung zur Anthroposophie. deren Wesen er gar nicht begriffen hatte, versetzte uns in einen leichten Schreck. denn sofort begannen seine Kreuzzüge. ${ }^{38}$

Um diese Darstellungen und Charakterisierungen von Ėllis aus der Sicht seiner Zeit genossen abzuschlieBen. soll an dieser Stelle noch Fedor Stepun zu Wort kommen. der Ėllis in den Jahren 1909 bis 1911 in Kreisen um den Verlag "Musaget" und in anderen literarischen und philosophischen Zirkeln erlebte:

Der Baudelairianer Ellis |.... e ein waschechter "bohémien" und edelmütiger Kampfhahn. der infolge seiner bitteren Armut nur ein Vorhemdchen unter dem eleganten Gehrock trug. formuliente sein Credo in einem Buch, das den Führern des Symbolsimus Balmont. Brjussow und Belyj ge widmet war, und in der Gedichtsammlung "Stigmata". Die Aufsätze und Gedichte Ellis' waren nicht sein Bestes. Die wirkliche Begabung dieses seltsamen Menschen [... l lag auf einem anderen Gebiet. Leo Lwowitsch war ein geradezu genialer Imitator; wer ihn als solchen erlebt hat, wird ihn nie vergessen. Seine lebenden Portäts waren jedoch keineswegs harmlose naturalistische Nachahmungen. sondern meistens blutlose Hinrichtungen des von ihm karikierten Menschen. Ellis war in den Jahren, von denen ich berichte, wohl der scharfsichtigste Aufspürer und der fanatischste Hasser wohlanständig-bürgerlicher Plattheit. Am schärfsten und dabei überzeugendsten geißelte er die bekannten Vertreter des akademischen und liberal-politischen Olymps. Gipfelleistungen seines Scharfsinns waren die Reden. die Ellis seinen Opfem in den Mund legte, um sie zu $\mathrm{z}$ wingen, sich selber grausam zu verspotten. ${ }^{39}$

Aus all den angeführten ÄuBerungen und Beschreibungen wird deutlich. daB Ėllis in der ersten Dekade dieses Jahrhunderts unter den Moskauer Symbolisten eine recht auffallige, aktive Rolle gespielt hat. Sein Auftreten hinterlieB durch seine Rede- und Schauspielbegabung einen starken Eindruck bei seinen Zeitgenossen. Seine unpraktische Art lieB ihn an den elementarsten Dingen des alltäglichen Lebens scheitem und führe zu häufigen Zwischenfällen und Skandalen. Finanziell war Ëllis stets schlecht gestellt: er besaB allerdings auch nicht die Fähigkeit, seine gelegentlichen Einnahmen wirtschaftlich zu nutzen. Sicher wäre er völlig verwahrlost, wenn seine Freunde ihn

37 A. Cvetaeva: Vospominanija. a.a.O.. S. 258.

38 M. Woloschin: Die grüne Schlange. Lebenserinnerungen einer Malerin. Hamburg 1982. S. 235.

${ }^{39}$ F. Stepun: Vergangenes und Unvergängliches. Aus meinem Leben. Erster Teil 1884-1914. München 1947. S. 315f. (Stepuns Memoiren erschienen zuerst in deutscher Sprache, nach der Erstausgabe wurde zitient.) 
nicht mitversorgt und sich um seine Körperpflege gekümmert hätten. Ein ausgeprägtes Zeit- und Taktgefühl schien ihm gänzlich gefehlt zu haben.

All diese Besonderheiten zeigen, daB Ėllis' Leben nicht den ïblichen Normen der Gesellschaft entsprach und sich gewissermaßen als "gelebter Symbolismus" beschreihen läßt ${ }^{40}$. Dies könnte vordergründig der engen Verhindung von Kunst und l,ehen entsprechen, die die "jüngeren" Symbolisten, zu denen Ëllis ja zählt, anstrebten. Durch seine Offenheit wird der Symbolismus als modeme Kunst charakterisien. Ein symbolistisches Kunstwerk ist cin unvollendetes, "offencs, intelligibles Gcbildc"4l, das sich an den Rezipienten richtet, an ihn appelliert, und erst der Rezipient strukturiert das Kunstwerk zuende. Das Wesen des symbolistischen Symbols ist es, offen und kreativ zu sein. Das Unbehauste, Offene, Unstete in Ëllis' Leben entspricht - für den Autor selbst möglicherweise gar nicht einmal tewuBt - diesen Hauptmerkmalen des symbolistischen Kunstwerks.

Bei allen "jüngeren" Symbolisten findet sich immer wieder das Symbol der Mas$k^{42}$. Mit der Maske sollte die Künstlichkeit der Kreation nach drauBen getragen werden. Die Maske ist jedoch ambivalent: jemand oder etwas kann sich hinter ihr verbergen, oder sie täuscht den Adressaten (als Trugbild, Fatamorgana). Auch in Ellis' Le ben war die Maske von großer Wichtigkeit, wenn er seine Mitmenschen karikiert. verschiedene Rollen spielt. Das groteske Verzerren ist hier bei Ėllis eine charakteristische Eigenschaft der Maske.

Ëllis wird häufig als Décadent oder Dandy bezeichnet ${ }^{43}$. Während er zwar durch sein Auftreten und seine Aktivitäten als stimulierende Persönlichkeit auf seine Mit menschen wirkte, äußem sich jedoch die meisten seiner Zeitgenossen eher abwertend über sein Werk: Seine Gedichte seien von übertriebenem Pathos geprägt, eklektisch und wenig originell, seine Übersetzungen schlecht und falsch und seine publizistischen Arbeiten und Kritiken mittelmäRig ner einseitig 44 Positiveren Eindnck da gegen haben seine Vorträge und spontanen Repliken in literarischen und philosophischen Diskussionen hinterlassen 4.5 .

So mag es scheinen, daB Ėllis' Leben und Wirken, nicht aber sein Werk, seine literarische Hinterlassenschaft, von Interesse und Bedeutung gewesen seien. Um jedoch ein derantiges Urteil zu bestätigen, muB man sich kritisch mit Ellis' Gesamrwcrk befassen, was bis jetzt in der Forschung noch nicht geleistet worden ist ${ }^{46}$. Erst dann kann man die Frage beantworten, ob Ëllis und sein Werk zu Recht in Vergessenheit geraten sind und in der modemen Symbolismusforschung kaum Beachtung finden. Wenn Ellis' Lebensweise und sein Auftreten in Moskau zur Zeit des russischen Symbolismus von großer Bedeutung waren, wie die zitierten Zeugnisse seiner Zeitgenossen zeigen, darf auch sein Euvre nicht ignoriert werden. Deshalb soll in den folgenden Kapiteln der vorliegenden Arbeit das literarische, theoretische, literaturkritische

40 Ėllis ist jedoch kein Einzelfall. Vgl. hierzu auch die Arbeit von I.P. Smimov: Simvolizm, ili isterija. In: Russian Literature, 36, 1994, S. 403-426.

$4 \mid \mathrm{Vgl}$. R.-D. Kluge: "Der russische Symbulismus", a.a.O., S. 89.

42 Wohl das berühmteste Beispiel hierfür ist A. Bloks Gedichtzyklus "Снежная маска" (1907): bei A. Belyj begegnet die Maske des roten Domino: cr sclbst lief mitunter als roter Domino verkleidet durch die Straben Moskaus underschreckte und verwime die Leute. Vgl. hierzu auch R.-D. Kluge: Westeuropa und RuBland..., a.a.O.. S. 126, 325.

${ }^{43}$ Z.B. von N. Valentinov: Dva goda s simvolistami, a.a.O., S. 159; A. Belyj weist in seinen Memoiren wiederholt darauf hin, daB Ellis bestrebt war, sich die Dandy-Posen Baudelaires anzueignen (2.B. in: Vospominanija o A. Bloke, a.a.O.. S. 107).

44 Darauf wird im folgenden noch näher eingegangen werden.

$45 \mathrm{Vgl}$. die bereits angeführte Memoirenliteratur.

$46 \mathrm{Vgl}$. oben. S. $9 f$. 
sowie geistes- und kulturgeschichtliche Werk Ėllis' einer kritischen Untersuchung unterzogen werden mit dem Ziel, seinen Platz als Autor (und nicht nur als stimulerende Persönlichkeit) im russischen Symbolismus und in der russischen Literaturgeschichte zu bestimmen. 


\section{Werk}

\section{A. Allgemeiner Überblick}

Die Werke aus Ellis' "russischer" Schaffensperiode gliedem sich in Lyrik, literaturkritische und -theoretische Arbeiten und Übersetzungen.

Ab 1903, besonders 1904 trat Ėllis als Übersetzer hervor. Sein zweiteiliges Werk "Иммортели" besteht im wesentlichen aus Übertragungen von Gedichten französischer und belgischer Symbolisten. In den folgenden Jahren (1907-1911) erschienen Werke von Rodenbach, Verhaeren und Baudelaire sowie einige Teile aus Dantes "Divina Commedia" in Ellis' Übersetzung.

Seinen Weg als Lyriker begann Ellis ebenfalls 1904: in "Иммортели" publizierte er erste eigene Gedichte. Neben vereinzelten Gedichtveröffentlichungen in Zeitschriften. Anthologien und Sammelbänden findet sich Ellis' lyrisches Werk vor allem in seinen zwei Gedichtbänden "Stigmata" (1911) und "Apro" (1914).

Als Literaturkritiker und Theoretiker des russischen Symbolismus erweist sich Ellis vor allem in seinen zahlreichen Rezensionen. Kritiken und theoretischen Aufsätzen in der Zeitschrift "Bесы" (in den Jahren 1907-1909) sowie in seinem umfangreichen Werk "Русские Символисты" (1910), worin er sowohl die Entwicklung des westeuropäischen als auch des russischen Symbolismus darstellt und im Hauptteil als wichtigste Vertreter des russischen Symbolismus Bal'mont, Brjusov und Belyj be-

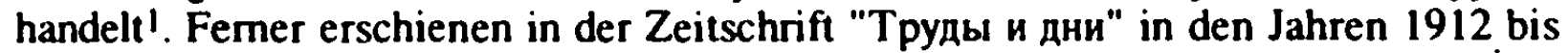
1914 einige theoretische Arbeiten. Den Traktat "Vigilemus!" (1914) bezeichnete Ellis als Fortsetzung seiner "Русские Символисты" und als "Programm" seiner zukünftigen Arbeiten ${ }^{2}$. Zugleich findet darin aber auch seine Abrechnung mit der Anthroposophie statt.

Gedichte, Übersetzungen und kritische Arbeiten hat Ėllis auch in weiteren (symbolistischen) Zeitschriften, Anthologien und Sammelbänden der ersten Dekade des 20. Jahrhunderts publizien. zum Beispiel in den Zeitschriften "Pусская мысль" und "Перевал" ("Der Übergang"), den Almanachen bzw. Anthologien der Verlage "Grif" (1904) und "Musaget" (1911), den Sammelbänden "Свободная совесть" I und II (1906), "Молодая Бельгия" ("Junges Belgien", 1907), "Воздетые руки" ("Erhobene Hände", 1908) etc. 3

Neben zwei unveröffentlichten Dramen. Gedichten und Übersetzungsentwürfen wurden für die vorliegende Untersuchung auch noch nicht publizierte Korrespondenzen und Notizen aus Ellis' NachlaB in Moskauer Archiven ausgewertet ${ }^{4}$.

\footnotetext{
' Es spricht gegen die Objektivität von Ëllis' "Русские символисты" bzw. ist wohl kennzeichnend für seine kritische Sensibilität, daB er A. Blok und Vjac. Ivanov in einem umfassenden Werk über die russischen Symbolisten nicht oder nur am Rande wahrnimmt. Diese Tatsache stellt eine Diskrepanz zur heutigen wissenschaftlichen Meinung dar. gemäB derer Blok und lvanov eindeutig zu den wichtigsten Vertretem des russischen Symbolismus zu zählen sind

2 Ellis: Vigilemus! Moskva 1914. S. VI.

3 Vgl. unten. die "Bibliographie von Ėllis' Werken".

${ }^{4}$ Im Russischen Staatsarchiv für Literatur und Kunst (РГАЛИ) und in der Handschriftenabteilung der Russischen Staatsbibliothek (PO PГБ) befinden sich viele, zum Grobteil noch nicht publiziene Materialien aus Ëllis' erster Schaffensperiode: Gedichte, Übersetzungsent würfe. Aufzeichnungen. Hefte mit Notizen sowie Vorlesungs- und Vortragsmitschriften (u.a. zu Steiner und zur Anthroposophie), unveröffentlichte Manuskripte (daunter ein "symbolistisches Drama" und ein "Fantasiestück"). verschiedene Briefe und Briefwechsel. Von besonderem Interesse hierbei sind Ellis' erwähnte Briefe an seinen Studienfreund Vasilij Grejner ("Крнтиха раднкальной нден". РГАЛИ. Ф. 575. опись 1, ед.хр. 18). der Briefwechsel mit Marija Ivanovna Sizova (РГАЛИ. Ф. 575. опись 1. ед.xp. 20 und 44), in dem es u.a. um die Bedeutung von Kindheit und Traum geht, und der umfangreiche Briefwechsel zwischen
} 
Éllis und Ė.K. Metner (1907-1914, PГБ. Ф. 167. картоны 6, 7, 8) über den Verlag "Musaget" (Plàne zur Gründung des Verlags, Probleme. Schwierigkeiten), über Ëllis' Verhältnis zur Anthroposophie und über seine Auffassung von Kultur überhaupt, von Literatur und Symbolismus. 


\section{B. Ellis als Übersetzer}

Das zweiteilige Werk "Иммортели" (1904) ist, abgesehen von einer kleinen Publikation im Sammelband "Итоги" ("Ergebnisse", 1903), das erste bedeutende Ergebnis von Ëllis' übersetzerischer Tätigkeit. Im ersten Teil finden sich 84 Gedichtübertragungen aus $\mathrm{Ch}$. Baudelaires "Les fleurs du mal" ("Цветы зла") sowie drei eigene Gedichte (ein Sonett an den Leser und zwei Gedichte an Baudelaire). Ellis befaBte sich damals intensiv mit Baudelaire, dem französischen und dem belgischen Symbolismus. Seine ersten Übersetzungsversuche aus Baudelaires Werk wurden allerdings von Brjusov in "Bесы" 1 aufs heftigste kritisiert: Elllis habe weder dichterisches Talent noch beherrsche er zureichend die französische Sprache ${ }^{2}$. Seine Übersetzungen seien schlechte "Nacherzählungen" in "welken Versen"3; er verändere, banalisiere und verfälsche Stil und Inhalt des Baudelaireschen Originals. AuBerdem stütze er sich sklavisch auf Übersetzungen, die Petr Jakubovič schon 1895 angefertigt habe, dessen Fehler er wiederhole. Brjusovs tadelnde Rezension gipfelt in folgender Schlußbemerkung:

Во всяхом случае "Иммортели" Эллиса - не нмеют никаких прав на существование. и очень жаль, что он обещается в будущем разделаться подобным же образом. как с Бодл эром, еще с Верлэном. с Прюдомом. Роденбахом. Нищше. Данте и другими. ${ }^{4}$

Dennoch beschäftigte sich Ellis in den folgenden Jahren weiterhin mit Baudelaire und überarbeitete und erweiterte seine Übersetzungen der "Fleurs du mal". Sie erschienen 1908 als eigener Band 5 . In diesem Zusammenhang ist allerdings erwähnenswert, daB 1970 eine in Moskau erschienene russische Ausgabe des gleichen Gedichtbands von Ch. Baudelaire ${ }^{6}$ etliche Übertragungen von Elllis in der Fassung von 1908 enthält. Ferner übersetzte Ėllis Baudelaires Tagebuch "Mon coeur mis a nu" ins Russische? sowic seine "Petits poèmes en prose"8. Neuausgaben von Ellis' Baudelaire-Übersetzungen sind 1993 in Tomsk und Moskau erschienen?.

Nur wenige Monate nach dem ersten erschien der zweite Teil von "Иммортели". in dem sich Übertragungen von Gedichten P. Verlaines. G. Rodenbachs, M. Maeterlincks, S. Prudhommes, Dante Alighieris, L. Stecchettis. D. Leopardis, F. Nietzsches, Th. Moores. G. Byrons und anderer finden (neben wenigen eigenen Gedichten bzw. Dante- und Nietzsche-Nachahmungen wie z.B. "Dante Alighieri", "Данте и Беатриче" ["Dante und Beatrice"], "На мотив из Заратустры" ["Auf ein Motiv aus Zara-

\footnotetext{
'Nr. 4. 1904. S. 42-48: Brjusov schrieb die Rezension unter dem Pseudonym "Avrelij".

2 Ėllis habe zum Beispiel "le libertin" mit "cвоболнын" (anstatt "pacnyтник") übersetzt, "mensonge" ("ложь") mit "невинная простота", den Satz: "Vous sentez tous la mort" ("вы все пахнете смертьк". "от вас исходит запах трупа") mit "вы все подобны скелетам" еtс. (Весы. Nr. 4, 1904. S. 48).

3 "|... Эллис только пересказъвает вятыми стихами содержание французских стихов [...]" (Весы. Nr. 4, 1904, S. 42).

4 Becы. Nr. 4, 1904. S. 48.

5 S. Bodlèr: Cvety zla. Perevod Ėllisa. Moskva 1908.

Vgl. zu Ëllis' Übersetzung auch die kritischen Äußerungen von S.P. Bobrov in seinem Brief an A. Belyj vom 20.8.1909 (in: Lica. 1. 1992. S. 130f.).

$6 \zeta$. Bodler: Cvety zla. Moskva 1970.

7 S. Bodlèr: Moe obnažennoe serdce. Perevod Ėllisa. Moskva 1907.

8 S. Bodler: Stichotvorenija v proze. Perevod Ėllisa. Moskva 1911.

9 S. Bodler: Cvety zla i Stichotvorenija v proze v perevode Ėllisa. Tomsk 1993; \$. Bodler: Cvety Zla. Stichotvorenija v proze. Dnevniki. Moskva 1993 (in diesem Band sind die "Стихотворения в прозе" sowie eine grobe Anzahl von Gedichten aus "Lветы зла" in Ëllis" Übersetzung abgedruckı).
} 
thustra"]). Brjusov rezensierte auch diesen zweiten Teil von "Иммортели"10 und warf Ëllis emeut Unfähigkeit und mangelndes Talent vor: die Übersetzungen banalisierten die Originale und gäben einen falschen Eindruck der ausländischen Dichter. $\mathrm{Da}$ Ëllis die Sprachen, aus denen er übersetzt, ungenügend beherrsche, verstehe er die Gedichte häufig nicht richtig und gebe ihnen einen falschen Sinn. Brjusov schlieBt seine Besprechung mit einem Dante-Zitat: "Lasciate ogni speranza!" II, das er auf Ellis' Übersetzertätigkeit bezieht.

Eine andere Rezension zu Ėllis' "Иммортели", die in der Zeitschrift "Мир Божий" ("Gottes Welt") 12 erschien, weist zwar auch darauf hin, daß es Ellis an Talent mangele, seine Übersetzungen ungenau und seine Verse blaB, schwerfallig und ausdruckslos seien, hebt aber immerhin einige positive Ausnahmen hervor ${ }^{13}$.

Ähnlich lautet das Unteil des Rezensenten in der Zeitschrift "Русская мысль"14, der zwar moniert, daB es Ėllis nicht gelungen sei, Geist und Stimmung der Originale zu vermitteln, aber immerhin anerkennt, daB die Übersetzungen des zweiten Teils von "Иммортели" besser seien als die des ersten, das gelte besonders für Übertragungen aus Dantes Werk.

Der Komponist Sergej Taneev war dagegen durchaus von Ėllis' lyrischen Versuchen angetan und komponiene 1905 und 1908 einige Romanzen auf Übersetzungen aus dem zweiten Teil von "Иммортели" 15.

In den folgenden Jahren übertrug Ėllis neben den bereits genannten Gedichten Baudelaires Werke belgischer Symbolisten: Die Dramen "Le voile" von George Rodenbach ${ }^{16}$ und "Le cloître" von E. Verhaeren ${ }^{17}$ sowie lyrische Gedichte im Sammelband "Молодая Бельгия" 18. Während diese Übersetzungen in einer Rezension von A. Pečkovskij 19 wenigstens als teilweise gelungen bezeichnet wurden. hat A. Blok eine vernichtende Kritik von Ėllis' Übersetzung von Verhaerens "Le cloître" publi$z_{i e r}{ }^{20}$. Er nennt Ėllis einen mittelmäBigen Dichter und schlechten Übersetzer. Verhaerens Werk sei blaß und fade übertragen, die Verse mitunter durch Prosa ersetzt und ihr Rhythmus ignorien worden. Zudem fanden sich Fehler, Ungenauigkeiten und Geschmacklosigkeiten, selbst mangelnde Kenntnis der Grammatik falle auf ${ }^{21}$. Besonders bedauerlich findet Blok, daB Belyj einer derart mangelhaften Übersetzung ein Vorwort gewidmet habe und dieser darin sogar "künstlerischen" Wen zuerkenne. Am

10 Die Rezension erschien wiederum in "Vesy", Nr. 7, 1904. S. 50-53 unter gleichem Pseudonym.

11 "LaBt jegliche Hoffnung fahren!" (Becы, Nr. 7, 1904. S. 53).

12 Nr. 7, 1904, S. 61f.; mit "L.V." unterzeichnet.

13 "Справедливость требует. однако. указать те немногне стихотворения, которые r. Эллису улалось перевести недурно. Таков перевод знаменитого «Аль батросаж. жГармония вечера». "Коuпка (I пьеса) и жСлетыж." (Мир Божнй. Nr.7, 1904. S. 62).

14 Nr. 11, 1904. S. 365-367.

$15 \mathrm{Vgl}$. oben. S. 29, sowie unten. die "Bibliographie von Ëllis' Werken", S. 235.

16 Ž. Rudenbach: Pokryvalo. Drama. Perevod Ëllisa. Moskva 1907.

17 E. Vercham: Monastyr'. Perevod s francuzskogo Ellisa. S predisloviem A. Belogo. Moskva 1908.

18 Moskva. 1907

19 In der Zeitschrif "Пlepeвar", Nr. 5, 1907, S. 48f.

20 In der Zeitschrift O6pa зованне, Nr. 7, 1908. S. 74-76.

21 Blok schreibt: "|...। на стр. 73 Эллис смешнвает слово hanche (6едро) со словом hache (топор) [...]; постоянно попадаются прозанзмы: кпускай мне бок сверлит копье» (стр. 29). «пусть весь мой дух зажжется вхруг" (стр. 31); рнскованные или несовсем русские выражения: «дно алькова» (стр. 46). «жить отчужденным от алтаря» (стр. 53); неверные ударения: «опо́ен». «то́рги», «тро́зней»; в стихах употребляются сплошь и рядом слова: экстаз. энергия. культ. монотоню. авторитет; и. нахонец. неужели худокественны следуюияе стихи:

« жажду ран. я жаклу. чтоб

Ногамм мне сквернили лоб.» [...]." Blok füht zahireiche weitere Beispiele für unkünstlerische. ungenaue und falsche Übersetzungen an (vgl. O6paзованне. Nr. 7, 1908. S. 75). 
SchluB von Bloks Rezension heiBt es: "Ax, оставаться бы ему в «секретном месте» [...] без предисловий г. Белого, стоящего на страже русской литературы!" 22

Ellis als Übersetzer wurde also seinerzeit durchweg abgewertet und negativ beurteilt: ungeachtet dessen werden seine Übertragungen jedoch heute wieder aufgelegt ${ }^{23}$.

Daneben übersetzte Ėllis kontinuierlich aus dem Werk Dantes, das er während seiner ganzen Moskauer Schaffensperiode besonders verehrte. Neben einer Kanzone aus der "Vita Nuova" (in "Иммортели", 1904) übertrug er aus der "Göttlichen Komödie" ("Divina Commedia") Teile des "Inferno" (im zweiten Teil von "Иммортели", 1904), des "Purgatorio" (in der Zeitschrift "Русская мысль", 1904) und des "Purgatorio" und "Paradiso" (in "Свободная совесть I", 1906, sowie in "Труды и дни", 1914). In der erwähnten Rezension zu "Иммортели" in "Русская мысль" 24 werden Ėllis' Dante-Übersetzungen positiv hervorgehoben:

Недурны. пожалуй. переводы Данта. Г. Эллис овладел терциной и только в редких случаях этот размер у него несколько запинается. Переводы отрывков из "Божественной комедин" и подражання им пронзводят некоторое впечатление. 25

Vera Pepitoni hat in ihrer Diplomarbeit und in ihrem Aufsatz "Ellis Kobilinskij tra Dante e Marx" 26 Ellis' Dante-Übersetzungen genau analysiert und mit dem Original verglichen (mit vielen Beispielen). Sie kommt dabei zu folgendem Ergebnis:

Ellis' Übertragungen aus dem "Inferno" zeigen, was die Auswahl anbelangt, keine Originalität ${ }^{27}$. Er behält zwar Dantes Terzinen und dessen Reimschema bei, verwendet aber anstelle von Dantes 11-Silber 5- und 6-füBige Jamben mit einer zwischen 10 und 13 variierenden Silbenzahl. Dantes Bilder gibt Ëllis nicht immer genau wieder. Abgesehen von gelegentlichen Imtümern und Fehlem verfälschen seine Veränderungen (Auslassungen oder Zusätze) den Inhalt zwar nicht grundsätzlich, lassen die Verse jedoch schwerfälliger erscheinen. Außerdem versieht Ellis seine Übersetzungen mit Anmerkungen. Im Rahmen seines Aufsatzes "Венец Данте" ("Dantes Dichterkranz") 28 überträgt Ëllis Teile aus dem "Purgatorio" und "Paradiso", die von der Auswahl her schon origineller seien und die Pepitoni als "im allgemeinen ziemlich gute Übersetzungen" 29 bezeichnet.

Auch W. Potthoff behandelt Ellis' Übersetzungen aus Dantes Werk ${ }^{30}$. Er geht allerdings weniger auf die Qualität dieser Übertragungen ein, sondem hebt vor allem die - seiner Meinung nach - wichtige Bedeutung hervor, die Ėllis als Übersetzer der Werke Dantes zur Zeit des russischen Symbolismus gehabt habe:

Einen Schwerpunkt in der symbolistischen Übersetzung Dantes stellt. vielleicht unerwartet. Ellis dar. Er erweitert den Bereich der übersetzten Texte um die Vita Nuova. aus der er 1904 Kanzone XXIII überträgt. Wir dürfen hier eine unmittelbare Wirksamkeit des Argonautenkreises voraussetzen: auch Sergej Solov'ev übersetzt dann aus der Vira Nuova.

22 Ebd.. S. 76.

$23 \mathrm{Vgl}$. oben. S. 47, Anmerkungen 6 und 9.

24 Nr. 11.1904.

25 Русская мысль, Nr. 11. 1904. S. 367.

26 Erschienen in dem Sammelband: Dantismo Russo e Comice Europea. Firenze 1989, S. 293-314.

27 Er übersetzt im wesentlichen die Teile, die vor ihm schon viele andere übersetzt haben: den ersten Gesang, die Inschrift am Eingang des Inferno. die Episode von Paolo und Francesca und die Erzählung des Grafen Ugolino.

28 In: Свободная совесть I, 1906.

29 "[...] in generale sono traduzioni abbastanza buone [...|" (V. Pepitoni: Ellis Kobylinskij tra Dante e Marx. a.a.O., S. 308).

30 $\mathrm{Vgl}$. W. Potthoff: Dante in RuBland. Zur ltalienrezeption der russischen Literatur von der Romantik zum Symbolismus. Heidelberg 1991. 
Aus der Divina Commedia übersetzt Ėllis eine ganze Reihe von Textstellen, die nun eben eindeutig den engen Bereich des Infermo verlassen und etwa zu gleichen Teilen dem Purgaturio und Paradiso entnommen sind. ${ }^{31}$

Ungeachtet der scharfen Kritik und schlechten Beurteilungen seiner Übertragungen darf jedoch Ėllis' Bedeutung als Übersetzer nicht ignorien werden. Seinen Übersetzungen stellte er Vorworte über die betreffenden Dichter voran, publizierte Aufsätze und hielt Vorträge über sie; auBerdem plante er ein umfassendes Werk über den französischen und belgischen Symbolismus ${ }^{32}$. Er trat als aktiver Vermittler der zeitgenössischen westeuropäischen Literatur in RuBland auf, galt seinerzeit als guter Baudelaire-Kenner und -Verehrer ${ }^{33}$, oder als Rodenbach-Spezialist ${ }^{34}$ und leistete Wichtiges bei der Vermittlung Dantes nach RuBland ${ }^{35}$.

Der Wert von Ëllis' Übertragungen liegt jedoch nicht nur in der Einschätzung und Vermittlung der übersetzten Autoren, sondern auch in ihrer Auswahl und vor allem in ihrer Transformation durch Ellis' Temperament und durch seinen subjektiven Stil. Die Kritik an seinen Übersetzungen bezieht sich häufig gerade auf diesen Stil und auf Ellis als Autor und Person, ist oft nicht frei von persönlichen Sympathien und Antipathien. Diese subjektive Art der Kritik war allerdings zur Zeit des Symbolismus allgemein üblich, wie sich den zahlreichen Rezensionen von Übersetzungen in den einzelnen Zeitschriften entnehmen läßt. In ihnen spiegeln sich häufig die persönlichen Beziehungen zwischen Übersetzer und Kritiker wider.

Die russischen Baudelaire-Ausgaben von 1970 und $1993^{36}$ zeigen deutlich, daB Ėllis als Übersetzer bis heute nicht in Vergessenheit geraten ist.

31 Ebd.. S. 522.

32 РО РГБ. Ф. 167. картон 10, ед.хр. 3-5. 7.

33 "|...| Отдельные веци Бодлэра мнотие переволили: и Бржосов. и Бальмонт, и Мережковский. но. вероятно. никто из них так хорошо. как Эллис. не знал Бодлэра и. что уже можно сказать уверенно. никто из них. и вообе [нз] символистов. не был таким его поклонником." (N. Valentinov: Dva goda s simvolistami. a.a.O.. S. 154.)

$34 \mathrm{Vgl}$. die Rezension zu "Молодая Бельгия" іn "Перевал". Nr. 5, 1907, S. 49.

$35 \mathrm{Vgl}$. W. Potthoff: Dante in RuBland. a.a.O., S. $522 \mathrm{f}$.

$36 \mathrm{Vgl}$. die Anmerkungen 6 und 9 dieses Kapitels. 


\section{Ellis als Lyriker}

Die beiden Gedichtbände "Stigmata" (1911) ${ }^{1}$ und "Apro" (1914) stellen das wesent liche Produkt von Ėllis' lyrischem Schaffen dar und sollen an dieser Stelle charakterisiert und diskutien werden.

In seinem Vorwort zu "Stigmata" hebt Ėllis hervor, daB der vorliegende Lyrikband neue Gedichte enthalte. Es handele sich dabei aber nicht um einzelne, selbständige lyrische Erlebnisse, sondern um die symbolische Darstellung eines in sich geschlossenen, ganzheitlichen mystischen Weges. In diesem Vorwor weist Ëllis, wie auch in seinen theoretischen Arbeiten zum Symbolismus ${ }^{2}$, darauf hin, daB symbolistische Kunst bzw. Lyrik Gebiete berühre, die über die sogenannte "reine Kunst" (чистое искусство) hinausgehen. Die rein künstlerische Aufgabe des Buches bestehe darin. dasjenige symbolisch darzustellen. was in der Seele aus religiösem Suchen heraus entstanden sei. In der Krise des zeitgenössischen Symbolismus ${ }^{3}$, die ihrem Ende zugehe, sieht Ëllis nur den Verfall des sogenannten Âsthetizismus und charakterisiert die Entwicklung innerhalb des Symbolismus folgendermaßen:

Это обращение от эстетического иллюзионизма к мистициму, говоря совершенно точно. - к христнанству, внутри "современного символизма" является. быть может. самым сушественным симттомом его развития, от Верлэна и Гюнсманса и до Роденбаха и Рильке. На этом пути неизбежно символизм приходит в интимнуо связь с священной символикой католицима. нал которой склоняется светлая тень величайшего нз поэтов с его потря саюиим благословением. тень Данте. ${ }^{4}$

Dieser Gedichtband von Ėllis steht daher ganz unter dem Einfluß Dantes und des Kults des westlichen Mittelalters. Wilfried Potthoff bezeichnet ihn als Nachbildung und teilweise Nachdichtung der einzelnen Stufen der "Divina Commedia" Dantes. Dies sei wahrscheinlich der einzige Fall einer "Nachdichtung" der "Divina Commedia", in der zusätzlich auch das System der mittelalterlichen Mystik beibehalten wur$\mathrm{de}^{5}$.

Entsprechend der "Divina Commedia" besteht Ėllis' Gedichtband aus drei Teilen. Jeder dieser drei Teile wird durch ein Zitat aus dem Anfang des entsprechenden Teils der "Divina Commedia" und seine russische Übersetzung eingeleitet.

Auf die einleitenden Gedichte "Клеопатре Петровне Христофоровой" ("An Kleopatra Petrovna Christoforova") und "Stigmata" folgt der erste Teil, dem die Verse 118-122 aus dem ersten Gesang des "Infemo" von Dantes "Divina Commedia" vorangestellt sind:

E vederai color che son contenti nel foco. perché speran di venire quando che sia a le beate genti.

A le qua' poi se tu vortai salire. anima fia a ciò più di me degna: $|. .|^{6}$

1 Den Umschlag zum Gedichtband "Stigmata" hat Asja Turgeneva künstlerisch gestaltet (vgl. M. Cvetaeva: Plennyj duch, a.a.O., S. 243).

$2 \mathrm{Vgl}$. die folgenden Kapitel der vorliegenden Arbeit.

3 Zur Krise des Symbolismus vgl. auch unten. S. 89. Anm. 5.

${ }^{4}$ Ëllis: Stigmata. Kniga stichov. Moskva 1911. S. V.

5 W. Pothoff: Dante in RuBland, a.a.O.. S. 445.

${ }^{6}$ Dante Alighieri: Die gö̈tliche Komödie, italienisch und deutsch. Übertragung und Erläuterung von August Vezin: Einfuihnung von Manfred Hardt. Basel, Rom 1989, S. 12. 
Den ersten Teil der Gedichte beherrscht das Böse. Neben den entsprechenden Themen und Motiven Dantes finden sich Schilderungen des Jüngsten Gerichts, präraffaelitisch stilisierte mittelalterliche Ritterlichkeit, Szenen unter präraffaelitischen "gotischen" Bögen und dergleichen ${ }^{7}$. In fast allen diesen Gedichten herrscht eine düstere Infernostimmung. die teilweise bereits in den Titeln anklingt: "В стране безумия" ("Im Land des Wahnsinns"), "Роза ада" ("Die Rose der Hölle"), "Злая лампада" ("Das böse Lämpchen"), "Возмездие" ("Die Vergeltung"), "Тень" ("Der Schatten"), "Экзорцизмы" ("Exorzismen"), "День облекающий" (Из Корана) ("Der bedeckte Tag", aus dem Koran), "Исторгающий" ("Der Verstoßene"), "Великий ИнквизиTop" ("Der GroBinquisitor"), "Museum Anatomicum", und "Dies Irae"8.

Als exemplarisches Beispiel aus dem ersten Teil dieses Lyrikbandes sei das Sonett "В стране безумия" angeführt:

\footnotetext{
Безумне. как черный монолит. ниспав с небес. воздвитлось саркофагом; деревьев строй подобен спяшим магам. луны ущербной трепетом облит.
}

\begin{abstract}
Здесь вечный мрак с молчаньем вечным слит; с опушенным забралом. с черным стягом. здесь бродит Смерть неумолимым шагом. как часовой среди беззвучных плит.
\end{abstract}

Здесь тенн тех. кто небо оскорбил 6огохуленьем замыслов безмерных. кто. чухлл земли вилений зфемерных.

Зла палалином безупречным был: здесь дуин тех. что сохранилн строго безумный лих отвергнутого Бога. 9

Dieses regelmäBige Sonett in fünffüBigen Jamben beeindruckt durch seine poetische Qualität: überzeugende, klare, zum Teil originelle Bilder und Metaphem, eine kunstvolle, gehobene, aber nicht gezwungene Sprache, ausschlieBlich genaue Reime und in der strengen Gedichtform eine verhaltene, aber sich steigernde Intensität der Aussage.

7 Vgl. hierzu auch W. Potthoff: Dante in RuBland, a.a.O., S. 446.

Die Gemeinschaft der Präraffaeliten ("Pre-Raphaelite-Brotherhood". 1848 gegründet von D.G. Rossetti. W.H. Hunt und J.E. Millais) war um Klarheit, Unmittelbarkeit der Gefühle und grobe Nähe zur Natur bemüht. wie sie in den Werken der italienischen Künstler in der Epoche vor Raffael vorgeherrscht hatten. Während die Technik der Präraffaeliten eher derjenigen der Renaissance entspricht. herrschen in ihren Kunsiwerken die Themen der Gotik und eines ausgeprägten Mittelalterkults vor. In der Dichtung heißt das vor allem: eine starke Verehrung Dantes und ein Bevorzugen der von religiösen Stimmungen durchdrungenen Lyrik des Mittelalters.

Besonders die "jüngeren Symbolisten" in Moskau standen in ihrer Frühphase ("Argonautenkreis") stark unter dem EinfluB der englischen Präraffaeliten, von dem sich Ëllis, vor allem in seiner Lyrik. nie ganz befreil hat: Die Größe und Vorherrschaft der römisch-katholischen Religion. die von den Präraffaeliten betont wurde, ist pragend für Ëllis' gesamtes lyrisches Werk. Vermutlich hat er sich sein Pseudonym nach einem den Präraffaeliten nahestehenden Dichter zugelegt: Edwin J. Ellis (vgl. hierzu W. Potthoff: Dante in RuBland, a.a.O., S. 182).

" Weitere Gedichte dieses ersten Teils: "Жених" ("Der Bräutigam"), "Tpyбa" ("Die Posaune"), "Рышарь двойной звезды" (Баллада) ("Der Ritter des doppelten Stem", Ballade). "Tантейзер на Турнире" (Баллада) ("Tannhäuser auf dem Turnier", Ballade), "Сфинкс" ("Die Sphinx"), "Жениина с веером" (Картина Пикассо) ("Die Frau mit dem Fächer", Bild Picassos), "Изранmo" ("An Israel"), "Римской Проститутке" ("An die römische Prostituierte") und "Экзотический закат" (При переводе "Цветов зла" Ш. Бодлэра) ("Der exotische Sonnenuntergang", beim Übersetzen der "Blumen des Bösen" von Ch. Baudelaire). (Ëllis: Stigmata, S. 5-52.)

${ }^{9}$ Ebd., S. 7. 
Die beschriebene Infernostimmung (Dunkelheit, ewiges Schweigen, Tod; das Reich des Bösen, Unheimlichen) erinnert an Baudelaire und F. Sologub, bei denen derartige Stimmungen jedoch Selbstzweck sind, während Ellis' Sonett funktional eingebunden ist in den Kontext des Infemo. Für die Schatten, die in dieses Reich der Finsternis verbannt sind, gibt es keine Hoffnung auf Erlösung. Dem Reich des Todes können sie nicht entrinnen. Die meisten Gedichte dieses ersten Teiles sind durch eine ähnlich düstere, traurige, pessimistische Stimmung geprägt und nur in seltenen Fällen läßt sich am SchluB ein schwacher Hoffnungsfunke erkennen.

Dem zweiten Teil von "Stigmata" 10 sind die Verse 4-6 aus dem ersten Gesang des "Purgatorio" vorangestellt:

E canterò di quel secondo regno. dove l'umano spirito si purga e di salire al ciel diventa degno." 1

In nahezu allen Gedichten dieses zweiten Teils drückt sich ein Streben nach etwas Überirdischem, Göttlichen aus. Das lyrische Ich möchte zum Himmel aufsteigen. Auch hier werden, neben den entsprechenden Themen und Motiven Dantes, wiederholt der Tag des Jüngsten Gerichts sowie mittelalterliches Rittertum und Gotik gestaltet ${ }^{12}$. Die Sehnsucht nach dem Paradies und die Ahnung, don schon einmal gewesen zu sein sowie die Hoffnung auf Errettung und Erlösung beherrschen viele dieser $\mathrm{Ge}$ dichte.

Einen relativ breiten Raum in diesem Teil nimmt das recht umfangreiche Gedicht "Фаэтон" ein ${ }^{13}$, eine dichterische Gestaltung der Sage vom Sohn des Sonnengottes Helios, der Ėllis ein Motto aus Ovids Phaëthon-Dichtung in den "Metamorphosen" voranstellt. In "Золотой город" ("Die goldene Stadt")14, einem ebenfalls ziemlich langen Gedicht, wird das Thema des Überschreitens der Grenze vom Diesseits zum Jenseits bildlich dargestellt: Das in der Hölle lebende lyrische Ich hält es don nicht länger aus und geht fort, auf die Erde, wo es bei Sonnenuntergang im Vorgefühl des Todes versucht, seinen Blick "hinter den Horizont" zu richten:

И ткхо мсркнул день, и отторал Захат...

я Смерти чувствовал святое дуновенье.

и я за горизонт вперил с надежлой взгляд

и я чего-то ждал... и выросло виденье. 15

Ihm erwächst die Vision einer goldenen Stadt, die plötzlich wieder verschwindet; jedoch die Seele des lyrischen Ich vergißt diese goldene Stadt nicht mehr.

Die übrigen Gedichte dieses Teils gestalten auf verschiedene Weise die Möglichkeiten der Überwindung des begrenzten irdischen Daseins, was zum Teil bereits in ihren Titeln ausgedrückt ist: "Ангел преддверия" ("Der Engel des Vorhofs"), "Ночные стигматы" ("Nächtliche Stigmata"). "Два голоса" ("Zwei Stimmen"), "Предсуществование" ("Das frühere Dasein"), "Погибшая" ("Die Verlorene"), "Requiem", "Видение" ("Die Vision"), "Обреченный" ("Der dem Untergang Geweihte"), "Последний полет" ("Der letzte Flug"), "Любовь и смерть" (Три сонета) ("Liebe und

${ }^{10}$ Ebd.. S. 53-104.

11 Dante Alighieri: Die göttliche Komödie, italienisch und deutsch, a.a.O., S. 380.

12 Z.B. das "gotische Fenster" in "Нал веснӧ" ("Über dem Frühling", Ėllis: Stigmata. S. 74).

13 Ëllis: Stigmata. S. 87-97.

14 Ebd., S. 98-104

15 Ebd., S. 101. 
Tod", drei Sonette), "Signum Mortificationis", "Ночь Алькадра" ("Die Nacht der Bestimmung")16, "Смерть Бедуина" ("Der Tod des Beduinen") 17.

Ein exemplarisches Beispiel dieses zweiten Teils stellt das Gedicht "Ночные стиrматы" dar:

Схимнци ноная в саване черном.

бледные руки слагая на грудь.

с взором померкшнм. понгашим. покорным.

Ночь совершает свой траурный путь.

Гаснут под взором ее. умярая.

краски и крьињя. глаза и лучн.

лишь за оградой далекого Рая.

внятней гремят золотые ключи.

Стротие смутны ее очертанъ:

саван цирокий. высокий клобук.

горькие вздохн. глухие рыданья

стелются сзади за нею... но вдрут

все ее очн на небо потьяты.

все мирналы горяиях очей.

блешут ее золотые ститматы.

в слапхом опне нисходяиих мечей.

Кровоточа. как багровая рана.

рдеет луна на разверстом белре.

Там в небесах по ступеням тумана

Ангелы схољт, восходят горе.

Боже! к Тебе простирако я длани.

о низведи сожитаюинй меч.

чтобы в отне нестерпимых пыланий

мог я ночные ститматы зажечь! 18

Das Gedicht besteht aus sechs vierzeiligen Strophen (im Kreuzreim) in regelmäBigen vierfüBigen Daktylen. Es beschreibt die Nacht - eine junge Nonne im Totengewand, die alles ersterben läßt: aber zugleich gibt es zahlreiche Hinweise auf den Himmel, das Paradies, die Engel, also auf etwas Überirdisches, Besseres, die Hoffnung auf einen Erlösung bringenden Gott, dem das lyrische Ich seine Hände entgegenstreckt. Die Sprache dieses Gedichts ist gekünstelt, klischeehaft, mitunter pathetisch, weist jedoch etliche Stilbrüche und Schwächen auf (vgl. z.B. "но вдруг" in der 4. Zeile der 3. Strophe 19 und im Gegensatz dazu "ллани" statt "руки" in der 1. Zeile der letzten

16 Übersetzung der Sure 97 aus dem Koran, die den Titel "al-qadr innā anzalnăhu" trägt.

17 Weitere Gedichte dieses Teils: "Петелийская надиись" ("Die Aufschrift von Petelos") [die genave Bedeutung dieses Titels konnte von der Verfasserin nicht ermittelt werden; da das Gedicht in Griechenland spielt, bezieht sich der Name möglicherweise auf Petelos (= ein unbekannter On in der Gegend zwischen Lesbos und Tenedos)|. "Черньй рыцарь" ("Der schwarze Ritter"). "У вечернего грота" ("Bei der abendlichen Grotte"). "Далекой" ("An die in der Ferne Weilende"). "Над весной" ("Über dem Frühling"). "Пряxa" (Баллада) ("Die Spinnerin", Ballade). "Бельй pыцарь" ("Der weiße Ritter"). "Рассказ Илармо" ("Eine Erzählung über llarion").

18 Ëllis: Stigmata. S. 57.

${ }^{19}$ Dieses "но вдруг" hat A. Cechov bereits 1883 in seiner Erählung "Смерть чиновянка" ("Der Tod eines Beamten") parodiert. die folgendermaBen beginnt: "В один прекрасный вечер не менее трекрасний экзекутпр. Иван Пмитрич Червяков. сидел во втором ряду кресел и глядел в бинокль на "Корневильскне колокола". Он глядел и чувствовал себя на верху блаженства. Но вцуут В рассказах часто встречается зто кно вдрут». Авторы правы: жизнь так полна внезапностей!" (A.P. Čechov: Polnoe sobranie soxinenij i pisem v 30-i tt. Soxinenija v 18-i tt. Tom 2. 
Strophe; oder die ersten beiden Verse der 5. Strophe; vgl. auch die Tautologie in der zweitletzten Zeile sowie den Widerspruch in der ersten Zeile der dritten Strophe). Anstelle der für symbolistische Gedichte charakteristischen Dissonanz (z.B. die zwei Monde in V. Brjusovs Gedicht "Творчество") herrscht bei Ëllis Heterogenität vor: Sobald man sich auf eine Stimmung einläBt, wird sie gleich wieder gebrochen (etwa die Stimmung der Nacht, die in der 1. Strophe erzeugt wird). So muB "Ночные ститматы" als konstruiertes, nicht gelungenes symbolistisches Gedicht bezeichnet werden.

Dem dritten und umfangreichsten Teil von "Stigmata" 20 sind die Verse 88-90 aus dem dritten Gesang des "Paradiso" vorangestellt:

Chiaro mi fu allor come ogni dove in cieloe paradiso, etsi la grazia del sommo Ben d'un modo non vi piove. 21

In diesem dritten Teil findet sich neben Themen und Motiven Dantes vor allem ein ausgeprägter Madonnenkult. Das lyrische Ich hat häufig Visionen des Paradieses, Begegnungen mit Beatrice, Engeln, Heiligen, der Gottesmutter; die irdischen Qualen sind vorüber, der Aufstieg in den Himmel ist vollendet und der Zustand paradiesischer Glückseligkeit erreicht. Die Gedichte dieses Teils sind in fünf Untergruppen zusammengefaßt:

I. Врата (Das Tor): "Пролог" (Из Фельмеллера) ("Prolog", aus Fel'meller)22. "Братям-Рыцарям" ("An die Ritter-Brüder"), "Молитва" ("Gebet"), "Благая весть" ("Die gute Kunde"), "Избраннику" ("An den Auserwählten"), "Tемплиер" ("Der Templer").

2. Узорное окно (Das bunte Glasfenster): "Признание" ("Das Eingeständnis"), "Узорное окно", "Божий сад" ("Gottes Garten"), "Сновидение" ("Das Traumgesicht").

3. Беатриче (Beatrice): "Данте и Беатриче" ("Dante und Beatrice"), "Беатриче умерла" ("Beatrice ist gestorben"), "Свидание" ("Das Wiedersehen"), "Сон" ("Der Traum"). "Беатриче", "Ha «Vita Nova» Данте" (из О. Уайльда) ("Auf Dantes "Vita Nuova»", aus O. Wilde), "В духе Петрарки" (Из И.М. Эредиа) ("Im Geist Petrarcas", aus J.M. Hérédia), "Псалом радостный" ("Der Freudenpsalm").

4. Sancti: "Святой Суза" ("Der Heilige Suso")23. "Святой Луиджи" (Св. Людовик Гонзагский) ("Der heilige Luigi" [Der heilige Ludovico Gonzaga]), "Видение сердца Йисусова блаженной Маргарите Алаквийской" ("Die Vision des Herzens Jesu der seligen Margareta Alacoque"), "Видения святой Терезы" ("Die Vision der heiligen Theresia"), "О Кресте святой Терезы" ("Über das Kreuz der heiligen The resia"), "Святой Терезе" ("An die heilige Theresia").

5. Ave Maria: "Молитва о падшей" ("Gebet über eine Gefallene"), "Перед боем" ("Vor der Schlacht"), "Maris Stella", "Rosa Mystica", "Моей Мадонне" ("An meine Madonna"). "Две Марии" ("Zwei Marien"), "Молитва св. Бернарда Деве Марии" (Из Данте Алигиери) ("Das Gebet des heiligen Bemard an die Jungfrau Maria", aus

Moskva 1975, S. 164); es kann nicht emstgenommen werden und fühn han an die Grenze der unfreiwilligen Parodie.

20' $\dot{1 l l i s: ~ S t i g m a t a, ~ S . ~ 105-166 . ~}$

21 Dante Alighieri: Die göttliche Komödie, italienisch und deutsch, a.a.O., S. 788.

22 Die Verfasserin konnie nicht ermitteln, welcher Dichter sich hinter dem Namen Fel'meller verbirgt.

$23 \mathrm{Vgl}$. unten. $\rightarrow$ Heinrich Seuse (im "Namenregister"). 
Dante Alighieri), "Ave Maria", "Stabat Mater Dolorosa", "Ave Maris Stella", "Cnaсение" ("Die Erlösung").

In den Gedichten der ersten Gruppe befindet sich das lyrische Ich noch vor den Toren des himmlischen Paradieses, in einer Erwartungshaltung. In denen der zweiten schaut es durch ein Fenster in den Paradiesesgarten, träumt vom Paradies. In den Gedichten der dritten Gruppe weilt das lyrische Ich bereits in der überirdischen. himmlischen Welt, in der es Beatrice begegnet. Die Gestalt der Beatrice wird hier von Ėllis zu einem kombinierten Symbol für Göttlichkeit. Harmonie und das Ewig-Weibliche. Beschützende stilisien ${ }^{24}$, was jedoch nicht originell ist, sondem auf Goethe und V1. Solov'ev (die Gestalt der Sophia) zurückgeht und einen gängigen symbolistischen Topos darstellt (etwa in A. Bloks früher Lyrik, vor allem in den "Стихи o Прекрасной Даме"). Die Gedichte der vierten Gruppe haben das Leben, die Leiden und Qualen, das Martyrium und die Visionen verschiedener Heiliger zum Gegenstand, während in den Gedichten der letzten Gruppe die Gestalt der Jungfrau Maria, die Gottes mutter im Zentrum steht.

Als ein Beispiel dieses dritten Teils von "Stigmata" sei das Gedicht "Сон" aus der Gruppe "Беатриче" angeführ:

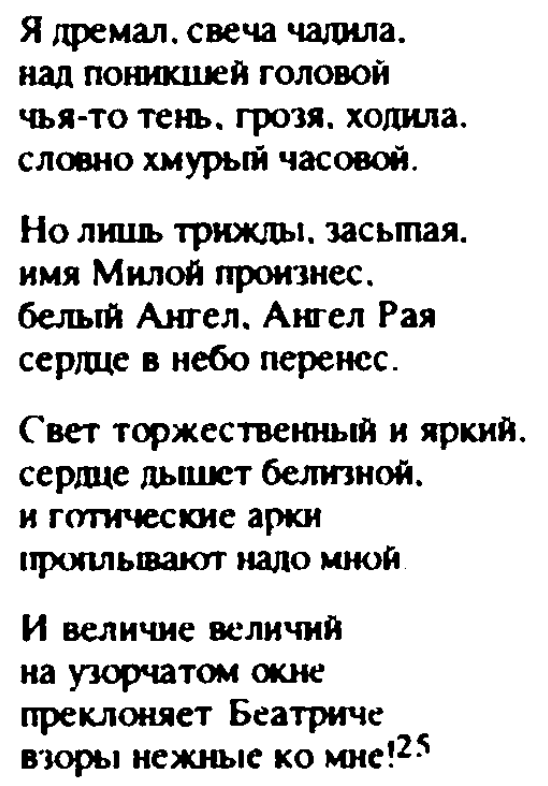

Dieses vierstrophige Gedicht mit jeweils vier kurzen kreuzgereimten Zeilen in regelmäBigen vierfüBigen Trochäen beschreibt einen Traum: Ein Paradiesesengel trägt das Herz des lyrischen Ich ins Paradies, wo Beatrice ihm ihre zärtlichen Blicke zuwendet. Es ist zugleich ein Musterbeispiel für Ëllis' stilisienten Mittelalterkult (vgl. die gotischen Bögen und die bunten Glasfenster). Das feierliche, helle Licht des Paradieses steht in starkem Kontrast zum düsteren irdischen Schattendasein, das zu Beginn dieses Gedichts und vor allem im ersten Teil von "Stigmata" beschrieben wird. Aber auch dieses Gedicht ist sprachlich nicht allzu überzeugend, wirkt heterogen und an den Stellen, wo es besonders erhaben und feierlich scheinen soll, beinahe komisch (vgl. die ersten beiden Zeilen der letzten Strophe) durch Kombination einer abstrakten Hyperbel ("величие величий") mit einem ungenauen, banalen Bild ("узорчатое окно").

Betrachtet man die Gedichte in "Stigmata" insgesamt, fallt auf, daB sie eigentlich alle in traditionellen syllabotonischen Versformen geschrieben sind. Neben vielen Ge-

$24 \mathrm{Vgl}$. W. Potthoff: Dante in RuBland, a.a.O., S. $447 f$.

25 Ellis: Stigmata. S. 123. 
dichten mit einer unterschiedlichen Anzahl vierzeiliger Strophen, meist im Jambus (mitunter finden sich aber auch andere VersmaBe wie Trochäus, Daktylus, Amphibrachus, selten Anapäst), gibt es, vor allem im dritten Teil, etliche Gedichte in Terzinen (fünffüßige Jamben, Reimschema wie in Dantes "Divina Commedia"), einige Sonette sowie auch Gedichte mit zwei-, drei-, fünf- und sechszeiligen Strophen. Fast alle Gedichte haben ein regelmäBiges, festes Reimschema mit genauen Reimen. Die Sprache wirkt häufig recht stilisien, phrasen- und klischeehaft, mitunter archaisch und an betont feierlich-pathetischen Stellen zuweilen überzogen, bis zum UngewolltKomischen, was durch Stilbrüche ausgelöst wird. Bestimmte Schlüsselworte, wie etwa "стигмата" ("Stigmata"), "лампада" ("Lämpchen"), "рыцарь" ("Ritter"), "роза" ("Rose"), "крест" ("Kreuz"), "узорное окно" ("buntes Glasfenster"), "готические арки" ("gotische Bögen"), "Дева Мария" ("Jungfrau Maria") (mit den entsprechenden Adjektiven) tauchen immer wieder auf und haben die Funktion von Leitmotiven.

Im April 1911 schrieb VI. Vol'kenštejn in der Zeitschrift "Современный мир" ("Modeme Welt") eine kurze Rezension zu Ėllis' Gedichtband "Stigmata", in der er Ellis' Weltanschauung sehr treffend als "katholischen Symbolismus" mit "Buchcharakter" (книжный характер) bezeichnet. Es heißt in dieser Rezension:

[...] Не говоря уже 06 односторонней. преувеличенной. явно безжнзненной тенденции автора. сборник стихов не может быть ясным и убедительным выраженнем "цельного мистического пути"; автор напрасно пренебрегает художественњымн задачамн [...] Стихн г. Эллиса, в хачестве "лирических переживаний" (ведь. это. все-тахи. стнхи!) слииком реторичны $[\ldots]^{26}$

Man spüre in Ėllis' Gedichten deutlich den Einfluß Dantes und Baudelaires und von den zeitgenössischen Dichtern vor allem Brjusovs (was die Form betrifft). Gelegentlich seien die Gedichte jedoch effektvoll (z.B. "Фаэтон") und vom Gedankengang her interessant (Z.B. "Израилю")27.

Der Gedichtband "Apro" ist dem Andenken VI. Solov'evs gewidmet. In seinem Vorwort zu diesem Werk ${ }^{28}$ weist Ėllis darauf hin, daB die Gedichte im vorliegenden Band zwischen 1905 und 1913 entstanden seien aus den verschiedensten Erlebnissen. Bestrebungen und Einflüssen heraus, aber dennoch eine innere Einheit bildeten. Die ses Vorwor, im Oktober 1913 in Stuttgan verfaBt ${ }^{29}$, trägt programmatischen Charakter und erläutert den Aufbau des vorliegenden Lyrikbandes. Dabei paßt sich Ėllis oberflächlich und abstrakt der Diktion Vjax. Ivanovs. Bloks und Belyjs zur Zeit des "Symbolistenstreits" 1909-1910 an, die jedoch Ende 1913 längst überwunden war. Ėllis ignorient völlig die Weiterentwicklung des Symbolismus und die Abspaltung modemistischer Strömungen, wie zum Beispiel die der Akmeisten und Futuristen. Am Vorabend des Ersten Weltkriegs schafft er ein Werk. das ein Gemisch aus Romantik und frühem Symbolismus darstellt. also ganz unzeitgemäB und veraltet erscheint. Er ruft die Leser auf, sich zurückzuwenden zum "verlorenen Paradies" (yтpaченный рай) und die "vergessenen Gelübde" ( забытые обеты) zu emeuem. Der zeitgenössische Dichter müsse sich den Stimmen der Kindheit hingeben, diesem kleinen, verlorenen Paradies mit seinen Trugbildern. Träumen und Märchen, müsse an sie glauben. Dabei entspricht Ellis' Auffassung der Kindheit weitgehend dem romantischen Kindheitstopos: Kindheit als Rückkehr in einen naiven Zustand der Reinheit

26 Sovremennyj Mir. Ežemesjažnyj literaturnyj. nauð̌nyj i politiđ̌eskij Žumal. Nr. 4, Aprel'. SPb. 1911 . S. 357.

27 Ebd., S. 356f.

28 Ëllis: Argo. Moskva 1914, S. IX-XI.

29 Ebd., S. XI. 
und Geborgenheit; daneben finden sich aber auch Anklänge an das symbolistische Kindheitsverständnis: Kindheit, verstanden als ein anderes Sehen der Welt, als ein anderer BewuBtseinszustand ${ }^{30}$. Eine abenteuerliche Kombination von Romantik und Symbolismus findet sich in Ëllis' Wamung vor dem Reich der "blauen Blume" (= Romantik), der "Gobelins" und der "Masken" (= Symbolismus), wo alles Lug und Trug sei (ohne Religion und Glaube). Der Dichter müsse sich zurückwenden, um die vergessenen Gelübde zu erfüllen; erst dann könne er sein verlorenes, himmlisches Paradies in weiter Feme erblicken, zu dem drei Wege führen. die eine Einheit bilden: der Weg der geistigen Armut, der Reinheit und der Demut ("путь нищеты духовной, чистоты и смирения"). Ëllis verweist hier nachdrücklich auf das Ideal des asketischen mittelalterlichen Rittertums; das erinnert stark an die frühe Lyrik Bloks, die deutlich romantische Züge trägt. Er führ weiter aus, daB demjenigen, der diesen drei Wegen folgt, drei große und ewige Symbole erscheinen: das Mönchskreuz, der Ritterkelch und der Pilgerstab ("крест монаха, чаша рыцаря и посох пилигрима") ${ }^{31}$. Wer diese drei Wege und diese drei Symbole würdig besinge, so hebt Ėllis weiter hervor, werde ein wahrhaft religiöser Dichter; wer sie vollkommen annehme, werde ein heiliger Dichter. Der Dichter müsse ein Ritter werden. Da er noch nicht das Paradies und das himmlische Jerusalem sehe, müsse er ihre irdischen Ebenbilder preisen: die Städte Jerusalem und Assisi. Ein solches Loblied werde zum Wunschtraum der zukünftigen Wiedergeburt der christlichen Kunst. Ėllis beendet sein programmatisches Vorwor mit dem Satz: "Не веря иным путям, мы верно ждем Рыцаря БедHoro." 32

Der Gedichtband "Apro" besteht aus drei Teilen: 1. Apro; 2. Забытые обеты; (Vergessene Gelübde) 3. das Ritterpoem Мария, die ihrerseits wieder in Untergruppen untergliedert sind.

Dem ersten Teil ist das Gedicht "Apro" vorangestellt, das aus der Zeit der "Argonautentreffen" bei A. Belyj (1905) stammt:

В волнах солнечньй иит отрахается.

вечно пльть мы усталн давно:

на холу быстрын Арго качается.

то Борен roнort наuке судно.

В волнах солнечный иит отражается...

Чьн-то слезы смочкли канаты утругие.

за кормоно - струн серебра...

"Ах. увижу ль зарно снова. друти. я.

${ }^{30}$ Ein Beispiel hierfür ist A. Belyjs "Koтиk Летаeв" (1922): die Aufarbeitung der Kindheit durch den BewuBtseinsstrom.

31 Ëllis: Argo, S. XI.

Auch diese "ewigen" Symbole sind nicht originell, sondern finden sich schon viel früher bei den anderen Symbolisten und ihren Vorläufern (VI. Solov'ev, Blok. Vjac. Ivanov I"Пlocox свой доверял я Gory" - "Meinen Pilgerstab habe ich Gott anvertraut"I. Dobroljubov; aber auch bei R. Wagner [Gral], der ja von grober Wichtigkeit für die russischen Symbolisten war).

$\$ 2$ Ėllis: Argo. S. XI.

Als Quelle für das Motiv des "Pьцарь Бедный" ("Armen Ritters") diente Ėllis u.a. Pußkin. wobei er jedoch gewiB den ironischen Charakter von Puskins "Сцены из рыщарских времен" ("Szenen aus der Ritterzeit") überlesen hat. Hierzu und auch zum Aufbau von "Apro" vgl. den Aufsatz von L.V. Sproge: Motiv "Rycarja Bednogo" v poezii simvolistov. (Otganizacija chudożestvennogo edinstva knigi stichov Ėllisa "Argo"). In: Puskin i russkaja literatura. Sbomik nauenych trudov. Riga 1986. S. 102-109.

Die Kluft zwischen dem zeitgenössischen Symbolismus und Ellis' mystisch-religiösen Ergüssen in "Apro" wird besonders deutlich, wenn man bedenkt, daB A. Belyj etwa gleichzeitig seinen Roman "Пleтербурr" publizierte (in drei Heften des Almanachs "Сирин" I= mystischer Vogel mit Frauengesicht und -brust] 1913/1914). 
илн бросять нам якорь пора?"

Чьи-то слезы смочнли канаты упрутие...

Стонет ветер... Безмолвно столшилась на палубе Аргонавтов печальных семья..

Стонет ветер. нет отзыва горестнй жалобе...

"Где вы. где вы, иные края?!"

Нет ответа их горестной. горестно̆ жалобе...

Что? стоим? То Нептун своей дланью могучею держит зыбкое наше судно...

Словно тогою. небо закуталось тучею. солнга шит потрузился на дыо. Взор слезою наполнился жгучею... Где же ты. золотое руно?33

Das Gedicht besteht aus drei fünfzeiligen und einer abschließenden sechszeiligen Strophe mit Kreuzreim in drei- und vierfüBigen, bisweilen unregelmäBigen Anapästen und gestaltet in recht schwülstiger, überladener Sprache (zum Beispiel die erste Zeile der zweiten Strophe oder die gesamte vierte Strophe) die Suche und Sehnsucht der Argonauten: Die Sonne spiegelt sich im Wasser, das Schiff Argo schaukelt auf den Wellen (der schaukelnden Wellenbewegung entspricht der aus dem Wechsel von Lang- und Kurzzeilen hervorgehende Rhythmus); die Argonauten sind müde von ihrer langen Irrfahr auf dem Wasser; sie sind traurig und sehnen sich nach "anderen Ländem" (иные края); sie klagen. Der Himmel bedeckt sich mit Wolken, der Blick füllt sich mit Tränen. Neptun hält das schwankende Schiff in seiner mächtigen Hand. Wo ist das Goldene Vlies? Werden sie es finden? Dieses Gedicht drückt symbolisch das Verlangen und Streben jener symbolistischen Dichter aus, die seit 1902/1903 im "Argonautenkreis" zusammenkamen und auf der Suche nach etwas Neuem waren. Ihre überspannten Erwartungen und Illusionen wurden nicht erfüllt, und so wanten sich die meisten unter ihnen enttäuscht und desillusioniert von dieser mystisch-romantischen Position ab (ein Beispiel dafür ist Bloks lyrisches Drama "Балаганчик" ["Die Schaubude"]), während Ellis die mystisch-religiösen Bestrebungen der "Argonauten" verstärkte und weiterführe bis hin zu seinem "katholischen Symbolismus".

Die folgenden Gedichte dieses ersten Teils sind in drei Gruppen zusammengefaBt:

1. Табакерка с музыкой (Die Spieldose); 2. Голубой цветок (Die blaue Blume) und 3. Гобелэны (Die Gobelins).

In der ersten Gruppe ${ }^{34}$ finden sich vor allem Kindergedichte oder Gedichte, die Kinder oder Märchenmotive thematisieren. In einigen Gedichten klingt an. daB die Kinder noch einen unmittelbaren Zugang zur überirdischen Welt haben. Sie werden von ihrem "Schutzengel" (dem "ангел хранитель". der in vielen Gedichten vorkommt) behütet. Einige Gedichte haben die Natur, Blumen, Schmetterlinge zum Gegenstand. Aber nicht nur das ungetrübte Reich der Kindheit wird gestaltet, sondem auch der Verlust des direkten Zugangs zum Paradies klingt in manchen Gedichten an (z.B. in "Отрава" - "Gift"35). Viele Gedichte in dieser Gruppe sind Kindern gewidmet, einige auch den Schwestern Marina und Anastasija Cvetaeva. Die Titel der meisten Gedichte verweisen auf die Thematik, die im Gedicht gestaltet wird: häufig kommt das Kindliche im Titel bereits durch Diminutiva zum Ausdruck: "Органчик" ("Die Spieluhr"), "Колокольчкк" ("Die Glockenblume"), "Одуванчик" ("Der Löwenzahn"), "Елка" ("Der Tannenbaum"), "Мотылек" ("Der Schmetterling"), "Де-

\footnotetext{
33 Ėllis: Argo. S. 3.

34 Ebd. S. 5-38.

35 Ebd., S. 36.
} 
вочке в розовом" ("Dem Mädchen in Rosa"), "В миг пробужденья" ("Im Moment des Erwachens"), "Четыре слезы" ("Vier Tränen"), "Бедный юнга" (Баллада) ("Der arme Schiffsjunge", Ballade), "Прежней Ace" ("An die frühere Asja"), "Мальчик с пальчик" ("Der Däumling"), "В раю" ("Im Paradies"), "Ангел ребенку" ("Der Engel zum Kind"), "Снежинка" ("Die Schneeflocke"), "В рай" ("Ins Paradies"), "Песня кукол" ("Das Puppenlied"), "Ангел хранитель" ("Der Schutzengel") $)^{36}$.

Die Gedichte der zweiten Gruppe ${ }^{37}$ zeichnen sich insgesamt durch eine recht traurige Sehnsucht nach dem verlorenen Paradies, nach Harmonie und Schönheit sowie durch Einsamkeit aus; dies geht aus den meisten Titeln bereits hervor: "Печальный малригал" ("Das traurige Madrigal"), "Одиночество" ("Einsamkeit"), "Самообман" ("Selbstbetrug"), "Résignation", "Призрак" ("Das Trugbild"), "Дым" ("Rauch"), "Смерть облака" ("Der Tod der Wolke"), "Мертвый сад" ("Der tote Garten")38. Neben Trauer, Tod und Trugbildem flackert in einigen Gedichten jedoch ein schwacher Hoffnungsschimmer.

Eine besonders schmerzlich-düstere Stimmung der Trauer und Vergänglichkeit gestaltet Ellis in seinem A. Blok gewidmeten Gedicht mit dem literaturgeschichtlich gewichtigen Titel "Résignation"39. Es lassen sich zwar bei Ëllis keine direkten Belege finden, die auf Schillers berühmtes Gedicht "Resignation" (1784) ${ }^{40}$ und auf Turgenevs Novelle "Jakov Pasynkov" (1855), die um dieses Gedicht und die Wirkung Schillers kreist ${ }^{4}$, verweisen, aber das Motiv des stillen Erleidens und Duldens von Schmerz, Kummer, Trauer und Untergang und das Empfinden von Wehmut und "süBem Schmerz"42 wird sehr deutlich in Ëllis' Gedicht in neun vierzeiligen kreuzgereimten Strophen in vierfüBigen Jamben gestaltet. Das lyrische Ich besingt alles Schwindende, Untergehende, und fühlt sich zu Leid, MiBgeschick. Hoffnungslosigkeit und den Armen der Welt hingezogen:

Люблю я кротость увяданья

и воск покорного лица.

лкблк страданье лля страданья

и безнадежность без конаа!

[...]

И вас. нссякиувише рехи.

36 Weitere Gedichte dieser Gruppe: "Berceuse", "В апреле" ("Im April"), "Весной" ("Im Frühling"). "Меланхолия" ("Melancholie"). "Декламация" ("Rezitation"), "Oceнь" ("Herbst"), "Гаммы" ("Tonleitem"), "Безмолвие" ("Das Schweigen"), "Святая книта" ("Das heilige Buch").

37 Ebd.. S. $39-61$.

38 Das erste Gedicht dieser Gruppe trägt den Titel "Голубой цветок" ("Die blaue Blume"). der - als Symbol der (deutschen) Romantik (Novalis) - die Sehnsucht nach göttlicher Harmonie, Vollkommenheit und ewiger Schönheit signalisien: das schöne Bild der "blauen Blume" soll dem traurigen. einsamen lyrischen Ich als fernes Ideal erscheinen und Trost spenden. Weitere Gedichte dieser Gruppe: "Mog звезда" ("Mein Stem"). "Пожатие" ("Der Händedruck"), "Встреча" ("Die Begegnung"), "Водомет" ("Der Wasserwerfer"). "Aнтел скривки" ("Der Geigenengel") und "B вarote" ("Im Waggon").

${ }^{39}$ Ebd., S. 50f. Dieses Gedicht entstand wahrscheinlich 1910, nach Bloks Beitrag im "Anorлoн": "O современном состоянин руссхого символизма", der Ëllis so begeisterte, daB er sich mit Blok aussöhnte (vgl. hierzu auch oben, S. 38).

$40 \mathrm{Vgl}$. Schillers Werke. Nationalausgabe. Bd. 1. Weimar 1943. S. 166-169; Bd. 2. Teil 1. Weimar 1983. S. $401-403$.

$41 \mathrm{Vgl}$. I.S. Turgenev: Polnoe sobranie socinenij i pisem $v$ tridcati tomach. Socinenija $v$ dvenadcati tomach. Tom 5. Moskva 1980. S. 49-89, 401-412: R.-D. Kluge: Ivan S. Turgenev. Dichtung zwischen Hoffnung und Entsagung. München 1992. S. 127, 149.

$42 \mathrm{Vgl}$. das Ende von Turgenevs Novelle. 
сердиа. закованные в лед. вас горемьки. вас калеки мое 6езумне noet! 43

\section{Am Ende des Gedichts heißt es:}

Но нет душе испепеленной святей. как все отнимет даль. тебя. любви неразделенной неизреченная печаль! 44

Das letzte Gedicht dieser zweiten Gruppe des Teils "Apro" ist A. Belyj gewidmet und trägt den Titel "B вагоне"45, sicher ein direkter Bezug von Ėllis auf Belyjs Lyrikband "Пепел" ("Asche", 1908), in dem die Eisenbahn usw. eine Rolle spielt ${ }^{46}$. In diesem Gedicht aus sieben vierzeiligen kreuzgereimten Strophen in vierfüBigen Trochäen herrscht eine Stimmung der Einsamkeit und Verzweiflung ${ }^{47}$. Allein im leeren Waggon, von Finsternis umgeben, jagt das lyrische Ich schon "jahrhundertelang" ("целые столетъя") umher und ist dem Wahnsinn nahe; jedoch wie ein Leitmotiv zieht sich durch das ganze Gedicht der zarte Schein des "grünen Lämpchens", der das lyrische Ich tröstet und seinen Kummer linder. Dieses dreimal zitierte "Утоли моя печали" 48 (jeweils in der letzten Zeile der ersten, vienten und siebten Strophe) verweist auf den Namen einer bekannten russischen Ikone und suggerien, daB der Trost in der christlichen Religion, im Glauben zu suchen sei. Die drei letzten Strophen des Gedichts lauten:

Для погибинх нет свнданья.

для безумюых нет разлуки.

буду я. тая рыданья.

мчаться век. ломая руки!

Мой двойник из тъмы оконца

мне насмешливо кивает.

"Мы летим в страну без Солнца".

и. кивая. упльвает.

Но со мной моя загалка.

грезы сердце ухачаля.

плач. зеленая лампапка

"Утоли моя печали" .49

In den Gedichten der dritten Gruppe ${ }^{50}$ wird eine Traum- und Bilderwelt gestaltet. Durch die dargestellten Szenen auf Bildem und Gobelins werden Wände belebt. man gerät ins Träumen und vermag nicht mehr zwischen Traum und Wirklichkeit zu unterscheiden. Auch die Beschreibung von Maskenbällen, Illusionen und Gemälden ge hört in diese Gedichtgruppe. Allein in einem Zimmer mit Gobelins fühlt sich das lyrische Ich nicht einsam, denn auf den Wänden spielt sich das Leben ab, an dem das lyrische Ich teilnimmt. Auf ein einleitendes Gedicht über Gobelins und die "Терцины

43 Ėllis: Résignation (6. und 8. Strophe). In: Ders.: Argo, S. 50 f.

44 Ebd.. 9. Strophe, S. 51.

45 Ëllis: Argo, S. 61 f.

46 Vgl. hierzu auch A. Lavrov: A. Belyj v 1900-e gody, a.a.O., S. 258.

47 Auch das entspricht der dominierenden Stimmung in Belyjs Lyrikband " Пener", der entstand. nachdem sich Belyjs Hoffnungen und Ideale der "Argonautenphase" als nicht realisierbar erwiesen hatten.

48 Ëllis bedient sich hier des Kirchenslavischen.

${ }^{49}$ Ėllis: V vagone, Strophe 5-7. In: Ders.: Argo. S. 61 .

50 Ėllis: Argo, S. 63-96. 
в честь Жиля Гобелэна" ("Terzinen zu Ehren Gilles Gobelins ${ }^{51 ") ~ f o l g t ~ e i n ~ Z y k l u s ~}$ mit sieben Gobelin-Gedichten, in denen die strenge Form des italienischen Sonetts stets gewahrt ist (es handelt sich also um einen halben Sonettkranz) und die im Gesamtkontext von Ëllis' Lyrik als recht gelungen bezeichnet werden können; und zwar einmal durch die Originalität des Themas: Bilder, Reliefs, Skulpturen u.a. aus der bildenden Kunst sind häufig in Gedichten als Auslöser von Fantasie und Einbildung eingesetzt worden, weniger aber Gobelins und überhaupt Gewebe. AuBerdem be herrschte Ëllis die Sonettform und verwendet in den "Gobelin-Sonetten" geeignete und teilweise originelle Metaphern und Bilder. Auch sprachlich sind diese Gedichte insgesamt überzeugender als die meisten anderen. Als Beispiel soll das dritte "Gobelin-Sonett" angeführt werden:

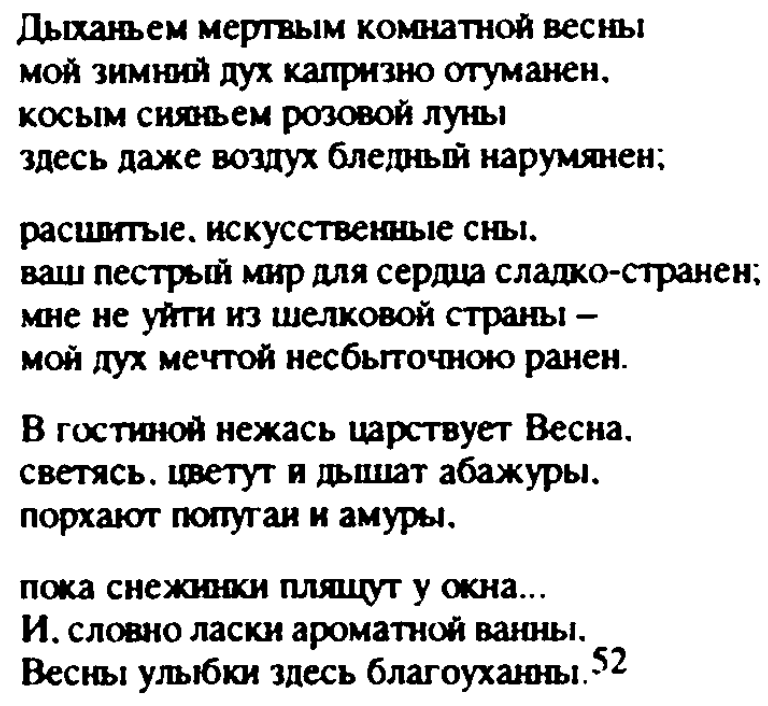

Der Leser wird in diesem Sonett aus der winterlichen Realität in die Traumwelt des duftenden Frühlings auf den kunstvoll gestickten Wandteppichen geführ, und es bleibt seiner schöpferischen Fantasie überlassen, sich diese künstliche Paradieswelt weiter auszumalen. Die zunächst recht sonderbar, beinahe kühn, avantgardistisch an mutende Metapher in der ersten Zeile ("комнатной весны" - "Zimmerfrühling") korrespondiert mit der "aromatischen Wanne"("ароматной ванны") in der zweitletzten Zeile und erzeugt so sehr überzeugend verklammernd die unwirklich künstlich stilisierte Atmosphäre und ihre Wirkung auf das empfängliche, ideale Schönheit suchende lyrische Ich im Kontrast zur Natur, die nur sparsam drauBen angedeutet wird. $\mathrm{Zu}$ dieser Aussage des Künstlichen, des symbolistischen artifiziellen Raumes paBt die strenge Sonettform gut. Die fünffüBigen Jamben sind regelmäBig und fließend, und die kunstvoll gehobene Sprache ist dem Inhalt angemessen.

Auf diese "Gobelin-Sonette" folgen die Gedichte: "Последнее свидание" ("Das letzte Wiedersehen"), "Ночная охота" ("Die nächtliche Jagd"), "Маскарап" ("Die Maskerade"), "Менуэт" ("Das Menuett"), "Иллюзия" ("Die Illusion"), "В парке" ("Im Park"), "Комната" ("Das Zimmer"), "Красная комната" ("Das rote Zimmer"), "Даме луне" ("An die Dame Luna"), "Больные лилии" ("Die kranken Lilien"), "Tourbillon", "Rococo triste", "Rococo gai".

51 Möglicherweise ein Mitglied der französischen Färberfamilie Gobelin (15. Jahrhundert).

52 Ėllis: Argo. S. 72. 
Der zweite Teil des Gedichtbandes "Apro" mit der Überschrift "Забытые обеты"53 ist in zwei Gruppen untergliedert: 1. Pietà und 2. Beauséant ${ }^{54}$. Diesen beiden Gruppen vorangestellt ist das Gedicht "Забытые обеты" (1913), sozusagen als Motto oder Leitfaden dieses gesamten zweiten Teils:

В день изтнанй. в час уныния.
изнемогшнй. фужденный.
славословь трн вечных розы.
трн забьтые обета.

Роза первая - смиренье.

Бедняка Хрнстова сердие. роза скорбн. обрученъе

со святон Нищетою!

Славословь другую розу целомудрне святое.

серщие кроткое Марнн.

предстоящей у Креста.

Роза третья - сердце Aтнца.

роза страшных послушанкй.

роза белая Грааля.

отверзаюирая Рай! ${ }^{55}$

Dieses Gedicht, das aus vier reimlosen (bei Ėllis recht selten) vierzeiligen Strophen im vierfüBigen Trochäus besteht, beschreibt die vergessenen Gelübde, die gepriesen werden sollen: die Demut (Armut im Geiste) ${ }^{56}$, die Reinheit/Keuschheit und den unbedingten Gehorsam. Die drei "ewigen Rosen" als Symbol dieser drei Gelübde sind: das innere Wesen des armen Mannes Christus, das sanftmütige Herz Marias und das lebendige Wesen des Lammes Gottes. Entsprechend geht es in den Gedichten der nun folgenden zwei Gruppen um christlich-religiöse, mystische Themen, um Marienverehrung. Madonnenkult und stilisiente Frömmigkeit. Wiederholt klingt in diesen Gedichten die Trauer um den Verlust des echten Glaubens vor sechs Jahrhunderten (also im 13. Jahmundert) an, ein Motiv, das sich auch in Ėllis' Aufsätzen und seinem Traktat "Vigilemus!" findet 57 . Gleichzeitig wird in einigen Gedichten der Hinweis auf die Wiederkehr der vergessenen heiligen Zeit (13. Jahrhundert und früher) und des Glaubens ausgesprochen. Das lyrische Ich hat wieder Zugang zu transzendenten Welten. hör die Stimmen der Engel im Paradies, hat Paradiesesvisionen oder schaut die Jungfrau Maria mit dem Kind.

\footnotetext{
53 Ebd.. S. 97-148.
}

54 Auffallend sind, auch schon in "Stigmata", aber in verstärktem Maße hier in "Apro", die vielen fremdsprachigen Titel, die Ëllis seinen Gedichten und den einzelnen Teilen in seinem Lyrikband gibt. Man muB sich fragen, ob er sich dadurch prononcien von der russischen poetischen Kultur absetzen wollte (im Gegensatz etwa zu Blok. Belyj u.a., bei denen es zwar auch fremdsprachige Titel gibt, aber nicht in so grober Anzahl)? Wie stand er überhaupt zur russischen Tradition? In Ëllis' Werk herrscht deutlich ein westeuropäischer Mittelalterkult vor. Auch "Stigmata" als Nachbildung bzw. Nachdichtung von Dantes "Divina Commedia" hat die westeuropäische, nicht die russische Kultur zum Vorbild. Das könnte die fremdsprachigen Titel erklären. Außerdem wendet sich Ellis dadurch nicht nur an den "normalen" Durchschnittsleser, sondem an die geistige Elite. den (westeuropäischen) Gebildeten. was seiner Kunst- und Symbolismusauffassung entspricht (vgl. hierzu auch unten, S. 92).

55 Ėllis: Argo. S. 99.

$56 \mathrm{Vgl}$. die Seligpreisungen der Bergpredigt, die der Auslöser hierzu sind.

57 Dem 13. Jahrhundert maB Ëllis grobe Bedeutung bei. Hierzu und zu Ëllis' Verständnis des Mittelalters vgl. unten, $S$. $129 f$. 
Die erste Gruppe, "Pietà"58, beginnt mit drei Gedichten über die großen Dome in Köln, Mailand und Florenz. Es folgen weitere Gedichte, die vorwiegend entweder heiligen Stätten 59 oder der Preisung und Verehrung der Jungfrau Maria gewidmet sind: "Tomba di S. Domenico", "В Ассизи" ("In Assisi"), "Сон" ("Der Traum"), "Ave Maria", "Баллала о Пресвятой Деве" ("Ballade über die heilige Jungfrau"), "Черная барка" (Баллада) ("Die schwarze Barke", Ballade), "В преддверия" ("Im Vorhof"), "Перед Мадонной Чимабуэ" ("Vor der Madonna von Cimabue"), "De Beata Maria Virgine", "Из святого Франциска Ксаверия" ("Aus dem heiligen Franz Xaver"), "Невеста Христова" ("Die Braut Christi"), "Sacramentum".

In der zweiten Gruppe dieses zweiten Teils, "Beauséant" 60 . finden sich die folgenden Gedichte über Heldentum. Rittertum, Ritter, Heilige, Pilger und Wanderer: "Три обета" ("Drei Gelübde"), "Черный орел" ("Der schwarze Adler"), "Святой Георгий" ("Der heilige Georg"), "Ричард пред Иерусалимом" ("Richard vor Jerusalem"), "Ангел гнева" ("Der Engel des Zorns"), "Вестники" ("Die Boten"), "Странник" ("Der Fremdling"), "Монсальват" ("Monsalvat"), "Рыцарь Бедный" ("Der Arme Ritter"). Ėllis gestaltet das Rittertum des Mittelalters, die Zeit der Kreuzzüge. Die Zurückeroberung des Heiligen Landes, der Stadt Jerusalem, steht bei ihm symbolisch für die Wiederkehr des alten verlorengegangenen mittelalterlichen christlichen Glaubens. Auch die 12 Gralsritter treten wiederholt auf. Die Gestalt des "Рыцарь Бедный" ist für Ëllis der Prototyp des edlen Ritters überhaupt: der wahre Ritter braucht weder Prunk noch weltlichen Reichtum, sondem übt sich in Askese und Frömmigkeit. Diese Gedichte weisen jedoch auch die für Ëllis' lyrisches Werk typischen Schwächen auf: schwülstige, übertrieben pathetische Sprache, mitunter archaisch und klischeehaft, bisweilen hart an der Grenze zu Kitsch und Komik. Stimmungen werden häufig gebrochen, und es fehlt an Spannung, da die Dinge meist gleich beim Namen genannt werden, wie zum Beispiel in dem Gedicht "Странник":

Идет навстречу мне странник.

высож. величав и строг.

"Кто Ты. Божий посланних?"

(ттвечает он тихо: "Я - Боr!"61

Es genügt, die erste Strophe dieses achtstrophigen Gedichtes hier anzuführen, um deutlich zu machen, was gemeint ist: Nachdem der Wanderer/Pilger gleich in der ersten Strophe seinen Namen verrät, wird dem Gedicht insgesamt jegliche Spannung und Rätselhaftigkeit. Andeutung und Verschwommenheit, die typisch für symbolistische Gedichte ist und den Leser zum Mitgestalten. Enträtseln, Weiter- und Zuendedichten anregen soll, genommen und die verbleibenden Strophen vermögen keine fesselnde, mitreißende Wirkung mehr auszuüben. Dabei muB man allerdings sicher den von Ëllis kalkulierten Überraschungseffekt berücksichtigen, nämlich, daB sich der Wanderer/Pilger auch noch still (!) als "Gott" vorstellt, was in starkem Kontrast zur Größe und Bedeutung Gottes steht, dessen Rede im folgenden als "Donnernuf" ("гром призывный") ertönt. Jedoch nach dieser naiv-komischen Enthüllung in der ersten Strophe gelingt es Ëllis im Verlauf des Gedichts nicht mehr, eine emste, erhaben-feierliche Stimmung zu erzeugen, wenn dieser Fremdling, der sich "Gott" nennt, dann auch noch ein Kästchen in Händen hält, in dem sich das Gralsgeschehen im Tempel abspielt!

58 Ëllis: Argo, S. 101-127.

59 Da Ėllis seit 1911 durch Deutschland, die Schweiz und Italien reiste, ist anzunehmen, daB er die in seinen Gedichten gestalteten Orte und Bauwerke wohl aus eigener Anschauung kannte.

${ }^{60}$ Ëllis: Argo, S. 129-148.

61 Ebd.. S. 142. 
Die Gedichte des Lyrikbandes "Apro" bestehen überwiegend aus einer unterschiedlichen Anzahl gereimter (meist Kreuzreim oder umarmender Reim) vierzeiliger Strophen in syllabotonischen Versmaßen (häufig im Jambus). Daneben gibt es Sonette und wenige Gedichte mit zwei-, drei-, fün- und sechszeiligen Strophen, einige reimlose und in seltenen Fällen Gedichte ohne festes bzw. eindeutig bestimmbares VersmaB. Ellis hat also nicht mit neuen Formen experimentier. Seine Lyrik ist traditionell und stellte zur Zeit ihres Erscheinens weder formal noch inhaltlich eine Innovation innerhalb der Dichtung des russischen Symbolismus dar.

Der thematisch-inhaltliche Aufbau des Gedichtbandes "Apro" läBt sich folgendermaßen beschreiben: In der Kindheit lebt man in einer Märchenwelt, versteht die Sprache der Natur und hat Verbindung zum Paradies, zu den Engeln. Diese Fähigkeiten gehen jedoch im Zuge des Heranwachsens verloren. Die Folgen dieses Verlusts sind Pessimismus, Resignation, Trauer und Einsamkeit auf der Erde, denen man durch Flucht in künstliche Paradiese (Träumereien, Bilderwelten, Gobelins) entgehen kann (1. Teil von "Apro"). Durch Askese, Frömmigkeit und Gebet kann man wieder einen Zugang zur überirdischen, göttlichen Welt erlangen, asketisches Rittertum und Marienverehrung sind der Weg zur geistigen Glückseligkeit (2. Teil von "Apro").

Die Gestalt des "Рыцарь Бедный" zieht sich wie ein Leitfaden durch die einzelnen Teile des Lyrikbändes "Apro" und verbindet diese thematisch mit dem folgenden Ritterpoem "Мария"62, dessen Sujet dem der vorangegangenen Gedichte entspricht und deren Aussage noch bekräftigt. Diese Gestalt trägt einerseits Attribute des Puškinschen "Рыцарь Бедный"63, andererseits vereinigt sie in sich Motive aus der Gralslegende, aus mittelalterlicher Ritter- und Madonnendichtung und steht in Verbindung mit der Gestalt des Don Quichote ${ }^{64}$. Einen ähnlichen Themen- und Motivkomplex hatte A. Blok bereits in seiner frühen Lyrik gestaltet, vor allem in den "Стихи о Прекрасной Даме" (1901-1902), die ja von den Moskauer "Argonauten" besonders verehrt wurden ${ }^{65}$. Somit ist der mittelalterliche Ritterkult noch nach 1910 bei Ėllis nicht originell, sondern wirkt eher unzeitgemäB und veraltet; er kann als eklektisches Fortühren frühsymbolistischer Tradition beurteilt werden.

Ellis' Ritterpoem beginnt mit einem Widmungssonett an Maria, "Посвящение" (Berlin, April 1912!), sozusagen das Motto dieses Werks: Es gab eine Zeit, da glaubten die Menschen wie Kinder, der Engel kam zu ihnen; dann ging er fort ohne Wie derkehr; jetzt sind sie Waisen und beten unter Tränen zur Gottesmutter, daB sie ihre Herzen retten möge, die in Lügen verstrickt sind.

Der folgende Prolog und die fünf Gesänge des Poems bestehen jeweils aus einer unterschiedlichen Anzahl sechszeiliger Strophen in füffüBigen Jamben mit festem Reimschema (ababcc; eventuell eine Variante von Terzinen). Ihnen sind Teile eines alten Mariengesangs von Adam de Saint-Victor auf Latein vorangestellt ("Sequentia de Beata Maria Virgine").

Das Poem hat die Suche nach dem echten, verlorengegangenen Glauben auf der Welt zum Thema: Zwei Ritter verbinden sich mit Maria, die ihre Schwester genannt wird, bevor sie sich auf den Weg ins Heilige Land aufmachen. Als sie jedoch nach sieben Jahren zurückkehren, haben sie auf der Welt durch ihre Heldentaten Reichtum. Anerkennung und irdisches Wissen erlangt. Diese Weltlichkeit verhindert ihre emeute

62 Ebd.. S. 149-189.

63 Vgl. Puskins Gedicht "Жил на свете рыщарь Geдный ..." ("Es lebte ein armer Ritter auf der Welt

...) in seinen "Сцены нз рышарских времен" (1835).

$64 \mathrm{Vgl}$. hierzu den bereits in Anm. 32 (dieses Kapitels) erwähnten Aufsatz von L.V. Sproge: Motif "Rycarja Bednogo", a.a.O.

65 Vgl. hierzu auch R.-D. Kluge: Westeuropa und RuBland.... a.a.O., S. $34 f$. 
geistige Verbindung mit Maria, und sie ziehen wieder fort. Parallel dazu werden die 12 Gralsritter und das Gralsgeschehen gestaltet. Die Ritter ziehen traurig durch die Welt, geben Reichtum und Anerkennung auf, verzichten auf Wissenschaft und Ruhm. Am Ende des Poems wird suggerier, daB ihnen durch die Gottesmutter wieder fröhlichere Tage beschieden sein und sie wohl eines Tages wieder den Weg zu ihr ins Paradies finden werden.

Neben unveröffentlichten Gedichten 66 sind vereinzelte lyrische Werke von Ėllis in den genannten symbolistischen Publikationsorganen. Almanachen und Sammelbänden abgedruckt67; hierbei handelt es sich teilweise um Gedichte, die sich in "Stigmata" und "Apro" wiederfinden, teilweise aber auch um andere, zum Beispiel "Мечты погибшие" ("Zerstörte Träume"), "Джиакомо Леопарди" ("Giacomo Leopardi"), "У окна" ("Am Fenster"), "Донне" ("An die Doña") und "Лебедь" ("Der Schwan") in "Воздетые руки"68 oder "Поэту наших дней" ("An den Dichter unserer Tage")69. Das letztgenannte Gedicht beschreibt in 12 vierzeiligen kreuzgereimten Strophen im vierfüBigen Jambus den Prototyp des zeitgenössischen Dichters, der für Ėllis zu der Zeit (1907) von Brjusov verkörpert wurde. Er stellt seinem Gedicht ein Motto Brjusovs voran: "Разуверение во всем!" ("Der Glaubensverlust an allem!") und gestaltet im Gedicht das Bild eines großen Individuums, eines Übermenschen, der auf Erden ein Gefangener ist und von seiner Umwelt nicht verstanden wird. Ellis verleiht Brjusov hier die Züge jenes Typs des idealen Dichters, die für ihn stets Baudelaire auszeichneten. In Brjusov sieht Ėllis einen Künstler, der die höchsten Höhen des Symbolismus erreicht hat und alle anderen zeitgenössischen Dichter weit hinter sich läßt. Die letzte Strophe des Gedichts lautet:

\footnotetext{
Примк ж восторт монх приветов

Ты. чар не знавинй. чародей.

Счастливейши срели поэтов.

Несчастнейивй среди людей. 70
}

An dieser Stelle muß noch cin weiterer Lyrikband von Ëllis genannt werden, der allerdings unveröffentlicht blieb. Er trägt den Titel "Крест и Лира" ("Kreuz und Lyra") und enthält Gedichte aus der Zeit zwischen 1920 und 1938, also aus Ellis' zweiter Schaffensperiode. Wie Ėllis selbst im Vorwort zu diesem Band ausfühn, stellt er eine Fortsetzung von "Stigmata" und "Apro" dar und beinhaltet Gebete, Heiligenlegenden. Ritterballaden und Übersetzungen aus Dante, Petrarca, Michelangelo u.a. Das Manuskript befindet sich in der Bibliothek Pontificium Collegium Russicum in Rom?1.

Bevor Ëllis' lyrisches Gesamtwerk abschließend kritisch bewertet wird. sollen an dieser Stelle noch einmal einige symbolistische bzw. den Symbolisten nahestehende

66 Darunter ein Heft mit zehn Gedichten "K Huwue" ("An Nietzsche"; füf davon in Sonettform: PГАЛИ. Ф. 575. on. 1, ед.xp. 4; vgl. dazu auch A. Lavrov: A. Belyj v 1900-e gody, a.a.O., S. 110) und das Gedicht "Ангрею Белому" ("An Andrej Belyj"; РО РГБ. Ф. 25. ед.xp. 31), das den Mythos von Belyjs "Gotterwähltheit" (6oroнз6ранность) propagien (vgl. hierzu auch A. Lavrov: A. Belyj.... a.a.O.. S. 146f.). Weitere unveröffentlichte Gedichte vgl. unten. "Materialien von/über Ėllis aus Moskauer Archiven", S. $241 \mathrm{ff}$.

$67 \mathrm{Vgl}$. oben. S. 45.

${ }^{68}$ Moskva 1908. S. 148-156.

69 In: Becы, Nr. 11, 1907, S. 15-17

70 Весы. Nr. 11, 1907, S. 17.

71 Zu diesem unveröffentlichten Gedichtband vgl. F. Poljakov: Neizvestnyj sbornik stichotvorenij $i$ perevodov Ëllisa (L. Kobylinskogo). In: Simvol, Nr. 28, 1992, S. 279-285 und Ellis: Gimny Orfeja. ebd., S. 286-294. 
Zeitgenossen von Ėllis zu Wort kommen, die sich über seine Gedichte in Rezensionen und kritischen Anmerkungen geäußer haben.

A. Blok charakterisier Ëllis' Gedichte in seiner Rezension des zweiten Bandes von "Свободная совесть" folgendermaßen:

[...] На втором месте стоят стихи Эллнса. сильно растянутые. но в общем. сколько я знаю, лучшие из всего, что писал этот поэт. В "Фаэтоне". "Анатомнческом театре" и "Золотом городе" есть дух истинной и живой поэзин.72

Dabei muB man berücksichtigen, daB diese positive Kritik Bloks aus der Zeit 1906/1907 stammt, als sich Ëllis und Blok versöhnt hatten und die gemeinsame Herausgabe eines Almanachs mit dem Titel "Vox Coelestis" planten 73.

Wesentlich negativer fallen die Uneile von N. Gumilev und V. Brjusov über Ėllis' Gedichte aus.

Gumilev findet Ėllis' Gedichte künstlich, blaB und langweilig. Ellis denke nicht in Worten und Bildern, wie es Dichter tun, sondem er reflektiere wie ein Theoretiker, zu abstrakt; ihm mangele es an Talent:

Стих у r. Эллиса вялый и бескостиый; [...] Темы его стихов интересны, переживания глубокн. но, чтобы сиравиться с нимн, нужен большой талант, а у г. Эллиса его нет. ${ }^{74}$

Über die Gedichte in "Stigmata" sagt Gumilev:

[...] И стихам-изображениям, стихам-средству не хватает внутреннего самоотравдання, радостного горения и подъема стихов-самоцели. Может быть. о своем мнстическом пути. подлинно пережнтом и ценном. г. Эллис мог бы написать прекрасную книту размышлений и отисаний, но причем здесь стихи, я не знаю $[. ..] .^{75}$

Über Ėllis' Gedichte in der Musaget-Anthologie äußert sich Gumilev negativ: "Эллис пишет длинно, скучно, с претензиями на изысканность и с большими промахами. " 76

Auch Brjusov vermiBt in Ėllis' Gedichten den künstlerischen Ausdruck. Die Themen seien erhaben und edel, die Gedichte dabei schablonenhaft, blaB und uninteressant 77 . Über "Stigmata" äußert er sich folgendermaßen:

Интересный критик. г. Эллис таким остается и в книге стихов. У него встречаются стояшие внимания мысли. красивые сравнения. энергические выражения. но духа истинной поэзин нет в его стихах [...]. Препараты. притотовленные иногда искусно. иногда не без существенных промахов, - стихн г. Эллиса могут заннтересовать. но не увлечь. их можно чнтать, но не хочется помнтть нанзусть. ${ }^{78}$

In den zeitgenössischen Kritiken wird Ėllis also vorwiegend mangelndes poetisches Talent und mangelnde künstlerische Begabung vorgeworfen, wohingegen nicht be-

72 A. Blok: Sobranie soxinenij v vos'mi tomach. Bd. V. Moskva-Leningrad 1962, S. 632.

Diese von Blok positiv hervorgehobenen Gedichte sind alle in den Band "Stigmata" aufgenommen worden. Das Gedicht "Фaэтor" wurde auch in der erwähnten Kritik von Vl. Vol'kenštejn in "Coвpeменньй мир" als effektvoll charakterisient (vgl. oben. S. 57).

${ }^{73}$ Im März 1904 nach Erscheinen des 1. Teils von "Иммортели" hatte sich Blok noch ganz anders über Ėllis' dichterische Fähigkeiten geäußert: "Эллис [...] никогда поэтом не был и не будет. Бодлэра совсем не поннмает [...]" (A. Blok: Sobranie socinenij, a.a.O.. Bd. VIII, S. 96). (Zum wechselnden Verhältnis zwischen Ėllis und Blok. das sich gewissermaben in ihren gegenseitigen Rezensionen widerspiegelt. vgl. auch S. 37f. und S. 48f. der vorliegenden Arbeit.)

74 Алоллон, No. 3, 1909, S. 46.

75 Аполлон. №. 5, 1911, S. 78.

76 Аполлон, No. 7, 1911 , S. 77.

77 Vgl. Brjusovs Kritik zu "Apro" in "Русская мысль", Nr. 7. 1914, otd. Ill. S. 21.

78 Русская мькль. Nr. 7, 1911, otd. III, S. 23. 
stritten wird, daB seine Gedichte inhaltlich wertvoll sind und interessante Gedanken enthalten.

Eine Betrachtung von Ėllis' lyrischem Werk insgesamt ergibt, wie von der zeitgenössischen Kritik bereits hervorgehoben, daB es sich meist um konstruierte, sprachlich wenig überzeugende Gedichte handelt. Ėllis' Sprache wirkt häufig thetorisch und literarisch trocken (книжно); Stilbrüche rufen unfreiwillig eine komisch-parodistische Wirkung hervor. Die eigentliche Sprengkraft, Spannung, Dissonanz und Ambi valenz des symbolistischen Gedichts sind bei Ellis nicht vorhanden. Unbestimmte Andeutungen, Verschwommenheit und Rätselhaftes fehlen. Ėllis' Gedichte entsprechen großenteils noch der Lyrik des frühen Symbolismus und stellen zur Zeit ihres Erscheinens keine originellen Innovationen im Kontext symbolistischer Lyrik dar. Häufig verwendet Ėllis in seinen Gedichten zwar die typischen Farben symbolistischer Lyrik, z.B. "лазурь" ("Azurblau"), "румянец" ("Röte") und auch Ausdrücke, ja Schlüsselworte des Symbolismus, wie z.B. "заря" ("Morgenröte"), "закат (солнца)" ("[Sonnen]untergang"), "лампада" ("Lämpchen"), "роза и крест" ("Rose und Kreuz"), die sich ebenfalls in den Versen seiner symbolistischen Mitstreiter Brjusov, Blok, Belyj etc. finden, aber insgesamt reichen seine lyrischen Werke in ihrer Konstruiertheit und Stilisiertheit nicht an diejenigen seiner begabten Zeitgenossen heran. Wenige Ausnahmen bilden einige Sonette (zum Beispiel "В стране безумия" und einige der "Gobelin-Sonette"), die sprachlich und von der Stimmung her gelungener sind. Die von Ëllis erzeugten Stimmungen in seiner Lyrik sind allerdings nie Selbst zweck, sondern stets funktional eingebunden in einen größeren inhaltlichen Gesamtkontext. "Gegenstandslose" Gedichte, wie etwa "Песня" von Z. Gippius oder "Творчество" von V. Brjusov, gibt es bei ihm nicht.

In diesem Zusammenhang ist auch auf die Ergebnisse unserer Analyse der künstlerischen Form zu verweisen: Ellis' Gedichte sind meist traditionell syllabotonisch, mit festem Reimschema und VersmaB. Nur selten finden sich bei ihm Gedichte in freieren Formen, wie 2.B. strophenlose Aneinanderreihungen mehrerer Zeilen, freiere VersmaBe (Dol'nik) oder reimlose Gedichte. Ein Experimentieren mit traditionellen Versformen oder akzentuierende Gedichte, wie sie z.B. bei Blok und Belyj auftauchen ${ }^{79}$, gibt es nicht in Ëllis' lyrischem Werk.

Was die Thematik seiner Gedichte betrifft, so stehen sie im wesentlichen ganz in der Tradition symbolistischer Dichtung: Entgrenzung aus der irdischen Realität in eine überirdische. Visionäre Erlebnisse, Träume, Grenzüberschreitungen von der irdischen in eine transzendente Welt (meist ins Paradies) stehen im Mittelpunkt der meisten seiner Gedichte und rücken diese zum Teil in die Nähe der frühen Lyrik Bal'monts und Bloks. Eine Grenze zwischen diesseitiger und jenseitiger Welt wird bewuBt empfunden, sie muB zu überwinden bzw. überschreiten versucht werden. In der Kindheit ist dies noch problemlos möglich. Vor allem in den "Gobelin-Sonetten" klingt das Motiv der "künstlichen Paradiese", wie es bereits bei Baudelaire gestaltet wird, an. Aber zugleich warnt Ellis vor einer toten Traumwelt ohne Glaube, ohne Gott. In seinem Vorwort zu "Stigmata" weist er auf die Entwicklung des Symbolismus als ästhetischer Schule zum Symbolismus als Weltanschauung hin, was für ihn heiBt: zum Mystizismus und zum Christentum, wie es im Mittelalter existierte. Entsprechend nehmen die folgenden Themen besonders großen Raum in Ellis' Dichtung ein: präraffaelitisch stilisierter Mittelalterkult, Dante-Verehrung und das Ideal des Ewig-Weiblichen in der Gestalt der Beatrice (das führte ihn zu Nachdichtungen und Nachbildungen von Dantes Werk), mittelalterliches Rittertum. Gralssuche, mittelalterliche Helden- und Heiligenverehrung. Marienverehrung und Madonnenkult. All

${ }^{79} \mathrm{Vgl}$. oben. S. 23. 
dies läßt sich sehr treffend durch den von Vol'kenštejn geprägten Ausdruck "katholischer Symbolismus" ("католический символизм") charakterisieren ${ }^{80}$.

So läßt sich abschließend feststellen, daB Ėllis' Lyrik jenem Zweig des Symbolismus zuzurechnen ist, der sich an der mimetisch-romantischen Tradition orientien. Sie ist - verglichen mit den Werken anderer symbolistischer Dichter - insgesamt wenig originell und neben den Gedichten symbolistischer Lyriker wie Brjusov, Belyj, Blok u.a. eher als eklektisch einzuschätzen.

${ }^{80} \mathrm{Vgl}$. oben. S. 57. 
00051902

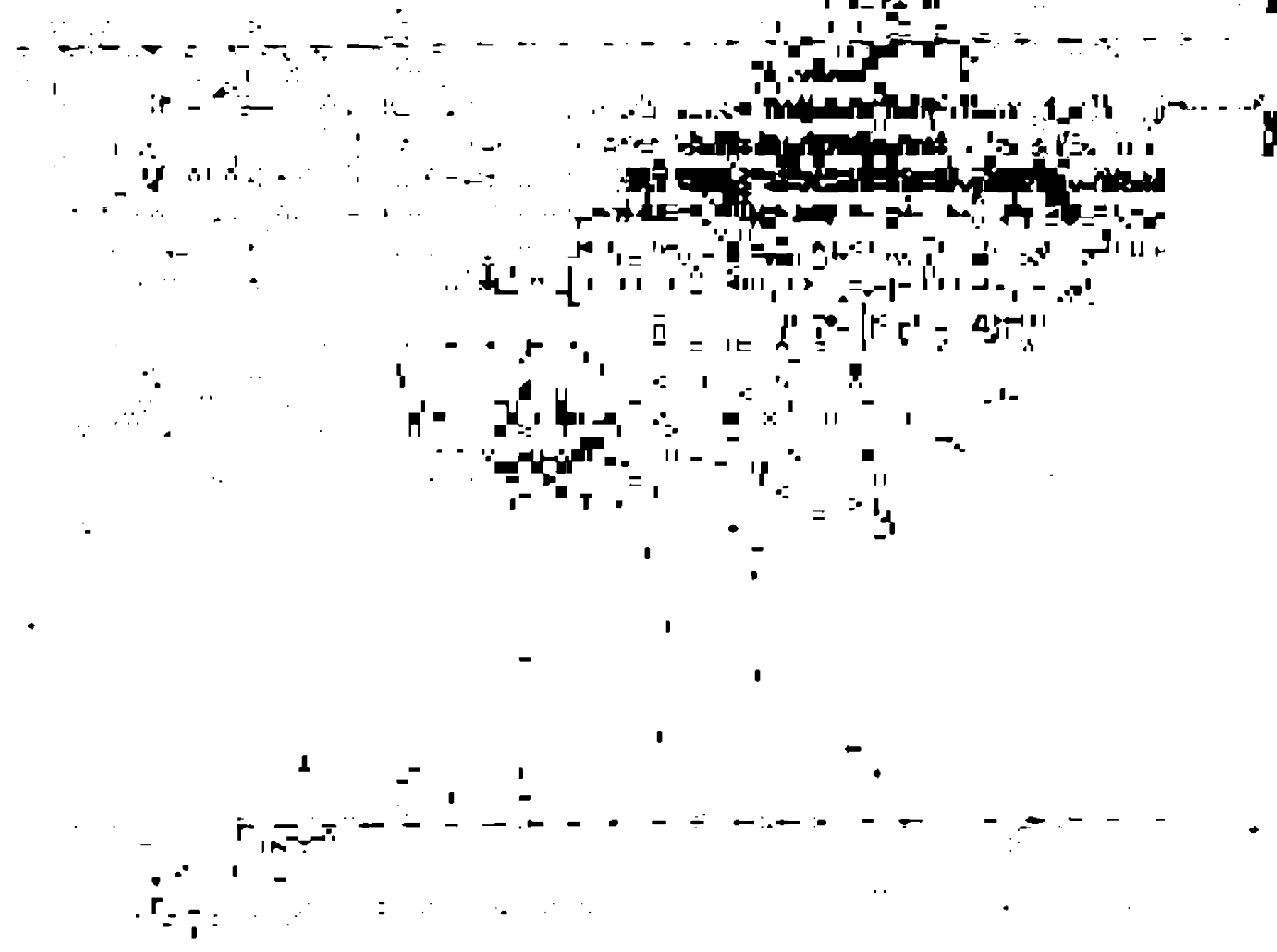




\section{Ellis als Theoretiker und Kritiker}

\section{a. Die Zeitschrift "Becы"}

Die Zeitschrift "Весы" erschien sechs Jahre lang, von 1904 bis 1909, und war zunächst das wichtigste Organ des russischen Symbolismus, später das der Moskauer Fraktion'. Herausgegeben wurde "Bесы" in Moskau vom Verlag "Skorpion", den Sergej A. Poljakov 1899 gegründet hatte. Poljakov war auch der offizielle Redakteur und Herausgeber und stellte die finanziellen Mittel zur Verfügung. Tatsächlich muB "Bесы" allerdings eher als Brjusovs Zeitschrift bezeichnet werden, der neben zahlreichen Beiträgen die wesentlichsten Redaktionsarbeiten leistete (auBer im letzten Erscheinungsjahr).

1904 und 1905 erschien "Весы" als "kritisch-bibliographische Monatsschrift" ("критико-библиографический ежемесячник") über Literatur und Kunst, ohne einen Belletristikteil und ohne Beiträge zum politischen und gesellschaftlichen Leben. 1906 kam zu dem theoretischen literaturkritischen Teil die Primärliteratur hinzu: In den folgenden Jahren (1906-1909) wurden neben philosophischen und kritischen Aufsätzen auch Gedichte, Erzählungen, Romane, Dramen etc. veröffentlicht.

In der ideell-ästhetischen Entwicklung von "Bесы" kann man drei Etappen unterscheiden ${ }^{2}$ :

Die erste Etappe dauerte von 1904 bis zur Nr. 3-4, 1906: Die in "Северные цвеTы" ("Nördliche Blumen") 3 begonnene Taktik der Vereinigung der Symbolisten wurde unter dem in der Zeitschrift allgemein dominierenden EinfluB der Kunsttheorie Brjusovs forgeführt. Man strebte danach, den Symbolismus als souveräne, ideellästhetische Strömung zu festigen und zu legitimieren und kämpfte gemeinsam gegen die ihn befehdenden, ablehnenden ideell-künstlerischen Richtungen, vor allem gegen realistische Strömungen in der Literatur und gegen Positivismus und Materialismus auf dem Gebiet der Philosophie.

Während der zweiten Etappe (Nr. 5, 1906, bis Ende 1908) stand die innersymbolistische Polemik im Vordergrund und lenkte die "Весы"-Mitarbeiter von Angriffen auf außersymbolistische Strömungen weitgehend ab. In "Весы" wurde ein extremer Individualismus vertreten, die Freiheit der Kunst und des Künstlers propagien. Demgegenüber gab es Bestrebungen wie den "mystischen Anarchismus" ("мистический анархизм") G. Čulkovs und Vjač. Ivanovs "соборность" (Gemeinsamkeitserfahrung [einer universellen christlichen Glaubensgemeinschaft]). Es kam zu einer

\footnotetext{
1 Ausfuihrlich zur Geschichte von "Becы" vgl.: A.V. Lavrov, D.E. Maksimov: "Vesy". In: Russkaja literatura i žurnalistika načala XX veka. 1905-1917. Buržuazno-liberal'nye i modemistskie izdanija. Moskva 1984, S. 65-136; K.M. Azadovskij, D.E. Maksimov: Brjusov i "Vesy" (K istorii izdanija). In: Valerij Brjusov. Moskva 1976, S. 257-324 (= Literatumoe Nasledstvo, 85): B. Solov'ev: "Vesy" ili "koran moskovskich upadocnikov". In: Ders.: O istorii k sovremennosti. Stat'i, oxerki, polemika. Moskva 1976, S. 140-185; O.A. Kling: Brjusov v "Vesach" (K voprosu o roli Brjusova v organizacii i izdanii żumala). In: Iz istorii nusskoj żumalistikj nacala XX veka. (Pod red. B.I. Esina). Moskva 1984, S. $160-186$.

2 A.V. Lavrov, D.E. Maksimov: "Vesy", a.a.O., S. 72.

3 Die drei Almanache "Северные uветы" erschienen 1901, 1902 und 1903 im Verlag "Skorpion". In ihnen drückte sich das Bestreben aus, eine Vereinigung alter führenden Vertreter des nussischen Symbolismus herbeizuführen. Aber bereits hier zeigte sich der dominierende EinfluB der ideell-ästhe tischen Position Brjusovs mit dem für ihn charakteristischen vorherrschenden Interesse für rein literarische Fragen und der Gleichgültigkeit gegenüber religiös-philosophischen Problemen.
} 
hitzigen Zeitschriftenpolemik zwischen "Весы" und "Золотое руно" 4 , die Einheit des Symbolismus - falls es sie je gegeben hat - zerbrach, und die Moskauer Fraktion ("Весы") wendete sich gegen die Petersburger ("Золотое руно")5.

Die dritte Etappe umfaBt das letzte Erscheinungsjahr von "Bесы", 1909: Die polemische Linie der Zeitschrift kam zum Erliegen. Allgemein versöhnliche Tendenzen gegenüber den früheren Gegnern wurden bemerkbar, bzw. es formierten sich zwei neue Lager innerhalb des russischen Symbolismus, die ihre 1909 begonnene Debatte schlieBlich 1910 in der in Petersburg neugegründeten Zeitschrift "Anоллон"6 austrugen: Die Anhänger des Symbolismus als formal-ästhetischer literarischer Schule mit Brjusov an der Spitze opponierten gegen die Verfechter des Symbolismus als Weltanschauung (Vjač. Ivanov, A. Blok. A. Belyj u.a.) ${ }^{7}$. Brjusov zog sich 1909 zunehmend von der leitenden Position in der Zeitschrift "Bесы" zurück. Da es aber keine neue ideelle Richtung gab, die alle führenden Mitarbeiter der Zeitschrift hätte vereinigen können, war das Ende von "Весы" gewissermaßen zwangsläufig.

Ellis' Mitarbeit in "Bесы" erstreckte sich von der Nr. 5, 1907, bis zum Ende des Be stehens der Zeitschrift. Während der ersten drei Erscheinungsjahre von "Becbl" hatte Ellis in heftigem Konflikt mit Brjusov gestanden und sich deshalb vom Verlag "Skorpion" und den dortigen Aktivitäten ferngehalten. Als Ėllis 1907 zu "Beсы" kam, war er bereits leidenschaftlicher Verfechter des "orthodoxen" Symbolismus und die Polemik um den "mystischen Anarchismus" zwischen der Moskauer und der Petersburger Fraktion des Symbolismus war in vollem Gange ${ }^{8}$. Er stieg sofor mit dem ihm eigenen fanatischen Eifer in die Polemik ein und verteidigte den "reinen" Symbolismus, die Ästhetik Brjusovs und den extremen Individualismus gegen die Petersburger Gegner. AuBerdem unterstützte er den Kampf, den "Becы" gegen auBersymbolistische Strömungen führte, vor allem gegen die Autoren der "Znanie"Verlagsgemeinschaft ${ }^{9}$ und bekämpfte das - in seinen Augen - literarische Epigonen-

4 "Золотос руно" erschien von 1906-1909 in prächtiger Aufmachung in Moskau, herausgegeben und finanzient vom Kunstmazen N.P. Rjabušinskij. und kann zunächst als $A$. Helyjs \%eitschrift bezeichnet werden. Ab 1907 trennten sich jedoch die meisten der Moskauer Symbolisten von dieser Zeitschrift und publizierten überwiegend in "Beсы" (Zeitschriftenpolemik!). Als ständige Mitarbeiter von "3ajoтое руно" können Vjac. Ivanov. A. Blok und G. Culkov genannt werden. (Zur Geschichte der Zeit schrift vgl.: A.V. Lavrov: "Zolotoe runo". In: Russkaja literatura i zuurnalistika nacala XX veka, a.a.O., S. 137-173.) Zum Verhältnis bzw. zur Polemik zwischen "Весы" und "Золотое руно" vgl. A. Lavrov: A. Belyj v 1900-e gody, a.a.O., S. 228-233.

5 Belyj nennt die Zeit des literarischen Lebens in RuBland von 1906 bis 1908 "Голы полемики" ("Jahre der Polemik": vgl. A. Belyj: Meždu dvuch revoljucij, a.a.O., Kapitel 4, sowie A. Lavrov: A. Belyj v 1900-e gody. a.a.O. S. 215-250).

"Der Gründer und Herausgeber von "Аполлон" (1909-1917) war Sergej K. Makovskij. Zur Geschichte dieser Zeitschrift vgl. I.V. Koreckaja: "Apollon". In: Russkaja literatura i žumalistika nacala XX veka, a.a.O.. S. 212-256.

7 Zum sogenannten "Symbolistenstreit" vgl. die Ausfuihrungen im Einleitungsteil der vorliegenden Arbeit (S. 17f.).

${ }^{8}$ Zu dieser Polemik, vor allem Belyjs Anteil daran. vgl. A. Lavrov: A. Belyj v 1900-e gody, a.a.O., S. 220-228.

9 Die "Znanie"-Verlagsgemeinschaft war 1898 ursprünglich auf Initiative von K. Pjatnickij gegründet worden. 1900 wurde sie unter der faktischen Leitung M. Gor'kijs zum Zentrum konservativ realistisch schreibender Autoren mit sozialistischer Ausrichtung. die sich gegen den Symbolismus und andere avantgardistische Strömungen richteten. Von 1904-1913 erschienen. unter aktiver Mitarbeit von N. Telešov, 40 Nummem der Sammelbände "Знание" ("Das Wissen"), in denen neben den Werken der russischen Realisten jener Zeit auch Werke westeuropäischer Autoren in Übersetzung publizien wurden (Hauptmann. Flaubert. Hamsun u.a.). Neben Gorkij publizienten in dieser Verlagsgemeinschaft u.a. I. Bunin, E. Čirikov, N. Telešov, A. Serafimovič, L. Andreev, S. Juškevič, A. Kuprin, Skitalec (S. Petrov) 
tum. 1909, als Brjusov sich merklich von "Bесы" distanzierte, war Ëllis neben A. Belyj der aktivste Mitarbeiter dieser Zeitschrift und führte im Sommer eine Zeitlang sogar vertretungsweise allein die Sekretärs- und Redaktionsarbeiten durch ${ }^{10}$.

Neben zahlreichen Rezensionen von Sammelbänden, einzelner Werke und Autoren, von Übersetzungen und Arbeiten zum Theater, die meist recht ablehnend waren (au Ber wenn es sich um Werke und Übersetzungen von Brjusov und später auch von Vjac. Ivanov handelte), publizierte Ëllis in "Beсы" kritische Betrachtungen und Abhandlungen über den Symbolismus, über die Realisten, das "Epigonentum" in der Literatur, einen umfangreichen Aufsatz über "Gogol' und das Lachen" sowie einige Gedichte.

Ėllis' Rezensionen von Sammelbänden und Almanachen fallen insgesamt sehr negativ aus. Er lehnt Almanache ab, da sie jeglicher Einheit entbehrten und ihnen keine gemeinsame Idee zugrundeliege. Sie seien Ausdruck der Ungebildetheit der russischen Gesellschaft, Zeugnis des Untergangs der russischen Literatur und Kultur "I. Den zeitgenössischen Almanach definiert er folgendermaßen:

Что такое альманах? Это соединение литературных имен без всякого натравления. переплетенне всех течений без разбора и выбора. соединенне всякого под руку попавшегося матернала с олной. единственной целью: "лишы была бы кникка".12

Ellis vergleicht die Almanache mit der zufälligen Beute aus einem Fischnetz, das in die unergründlichen Tiefen der gegenwärigen Literatur ausgeworfen worden sei ("литературный невод" - "literarisches Fischnetz") und neben Schlamm, Algen und Krabben auch hin und wieder einen "märchenhaften goldenen Fisch" enthalte ${ }^{13}$, also einen künstlerisch hochwertigen Beitrag 14 .

Die von Ellis kritisierten Almanache sind als Ausdruck der Unsicherheit und Suche der Zeit zu verstehen und enthielten in der Tat qualitativ recht uneinheitliche Beiträge bekannterer und weniger bekannter, erstrangiger und zweitrangiger Dichter und Literaten 15 .

Insgesamt sind in Ėllis' Rezensionen stark subjektive Züge nicht zu übersehen: Die Werke derjenigen Dichter, die ihm auch persönlich nahestehen, hebt er positiv und lobend hervor, während er Arbeiten von Autoren, die andere Kunstauffassungen ver-

und V. Veresaev. 1913 stellte der Verlag seine Tätigkeit ein. (Vgl. W. Kasack: Lexikon der russischen Literatur des 20. Jahrtunderts, a.a.O., S. 1467.)

10 Darüber berichtet Ėllis E. K. Metner in seinem Brief vom Sommer 1909 (PO РГБ. Ф. 167. карт. 7. ед.xp. 14).

11 Vgl. Ellis' Rezensionen des Gedicht- und Prosabandes "Kopa6ru" ("Schiffe", in: Becb. Nr. 5. 1907. S. 73-76), des zweiten, vierten und fünften Almanachs des "Sipovnik"-Verlags (in: Becb. Nr. 8, 1907, S. 65-68 und Nr. 10. 1908, S. 81-86), des ersten Almanachs "Kopora" ("Die Krone", in: Becb. Nr. 6, 1908, S. 62f.) und der Almanache "Bepurtb" ("Gipfel"), "Прибой" ("Die Brandung"), "Колосья" ("Die Äbren") und "Творчество" ("Das künstlerische Schaffen") (in: Becы, Nr. 5, 1909. S. 69-75).

12 Весы. Nr. 5. 1909. S. 75.

13 Весы, Nr. 10. 1908, S. 86.

14 Als solche hebt Ėllis 2.B. A. Belyjs Gedichtzyklus "Усталость" ("Müdigkeit") im Almanach "Kopora" (Becы. Nr. 6, 1908, S. 63) oder Brjusovs "romantisches Poem" "Kcnoлnенное обешание" ("Das erfüllte Versprechen") und auch L. Andreevs "Pассказ о семн повешенных" ("Erzählung von den sieben Gehenkten") in den Almanachen des "Šipovnik"-Verlags (Becы. Nr. 10, 1908, S. 84-86) hervor.

15 Ëllis selbst hatte 1904 einige Gedichte und Übersetzungen im Almanach des Verlags "Grif" publiziert und veröffentlichte - wie oben erwähnt - Gedichte, Übersetzungen und theoretische Arbeiten in Sammelbänden (z.B. in "Свободная совесть" I und II, "Молодая Бельгия". "Воздетые руки", der Anthologie des "Musaget"-Verlags u.a.). 
treten oder anderen literarischen Richtungen angehören, durchweg heftig kritisien und ablehnt. Ein Beispiel hierfür ist seine Rezension des zweiten Almanachs "Фaкелы" (1907) ${ }^{16}$, in der er den "mystischen Anarchismus" und dessen Vertreter vehe ment und direkt angreift und alle Beiträge, mit Ausnahme von L. Šestovs Aufsatz "Похвала глупости" ("Ein Lob der Dummheit") 17, sehr negativ kritisiert:

[...] все остальные статьи и статейки "Факелов" решительно плохи. голословны, запутаны, исполнены кричаших противоречий. а. главное. нестерпимо претенциозны и. не взнрая на последнее. - скучны. скучны и скучны!... 18

Besonders ablehnend bespricht er die Beiträge von Vjač. Ivanov ${ }^{19}$ und G. Čulkov 20 , dem Initiator von "Факелы"21. Geradezu bösartig ist sein Ton. wenn er sich direkt an Čulkov wendet:

Что вы создали, кроме книти плохих стихов. нескольких рецензий и статей. в роде настоящей? В ваших устах только комичен тон. которым постеснился бы говорить сам Бакунин!..22

Den von linksorientierten Realisten herausgegebenen zweiten literaturkritischen Sammelband "Литературный распал" ("Literarischer Verfall")23, der gegen die zeitgenössische russische Literatur gerichtet ist, bezeichnet Ėllis als klassisches Beispiel für "Vandalismus in der Kritik"24. Die Kritiker seien unverschämt und würden die symbolistische Literatur entstellen. Sie würden unterschiedslos die ganze zeitgenössische russische Literatur verneinen, diese insgesamt als Dekadenz bezeichnen und dabei nicht zwischen den einzelnen Schriftstellern und verschiedenen Strömungen differenzieren. Derartige Publikationen mußte Ėllis, der sich selber als Symbolist und damit Vertreter der - im Selbstverständnis des Symbolismus - einzigen maBgeblichen literarischen Richtung seiner Zeit verstand, vehement ablehnen und radikal verwerfen.

Ėllis' Rezensionen einzelner Werke und Autoren fallen stets negativ aus. wenn sie nicht seinem eigenen Kunst- und Literaturverständnis entsprechen. Anderen Auffassungen gegenüber zeigt er wenig KompromiBbereitschaft und Toleranz.

Während er Stepnjak-Kravčinskijs gesammelten Werken zwar jeglichen künstlerischen Wert abspricht. aber immerhin große ethische und gesellschaftliche Bedeutung zugesteht ${ }^{25}$. hält er S.A. Vengerovs "Очерки по историн русской литературы" ("Studien zur Geschichte der russischen Literatur") für gänzlich unangebracht und überflüssig ${ }^{26}$. Als Symbolist kann Ėllis prinzipiell nicht mit Vengerovs soziologischer

16 Becb. Nr. 6. 1907. S. 55-62.

In den Almanachen "Факелы" (1906-1908) publizienten neten G. Culkov und unbekannteren Anhängem des "mystischen Anarchismus" auch A. Blok und V. Ivanov. (Vgl. hierzu auch oben, S. 32f.)

17 Факель. 1907. S. 137-161.

18 Becb. Nr. 6, 1907, S. 61.

19 "О лкбви дерзакщкй" ("Über die gewagte Liebe". in: Факелы. 1907. S. 229-238).

20 "О6 утвержленин личности" ("Über die Bestätigung der Persönlichkeit", in: Факелы, 1907. S. 1-25) und "Тая̆на лкбвн" ("Das Geheimnis der Liebe", ebd.. S. 209-227).

21 Das ist ein deutlicher Beleg für die Polemik zwischen den Moskauer und den Petersburger Symbolisten.

22 Becы. Nr. 6. 1907, S. 61. Dieser Tonfall entspricht demjenigen von Belyjs Polemiken zur selben Zeit (vgl. A. Lavrov: A. Belyj v 1900-e gody, a.a.O., S. 225-228).

23 Sanki-Peterburg. 1909.

24 Vgl. Ėllis' Rezension "О вандализме в современной критике" ("Über den Vandalismus in der zeitgenössischen Kritik", in: Becы. Nr. 3. 1909, S. 83-87).

25 Beсы. Nr. 9. 1907. S. 66-68.

26 Весы, Nr. 10. 1907. S. 54-57. 
Auffassung. jede literarische Erscheinung sei gesellschaftlich bedingt und dement sprechend zu bewerten, übereinstimmen. Er vertritt die gängige symbolistische Position, wenn er betont, daB man Politik (Gesellschaft) und künstlerisches Schaffen (Kunst) nicht vermischen dürfe, sondern diese beiden Gebiete voneinander isolieren müsse; der Traum eines jeden Künstlers sei, sich von den elenden Verpflichtungen des Alltags zu befreien.

Recht ablehnend äußert sich Ėllis auch über Ivanov-Razumniks "История русской общественной мысли" ("Geschichte des russischen gesellschaftlichen Denkens"), die er als eine einzige Begriffsverwirrung und Anhäufung von Fakten charakterisier ${ }^{27}$. Positiv hebt er jedoch das letzte Kapitel dieses Werks hervor, worin Ivanov-Razumnik die Dekadenz behandelt, die er zwar nicht vollständig erfaBt und verstanden habe, aber der Wunsch eines "typischen Schriftstellers der Intelligenz" ("типично-интеллигентского писателя") $)^{28}$, sich auf irgendeine Weise dieser neuen Strömung in der russischen Dichtung zu nähem, sei bedeutsam und erfreulich.

Großes MiBfallen ruft bei Ėllis auch N. Berdjaevs Aufsatz "Декадентство и общественность" ("Dekadenz und Öffentlichkeit") hervor, der in der Zeitschrift "Русская мысль" erschien"29. Ellis wifft "Русская мысль" eine ungewöhnliche Wendigkeit und Widersprüchlichkeit vor, seit sie ab 1907 unter einer neuen Redaktion erscheint. Die Zeitschrift versuche, der Kunst zu dienen, und publiziere gleichzeitig einen Aufsatz, der gegen die Kunst gerichtet sei. Bereits 1904 habe Brjusov in "Beсы" die völlige Freiheit des künstlerischen Schaffens deklarient ${ }^{30}$, und nun fordere Berdjaev, die Kunst wieder in den Dienst gesellschaftlicher und politischer Auf gaben zu stellen, also ihre Selbständigkeit zu unterdrücken und ein Mittel aus ihr zu machen!

Sehr positive Rezensionen schreibt Ėllis über V. Brjusovs Lyrikband "Пути и nepenyтья" ("Wege und Kreuzwege") 31 und über Vją̌. Ivanovs Buch "По звездам" ("Den Stemen entgegen") ${ }^{32}$. Ellis preist den Gedichtband Brjusovs als "echtes Kunst werk" ("истинное художественное пронзведение") ${ }^{33}$ und weist Brjusov unter allen zeitgenössischen russischen Dichtem den ersten Platz zu, sowohl bezüglich seiner Lyrik als auch seiner Prosa.34.

Die lobende Rezension von Vjač. Ivanovs Werk "Пlo звездам" kann als deutlicher Beweis gelten, daB die innersymbolistische Polemik um den "mystischen Anarchismus" zwischen den Moskauer und den Petersburger Symbolisten inzwischen, das heiBt 1909, beendet ist ${ }^{35}$. Trotz der Vielfalt der Formen und Themen bezeichnet Ėllis dieses Buch als ein harmonisches Ganzes. Es weise eine Zielgerichtetheit auf, habe große Bedeutung, berühre tief und rege zum Denken an. Ėllis diskutien einige der Aufsätze Ivanovs, darunter "Две стихии в современном символизме", und hebt dessen neue Gedankengänge und seine Verdienste für den russischen Symbolismus

27 Весы, Nr. 11, 1908, S. 54-57.

28 Ebd.. S. 57.

29 Vgl. hierzu Ėllis' Ausführungen in "B зашиту декадентства" ("Zur Verteidigung der Dekadenz". in: Becbs. Nr. 8, 1907, S. 69-71). Man darf in diesem Zusammenhang nicht ubersehen. daB Berdjaev damals noch "legaler Marxist" war.

30 Ėllis verweist an dieser Stelle auf Brjusovs programmatischen Aufsatz "Клюон тайн" (Весы. Nr. 1, 1904, S. 3-21).

31 Весы, Nr. 1, 1908, S. 82-86.

32 Becы. Nr. 8, 1909, S. 53-62.

${ }^{33}$ Ebd., Nr. 1, 1908, S. 82.

34 Zum extremen "Brjusov-Kult" in "Becb", den 1907/1908 neben Ėllis auch Belyj vertrat, vgl. auch A. Lavrov: A. Belyj v 1900-e gody, a.a.O., S. $235 f$.

35 Auch Belyj hatte sich am 30.12.1908 brieflich mit Vjac. Ivanov versöhnt (vgl. A. Lavrov: A. Be lyj..., a.a.O., S. 244f.). 
hervor. In diesem Zusammenhang macht er jedoch auf etliche stilistische Mängel und die "Verworrenheit der Termini" in Ivanovs theoretischen Arbeiten aufmerksam ${ }^{36}$, weshalb man Ivanov auch einen großen Anteil der Verantwortung für den "mystischen Anarchismus" zugeschrieben habe. Ivanov habe sich jedoch lediglich gleicher Termini wie die "mystischen Anarchisten" bedient, inhaltlich aber dieser Strömung stets ferngestanden. Trotz dieser Kritikpunkte bewertet Ellis Ivanovs Essayband insgesamt sehr positiv als "wichtigen Meilenstein" und "wahrhaftigen Stemenweg"37.

Ellis rezensien femer einige russische Übersetzungen von Werken französischer und belgischer Symbolisten, die er entweder auch selbst ubersetzt hat oder mit denen er sich intensiv beschäftigte (Baudelaire, Verhaeren und Rodenbach). Dabei geht er in diesen Rezensionen nicht nur auf die jeweilige Übersetzung ein, sondern charakterisien, zum Teil recht ausführlich, die übersetzten Werke und ihre Autoren, hebt deren Bedeutung und Wert hervor ${ }^{38}$.

Brjusovs Buch "Французские лирики XIX века" ("Französische Lyriker des 19. Jahrhunderts") mit Übersetzungen von Werken französischer Lyriker des 19. Jahrhunderts beurteilt Ellis sehr positiv und spricht ihm künstlerischen Wer und große Bedeutung zu ${ }^{39}$. Brjusov habe ein Bild der literarischen Bewegungen eines Jahrhunderts in Frankreich gegeben und dabei dem Symbolismus besondere Aufmerksamkeit zugewandt. Ėllis benutzt diese Rezension, um allgemeine Aussagen zur Stilformation des Symbolismus zu machen, als deren gröBte Lehrer er Baudelaire und Nietzsche hervorhebt. Gegenwärtig befinde sich der Symbolismus in einer Krise ${ }^{40}$, die nur überwunden werden könne, wenn man die europäische Literatur der letzten Jahrzehnte studiere und eine Verbindung zu ihr herstelle, wie es beispielsweise Brjusovs Werk leiste. Lediglich zwei schwierige Begriffe habe Brjusov nicht deutlich genug voneinander abgegrenzt:

[...] скмволкзм. как конхретно-нсторическую литературную иколу, и снмволизм. как новсе ученне и новый метол художественного творчества. еще нитде не получивший пока нсчерпывающето воплощения. метол. ()ращенный к будуиям вскам и бессознательно примсняемый и в прошлом. ${ }^{41}$

Diese Definition des Symbolismus als neue, zukünftige Lehre und Methode, die gleichzeitig unbewuBt bereits in der Vergangenheit angewendet wurde, ist Ausdruck der Legimitationsstrategie der Symbolisten, wie sie bereits 1896/1897 von Merežkovskij im Titel seines Werks "Вечные спутники" ("Ewige Gefährten", Hervorhebung von mir, H.W.) formulient wurde. Ellis' Unterscheidung der zwei Arten von Symbolismus findet sich in allen seinen literaturtheoretischen und -kritischen Arbeiten zum

36 Éllis spricht von "гибельная спутанность терминов", an anderer Stelle von "запутанность в терминах". (Vgl. Весы. Nr. 8. 1909. S. 59f.)

37 "Да. вомстину эта книта В. Иванова пумь по звездам". heiBt es am Ende von Ėllis' Rezension (vgl. ebd., S. 62).

38 Die Übersetzungen A. Panovs von Baudelaires "Les fleurs du mal" ("Цветы зла") und N. Vasil'evs von Verhaerens "Les villages illusoires" ("О6езумевшие деревнн") [Весы, Nr. 7, 1907, S. 75-77 und Nr. 10, 1907, S. 64-67] bewertet Ëllis sehr negativ als nicht gelungen. unpoetısch und fehlerhaft. während er M. Veselovskajas Übersetzung von G. Rodenbachs "L ant en exil" (" Искусств) в изгиания") (Весы, Nr. 3, 1909, S. 95-97) als insgesamt richtig und genau bezeichnet und ihr künst lerische Bedeutung zuspricht.

39 Becы. Nr. 7, 1909. S. 87-93.

40 "Zur "Krise des Symbolismus" vgl. das folgende Kapitel, S. 89, Anm. 5.

41 Весы, Nr. 7, 1909, S. 93. 
Symbolismus wieder, wobei für ihn das eigentliche Wesen des Symbolismus in dessen "überzeitlicher" Komponente liegt ${ }^{42}$.

In seinen Rezensionen von Arbeiten zum zeitgenössischen Theater diskutient Ėllis die Möglichkeit eines symbolistischen Theaters und kommt in diesem Zusammenhang wiederholt auf das Wesen des Symbolismus zu sprechen.

Dem im "Šipovnik"-Verlag erschienenen Essayband "Книга о новом театре" ("Buch über das neue Theater") 43 wirft Ėllis das Fehlen jeglicher Bezüge zwischen den einzelnen Beiträgen vor, die er mit wenigen Ausnahmen allesamt verurteilt ${ }^{44}$. $\mathrm{Er}$ beklagt die Nichtexistenz eines zeitgemäßen russischen Theaters:

Что касается настоящего нашего театра. то. говоря по-совести. нам невозможно уже
пасть ниже "Балаганчика" и "Жнзни человека"; в 6лнзком будущем уже грозит. как
последняя ступень сверх-пошлости. театр марнонеток [...].45

In der ihm eigenen Weise lehnt Ėllis hier radikal und kompromiBlos zwei zeitgenössische Theaterstücke ab (A. Bloks "Балаганчик" und L. Andreevs "Жизнь человеka" - "Das Leben des Menschen"), die als bedeutender Versuch und wichtige Bei spiele symbolistischen Theaters gelten müssen ${ }^{46}$. Es entgeht ihm jedoch Wesentliches an symbolistischer Poetik, wie sie in den kritisierten Dramen zu gestalten versucht wurde: die Modellierung der Zwänge modemen Lebens (der modemen technischen Zivilisation), hilflose Fluchtversuche in Mystizismus und Okkultismus, die Integration von Folklore und Stegreifspiel (Blok legte seinem "Балаганчик" die Struktur der Commedia dell'arte zugrunde) sowie schlieBlich der Bruch mit dem realistischen Illusionstheater, das Hervorheben des Spielcharakters und die Öffnung des Stückes im provozierenden Einbezug des Publikums. Brjusov hatte $1902 \mathrm{mit}$ dem programmatischen Aufsatz "Ненужная правда. По поводу ходужественного театра" ("Unnötige Wahrheit. AnläBlich des Künstlertheaters") ${ }^{47}$ die symbolistische Dramen- und Theaterdiskussion eingeleitet, indem er ein bewuBt stilisientes Theater forderte. Der Regisseur Mejerchol'd griff diese Ideen auf und entwickelte sie weiter zu einer anti-illu sionistischen Theaterkonzeption. Seine Inszenierung und Aufführung von Bloks "Ба лаганчик" mit Musik von M. Kuzmin im Dezember 1906 stellt ein wichtiges Ereignis in der Geschichte des russischen Theaters dar. Auch Vjač. Ivanovs durch Wagner und Nietzsche inspirierte Arbeiten und Entwürfe einer symbolistischen Tragödientheorie ab 1904 und seine Idee des "Volkstheaters" 48 müssen in diesem Zusammenhang erwähnt werden: Ivanov entwickelte das utopische Konzept eines kollektiven kultischen Theaters, das eine Synthese der Künste (im Sinne von Wagners Gesamtkunstwerk)

\footnotetext{
$42 \mathrm{Vgl}$. hierzu auch die Ausführungen im folgenden Kapitel.

43 Teatr. Kniga o novom teatre. Sbornik statej. SPb. 1908, mit Beituägen von A. Lunacarskij. E. Anickov, A. Gornfel'd. A. Benua, Vs. Mejerchol'd, F. Sologub, G. Culkov, S. Rafalovic, V. Brjusov und $A$. Belyj.

$44 \mathrm{Vgl}$. Ellis' Ausführungen in "Что тахое театр? ("Was ist Theater", in: Bесы. Nr. 4, 1908, S. 85-91).

45 Ebd., S. 86.

46 Nicht-symbolistische, aber zeitgenössische Theaterstücke, wie etwa die Dramen L. Tolstojs. Cechovs und Gor'kijs, ignorient Ėllis hier völlig. (An anderer Stelle lehnt es Gor'kijs Stücke ab, vgl. unten. S. 82f.)

47 V. Brjusov: Sobranie soxinenij v 7-i tt. Tom 6. Moskva 1975. S. 62-73, 582-584.

$48 \mathrm{Vgl}$. hierzu z.B. Vjac. Ivanov: PredČuvstvija i predvestija. Novaja organičeskaja épocha i teatr bu duscego. In: Ders.: Sobranie soxinenij. Tom Il. Brjussel' 1974, S. 86-103 (erstmals wurde diese Arbeit 1906 in der Zeitschrift "Золотое руно" (Nr. 5-6) publiziert). Vgl. hierzu auch L. Kleberg: Vjaceslav Ivanov and the Idea of Theater. In: L. Kleberg. N.A. Nilsson (Hrsg.): Theater and Literature in Russia 1900-1930. A Collection of Essays. Stockholm 1984, S. 57-70.
} 
darstellen und die Zuschauer zum gemeinsamen schöpferischen Handeln ("соборно действо") aufrufen sollte; Theater sollte zum authentischen Ausdruck des echten Volkswillens werden ${ }^{49}$ :

Довольно лищедейства. мы хотим действа. Толпа зрителей должна слиться в хоровое тело. полобное мистической обинне стародавних коргий» и кмистерий».50

A. Belyj widerspricht Ivanovs Theatertheorie und verieidigt - wie Brjusov - das symbolistische Drama als Lesedrama. Bei der Inszenierung symbolistischer Dramen müsse man auf wirklichkeitsnahe Darstellung verzichten und zur stilisierten Darstellung, zum Marionettentheater zurückkehren ${ }^{51}$.

Ebenso wie man das reale Element in der Kunst nicht ganz unterdrücken könne, hält Ėllis es für unmöglich, den Realismus auf der Bühne völlig zu vemeinen. Das Theater fordere eine besondere Form der Verbindung von Realismus und Symbolismus. Brjusov kritisiere in seinem Aufsatz "Реализм и условность на сцене" ("Realismus und Konvention auf der Bühne" ${ }^{52}$, den Ëllis für den besten des vorliegenden Sammelbands hält, wie fast alle anderen Autoren auch, den Realismus auf der Bühne, versuche dabei aber, eine Grenze der Zulässigkeit von Realismus im Theater festzulegen, indem er die Frage erörtere, in welchem Verhältnis Realismus und Symbolismus im Theater vertreten sein sollen. Er rufe dazu auf, sich den Kunstgriffen des antiken und des Shakespeare-Theaters zuzuwenden und komme, wie auch A. Belyj in seinem Beitrag "Театр и современная драма" ("Theater und zeitgenössisches Drama") 53, zu dem SchluB, daB man zum Shakespeare-Theater zurückkehren müsse. Das findet im wesentlichen Ellis' Zustimmung.

Alle anderen Beiträge verurteilt Ėllis. Er hält reinen Symbolismus auf der Bühne für nicht realisierbar, da das Wesen des Symbolismus nicht für das Theater geschaffen sei:

Суиность символизма - умение ловить тончайшие намеки вещей. не кскажая их реального лика $[\ldots]$

Сушность символизма - comespondences. бесчксленные. неуловимые. едва и лишы ютчасти воплошаемые. никогда не совпадающие с миром явлений cortespondences, и единствснным средством перелачн их всегда были и булут те "confuses paroles" лирнческого поэта. самым суикственным свойством которых должно быть прнзнано их недоступность среднему. переполненного трепетом хизни. человеку. их арнстократическая исключительность н абсолктная непрнголность лля каких бы то ни было общественных зкспериментов. 54

49 Vjac. Ivanov: PredCuvstvija i predvestija, a.a.O.. S. 103.

50 Ebd.. S. 95.

51 Vgl. A. Belyj: Teatr i sovremennaja drama. In: Ders.: Simvolizm kak miroponimanie. Moskva 1994. S. 153-157. (Belyj hatte diese Arbeit 1907 geschrieben und erstmals 1908 in: Teatr. Kniga o novom teatre. SPb. 1908. S. 261-289 (sowie 1911 in seinen "Arabeski", S. 17-41) publiziert).

Zum symbolistischen Theater zu Beginn des 20. Jahrhunderts und den genannten Stücken vgl.: F. Stepun: Mystische Weltschau. Fünf Gestalten des russischen Symbolismus. München 1964, bes. S. 232-236; Ch. Ebert: Das Drama des symbolistischen Dramas. In: Dies.: Symbolismus in RuBland. Zur Romanprosa Sologubs, Remisows, Belys. Berlin 1988, S. 55-62: E. ReiBner: Andrejew. Das Leben des Menschen. In: B. Zelinsky (Hrsg.): Das russische Drama. Düsseldorf 1986, S. 213-223, 390f.; G. Langer: Blok. Die Schaubude. In: B. Zelinsky (Hrsg.): Das russische Drama, a.a.O., S. 224-238, 392394; R.-D. Kluge: Majakowskij. Mysterium buffo. In: B. Zelinsky (Hrsg.): Das russische Drama. a.a.O., S. 252-263, 396f.: R.-D. Kluge: Balaganxik and Misterija-Buff: A Sinuctural Comparison of Russian Symbolist and Avant-Garde Drama. In: A. Donskov, R. Sokoloski (ed.): Slavic Drama. The Question of Innovation. Otawa 1991, S. 157-164.

52 In: Teatr. Kniga o novom teatre. SPb. 1908. S. 243-259.

53 Ebd., S. 261-289.

54 Becb. Nr. 4, 1908, S. 89 f. 
So sei es kein Zufall, daß die größten symbolistischen Dichter der gegenwärtigen Epoche schlechte oder gar keine Dramatiker gewesen seien 55 .

In seiner Rezension über den Essayband "Кризис театра" ("Die Krise des Theaters") ${ }^{56}$ bringt Ëllis die Krise des zeitgenössischen Theaters mit der Krise des russischen und auch des europäischen Symbolismus - wie er sie versteht - in Zusammenhang, lehnt emeut Mejerchol'ds Versuche, Bloks "Балаганчик" und Andreevs "Жизнь человека" als nicht gelungen ab (ohne dies jedoch näher auszuführen oder zu begründen $)^{57}$ und legt in unkritisch-exaltienter Weise die Gründe für diese Krise dar:

Крнзис символизма в том. что он перестал бьть тольо Мечтой и Молитвои, а стал "пеиися о завтрашнем дне". утратил лебедињые крылья и стал откармливаться всюду, как гусь!.. [...]

Мы прнветствуем хрнзис театра. ках форму крнзиса символнзма. 60 это - хороин симттом. что болезнь болезней (вульгарнзашия) всяхой свяшенюой идеи доститла высшей точки. что следующая стадия или выздоровленне и возврат в пещеру Заратустры или гибель всего. Но да здравствует и такая гибель!.. Впрочем. возможна ли гибель там. где веет сама Вечность? Вы же. любяшие человечество больше самон Вечности. оставьте rac!58

Mit diesem pathetisch-effektvollen Schluß beendet Ėllis seine Rezension, in der er kaum auf die einzelnen Beiträge eingeht, sondem in recht abstrakt-allgemeiner Form das Theater- und Symbolismusverständnis kritisiert. Den Verfassem der Beiträge des rezensierten Bandes wirft er insgesamt mangelnde Kenntnis der Entwicklungsge schichte des Symbolismus vor. Dabei gelingt es ihm jedoch nicht, konkret darzulegen. was nun eigentlich unter Symbolismus und symbolistischem Theater zu verstehen sei.

Zu Ėllis' Arbeiten zum zeitgenössischen Theater gehör ferner eine Kritik, die er anläßlich einer Aufführung von Maeterlincks Märchenstück "Голубая птица" ("Der blaue Vogel") im Moskauer Künstlertheater schrieb59. Insgesamt habe er die Aufführung dieses bemerkenswerten "Märchens für Kinder" ("сказка для детей") eines der "bedeutendsten zeitgenössischen romantischen Symbolisten" ("одного из величайших современных символистов-романтиков") 60 aufmerksam verfolgt und sie habe ihm. abgesehen von kleineren, sekundären Mängeln. gefallen. Er geht ausführlich auf die große Bedeutung eines Märchens für Kinder ein und betont die enge Verbindung zwischen Romantik und Symbolismus ${ }^{61}$. Ein Märchen sei ein reiner, wunderbarer

55 Das stimmt so natürlich nicht: man denke etwa an M. Maeterlinck. A. Schnitzler, O. Wilde, H. Ibsen. A. Strindberg. A. Blok u.a.

$56 \mathrm{Vgl}$. Ëlis: Krizis sovremennogo teatra. In: Becы. Nr. 9, 1908. S. 63-66.

Der Band "Krizis teatra. Sbornik statej" erschien 1908 in Moskau im Verlag "Problemy Iskusstva" und enthält folgende Beiträge: Ju. Steklov: Teatr ili kukol'naja komedija? (S. 3-53), V. Bazarov: Misterija ili byt? (S. 54-81). V. Suljatikov: Novaja scena i novaja drama (S. 82-125). V. Carskij: Chudożestvennyj teatr (S. 126-156) und V. Frize: Teatr v sovremennom i buduscem obscestve (S. 157185).

$57 \mathrm{Vgl}$. hierzu auch oben. S. 77f. der vorliegenden Arbeit.

58 весы. Nr. 9, 1908, S. 66.

59 Becы. Nr. 12. 1908, S. 95-100.

${ }^{60}$ Ebd.. S. 95.

61 In einer Anmerkung weist er darauf hin. daB er den Titel von Maeterlincks Stück. "Oiseau bleu". bewuBt mit "Голубая птица" (und nicht, wie auch schon in RuBland geschehen, mit "Спняя птица") übersetzt, was er folgendermaßen begründet: "Между тем голубон цвет, "bleu", преемственнозакмствованньй ттицей Матерлина от "Гояубого иветка" Новалиса и стояиий в прямой связи с лазуршым (т.е. голубым) царством будущего. откуда и добывается "голубая птица", является основой символизма всей песы." (Ebd., S. 95). 
Traum, nach dem man stets suchen müsse. Die Feinde der Romantik (dieser höchsten Form des Symbolismus [sic!]) würden behaupten, daB sich dieser Traum im literarischen Kunstwerk nicht gestalten lasse. Die Dichter besäßen jedoch die Gabe, in Andeutungen zu sprechen, wodurch es ihnen gelinge, den Traum "wirklich" werden zu lassen. In diesem Zusammenhang weist Ėllis auf die Entwicklung des Symbolismus hin bzw. zeigt seine zwei entgegengesetzten Richtungen auf:

[...] мы знаем. что все более и более символизм становится лишь средством-методом для чнсто-релитиозных (догматических. даже общественно-теократическнх) исканий. для моральных построений. Превращение символизма только в средство для вне-поэтических целей. влервые совершенное с убийственно-гениальной мощњю $Ф$. Нишие и с варварскои бессознательностью Г. Ибсеном. навсегда раскололо символизм на два противоположные русла.

Симеолизи, как цель - символнзм шхолы Э. По. Бодлзра, Уайльда. Роденбаха. Матерлинка. и символизм, как средство) в творениях великих моралистов современнисти (Ницше. Ибсен. Достоевский. Мережковский) - два разные понятня. Смеиивать их невозможкHo. ${ }^{62}$

In dieser Aussage formulien Éllis die alte Antithese, die schlieBlich 1909/1910 im sogenannten "Symbolistenstreit" 63 zu zwei deutlich voneinander getrennten literarischen Positionen führte: eine rein ästhetische Kunstauffassung, ein l'art pour l'art (die Position Brjusovs und seiner Schule, die später auch von den Akmeisten vertreten wurde), gegenüber Kunst als Weltanschauung, als Modellierung von "Leben" (die Position der "jüngeren" Symbolisten, wie sie etwa von Belyj, Blok und Vjač. Ivanov vertreten wurde).

In seinen literaturtheoretischen Aufsätzen in "Весы" äuBert sich Ellis insgesamt sehr negativ über die Realisten und die - wie er sie nennt - Epigonen und versucht, das Wesen des wahren Symbolismus (wie er es versteht) am Gegenbild zu definieren und darzulegen.

GewissermaBen eine Sonderstellung unter diesen Beiträgen nimmt seine recht interessante Studie über Gogol' ein mit dem Titel "Человек, который смеется. O ('трашном Суде Гоголя нал миром и нал самим собой" ("Der Mensch. der lacht. Vom Jüngsten Gericht Gogol's über die Welt und über sich selbst")6-4. In dieser Arbeit geht Ellis auf das Lachen Gogol's und auf seine tragische Doppelnatur ein. Gogol's Lachen sei ein bitteres Lachen, eine Grimasse gewesen, alles habe sich für ihn ins Lächerliche verkehrt. Zwischen dem Menschen Gogol' und dem Künstler Gogol' habe ein großer Konflikt bestanden. Je ganzheitlicher und vollkommener seine künstlerische Persönlichkeit wurde, desto stärker habe sie seine Seele erdrückt, desto stärker habe seine Seele ohne Liebe, Wahrheit und menschliches Glück "gehungert". Der Künstler Gogol' habe seine Seele dem Teufel hingegeben, während der Mensch Gogol' danach gedürstet habe, die große Sünde des Künstlers Gogol' zu sühnen. Gogol' habe sein ganzes Leben lang unter dieser Spaltung gelitten. Er sei bestrebt gewesen. wenigstens eine ideale, positive Gestalt in seinen Werken zu schaffen, aber so sehr er sich auch abgemüht und gequält habe, sei ihm dies nicht gelungen 65 .

62 Ebd., S. 99.

$63 \mathrm{Vgl}$. oben. S. $17 f .$, "Einleitung" der vorliegenden Arbeit.

64 Весы. Nr. 4, 1909, S. 84-94. Ein grober Teil dieser "Becы"-Nummer war Gogol's 100-jährigem Geburtstag gewidmet (vgl. ebd.: "Памяти Гоголя" |"Dem Gedenken Gogol's"|, S. 63-120) und enthielt neben Ėllis' Aufsatz Arbeiten von Belyj. Brjusov, S. Durylin und B. Sadovskoj über Gogol'.

65 Die Beschäftigung mit Gogol' und das Thema seiner unglücklichen Künstlematur griff Ėllis später in seiner zweiten Schaffensperiode wieder auf (vgl. Teil Il der vorliegenden Arbeit, S. 219f.). 
Ėllis, der zur Zeit seiner "Becb"-Beiträge bemüht war, die ästhetische Position Brjusovs zu vertreten und einen "reinen". individualistischen Symbolismus zu propagieren ${ }^{66}$, lehnte alle anderen Strömungen in der russischen Literatur ab, und zwar sowohl andere Richtungen innerhalb des Symbolismus, die seiner eigenen Position widersprachen, als auch die realistischen Strömungen.

In seinem Aufsatz "Наши эпигоны" ("Unsere Epigonen") mit dem Untertitel "O стиле Л. Андрееве, Борисе Зайцеве и о многом другом" ("Über den Stil L. Andreevs. Boris Zajcevs und über vieles andere") 67 versucht Ėllis die Stilrevolution zu charakterisieren, die um die Jahrhundertwende stattgefunden und alle Schaffenssphären in der Literatur ergriffen habe: Lyrik und Prosa. Fast alle großen Emeuerer der Lyrik Ende des 19. Jahrhunderts seien gleichzeitig Emeuerer der Prosa gewesen: Poe, Baudelaire, Rodenbach, Wilde, Rilke, Hofmannsthal; in RuBland: Brjusov und Belyj68. Den Bruch innerhalb des russischen Prosastils setzt Ëllis zwischen Čechov und Brjusov an:

[...] будуиий историх стиля тољько тогда поймет всю меру переворота в нашей прозе. если он тиательно слнчт лучше страниы честно-реалнстической бледной, но не бесцветной. робкой. но грациозной. а. главное. - мудрой прозы Чехова. этого последнего самостоятельного стилиста до-революинонного пернода русской прозы. с беспощаднообразным. утонченно-выразнтельным и всегда достигаюошим символически обобщений классически-строгим языком Брюсовской "Земной оси" 69

Hier scheint Elllis eine innovatorische Symbolismusauffassung zu vertreten, indem er, zumindest stilistisch, den Symbolismus als etwas ganz Neues, als radikalen Bruch mit der russischen Literaturtradition des 19. Jahrhunderts bezeichnet:

Or Пуикина к Гоголю. от Гоголя к Тургеневу и Толстому. н от Толстого к Чехову илет нить развития нацией "стария" прозы. От Чехова до Брюсова - скачек. пропасть: здесь зарожденне "новоя" прозы. 70

Soweit bemüht sich Ėllis, die Entwicklung des Stils in der russischen Literatur objektiv darzustellen. Dabei bedauen er, daB die Sprache Belyjs (ungeachtet seiner Originalität), Gippius', Sologubs, Vjač. Ivanovs oder Merežkovskijs nicht in der Lage sei, die Errungenschaften des neuen Stils auf dem Gebiet der Prosa begrifflich klar zu formulieren.

Deutlich subjektiver, unwissenschaftlicher und extremer wird Ellis' Tonfall, wenn er auf die von ihm wenig geschätzten Spätrealisten und "Epigonen" zu sprechen kommt:

Банальная традиция выводить М. Горького из Чехова. Л. Аңхеева - из Горького и Б. Заһ̆цева - из Аниреева. Все - это решитељьне недоразумение. М. Горький. как реалист (если только можно говорить серьезно о нем. как о пнсателе) является абсолютною противоположностьк Чехова во всех смыслах и отношениях. ${ }^{71}$

Solche überspitzten, nicht näher begründeten Urteile sind typisch für Ëllis' kritischpolemische Essays.

In L. Andreev sieht Ellis den Prototyp des Epigonen:

66 Was Ėllis darunter versteht bzw. wie er versucht. Symbolismus zu definieren, wird im Zusammenhang mit der Diskussion seiner theoretischen Aufsäıze und Arbeiten zum nussischen Symbolismus erläutert.

67 Becы. Nr. 2. 1908, S. 61-68.

${ }^{68}$ Ebd., S. 63.

${ }^{69}$ Ebd.. S. 64.

70 Ebd.. S. 65.

71 Ebd. 
Будуший историх "нового стиля" в Россин тщетно будет искать новой прозы в несчастных. рыночно-безвкусных томах произведений наших современных эпигонов. тех полуреалистов. полу-декадентов. во главе которьх стоит олин из самых смелых по замыслам и самых безвкусных и беспомошных по методу эпнтонов. Леонил Андреев. ${ }^{72}$

Seine Charakteristik von B. Zajcev als klassischem Epigonenschriftsteller grenzt in ihrer konstruierten, gequält wirkenden Ironie ans Komische und trägt sicher nicht dazu bei, Ellis' Ansehen und Ruf als emsthaften Literaturtheoretiker zu festigen:

Борис Зайцев - классический тип писате дя эпигона. Он всегда и во всем эптон и только эпигон. Если с исторической точки зрения Л. Андреев является эпитоном-эклектиком Чехова и "декадектства". то Зайцев - आитон आитонизма и эклектик срели эклектиков. И когда сльпииш иной раз, что у Зайщева есть тоже своя икола прозаиков. невольно спрашиваешь себя. куда же отнести его последователей. к каким эпигонам эпигонов этитонизма! ${ }^{73}$

Als wunden Punkt in der zeitgenössischen Prosa, vor allem in den Werken der "Epigonen" L. Andreev und B. Zajcev, sieht Ëllis die Verbindung des Realismus mit dem Symbolismus. Keiner der zeitgenössischen Prosaiker habe diese schwierige Aufgabe befriedigend gelöst. Ėllis hat richtig erkannt, daB sowohl Andreevs Werk, das dem russischen Spätrealismus zugerechnet wird, als auch Zajcevs Euvre stark symbolistische Züge trägt (bei Andreev trifft dies in zunehmendem MaBe auf seine Dramen zu), auch wenn Ellis diese Tatsache negativ bewertet.

An Beispielen, die die Uneinheitlichkeit von Zajcevs Stil verdeutlichen und anhand der Darstellung von Zajcevs Entwicklungsgeschichte als "allmählichen Abstieg" ("noстепенный упадок" ${ }^{74}$ versucht Ėllis am SchluB seines Aufsatzes, den krassen Unterschied zwischen diesem "Epigonen" und dem "wahren" russischen Symbolismus zu verdeutlichen, was er wieder in der ihm eigenen Hyperbolik tut:

Русский символизм - сьн запағного. велнкого обновления искусства; ему нужен стровці меток); мы слишком страдали. чтобы умалиться и скокюкать тогда. когда борьба еще не кончена; после Бодлэровской прозы. где кажлсе слово - огненный стигмат. после отравлекного ароматами стиля Гюнсманса. после детски-целомуденной и строгой. ках орган. прозы Рильке. после колокольного звона Роленбаховской метафоры. нам стылно пленятья чуйками и поллевхами Заңцевских аляповатых и лубочных образов! Не лучше ли просто перечитать еще раз Гл. Успенского. Чехова и Толстого?..75

Ėllis' erwähnte Kritik an Gor'kij wird in seinem Beitrag über dessen letzte Dramen ("Варвары" ["Die Barbaren"], "Враги" ["Die Feinde"], "Последние" ["Die Letzten"]) mit dem bezeichnenden Titel "Eще о соколах и ужах" ("Noch einmal über Falken und Nattem") 76 wieder aufgegriffen und näher ausgefühn. Er bezeichnet diese Dramen als Verfall von Gor'kijs Schaffen. Zwar gesteht er Gor'kij eine elementare Begabung zu, - seine frühen Erzählungen seien nicht ohne Interesse gewesen -, jedoch muBte sie ohne Selbsterziehung und Kultivierung verkümmern. Gor'kij hätte besser Publizist, Agitator oder Staatsmann werden sollen, anstatt Dramen zu schreiben.

\footnotetext{
72 Ebd., S. 63.

73 Ebd., S. 66.

${ }^{74}$ Ebd.

75 Ebd., S. 68.

76 Becы. Nr. 7, 1908, S. 53-58.
}

Als "Coкалы" ("Falken") und "Ужи" ("Nattern") hatte K. Cukovskij die Hauptpersonen in Gorkijs Erzählungen und Dramen charakterisien. (Darauf weist Ellis in seinem Beitrag hin: vgl. ebd., S. 56.) 
Inhaltlich scheine Gor'kij sich zu entwickeln: vom Landstreicher ("боcяk") bis hin zum Proletarier. Jeder Herausgeber einer "dekadenten" Zeitschrift sei jedoch eher Arbeiter und Proletarier als Gor'kij auf Capri! Der Inhalt von Gor'kijs Werken werde zunehmend seichter; in den Dramen sei er stereotyp; ihre Form sei langweilig und farblos; zudem hätten sie keinen eigenständigen Stil. Ėllis vermiBt Gor'kijs Sozialismus und hofft, daB "Последние" tatsächlich sein letztes Drama bleibe.

Es ist nicht verwunderlich, daB Ėllis als symbolistischer Literat die Werke und den Entwicklungsgang eines wichtigen Vertreters der spätrealistischen Stilformation ablehnt. Dem stellt er am SchluB seines Aufsatzes den seiner Meinung nach einzig richtigen Weg des echten, freien Dichters gegenüber:

\begin{abstract}
Для поэта не должно бы партий. классов. программ и параграфов. Для поэта все только средства и объекты рали высших не -еловеческах целей. Поэт - везде и всегда отверже нец; он это должен знатъ. в этом его высшая гордость и высочайшее достойнство. Что бы нн говорили нам лукавые нли простоватые люди о "соборности" - ве нолты от Данте и до Верхарна, от Гомера и до Лермонтова бьли "не от мира сего", были полубогами и отверженцамн. были мстителями и париямн. были палачамя и жертвами! Всюду поэт может найти сочувствие и пониманне. всюду он видит свое отраженне. но все-таки он всегда и везде одинок! Этот путь отверженства и одиночества, т.е. путь строжая̆шего инднвидуализма. и есть единственный, постойньй путь художнка-твориа. ${ }^{77}$
\end{abstract}

Die Aufgabe, die Ėllis dem symbolistischen Dichter zuweist, erinnert stark an die Rolle des romantischen Dichters als Prophet und Richter, der von der Menge nicht verstanden wird (vgl. etwa Puškins Gedicht "Поэт и толпа" - "Der Dichter und die Menge", 1828). Deshalb wird im abschließenden Kapitel dieses I. Teils über Ėllis' Symbolismus- und Kunstauffassung noch genauer zu prüfen sein, inwieweit man bei Ëllis eher von Neoromantik als von Symbolismus sprechen sollte.

Die theoretischen Aufsätze über den zeitgenössischen Symbolismus indes enthalten immer wieder Ellis' ambivalente Symbolismusauffassung. Einerseits versteht er Symbolismus nicht als Innovation, als Bruch mit der mimetischen Tradition, sondern als Kontinuität, als Wiederaufgreifen und Fortsetzung alter Traditionen. Der Symbolismus habe tiefe, ideelle Wurzeln in der Vergangenheit ${ }^{78}$. So schreibt er zum Beispiel:

Русский символизм [...] не только не отменил. не победил кахую-то старую шхолу во имя бесконечного новото илн "нового слишвом нового", а. наоборот, явился ортаннческим. глубоко-последовательным и неизбежным исторнчески и психологически дальнейін:развитием. утончением и усложнением өсех самых заветных. самых глубоких и прочных течени и устремлений русского словесното творчества. ${ }^{79}$

Andererseits weist Ėllis wiederholt darauf hin, daB der Symbolismus als Welterscheinung keineswegs überwunden. sondem bei weitem noch nicht richtig begriffen sei, daB alle Fragen und Probleme des zeitgenössischen Symbolismus noch nicht gelöst seien $^{80}$. Im Symbolismus gehe es nicht einfach um eine neue Form, sondem um einen

${ }^{77}$ Ebd.. S. 58.

78 Dies führt Ellis z.B. recht ausführlich in seinem Aufsatz "O современном символизме. о «чортеж и о «действеж" ("Über den zeitgenössischen Symbolismus, den *Teufel « und die *Tat *", in: Becы, Nr. 1, 1909, S. 75-82) aus. worin er die einzelnen europäischen Symbolisten anfuihrt und zeigt. daB sie eigentlich nichts Neues gebracht hätten. sondern alles schon irgendwie aus der Vergangenheit bekannt sei.

${ }^{79}$ Ebd.. S. 75.

80 Ebd., S. $78 f$. 
Umbau des gesamten Kulturgebäudes: die gegenwärtige Kultur sei nur durch ihre Ausrichtung auf die Zukunft wertvoll 81 .

Diese ambivalente Symbolismusauffassung zieht sich durch Ellis' gesamtes symbolistisches Werk und spitzt sich immer mehr zu. In seinem Traktat "Vigilemus!" schlieBlich spricht er von den "два лика символизма" ("zwei Antlitzen des Symbolismus")82. Indem Ëllis die Entwicklung des Symbolismus beschreibt, versucht er, die Ambivalenz seiner Symbolismusauffassung aufzulösen und das Neue im Symbolismus, seine Ausrichtung auf die Zukunft. mit dem Kontinuitätsgedanken zu vereinbaren:

Сперва символизм. как новое и односторонне-зстетическое учение. сам приблизился $к$ культуре. желая облачиться в старые доспехн ... но все эти доспехн оказались ржавыми и лряблыми. и вот новое учение незаметно. шаг за шагом. стало перечеканивать все. решительно все культурные ценности: так невольно из жажлы культуры символизм стал источником. эту жажпу утоляюиям. И тогда совершилось чудо: новое учение оказалось старым. исконным. но сохраняло и вско свон трепетную. огненную юнкть; разрушая все. оно созилало. отрищая - утверждало. богохульствуя - молилось и. сомневаясь во всех "ценностях культуры". само стало жнвым воплощением культуры. 83

Diese Äußerung von Ėllis entspricht dem Prinzip der Destruktion und Konstruktion. wie sie Ch. Baudelaire in seinem "Fundamentalsatz der modemen Ästhetik" ausgedrückt hat: "Die Phantasie zerlegt (décompose) die ganze Schöpfung; nach Gesetzen. die im tiefsten Seeleninnem entspringen, sammelt und gliedert sie die [dadurch entstandenen] Teile und erzeugt daraus eine neue Welt." 84

Ellis weist darauf hin. da $B$ jede Kulturepoche eine eigene, einzige Antwort auf die alte, allgemeine Frage, was Kultur eigentlich bedeute, habe. Die gegenwärtige Epoche habe ihr Hauptkulturkriterium bestimmt, indem sie die grobe "Losung" des Kampfes "für den Symbolismus als neue Weltanschauung" ("за символизм, как за новос мирхсозерцание") 85 ausgesprochen habe:

ПЈоэтому борьба за символизм есть и будет борьбой притив догмата. против змпиризма мысли. против реализма в творчестве и притив суверенитета теоретического разума ("чистого разума").

In dieser Äußerung definien Ėllis (bewußt oder unbewuBt) Symbolismus als Bruch mit der Tradition. wobei Realismus für "Mimesis" steht.

Bei seinem Versuch, die Frage zu beantworten, was Kultur eigentlich sei, charak terisier Ëllis recht oberflächlich und knapp die materialistischen und idealistischen Philosophen seit Kant und spricht sich gegen den Positivismus aus. Er kommt zu dem SchluB. daB es nicht verwunderlich sei, wenn mit der Zeit bewiesen würde. daB alle "philosophischen Systeme" immer nur von ein und demselben gesprochen hätten, aber angesichts der Verwirrung der Termini und der angeborenen solipsistischen Neigung ihrer Autoren einander nicht verstanden hätten und daB alle Philosophen die

"1 Diese recht "offene", innovative Symbolismusauffassung legt Ëllis ausführlich in sciner umfassenden Arbeit "К ультура и символнзм" ("Kultur und Symbolismus". in: Becы. Nr. 10-11. 1909. S. 153-168) dar, in der er von zwei Grundsätzen ausgeht: 1. "('имволизм - это культура" und 2. "Культура - это символизм" (ebd.. S. 153).

×2 Vgl. Ëllis: Vigilemus! Moskva 1914. S. 56-59 und das "Vigilemus!"-Kapitel der vorliegenden Arbeit.

83 Beсы. Nr. 10-11, 1909, S. 155.

${ }^{84}$ Zitien nach H. Friedrich: Die Struktur der modernen Lyrik. Reinbek 1992. S. $55 f$.

x 5 Ëllis: Kul tura i simvolizm. In: Becы, Nr. 10-11, 1909, S. 156.

xh Ebd. 
gleichen Fehler gemacht hätten. Nun sei es an der Zeit, das "Reich der Abstraktionen" durch das "Reich des neuen Idealismus", das "Reich der Symbole", abzulösen87.

Wiederholt weist Ellis auf die Verbindung des Symbolismus mit der Vergangenheit und der Gegenwant hin: Der Symbolismus stehe in Beziehung zu dem großen Umbruch des BewuBtseins und des Stils, der im Verlauf der zweiten Hälfte des 19. Jahrhunderts vonstatten gegangen sei. Das freie, schöpferische Bestreben solle mit der Umwertung aller Ergebnisse der Philosophie seit Kant verbunden werden (E. Poe und Mallarmé). Die wesentlichen Ziele, Hoffnungen und Aufgaben des Symbolismus lägen jedoch in der Zukunft. In diesem Zusammenhang gibt Ëllis eine wichtige Definition des Symbolismus, wie er von den sogenannten "jüngeren" Symbolisten verstanden und vertreten wurde:

\begin{abstract}
Являясь самой последней и самой совершенной формой искусства, символизм. и только символизм. являет собою уже и нечто большее. чем искусство, представляя собой первую. новую форму иного состояния сознания человечества |Hervorhebung von mir. H.W.J. новую форму проявления современной сложной и тонкой общей душн и первьй намек на еще более совершенные стадия ее эволюини в будушем. Давно же символизм из жажыы "свободного стиха" стал жаждать "свободной мичности". 88
\end{abstract}

(Zu diesem Ergebnis kommt Ellis auch in seinem SchluBkapitel von "Pусские символисты".)

Der Symbolismus sei vor allem als Weg der Befreiung wertvoll, der unausweichlich zu einer lebendigen Einheit von Willen und Wissen führe und zum Primat des künstlerischen Schaffens über die Erkenntnis. Ėllis nennt den Symbolismus in seiner zukünftigen idealen und vollendeten Form "тем [...] исповеданием, которое мы без колебания решаемся назвать великой религией будущего" 89.

Erwähnenswert sind in Ėllis' theoretischen Arbeiten zum Symbolismus seine Ausführungen über D. Merežkovskij, dem er unter den "Über-Individualisten" ("Cвepxинливилуалисты"; damit meint Ellis die Petersburger Symbolisten) einen besonderen Platz einräumt ${ }^{90}$. Schon seit längerem trete Merežkovskij gegen die zeitgenössische russische Literatur auf, die er ursprünglich selbst als einer der ersten russischen Symbolisten hervorgehoben und verkündet habe" ${ }^{91}$. Ellis nennt dies "ProzeB der Selbstverneinung" ("процесс самоотрицания") bei Merežkovskij, den er mit Gogol" und Tolstoj vergleicht. Verständnisvoll analysiert er Merežkovskijs Dilemma: Merežkovskij wolle handeln, "die Menschheit neu beleben". Offen und ehrlich bezichtige er die gesamte zeitgenössische russische Literatur der Seichtheit und Oberflächlichkeit, was zwar weitgehend gerechtfertigt sei, jedoch habe er dabei den "echten" Symbolismus übersehen, den Ëllis als "rettende Oasen in der Wüste der zeitgenössischen Literatur" umschreibt ${ }^{92}$. Er gesteht Merežkovskjjs Ideen zwar keine gesellschaftliche, wohl aber individuelle Bedeutung zu und charakterisiert seinen Weg folgendermaBen:

Путь от символа к догмату - вот путь Мережковското.

${ }^{87}$ Ebd., S. 157-166.

88 Ebd., S. 168.

${ }^{89}$ Ebd., S. 168.

90) $\mathrm{Vgl}$. hierzu vor allem Éllis' Ausführungen in seinem Aufsatz "O современном символизме. о "чортеж и о ждействеж" (Весы. Nr. 1, 1909, S. 79-82).

91 Ëllis meint hier sicher den 6. Teil von Merežkovskijs umfassender Abhandlung "O причннах упадка и о новых течениях современной русской литературы" mit dem Titel "Современное литературное поколеняе" ("Die zeitgenössische literarische Generation"), in dem sich Merežkovskij zur zeitgenössischen russischen Literatur äußer.

92 "Мережковский [...] не вилит спасительных оазисов. в пустыне современной нашей литературы" (Весы, Nr. 1, 1909, S. 80). 
Путь от созсриания $\mathbf{x}$ действию. от литературы $\mathbf{k}$ новой церкви. ${ }^{93}$

Interessant an diesen Ausführungen über Merežkovskij ist, daß Ėllis selbst später einen ähnlichen Weg wie denjenigen einschlug, den er hier Merežkovskij zuschreibt. 94

In den vorgeführten Rezensionen und Aufsätzen tritt uns Ėllis erstmals als Theoretiker und Kritiker des russischen Symbolismus entgegen. Auch hier fallen sein panegyrischer Stil und sein übertriebenes Pathos auf, wodurch das Verständnis seiner Arbeiten erheblich beeinträchtigt und die Stringenz seines Argumentierens gestört wird. Seine Rezensionen und Aufsätze sind häufig antithetisch aufgebaut und erinnem mit unter an Schwarz-WeiB-Malerei ohne abschattende Nuancen.

Auf der Suche nach dem wahren Wesen der Kunst und des Symbolismus verurteilt Ellis kompromiBlos alles, was er rezensier, wenn es seinem Kunst- und Literaturverständnis widerspricht; die Arbeiten anderer bewertet er sehr negativ (auBer denen seiner großen Vorbilder, unter den russischen Symbolisten zu jener Zeit vor allem V. Brjusov, daneben A. Belyj und ab ca. 1908/1909 Vjač. Ivanov).

In seinen Beiträgen wird deutlich, daB er unter einem ständigen Legitimationsdruck steht und sich dauemd zu rechtfertigen sucht. Es fällt ihm schwer, sich klar, deutlich, objektiv oder gar wissenschaftlich auszudrücken und es gibt keine Stelle, an der er explizit darlegt, was er nun eigentlich unter echter Kunst und wahrem Symbolismus versteht. Er formuliert nur ex negatione oder beschreibt den "echten" Symbolismus mit pathetischen Vergleichen und Metaphem:

Тах мы все были выведены из Егитта. но никто не вндал свонми глазами земли Хана анской! Так началось наше скитаняе по пустьне ... но в этом скитаняи нам был лан огненньй столю. ведуший и угрожаюший. и мы знаем теперь его названне. Это - символизм! Лучиие средн нас уже погибли в пустыне. те, кто сейчас илет впереди, неизбежно погибнут, быть может, завтра же. но столт не угаснет никогда ...95

Mitunter ist es Ėllis jedoch gelungen, das Neue, Innovative des Symbolismus in seinen Definitionsversuchen anklingen zu lassen. Der Symbolismus leitete ja die Öffnung des bisher geschlossenen traditionell-mimetischen Kanons der russischen Literatur ein. Diese Offenheit des Symbolismus und des symbolistischen Symbols erschwert eindeutige klare Definitionen. Ellis erkennt diese typische Eigenart des Symbolismus immer dann, wenn er von seiner Ausrichtung auf die Zukunft spricht. In der Zukunft ist noch alles möglich: sie muB erst erschaffen werden und läBt sich nicht genau definieren. Sich dieser "offenen", unbekannten Zukunft zuzuwenden, bedeutet Freiheit; aber auch sie läBt sich nicht eindeutig beschreiben.

Das Suchen und die UngewiBheit in seinen theoretischen Aufsätzen über den Symbolismus weisen Ėllis deutlich als Zeitgenossen eines Prozesses aus, der noch nicht abgeschlossen ist, und als solcher muB der Symbolismus in der ersten Dekade dieses Jahrhunderts ja verstanden werden. Neben seiner Bereitschaft, das Neue des Symbolismus zu erkennen, rekurrier Ėllis jedoch immer wieder auf die Vergangenheit, auf die groBen Verdienste der Romantik und vergangener Kulturepochen. Bisweilen erscheint er eher als Neoromantiker denn als Symbolist. Indem er den Symbolismus

93 Ebd., S. 82.

94 Im Kontext seiner theoretischen Arbeiten zum Symbolismus wäre noch Ëllis' Aufsatz "Итоrи символизма" (Весы, Nr. 7, 1909. S. 55-74) zu erwähnen, den er ja am 25.2.1909 als Vortrag im "Общество свободной эстеткки" gehalten hatte (vgl. oben, S. 3if.) und in dem er zu definieren versucht, was Symbolismus eigentlich sei. Da Ėllis in diesem Beitrag jedoch im wesentlichen dieselben Gedanken ausführ, wie im ersten Kapitel seiner "Русские символисты", soll an dieser Stelle nicht näher auf diese Arbeit eingegangen werden.

95 Ëllis: Kul'tura i simvolizm. In: Becb. Nr. 10-11, 1909. S. 154. 
als Fortsetzung der Romantik bezeichnet ${ }^{96}$, kann er einen Halt finden vor der grenzenlosen Offenheit und Freiheit im symbolistischen Kunstwerk, die er, wenn auch nur für kurze Momente, wahrzunehmen scheint.

Was Ėllis' Arbeiten über das zeitgenössische Theater anbelangt, so verwechselt er hier Symbolismus mit Impressionismus. Auffällig ist, daB er in diesem Zusammenhang nicht auf Čechov und die Inszenierungen seiner Stücke im Moskauer Künstlertheater eingeht, der damals für das Theater von auBerordentlich großer Bedeutung war und dessen Stücke von den Symbolisten eifrig rezipiert wurden ${ }^{97}$. Die damaligen neuen Entwicklungen bezüglich des symbolistischen Theaters hat Ëllis entweder nicht verstanden oder bewuBt ignoriert. Mejerchol'ds Versuche auf der Bühne, Bloks "Бaлаганчик" oder Andreevs "Жизнь человека" in einer derartig kurzen und negativen Weise abzutun, legt den SchluB nahe, daB Ėllis das spezifisch Symbolistische des Theaters nicht erkannt und begriffen hat. Was er über Shakespeare und das antike Theater ausführt. geht auf Ivanov zurück, von dem es Belyj und Brjusov übemommen haben. Das würde Ėllis als typisch eklektischen Denker ausweisen.

Betrachtet man parallel zu Ėllis' Beiträgen in der Zeitschrift "Весы" die theoretischen Arbeiten seiner Zeitgenossen (etwa diejenigen Bloks, Belyjs und Vjač. Ivanovs) über Wesen und Aufgabe des Symbolismus, so fällt auf, daB auch sie sich schwertun. klar und deutlich das Wesen des zeitgenössischen Symbolismus zu definieren und zu charakterisieren. Nicht nur Ëllis scheint dauernden Legitimationszwängen unterworfen zu sein. Vergleicht man aber seine Aufsätze mit denen Brjusovs und auch der anderen genannten Vertreter des Symbolismus, so läBt sich ein gewisser Eklektizismus nicht übersehen. Bereits 1894 im Vorwort zu seinen "Русские символисты" hatte Brjusov darauf hingewiesen, daB diejenigen Dichter dem Symbolismus nahestünden, die sich bemühten, die "тонкие, елва уловимые настроения" ("die feinen, kaum faBbaren Stimmungen") auszudrücken, und hatte das Ziel des Symbolismus folgendermaßen definiert: "Цель символизма - рядом сопоставленных образов как бы загипнотизировать читателя, вызвать в нем известное настроение." 98

Ehe jedoch ein endgültiges Uneil über Ėllis als Theoretiker und Kritiker des russischen Symbolismus gebildet werden kann, müssen zuvor seine weiteren Arbeiten zu diesem Themenkomplex genauer betrachtet werden.

96 Ëllis vertritt eine sehr harmonische Romantikauffassung. geht von einem harmonisierten Romantikbild aus.

$97 \mathrm{Vgl}$. beispielsweise Brjusovs. Belyjs und Gippius' Arbeiten über Čechovs "Вишиевый сад" ("Der Kirschgarten").

98 V. Brjusov: Sredi stichov. 1894-1924. Manifesty - stati-recenzii. Moskva 1990. S. 35.

Ėllis' Symbolismusdefinition in "Yro takoe теaтp?" (Bесы. Nr. 4, 1908, S. 89f.) entspricht diesen Ausführungen Brjusovs. ( $\mathrm{Vgl}$. auch oben. S. 78.) 


\section{b. "Русские символисты"}

Die Entstehung von Ellis' Werk "Русские символисты" steht in engem Zusammenhang mit einem "Skandal" im Sommer 19091: Ellis arbeitete zu der Zeit an seinem Buch im Lesesaal des Rumjancev-Museums (heutige Russische Staatsbibliothek [РГБ]) in Moskau. Er verwendete dabei nicht nur die Bücher aus der Bibliothek, sondern hatte zum Teil auch seine eigenen Exemplare dabei, aus denen er Seiten herausschnitt und als Zitate in sein Manuskript klebte. Einmal (Ende Juli oder Anfang Au gust 1909) schnitt Ellis versehentlich zwei Seiten aus Bibliotheksexemplaren heraus (je eine Seite aus A. Belyjs "Sinfonien" "Северная симфония" ["Nördliche Sinfonie"] und "Кубок метелей" ["Pokal der Schneegestöber"]), anstatt aus seinen eigenen Büchem. Ein Aufsichtshabender bemerkte dies, sagte aber nichts. Als Ėllis ging und - wie immer - seine Aktentasche mit allen Materialien bei der Aufsicht der Bibliothek zurücklieB, wurde sein "Vergehen" aufgedeckt, und es kam in der Folgezeit zum "Skandal": Die Zeitungen begannen eine Hetzkampagne gegen Ëllis, Verleumdungen wurden ausgestreut; Prof. Cvetaev, der damalige Direktor des Rumjancev-Museums, wollte den Fall vor Gericht bringen.

Dieses Ereignis ist sowohl für den zur Hysterie und Hektik neigenden Elllis charakteristisch als auch für die damalige Zeit. Ellis' Versehen lieferte den Anhängern der traditionellen Literaturkritik und den Anhängem der Stilformation des Spätrealismus einen willkommenen AnlaB, um gegen die konkurrierende Strömung des Symbolismus zu polemisieren und der Öffentlichkeit kundzutun, wie lächerlich und nicht emst zu nehmen das Auftreten und Handeln der Symbolisten doch sei. So weist zum Beispiel "Голос Москвы" ("Die Stimme Moskaus", vom 6. August 1909) darauf hin, daB man den Dichter Bal'mont des Plagiats überfühn habe, was aber nichts Außergewöhnliches sei. Alle Dichter dieser "Herde" seien im Grunde Plagiatoren und sogar Diebe, denn sie griffen Gedanken und Motive aus der ausländischen Literatur auf, um sie einfach zu übersetzen und zu bearbeiten. So nutzten sie die Unwissenheit des russischen Publikums aus, um Ruhm zu erheischen. Einen dieser "Diebe", Herm Ëllis. habe man im Rumjancev-Muscum gefangen. Er habe Seiten aus Büchern herausgeschnitten und sie heimlich in seiner Aktentasche davongetragen. Was könnten da die "Andrej Belyjs" und "Ivan Seryjs"2 noch zur Verteidigung ihres Freundes, des Herm Ėllis, sagen? Zwei Tage später berichtet "Голос Москвы", daß Ëllis' Ruf als unkorrekter Mensch schon seit langem bekannt sei; er sei unaufrichtig, unfrei in seinen literarischen Meinungen und Sympathien, unbeherrscht, nervös, hysterisch und verblüffe häufig durch unsinnige Ausschreitungen. Seine Handlungen und Meinungen seien völlig unvorhersehbar. Am SchluB des Artikels wird Ellis sehr negativ charakterisien, und es wird auch noch ein Gerücht in Umlauf gebracht:

Для характеристики Эллиса не лишен интереса факт забаллотирования его в члены литературно-художественного кружка в прошлом году.

О6 Эллисе же рассказывают. что он когда то в универсктетской библиотеке вырезал целую главу из редкого собрания сочинений Канта. ${ }^{3}$

1 Vgl. hierzu auch Ėllis' eigene Aussagen in seinen Briefen an Ė.K. Metner (PO РГБ. $\$$. 167. карт. 7. ед.xp. 11. 18f.); Belyjs Bericht in: Meždu dvuch revoljucii, a.a.O., S. 328-334. 535-538; K.Ju. Postoutenko: Pis'ma S.P. Bobrova k Andreju Belomu 1909-1912. In: Lica. 1. 1992. S. $133 f$.

2 "Ivan Seryj" ist ein vom Kritiker erdachter, in Analogie zu Andrej Belyj gebildeter Name und meint einen typischen Vertreter des Symbolismus.

${ }^{3}$ Голос Москвы. Nr. 181, vom 8. August 1909. Weitere Berichte dieses Vorfalls finden sich in den Zeitungen Pyсcкие Ведомости ("Russische Mitteilungen"). Nr. 179 (vom 5. August 1909), Pаннее Утро ("Früher Morgen"). Nr. 179 (vom 5. August 1909), Pyсcкое Cлово ("Das russische Wort"), Nr. 
Ėllis ersetzte dem Rumjancev-Museum sofort die zwei Bücher, die er "beschädigt" hatte. Völlig bereinigt wurde der Skandal jedoch erst im November $1909^{4}$. Das Gericht erkannte Ellis' Vergehen als eine unbeabsichtigte Handlung an, er sei kein Dieb, nur sehr zerstreut. Ellis wurde auch in den Zeitungen wieder rehabilitien.

Éllis' recht umfassendes Werk "Русские символисты", das im Sommer 1910 im "Musaget"-Verlag erschien, besteht aus fünf Kapiteln: Im ersten Kapitel versucht Ëllis, das Wesen des Symbolismus zu charakterisieren ("О сущности символизма" "Vom Wesen des Symbolismus"). Die Kapitel zwei bis vier bilden den Hauptteil des Buches und sind den drei - nach Ellis' Meinung - Hauptvertretern des russischen Symbolismus gewidmet: K. Bal'munt, V. Brjusov und A. Belyj. Im letzten Kapitel geht es um die Zukunft des Symbolismus ("Символизм и будущее" - "Symbolismus und Zukunft").

Bereits im Vorwort nennt Ėllis das Hauptproblem bzw. die Hauptfrage, die er sich in diesem Buch gestellt hat: Der gegenwärtige Symbolismus befinde sich in einer Krise $^{5}$. Bedeutet die Krise des zeitgenössischen Symbolismus nun das Ende dieser Stilformation oder wird der russische Symbolismus weiterleben, zu neuer Geltung gelangen?

Im ersten Kapitel ${ }^{6}$, über das Wesen des Symbolismus, versucht Ėllis zu definieren, was Symbolismus überhaupt sei:

Обычно слово "символизм" конкретно и точно обозначает живое литературное и вообще идейное двнженне. возникновение около середины XIX в. новой художественной школы. явившейся выразительнящей общего культурного перелома середины прошлого века. ${ }^{7}$

In dieser Definition weist Ėllis den Symbolismus als bereits affirmierte literarische Stilformation aus. Das einleitende "обычно" ("gewöhnlich") soll auf den selbstverständlichen Gebrauch des Terminus "Symbolismus" verweisen. Eine entsprechende Legitimationsstrategie findet sich bereits 15 Jahre früher bei Brjusov im Vorwort $\mathrm{zu}$ seinen "Русские символисты" sowie auch immer wieder bei den anderen Symboli-

179 (vom 5. August 1909) und Московскне Bедомости ("Moskauer Mitteilungen"). Nr. 180 (vom 6. August 1909).

${ }^{4} \mathrm{Vgl}$. hierzu die Veröffentlichung von Ėllis' Brief an die Redaktion sowie der Gerichtsresolution vom 7. November 1909 in Pyсcкие Bедомости. Nr. 260 (vom 12. November 1909).

5 Diese Einschätzung von der Krise des Symbolismus gegen Ende der ersten Dekade des 20. Jahr hunderts ist richtig. wurde auch von Ëllis' Zeitgenossen empfunden (z.B. von Belyj: vgl. auch M. Ljunggren: The Russian Mephisto. a.a.O.. S. 43f.) und wird durch die Symbolismusforschung zu diesem Problem bestätigt. Vgl. etwa M. Deppermann: Andrej Belyjs ästhetische Theorie des schöpferischen BewuBtseins. Symbolisierung und Krise [Hervorhebung von mir, H.W.] der Kultur um die Jahrhundert wende. München, 1982: Dies.: RuBland um 1900: Reichtum und Krise [Hervorhebung von mir, H.W.] einer Epoche im Umbruch. In: Musik-Konzepte 37/38. Aleksandr Skrjabin und die Skrjabinisten II. München, Juli 1984, S. 61-106; G. Langer: Kunst - Wissenschaft - Utopie. Die "Überwindung der Kulturkrise" [Hervorhebung von mir, H.W.] bei V. Ivanov, A. Blok, A. Belyj und V. Chlebnikov. Frankfurt/Main 1990. In der Forschung gab es damals sowie heute zwei entgegengesetzte Meinungen: Die Stilformation des Symbolismus habe um das Jahr 1910 ihr Ende erreicht, werde von neuen literarischen Strömungen abgelöst versus sie spiele auch nach 1910 noch eine führende Rolle innerhalb der Entwicklungsgeschichte der nussischen Literatur (vgl. A. Belyjs 1928 verfaBte Schrift: "Potemu ja stal simvolistom i poxemu ja ne perestal im byt' vo vsech fazach moego idejnogo i chudožestvennogo razvitija"). (Vgl. hierzu auch oben, S. 19.)

6 Ellis: Russkie simvolisty. Moskva 1910, S. 1-48.

${ }^{7}$ Ebd.. S. 1. 
sten $^{\mathbb{8}}$. Dadurch sollte der überwiegenden Ablehnung durch die traditionelle zeitgenössische Kritik vorgebeugt werden, die Symbolismus als neue, modische Erscheinung sah, ihn jedoch als literarische Strömung nicht emst nahm.

Ellis bemüht sich, den komplexen Entwicklungsproze B sowohl des westeuropäischen als auch des russischen Symbolismus in seinen Hauptzügen darzustellen und seine wichtigsten Vertreter kurz zu charakterisieren. In einem Schema versucht er, die wesentlichen Richtungen aufzuzeigen, in die sich die - seiner Meinung nach - ursprüngliche Einheit des Symbolismus im Verlauf der 50 Jahre seines Bestehens verzweigt habe":

А) Символизм художественный в собственном смысле (как самоцель) - Э. По. Бодлэр. Верлэн. Маллармз и их ближайшне ученнки: К. Бальмонт ("Будем. как солнще"). В. Брюсов. А. Бельй ("Золото в лазури". "Симфония").

а) Эстетизм. - Гюонсманс (ках автор "А rebours"). Уайльд.

b) Нео-романтизм - Мэтерлинк. Роденбах. К. Бальмонт ("Тишина").

В) Символизм (идейный), как средство:

а) моралистический (Ибсен).

b) метафизический (С. Маллармз. Р. Гиль).

c) чнсто мистический (Алексанцр Добролюбов),

d) индивидуалистический (Ф. Нишше).

е) коллективный ("соборный", "всенародный").

1) с соцнальным оттенком (Э. Верхарн).

2) с теократическим и релитиозно-общественным уклоном (Гюисманс. Д.

Мережковскнй. В. Иванов). ${ }^{10}$

Dieser interessante Versuch der Bestimmung des Symbolismus wird bis heute von der Symbolismusforschung rezipien und beachtet "I.

Alle Symbolisten verbinde jedoch ihr gemeinsames Streben in die Zukunft, nach neuen Erfahrungen. gänzlicher Erneuerung der bisherigen kulturellen Normen und Werte. Ëllis kommt zu zwei wichtigen Ergebnissen bezüglich des Symbolismus:

Bonервьц Мы всегда непосредственно онутим что-то новое. что-то нензведанное и раньие неизвестное. нечто гораздо более совершенное в самом потроенин и особенно взаимном сочетанин художественных образов. [...]

Это "чувство [нового] стиля" объединяет и держит вместе даже самые различные формы символизма.

Во-ыторьх. Простая справелливость заставит нас признать, что "символизм" с перыых дней своего существования и до настоящего времени всегда оказывался той бесконечночуткой. сложной и тонкой формой выявления всех идейных запросов, исканкй и переворотов сознания современного человечества. которую без преувеличения мы можем назвать олновременю зрением. осязанием. слухом и даже совестьк современной души. 12

${ }^{8}$ Etwa bei Merežkovskij im Titel seines Werks "Bечные спутники" oder in seinen Ausführungen über die Vorläufer der Symbolismus in seiner programmatischen Schrift "О причинах упадка и о новых теченнях современной русской литературы"; ebenfalls bei Belyj und Vjac. Ivanov. Vgl. hierzu auch die Arbeit von W. Potthoff: Zum Begriff des "Überzeitlichen Symbolismus". Am Beispiel der russischen Literatur. In: Obdobje simvolizma v slovenskem jeziku, kniževnosti in kulturi. Drugi del. Ljubljana 1983. S. 185-196.

9 Der explizite Verweis auf die lange Dauer des Bestehens des Symbolismus ist auch Bestandteil der erwähnten Legitimationsstrategie.

10 Ellis: Russkie simvolisty. S. 2.

11 Vgl. A.A. Hansen-Löve: Der nussische Symbolismus. a.a.O.. S. 29.

12 Ellis: Russkie simvolisty, S. 4.

Im 2. Punkı formulien Ellis einen gängigen Symbolistentopos: Synthetismus auf Grund von Synàsthesien. 
Ėllis weist aber zugleich darauf hin, daB sich die Bedeutung des Terminus Symbolismus erweitern lasse bis hin zum Begriff des künstlerischen Schaffen überhaupt: "Творить, создавать художественные образы - значит символизировать. "13

Von diesem Standpunkt aus gesehen sei jedes gelungene künstlerische Werk zugleich symbolistisch. Gemäß dieser Theorie sei es sinnlos, den Symbolismus als eine konkrete historische Schule zu bestimmen, als eine spezifische Methode, die zu einem bestimmten Zeitpunkt entstanden sei. Diese Theorie schließe die Möglichkeit einer Unterteilung künstlerischer Werke in symbolistische und nicht-symbolistische aus und verwische sogar den Unterschied zwischen Realismus und Symbolismus.

Ellis stöBt also auf einen Widerspruch: einerseits sei Symbolismus eine neue Stilformation, eine literarische Schule, ein zeitlich auf eine bestimmte Periode begrenztes Phänomen; andererseits sei alle wahre Kunst, sei Dichten "ein ewiges Symbolisieren", der Symbolismus sei nicht zeitlich begrenzt, sondem ein ständig gültiges künstlerisches Verfahren. Dieser Widerspruch entsteht dadurch, daB Ellis, wie viele seiner symbolistischen Zeitgenossen (zum Beispiel Merežkovskij, Belyj, Blok, Vjač. Iva nov), um den Symbolismus zu legitimieren, nicht zwischen "symbolisch" und "symbolistisch" unterscheidet (vgl. den Symbolbegriff bei Goethe und Merežkovskij) $)^{14}$.

Um beide Seiten des vorliegenden Widerspruchs zu versöhnen, versucht Ëllis in seinen Ausführungen zu beweisen, daB die Suche nach einem Symbol das Wesen eines Kunstwerks ausmache und daB gerade die Methode des zeitgenössischen Symbolismus diese Forderung des Kunstwerks am besten befriedige. Er bestimmt das Wesen eines Kunstwerks, indem er sich einer alten idealistischen Position bedient, der nichts spezifisch Symbolistisches anhaftet: "Сущность художественного творчества та же, что и сущность всех высших областей душевной деятельности, она - познание." 15

In seinen folgenden Ausführungen über Anschauung und Erkenntnis ("coзepuaние" und "познание") bezieht er sich vorwiegend auf Schopenhauer und Goethe, daneben auf Schelling ${ }^{16}$. Er beschlieBt seine Ausführungen folgendermaßen:

\footnotetext{
Чем глубже н сознательнее художественное творчество. тем более и более оно начи наст смотреть на все вилимх. реальное - лииь, как на (ileichnis. лить как на значек. как на оболочку или символ великого нензвестного. определить которое и представляется возможным. елинственно отправляясь от преходящего. как от искаженной и отраженной котии Вечного. Если мы добавнм к этому. что основным учением. основным требованием и убежлением современного символизма является именно зто самое воззренне на художественне творчество. ках на претворенне всех реальностей в значки. то-есть символы
}

13 Ebd., S. 5.

Diese Vorstellung entspricht der romantischen Literaturkritik. z.B. den Worten A.W. Schlegels, daB Dichten "ein ewiges Symbolisieren" sei. die zum Allgemeingut der Symbolisten wurden. (Vgl. hierzu auch W. Potthoff: Dante in RuBland. a.a.O.. S. 463.)

14 A. Belyj spricht beispielsweise vom "Symbolismus aller Zeiten" ("символизм всех времен". vgl. A. Belyj: I. Skartaccini. Dante. Peterburg 1905 g. In: Becы. Nr. 11, 1905. S. 75). Vjac. Ivanov vom "Symbolismus jeder wahren Kunst" ("символизм всяхого истинного искусства", vgl. V. Ivanov: O sekte i dogmate. In: Ders.: Sobranie soxinenij. Tom II. a.a.O.. S. 613). Vgl. zu diesem Problem auch den erwähnten Aufsatz von W. Potthoff: Zum Begriff des 'überzeitlichen Symbolismus', a.a.O., sowie oben. S. 23 der vorliegenden Arbeit.

is Ëllis: Russkie simvolisty, S. 7.

$16 \mathrm{Vgl}$. ebd.. S. 7-16.

Auf die Beziehung zwischen Anschauung und Erkenntnis nahmen auch idealistische Philosophen wie Hegel und Belinskij Bezug. Es verwunden jedoch nicht, daB Ellis diese hier nicht erwähnt, da er sich nur auf die Denker stützt, die die intuitiven Kräfte höher stellen als die der abstrakten Philosophie. 
воплощенных в них идей. то станет совершенно понятным. почему мы считаем именно современны символизм самой сознательной и самой высшей формой искусства. ${ }^{17}$

Ėllis erörtert die Entwicklung des Symbolismus allgemein im Zusammenhang mit der Entwicklung des Begriffs "Symbol" und zeigt die Stilrichtungen der ersten (europäi schen) Symbolisten auf (Poe, Baudelaire, Mallarmé, Verlaine, Huysmans, Rodenbach. Wagner, Nietzsche u.a.), bevor er zum eigentlichen Gegenstand seiner Arbeit kommt: der Untersuchung des russischen Symbolismus am Beispiel des Werks von Bal'mont, Brjusov und Belyj.

In seiner Definition des Symbolismus als "созерцание [...] жизни сквозь призму искусства" 18 hat Ellis zweifellos einen wesentlichen Zug dieser Stilformation erfaßt: Symbolistische Kunst will nicht das Leben abbilden, wie es ist oder sein könnte, sondem will "Leben erschaffen". Die Kunst ist das Primäre, nicht das Leben!

Ėllis weist auf zwei Gefahren für den Symbolismus hin: "Эти две опасности возврат к реализиу (в какой бы то ни было форме) и смерть в догматизме" 19 , denen die Romantik, die Ėllis als "älteren Bruder des zeitgenössischen Symbolismus" (sic!) bezeichnet, erlegen sei. Symbolismus dürfe weder in der Dogmatik der katholischen Kirchlichkeit erstarren noch in die Abhängigkeit verschiedener Formen der Lebensrealität und Gesellschaft geraten, sondem müsse seine individuelle Freiheit bewahren ${ }^{20}$. In begeistert-exaltierter Weise bestimmt Ėllis in diesem Zusammenhang das "wahre" Wesen des Symbolimus:

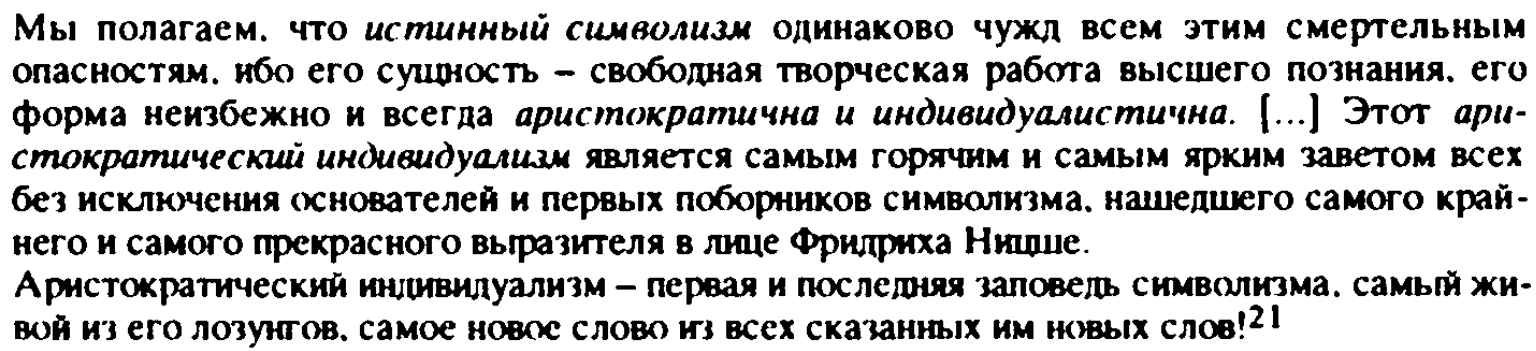

Wie auch bereits in seinen in der Zeitschrift "Bесы" publizierten literaturtheoretischen Aufsätzen über den Symbolismus plädien Ėllis hier für einen elitären Individualismus 22 innerhalb des Symbolismus, um dessen "Reinheit" zu erhalten und ihn nicht als Modeerscheinung der Masse und dem Pöbel auszuliefern, wodurch er verdorben würde. Auch an dieser Stelle betont Ellis wieder, daB sich der Symbolismus von der Freiheit in der Form zur Freiheit der Weltanschauung entwickelt habe ${ }^{23}$, was in etwa der Einteilung in "ältere" und "jüngere" Symbolisten entspricht ${ }^{24}$.

17 Ebd.. S. 17.

Dieses Zitat läbt deutlich werden. daB Ellis Goethe mıBverstanden hat, der zwischen Gleichnis und Symbol unterscheidet. Für Goethe ist zum Beispiel die "Faust"-Dichtung ein Gleichnis für menschliches Leben als etwas Vergängliches. Das Symbol versteht Goethe dagegen als künstlerisches Verfahren. um im literarischen Bild. als im Vergänglichen, das innere, unvergängliche Wesen einer Sache wahmehmbar zu machen, wobei das Symbol das Wesen der Sache, für die es steht, auch substantiell enthalten muB (2.B. "Kerze" als Symbol furr "Feuer", "Feuersbnunst" usw.), im Unterschied zur Allegorie (z.B. "Roter Hahn" für "Feuer", "Brand" etc.).

18 Ellis: Russkie simvolisty, S. 17.

19 Ebd., S. 27.

20 Mit dieser Äußerung richtet sich Ėllis nicht nur gegen die Realisten und Dogmatiker, sondem zugleich auch gegen die "co6opHocts"-Bestrebungen der Petersburger Symbolisten.

21 Ebd., S. 30.

22 Das Adjektiv "армстократический" ("aristokratisch") ist ungeschickt gewählt, da es "adelig" bedeutet. also eine bestimmte Gesellschaftsschicht anspricht: Ëllis meint aber wohl eher "elitär".

23 Ellis' immer wieder ähnlich auftretende Formulierung: "нз искания жсвоболного стиха» сим волизм сделался нсканнем "своболной личности " (Ëllis: Russkie simvolisty, S. 31) nennt die zwei 
Im Kapitel über K. Bal'mont 25 betrachtet Ëllis dessen künstlerisches Werk bis etwa 1909 im Zusammenhang mit der Entwicklung des russischen Symbolismus und liefen durch Exkurse über Joumalismus und Literatur in RuBland in der letzten Dekade des 19. Jahrhunderts ${ }^{26}$ und über den zeitgeschichtlichen Hintergrund zu Beginn des 20. Jahhunderts ${ }^{27}$ die notwendigen Zusatzinformationen für das Verständnis von Bal'monts Werdegang. Besonders ausführlich diskutiert er Bal'monts frühe Lyrikbände "Под северным небом" ("Unter nördlichem Himmel", 1894), "В безбрежности" ("In der Unendlichkeit", 1895), "Тишина" ("Stille", 1898), "Горящие здания" ("Brennende Gebäude", 1900) und "Будем как солнце" ("Laßt uns wie die Sonne sein", 1903) und charakterisiert in diesem Zusammenhang Bal'monts allmähliche Entwicklung vom Romantiker zum Symbolisten. Sehr richtig nennt er Bal'mont (ne ben Brjusov) einen der ersten bedeutenden russischen Symbolisten, dessen frühe $\mathrm{Ge}$ dichtbände zur Zeit der ersten Periode des russischen Symbolismus erschienen seien. die Ėllis die "Untergrundperiode" ("подпольный период" 28, 1895-1900) nennt.

Ellis betont in seiner Analyse der frühen Lyrik Bal'monts dessen große Sensibilität und Aufnahmefähigkeit für subtilste Empfindungen und differenzierteste Stimmungen und hebt den musikalischen Charakter seiner Gedichte hervor. Einen weiteren charakteristischen Zug sieht er in Bal'monts ungewöhnlichem Einfühlungsvermögen und der Subjektivität vieler seiner Gedichte. Ellis hat die kennzeichnenden Merkmale von Bal'monts Dichtung erkannt, wie sie bis heute von der Symbolismusforschung und in Literaturgeschichten hervorgehoben werden 29.

Die frühe Lyrik Bal'monts in "Под северным небом" bezeichnet Ėllis zutreffend als überwiegend romantisch und hebt als ihre wesentlichsten Motive die doppelte Gegenüberstellung von Wirklichkeit und Traum, von der düsteren, traurigen Kraftlosigkeit des "Hier" und dem grenzenlosen Höhenflug des "Dort", von der bitteren Einsamkeit auf der Erde und dem betenden Suchen nach dem christlichen Himmel 30 hervor. Dieser Dualismus ist kennzeichnend für Žukovskij und den frühen Blok, worauf Ellis allerdings nicht verweist. Er unterstreicht den großen dichterischen Went der frühen lyrischen Werke Bal'monts. vor allem ihre lautlich-musikalische Seite, und sicht in ihnen gleichsam eine Fortsetzung der romantischen Lyrik Fets (für den dieser Dualismus jedoch nicht zentral ist) ${ }^{31}$. Er findet in Bal'monts fruher Lyrik alle kennzeichnenden Charakteristika der Romantik:

unterschiedlichen Grundpositionen der Symbolismusauffassung. die 1909/1910 den sogenannten "Symbolistenstreit" auslösten.

$24 \mathrm{Vgl}$. hierzu die Symbolismusforschung. gute Zusammenfassung in: A.A. Hansen-Löve: Der russische Symbolismus, a.a.O.. S. 16. $29 \mathrm{ff}$.

25 Éllis: Russkie simvolisty, S. 51-121.

26 Ebd.. S. 63-77.

${ }^{27}$ Ebd.. S. $114-116$.

${ }^{28}$ Ebd., S. 76.

Der Begriff "nоmолье" ("Untergrund") ist im Russischen durch den Gebrauch von Dostoevskij vorbelastel und hat dadurch auch ein subversives Konnotat, was Ëllis jedoch nicht zu berücksichtigen scheint.

29 Vgl. etwa R.-D. Kluge: Der russische Symbolismus, a.a.O., S. 41: A. Stender-Petersen: Geschichte der nussischen Literatur. Teil II, a.a.O.. S. $519 f$ f.

${ }^{30}$ Ėllis: Russkie simvolisty. S. 54.

31 Der groben Verwandtschaft zwischen der Lyrik Bal'monts und Fets, die auch von der Literaturgeschichtsschreibung hervorgehoben wird (vgl. A. Pyman: A History of Russian Symbolism, a.a.O.. S. 11.13), ist in neverer Zeit eine eigene Untersuchung gewidmet worden: S. Althaus-Schönbucher: Konstantin D. Bal'mont. Parallelen zu Afanasij A. Fet. Symbolismus und Impressionismus. Bern. FrankfurdM. 1975. 
[...] музыка теней. невоплощенных и полу-воплощенных фбликов. тревожное желание. созерцая. высвободится из-под опеки вещей и постичь бесконечное на ином плане. чем мир конечных явлений. желание не столько познавать, сколько любить вселенную. умение с какой-то почти детской. трогательной искренностью. с какой-то женственностью. этой музыкой нежности. коснуться каждого цветка и все-таки оставаться груст. ным и обманутым - все эти типичные для кажлого истинного романтика черты сближаются в самых интимных созвучиях и линнях лирикн Бальмотта и Фета. ${ }^{32}$

Diese einfühlsame Beschreibung der frühen Lyrik Bal'monts ist zugleich ein Beispiel für die typische Legitimation des Symbolismus; nur fehlt der Hinweis auf das Neue, Originelle des Symbolismus, das sich bereits in Bal'monts Frühwerk ankündigt: Er schuf eine ganz eigene "Poesie der Assonanzen" (zum Beispiel im Gedicht "Чёлн томления" - "Kahn der Sehnsucht", 1894)33, einen eigentümlich einlullenden Rhythmus (etwa in "Ангелы опальные" - "In Ungnade gefallene Engel", 1899). Die Klangfülle schafft eine impressionistische Stimmungslyrik von bezaubernder und betörender Wirkung.

Als weiteren wichtigen Lehrer und Inspirator Bal'monts in seiner frühen Schaffensperiode nennt Ellis Shelley und weist darauf hin. daB Bal'mont die lyrischen Werke Shelleys studiert und übersetzt hat ${ }^{34}$. Ferner untersucht er den EinfluB Poes und Baudelaires auf Bal'mont ${ }^{35}$. Eine Analyse einzelner früher Gedichte Bal'monts läßt ihn zu folgendem Ergebnis kommen:

[...] уже в первой книге Бальмонта мы встречаем поразительно правильные прнемы построения символа. богатство образов. естественно и проникновснно устанавливаюирх ту "cortespondance" межлу внешним и внутренним мнрами. которую Ш. Бодлэр полагал суциностью всякой символизация. ${ }^{36}$

Im Titel von Bal'monts zweitem bedeutenden Lyrikband "B безбрежности" sieht Ellis die sehnlichsten Bestrebungen der Romantik ausgedrückt und zugleich den wohlwollenden Widerhall der Hauptideale der zeitgenössischen europäischen Symbolisten, nämlich ihre vielen Versuche, die äuBere Welt zu symbolisieren, das heiBt, das Ewige im Zeitlichen zu suchen und im Endlichen und Vergänglichen einen Abglanz. der Unendlichkeit ${ }^{37}$.

Der dritte Gedichtband Bal'monts, "Тишина", sei durch eine viel größere Komplexität und Vielfältigkeit der Motive ausgezeichnet, durch einen größeren Umfang schöpferischen Gedankenguts und durch größere Feinheit der Symbolisierungsmethoden. dafür sei jedoch die Betrachtung weniger zielgerichtet und die Stimmung weniger kühn. In "Тишина" handele es sich bereits überwiegend um eine Art von Lyrik. die Bal'mont selbst später "лирика современной души" genannt habe ${ }^{38}$.

Der folgende Band. "Горящие здания", sei "Dichtung der zeitgenössischen Seele" ("лирика современной души") 39 . In ihm sieht Ėllis die bemerkenswertesten Erschei nungen des Seelenlebens gestaltet, es handele sich um eine beinahe völlige Metamorphose der Persönlichkeit. "Горящие здания" verkörpere jedoch nur eine Übergangs-

32 Ėllis: Russkie simvolisty, S. 55.

${ }^{33} \mathrm{Vgl}$. hierzu auch: Kindlers Neues Literaturlexikon. Bd. 2. München 1989, S. $112 \mathrm{f}$

34 Ėlis: Russkie simvolisty, S. 55f. Zum Verhältnis Bal'mont - Shelley vgl. auch A. Pyman: A History of Russian Symbolism, a.a.O.. S. 61.

35 Ellis: Russkie simvolisty, S. 56f.

36 Ebd., S. 61. Ellis fühn einige Beispiele an, z.B. das Sonett "Jlactorkn" ("Die Schwalben").

${ }^{37}$ Éllis: Russkie simvolisty, S. 80.

38 Ebd., S. 84f.

${ }^{39}$ Ebd., S. 93. 
periode in Bal'monts Wandlung vom Dualismus zum Pantheismus, von der Romantik zum reinen Symbolismus, von einem ewigen Suchen zur zeitgenössischen Lyrik ${ }^{40}$.

Den nächsten Gedichtband. "Будем как солнце" (1903), hält Ėllis für das Bedeutendste, was Bal'mont geschrieben hat. Bal'mont finde darin endgültig seinen Weg:

[...] путь экстатического проникновекия в душу мира. в сущность мироздания, окончательное оправдание всего многообразия вселенной. великое "Да", которого он мучительно-тиетно искал всю жизнь. ${ }^{41}$

Высочайший полет и самое глубокое падение - основная тема этой замечательной кни ru. $^{42}$

In den weiteren Werken Bal'monts, die Ėllis nur noch recht kurz behandelt, sieht er ein Sinken der schöpferischen Phantasiekräfte, ein Nachlassen der Gespanntheit der seelischen Emotionen. Die künstlerische Form beginne, Risse zu bekommen und zu zerfallen 43 (bereits in "Только любовь" ["Nur Liebe", 1903] und "Литургия красоты" ["Liturgie der Schönheit", 1905] sowie dann in verstärktem Maße in "Злые чары" ["Böse Zauber"], "Жар Птица" ["Der Feuervogel", 1907], "Зеленый вертоrрaй" ["Der grüne Garten", 1909] und "Птицы в воздухе" ["Vögel in der Luft"])44.

Ellis sieht in Bal'mont einerseits einen der ersten bedeutenden Symbolisten, der in seinen frühen Lyrikbänden (bis zu "Будем как солнце", 1903) einen neuen Stil geschaffen und großen EinfluB auf die nachfolgenden russischen Symbolisten ausgeübt habe. Andererseits habe Bal'mont in seinen späteren Werken jedoch seine eigenen Neuenungen karikiert und parodiert ${ }^{45}$ :

[...] до сих пор [Бальмонт] считается мнотими главой новой символнческой шхолы в Россин. до сих пор лишь немногие читатели и критикн умеют разобраться во всей груде созданного им. различать два исключающих пруг лруга его лика, лик бессмертного. вели ксто и вдохновенно-дерзкого искателя новых образов и созвучия. Бальмонта твориа новой поэзии в Россин. заслуги которого не могут быть достаточно взвешены и оценены по лостоннству. и лик сгоревшего. налломленного и утратившего себя. бессильного и претенциозного исказителя всех стилей. жалкого пародиста всех свонх лучших и заветных напевив $[\ldots]$

Из поэтов наших дней никто. быть может, не писал лучше Бальмонта. нихто не писал хуже его. но вечно только прекрасное! 46

In dieser abschließenden Charakteristik Bal'monts drückt sich wieder Ėllis' ganze KompromiBlosigkeit aus, und er spant nicht mit antithetischen Adjektiven, um die seiner Meinung nach - starke Polarität der zwei Schaffensphasen Bal'monts zu verdeutlichen.

40 Ebd.. S. 95.
41 Ebd., S. 101.
42 Ebd. S. 113.
43 Ebd.. S. 116.

44 Ėllis' Einteilung von Bal'monts Werk in zwei Phasen: eine erste. dichterisch wertvolle und eine zweite, weniger fruchtbare, die deutliche Spuren des Verfalls trägt. entspricht in etwa der Gliederung in der einschlägigen Sekundärliteratur über Bal'mont. die den Beginn der zweiten Phase ungefähr 1905 ansetzt (vgl. Kindlers Neues Literaturlexikon, Bd. 2. a.a.O., S. 113; S. Nthaus-Schönbucher: K.D. Bal'mont. Parallelen zu A.A. Fet, a.a.O., S. 7: W. Kasack: Lexikon der russischen Literatur des 20. Jahrhunderts, a.a.O., S. 108: R. Peterson: A History of Russian Symbolism. a.a.O., S. 77). Jedoch gibt es in der Bal'mont-Forschung auch eine gegenteilige Meinung. gemäB derer Bal'mont in der $z$ weiten Phase ebenfalls gute Werke geschaffen habe (vgl. z.B. VI. Markov: Balmont. A Reappraisal. In: Slavic Review. XXVIII |1969] 2, S. 221-264).

45 Ëllis: Russkie simvolisty, S. $118 \mathrm{f}$.

${ }^{46}$ Ebd.. S. 121. 
Im dritten Kapitel seiner "Русские символисты" untersucht Ėllis Brjusovs Werk in seiner Entwicklung (bis etwa 1909) ${ }^{47}$, das aus Lyrik, Drama und einem "psychologischen Roman" bestehe, also alle Gattungen beinhalte, jedoch durch eine verblüffende Einheit gekennzeichnet sei. Ėllis charakterisiert Brjusovs Lyrik, die sich beinahe gleichzeitig mit der Lyrik Bal'monts entwickelt und durchgesetzt habe, als "männlich", plastisch und apollinisch-klar und sieht sie im krassen Gegensatz zur "weiblichen", romantischen Lyrik Bal'monts stehen ${ }^{48}$ :

[...] если Бальмонт сразу же почти чудесно овладел тайной поэтического ритма. а в конце своего пути пришел К самопародированию. то Брюсов, напротив, начал с резких диссонансов, которые теперь в сравнении с лучшнми перлами его творчества. созданными лишь в конце 49 , кажутся чем-то в роде пародий, а лишь после сложного искуса достит безошибочной меткости и точности своего резца. 50

1894 und 1895 erschienen die ersten drei Ausgaben von Brjusovs "Русские символисты", die Ëllis als das erste Manifest, den ersten Versuch des russischen Symbolismus hervorhebt und darauf verweist, daB Brjusov den Symbolismus "Dichtung der Andeutungen" ("поэзия намёков") nenne ${ }^{51}$. Ėllis betont hier einen wichtigen Zug des frühen russischen Symbolismus, den man - mit Brjusov - als poetischen Impressionismus bezeichnen kann. In der russischen Literatur hat es jedoch keinen Impressionismus als eigenständige Stilformation gegeben.

Im folgenden analysient Ellis Brjusovs lyrisches Werk. Als seinen ersten originellen Gedichtband hebt er die im Mai 1895 erschienenen "Chefs d'œuvres" hervor und verweist auf das provozierende Moment dieses Titels ${ }^{52}$. Im Gegensatz zu Bal'monts etwas früher erschienenem Lyrikband "Под северным небом", der überwiegend romantisch sei, spreche Brjusov in den "Chefs d'œuvres" auf "neue Weise über das Neue" ("о новом по-новому"):

\begin{abstract}
Автор ее уже сознательно определяет себе место и ставнт вполне определенные залачи зтой "последней книге его юности" и первой кните юности русского символизма Крайний инливндуализм. перенесение центра в личность художниха (субъективизм). исповедание логмата о самоценности художественного творчества. подчеркнутое значение самой художественной формы - вся позднейшая боевая программа новой uколы уже точно формулированы в "Предисловин" автором [...]. ${ }^{53}$
\end{abstract}

Der folgende Gedichtband. "Me eum esse" (1897 erschienen), stelle in seinen Haupt zügen eine Fortsetzung der Ideen und Motive von "Chefs d'œuvres" dar. Brjusov versuche darin bewuBt sein "Neuerenum" ("новаторство") hervorzuheben, seinen soge nannten "Modernismus", indem er diesen Gedichtband selbst "новая книга стихов" ("neuen Gedichtband") nenne ${ }^{54}$. Ellis weist darauf hin, daB der Beginn des "freien Verses" (свободный стих, vers libre) in diesem Gedichtband Brjusovs liege. (Als Beispiele fühn er die Gedichte "Как царство белого снега" ["Wie das Reich des

${ }^{47}$ Ebd.. S. 125-206.

48 Ebd.. S. 126.

${ }^{49}$ Man darf nicht vergessen. dab Ëllis dies alles bereits $1909 / 1910$ geschrieben hat. Brjusov jedoch erst 1924 starb und nach 1910 noch wesentliche Werke geschrieben hat.

50 Ëllis: Russkie simvolisty. S. 127

51 Ebd.. S. 134.

Merežkovskijs Arbeit "O прнчинах упапка н о новых теченнях современной русской литературы" war allerdings schon 2 Jahre zuvor erschienen, beinhaltet jedoch Kritik und Theorie, nicht dichterische Praxis.

52 Ėllis: Russkie simvolisty, S. 138

${ }^{53}$ Ebd.. S. 139.

54 Ebd., S. 143. 
weißen Schnees"] und "Месяц бледный, словно облако" ["Der bleiche Mond, gleich einer Wolke"] an.) ${ }^{55}$ Brjusovs Vorbild sei P. Verlaine, insbesondere sein "Art poétique" gewesen. Später habe der "freie Vers" seine Vollendung bei Bal'mont, Gippius, A. Belyj und A. Blok gefunden 56 .

Die "Untergrundperiode" ("подпольный период") des Symbolismus sei 1900 beendet und es beginne eine neue Epoche des russischen Symbolismus: "период дружного, широкого и открытого боевого выступления"57. Eben dieses Jahr, so betont Ellis, sei auch wichtig für Brjusov gewesen:

С этого момента его воззрения на новое искусство (на снмволизм как прежде всего на "поэзию намеков", как на долженствующую господствовать новую школу, неизбежно и преемственно замещающую две предшествуюшне школы - классическую и романтическую) отступают на второй план перед провозглашением главной миссии новой школы абсолютниои свободы худохественного твориества. 58

In diesem Zitat weist Ellis deutlich darauf hin. daB sich der russische Symbolismus vom poetischen Impressionismus zum freien künstlerischen Schaffen entwickelt habe und formulien somit (bewuBt oder unbewuBt) den zentralen Aspekt der Kreativität. die konsequenterweise zur Ablehnung der Mimesis führen müßte: kreatives, künstlerisches Schaffen unterliegt keinen Zwängen und Vorbildern, der symbolistische Dichter ist vollkommen frei. Diese absolute künstlerische Freiheit wurde jedoch unterschiedlich aufgefaßt von Brjusov auf der einen Seite und Belyj, Blok und Vjač. Ivanov auf der anderen ${ }^{59}$. Ėllis hebt hervor, daB "neue Kunst" für Brjusov fortan vor allem Verwirklichung von Freiheit in der Kunst überhaupt heißt:

[...] свобола и равноправность всех икол н направлений перед единым ликом Истины внутренняя свобода искусства н полная независимость художественного творчества от всяких внеиних условия и моментов [...] Новое искусство. символизм, современное направление в нскусстве - это все лишь формулы для искусства. сознательно и бесповоритно ссвободившего себя от всех внешних рамок и всяких внутренних перегородок.

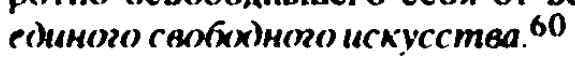

In seiner Schrift "O [sic!] искусстве" ("Über die Kunst", 1899) spreche sich Brjusov für völlige Freiheit des künstlerischen Schaffens aus, für das Recht der Selbstbestimmung und Souveränität des Künstlers. für die Verkündung des einzigen Zieles der Kunst. der Einheit mit der Künstlerseele. Brjusovs Subjektivismus wird hier treffend von Ellis hervorgehoben. Dieser Kult der absoluten Freiheit des Schaffens trennt - nach Ellis - die ersten russischen Neuerer grundsätzlich von ihren europäischen Vorläufem 61 .

55 Ebd., S. $147 f$.

56 DaB Brjusov den "vers libre" in die russische Lyrik eingeführt hat, wird von der Forschung bestätigt: vgl. G. Donchin: The Influence of French Symbolism on Russian Poetry. S'Gravenhage 1958. S. 181-184, bes. S. 183. Donchin weist auch auf den groben EinfluB E. Verhaerens auf Brjusov bezüglich dieser Versform hin. Zu Bal'mont vgl. G. Donchin: ebd.. S. 185. Auf Belyjs und Bloks Verstechnik ist ja bereits hingewiesen worden (vgl. oben. S. 23).

\$7 Ėllis: Russkie simvolisty. S. 151.

58 Ebd.

$59 \mathrm{Vgl}$. oben. die Ausfühnungen zum "Symbolistenstreit" im Einleitungsteil der vorliegenden Arbeit. S. $17 f$.

${ }^{60}$ Ëllis: Russkie simvolisty, S. $151 f$.

61 Ebd., S. $152 f$.

Diese Aussage ist falsch: was z.B. Novalis, Schlegel und Nietzsche über die Kunst und die Freiheit des künstlerischen Schaffens gesagt haben, unterscheidet sich nicht von dem. was Ëllis Brjusov als Neuerer zuschreibt. 
Ëllis charakterisien Brjusovs erste Entwicklungsstufe als Periode der Vorahnungen. Die zweite Phase, die bis zur Gegenwart [= 1909/1910] andauere, nennt er Verwirklichung und Verkörperung. Undeutliche Vorahnungen. Andeutungen und $\mathrm{Be}-$ trachtungen, die Brjusov in der ersten Periode - vor allem in "Me eum esse" - zufällig und rein impressionistisch gestaltet habe, bekommen nun eine wahrnehmbare, feste und plastische Form. Die späteren vier Gedichtbände ("Tertia Vigilia" [1900], "Urbi et Orbi" [1903], "Stephanos" [1906] und "Bce напевы" ["Alle Gesänge", 1909]) bezeichnet Ėllis als vier harmonische Stufen, die zum gleichen Ziel führen: " $\kappa$ постиженик) внутреннего мира через внешний путем свободного, творческого созидания пластически-законченных символов" 62 .

"Tertia vigilia" ist für Ëllis das beste lyrische Werk Brjusovs:

Bce отделы еe [= "Tertia vigilia"] правильно и четко насланваются прут на друта подобно скульттурным барельефам. все они имеют органическую связь с его булушими создания мн: почти в каждой строфе чувствуется удар опытного резца. в каждом аккорде новая. оритинальная и уверенная нота. ${ }^{63}$

Nach einer Analyse der fünf Teile dieses Lyrikbandes zitiert Ėllis als Beispiel für Brjusovs perfekten Stil und Vers das Sonett "Ты - женщина, ты - книга между книг" ("Du bist eine Frau, Du bist ein Buch unter Büchem")64.

Die vier oben erwähnten Gedichtbände seien nicht nur für die zweite Schaffensperiode des Dichters charakteristisch. sondem für Brjusovs Lyrik überhaupt:

Поэтическое творчество для В. Брнсова не прекрасная забава. не божественная игра. не ббщественно-полезная работа. даже не долт перед самим собой; оно для него - нензбежность, но и не только нензбежность. а священная миссия. своего рода культ. Оно долт не перед равными. не перед люпьми (того менее перед современниками). не перед самим собой. а перед Высиямн Силами. перед самой Вечностью. ${ }^{65}$

Ëllis erkennt die formale künstlerische Meisterschaft Brjusovs, der souverän alle Verfahren und "priemy" der lyrischen Dichtung so perfekt beherrscht. daB Ėllis ihn als "Instrumentaldichter" ("поэт-инструменталист") 66 bezeichnet. Das soll bedeuten. daB Brjusov alle formalen Verfahren der Poetik so hervorragend meistert wie ein Musiker, der sein Instrument perfekt beherrscht, und verweist auf die besondere, andersartige Wirkung, die Brjusovs Verse hervomufen.

Das Wesen eines jeden geschaffenen Kunstwerks sei dualistisch:

Художник обожает мир. как целое. как данное. ибо из него он научается тайнам всех вещей и из него черпает краски и звуки и в то же время для него каждая вешь лишь облачко. лишв преходяций образ Вечното Символа |.....67

Dieser Dualismus drücke sich auch in den besten Werken Brjusovs aus, die ihn als Dichter zugleich als "Henker" und "Opfer", als "Herm" und "Sklaven" erscheinen lieBen.

Auch in seiner künstlerischen Prosa sei Brjusov ein ebenso strenger, folgerichtiger Symbolist, wie in seiner Lyrik. Ëllis erönten Brjusovs Prosa: die Erzählungen ("B зеркале" - "Im Spiegel", "Республика южного креста" - "Die Republik des Südkreuzes", "Сестры" - "Die Schwestern", "Tеперь, когда я проснулся" - "Jetzt, da ich erwacht bin", "Мраморная головка" - "Das Marmorköpfchen" u.a.), das Drama

62 Ėllis: Russkie simvolisty. S. 154.

${ }^{63}$ Ebd. S. 162.

${ }^{64}$ Ebd., S. 165.

65 Ebd.. S. 166.

66 Ebd., S. 186.

${ }^{67}$ Ebd.. S. $174 f$. 
"Земля" ("Die Erde") und den "psychologischen" Roman "Oгненный ангел" ("Der feurige Engel"). Obwohl Ėllis, wie vorn ausgeführt ${ }^{68}$, die Möglichkeit eines rein symbolistischen Theaters bestreitet und sich kritisch über zeitgenössische Dramatiker und ihre Werke äuBert, bezeichnet er hier das Drama "Земля" als das Bedeutendste, was Brjusov überhaupt geschaffen habe:

Трагкческий пессимизм Брюсова. весь его геронческия интивилуализм и сумрачное безумие его потрясающей фантазин. взанмно оттеняя лруг пруга. огненными буквами залечатлены в лучших сценах этой великой трагелин. героем которой является все человечество. 69

Die Kritik bewerte im allgemeinen Brjusovs Prosa niedriger als sein lyrisches Werk. was jedoch nicht gerechtfertigt sei: Brjusov erweise sich in seinem Prosawerk ebenso als Symbolist, wie in seiner Lyrik. Dieser frühe Hinweis auf die Bedeutung symbolistischer Prosa am Beispiel Brjusovs muB als wichtiges Verdienst von Ėllis' "Pycckue скмволисты" innerhalb der frühen Symbolismusforschung hervorgehoben werden.

Brjusovs künstlerische Entwicklung sei, im Gegensatz zu derjenigen Bal'monts, kontinuierlich und in sich geschlossen; Ellis charakterisient sie abschlieBend folgendermaßen:

\begin{abstract}
Многопбразно. но в стройой преемственности форм и методов вьявлялось единое творческое "я", начиная с дерзких и сумрачно-отрешенных его первых созерцаннй и предчувствий. облеченньх бессознательно и мучтельно в форму самого резкого импресснонизма. продолжаясь через упорное искание пластической. осязательной. почти парнасской формы пля закрепления символа и наконец завершаясь двумя гранднозными. доститиями совершенного синтеза формы и содержания. созданиями. драмой "Земли" и романом "()тненный Ангел". 70
\end{abstract}

Im vierten Kapitel analysien Ëllis Andrej Belyjs Werk (bis 1909)71, vor allem seine vier "Sinfonien" und drei Gedichtbände: "Золото в лазури" ("Gold im Azur", 1904), "Ilener" ("Asche", 1909) und "Урна" ("Die Ume", 1909) und versucht, seine Sonderstellung unter den russischen Symbolisten zu verdeutlichen, indem er immer wieder Belyjs Vielseitigkeit hervorhebt und betont, daB die Bedeutung von Belyjs Schaffen weit über den streng-künstlerischen Rahmen hinausreiche. Während die Hauptaufgabe des Werkes der zwei ersten russischen Symbolisten, Bal'mont und Brjusov, darin bestanden habe, ein für allemal eine scharfe Grenze zwischen dem Realismus und dem Symbolismus in der Kunst zu ziehen und am Beispiel des eigenen Schaffens zu zeigen. wie sehr sich die "neue Kunst" prinzipiell von allen früheren Methoden des künstlerischen Schaffens unterscheide, sei die spezielle Aufgabe oder Mission Andrej Belyjs, des dritten Führers des russischen Symbolismus, die folgende gewesen:
[...] показать вско безграничность симвализма во всех его универсальных устремлениях. сделать все возможные. крайнне выводы из теорнн художественного творчества. как со- зерцания суиностей в явленнях. установить теореткчески и прахтическн все самьх сложные связи символизма с чнстой мастикой (вплоть до духовидения и теургия). совре- мекной научной философней. и главнымн формами "нового релитиозного сознания" $[\ldots] \cdot{ }^{72}$

Der Symbolismus als rein künstlerische Methode sei für Belyj nur ein Mittel gewesen, um seine Visionen und Wahmehmungen zu beschreiben. Er habe von Anfang an ei-

\footnotetext{
$68 \mathrm{Vgl}$. S. 77-80 der vorliegenden Arbeit.

${ }^{69}$ Ëllis: Russkie simvolisty. S. 196.

71) Ebd., S. 205.

71 Ebd., S. 209-316.

72 Ebd., S. 209.
} 
gene neue Erfahrungen und Impulse in die neue literarische Stilformation des Symbolismus eingebracht, sei ein "vielgesichtiger" und stets tragisch-widersprüchlicher Mensch und habe vor allem unter dem EinfluB der Antipoden Vl. Solov'ev und F. Nietzsche gestanden.

Die Entwicklungswege der drei von ihm untersuchten "Hauptvertreter" des russischen Symbolismus grenzt Ėllis folgendermaßen voneinander ab:

\footnotetext{
Если исторня творчества К. Бальмонта - ряп глубоких метаморфоз поэтической личности. почти мгновенно находящих свою форму, если история развития В. Брюсова - орга ническое. стройное и цельное в своей последовательности раскрытие одной сложной и тонкой формы. то весь пройденный А. Белым путь - мятежное и внешне-непоследовательное чередование разных форм. трепетный подбор все новых и новых форм лля выявления одной, всеобъединяющей идеи, для определення все той же сушности, лля изображения все того же еднного Лика. ${ }^{73}$
}

Nicht umsonst wird in der Forschung zwischen zwei Symbolistengenerationen unterschieden, und Ellis hat richtig erkannt, daB Belyjs Werk etwas ganz anderes, Neues im Gegensatz zu Bal'mont und Brjusov darstellt; Belyj gehört ja zu den sogenannten "jüngeren" Symbolisten, für die Symbolismus nicht nur eine literarische Schule, eine zeitlich begrenzte Stilformation und eine rein ästhetische Erscheinung war, sondern zur Weltanschauung und Lebenspraxis wurde. Doch tut sich Ellis besonders hier, in seinem umfangmäBig längsten Kapitel, sehr schwer, überzeugend und klar zu argumentieren, verständlich und reflektiert zu formulieren. Seine stellenweise recht verworrene und nur schwer nachvollziehbare Argumentation wird etwa in den nachfolgenden Ausführungen über Belyj deutlich:

\begin{abstract}
Все. что создано А. Белым. вся его патетическая лириха и вся музьха его четырех "Симфоний" - одно Видение: [...] в том-то и заключается глубокое влияние и современность проповеди А. Белого. что он сослиняет в себе и своболное художественное созерцание (символизм), и лищезрение тайны. что он и рассказывает о новом Боге, ках о грялущем. и вицит его внутри себя. Это соелинение символизма с мессианизмом- суцность А. Бслого. Это - его "все" и "все" его дела... [...] Миссией А. Белого является сселинение нового релитиозного откровения с хуложественной формой современного символизма. ${ }^{74}$
\end{abstract}

Zu Recht hebt Ėllis den Kult des Ewig-Weiblichen als Hauptmerkmal von Belyjs Symbolik hervor.

Er teilt Belyjs bisheriges künstlerisches Schaffen (bis 1909) in zwei Phasen ein und erkennt gegenwärtig erste Anzeichen einer neuen, dritten Periode.

Zur ersten Schaffensphase zählt Ėllis Belyjs ersten Lyrikband "Золото в лазури" (1904) und seine ersten beiden "Sinfonien": "Северная симфония" (1904) und "Драматическая" ("Die Dramatische", 1902). Diese Periode sei ganz vom symbolistischen Kult des Ewig-Weiblichen und dem Verlangen nach einer "theurgischen Handlung" bestimmt, von Optimismus und Zuversicht. Ellis bezeichnet diese Haltung als Belyjs anfängliches "Ja" ("первое «Да»"). Die dritte "Symphonie" ("Возврат" "Rückkehr", 1905) drücke eine "schwankende Übergangsperiode" ("переходный, колебательный периол") aus, die zum Pessimismus, zur Selbstverneinung und zum Glaubensverlust der zweiten Schaffensphase führe, zu der die vierte "Sinfonie" ("Kyбок метелей", 1908) sowie die Lyrikbände "Пепел" und "Uma" gehören. Diese zweite Periode nennt Ėllis Belyjs "великое безнадежно-горькое «Нет» всему, его "разуверение во всем»"75. Im dritten und (bis 1909/1910) letzten Lyrikband. "Уp-

73 Ebd., S. 215.

${ }^{74}$ Ebd.. S. $215 f$.

${ }^{75}$ Ebd., S. 221 f. 
на", sei Belyj zwar noch Pessimist, doch sieht Ellis darin den Beginn einer neuen Phase angedeutet.

Ëllis diskutien ausführlich alle vier "Sinfonien" Belyjs ${ }^{76}$ und weist in diesem $\mathrm{Zu}$ sammenhang darauf hin, daB der Symbolismus seinem Wesen nach immer schon eine Neigung zur Verbindung mit dem Mystizismus und mit "Hell-/Klarsichtigkeit" ("ясновидение") gehabt habe77.

Wie bereits in seinen "Bесы"-Aufsätzen 78 definier Ėllis auch hier das Wesen des Symbolismus als "установление точных соответствий между вицимым и невидимым мирами"79 (vgl. Baudelaire: "Correspondances") und sieht es in Belyjs "Sinfonien" realisiert. Er hebt die dreifache Bedeutung hervor, die Belyj selbst seinen "Sinfonien" zuspricht: musikalische, satirische und ideell-symbolische ${ }^{80}$, und analysiert sie nicht nur inhaltlich sondern auch formal: Ihr Stil sei ekstatisch, halb-künstlerisch und halb-visionär. Die charakteristische Musikalität sei eine wichtige Eigenschaft dieser Werke Belyjs ${ }^{81}$.

Auch Belyjs Lyrik untersucht Ellis sowohl nach inhaltlichen als auch nach formalästhetischen Kriterien. Er bemüht sich sehr, das Neue, Originelle darin aufzuzeigen. tut sich aber wieder mit verständlichen, reflektierten Formulienungen sehr schwer und führt stattdessen überwiegend hohle, nichtssagende Kriterien an. Dennoch muB Ėllis' Bemühen, die Neuartigkeit der Lyrik eines gleichaltrigen Zeitgenossen ohne zeitlichen Abstand zu erfassen und zu charakterisieren, ungeachtet des nebulösen Ergebnisses honorien und positiv hervorgehoben werden:

\begin{abstract}
Я называю лирику А. Белого оритинальной в том смысле, что она является не талько новой художественно̆ формой. построенной на впервые намеченных н развитых им зстетических нормах. но н новым содержаннем лушн н новым ясповеданнем лнчности. в первый раз пробужденной к порывам. созерцаниям и вялениям. которых никогда раньше она не ведала.

Лирнка А. Белого - не есть созерианне вечных. нензменных и лежаиих во вне ценностей. не есть музыка внутренних настроеннй; одним словом она не имеет ничего общего с "парнасизмом". она романтична только в внде нсключения. Ее нель зя назвать строго-снмволинескоЯ. хак строто-созерцательнуко лириху Брносова. нбо она почти всегда смельмн н стремительньми порывами переступает грань зстетического постижекня. пределы чнстого созерцания. становясь подобно "Симфониям" пафосом ясновидення. живым трепе том предчувствия и предвестия. прозорливо-чутким стилем предоцущения всегда чегото большего. чем только новое чнсто-художественное откровение. Каждое почти стихотворенне А. Белого неминуемо стремитя превратиться или в молитву, или в дифирамб. илн в слишхом инткмное для поэта прнзнанне. в нсповедь своей последней глубины н послелнего основания своего сокровенного " $a$ ", исповедь. окрашенную в символико-мнстический характер. ${ }^{82}$
\end{abstract}

Ėllis erörtert in diesem Zusammenhang den EinfluB von Nietzsches "intimer". "subjektiver" Lyrik auf Belyj und die große Bedeutung der Lyrik VI. Solov'evs für Belyjs Gedichtband "Золото в лазури":

Вл. Соловьев и Фр. Ниияе - эти два спутниха. зовуине в разные стороны. два вожля. говоряияе на разных наречиях - долто будут самыми близкимн. самыми доротимн учителямн А. Белого. ках бы двумя перекладинамн его креста. ${ }^{83}$

\footnotetext{
${ }^{76}$ Ebd., S. 223-250.

${ }^{77}$ Ebd., S. 229.

${ }^{78} \mathrm{Vgl}$. oben. S. 83-86 der vorliegenden Arbeit.

${ }^{79}$ Ëllis: Russkie simvolisty, S. 232.

${ }^{80}$ Ebd., S. 240.

81 Ebd., S. 242-247.

82 Ebd., S. 250 f.

${ }^{83}$ Ebd.. S. 254.
} 
Was die formale Seite von Belyjs Lyrik betrifft, nennt Ellis ihn in "Золото в лазури" einen "Meister des «freien Verses»"84.

Anschließend diskutient Ëllis Belyjs folgenden Gedichtband. "Пепел", der, wie Ėllis richtig erkennt, stimmungsmäBig das absolute Gegenteil von "Золото в лазури" darstellt ${ }^{85}$. Ellis versucht, die verschiedenartigen Motive der Verzweiflung, des Pessimismus und der Desillusionierung, die in diesem Lyrikband Ausdruck finden, durch die historische Entwicklung (die gescheiterte Revolution von 1905) und die Entwicklung innerhalb des russischen Symbolismus zu erklären ${ }^{86}$ : Der russische Symbolismus, der sich zunächst behaupten und legitimieren muBte, habe sich in den Jahren 1904 bis 1909 auf allen Gebieten weiterentwickelt, sei einfluBreich geworden und allgemein anerkannt, wozu die Werke Bloks (vor allem seine "Стихи о Прекрасной Даме"), D. Merežkovskijs, Z. Gippius', F. Sologubs und Vjač. Ivanovs ("Кормчие звезды" - "Leitsteme", "Прозрачность" - "Durchsichtigkeit" und "Эрос" - "Eros") nicht unmaBgeblich beigetragen hätten. Die symbolistisch ausgerichteten literarischen und philosophischen Zirkel in Moskau und Petersburg hätten große Bedeutung im kulturellen Leben der Öffentlichkeit erlangt, auf dem Gebiet der Publizistik hätten symbolistische Zeitschriften die Hauptrolle gespielt (Ëllis nennt "Мир искусства", "Новый путь", "Весы", "Золотое руно", "Перевал" и.a.), und immer mehr Verlage seien gegründet worden. wodurch die Öffentlichkeit in zunehmendem Maße mit ausländischer und inländischer zeitgenössischer Literatur bekanntgemacht werde. In die sem Zusammenhang beklagt Ellis. daB der russische Symbolismus somit in das "gefährliche Stadium" einer Monopolherrschaft gelangt und zur Modeerscheinung ge worden sei, oberflächliche und mitunter sogar vulgäre Züge trage und seine ursprüngliche "Reinheit" (damit meint Ellis das ursprüngliche hohe Niveau) nicht mehr gewahr habe. Bereits 1906 sieht Ëllis innerhalb des russischen Symbolismus eine unüberwindliche Kluft zwischen zwei Schulen: auf der einen Seite stehe die individualistische Schule Brjusovs, auf der anderen Seite die der Überindividualisten ("свсрх-индивилуалисты"), die mit D. Merežkovskij begınne und bald Vjač. Ivanov mit seiner Theorie des "мифотворчество" 87 zum Führer erhebe. Zwischen diesen beiden Schulen sei eine äußerst heiße Polemik entflammt (Ëllis verweist hier auf die Polemik um den "mystischen Anarchismus" 88 . nicht auf den "Symbolistenstreit", der

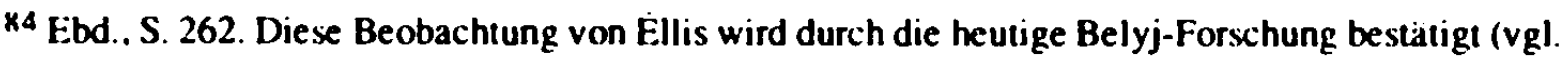
A. Lavrov: A. Belyj v 1900 e gody, a.a.O., S. 1.54).

85 Belyj hat "Ilene ${ }^{\prime}$ dem Andenken N.A. Nekrasovs gewidmet, der in der russischen Literatur als "поэт мести и печали" ("Dichter der Rache und Trauer") bezeichnet wird (diese Bezeichnung geht auf Nekrasovs poetologisches Gedicht "Замолкнн. Муза мести и печали!" ["Schweig'. Muse der Rache und Trauer", 1856| zuruick): mit ihm und seinem Werk haben sich viele russische Symbolisten auseinandergesetzt. Zum Verhältnis Belyj - Nekrasov vgl. auch A. Lavrov: A. Belyj v 1900-e gody. a.a.O., S. 257f. (don gibt es weitere Literaturangaben zum EinfluB Nekrasovs auf Belyj): zum Unterschied zwischen Belyj und Nekrasov vgl. ebd., S. 260-262.

${ }^{86}$ Ëllis: Russkie simvolisty. S. 264-282.

87 Im "Mythenschaffen" liegt für Vjac. Ivanov die Funktion der Kunst: (vgl. hierzu auch M. Deppermann: Andrej Belyjs ästhetische Theorie des schöpferischen BewuBtseins, a.a.O.. S. 72). Wahre Dichtung (des "realistischen Symbolismus") sei "Mythenschöpfung" ("мифотворчество"): (vgl. den 8. Teil von Vjač. Ivanovs Aufsatz "Две стихин в современном символизме" mit dem Titel "Реалистический символнзм н мифотворчество" ["Realistischer Symbolismus und Mythenschöpfung"]). Aufgabe des "мкфотворчество" sei es. unsichtbare Dinge aufzudecken, real darzustellen. Der Mythos ist im Symbol bereits enthalten, wird vom "realistischen Symbolismus" im Symbol erschlossen, ist Abbildung der dargestellten Wirklichkeit. Er muB verstanden werden als Modell von Welterkenntnis. (Vgl. Vjač. Ivanov: Dve stichii v sovremennom simvolizme. In: Ders.: Sobranie soxinenij. Tom II, a.a.O., S. 536-56I, hier bes. S. 554-561.)

\$x Vgl. oben. S. 32f. der vorliegenden Arteit. 
1910 vor allem im "Аполлон" ausgetragen wurde) ${ }^{89}$. Belyj habe unter dieser Spaltung sehr gelitten. Hinzu komme noch, daB A. Blok, einer der Dichter, die Belyj am nächsten standen, in seinem "Балаганчик" grob und zynisch über den Kult des EwigWeiblichen gespottet habe, über eben jenen Kult, der die Verse Bloks und Belyjs einander angenäher habe.

Ellis schildert hier sehr anschaulich und richtig, wenn auch in seiner eigenen, subjektiven Interpretation, die Entwicklung des russischen Symbolismus in der ersten Dekade des 20. Jahrhunderts, die die anfängliche Hoffnung und Begeisterung der "jüngeren" Symbolisten, die sich im "Argonautenkreis" zusammengefunden hatten, in Enttäuschung und Desillusionierung umschlagen und nach neuen Zielen und Idealen suchen lieB90, sowie auch den Stimmungsgegensatz in "Золото в лазури" und "Пепел" plausibel macht. Seine dargelegte Einschätzung und Charakteristik wird vom heutigen Forschungsstand bestätigt.

Belyjs dritten Lyrikband: "Урна", bewertet Ėllis als Versuch, ein Gleichgewicht zwischen den völlig entgegengesetzten Bestrebungen in "Золото в лазури" und "Пепел" darzustellen, zwischen dem anfänglichen Optimismus und dem folgenden Pessimismus 91 .

Ėllis versucht, Belyjs gesamte Entwicklung zu charakterisieren, wobei wieder sein kryptischer, exaltierter Stil auffällt, der allerdings der Diskussion der Zeit (vgl. den "Symbolistenstreit" von 1909/1910) entspricht, die Emotionen und Theorie vermengte und der es nicht gelang, die vagen Stimmungen und Vorstellungen argumentativ überzeugend und deutlich zu formulieren ${ }^{92}$ :

[...] сводя зволюцию А. Белого к одному символу, мы можем сказать с уверенностью. что первый. самьй безумнњй полет его к Солнцу не удался. он был сожоен, как и все подобные ему безумцы; испепеленњы труп его пал на землю и был развеян по долам и весям. там. где всчны тољко страланне. смерть и юдоль. Но сердще поэта не сгорело в небесном огне. оно положено в мраморную урну и нал ним зажжена "Пылающая звсзда". великий знак пентаграммы. ${ }^{93}$

\begin{abstract}
Экстатическое по суиности. патетическое по форме. всестороннее прннтне вселенно и символизация ее ПІерво-суиности. как "золота в лазури", приводит поэта к решительному кризису. к персоненхе самых основньг символов. к "разуверенио во всем". Не доверияв своего исполинского полета к Солнцу мира. своего воздушпото аргонавтического пути. он испепелен. и его пепел неразлучен с грудамн пепла. на которые распался теперь весь мир. сотканный. как недавно еше верилось. только из золота и лазури. из небесного огня и чнстейшего зфира. Однако это испепеление и распьление поэта и его мнра не могло быть абсолютным; последнее оказалось стољ же невозможным. как и осуществление до конща абсолютного устремления ввысь "Золота в лазурн". 94
\end{abstract}

Ėllis geht, wenn auch nur kurz, ebenfalls auf Belyjs Prosa ein. und zwar auf seinen Roman "Серебряный голубь" ("Die silbeme Taube"), den er der Tradition Gogol's

${ }^{89} \mathrm{Vgl}$. oben. S. $17 f$. der vorliegenden Arbeit

$90 \mathrm{Vgl}$. z.B. auch die Wandlung. die Vjac. Ivanov, Blok und viele andere Verureter dieser Stilformation durchmachten.

91 Ellis: Russkie simvolisty, S. 298. Ellis' richtige Einschätzung dieses Lyrikbandes von Belyj wird von der heutigen Belyj-Forschung bestätigt (vgl. A. Lavrov: A. Belyj v 1900-e gody. a.a.O., S. 263269).

92 Z.B. A. Bloks Beitrag zum "Symbolistenstreit". "O современном состоянии русского символизма", entspricht Ëllis, ist allerdings poetisch besser ausgedrückt: zur wirklichen Theorie vermochte allein Vją. Ivanov die unklaren Stimmungen und vagen Vorstellungen zu klären (in " Заветы символизма").

${ }^{93}$ Ėllis: Russkie simvolisty. S. 223. Vgl. hierzu auch Belyjs Vorwort zu "Ypwa" sowie A. Lavrov:

A. Belyj v 1900-e gody, a.a.O., S. 263.

94 Ellis: Russkie simvolisty, S. $298 f$. 
verpflichtet sieht ${ }^{95}$, künstlerisch hoch einschätzt und auf eine Stufe mit Brjusovs "Огненный ангел" stellt96.

Am Ende dieses vierten Kapitels formulier Ëllis zusammenfassend das Hauptmerkmal von Belyjs Schaffen und Weltanschauung, das seiner Persönlichkeit, seinem künstlerischen Werk und seiner ganzen Lehre eine geheime Einheit verleihe:

\begin{abstract}
Эта основная черта - всепоглощающее. растущее из его последнего "я" - стремление превратить символизм. как созерцание. в символику тайновидения и тайнодействия. современное эстетическое миросозерцаяне. осознавшее себя. как символизм. в синтетическую систему. в символизм. ставиий миросозерцанием. Эта основная черта - стремление чисто-практическое; она последовательно и неминуемо приводит А. Белого к нефоходимости существенно переступить границы "символического искусства" и коснуться самых последних тайн окхультизма. более того. коснуться последнего и страшпого вопроса 06 осуцествлении того пути. одним из неизбежных этапов которого является дар теургического лействования и необходимость превращения не только созерцающего и творящего сознания. но и всего "я" в живое. цельное и единое символическое "я".97
\end{abstract}

Im letzten Kapitel seines Buches, "Символизм и будущее"98, resümiert Ėllis die Hauptcharakteristika der drei typischen Vertreter des russischen Symbolismus (Bal'mont, Brjusov, Belyj), um auf dieser Grundlage SchluBfolgerungen über die gegenwärtige Krise des Symbolismus und die Zukunft der symbolistischen Bewegung in RuBland zu ziehen.

Bal'mont, Brjusov und Belyj repräsentieren drei einander abwechselnde Stadien des Symbolismus: Das romantische Stadium mit seinem Kult des weltentfremdeten Traumes, das klassische oder symbolistische im engeren Sinne mit seiner Methode der "Entsprechungen" (correspondances) und dem Verlangen nach kontemplativem Erfassen der Welt und schlieBlich das "ekstatische" Stadium, das Ëllis auch als "символизм ясновидения" 99 bezeichnet, das die Ästhetik in Weltanschauung verwandele und bestrebt sei, alle künstlerischen Symbole zu einer einzigen, systematisch-hierarchischen Symbolik zu vereinen, die im Verborgenen/Geheimen wirke. Diese Ergebnisse fühn Ellis in dem folgenden Schema vor ${ }^{100}$

\title{
ОБЩАЯ СХЕМА РАЗВИТИЯ РУССКОГО СИМВОЛИЗМА
}

\begin{tabular}{|c|c|c|c|}
\hline Предсmosumesu & К. Баньмонт & B. Бркосон & A. Besbü \\
\hline Форма символизма & $\begin{array}{l}\text { Романтическнй скм- } \\
\text { волизм }\end{array}$ & $\begin{array}{l}\text { Эстеткческий симво- } \\
\text { лизм в строгом смы- } \\
\text { сле термина }\end{array}$ & $\begin{array}{l}\text { Символитм ясновиде- } \\
\text { ния }\end{array}$ \\
\hline Спос 06 символизацин & Отрешенное грезенне & $\begin{array}{l}\text { Сосредоточенно-со- } \\
\text { зерцательное пости- } \\
\text { жение }\end{array}$ & $\begin{array}{l}\text { Экстатическое слия- } \\
\text { ние }\end{array}$ \\
\hline
\end{tabular}

95 Diese richtige Beobachtung wird auch heute noch von der Forschung bestätigt, vgl. A. Lavrov: A. Belyj v 1900-e gody, a.a.O., S. 279-285, 290 (in den Anmerkungen finden sich weitere bibliographische Angaben).

${ }^{96}$ Ëllis: Russkie simvolisty, S. 222, 314

97 Ebd., S. 314f.

98 Ebd., S. 319-336.

99 Die Übersetzung von "ясновиление" ist problematisch. Das deutsche "Hellsehen" mit seinen Konnotationen (des Wahrsagens usw.) ist hier nicht die korrekte Entsprechung für "ясновиденне". Was Ëllis ausdrücken will, ist die Fähigkeit, durch eine Hülle oder Oberfläche hindurchzusehen, das klare Erkennen oder Wahmehmen von etwas Transzendentem: "ясновидение" wäre also mit "Hellsichtigkeit" oder "Klarsichtigkeit" zu übersetzen oder mit "Hellseherei" mit der Konnotation von "mystischem Ausnahmezustand" (entsprechend dem französischen "voyant": Rimbaud und die Tradition des dichterischen Sehertums).

100 Ėllis: Russkie simvolisty, S. $320 f$. 


\begin{tabular}{|c|c|c|c|}
\hline $\begin{array}{l}\text { Преображение теs } \\
\text { через }\end{array}$ & Мечту & Прозрекие & Видение \\
\hline Метод символизации & $\begin{array}{l}\text { Противопоставление } \\
\text { res н realiora }\end{array}$ & $\begin{array}{l}\text { Ощушение в res- } \\
\text { realiora }\end{array}$ & $\begin{array}{l}\text { Слиание с realiora и } \\
\text { восхожденне к Ens } \\
\text { realissimum } \\
\end{array}$ \\
\hline $\begin{array}{l}\text { Oбинй характер } \\
\text { творчества }\end{array}$ & $\begin{array}{l}\text { Иллюзионистический } \\
\text { идеализм }\end{array}$ & Идео-реализм & $\begin{array}{l}\text { Teургическая симво } \\
\text { лика } \\
\end{array}$ \\
\hline $\begin{array}{l}\text { Формально-худо- } \\
\text { жественное опре- } \\
\text { деленне }\end{array}$ & $\begin{array}{l}\text { Эстетика отражений } \\
\text { и чистая лирика теней }\end{array}$ & $\begin{array}{l}\text { Ритмика соответ- } \\
\text { ствий ("coтrespon- } \\
\text { dances") и символика } \\
\text { полярностей }\end{array}$ & $\begin{array}{l}\text { Мистика Все-един- } \\
\text { ства }\end{array}$ \\
\hline $\begin{array}{l}\text { Исходная точка миро- } \\
\text { созериания }\end{array}$ & $\begin{array}{l}\text { Крайний импрессио- } \\
\text { низм (философия } \\
\text { мтновенья. иммора- } \\
\text { лизм) }\end{array}$ & $\begin{array}{l}\text { Стремление к диффе- } \\
\text { ренцнашни. Оъъкти- } \\
\text { визму и специализа- } \\
\text { ци }\end{array}$ & $\begin{array}{l}\text { Жажда иентрального } \\
\text { синтеза }\end{array}$ \\
\hline $\begin{array}{l}\text { Философская перво- } \\
\text { посьчиха }\end{array}$ & Пторализм & Дуализм & Монизм \\
\hline $\begin{array}{l}\text { Этическое самоотр- } \\
\text { деление }\end{array}$ & $\begin{array}{l}\text { Илеал прекрасной } \\
\text { влюбленности }\end{array}$ & $\begin{array}{l}\text { Идея жертвенного } \\
\text { достнження } \\
\end{array}$ & $\begin{array}{l}\text { Культ священной } \\
\text { любви }\end{array}$ \\
\hline $\begin{array}{l}\text { Преобладаюирая сто- } \\
\text { рона духа }\end{array}$ & Чувство & Разум & Воля \\
\hline $\begin{array}{l}\text { Центральное устрем- } \\
\text { ленне творчества }\end{array}$ & $\begin{array}{l}\text { Лирнка женственно- } \\
\text { сти и чувственной } \\
\text { неги }\end{array}$ & $\begin{array}{l}\text { Эротика и культ } \\
\text { страсти }\end{array}$ & $\begin{array}{l}\text { Релитиозный пафос } \\
\text { Вечной Женственно- } \\
\text { сти }\end{array}$ \\
\hline Перво-цель & Oтрешение & Созериание & $\begin{array}{l}\text { Прнзыв (и жажла дей- } \\
\text { ства) }\end{array}$ \\
\hline $\begin{array}{l}\text { Отношение к общест- } \\
\text { венности }\end{array}$ & Эготизм & Индиввдуализм & Соборность \\
\hline Верховный идеал & Красота & Истина & Совершенство \\
\hline $\begin{array}{l}\text { Форма развития твор- } \\
\text { ческого "я" }\end{array}$ & $\begin{array}{l}\text { Полная трансформа- } \\
\text { шня "я" }\end{array}$ & $\begin{array}{l}\text { Органическая эволю- } \\
\text { ция }\end{array}$ & $\begin{array}{l}\text { Хаотнческая динамнка } \\
\text { форм прн некзменно } \\
\text { сти центральноя кщеи }\end{array}$ \\
\hline $\begin{array}{l}\text { (Хиее определение } \\
\text { творчества }\end{array}$ & $\begin{array}{l}\text { Искпкчительно-поэ } \\
\text { тическое творчество }\end{array}$ & $\begin{array}{l}\text { Поэтика. слитная с } \\
\text { метафкзическим са- } \\
\text { моотределекием и } \\
\text { научиым методом }\end{array}$ & $\begin{array}{l}\text { Всесторонне-синте- } \\
\text { тическое творчество } \\
\text { (позтиха. философия. } \\
\text { наука. мистика) } \\
\end{array}$ \\
\hline $\begin{array}{l}\text { Главное поэтическое } \\
\text { средство }\end{array}$ & Рифма & Эпитет & Ритм \\
\hline \begin{tabular}{|l|} 
Исторнческог место в \\
развнтин символиззма
\end{tabular} & Прошиле скмволизма & Настоящее & Будущке \\
\hline
\end{tabular}

Dieses Schema ist zwar einerseits recht detailliert und pedantisch, andererseits aber durchaus hilfreich und emstzunehmen als Raster bzw. Versuch der Einordnung der russischen symbolistischen Dichter, wenn es auch allerdings eher als Kommentar zu Vjac. Ivanovs Aufsatz "Заветы символизма" erscheint (wie Bloks Beitrag "O coвременном состоянии русского символизма"). Es ist bis heute von Interesse und erfaBt die - nach Ëllis - typischen Vertreter der drei zentralen Richtungen im russi schen Symbolismus. Mit Hilfe dieses Schemas meint Ëllis auch die anderen Symbolisten einordnen zu können, unterzieht sie aber keiner genauen Analyse: zum Beispiel Sologubs Solipsismus. Bloks chaotische Verbindung der Elemente extremster Romantik mit dem Realismus ${ }^{101}$, das äußerst tiefe Synthese-Bestreben Vjač. Ivanovs,

101 Eine derartige Charakteristik Bloks ist wissenschafulich nicht haltbar! 
den Parnassismus und "Klarismus" der neueren Epigonen (womit Ėllis wohl die Akmeisten meint) etc. Er führt das aber nur noch andeutungsweise aus.

Er sieht eine genaue Parallele in der Entwicklung des russischen und des westeuropäischen Symbolismus:

\begin{abstract}
Основная тенленция символизма - безграничное самоуглубление в процессе развипия. последовательно превратившая его из "жажды новых форм" в "переоценку всех ценностей". из эстетической школы в новое. синтетическое миросозерцание. в предчувствне новой культурной эпохи. из создания "свободного стиха" в самоопеделение "свободного луха" - одинаково сказывалась в кажлом шаге обокх течений - русского в той же мере. как и запално-европейского. ${ }^{102}$
\end{abstract}

Sowohl im westeuropäischen als auch im russischen Symbolismus unterscheidet Ellis drei Hauptperioden: die revolutionäre Periode. die Periode der Selbstausdehnung und der äuBerlichen Führerrolle und die Periode der Krise. Die ersten Werke Bal'monts und Brjusovs seien deutlichste Zeugnisse der ersten revolutionären Periode. Ihre späteren Werke eröffneten die zweite Periode. Mit ihnen und den ersten Werken Belyjs erreiche der Symbolismus seinen Höhepunkt. Zur Periode der Krise zählt Ėllis die letzten Werke Brjusovs sowie Belyjs wertvolle und vielseitige Arbeiten. AuBerdem sei die Epoche der Krise des russischen Symbolismus durch das schnell anwachsende und tiefgründige Werk Vjač. Ivanovs gekennzeichnet, das endgültig den Ästhetizismus und Illusionismus überwinde und nach einer Synthese der symbolistischen Kunst mit der "hierarchischen Mystik" (иерархическая мистика) strebe, die die Lehre vom künstlerischen Schaffen mit der Idee der Symbolik verbinden wolle (Ivanovs Lehre des "мифотворчество") ${ }^{103}$.

Ellis sieht die Krise des russischen Symbolismus einerseits äuBerlich bedingt und bringt sie in Zusammenhang mit den gescheiterten revolutionären Bestrebungen von 1905-1906. die er als große politische und allgemein moralische Krise bezeichnet. Ihre Hauptursache sei jedoch im eigenen inneren Widerspruch des Symbolismus zu suchen, der überwunden werden müsse, nämlich im zwiespältigen Charakter der symbolistischen Bewegung. Ellis weist auf die zwei Strömungen innerhalb des Symbolismus hin. die er als "rein ästhetische" und "ideelle", das heißt "synthetische". bezeichnet ${ }^{104}$ und, nach einem kurzen Überblick über die wichtigsten Vertreter des europäischen Symbolismus ${ }^{105}$, folgendermaBen charakterisiert:

102 Ëllis: Russkie simvolisty, S. 322.

103 Ebd., S. 323f. (Vgl. auch oben. S. 102, Anm. 87.)

Ellis verweist hier auf Vjax. Ivanovs Aufsatzband "Пl звездам" (1909 erschienen), in den u.a. Ivanovs wichtige umfassende Arbeit "Две стихин в современном символизме" (erstmals in der 7eitschrift "Золотое руно". Nr. 3-4 ч. 5, 1908, publiziert) aufgenommen wurde. In diesem Aufsatz grenzt Ivanov den "realistischen" (religiösen) Symbolismus deutlich vom "idealistischen" ab. Letzterer begegne im "Parnassismus" und in der "Dekadenz" und müsse als Illusionismus, als entanete Kunst verstanden werden. Als wahre Kunst, die zugleich religiös sei, hebt Ivanov den "realistischen Symbolismus" hervor mit seiner Devise "a realibus ad realiora". (Ivanovs Arbeit findet sich im 2. Band der Sobranie soxinenij, Brjussel' 1974, S. 536-561). Die von Ėllis erwähnte Krise ist zugleich ein indirekter Hinweis auf den "Symbolistenstreit" von 1909/1910 (vgl. "Einleitung" der vorliegenden Arbeit, S. 17f.). in dem es ja um eben dieses Problem ging: ist Kunst, Literatur als rein ästhetische Erscheinung zu verstehen oder muB Symbolismus zur Weltanschauung werden. die Totalität des geistigen Lebens ergreifen? Diese Debatte zeigt und beweist jedoch. dab gerade zur Zeit des Erscheinens von "Pycckre символисты" beide Symbolismuspositionen nebeneinander existierten, so daB man - im Gegensatz zu Ëllis - nicht von einer endgültigen Überwindung des Ästhetizismus und Illusionismus sprechen kann.

104 Dieser Hinweis auf die zwei Strömungen innerhalb des Symbolismus ist richtig, nur hat sich Ellis' Bezeichnung in der heutigen Symbolismusforschung geändert: man spricht von den "älteren" und "jüngeren" Symbolisten.

Ii) Ėllis: Russkie simvolisty, S. 329-333. 
С одной стороны он [= символизм] очень скоро стал синтетическим миросозерцанием. он достиг той сталия, когда иной мир стал доступен ему. как устойчивая высшая сфера. как realiora. он уже стал отлагаться в строгие формы единой символики. он замыслил уже о новой культуре и новой личности.

С другой стороны он продолжал очень долго (частью делает это и сейчас) хранить узкие рамки первоначальной формации, нсповедывать канон "чнстого искусства". догмат имморалнзма и безграничного индивипуализма. боясь всякой устойчивости. всякого чувства действительности (хотя бы и потусторонней), по-прежнему считая себя импрессионизмом par excellence. 106

Auch die russischen Symbolisten hätten, wie ihre europäischen Vorläufer, zunächst nur rein äußerlich den Ästhetizismus unterstützt. Merežkovskij habe als erster versucht, die weltanschauliche Seite des Symbolismus in den Vordergrund zu stellen, was bei ihm jedoch zur Verneinung jeglicher Ästhetik überhaupt führte; sein Symbolismus sei Dogmatik geworden 107.

Brjusov und Belyj hätten im Symbolismus nicht nur eine "literarische Schule" oder neue Poetik gesehen. sondem einen Dienst an der Kunst (служение). Ėllis verweist in diesem Zusammenhang auf Brjusovs Aufsatz "Священная жертва" 108, in dem Brjusov unter anderem vom Dichter fordert: "Пусть поэт творит не свои книги, а свою жизнь. [...] На алтарь нашего божества мы бросаем самих себя. Только жреческий ножь рассекающий грудь, дает право на имя nоэта." 109 Außerdem zitiert er entsprechende Stellen aus Belyjs Aufsätzen "Чехов" ("С̆echov") und "Окно в вечности" ("Fenster in der Ewigkeit") 110 . Brjusovs und Belyjs Symbolismus habe bereits die Phase der Suche nach einem "einheitlichen Ursprungssymbol" ("Единый Первосимвол") erreicht; ihnen stehe der Weg in die Ewigkeit offen und folglich auch in die Zukunft ${ }^{\prime \prime l}$.

Deshalb hält Ėllis die gegenwärtige Krise des Symbolismus nicht für sein Ende, sondem nur für eine letzte und unbedingt notwendige "Prüfung", für die Folge seiner anfänglichen Fehler, die nicht ausreichend erkannt und verbessent worden seien. Er beschlieBt sein Werk im festen Glauben an eine groBe, weltweite Zukunft des Symbolismus.

Unter den zeitgenössischen Kritiken zu Ėllis' "Русские символисты" finden sich durchaus positive Töne, etwa im "Вестник Литературы" ("Der literarische Bote")112: Noch keine literarische Strömung sei wohl zu Beginn so scharf angegriffen worden wie der Symbolismus, aber mit der Zeit habe er dennoch immer mehr an Bedeutung

106 Ebd.. S. 333f.

${ }^{107}$ Ebd.. S. 334. Vgl. hierzu auch oben. S. 85f. der vorliegenden Arbeit.

108 Becb. Nr. 1, 1905 . (Auch abgedruckt in: V. Brjusov: Sobranie soxinenij v 7-i tt. Tom 6. a.a.O., S. 94-99.)

109 Ebd.. S. 99. Ėllis meint mit "служенне" ein religiöses Dienen. was ein MiBverstehen Brjusovs ist. der dem symbolistischen Dichter zwar die gleiche Macht wie dem Opferpriester zuspricht. Dichtung aber keineswegs weltanschaulich vereinnahmt wissen wollte. Auch andere Symbolisten verstanden diesen Aufsatz Brjusovs falsch. z.B. A. Belyj (vgl. seine Ausführungen in "Венок или Венец" [Аполлон. Nr. 11, 1910. Хроника S. 1-4] im Kontext des "Symbolistenstreits").

110 In: Becы. 1904, Nr. 8 und 12.

111 Ėllis: Russkie simvolisty. S. 335f.

Diese Gleichsetzung von Ewigkeit und Zukunft ist äuBerst bedenklich, da es sich um zwei nicht zusammenhängende Begriffe handelt. Ëllis möchte aufzeigen, daB wahrer Symbolismus, wie Brjusov und Belyj itn praktizieren. "überzeitlich" ist und nicht als abgeschlossene literarische Stilformation be trachtet werden kann. 341.

112 Vgl.: Naši Simvolisty. - Ozerk N. Nadezdina. In: Вестник Литературы, 1910, Nr. 12, S. 339- 
gewonnen. Ėllis' Buch sei das erste Werk, das versuche, die Theorie des Symbolismus umfassend zu erhellen. Es sei ein interessantes Buch, das sich zudem mit der Interpretation des Werks dreier Symbolisten befasse: Bal'mont, Brjusov und Belyj. Nur eines sei unklar: Warum gerade diese drei Namen und nicht noch drei bis vier weitere, z.B. Gippius und Merežkovskij? Der Verfasser der Kritik, N. Nadeždin, stimmt Éllis' Aussagen weitgehend zu, vor allem seinen Ausführungen über die Neuerungen der inneren und äußeren Formen des Symbolismus (obwohl sich Ëllis - wie dargelegt - schwer tut, konkret zu formulieren, was dieses "Neue" eigentlich sei) und über Brjusov und Bal'mont. Die philosophische Rechtfertigung des Symbolismus in Ëllis' Buch wirke jedoch häufig gezwungen. Den Symbolisten selbst sei wohl ihr System bei weitem nicht immer ganz klar. Auch Ellis' Ansicht über Belyj kann Nadeždin nicht teilen. Aber insgesamt ist diese Kritik sehr wohlwollend:

В заключение нельзя не сказать, что едва ли не самыми убедительными доводами в nољ зy raison d'être символизма являются те страницы книги r. Эллиса. где он говорит о новизне его внешних и внутренних приемов. о6 удивительной технике, о поражающей музыкальности его стиха. действительно глубоко и неотразимо чарукщей слух и пушу. ${ }^{113}$

Andere Kritiker äußem sich jedoch recht negativ, richten sich damit aber weniger gegen Ëllis' Werk direkt als allgemein gegen den Symbolismus.

In "Pocсия" ("RuBland", 4./17. August 1910) heiBt es, daB man den Symbolismus zwar nicht ganz ignorieren könne, aber die Dichtung eines Bal'mont. Brjusov oder Belyj könne nie mit der wahren Dichtung eines Puškin verglichen werden. Besonders ablehnend müsse man sich gegenüber dem ideellen und gesellschaftlichen Inhalt der Dichtung des Symbolismus verhalten. Ëllis erforsche in seinem Werk zwar ausführlich die Erscheinung des Symbolismus, gehöre aber selbst dieser Bewegung an und bediene sich einer symbolistischen Sprache. Der Kritiker wirft Ëllis also mangelnde Objektivität vor.

Eine weitere Kritik (in "Новое Время" - "Die neue Zeit", 11./24. September 1910) mit dem Titel "Boоружаются!" ("Sie rüsten sich!") weist darauf hin. daB zu einer Zeit, da ein Teil der Presse laut den Zusammenbruch des Symbolismus verkünde, nun die Symbolisten selbst in umfangreichen Werken das Gegenteil deklarienten (Ëllis in seinen "Русские символисты" und A. Belyj in seinen Aufsatzbänden "Символизм" ["Symbolismus"] und "Луг Зеленый" ["Die grüne Wiese"], beide auch 1910 erschienen). Der Verfasser der Kritik ist jedoch, ungeachtet aller Zukunftsprognosen in Ëllis' Buch, vom sicheren Ende der Kunst der Symbolisten überzeugt.

Insgesamt betrachtet war Ėllis' umfangreiches Werk "Русские символисты" zumindest zur Zeit seines Erscheinens (1910) von nicht unerheblicher Bedeutung.

Obwohl diese Arbeit einen recht umfassenden Titel trägt - "Русские символисты" -. behandelt Ellis darin im Hauptteil ausführlich jedoch nur drei - wie er meint - ty pische Venteter der russischen Symbolisten. die zudem alle dem Moskauer Lager des Symbolismus angehörten. Den "Petersburger Symbolisten" - Merežkovskij. Gippius, Sologub, Vjač. Ivanov, A. Blok -, die er in seiner Arbeit wiederholt erwähnt, gesteht er zwar auch eine gewisse Bedeutung zu, vor allen Dingen dem Frühwerk Merežkovskijs, der frühen Lyrik Bloks und dem "Spätwerk" (damit sind die Arbeiten von 1908-1909 gemeint) Ivanovs, ihre Bedeutung falle allerdings nicht so sehr ins Gewicht wie die der drei behandelten Moskauer Symbolisten. Dadurch ist Ëllis' Arbeit. objektiv betrachtet, natürlich recht einseitig. Diese Schwerpunktsetzung von Ėllis kann und muB man wohl hauptsächlich aus der Situation heraus bzw. dem Vertältnis

113 Ebd., S. 341. 
zwischen Moskauer und Petersburger Symbolisten erklären: der Polemik von 19071908 um den "mystischen Anarchismus" und die "соборность"-Bestrebungen sowie der daraus sich ergebenden Symbolismusdebatte, an der Ellis aktiv beteiligt war und in der er eine deutliche Position bezog 114 .

Wie bereits in seinen "Becы"-Aufsätzen (1907-1909)115, so bezieht Ėllis auch in seinen "Русские символисты" die Position des "strengen" Symbolismus 116: Für ihn ist wahre Kunst (= reiner Symbolismus) die Angelegenheit weniger auserwählter Individuen und nicht die der Masse. Der äußere Sieg des Symbolismus in den Jahren 1907-1909 über konkurrierende literarische Strömungen (wie etwa den Spätrealismus) habe zugleich zu seiner inneren Krise geführt.

Brjusov verkörpente für Ėllis zu dieser Zeit das gegenwärtige Stadium des Symbolismus (wie auch aus Ellis' Schema deutlich wird). Vor allem 1907 und 1908, aber auch noch in einem Brief vom 29. April 1909 an Brjusov 117 fordert Ellis ihn auf, als Autoritäts- und Führerperson an die Spitze der gesamten russischen symbolistischen Bewegung zu treten. Nur Brjusov als der Symbolist schlechthin könne den russischen Symbolismus retten.

1910, als "Русские символисты" erschienen, hatten sich die Wege von Ellis und Brjusov b\&reits getrennt, das Trio Ėllis-Brjusov-Belyj war zerfallen und das neue Trio Ëllis-Belyj-Metner um den Verlag "Musaget" hatte sich zusammengefunden ${ }^{118}$. Dennoch nimmt Brjusov in Ėllis' Symbolismusschema den zentralen Platz ein. Ėllis geht aber (in seinem Buch) von Brjusov weiter zu A. Belyj, den er als Repräsentanten der Zukunft des russischen Symbolismus ansieht.

Mit seiner relativ gründlichen Analyse der Werke Bal'monts, Brjusovs und Belyjs hat Ëllis wichtige und nützliche Arbeit geleistet und viel Charakteristisches dieser drei Venreter des russischen Symbolismus richtig und angemessen erfaBt. Dabei darf nicht übersehen werden, daB Ellis' Werk zu einer Zeit erschien, als die Zeitgenossen, über die er schrieb, noch gar nicht ihr Gesamtwerk verfaBt hatten und im Fall von Belyj und Blok noch recht jung waren (das bekannteste Werk Belyjs 2.B., der Roman "Ileтepxypr" ["Petersburg"], war zu der Zeit noch gar nicht geschrieben). Sehr einfühlsam beschreibt Ellis Bal'monts frühe symbolistische Lyrik mit ihrem romantischmusikalischen Charakter ${ }^{119}$ und hebt Brjusovs formale Meisterschaft, seinen Idealismus und sein Streben nach absoluter Freiheit in der Kunst treffend hervor. DaB Be lyjs Werk in seinem Bestreben, einen neuen BewuBtseinszustand zu schaffen, etwas ganz Neues darstellt, hat er ebenfalls gut erkannt. Zu Recht wird Ellis' Arbeit bis heute von der Symbolismus- und Belyj-Forschung rezipien ${ }^{120}$.

114 Diese Debatte darf allerdings nicht mit dem erwähnten "Symbolistenstreit" verwechselt werden. der 1910 (nach Erscheinen der "Русские символнсты") auf den Seiten des "Аполлон" ausgetragen wurde und in dem Ëllis. wenn auch nicht aktiv, auf Ivanovs. Bloks und Belyjs Seite stand. In seinen "Русские символисты" honorient er zwar Brjusovs Haltung noch, hat sie aber möglicherweise falsch verstanden: zur Zeit des "Symbolistenstreits" (ab ca. 1910) trennen sich Brjusovs und Ėllis' Wege endgültig.

II5 Vgl. oben. S. 83-86 der vorliegenden Arteit.

116 Vgl. hierzu auch V. Fedjuschin: RuBlands Sehnsucht nach Spiritualität, a.a.O.. S. 180f.

117 PO PIБ. Ф. 386. карт. 109. eд.xp. 44.

$118 \mathrm{Vgl}$. das folgende Kapitel "Die Zeitschrift «Tруды и дниж".

119 Vgl. oben. S. 93f. Neben A. Fet hätte Ėllis in diesem Zusammenhang jedoch auch auf V. Žukovskij verweisen müssen, den wohl musikalischsten Dichter vor Bal'mont.

$120 \mathrm{Vgl}$. z.B. das bereits erwähnte Werk von A. Hansen-Löve: Der russische Symbolismus, a.a.O.. S. 29); ebenfalls M. Deppermann: Andrej Belyjs ästhetische Theorie des schöpferischen BewuBtseins. a.a.O., S. 132: auch A. Lavrov (A. Belyj v 1900-e gody, a.a.O.) verweist wiederholt auf Ėllis' "Pycckne символисты". 
Auffällig ist Ėllis' vergebliches Bemühen, klare und deutliche Definitionen vom eigentlichen Wesen des Symbolismus zu geben. Klassifizierungen vorzunehmen, die neue Kunst systematisch zu beschreiben. Sein Stil ist viel zu exaltiert, mitunter schwülstig und konfus, so daB ihm sein Anliegen nicht gelingen konnte. Er war viel zu sehr Mithandelnder und unmittelbar Betroffener der Epoche, die er - ohne zeitlichen Abstand - zu beschreiben versucht. Zudem darf man nicht übersehen, daB es auch für seine berühmten Zeitgenossen ein großes Problem war, das Wesen des russischen Symbolismus klar und eindeutig zu definieren, denn gerade das Unklare, nich FaBbare, Unvollkommene, noch nicht Fertige, Unausgesprochene macht ja das eigentliche Wesen des Symbolismus aus und läBt sich nicht so einfach in Worte kleiden. Wenn man diese Tatsache berücksichtigt, muß man Ëllis' Werk und sein Ergebnis, die Schemata 121 , als interessanten, frühen Versuch einer recht umfassenden Darstellung und Charakterisierung des russischen Symbolismus bewerten, das nicht nur ein wichtiges Zeit- und Selbstzeugnis darstellt, sondern auch für den heutigen Symbolismusforscher noch von Wert und Interesse ist. Dieser frühen Selbstreflexion gebün ein Platz neben anderen frühen theoretischen Arbeiten über den russischen Symbolismus, z.B. Belyjs Essaybänden ("Символизм", "Луг зеленый", "Арабески" ["Arabesken"]), Ivanovs Arbeiten, M. Gofmans "Поэты символизма" ("Dichter des Symbolismus") u.a. Das rechtfertigt die 1996 in Tomsk erschienene (leider unkommentierte) Neuausgabe, in der Éllis' Arbeit allerdings in übertriebenem MaBe vom Verlag "Vodolej" angepriesen wird:

\begin{abstract}
Книга замечательного русского поэта-символнста Л.Л. Кобьлинского (Эллиса) - одно из лучших исследования творчества К. Бальмонта. В. Брносова и А. Белого. На примере свонх геннальных современннков Эллнс рассматрнвает основные теоретические положения русского символизма, аналнзкрует его связь с ролственнымн европейскими течениями и провилит ожилающке скмволизм вневременное мировое будуцее. $[\ldots]^{122}$
\end{abstract}

Eine andere Frage ist natürlich, ob Ėllis die Entwicklung des russischen Symbolismus vollständig erfaBt hat. Dies muB man sicher vemeinen. Erstens war es dazu wohl noch zu früh (Ëllis' Buch entstand ja im wesentlichen 1909), zweitens war Ėllis dazu zu subjektiv und zu sehr eingenommen von seiner eigenen Position als selbst Betroffener. Sein Werk stellt aber wohl den ersten Versuch dar, die Bewegung des russischen Symbolismus im Kontext des europäischen in ihrer Gesamtheit zu erfassen ${ }^{123}$. Es gab zwar zahlreiche Aufsätze über das Wesen des russischen Symbolismus und über seine einzelnen Vertreter, in denen interessante Theorien entwickelt und Einzelaspekte teilweise deutlicher und umfassender dargestellt wurden als bei Ëllis (man denke z.B. an Belyjs oben erwähnte Aufsatzbände), aber der Versuch, diese Bewegung mit ihren Vertretern in ihrer Entwicklung ganzheitlich zu erfassen, stellte zur Zeit des Erscheinens von "Русские символисты" ein Novum dar.

Auffälig ist, daB Ėllis in seinem Werk gar nicht auf den "Symbolistenstreit" eingeht, der ab Mai 1910 vorwiegend im "Аполлон" ausgetragen wurde, sich aber durch Vorträge und öffentliche Diskussionen schon ab 1909 angebahnt hatte, so daB Ellis zur Zeit der Entstehung seines Buches davon gewuBt haben muB. In diesem Streit hätte er die Position Belyjs, Bloks und Ivanovs vertreten und sich ganz von Brjusov abkehren müssen, er hätte Brjusov nicht mehr als den Führer des russischen Symbolismus darstellen können. Aber offensichtlich entstand Ėllis' Werk hauptsächlich in der ersten Jahreshälfte 1909; im Sommer 1909 war er mit seiner Arbeit schon ziem-

121 Ellis: Russkie simvolisty. S. 2, 320f.: S. 90 und 104f. der vorliegenden Arbeit.

122 Ëllis: Russkie simvolisty. Tomsk 1996, Rückseite des Titelblatts.

$123 \mathrm{Vgl}$. Ėllis: Russkie simvolisty. 1. Kapitel sowie sein darin angeführtes Schema (S. 90 der vorlie genden Arbeit). 
lich weit gediehen, so daß die eigentliche Entstehung von "Русские символисты" tatsächlich vor dem "Symbolistenstreit" liegt, wodurch sich Ëllis' Schema, in dem Brjusov den zentralen Platz einnimmt, verstehen läBt. DaB Ëllis den "Symbolistenstreit" aufmerksam verfolgte, zeigt zum Beispiel die Tatsache, daB er von Bloks Vortrag "О современном состоянии русского символизма" so begeistert war (weil er ja mit seiner eigenen, recht konfusen Position übereinstimmt!), da $B$ er sich daraufhin mit Blok aussöhnte und ihm seine Übersetzung von Baudelaires "Petits poèmes en prose" schenkte 124 .

Als "Русские символисты" erschien, war Ëllis aktiver Mitarbeiter und Organisator der Arbeitskreise um den neugegründeten Verlag "Musaget" und zudem bestrebt, zusammen mit Metner und Belyj eine eigene Zeitschrift zu gründen, die dem "echten" Symbolismus gewidmet sein sollte, also Symbolismus als religiös-philosophische Weltanschauung propagiente. So läBt es sich erklären, daB er nicht im "Аполлон" mitwirkte; diese Zeitschrift wurde ja später - wie erwähnt - zum bevorzugten Organ des Akmeismus, einer Literaturströmung, die gegen den Symbolismus polemisiente und die Ėllis dementsprechend ablehnte. Ėllis' religiös-mystische Haltung, die eher durch die romantische Tradition als durch das Neue, Innovatorische innerhalb des nussischen Symbolismus geprägt ist, begegnet deutlich in seinen Gedichtbänden wie auch in seinen Aufsätzen in der Zeitschrift "Труды и дни" 125; die endgültige Abkehr vom Symbolismus und allen zeitgenössischen Strömungen in der russischen Literatur bildet sein Traktat "Vigilemus!" (1914).

124 Vgl. hierzu A. Lavrov: Pis'ma Ëllisa k Bloku, a.a.O., S. 278f. und oben. S. 38 der vorliegenden Arbeit.

$125 \mathrm{Vgl}$. das folgende Kapitel der vorliegenden Arbeit. 


\section{c. Die Zeitschrift "Труды и дни"}

\section{1) Zur Geschichte der Zeitschrift}

Die Zeitschrift "Труды и дни" erschien in Moskau ab 1912 als Zweimonatsschrift des Verlags "Musaget" (Двухмесячник издательства "Мусагет")1. Die Geschichte dieser Zeitschrift ist mit der des "Musaget"-Verlags (1910-1917) eng verbunden. "Труды и дни" war nur die konkrete Realisierung des "Musaget"-Programms im Rahmen einer Zeitschrift. Thre Herausgeber verfolgten ein doppeltes Ziel:

Труды и Дни ставят себе цвойную иель:

Первое. спеццальное назначение журнала - способствовать раскрытию и утвержлению принциов подлинного символизма в области художественного творчества.

Другое и более обиее его назначение - служить истолкователем идейной связи. объе аиняющей разносторокние усилия групшы художников и мыслителей. сплотививхся под знаменем Мусагета.

Соответственно этой двойной цели. журнал состоит из двух частей.

В первом отделе найдут себе место теоретические и критические статъи, посвященные обиим вопросам и отлельным явлениям художественного творчества.

Во втором - будут разработываться проблемы современного философского и религиозно-нравственного сознания. наравне с темами зстетики. изучаемой в обще-философской связи. ${ }^{2}$

Erste Pläne, eine symbolistische Zeitschrift in der Ar von "Труды и дни" zu gründen, gab es bereits zu Beginn des Jahrhunderts im "Argonautenkreis" 3 . Den "Argonauten" fehlte ein adäquates Sprachrohr, um ihre utopischen Erwartungen und mystischen Ziele zu verkünden: die von Ëllis geplante Reihe "Argo" blieb ein Projekt ${ }^{4}$, die beiden literarisch-philosophischen Sammelbände "Свободная совесть" (1906) enttäuschten durch ihren eklektischen Inhalt, ihr dürftiges literarisches Niveau und konnten folglich die in sie gesetzten Hoffnungen nicht erfüllen. Deshalb planten Ëllis. Metner und Belyj bereits 1907 eine neue Zeitschrift und ein "ästhetisches Zentrum". suchten nach geeigneten Sponsoren und Finanzierungsmöglichkeiten und arbeiteten erste Programm- und Konzeptentwürfe konkret aus5. Jedoch gelang es damals, 1907. als die innersymbolistische Polemik um den "mystischen Anarchismus" ihren Höhepunkt erreicht hatte ${ }^{6}$, nicht, diese Idee zu verwirklichen. Erst zwei Jahre später, als 1909 "Весы" und "Золотое руно" eingestellt wurden und die neue Petersburger Zeitschrift "Аполлон" an Einfluß gewann, wurde die Idee einer Zeitschrift, die die Symbolisten mit religiös-philosophischer Neigung vereinigen sollte, wieder aufge -

\footnotetext{
I Zur Geschichte von "Труды и лин" vgl. A.V. Lavrov: "Trudy i dni". In: Russkaja literatura i Zurnalistika, a.a.O., S. 191-211.

2 Tрулы и пни, Nr. 1. 1912, S. 1.

$3 \mathrm{Vgl}$. oben. S. 26-29 und S. 31, Anm. 47.

4 Vgl. hierzu A.V. Lavrov: Mifotvorそestvo "Argonavtov", a.a.O., S. 150.

S Vgl. A.V. Lavrov: "Trudy i dni", a.a.O.. S. $191 \mathrm{f}$.

Bereits 1907 spricht Metner in Briefen an Ėllis von einer Zeitschrift "Mycaret", die ab 1908 erscheinen sollte. und von einem Verlag "Kul'tura" für die geplante Zeitschrift, den man bereits 1907 gründen könne. (Vgl. den Briefwechsel zwischen Metner und Ellis 1907, РО РГБ. Ф. 167. карт. 6, en.xp. 1-5; Ф. 167, кapt. 7. eд.xp. 1, 3, 4, 9, 10). Ellis schlägt als Namen für den Verlag "Pedant" vor (ebd., kapt. 7. en.xp. 1): ein Programm für den Verlag hat er bereits ausgearbeitet (ebd., ea.xp. 4). Ėllis forden Metner 1907 in seinen Briefen auf, aus Deutschland nach RuBland zurückzukehren, dor "Kulturarbeit" zu leisten und ein "ästhetisches Zentrum" zu gründen (ebd., ea.xp. 3).

$6 \mathrm{Vgl}$. oben, S. 32f., 74.
} 
griffen. Es kam erneut zu Plänen und Verhandlungen?. SchlieBlich wurde 1910 der Verlag "Musaget" gegründet ${ }^{8}$, den zunächst Metner, Ėllis und Belyj leiteten ${ }^{9}$. Über die Bedeutung des Namens "Musaget" 10 sagt Metner:

Это имя подчеркивает аполлинизм (вовсе не отрывая его однако от пионицизма) и отмежевывается от эстетства, ибо означает объединение всех видов творчества в согласном служенин цели создания культуры. ${ }^{\prime 1}$

Die Hauptaufgabe des Verlags "Musaget" sollte also das "Erschaffen" und Erhalten der Kultur sein. Um den "Musaget"-Verlag entstanden verschiedene Arbeitskreise: zum Thema Versrhythmik und Metrik (unter der Leitung A. Belyjs), zur Philosophie (von Fedor Stepun geführt) und zur Ästhetik (unter Ëllis' Leitung) ${ }^{12}$. Zudem wurde die russische Ausgabe der "Internationalen Zeitschrift für Kultur der Philosophie": "Logos" die ersten vier ihrer fünf Erscheinungsjahre (von 1910-1913) vom "Musaget"-Verlag herausgegeben ${ }^{13}$.

Die Planungen und Diskussionen der zukünftigen Zeitschrift "Труды и дни" 14 gingen unterdessen nach der Gründung des "Musaget"-Verlags $(1910,1911)$ weiter15. Auch A. Blok und Vjaz. Ivanov, die gemeinsam mit Belyj im "Symbolistenstreit" im "Аполлон" (1910) den Symbolismus als "lebensschaffende", weltanschauliche Haltung verkündet hatten, beteiligten sich aktiv daran ${ }^{16}$. Während die Zeitschrift "Beсы" (1904-1909) den Symbolimus als neue zeitgenössische literarische Strömung vermittelt hatte, stützte sich "Труды и дни" auf die "zeitlosen Werte" des Symbolismus: Symbolismus sei gleichbedeutend mit echter Kunst und Kultur schlechthin. Belyj. Vjaž. Ivanov, Vl. Pjast u.a. waren bemüht, eine Synthese zu schaffen und die Auffassung vom Symbolismus als historisch verstandener literarischer Stilformation mit der überhistorischen Konzeption des Symbolismus zu vereinen 17. "Bесы" hatte vor allem

7 Vgl. Metners Briefe an Ėllis 1909 (vor allem PO РГБ. Ф. 167, кapr. 6. ед.xp. 12f.) und Ėllis' Briefe an Metner (ebd.. $\Phi$. 167. карт. 7. ед.xp. 11, 14-20). In Metners Briefen ist die Rede von einem Verlag "Simvol" und einer Zeitschrift "Mycaret", während Ėllis von einem Verlag "Plejada" spricht ( $\Phi$. 167, xapr. 7. ea.xp. 17). Auch einem Brief von A. Belyj an Metner können genaue Pläne für die Grïndung der Zeitschrift sowie für die Beiträge der ersten Nummern entnommen werden (Ф. 167, kapt. 2. ea.xp. 4).

8 Vgl. A.V. Lavrov: "Trudy i dni", a.a.O., S. $192 f$.

9 Zur Geschichte des Verlags "Musaget" vgl. G.A. Tolstych: Izdatel'stvo "Musaget". In: Kniga: Issledovanija i materialy, 56, (1988), S. $117 f$.; V. Sapov: V.I. Ivanov i E.K. Metner. Pererpiska iz dvuch mirov. In: Voprosy literatury, 2, 1994, S. 314f.

10' Zum Namen "Musaget" vgl. oben, S. 33, Anm. 56.

11 Труды и пня. Nr. 1, 1912, S. 55.

12 Vgl. die Magisterarbeit von Stefan Greiler: Zur Rezeption Rainer Maria Rilkes im Werk Boris Pasternaks: Weltanschauung. Ästhetik. Intertextualität. Regensburg 1991, S. 21: E. Pasternak: B. Pasternak. Materialy dlja biografii. Moskva 1989, S. 148, 172ff.: A. Belyj: Im Zeichen der Morgenröte, a.a.O., S. 543f.: Ders.: Meždu dvuch revoljucii, a.a.O., S. 342f., 350-353; M. Ljunggren: The Russian Mephisto, a.a.O., S. 43, 46. Über die Art der Beschäftigung mit Versthythmik und Metrik vgl. S. Bobrovs Ausführungen in seinem Brief an A. Belyj vom 14.1.1911 (in: Lica, 1, 1992, S. 149-152, 161f.).

13 Die deutsche Ausgabe der Zeitschrift "Logos" erschien von 1910/11-1933 (1.-22. Jahrgang) unter der Redaktion von Kroner und Mehlis in Tübingen bei Siebeck (im Verlag von I.C.B. Mohr). Zur Geschichte der Zeitschrift "Logos" vgl.: M.V. Bezrodnyj: Zur Geschichte des russischen Neukantianismus. Die Zeitschrift "Logos" und ihre Redakteure. In: Zeitschrift fuir Slawistik 37, 1992/4, S. 489-511.

14 Der Name entstammt Hesiods Lehrgedicht "Werke und Tage" (vgl. hierzu auch M. Ljunggren: The Russian Mephisto. a.a.O., S. 47).

15 РО РГБ. Ф. 167, карт. 7, ед.Xp. 23, 28.

16 Vgl. A.V. Lavrov: "Trudy i dni", a.a.O., S. $195 f$.

17 Vgl. Vjac. Ivanov: Mysli o simvolizme (in: Tруды н дни, Nr. 1, 1912, S. 3-10); A. Belyj: O simvolizme (ebd.. S. 10-24); VI. Pjast: Nexto o kanone (ebd., S. 25-35). 
in Verbindung mit der neuen französischen symbolistischen Schule gestanden, während "Труды и дни" und der "Musaget"-Verlag germanophil ausgerichtet waren. Deutsche Philosophie und Kultur spielten für Metner eine wichtige Rolle, für ihn waren Deutschland und RuBland geistesverwandt ${ }^{18}$. In einem Brief an Ellis (Oktober $1911)$ schreibt Metner: "Россия не может быть без Германии и Германии тоже нужна Россия. Это - двоюродные братья"19. Während jedoch "Bесы" die Epoche der Blütezeit der russischen symbolistischen literarischen Schule widergespiegelt hatte, muB "Труды и дни" als Zeugnis der Krise des Symbolismus gelten, der Perspektivelosigkeit, wie Z.B. selbst Éllis eingestehen muBte ${ }^{20}$. Innerhalb des russischen Symbolismus hatten sich im Verlauf des "Symbolistenstreits" immer mehr unterschiedliche Richtungen herausgebildet, das künstlerische System des Symbolismus wurde kritisch in Frage gestellt und zahlreiche avantgardistische Vereinigungen be gannen sich gegen den Symbolismus zu gruppieren21, so daB zur Zeit von "Труды и дни" nicht mehr vom Symbolismus als vorherrschender Stilformation gesprochen werden kann. Das Hervorheben der "überzeitlichen Wente" des Symbolismus in dieser Zeit muB zugleich als Legitimationsversuch für das Weiterleben dieser literarischen Richtung während ihrer Krise bewertet werden.

Die zehnjährigen intensiven geistigen Beziehungen zwischen Belyj und Metner lieBen sie zunächst gemeinsam die Redaktion von "Труды и дни" übernehmen, unter enger Mitarbeit von Vjač. Ivanov, A. Blok 22 und Ellis. Indem sich Metner in erster Linie auf die aktive Mitarbeit und schöpferische Energie Belyjs sowie auch auf die philosophisch-ästhetischen Konzeptionen von Ivanovs Symbolismus stützte, bemühte er sich in "Труды и дни" um die Erhaltung und Emeuerung der Kultur und maB in diesem Zusammenhang der Religion große Bedeutung für das kulturelle Schaffen bei. Das Verhältnis von Kultur und Religion war wiederholt Thema der in "Труды и дни" publizienten Beiträge ${ }^{23}$. Die Gegenwan durchlebte, so Metner, gerade die Epoche einer Kulturkrise. Die Hauptaufgabe der "Musaget"-Vereinigung bestand für ihn in der Überwindung dieser Krise. Die Zeitschrift "Труды и дни" sollte hierzu einen Beitrag leisten. Auf ihren Seiten sollten Fragen und Probleme aller kulturellen Bereiche (Kunst, Literatur, Musik, Philosophie, Religion) erörten und eine "neue, organische Kultur" geschaffen werden. Goethe und Wagner waren für Metner Symbolgestalten der Kultur, die "Musaget" als Vorbilder verkündete. Metner als Hauptredakteur von "Труды и дни" war bemüht, seine kulturologische Linie argumentativ zu vertreten. Die Ausarbeitung von Fragen der symbolistischen Weltanschauung und Ästhetik übertieB er Ivanov, Belyj und anderen 24 .

Man muB sich fragen. ob eine derartige Synthese überhaupt möglich ist? Den unterschiedlichen Symbolismusauffassungen entspricht eine Unterscheidung 2 wischen symbolistisch und symbolisch. Diese Unterscheidung wurde jedoch, wie erwähnt (vgl. oben, S. 23), im Selbstverständnis der soge nannten "jüngeren" Symbolisten nicht konsequent getroffen; sie faßten den Symbolismus als Synthese der neuen literarischen Schule und der "zeitlosen" Kultur auf. Zum Problem des "zeitlosen" Symbolismus vgl. W. Potthoff: Zum Begriff des "überzeitlichen Symbolismus", a.a.O.

$18 \mathrm{Vgl}$. A.V. Lavrov: "Trudy i dni", a.a.O., S. 194.

19 PO РГБ. Ф. 167, карт. 6. ед.Xp. 17.

${ }^{20} \mathrm{Vgl}$. A.V. Lavrov: "Trudy i dni", a.a.O., S. 195.

21 Vgl. R.-D. Kluge: Der russische Symbolismus, a.a.O., S. 85-88.

22 Blok verlor jedoch schnell das Interesse an "Трулы и дня" und publizierte, ungeachtet der beabsichtigten engen Mitarbeit, ab der dritten Ausgabe 1912 keine Beiträge mehr in dieser Zeitschrift: er näherte sich dem 1912 in Petersburg gegründeten Verlag "Sirin" an (vgl. A.V. Lavrov: Trudy i dni, a.a.O., S. 203).

$23 \mathrm{Vgl}$. Metners Ausführungen in: Tруды и лғя, Nr. 1, 1912, S. 56-60.

24 Vgl. A.V. Lavrov: "Trudy i dni", a.a.O., S. 197-199. 
Die Zeitschrift "Труды и дни" hatte keinen Belletristikteil, sondem bestand ausschlieBlich aus theoretischen Arbeiten, druckte überwiegend philosophische Aufsätze und lie $B$ den lebendigen literarischen Proze $B$ sowie die konkreten Ereignisse des kulturellen Lebens unberücksichtigt. Durch diese Orientierung auf die exigen Werte war die Zeitschrift von Anfang an nur für einen engen Kreis bestimmt und vermochte keine breite öffentliche Resonanz hervorzurufen. Auch Kritik kam nur aus den eigenen Reihen um den "Musaget" selbst ${ }^{25}$.

Angesichts der sehr unterschiedlichen Interessenausrichtungen konnte die notwendige Einheit unter den Zeitschriftmitarbeitern nicht erhalten bleiben und es bildeten sich schnell zwei Gruppen:

1. Metner, Belyj, Ivanov, Ellis, u.a.

2. Die idealistischen Philosophen, das heiBt, der Kreis um den russischen "Logos", mit Sergej Gessen, Fedor Stepun und Boris Jakovenko an der Spitze.

So gab es von Anfang an Differenzen. Die methodologisch strengen, neokantianischen Theorien Jakovenkos ließen sich zum Beispiel nur sehr schwer mit den mystischen Spekulationen von Ëllis und den schöpferisch-kreativen Elementen in Belyjs Aufsätzen verbinden 26. Stepun warf A. Belyj in seiner Rezension zu "Символизм"27 philosophischen Dilettantismus vor ${ }^{28}$; Belyj begann, nicht zuletzt unter dem EinfluB R. Steiners, gegen die Neukantianer zu polemisieren. Diese scharfe Polemik fand ihren Niederschlag in seinem Artikel "Круговое движение. (Сорок две арабески)" ("Kreisbewegung. 42 Arabesken")29. Es kam schlieBlich (Ende 1913/Anfang 1914) zum endgültigen Bruch mit den "Logos"-Mitarbeitem. 1914 verlieB der "Logos"Kreis für immer den "Musaget"-Verlag30.

Als ebenfalls äußerst konfliktreich erwies sich eine andere Opposition innerhalb der ersten Gruppe von "Musaget": der Gegensatz zwischen den kulturologischen Be strebungen Metners und der Anthroposophie Rudolf Steiners: Am 18. September/1. Oktober 1911 fuhr Ellis nach Deutschland, um Steiners Vorträge zu hören und wurde dort extremer Anhänger der anthroposophischen Lehre ${ }^{31}$. Er kehrte nie mehr nach RuBland zurick; das heißt, er war zur Zeit des Erscheinens von "Труды и дни" schon

$25 \mathrm{Vgl}$. ebd., S. $200 \mathrm{f}$.

$26 \mathrm{Vgl}$. ebd., S. 203.

$27=1910$ erschienene Aufsatzsammlung von A. Belyj.

28 Logos. Nr. 1, 1910, S. 281.

29 In: Tруљы н пня. Nr. 4-5, 1912, S. 51-73.

Der "Kantianer" Belyj wandte sich 1912 unter R. Steiners EinfluB vom Kantianismus ab und pole misierte in seinem Aufsatz "Круговое движение" hefiig gegen die Neukantianer, die er als "Idioten" bezeichnete. als "смесь младенща со старнчком - ни ребенок. ни муж. а гадкий мальчншка. оскопивипйся до наступления зрелости и потом удививинйся. что у вего ве растет борощы" (ebd.. S. 56f.). Der zeitgenössischen Philosophie - wie auch der Literatur, dem Theater und der Malerei - warf er vor, dab sie sich im Kreise drehen, anstatt sich spiralförmig weiterzuentwickeln. Die gegenwärige Philosophie sei scholastisch. Belyjs Arbeit rief heftige Kritik von seiten der "Logos"-Mitarbeiter hervor, $\dot{\mathrm{E}}$. Metner versuchte, eine versöhnende Mittlerrolle zu spielen. In der Folge trat Belyj als Redakteur von "Труды н дни" zurück. Ein offener Brief Stepuns an Belyj wurde in derselben Zeitschriftennummer wie Belyjs Aufsatz publiziert: darin rühmte Stepun zwar Belyjs essayistische Begabung und sein schriftstellerisches Talent, kritisiente jedoch den Inhalt von dessen Beitrag auf wohl wollende, aber prinzipielle Weise: Die Kreisbewegung spiele sich nicht in Theater, Literatur, Malerei und vor allem Philosophie ab. sondem in Belyjs Innerem; er habe sich von fremden Einflüssen leiten lassen, anstatt seine eigenen bedeutenden Worte zu sprechen. (Vgl. F. Stepun: Otkrytoe pis'mo Andreju Belomu po povodu stat'i "Krugovoe dviženie". In: Tруды и дни. Nr. 4-5, 1912, S. 74-86; ebenfalls zu diesem Thema: M.V. Bezrodnyj: Zur Geschichte des russischen Neukantianismus, a.a.O.. S. 497f., 510.)

${ }^{30} \mathrm{Vgl}$. M.V. Bezrodnyj: Zur Geschichte des russischen Neukantianismus, a.a.O., S. 496-498. 505.

31 Zum Thema "Ëllis und R. Steiner" vgl. das folgende Unterkapitel. 
gar nicht mehr persönlich in Moskau im "Musaget"-Verlag32, dem er sich jedoch weiterhin sehr verbunden fühlte: Alles, was er schrieb, schickte er nach Moskau an "MuSaget" 33 , stand in regem Briefwechsel mit Metner und verfolgte aufmerksam die Ent wicklung der Zeitschrift sowie das literarische und kulturelle Leben in Moskau. Im Februar 1912 reiste auch A. Belyj ins Ausland und schloB sich ebenfalls der Anthroposophie an. Infolgedessen kam es zu einer Spaltung innerhalb von "Musaget" und innerhalb des Redaktionskollegiums von "Труды и дни": Belyj und Ëllis wollten die Zeitschrift als Tribüne anthroposophischer Propaganda benutzen, was bei Metner und Ivanov auf entschiedene Ablehnung stieB. Man versuchte, sich darauf zu einigen, daB "Труды и дни" eine neutrale Linie verfolgen sollte: weder für noch gegen die Anthroposophie. Der programmatische "Status quo" von "Musaget" sollte erhalten blei ben: Kultur und Symbolismus, aber kein Okkultismus ${ }^{34}$. Eine gewisse Affinität zur Anthroposophie machte sich dennoch in einigen Beiträgen bemerkbar ${ }^{35}$.

Wie Ėllis und Belyj hielten sich auch Metner und Ivanov monatelang im Ausland auf. Diese Tatsache sowie die komplizierten Beziehungen zwischen den engsten Mitarbeitern von "Труды и дни" führten dazu, daß die Zeitschrift nicht regelmäBig erscheinen konnte: Nur 1912 erschien "Труды и дни", wie geplant, als Zweimonatsschrift. 1913, 1914 und 1916 wurde jeweils ein doppelter Band herausgegeben, wobei der letzte von 1916 nicht mehr der ursprünglichen Konzeption entsprach, sondern lediglich etliche verschiedenartige Arbeiten enthielt, die sich in der Redaktion angesammelt hatten ${ }^{36}$.

Metner blieb einziger Redakteur von "Труды и дни" und handelte auch als solcher. Bereits 1912 (Nr. 2) hatte er den Teil "Wagneriana" gegrüdet; 1913 kamen noch die Teile "Goetheana" und "Danteana" dazu. So sah die Aufteilung von "Труды и дни" ab 1913 folgendermaßen aus: Der erste Teil der Zeitschrift war dem Werk der großen Kulturträger: Dante, Goethe und Wagner gewidmet, während im zweiten Teil Fragen des Symbolismus und der Kultur behandelt wurden. In der Zuwendung zu eben jenen großen Kulturbegründem (Dante, Goethe und Wagner) sah Metner die einzige Möglichkeit, die Kulturkrise zu überwinden und dem "Chaos des gegenwärtigen Modernismus" zu entfliehen ${ }^{37}$. Ellis folgte Metner hierin, wie ihrem Briefwechsel in der Zeit von 1911 bis 1914 zu entnehmen ist ${ }^{38}$.

1912 wurden in "Труды и дни" neben zahlreichen Beiträgen von Metner (wobei er diejenigen über musiktheoretische Themen unter dem Pseudonym "Vol'fing" 39 publizierte) auch etliche Arbeiten von Belyj und Ivanov gedruckt. Insgesamt veröffentlichte die Zeitschrift 1912-1914 und 1916 neben einigen Aufsätzen von Ėllis vor allem Beiträge der Mitglieder des Jugendkreises "Молодой Мусагет" ("Der junge

32 Das letzte Projekt. das Ėllis aktiv im "Musaget"-Verlag durchfuihrte (neben den erwähnten Ar beitskreisen, die er leitete), war die Edition der "Musaget"-Anthologie im Frühjahr 1911 (vgl. hierzu M. Ljunggren: The Russian Mephisto, a.a.O., S. 46).

33 "Musaget" druckte Ëllis' Manuskripte allerdings nur teil weise; der nie realisiente Publikationsplan des Verlags enthielt z.B. Ëllis" Aufsatzsammlung "Релития и Россия. Фрагменты ненаписанной книги" ("Religion und RuBland. Fragmente eines ungeschriebenen Buches"), die nie veröffentliche wurde . (Vgl. hierzu auch M. Ljunggren: The Russian Mephisto, a.a.O.. S. 176. Anm. 37.)

34 PO РГБ. Ф. 167, карт. 7. ед.xp. 79.

$35 \mathrm{Vgl}$. A.V. Lavrov: "Trudy i dni", a.a.O.. S. $204 f$.

$36 \mathrm{Vgl}$. ebd., S. $206 \mathrm{f}$.

$37 \mathrm{Vgl}$. ebd.. S. 207f. Zu Metner und "Tруды и дни" vgl. auch M. Ljunggren: The Russian Mephisto, a.a.O., S. 47-63.

38 РО РГБ. Ф. 167. карт. 7. ел.хр. 31-88; Ф. 167. карт. 8. ел.хp. 1-28.

39 Vol'fing = Wölfing, der Name, den Siegmund (der mutterlose Wälsung) erstmals in der "Walküre" (R. Wagner) gebraucht. (Zu Metners Pseudonym vgl.: M. Ljunggren: The Russian Mephisto, a.a.O.. S. 25; R. Bartlett: Wagner and Russia, a.a.O., S. 148.) 
Musaget") 40 . Paradoxerweise enthielt die Zeitschrift "Труды и дни" јеdoch vor allem philosophisch-ästhetische und weltanschauliche Aufsätze, obwohl sie eigentlich als literarisches Joumal konzipiert worden war ${ }^{4}$.

In den Differenzen um die redaktionelle Ausrichtung von "Труды и дни" spiegelt sich deutlich die Ambivalenz zwischen Tradition und Moderne wider, die ja bereits im Einleitungsteil der vorliegenden Arbeit diskutien worden ist: Einerseits stellt der Symbolismus einen radikalen Bruch mit der mimetischen Kunst- und Literaturauffassung dar; neu im Symbolismus sind die Offenheit des Symbols und die Einbeziehung des Rezipienten; diejenigen Erscheinungen, die konstitutiv für die Avantgarde sind, sind bereits im Symbolismus vorhanden. Andererseits wird der Symbolismus auch immer wieder bestimmt durch eine Sehnsucht nach Harmonie, eine Rückwendung zu Traditionellem. Gleichzeitig fallt ein weiterer Parallelismus innerhalb des Symbolismus auf, der verstärkt ab 1909/1910 und dann besonders deutlich zur Zeit des Erscheinens von "Труды и дни" (um 1912) zutage tritt: Zu der Zeit, als die literarische Praxis des Symbolismus ihren Höhepunkt erreichte und so bedeutende Symbolisten wie Brjusov, Blok und Belyj symbolistische Werke höchsten Ranges schufen ${ }^{42}$, nahmen die theoretischen Widersprüche, ideologischen Diskrepanzen und die Zersplitterung der einzelnen weltanschaulichen Richtungen innerhalb des Symbolismus zu. Die Geschichte der Zeitschrift "Труды и дни" kann als Zeugnis und überzeugende Bestätigung für diese zunehmenden Widersprüche innerhalb der symbolistischen Ideologie dienen. Diese Inhomogenität im Symbolismus, vor allem im ideologischen Bereich, wurde dann in den einzelnen avantgardistischen Gruppierungen. die alle eine unterschiedliche Weltanschauung vertraten, noch verstärkt.

Bei Ausbruch des Ersten Weltkriegs war Metner in die Schweiz (nach Zürich) übergesiedelt ${ }^{43}$ und konnte von dort aus die Herausgebertätigkeiten nicht mehr wahrnehmen. Er übergab die "Musaget"-Angelegenheiten Vikentij Pašukanis und wünschte, daB "Труды и дни" weiterhin sporadisch erscheinen sollten. Als Resultat erschien 1916 nach zweijähriger Pause nur noch ein Band. Das war zugleich das Ende von "Труды и дни" 44 .

Bevor nun auf Ëllis' Beiträge in "Труды и дни" näher eingegangen wird, soll zuvor ein Unterkapitel über Ėllis und Rudolf Steiner folgen, da Ellis diese Arbeiten in Deutschland unter dem EinfluB der Anthroposophie verfaBt hat. Diese Phase stellt auberdem einen wichtigen Abschnitt in seinem Leben dar.

${ }^{40}$ Diesen Zirkel hatte der Bildhauer Kracht gemeinsam mit Ėllis gegrindet; ihm gehörten Durylin. Sidorov, Bobrov, Kiselev u.a. an. (Vgl. hierzu auch M. Ljunggren: The Russian Mephisto, a.a.O.. S. 43 sowie A.V. Lavrov: "Trudy i dni", a.a.O.. S. 207, und die Inhaltsverzeichnisse von "Tруды н гын".

41 Vgl. A.V. Lavrov: "Trudy i dni", a.a.O.. S. 209.

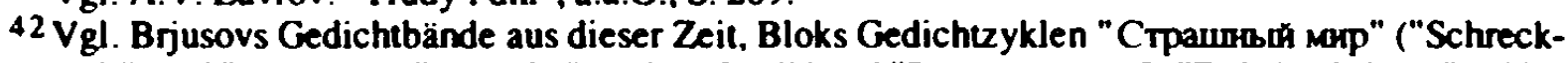
liche Welt") und "Bозмезmе" ("Rache"), seinen Lyrikband "Земля в cнery" ("Erde im Schnee", 1908) und seine "lyrischen Dramen" ("Балаганчrix". "Kороль на плошадн" - "Der König auf dem Platz". "Незнакомка" - "Die Unbekannte"), Belyjs Roman "Петербурr".

${ }^{43} \mathrm{Vgl}$. M. Ljunggren: The Russian Mephisto, a.a.O.. S. 86ff.

44 Vgl. A.V. Lavrov: "Trudy i dni", a.a.O., S. 211.

In diesem letzten Band "Труды и дни" wurde im "Danteana"-Teil u.a. J. van der Meulens Arbeit "O планетных сферах Дантова «Раям в свете астрософин" ("Über die Planetensphären in Dantes «Paradies» im Lichte der Astrosophie", S. 9-22) publiziert (angeblich in Ëllis' Übersetzung; vgl. M. Ljunggren: The Russian Mephisto, a.a.O.. S. 119). 


\section{2) Ellis und Rudolf Steiner ${ }^{45}$}

Gegen Ende der ersten Dekade dieses Jahrhunderts begannen sich immer mehr russische (symbolistische) Dichter, Schriftsteller, Denker und Künstler mit der Theosophie, vor allem in ihrer speziellen Ausprägung durch $\mathbf{R}$. Steiner und seiner daraus entwickelten anthroposophischen Lehre auseinanderzusetzen, waren von ihr begeistert, wurden von ihr angezogen oder auch abgestoßen. Viele Russen reisten nach Deutschland zu Steiner (darunter Ėllis und Belyj), hörten seine Vorträge, kamen zur Anthroposophischen Gesellschaft und halfen mit beim Bau des ersten Goetheanums in Dornach (Schweiz) ${ }^{46}$. Um zu verstehen, was die Russen (und unter ihnen Ėllis) an Steiner und der Anthroposophie faszinierte, soll zunächst ein kurzer Überblick über die Hauptzüge dieser Lehre gegeben werden.

Die Theosophie im neueren Sinn ist eine von Elena Petrovna Blavackaja begründete, buddhistische Elemente aufnehmende Lehre vom Übersinnlichen: Der innere Mensch, sein Wesenskem, sei unsterblich; Tod bedeute lediglich einen Übergang auf höhere Daseinsebenen; durch Wiederverkörperung (Reinkamation) werde der Mensch zur irdischen Ebene zurückgeführt, um seinen Entwicklungsgang fortzusetzen. Das jeweilige Lebensschicksal werde vom Karma, dem Gesetz göttlicher Gerechtigkeit. gestaltet. Der Fortschritt der Menschheit erfolge nach einem göttlichen Entwicklungsplan. Die einzelnen Religionen seien nur verschiedene Ausdrucksformen der ewigen Wahrheit. Das Endziel der menschlichen Entwicklungen sei das Wieder-Einswerden mit Gott ${ }^{47}$.

Elena Blavackaja und Henry Steel Olcott gründeten 1875 in New York die Theosophische Gesellschaft, die es sich zum Ziele machte, "die Bruderschaft der Menschheit zu verwirklichen, zum vergleichenden Studium der Religionen anzuregen und die unerklärten Naturkräfte zu erforschen, um den Materialismus einzudämmen und die Religiosität neu zu beleben" 48

Blavackaja und Olcott reisten 1879 nach Indien, wo sie in Bombay das Hauptquartier der Theosophischen Gesellschaft gründeten, das 1882 nach Adyar bei Madras verlegt wurde 49. 1907 übernahm die englische Theosophin Annic Besant die Präsidentschaft der Theosophischen Gesellschaft in Indien 50.

Die deutsche Sektion der Theosophischen Gesellschaft wurde ab 1902 von Rudolf Steiner geleitet. der bereits in seiner Wiener Zeit in den achtziger Jahren des vorigen Jahrhunderts in den dortigen theosophischen Kreis geraten war, sich jedoch zunächst

$45 \mathrm{Vgl}$. hierzu auch: Ch. Villich [H. Willich]: Ėllis i Štejner. In: Novoe literatumoe obozrenie, 9 (1994). S. 182-191: Dies.: L.L. Kobylinskij-Ėllis i antroposofskoe učenie Rudol'fa Štejnera. (K posta novke problemy) In: Serebrjanyj vek msskoj literatury: Problemy, dokumenty. Moskva 1996. S. 134146: D. Rizzi: Ellis i Stejner. In: Europa Orientalis, 14. 1995. 2. S. 281-294.

46 Vgl. hierzu V.B. Fedjuschin: RuBlands Sehnsucht nach Spiritualität, a.a.O.: M. Carlson: "No Religion higher than Truth". A History of the Theosophical Movement in Russia. 1875-1922. Prince ton. New Jersey 1993; R.v. Maydell: Dornach als Pilgerstätte der russischen Anthroposophen. In: K. Schlögel (Hrsg.): Russische Emigration in Deutschland 1918 bis 1941 . Leben im europäischen Bürgerkrieg. Berlin 1995. S. 295-303. Vgl. ebenfalls die Memoirenliteratur: A. Belyj: Vospominanija o Štejnere. Paris 1982: A. Belyj: Verwandeln des Lebens. Erinnerungen an Rudolf Steiner. Basel 1990; A. Turgenieff: Erinnerungen an Rudolf Steiner und die Arbeit am ersten Goetheanum. Stuttgan 2 1973; M. Woloschin: Die grüne Schlange. Lebenserinnerungen einer Malerin. Hamburg 1982; M. Vološina: Zelenaja zmeja. Istorija odnoj żizni. Moskva 1993.

47 DTV-Lexikon. Bd. 18. München 1969, S. 198.

48 Brockhaus Enzyklopädie in 20 Bänden. 18. Band. Wiesbaden 1973, S. 633.

${ }^{49}$ V. Fedjuschin: RuBlands Sehnsucht. a.a.O.. S. 58.

50) DTV-Lexikon. Bd. 2. München 1969. S. 119. 
sehr zwiespältig und kritisch gegenüber der Theosophie verhielt ${ }^{51}$. Gegen Ende des Jahres 1912 brach Steiner mit der Theosophischen Gesellschaft wegen der Ausrufung Krischnamurtis zum neuen Weltlehrer 52 und gründete am 28.12.1912 in Köln die "Anthroposophische Gesellschaft"53, die sich dann Anfang Februar 1913 auf einer Generalversammlung in Berlin konstituierte ${ }^{54}$. Jesus Christus und der Kreuzestod von Golgatha bedeuten für Steiner das zentrale Geschehen der Erd- und Menschheitsgeschichte, und er hat immer wieder betont. daB Christus nur ein einziges Mal auf Erden inkamiert war. Annie Besant jedoch hatte Krischnamurti als wiedergeborenen Christus proklamiert. Somit war durch diesen zentralen Unterschied in den Anschauungen ein Bruch mit der Theosophischen Gesellschaft unvermeidbar. Steiner hatte sich von Anfang an an der mitteleuropäischen Kultur orientiert und in seinem Anthroposophie-Verständnis schnell immer weiter von den indisch-asiatischen Wurzeln der Theosophie Blavackajas entfernt. Er legte die Termini, die er einiger Jahre theosophischer Lektüre entnommen hatte, wieder ab. Seinen Ausgangspunkt bildeten die in der westeuropäischen Geistesentwicklung wurzelnden Erkenntnisse. Auch die von den Theosophen angestrebte Synthese aller Religionen war in dieser Form für ihn unannehmbar, obwohl er sehr daran interessien war, jeder einzelnen Religion ihren legitimen Platz innerhalb der Anthroposophie zu zeigen.

Anthroposophie, Steiner spricht auch häufig von "Geisteswissenschaft", läßt sich definieren als "Erkenntnisweg, der das Geistige im Menschenwesen zum Geistigen im Weltall führen möchte"55, und "vermittelt Erkenntnisse, die auf geistige Art gewonnen werden" 56. In seiner Vorbemerkung zum Aufsatz "Philosophie und Anthroposophie" gibt Steiner folgende Definition:

Unter Anthroposophie verstehe ich eine wissenschafiliche Erforschung der geistigen Welt. welche die Einseitigkeiten einer bloBen Natur-Erkenntnis ebenso wie diejenigen der gewöhnlichen Mystik durchschaut, und die, bevor sie den Versuch macht, in die übersinnliche Welt einzudringen, in der erkennenden Seele erst die im gewöhnlichen BewuBtsein und in der gewöhnlichen Wissenschaft noch nicht tätigen Kräfte entwickelt, welche ein solches Eindringen ermöglichen. 57

Rudolf Steiner hatte erkannt. daß die zweifellos großen Erfolge und Errungenschaften von Naturwissenschaft und Technik die Menschen zu einem materialistischen Fortschrittsverständnis geführt hatten, dem jegliches geistiges Gegengewicht fehlte. Wenn aber für das BewuBtsein nur noch das existiern, was man mit seinen Sinnesorganen wahmehmen und mit technischen Instrumenten bearbeiten kann, gibt es

51 Über R. Steiner gibt es sehr viel Literatur. Eine gute kurze Einführung in Leben und Werk bietet Chr. Lindenberg: Rudolf Steiner mit Selbstzeugnissen und Bilddokumenten. Reinbek 1992. Uber Stei ners Vertältnis zur Theosophie in seiner Wiener Zeit vgl. ebd.. S. 31-33.

52 Brockhaus Enzyklopädie in 20 Bd. 18. Bd. Wiesbaden 1973. S. 63: Chr. Lindenberg: R. Steiner mit Selbstzeugnissen. a.a.O.. S. 95.

${ }^{53} \mathrm{Chr}$. Lindenberg: Rudolf Steiner. Eine Chronik 1861-1925. Stuttgant 1988. S. 324.

54 Chr. Lindenberg: R. Steiner mit Selbstzeugnissen, a.a.O.. S. 96.

Die Theosophische Gesellschaft hatte sich nach dem Tod der Blavackaja in mehrere Gesellschaften gespalten, die bis heute in vielen Ländern, so auch in Deutschland, bestehen. Die zentrale Vermittlung zwischen den einzelnen Theosophischen Gesellschafien in Deutschland, die freundschafulich zusammenarbeiten, wird über die "Theosophische Informationsstelle" in Frankfur/Main abgewickelt.

$55=1$. anthroposophischer Leitsatz (in: R. Steiner: Anthroposophische Leitsätze. Der Erkenntnisweg der Anthroposophie. Das Michael-Mysterium. Dornach/Schweiz 1976. S. 14).

$56=2$. Leitsatz (ebd.).

57 R. Steiner: Philosophie und Anthroposophie. Gesammelte Aufsätze. 1904-1918. Dornach/Schweiz 1965 (= Rudolf Steiner Gesamtausgabe Schriften. 35). S. 66. 
keine Welt des realen Geistigen mehr und alle diesbezüglichen Aussagen werden als Täuschung oder Himgespinst angesehen.

Steiner knüpfte also in seinem Theosophie-Verständnis an die europäische und christliche Überlieferung sowie an die modeme Wissenschaft an ${ }^{58}$ und bemühte sich dabei, von einer allgemeinen Menschenerkenntnis auszugehen und durch sie Anregungen und Hinweise für eine individuelle Menschen- und Selbsterkenntnis zu erlangen. 1904 veröffentlichte er seine Erkenntnisse in dem Buch "Theosophie"59.

Für Steiner besteht der Mensch aus Leib, Seele und Geist. Diese dem Menschen zugrundeliegende Dreiheit läBt sich weiter differenzieren ${ }^{60}$. So gelangt Steiner schlieBlich zu der folgenden Gliederung des Menschen:
1. Physischer Leib
2. Lebensleib
3. Astralleib
4. Ich als Seelenkem
5. Geistselbst als verwandelter Astralleib
6. Lebensgeist als verwandelter Lebensleib
7. Geistesmensch als verwandelter physischer Leib. ${ }^{61}$

Der physische Leib des Menschen ist aus Materie gebildet und zerfällt nach dem Tode. Er wird vom Äther- oder Lebensleib durchdrungen, dem sogenannten "Bilde Kräfte-Leib", der die Stoffe und Kräfte des physischen Leibes erst zum Leben aufruft. Der Astral- oder "Seelenleib" vermittelt unserem Körper die Gefühle von Schmerz und Freude, Lust und Unlust, Zuneigung und Abneigung, die Triebe und das Begehren. Erst das Ich, das in der Seele lebt, läBt den Menschen zum Menschen werden. Es ist göttlicher Natur und macht das eigentliche BewuBtsein des Menschen aus, sein Selbst. Die geistige Wesenheit des Menschen untergliedert Steiner in drei Teile: in das Geistselbst, den Lebensgeist und den Geistesmenschen ${ }^{62}$.

In diesem Zusammenhang ist Steiners Reinkamationslehre, das Gesetz der wiederholten Erdenleben, von großer Wichtigkeit: Der Mensch lebt nicht nur einmal, sondem erlebt viele Male Tod und Wiedergebur. Das Ich entwickelt sich in der Phase zwischen Torl und neuer Gebur weiter, bereitet sich auf ein neues Erdenleben vor, das folglich mit dem früheren Erdendasein und dessen Schicksal in Verbindung steht ${ }^{63}$

Ein zentraler Gedanke in Steiners Anthroposophie ist, daB das menschliche Erkenntnisvermögen entwicklungsfähig und der bewuBten Schulung zugänglich ist: das menschliche BewuBtsein ist gewissermaßen einer Steigenung fähig ${ }^{64}$. Steiner hat von seinen Jugendwerken an bis zum Lebensende in immer neuen Ansätzen Wege auf-

${ }^{58}$ Chr. Lindenberg: R. Steiner mit Selbstzeugnissen, a.a.O., S. 74.

${ }^{59} \mathrm{R}$. Steiner: Theosophie. Einführung in übersinnliche Welterkenntnis und Menschentestimmung. Domach/Schweiz 1980 (1. Aufl. Berlin 1904): vgl. dazu auch Chr. Lindenberg: R. Steiner mit Selbstzeugnissen, a.a.O.. S. $79 f f$.

${ }^{60} \mathrm{Vgl}$. R. Steiner: Theosophie, a.a.O.. S. 27-48.

61 Ebd., S. 48.

62 Ebd., S. $44 f$.

63 Ausführungen dazu in R. Steiners "Theosophie" (ebd.. S. 49-133) sowie in seinen beiden Vorträgen: "Reinkamation und Karma. Vom Standpunkte der modernen Naturwissenschaft notwendige Vorstellungen" und "Wie Karma wirkt" (beide Vorträge u.a. in einem Bändchen mit gleichem Titel: Dornach/Schweiz 1978).

64 Steiner knüpft in gewisser Weise an das Streben Fichtes. Schellings und Hegels nach einem BewuBtsein an, "das höhere als die gewöhnlichen Erkenntnisfähigkeiten zu betätigen vermag". (H.E. Lauer: Fichte, Scheiling, Hegel. In: Ders.: Der Kulturimpuls der deutschen Klassik. Schaffhausen 1974. S. 63-74, hier bes. S. 64.) 
gewiesen, auf denen ein an der zeitgenössischen Wissenschaft geschultes Denken durch neue Methoden auch solche Bereiche exakt wissenschaftlich bearbeiten kann. die der heutigen reinen Naturwissenschaft noch als unzugänglich erscheinen. Einen entscheidenden Schritt in diese Richtung hatte schon Goethe getan, der mit seinen organischen und morphologischen Arbeiten den Anspruch erhebt, wissenschaftlich nachprüfbare Aussagen getroffen zu haben. Die Behauptung Goethes wird heute auch von einigen namhaften Wissenschaftlern auBerhalb der Anthroposophie bestätigt (etwa von A. Portmann, W. Troll und C.F. von Weizsäcker). Steiner ist jedoch über Goethes "organische Methode" noch weit hinausgegangen. Er betont, daB seine geisteswissenschaftlichen Aussagen für denjenigen nachprüfbar seien, der sich der von ihm aufgewiesenen Methoden bediene ${ }^{65}$. So wie der Mensch vom Schlaf zum Traum und von diesem zum Wachen übergehen kann und das Erlebte durch Denken zu ordnen vermag, so kann er auch dieses Denken in eine neue Qualität erheben. Das großartigste Vorbild ist für Steiner in diesem Zusammenhang Goethe, der im Schauen der Urpflanze eine BewuBtseinsverfassung betätigt, die er - nach Kant - als anschauende Urteilskraft bezeichnet.

In seinem philosophischen Hauptwerk, "Die Philosophie der Freiheit", an dem Steiner 1891 in Weimar zu arbeiten begann, versucht er, die schöpferische Freiheit als das spezifisch Menschliche des Menschen nachzuweisen: Steiner geht in dieser erkenntnistheoretischen Arbeit von der Polarität zwischen Wahmehmung und Denken aus. Es kann keine Erkenntnis zustande kommen, ohne daB eine Wahmehmung - sei es eine sinnliche oder die eines Gefühls, ja sogar die eines auftauchenden Gedankens - mit dem ihr zugehörigen Begriff durch die Tätigkeit des Denkens verbunden wird. Aber es gibt eine einzige Ausnahme, die in der bisherigen Philosophie vor allem von J.G. Fichte und G.W.F. Hegel untersucht worden war ${ }^{66}$, nämlich wenn das Denken sich selber denkt bzw. beobachtet. In diesem einzigen Falle ist das Wahmehmungsorgan und das begriffserzeugende Organ ein und dasselbe. Steiner bezeichnet diese Situation als die Überwindung des Dualismus zugunsten eines Monismus. Man erlebt sich selbst als den Schöpfer einer neuen Einheit der sonst für den Menschen in Sein und BewuBtsein zerfallenden Welt. Hierauf beruht die menschliche Freiheit. In vierzehn ausführlichen Kapiteln wird der hier skizzierte Gedankengang entwickelt ${ }^{67}$.

65 Diese Gedanken Steiners finden sich vor allem in seinen folgenden Werken: Grundlinien einer Erkenntnistheorie der Goetheschen Weltanschauung (1886), Theosophie (1904), Wie erlangt man Erkenntnisse der höheren Weiten? (1904/1905) und Die Geheimwissenschaft im UmriB (1910).

66 Bereits ab 1877 hatte R. Steiner mit einem intensiven autodidaktischen Philosophiestudium begonnen und sich zunächst mit Kant, ab 1879 mit Fichte (das Thema seiner Dissertation [1891] lautete: "Die Grundfrage der Erkenntnistheorie mit besonderer Rücksicht auf Fichtes Wissenschaftslehre") und in den achtziger und neunziger Jahren mit Schelling, sehr intensiv mit Hegel, der idealistischen Philosophie insgesamt. mit Nietzsche und anderen Philosophen des 19. Jahrhunderts beschäfuigt und auseinandergesetzt, wodurch er für seine eigene Lehre viele Anregungen erfahren und Anknüpfungspunkte gefunden hat.

67 Vgl. R. Steiner: Die Philosophie der Freiheit. Grundzüge einer modemen Weltanschauung. Seelische Beobachtungsresultate nach naturwissenschafulicher Methode. Dornach/Schweiz 1981 (1. Aufl. Berlin 1894); vgl. dazu auch Chr. Lindenberg: Rudolf Steiner mit Selbstzeugnissen und Bilddokumenten. a.a.O.. S. 46-56.

Entgegen weitgehender Prognosen auch hochgebildeter Zeitgenossen und trotz eines Ignorierens durch die Universitäten sind Rudolf Steiners Gedanken dennoch zunehmend im Kulturleben nachzuweisen. vor allem aber auch seine kulturellen Impulse; es sei nur erinnert an die Waldorfpädagogik, die Heilpädagogik. die anthroposophische Medizin und die mit ihr verbundene Heilmittelherstellung, die biologisch-dynamische Landwirtschaft, die Christengemeinschaft. die Eurythmie sowie die anthroposophische Malerei. Bildhauer- und Schauspielkunst, die weltweite Verbreitung gefunden haben. 
Betrachtet man die hier nur sehr kurz und reduziert dargelegten Grundgedanken von Theosophie und Anthroposophie, so kann man die Faszination verstehen, die diese Strömungen auf jene russischen Symbolisten ausuibten, die nach höheren geistigen Erkenntnissen und Sphären suchten, in den großen Errungenschaften von Naturwissenschaft und Technik keine befriedigenden Antworten fanden und somit den positivistisch-materialistischen Fortschrittsoptimismus der Zeit anzweifelten.

Gegen Ende des 19. Jahrhunderts drangen erste vereinzelte Publikationen der Blavackaja nach RuBland, erste kurze Artikel wurden über sie und die Theosophie publiziern ${ }^{68}$. Erste Arbeitskreise zur Erforschung der Grundlagen der Theosophie bildeten sich Anfang des Jahrhunderts in Moskau (gegründet von Anna Sergeevna GonCarova) und Petersburg (gegründet von Anna Alekseevna Kamenskaja). Am 17. November 1908 wurde in Petersburg offiziell die "Russische Theosophische Gesellschaft" gegründet und die erste theosophische Zeitschrift "Вестник теософии" ("Воte der Theosophie") herausgegeben. In Moskau nahmen viele junge Künstler und symbolistische Dichter an den theosophischen Vorträgen und Versammlungen im Hause der Kleopatra Petrovna Christoforova teil, darunter A. Belyj und Ėllis ${ }^{69}$.

Ëllis wurde wohl 1909 oder 1910 durch K.P. Christoforova und Anna Rudol'fovna Minclova mit den Werken und Vorträgen $R$. Steiners bekannt und begann sich gleich für Steiner und dessen Lehre zu begeistem ${ }^{70}$. Gemeinsam mit Boris Grigorov und dem Komponisten Rejngol'd Glièr gründete Ëllis mehrere Arbeitskreise zur Erforschung der Theosophie und der Werke Steiners, an denen vorwiegend "Musaget" Mitarbeiter oder dem symbolistischen Verlag nahestehende Intellektuelle teilnahmen71. Er studierte 1910-1911 Steiners Werke, darunter Teile der "Geheimwissenschaft" und die "Theosophie72, propagierte den "Steinerismus" in Moskau und empfahl die Beschäftigung mit Steiners Werken und Lehre ${ }^{73}$. Er wandte sich in einem Brief persönlich an Steiner (1910 oder 1911), berichtete darin von dem großen Eindruck, den die Anthroposophie auf ihn machte ${ }^{74}$, und brach schlieBlich am 18. September/1. Oktober 1911 zu Steiner nach Deutschland auf.

Wie immer in Ellis' Leben, vollzog sich auch seine Hinwendung zu Steiner plötzlich und unvermittelt. Ellis war eben beständig auf der Suche nach einem geistigen Führer, dem er sich bedingungslos hingeben konnte, und glaubte nun, ihn in Steiner gefunden zu haben. A. Belyj charakterisien Ellis' plötzliche Hinwendung zu R. Steiner folgendermaßen:

${ }^{68}$ Unter anderem von VI. Solov'ev: "Recenzija na knigu E.P. Blavackoj «The key to Theosophy»" und "Zametka o Blavackoj" (in: Sobranie soxinenij. Tom 6. Brjussel' 1966, S. 287-292, 394-398).

${ }^{69} \mathrm{Vgl}$. V. Fedjuschin: Rublands Sehnsucht. a.a.O.. S. 64-72; M. Carlson: "No Religion higher than Truth", a.a.O., S. 38-73, 88-104.

70 "Влиянне Штейнера на меня - всепоглощающее" gesteht er am 9.7.1910 Ë.K. Metner in einem Brief (PO ГPБ. Ф. 167, kapt. 7. en.xp. 24). S. Bobrov schreibt am 16.2.1911 an Belyj. daB Ėllis im Frühjahr 1910 von Steiner erfuhr und sich gleich für ihn zu begeistern begann (Lica. I. 1992. S. 157).

71 Vgl. V. Fedjuschin: Rublands Sehnsucht, a.a.O., S. 99-101: M. Carlson: "No Religion higher than Truth", a.a.O.. S. 98 f.

72 Vgl. V. Fedjuschin: Rublands Sehnsucht. a.a.O., S. 101. Vor seiner Abreise im Sommer 1911 liest Ellis täglich Steiner (vgl. seinen Brief an M.I. Sizova. РГАЛИ. Ф. 575. on. 1. en.xp. 20. Blatt 76): einer Postkante von Dmitrij Viktorovic Alekseev vom 21.6.1911 (РГАЛИ. Ф. 575. on. 1. ел.хр. 24) kann entnommen werden, daB Ėllis ihm Steiners "Philosophie der Freiheit" besorgt hat.

${ }^{73} \mathrm{~S}$. Bobrov beschreibt Ėllis' "Steinermanie" sehr anschaulich in seinem Brief an Belyj vom 16.2.1911 (Lica. 1, 1992. S. 156f.).

$74 \mathrm{Vgl}$. V. Fedjuschin: RuBlands Sehnsucht, a.a.O., S. 186-188. Der Brief befindet sich unveröffentlicht in der R. Steiner-Nachlabverwaltung in Domach/Schweiz. 
Эллис. натура люиифернческая. всю жизнь несся единым махом: и всегда - перемахивал. никогда не достигал цели в прыжках по жнзни: его первый "MAX": с гимназической скамьи к Карлу Марксу [...] в результате: "УМАХ" к ... Боллэру и символизму [...] в Бодлэре совершился "УМАХ": от Бодлэра ... к Данте и к толкованию "ТЕОСОФИЧЕСКИХ БЕЗДН", т.е. в Данте совершился новый "УМАХ": от Данте к Штейнеру; в 11-ом году его снаряжали в путь: без денег, знания языка. опыта: прожив с друзьями. водившими и "мывшими" его в буквальном смысле. - этот "СЛИШКОМ МОСКВИЧ". в Берлине становится "СЛИЩКОМ ГЕРМАНЕЩ", сев в первый рял уютного помещения берлинской ветви на Гайсбургштрассе. ${ }^{75}$

Zunächst reiste Ėllis nach Karlsruhe, wo er vom 4.-14. Oktober Steiners Vortragszyklus "Von Jesus zu Christus" hörte 76 . Anschließend folgte er Steiner nach Stuttgar. wo er am 15. und 16. Oktober die Vorträge anläBlich der Einweihung des neu errichteten Zweighauses miterlebte, darunter (am 16. Okt.) Steiners Vortrag über das Verhältnis von Theosophie und Rosenkreuzertum ${ }^{77}$. Danach begab er sich - Steiner folgend - nach Berlin, wo er in der Motzstraße im Gartenhaus in unmittelbarer Nähe Steiners ein Quartier fand ${ }^{78}$.

Ausführliche Berichte über Ellis' (erste) Zeit in Deutschland bei Steiner finden sich in seinen Briefen an Marija I. Sizova ${ }^{79}$. Natal'ja A. Turgeneva ${ }^{80}$ und an Ėmilij K. Metner ${ }^{81}$.

In einem seiner ersten Briefe aus Deutschland an M.I. Sizova vom September/Oktober 1911 beschreibt Ellis den Lebensthythmus in Karlsruhe:

Мы живем здесь так дружно и тах строго. Вечером лекция. потом в кафе беседа о неважном [это необходимо, иначе ужасно охватывает душу]. Утром у фонтана в парке повторяем лекинн по записям. по-русски. ${ }^{82}$

Ëllis konnte nämlich noch kein oder nur recht schlecht Deutsch ${ }^{83}$. In der ersten Zeit in Berlin unterhielt er sich, wie er schreibt, in einer selbsterfundenen Sprache, einem Gemisch aus deutschen, französischen und russischen Wörtern, symbolischen Gesten und Mimik. mit Hilfe derer er schnell und auch ausdauernd über komplizienteste theosophische Fragen sprechen konnte 84 .

In seinen Briefen aus Deutschland äuBene sich Ellis begeistert über Steiner, dessen Vorträge und seine Anhänger. Er schloB gleich ganz Deutschland in sein Herz ${ }^{85}$. Von Steiner spricht er meist als "доктор" ("Doktor") oder "учитель" ("Lehrer") und sieht in ihm den unfehlbaren Meister, Führer und Lehrer der Menschheit, dem alle folgen

75 A. Belyj: Vospominanija o Štejnere, a.a.O., S. 49.

${ }^{76}$ Rudolf Steiner Gesamtausgabe (GA) 131; vg! dazu G. Wachsmuth: Rudolf Steiners Erdenleben und Wirken. Von der Jahrhundertwende bis zum Tode. Die Geburt der Geisteswissenschaft. Eine Biographie. Domach (Schweiz) ${ }^{2}$ 1951, S. 180; Chr. Lindenberg: R. Steiner. Eine Chronik. a.a.O.. S. 308.

${ }^{77}$ G. Wachsmuth: R. Steiners Erdenleben. a.a.O., S. 181ff.; Chr. Lindenberg: R. Steiner. Eine Chronik. a.a.O.. S. 309.

78 РГАЛИ. Ф. 575. on. 1. ед.xp. 20 und РО РГБ. Ф. 167, карт. 7. ед.хр. 34.

79 Sept. 1911 - Frühjahr 1912: РГАЛИ. Ф. 575, on. 1. ед.xp. 20.

80 Okt. 1911 - Okt. 1912: vgl. D. Rizzi: Iz archiva N.A. Turgenevoj. Pis'ma Ėllisa, A. Belogo i A.A. Turgenevoj. In: Europa Orientalis, 14, 1995, 2, S. 295-340: Ëllis' Briefe an N. Turgeneva: S. 301-313.

${ }_{81}$ РО РГБ. Ф. 167. карт. 7, ед.хр. 32-88 und Ф. 167. карт. 8. ед.xp. 1-28.

82 РГАЛИ. $\Phi$. 575, on. 1, en.xp. 20, Blatt 82.

83 M. Woloschin: Die grüne Schlange, a.a.O.. S. 236; A. Belyj: Vospominanija o Štejnere, a.a.O., S. 49: Briefe von Ėllis an Metner vom 22.10.1911 (PO РГБ. Ф. 167. карт. 7. ед.xp. 34) und von Metner an Ëllis vom 12.11.1911 (ebd., Ф. 167, kapr. 6, eд.xp. 20).

84 Brief an M.I. Sizova vom Sept./Okt. 1911, РГАЛИ. Ф. 575. on. 1. ед.xp. 20. Blatt 87.

85 Hiervon zeugen vor allem die Briefe an Metner, РО РГБ. Ф. 167. карт. 7. ед.xp. 32. 34. 
müBten. Er betrachtet Steiner gewissermaBen als Reinkamation Christi 86 und nennt ihn "наш Единственный Мейстер, Апостол и маг" 87. Alles um Steiner herum sei weiße Magie ${ }^{88}$. In einem Brief an Metner schreibt er über Steiner: "Д-р сильнее всех моих мечтаний и предположений; это действительно маг, рыцарь и Учитель."89

Ellis bemühte sich, die Moskauer Symbolistenkreise um den "Musaget"-Verlag zu "steinerisieren", d.h., alle Mitarbeiter für Steiner und die Anthroposophie zu gewinnen. "Musaget" sollte fortan nur Steiners Werke herausbringen und das, was dieser selbst empfehle 90 .

Immer wieder spricht aus Éllis' Briefen an die Sizova (1911-1912) seine Enttäuschung über "Musaget" und seine ehemaligen Moskauer Freunde, die sich offensichtlich nicht von seiner Steiner-Begeisterung anstecken ließen. Zur Zeit des "Argonautenkreises" sei der Moskauer Symbolismus von Einstimmigkeit und Leben erfüllt gewesen. "Musaget" dahingegen stehe nur noch für den untergehenden Symbolismus. Man müsse seine Seele ganz Steiner hingeben. Aber Moskau, "Musaget" und RuBland überhaupt seien dazu noch nicht bereit. So faBt Ellis den EntschluB, für immer in Deutschland, in Steiners Nähe zu bleiben. Gemeinsam mit Margarita Vološina. die Ëllis in der ersten Zeit in Deutschland sehr geholfen hat 91 und ihm z.B. die ersten Steiner-Vorträge referierte, als er noch nicht genügend Deutsch konnte, wollte er in Deutschland eine russische Kolonie, d.h. eine russische Gemeinde "im Namen des Doktors" gründen. Um den Doktor sei auch der Geist VI. Solov'evs zu spüren ${ }^{92}$.

In der ersten Phase seiner Begeisterung für Steiner war Ëllis fest von der Möglichkeit überzeugt, nun endlich die enttäuschten Hoffnungen und Erwartungen aus der Zeit des "Argonautenkreises" realisieren zu können. Er projizierte also in Steiner und die Anthroposophie genau das, was er sein Leben lang gesucht hatte, was jedoch nicht den Tatsachen entsprach. Folglich muBte seine Begeisterung für Steiner später zwangsläufig in Enttäuschung umschlagen. Rudolf Steiner hat sich in sämtlichen Lebensstadien von einer derartigen emotionalen Haltung distanzier, und als er bemerkte, daB seine Vorträge und Schriften häufig in einer übertrieben begeisterten Weise rezipiert wurden (wie etwa von Ellis), bemühte er sich um so mehr um einen trockenen, nüchternen Stil. Nur so schien ihm die "Gemütsfreiheit" seiner Zuhörer gesichen zu $\operatorname{sein}^{93}$.

Während Ellis sich in Deutschland aufhielt, sollte ihn der Verlag "Musaget" mit einem monatlichen Honorar von 60 Rubeln finanzieren. Als Gegenleistung schickte

${ }^{86}$ Briefe an M.I. Sizova 1911-1912. РГАЛИ. Ф. 575. on. 1. en.xp. 20. Blatt 95 und Blatt 130.

87 Brief an M.I. Sizova 1911. ebd., Blatt 123.

${ }^{88}$ Brief an M.I. Sizova 1911 , a.a.O.. Blatt 122 f.

89 PO РГБ. Ф. 167. карт. 7. en.xp. 34. Entsprechend äubert er sich in einem undatierten Brief an N.A. Turgeneva (Herbst 1911: vgl. D. Rizzi: Iz archiva N.A. Turgenevoj. a.a.O.. S. 301).

Allerdings war es nicht nur Êllis, der von Steiner und der besonderen Ausstrahlung seiner Person begeisten war: Die Mehrzahl aller, die Steiner persönlich erlebt haten. fühlte sich unwiderstehlich in seinen Bann gezogen. (Vgl. hierzu z.B. die Memoiren von A. Turgeneva. A. Belyj sowie den Band: Wir erlebten Rudolf Steiner. Erinnerungen seiner Schüler. Stuttgan ${ }^{7} 1988$.)

90 Brief an M.I. Sizova vom Jan.-Febr. 1912. РГАЛИ. Ф. 575. on. 1. en.xp. 20. Blatt 1.34.

91 РО РГБ. Ф. 167. карт. 7. ед.xp. 32. Später jedoch. in Berlin. entzweite sich Elllis mit M. VoloSina.

92 РГАЛИ. Ф. 575. on. 1. ед.xp. 20. Blatt 79f., 111-114, $116 \mathrm{f}$.

93 In "Mein Lebensgang" (Domach/Schweiz ${ }^{8} 1982$. Ende von Kap. 33. S. 325f.) äubert sich R. Steiner folgendermaßen zu diesem Thema: "Ich schildere dem Stile nach nicht so, daB man in den Sätzen mein subjektives Gefühlsleben verspürt. Ich dämpfe im Niederschreiben. was aus Wärme und tiefer Empfindung heraus ist. zu trockener, mathematischer Stilweise. Aber dieser Stil kann allein ein Aufwecker sein. denn der Leser muB Wärme und Empfindung in sich selbst erwachen lassen. Er kann diese nicht in gedämpfter Besonnenheit einfach aus dem Darsteller in sich hinüberflieBen lassen." 
inm Ėllis alles, was er in dieser Zeit schrieb und übersetzte. Metner jedoch war nicht bereit, Steiner und der Anthroposophie eine Sonderstellung einzuräumen und riet Ellis wiederholt, ihm nur rein literarische und literaturkritische Arbeiten zu überlas$\operatorname{sen}^{94}$. Immer wieder beklagte sich Ellis in seinen Briefen an M.I. Sizova und Metner über die Verzögerungen und UnregelmäBigkeiten bei der Auszahlung seines Honorars, die allerdings teilweise durch Ellis' häufigen Wohnortswechsel (zunächst reiste er Steiner überall hin nach) verursacht wurden. Viele seiner Briefe sind verzweifelt: Ellis fühlt sich einsam und verlassen, krank. ohne Geld etc. 95

In den Herbst- und Wintermonaten in Berlin stand Ellis bereits in engem Kontakt zu Steiner, führte häufig private Gespräche mit ihm und gab sich so intensiv Steiners Meditationsübungen hin, daB diese bei ihm heftige Anfälle, Herzattacken und nächtliche Alpträume auslösten ${ }^{96}$. Steiner wandte Ëllis besondere Aufmerksamkeit zu, kümmerte sich intensiv und mit großer Geduld um ihn, versuchte, sein ungestümes und impulsives Temperament zu bremsen und gewährte ihm auch finanzielle Hilfe ${ }^{97}$. Zudem beauftragte er eine seiner Schülerinnen, Johanna Polmann-Mooy, sich Ėllis' anzunehmen ${ }^{98}$. Doch Ellis' Extremismus und Eifer waren kaum zu bremsen und steigerten sich in beunnhigender Weise.

Ende Dezember oder Anfang Januar 1912 kam M.I. Sizova aus Moskau zu Ėllis nach Berlin und lemte dort Steiner und etliche von Ëllis' Bekannten kennen. Nach ihrer Abreise Ende Januar verfiel Ėllis in depressive Stimmung. seine nächtlichen Herzanfalle wiederholten sich, und er fühlte sich von "Musaget" und seinen Moskauer Freunden verlassen. Während Steiner im Januar und Februar zahlreiche Vortragsreisen durchführe und nur für kürzere Zeit in Berlin weilte ${ }^{99}$, kümmerte sich Ellis um einen blinden Juden und ein krankes Mädchen und bemühte sich, die Teilnahme möglichst vieler Russen aus Moskau und Petersburg an Steiners geplantem Vortragskurs in Helsingfors zu ermöglichen und zu organisieren 100.

94 PO РГБ, Ф. 167. карт. 6. en.xp. 20f.

95 Z.В. РГАЛИ. Ф. 575. ๓п. 1, ед.хр. 20, Вlatt 79, 87, 128. 141f.: РО РГБ. Ф. 167, харт. 7. ед.хр. 54-58,67.

In Berlin (2. (ktoberhälfte bis Jahresende 1911) nahm Ellis eifrig sowohl an den "Berliner öffenthchen Vortügen" teil. die teils im Architektenhaus, teils in der Philharmonie stattfanden (darunter am 19. Okt. "Der Mensch in seinem Verhältnis zu den übersinnlichen Welten", am 26. Okt. "Tod und Unsterblichkeit im Lichte der Geisteswissenschaft", am 9. Nov. "Der Sinn des Prophetentums". am 16. Nov. "Von Paracelsus zu Goethe", am 23. Nov. "Die verborgenen Tiefen des Seelenlebens", am 7. Dez. "Das Glück, sein Wesen und sein Schein"). als auch an den Vorrägen und Vortragszyklen für Mitglieder (Vortuäge über die Weltevolution vom Gesichtspunkt der inneren Erfahrung. über das Wesen Bodhisattvas. Buddhas, über Jeshu ben Pandira und über Christus). (Vgl. G. Wachsmuth: R. Steiners Erdenieben, a.a.O.. S. 184: Chr. Lindenberg: R. Steiner. Eine Chronik. a.a.O., S. 309f.) Am 10. De zember fand die "Generalversammlung der Theosophischen Gesellschaft" statt, anschlieBend ein Vortragskurs über "Pneumatosophie". Zum Jahresende (27. Dez. 1911 - 1. Jan. 1912) erlebte Ëllis in Hannover den Vortragszyklus über "Die Welt der Sinne und die Welt des Geistes" mit. (Vgl. G. Wachsmuth: R. Steiners Erdenleben. a.a.O., S. 184-187; Chr. Lindenberg: R. Steiner. Eine Chronik. a.a.O., S. 310-312.)

96 РГАЛИ. Ф. 575. on. 1. ед.xp. 20. Blatt 136-138.

$97 \mathrm{Vgl}$. A. Belyj: Verwandeln des Lebens. a.a.O.. S. 72

$98 \mathrm{Vgl}$. A. Belyj: Vospominanija o Štejnere, a.a.O., S. 49-51, 143; M. Woloschin: Die grüne Schlange, a.a.O., S. 235-237. 239; V. Fedjuschin: RuBlands Sehnsucht, a.a.O., S. 189-191 sowie D. Rizzi: Ellis i Štejner, a.a.O., S. 288. Ėllis selber äußen sich ausführlich über J. Polmann-Mooy in seinem Brief an N.A. Turgeneva vom September 1912, vgl. D. Rizzi: Iz archiva N.A. Turgenevoj, a.a.O., S. $307 f ., 310$.

${ }^{99}$ G. Wachsmuth: R. Steiners Erdenleben. a.a.O., S. 190-192; Chr. Lindenberg: R. Steiner. Eine Chronik. a.a.O., S. 314-316.

100 РГАЛИ. Ф. 575, ол. 1. ед.xp. 20. Blatt 140-143, 145, 147f., $150 f . .163$. 
Die erste Vortragsreihe Steiners in Helsingfors vom 3.-14. April 1912 über "Die geistigen Wesenheiten in den Himmelskörpern und Naturreichen" wurde tatsächlich ein wichtiges Ereignis für die Verbreitung der Anthroposophie in RuBland (wie auch der zweite Vortragskurs in Helsingfors im Juni 1913). Für die vielen Russen, die daran teilnahmen. hielt Steiner am 11. April 1912 eine besondere Ansprache über die Aufgaben der russischen Volksseele ${ }^{101}$, in der er auf die Entwicklung der Theosophie der letzten Jahre und die Persönlichkeit der Blavackaja einging. Beim Okkultismus müsse immer das allgemeinmenschliche Interesse im Vordergrund stehen; niemals dürfe ein spezielles Interesse überwiegen. Das Charakteristische der russischen Volksseele sieht Steiner in ihrer Sehnsucht nach dem Geist, der in der Theosophie zum Ausdruck kommt. Das russische Volk trage eine große Verantwortung. Es sei dazu prädestinier, den Geist zu "durchseelen". Dabei dürfe sich RuBland weder vom europäischen Westen noch von der spirituellen Kultur des asiatischen Ostens beeinflussen oder gar manipulieren lassen, sondem müsse verantwortungsbewuBt seine Pflichten gegenüber der eigenen Volksseele erfüllen, seine Eigenständigkeit bewahren ${ }^{102}$.

Mit fast allen anwesenden Russen führte Steiner in Helsingfors Einzelgespräche und nahm in der Nacht vom 6. zum 7. April an einem russisch-orthodoxen Ostergot tesdienst und anschlieBend am Ostermahl der russischen Besucher des Kurses teil 103 . Ellis beteiligte sich aktiv und begeistert an all diesen Ereignissen ${ }^{104}$, erlebte dort aber zugleich eine große Enttäuschung: M.l. Sizova, die er jahrelang als seine "Beatrice" und "geistige Schwester" verehrt hatte, war als Braut von V.M. Vikent'ev mit diesem nach Helsingfors gekommen ${ }^{105}$. Das führte zu einem jähen Ende von Ėllis' Briefen an die Sizova.

AnschlieBend kehrte Ëllis nach Berlin zurück.

A. Belyj und Asja Turgeneva waren mittlerweile nach Belgien gereist, wo Ellis sie Mitte Mai einige Tage in Brüssel besuchte ${ }^{106}$. Sie hatten Steiner erstmals Anfang Mai in Köln erlebt ${ }^{107}$ und wurden in der Folgezeit zu begeisterten Verehrem und Anhängem Steiners, hörten seine Vorträge und halfen beim Bau des ersten Goetheanums in Domach mit 108.

Wie den Ortsangaben auf seinen Briefen an Ė.K. Metner zu entnehmen ist, folgte Ellis im Frühjahr und Sommer 1912 im wesentlichen der Reiseroute Steiners ${ }^{109}$. Den Sommer verbrachte er in Pöcking bei München 110. In der zweiten Septemberhälfte

101 Chr. Lindenberg: Rudolf Steiner. Eine Chronik, a.a.O.. S. 317.

Steiners Ansprache ist abgedruckt in: R. Steiner: Der Zusammenhang des Menschen mit der elementarischen Welt. Domach/Schweiz 1968. S. 193-207.

102 Zur besonderen Mission, die Steiner RuBland in seiner Konzeption der Kulturentwicklung zuwies, vgl. auch R.v. Maydell: Dornach als Pilgerstätte der nussischen Anthroposophen. a.a.O.. S. 296.

103 Vgl. Chr. Lindenberg: Rudolf Steiner. Eine Chronik. a.a.O., S. 317: V. Fedjuschin: RuBlands Sehnsucht, a.a.O.. S. 103f.: M. Woloschin: Die grüne Schlange, a.a.O., S. $239 f$.

104 РО РГБ. Ф. 167. карт. 7. ед.xp. 59.

I05 Vgl. M. Woloschin: Die grüne Schlange, a.a.O.. S. 239: РО РГБ. Ф. 167, карт. 7, ел.xp. 66: Brief an Metner vom 21. Juli 1912.

I06 Vgl. A. Turgenieff: Erinnerungen an Rudolf Steiner, a.a.O., S. 23f.: Brief an Metner vom 15.5.1912: РО РГБ. Ф. 167, карт. 7. ел.хр. 60.

$107 \mathrm{Vgl}$. A. Turgenieff: Erinnerungen an R. Steiner, a.a.O.. S. 15, 18-23.

$108 \mathrm{Vgl}$. A. Turgenieff: Erinnenungen an Rudolf Steiner, a.a.O.: A. Belyj: Vospominanija o Štejnere. a.a.O.

109 Vom 2.-12. Juni 1912 hörte er Steiners Vortragszyklus "Der Mensch im Lichte von Okkuhismus. Theosophie und Philosophie" in Kristiania. (PО РГБ. Ф. 167, карт. 7, en.xp. 61f.).

110 Ebd., en.xp. 65-69.

Auch Steiner hielt sich vom 29. Juni - 7. September 1912 in München auf. Im August erlebte Éllis in München die Auffühnungen der ersten drei Mysteriendramen Steiners ("Die Pforte der Einweihung - 
folgte er Steiner nach Basel'11. AnschlieBend zog er nach Degerloch bei Stuttgart, wo er - mit kurzen Unterbrechungen - bis zum Frühjahr 1913 lebte.

Ellis machte in der zweiten Jahreshälfte 1912 eine besondere Krise durch und begann, an der Theosophie bzw. Anthroposophie 112 zu zweifeln. Dies drückt sich deutlich in seinen Briefen an Metner aus 113. RuBland brauche zwar Steiner als Führerpersönlichkeit, aber nicht seine Theosophie, die er speziell für Deutschland geschaffen habe 114 . Von Deutschland und den Deutschen ist Ellis nun enttäuscht 115 und klammert sich verzweifelt an Steiner, dessen intimer Schüler er werden will. Er schrieb ganze Hefte voll mit Fragen, die sich auf die verborgensten Erkenntnisse bezogen, und Steiner schrieb eigenhändig die Antworten daneben ${ }^{116}$. Er lebte relativ zurückgezogen, führte nur hin und wieder Gespräche mit Steiner, der auch skeptischer geworden sei ${ }^{117}$, und äuBerte sich in einem Brief an Metner folgendermaBen über ihn:

Тайна и трагедня личности St-r'a безпримерны.

OH- непонятый сверX-человек!

Я согласен. что реализация Его импульса. как теософская культура - не удалась. что символизм тоньше и музыкальнее, но самый impuls - незаменим. единствен. без него зальхал бы и символизм. ставши стилизацией, культура - музеем. Он - не матерналист. н60 все по Eго ученню сводится к Ur-geist'y. Опнахо метод Eго в "g.(eheim/wissenschafi" напоминает метол позитивистов-материалистов и опасен для нанвных пуш. Вндите, как всё здесь сложн!! 18

In dieser Zeit der aufkommenden und zunehmenden Zweifel an der Anthroposophie werden Ėllis' anhaltende Verehnung des Mittelalters und seine Liebe zu Dante immer stärker. In Briefen an Metner betont er, daB es ohne Madonnenkult keine Kultur gäbe.

Ein Rosenkreuzermysterium", "Die Prüfung der Seele" und "Der Hüter der Schwelle"). hörte Dr. Carl Ungers Vorträge und Steiners Vortragskurs "Von der Initiation - von Ewigkeit und Augenblick - von (ieisteslicht und Lebensdunkel" (25.-31. Aug.); zudem war Ėllis in München Zeuge des schwerwiegenden Entscheidungsprozesses von Steiner, der am Jahresende zur Trennung von der Theosophischen Gesellschaft und zur Gründung der "Anthroposophischen Gesellschaft" führte (vgl. G. Wachsmuth: R. Steiners Erdenleben, a.a.O.. S. 195-198: Chr. Lindenberg: R. Steiner. Eine Chronik. a.a.O., S. 318-320). Steiners Mysteriendramen beeindruckten Ėllis so sehr, daB er sie ins Russische übersetzen und im "Musaget"-Verlag publizieren wollte (PO РГБ. Ф. 167. карт. 7. ед.xp. 68). In dieser Zeit schrieb Ëllis seine "Мюнхенские письма" ("Münchner Briefe", veröffentlicht in der Zeitschrift "Tруды и лни", 1912. Nr. 4-5. S. 46-50 und Nr. 6. S. 49-62), in denen er versucht. Symbolismus und Okkultismus in Verbindung zu bringen (vgl. ebd., 1912. Nr. 4-5. S. 49f. (Auf diese "Мюнхенские пнсьма" wird im folgenden noch eingegangen werden. l).

111 Dort erlebte er vom 15.-24. September Steiners Vortragszyklus über "Das Markus-Evangelium" mit, in dem Steiner die von ihm vertretene Christusauffassung mil gröBter Eindringlichkeit darstellte. (Vgl. Chr. Lindenberg: Rudolf Steiner. Eine Chronik. a.a.O., S. 320: РО РГБ. Ф. 167. карт. 7. ед.xp. 70-72.)

112 Éllis verwendet diese beiden Begriffe meist synonym und versteht dann darunter Steiners Lehre und nicht die von der Blavackaja begruindete Theosophie im neueren Sinne.

113 PО РГБ. Ф. 167, карт. 7. ед.хр. 74-85.

114 Ebd., ед.xp. 77.

115 In seinem Brief an N.A. Turgeneva vom September 1912 nennt er alle Deutschen "Atheisten" und "Idioten" und betont, dab er nur noch mit Russen und Holländern spreche. (Vgl. D. Rizzi: Iz archiva N.A. Turgenevoj, a.a.O., S. 307f.)

$116 \mathrm{Vgl}$. A. Turgenieff: Erinnerungen an R. Steiner, a.a.O., S. 31.

Ob diese Hefte heute noch existieren und wo sie sich befinden. konnte von mir noch nicht geklär werden: eventuell sind sie in der Rudolf Steiner-Nachlabverwaltung in Domach archiviert. (Von dort bekam ich jedoch keine eindeutige Antwont.)

117 So Ellis Ende 1912 an Metner (PO PГБ. Ф. 167. xapt. 7. eд.xp. 85).

118 Ebd., ed.xp. 79. Rückseite Blatt 12 - Blatt 13. 
daB er die Wiedergeburt des Rittertums erwarte und von Mona Lisa träume ${ }^{119}$. Steiner selbst hat jedoch niemals Vergangenes wiedererwecken wollen, sondern war bestrebt, der Menschheit auf allen Gebieten neue Impulse zu geben. Diese Differenz zwischen Steiner und Ėllis kündigt an. daB sich ihre Wege in absehbarer Zeit trennen werden.

Steiner hielt zu dieser Zeit in Berlin Vorträge über das Leben zwischen Tod und neuer Geburt, über die Aufgaben der Geistesforschung für Gegenwan und Zukunft und über die Wege der übersinnlichen Erkenntnis. Auch bei seinem Vortragskurs in München Ende November, den Ėllis besuchte, sprach er über diese Themen. Ėllis war insgesamt enttäuscht von der Anthroposophie und dem Okkultismus. Er schrieb an Metner, daB er sich in Zukunft ablehnend über sie äuBern werde und "60 Prozent" 120 von dem, was Steiner tue, nicht akzeptiere'121.

Den Jahreswechsel 1912/1913 verbrachte Ėllis bei Steiner in Köln 122 und hatte dort ein längeres Gespräch mit ihm, über das er Metner folgendermaßen berichtet:

В Кёльне я имел продолжительную и бурную аудиенцию у Д-ра. на к-рой я безпошадно формулировал ему все свон contra теософии. отрицая 2 Haupt-punkt'a

1) возможность оккультизма для толпы

2) невозможность пвижения без иерархизма $[\ldots]^{123}$

Steiner habe aufmerksam zugehört und davon gesprochen, daB die Hierarchie erst in der fernen Zukunft geschaffen werde und erst im Verlaufe der Jahrhunderte eine bewuBte Religion in der Menschheit entstehen werde. So tief und gerechtfertigt Steiners Antworten auch sein mögen, innerhalb von "Musaget" dürfe nicht von Okkultismus und Magie die Rede sein. Jeder einzelne könne meditieren und an theosophischen Kreisen teilnehmen, aber "Musaget" werde innerhalb der strengen Grenzen der symbolistischen Kultur bleiben. Innerlich werde Ėllis jedoch stets mit dem Okkultismus verbunden bleiben 124 .

Im Laufe des Jahres 1913 wandte sich Ėllis zunächst von der Anthroposophie. später auch von Steiner ab.

Enttäuscht äußene sich Ellis gegenüber Metner über die neugegründete Anthroposophische Gesellschaft, die nicht besser als die Theosophische sei. Er wollte aber als intimer Schüler Steiners unter dessen Führung einen individuellen Weg gehen. Die Anthroposophie sei für den Westen bestimmt; Ellis' Weg jedoch sei der östliche ${ }^{125}$.

Asja Turgeneva berichtet in ihren "Erinnerungen", daB Ėllis zu Beginn des Jahres 1913 aus der Anthroposophischen Gesellschaft austrat. In einem Brief an sie und Belyj habe er seine Vorwürfe gegenüber der Anthroposophie formulien und hervorgehoben, daB er sich nun in den Schutz der heiligen Jungfrau und der katholischen Kirche begebe. A. Turgeneva und Belyj, die Ellis' extremen Charakter kannten, fuhren auf diesen Brief hin nach Stuttgart, um die Hefte mit Ėllis' Fragen und Steiners

${ }^{119}$ Ebd., en.xp. 77 und 79.

120 Diese Angabe ist ein typisches Beispiel für Ėllis' Hang zur Kategorisierung!

121 Brief vom 26. Nov. 1912. РО РГБ. Ф. 167. карт. 7. ед.xp. 81.

122 In Köln hielt Steiner vom 28.12.1912 bis 1.1.1913 den Vortragszyklus "Die Bhagavatgita und die Paulusbriefe": vor Beginn dieses Vortragskurses gründete er am 28.12. ohne besondere Feierfichkeit die bereits im September beschlossene "Anthroposophische Gesellschaft", indem die etwa 300 Anwesenden. unter ihnen Ëllis, in die Gesellschaft aufgenommen wurden. (Vgl. G. Wachsmuth: R. Steiners Erdenleben, a.a.O., S. 203: Chr. Lindenberg: R. Sieiner. Eine Chronik, a.a.O., S. 324f.)

123 Brief an Metner vom 13. Jan. 1913, РО РГБ. Ф. 167. кapr. 8. en.xp. 1.

Ellis' autoritärer Charakter tritt hier wieder deutlich hervor, wenn er der Theosophie Hierarchie losigkeit vorwirft und eine Bewegung mit Hierarchie fordert!

124 Ebd.

125 Brief an Metner vom 13. März 1913, ebd.. eд.xp. 3. 
Antworten zu holen, ehe Ėllis in seiner unreflektierten Enttäuschung und Verzweiflung MiBbrauch mit ihnen treiben konnte. Ëllis empfing seine Besucher nicht, sondem warf ihnen die Hefte durch einen Türspalt zu'126. Daraufhin fand die langjährige Freundschaft zwischen Belyj und Ëllis ein Ende ${ }^{127}$.

Im April wurde Ëllis mit der Familie, bei der er in Degerloch lebte, für einen Monat nach Italien eingeladen: Rom, Neapel, Capri. In seinen Briefen an Metner aus Italien betont Ėllis seine zunehmende Hingezogenheit zu "Musaget" und seine endgültige Entfernung von der Anthroposophischen Gesellschaft, die er nun radikal ablehnt. Er nähert sich Metners Position an: man müsse sich für den Erhalt der Kultur einsetzen ${ }^{128}$. Weder Theosophie noch Anthroposophie könne zur Volksbewegung werden, da sie ihrem Wesen nach für Bourgeoisie und Salons geschaffen seien ${ }^{129}$. Es gäbe keine strenge okkulte Schule bei Steiner, er habe 2000 Schüler, davon seien 1900 "Tanten"130 und unter ihnen 1500 "Hexen"131. Diese Art der ÄuBerung, die schwerlich emst genommen werden kann, zeigt deutlich das Subjektive und Emotionale von Ellis' Unteil und spiegelt seine innere Krise wider.

DaB ein neuer "Umschwung" in Ėllis' Leben stattgefunden hat, geht deutlich aus seinem Brief an Metner aus Königswinter hervor ${ }^{132}$, worin er alles ablehnt, was er zuvor bewunden und propagien hat. Er wirf Steiner vor, daB er alles verdrehe, die Menschen "auf den Kopf stelle" und Goethe, Kant, Dante und sogar Parsifal verzern und falsch darstelle. Erst in Assisi, wo Ėllis in der Zwischenzeit war ${ }^{133}$, habe er sich wieder "auf seine Beine gestellt". Seinen Weg zu Steiner beschreibt Ėllis als die alte Gralssuche; anstelle des Grals habe er jedoch ein "jüdisches Aquarium" erreicht. Auch diese konfusen Behauptungen von Ëllis, die jeglicher sachlichen Unteilsgrundlage entbehren, können nicht logisch erklärt werden, sondern müssen als Manifestation eines zur Hysterie neigenden nervenschwachen Menschen verstanden werden, der eine groBe Enttäuschung erlitten hat, einsam und entwurzelt dasteht und erst wieder einen Halt, neue Richtlinien und einen neuen Lebensinhalt finden muB. Ėllis verwirft Steiners Lehre als nicht annehmbar für RuBland. da er Jesus und Christus trenne 134; das russische religiöse SelbstbewuBtsein jedoch basiere auf der Einheit Jesu-Christi ${ }^{135}$.

Ende Juni 1913 kehre Ëllis nach Degerloch zurück, wo er - von wenigen kurzen Unterbrechungen abgesehen ${ }^{136}$ - bis mindestens Februar 1914 lebte ${ }^{137}$. Er hatte sich endgültig von der Anthroposophie abgewandt, begann, sich intensiv und ausschlieB-

$126 \mathrm{Vgl}$. A. Turgenieff: Erinnerungen an Rudolf Steiner, a.a.O., S. 45f.

127 A.V. Lavrov datien dieses Ereignis auf Ende Oktober 1913 (vgl. A.V. Lavrov: Andrej Belyj. Chronologiceskaja kanva žizni i tvořestva. In: A. Belyj: Problemy tvořestva. Moskva 1988, S. 788).

128 "Вообие мое влеченне $\mathrm{x}$ "Мусагету" все растет, растет желанне делать нечто свое. а не только трубить о чужом. ибо в Россин теософия немыслима. оккультизм опасен. а нужна культура. культура и культура". schreibt Ėllis am 25. April 1913 an Metner aus Capri (PO РГБ. Ф. 167. карт. 8. ед.хр. 6).

129 Ebd.

130 So wurden die älteren Damen bezeichnet, die Steiner besonders verehrten. regelmäBig seine Vorträge besuchten und sich für gute Anthroposophinnen hielten.

131 Brief aus Capri vom 16. Mai 1913, ebd.. eд.xp. 10.

132 Brief vom 21. Juni 1913, ebd., ed.xp. 11.

133 Gemeinsam mit J. Poolman-Mooy; vgl. M. Ljunggren: The Russian Mephisto, a.a.O.. S. 94.

134 Eine Darlegung von R. Steiners Christologie. an der dieser jahrelang arbeitete und die er in Hunderten von Vorträgen darlegte, würde den Rahmen der vorliegenden Arbeit sprengen. Hier sei nur darauf verwiesen, daB Steiner immer wieder davon gesprochen hat. wie sich während der Jordantaufe in den Menschen Jesus der göttliche Christus verkörperte. Jesus durch die Taufe zu Christus wurde.

135 PO РГБ. Ф. 167. карт. 8. ед.Xp. 11.

136 Ebd.. ед.xp. 16.

137 Ebd.. ед.xp. 28. 
lich mit dem Mittelalter und dem Katholizismus zu beschäftigen und studiente in Stuttgart in der Bibliothek ausführlich Kirchengeschichte und die Zeit der Kreuzzü$\mathrm{ge}^{138}$.

Da Steiner, wie Ėllis richtig erkennt, jedem Menschen unendliche Freiheit läßt, möchte er - ungeachtet seiner Kritik an dessen Lehre - unter Steiners Führung den "alten christlichen Weg" gehen und sich auf diese Weise immer mehr den Idealen des Mittelalters, Franziskus und Dante annähern. Er hebt wiederholt hervor, daB er die Geschichte nur bis zur Mitte des 14. Jahrhunderts verstehe; deshalb sieht er in der Zukunft eine Rückkehr in neuer Form zu den Idealen des Mönch- und Rittertums.

Ėllis versucht also einerseits. Steiner für sich, seine Ziele und Bestrebungen zu gewinnen, und andererseits ist er in einzelnen Fragen mit Steiner überhaupt nicht einverstanden und betont, daB er bei der Kirche und der alten Tradition bleibe ${ }^{139}$. Er wirft der Theosophie und Anthroposophie mangelnde Kraft des Glaubens vor, ohne die es keine Religion gäbe ${ }^{140}$. Sich selbst bezeichnet er als zerschlagenen, schwachen Menschen, der jedoch vom christlichen Glauben erfüllt sei ${ }^{141}$. Auch Steiner werde von den Theosophen nicht verstanden ${ }^{142}$. Das wahre Christentum sieht Ëllis nur im 13. Jahrhundert bis zur Renaissance und weist wiederholt darauf hin, daB er ein Mensch des 13. Jahrhunderts sei. gemäß den Vermächtnissen des 13. Jahrhunderts lebe, ganz in der Gotik und im Mittelalter. Die ganze Kultur nach dem 13. Jahrhunder (Renaissance, Aufklärung etc.) bezeichnet Ellis im wesentlichen als "Plagiat der Griechen" (er meint damit die Wiedergeburt der klassischen (heidnischen) Antike zur Zeit der Renaissance). Das gegenwärtige Deutschland stehe bedauerlicherweise vor dem Zerfall ${ }^{143}$.

Im Sommer 1913 schrieb Ėllis seinen Traktat "Vigilemus!", in dem er Religion, Kultur und Symbolismus gegen alle modern-theosophischen Strömungen verteidigte ${ }^{144}$. AnläBlich dieses Traktats kam es im Herbst 1913 zum Streit und in der Folge zum endgültigen Bruch zwischen Belyj auf der einen und "Musaget". Metner und

138 Bricf an Metner vom 27. Juni 1913, ebd. . ex.xp. 12.

139 Damu meint Ëllis den Katholızısmus und die tradıuonellen Wene des mittelalterlıchen Rıttenums.

141) Da Ëllis vom dogmatischen Glaubensideal des mittelalterlichen Katholizismus ausgeht und daran festhält. muB er verständlicherweise die Anthroposophie, die als modeme Weltanschauung vielmehr vom Bew'ußtsein ausgeht. als antikirchlich auffassen und kann somit die Ausführungen Steiners über Christentum und Religiosität nicht akzeptieren. Steiner war jedoch stets bemüht darauf hinzuweisen. daB verschiedene Zeiten und Welträume unterschiedliche Anschauungen benötigen, wodurch die einzelnen Weltreligionen in ihren verschiedenen Stadien und Entwicklungssitufen erklärt und gerechtfertigt werden konnen.

141 Brief an Metner vom 25. Juli 1913. PO РГБ. Ф. 167. xaps 8. en.xp. 13.

142 Ellis steht somit in zwei Widersprüchen: Er erkennt Steiner als geistige Autorität an und stellt sich dann wieder über ihn und verurteilt ihn. Das Christentum ist für ihn das Zentrale, und die Anthroposophie entspräche dem nicht: und doch scheint er beides zum Teil verbinden zu wollen.

$1 / 3$ Briefe an Metner vom 15. August und 1. September 1913. PO PГБ. $\Phi$. 167. карт. 8. en.xp. $14 f$.

Um diese wirren Ausfuihrungen nachvollziehen zu können, muB kurz verdeutlicht werden, was das Spezifische des Mittelalters bis zum Ende des 13./Anfang des 14. Jahrhunderts fur Ėllis bedeutet: In Übereinstimmung mit dem romantischen Mittelalterverständnis betrachtet Ëllis das 13. Jahrhunden als Idealzeit der gläubigen ritterlichen Gesellschaft des christlichen Abendlandes. Die überragende Rolle des Papsttums und die Idee der Einheit der Christenheit sind dabei von besonderer Wichtigkeit. In Kunst. l.iteratur und Wissenschaft herrschte eine gläubige Geisteshaltung. Die katholische Kirche war bemüht. die Glaubens- und Kultureinheit zu bewahren, die gemeinsame lateinische Kultur- und Bildungssprache zu ertalten. was zu einem recht einheitlichen Weltbild führe. Es wurden Kreuzzüge zur Festigung. Ausbreitung oder Wiederherstellung des katholischen Glaubens durchgefühn. Ellis klammen sich an dieses Mittelalterbild. Die russisch-orthodoxe Tradition (Byzanz. Kiever Rus') läBt er unbeachtet. (Im 13. Jahrhundert eroberten die Tataren die Hauptstadt Kiev und unterwarfen die Rus:)

144 Brief an Metner vom 16 29. Sept. 1913. РО РГБ. $\Phi$. 167. кapr. 8. en.xp. 17. 
Ėllis auf der anderen Seite. Belyj fühlte sich hintergangen; durch Ėllis' Traktat sah er Steiner und die Anthroposophie beschimpft, geschmäht und verraten und folglich versuchte er, die Publikation von "Vigilemus!" zumindest bei "Musaget" zu unterbinden. Metner hingegen sah in "Vigilemus!" keinen "antianthroposophischen Fanatismus", sondern einen "romantischen Ultramontanismus" ("романтическое ультрамонтанство") und fühlte sich nicht verpflichtet, den Druck dieses Werks zu verhindem 145

Gegen Ende des Jahres 1913 wandte sich Ëllis nun auch ganz von Steiner ab, dem er, wie zuvor der Anthroposophie, eine antichristliche Haltung vorwarf ${ }^{146}$. Er hob in diesem Zusammenhang hervor, daB er in Degerloch bei seinen Freunden und Gleichgesinnten wohne, wenig Ausgaben habe und nach dem mittelalterlichen Ideal der Askese und Armut strebe und begann, Steiner zu kritisieren: Statt Rittertum, dessen Vermächtnisse er vergessen habe, habe Steiner die Anthroposophie geschaffen, die Ellis "полу-религия, полу-мистерия, полу-масонство, полу-наука" nennt ${ }^{147}$.

In der zweiten Hälfte 1913 machte Ëllis also eine große Krise durch; er fühlte sich krank und elend. Zu Beginn des Jahres 1914 hatte er diese Phase dann überwunden. wie zwei lange Briefe an Metner vom 3. Febr. 1914 zeigen ${ }^{148}$, in denen sich in der ihm eigenen abstrusen, konfusen Art in zusammengefaBter Form seine Kritik an der Anthroposophie und an Steiner sowie Pläne für seine zukünftigen Aktivitäten und Beschäftigungen finden:

Der Symbolismus habe eine schicksalhafte Krise zu Beginn des 20. Jahrhunderts eingeleitet. Nun sei die Epoche der Vorahnungen zuende und eine neue Ära der Kreuzwege/Scheidewege ( эра neperrytй̆), der Suche nach einer Glaubenslehre (nскание допмата) habe begonnen ${ }^{149}$. Jetzt müsse man zur echten Religion zurückkehren, die alten Werte der europäischen Kultur bewahren (vor allem die altgermanische) und RuBland "erziehen"150. Ellis liest die Schriften des Thomas von Aquin und betont, daB das Mittelalter und Vl. Solov'ev jetzt die einzige Rettung vor den Verzemungen und Entstellungen der traditionellen kulturellen Werte durch den zeitgenössischen Okkultismus, die Theosophie und die Anthroposophie seien. Man dürfe die alten Traditionen nicht vergessen, müsse an Führer glauben. Außerhalb der Kirche gäbe es keine Zukunft für das Christentum; die wesentlichen Dogmen seien nicht ins Wanken geraten. In den gegenwäntigen "tempora pessima" müsse man gemeinsam gegen den Modernismus, gegen die verschworene "Anthroposophische Gesellschaft" kämpfen, die von Juden (sic!) durchdrungen sei. Deutschland hatte zwar das Recht, dem Papst tum einen Schlag zu versetzen ${ }^{151}$, habe aber nichts Drittes, Neues geschaffen; nun beginne es, wiedergeboren zu werden. Steiner habe das Christentum und den Gral verfalscht ${ }^{152}$. Seine Lehre sei ketzerisch und antichristlich; er sei der wiederverkör-

145 Zum "Vigilemus!"-Streit: Ėllis' Briefe an Metner vom Oktober bis Dezember 1913, ebd., eд.xp. 20-24, das Telegramm vom 10. Okt. 1913, РО РГБ, Ф. 167, карт. 9. eд.xp. 8 sowie Metners Dossier über "Vigilemus!" vom Dezember 1913, ebd., eд.xp. 11; vgl. auch M. Ljunggren: The Russian Mephisto, a.a.O., S. 69-71, 94. (Auf den Inhalt von "Vigilemus!" wird im folgenden Kapitel der vortiegenden Arbeit eingegangen werden.)

146 Briefe an Metner vom 27. und 29. Dezember 1913, РО РГБ. $\Phi$. 167. xapr. 8. eд.xp. $23 f$.

147 Brief an Metner 1913, ebd., eд.xp. 25.

148 Ebd., eд.xp. $27 f$.

149 Ebd., eд.xp. 28, B1. 9 (Rückseite).

150 Ebd., eд.xp. 27.

151 Dieser Gedanke entspricht Dostoevskijs Idee in seinen Ausführungen: "Германскй̆ мuposon̆ вопрос. Германия - страна протестуюшая" ("Die deutsche Weltfrage. Deutschland - ein protestierendes Land", in: F.M. Dostoevskij: Polnoe sobranie soxinenij v 30-i tt. Tom 25: Dnevnik pisatelja za 1877 god, janvar'-avgust. Leningrad 1983, S. 151-154).

152 РО РГБ. Ф. 167, карт. 8. ед.xp. 28. 
perte Manes und zerstöre das Rittertum; alle Orden, die Kirche etc. seien gegen ihn (auBer Belyj); es werde einen schonungslosen Kampf geben. Ėllis schildert seine Alpträume und Visionen, die er anläBlich Steiners Meditationsübungen hatte und in denen er - laut Steiner - seine früheren Inkarnationen erlebt habe. Er sei vor Steiner und der Anthroposophie nach Assisi geflohen, wo er vor dem Bildnis der Gottesmutter Askese und Kirchentreue gelobt habe. Außerdem habe er sich in die "Exerzitien" des heiligen Ignacio von Loyola veriieft, die ihn gerettet hätten. Verzweifelt habe er die Gottesmutter um Hilfe angerufen und sei durch sie "gesundet". Nun sei er bereit, mit seinem Blute das echte Christentum gegen Magie und Luziferismus zu verteidigen 153. Er legt Metner einen "план борьбы" ("Kampfplan") dar, nämlich wie er, Metner und ihre Mitstreiter Steiner und dessen Lehre widerlegen könnten. Metner soll Goethe verteidigen. Ellis - Dante, Račinskij - VI. Solov'ev, Vjač. Ivanov - Novalis; ein Naturwissenschaftler soll Steiners wissenschaftlich-biologische Theorien kritisieren. Für Kultur und Religion ist für Ėllis nur ein absolutistisches Modell denkbar. Man brauche in der Kunst, wie auch in der Religion, strenge Grenzen, gemeinsame Ziele, einen kompetenten Führer, der die Zielrichtung bestimmt. So ein "absolutistischer Herrscher" (im positiven Sinne) auf dem Gebiet der Religion sei Franz von Assisi innerhalb seines Ordens gewesen. Entsprechend müsse Metner auf dem Gebiet der Kultur die unumschränkte Herrschaft im "Musaget"-Verlag übernehmen und un bedingten Gehorsam fordem. Vor allem in RuBland träten die Vermächtnisse des hi storischen Mittelalters klar zutage, es werde die Linie des 13. Jahrhunderts fortgesetzt ${ }^{154}$.

In diesen wirren und recht subjektiv anmutenden Ausführungen beklagt Ėllis ausführlich A. Belyjs Hinwendung zu Steiner und zur Anthroposophie sowie dessen endgültigen Fortgang aus dem "Musaget"-Kreis. Dabei ignorient er völlig, daß seine eigene Haltung auch nach seiner Abkehr von Steiner keinesfalls mehr den kulturologischen Bestrebungen der Moskauer Symbolistenkreise entspricht und sein Konzept für Kultur und Kunst in Rußland unangemessen und unzeitgemäB ist. Da er selbst jedoch nicht mehr in sein Heimatland zurückkehrte, entfällt in seinem Fall eine direkte Konfrontation mit den realen Gegebenheiten, wie sie etwa $\mathrm{A}$. Belyj während des Ersten Weltkriegs bei seiner Rückkehr aus Dornach erlebte.

Trotz aller Streitigkeiten erschien Ėllis' Traktat "Vigilemus!" 1914 im "Musaget"Verlag. Dieser Traktat stellt jedoch weniger eine "Schmähschrift" ("пасквиль") gegen Steiner dar ${ }^{155}$, sondem zeigt vielmehr, daB Ėllis das Wesen der Anthroposophie nie richtig verstanden hat und im Grunde stets seinen alten Idealen (Mittelalter, Rit tertum. Madonnenkult, Katholizismus) treu geblieben ist. Bei Steiner und in der Anthroposophie suchte er vergebens einen Lehrmeister sowie feste Werte und Normen. an die er bedingungslos glauben und denen er sich gänzlich hingeben konnte (wie etwa den Dogmen der katholischen Kirche); da er dies alles nicht finden konnte. muBte er konsequenterweise Steiner und die Anthroposophie als antichristlich und antireligiös verurteilen.

Der Symbolismus als "wahre Kunst der Zukunft" sollte für Ėllis die verlorengegangene Verbindung von Kunst und Religion wiederherstellen. Er müsse sich in Zukunft weiterentwickeln und in christliche Kunst verwandeln. also mit der Weltan-

153 Ebd., ед.xp. 27.

154 PO РГБ. Ф. 167, карт. 8. ел.xp. 28.

155 So faBte A. Belyj dieses Werk auf und auch A. Turgeneva nennt es "Schmähschrift gegen Rudolf Steiner" (vgl. A. Turgenieff: Erinnerungen an R. Steiner, a.a.O.. S. 46: V. Fedjuschin: RuBlands Sehnsucht. a.a.O.. S. 192). Vgl. hierzu auch D. Rizzi: Ellis i Štejner, a.a.O.. S. 291. 
schauung des 13. Jahrhunderts verschmelzen ${ }^{156}$. Eine derartig eigenwillige Interpretation von Symbolismus hat nichts mehr mit einer literaturwissenschaftlichen Symbolismusdefmition gemein. Sie kann nur durch ein Verdeutlichen der Schwierigkeiten erklärt werden, vor denen die "jüngeren" Symbolisten standen, als sie die Theorie und Poetik des Symbolismus als Weltanschauung zu versprachlichen versuchten 157 .

Neben dem Vorwurf des "Antichristentum" ("антихристианство") und der Antireligiosität wirft Ėllis Steiner wiederholt vor, daB er den Menschen zu viel geistige Freiheit lasse, zu wenig Gehorsam und keine Unterwerfung unter eine "Hierarchie" fordere ${ }^{158}$. Aber die menschliche Freiheit stellt ja gerade einen Wesenszug der Anthroposophie dar ${ }^{159}$. Folglich muBte es zum Bruch zwischen Ėllis und Steiner bzw. der Anthroposophie kommen. Steiner dürfte Ėllis' Problem bezüglich der Freiheit erkannt haben; jedenfalls äuBerte er sich 1917 Asja Turgeneva gegenüber folgendermaBen:

Wir leben in einer Zeit, wo alles getan werden muB, um die Freiheit zu wahren, in einer Zeit, die aber am wenigsten Verständnis und Neigung zur Freiheit hat. Hätte ich eine Peitsche genommen und Ellis gesagt, wie Rasputin es tat: Du Hundesohn, leg dich zu meinen Füßen ... er wäre bis jetzt mein treuester Anhänger geblieben. - Rasputin wirkte direkt auf den Willen. Das darf nicht sein. Das wünschen aber die Menschen. 160

Margarita Vološina gibt in ihren Memoiren eine treffende kurze Zusammenfassung von Ëllis' Auseinandersetzung mit Steiner, die an dieser Stelle zitiert sei:

Rudolf Steiner wandte unendlich viel Zeit und Mühe auf, um diesen aufgeregten Menschen [Ëllis] ins Gleichgewicht zu bringen. Wir aber bekamen von Ellis nur Schimpfbriefe, in denen er uns allen Lauheit gegenüber Rudolf Steiner vorwarf. Das war die erste Phase. Dann kam die zweite. Ellis begann die ganze Anthroposophische Gesellschafi zu hassen und machte Rudolf Steiner den Vorwurf, daB er diese Menschen frei lasse, keinen Gehorsam von ihnen fordere. [...] Allmählich übertrug er seine Empörung aber von den Schülern auf den Lehrer und wurde später einerbitterter Feind der Anthroposophie und Rudolf Steiners. Er kämpfte in seinen Schriften in den Reihen derer, die der Menschheit keine geistige Freiheit gönnen. ${ }^{161}$

Ėllis' Auseinandersetzung mit Steiner und der Anthroposophie ist ein weiteres Beispiel für seinen unsteten Charakter, seine einseitige Begeisterung für eine Sache, in der er sein lang ersehntes und gesuchtes Lebensziel gefunden zu haben meint, die dann aber abrupt in Enttäuschung und Abkehr umschlagen kann oder sogar muB, wenn er erkennt, daB er sich getäuscht hat. Ėllis, ein Mensch der Extreme, kennt keine Kompromisse; für ihn gibt es nur entweder schwärmerische Begeisterung und Verehrung oder radikale Ablehnung und Verdammung; was er nicht mehr akzeptien. wird total verworfen. Diesem Extremismus fallen auch die Anthroposophie und Steiner zum Opfer. Weder sie noch der zeitgenössische Symbolismus in RuBland konnten seinem rastlosen, unsteten Leben eine Stütze, einen Halt oder die gesuchte absolute Führerpersönlichkeit bieten. Die neugewonnene Freiheit in Kunst, Literatur und Philosophie überforderte Ėllis. Enttäuscht wandte er sich also endgültig von allen zeitgenössischen modemistischen Strömungen und Bewegungen ab und ausschlieBlich der von ihm stets verehrten, alten Tradition, dem Katholizismus und Mittelalterkult zu.

$156 \mathrm{Vgl}$. V. Fedjuschin: RuBlands Sehnsucht, a.a.O., S. 196.

$157 \mathrm{Vgl}$. etwa den "Symbolistenstreit" von 1909/1910.

158 Vgl. M. Woloschin: Die grüne Schlange, a.a.O., S. 236f. "Hepapxuзм" ("Hierarchie") ist ein regelrechtes Schlagwort bei Ëllis.

$159 \mathrm{Vgl}$. oben, S. 121.

160 A. Turgenieff: Erinnerungen an R. Steiner, a.a.O., S. $86 f$.

161 M. Woloschin: Die grüre Schlange, a.a.O., S. $236 f$. 
Selbst wenn Ėllis das Wesen der Anthroposophie vielleicht nie richtig verstanden hat, hat er doch durch seine Beschäftigung mit ihr und seine zeitweise heftige Begeisterung für Steiner eine wichtige Rolle bei der Vermittlung dieser Lehre nach RuBland gespielt. Wenn es ihm auch nicht gelang, den "Musaget"-Verlag für Steiner und dessen Werk zu gewinnen, so hat er immerhin maBgeblich dazu beigetragen, daB sich die Literaten, Philosophen und Künstler in den Kreisen um "Musaget" kritisch mit dieser Lehre und den Werken Steiners auseinandersetzten. Falls eine "Geschichte der Esoterik in RuBland zu Beginn dieses Jahrhunderts" geschrieben wird, wird Ëllis als Vermittler von Theosophie und Anthroposophie darin möglicherweise eine größere Rolle spielen als innerhalb der Geschichte des russischen Symbolismus ${ }^{162}$.

\section{3) Ellis' Beiträge in "Tруды и дни"}

Ėllis' in den Jahren 1911 bis 1913 in Deutschland entstandene Arbeiten, die in "Tpyды и дни" publiziert wurden, sind nur ein Teil dessen, was er in dieser Zeit geschrie ben hat. Er schickte viel mehr Material an den "Musaget"-Verlag als tatsächlich in "Труды и дни" publiziert wurde 163 .

Seine dort veröffentlichten Beiträge lassen sich gliedern in Arbeiten zum Symbolismus $^{164}$, zu R. Wagner ${ }^{165}$ und zu Dante ${ }^{166}$.

\section{a) Beiträge zum Thema Symbolismus}

In seinen drei "Münchner Briefen" versucht Ėllis, den Symbolismus als längst legitimierte Strömung zu affirmieren und sein Fortbestehen auch in der gegenwärtigen Zeit zu garantieren.

Im ersten "Münchner Brief" mit dem Titel "Умер ли символизм?" ("Ist der Symbolismus gestorben?") 167 betont Ëllis die Nähe zwischen dem religiösen Symbolismus und dem zeitgenössischen deutschen "wissenschaftlichen Okkultismus". Goethe, Wagner und Nietzsche hätten die geistigen Grundlagen für diesen "Okkultismus" geschaffen ${ }^{168}$. Ėllis zeigt auf, daB man den Symbolismus isolien ohne "Okkultismus" nicht

$162 \mathrm{Vgl}$. hierzu auch D. Rizzi: Ëllis i Štejner, a.a.O.. S. 281.

163 Bei diesen Materialien handelt es sich hauptsächlich um Ëllis' Beschäftigung mit R. Wagner (Übersetzungsentwürfe der Musikdramen, Skizzen für theoretische Abhandlungen über Wagner), mit Okkultismus und Symbolismus, mit R. Steiner und dessen L.ehre. mit L.ermontov, sowie um Gedichte. die nicht in den L.yrikband "Apro" aufgenommen wurden. Die unveröffentlichten Manuskripte und Entwürfe befinden sich heute teilweise in der Handschriftenabteilung der Russischen Staatsbibliothek (PO) РГБ) und einige auch im РГАЛИ (vgl. unten. "Materialien von/über Ellis aus Moskauer Archi ven").

164 "Мюнхенские письма" ("Münchner Briefe", in "Труды и дни", 1912, Nr. 4-5 und Nr.6) und der Aufsatz "О залачах и целях служення культуре" ("Über Aufgaben und Ziele des Dienstes an der Kultur", in "Труљы и дни". 1912, Nr. 4-5).

165 " „Ilарсифаль» P. Barнера" ("Richard Wagners «Parsifal»", in "Труыы и лни. 1913).

166 "Учитель веры" ("Der Lehrer des Glaubens", in "Труды и лни", 1914).

167 Трупы н днк. Nr. 4-5, 1912, S. 46-50.

168 Was Ëllis in diesem "Münchner Brief" unter "современный немецкяй жнаучный оккультизм»" ("moderner deutscher «wissenschaftlicher (Okkultismus") versteht, definien er nicht genauer. Es läBt sich aber $\mathbf{z w i s c h e n ~ d e n ~ Z e i l e n ~ d e u t l i c h ~ h e r a u s l e s e n . ~ d a B ~ e r ~ d a m i t ~ d i e ~ l e h r e ~ R u d o l f ~ S t e i n e r s , ~ d i e ~}$ Anthroposophie, meint, da die Entstehungszeit dieser "Münchner Briefe" (Sommer 1912) in die Periode von Ëllis' intensiver Auseinandersetzung mit dieser Lehre fält. Da Metner jegliche Art anthroposophischer Propaganda im "Musaget"-Verlag und in der Zeitschrift "Труды и дни" strikt ablehnte. muBte Ėllis versuchen, sich "neutral" auszudrïcken, nicht in der Terminologie Steiners. Aus seinem Briefwechsel 
vollständig begreifen und erfassen könne. Man dürfe Symbolismus und "Okkultismus" nicht als etwas Getrenntes, Widersprüchliches verstehen. Echter Symbolismus strebe nach "Okkultismus"; andererseits tendiere der gegenwärige deutsche "wissenschaftliche Okkultismus" zum Symbolismus:

С одной стороны, искони так назьваемое ксимволическое двикение» в Европе и особенно в Россин было не только течением зстетнческим. философским или научным. С самого начала оно стремилось $\mathrm{x}$ сннтезу всех элементов культуры и даже полу-сознательно прнникло к первонсточнику, т. е. к области. лежащей глубже понятия жкульмураж. [...] С друтой стороны самое существенное и живое течение среди безчисленных выростаюших повсюду шхол и направлений в сфере кокхультизмаш, я говорю преимущественно о современном. немецком жнаучном оккультизие", всеми силами стремится к символике и символизму. ${ }^{169}$

In seinem zweiten "Münchener Brief" mit dem Titel "O грехе забвения, о долге дерзания, о первых «рыцарях символизма» и о религиозном искусстве" ("Von der Sünde des Vergessens, der Pflicht der Kühnheit, von den ersten «Rittem des Symbolismus» und der religiösen Kunst") ${ }^{170}$ spricht Ellis davon, daB der Symbolismus in allen seinen Erscheinungen in Vergessenheit geraten sei. Der Symbolismus sei schnell "aufgeblüht" und ebenso schnell wieder "verwelkt". Das gelte nicht nur für RuBland, sondem auch für Europa (Deutschland, Frankreich, Norwegen etc.). Nach der "Sünde der Selbstvergötterung" habe der Symbolismus die "Sünde des Vergessens" durchlebt 171. Nun müsse man das, was der Symbolismus erschaffen und erreicht habe, wieder aufgreifen und einer Revision unterziehen ${ }^{172}$. Auf euphorisch-exaltierte Weise prognostiziert Ëllis die große Bedeutung der zukünftigen symbolistischen Bewegung:

Движенне наше всегда пребудет новым духовным «крестовым походом», необходима лишь верность последнему симеоку, до сих пор никогда ннхому не изменивиему, до сих пор еше никем и нами - символистами пока еше не обретенному, и мы будем руховодимы свьпие и наша задача булет нсполнена! ${ }^{73}$

Eine derartige Symbolismus-"Definition" dürfte seinerzeit von den traditionellen oder realistisch ausgerichteten Literaturtheoretikem kaum emst genommen worden sein und ruft auch heutzutage Befremden hervor.

Ellis fragt fermer, was die ersten Verfechter des Symbolismus verbinde und führ die bereits aus "Русские символисты" bekannten zwei Antworten an 174:

1. Die äußere Bestimmung des Symbolismus als "Schule, Methode oder Kulturerscheinung" sei nur eine Teilantwort auf die Frage nach dem eigentlichen Wesen des Symbolismus.

Die zweite, für Ėllis maßgebliche Antwort lautet:

Или символизма. как духовного двнженяя sui generis, вовсе не было никогда. нли он всегда был. есть и всегда должен быть глубоким духовным двнжением всей нашей эохи. корни которого лежат глубже всех его художественных. фнлософских и научных обнаружений и обоснований: духовное теченне. лишв частично выразнвиееся в т. наз. новом

mit Metner geht deutlich hervor, daB letzterer die Teile der "Münchner Briefe", in denen es vorwiegend um Anthroposophie geht, nicht publizient hat. (PO PГБ, Ф. 167, xapt. 13, ex.xp. 7, Blatt 77f.: Brief von Metner an Ellis vom 25.4./8.5.1913; Blatt 84: Brief von Metner an Ėllis vom 8./21.5.1913; Blatt 94:

Brief von Metner an Ėllis vom 29.5./11.6.1913.)

169 Труды и дни, Nr. 4-5, 1912, S. 496.

170 Труды и дни. Nr. 6, 1912. S. 49-56.

171 Ebd., S. 50 .

172 Ebd., S. 52.

173 Ebd., S. 53.

$174 \mathrm{Vgl}$. oben. S. $90 \mathrm{f}$. 
искусстве, явилось в своем корне глубоким мистическим пољъемом всей куљьтуры и всей жизни нашей эпохи. знамением наступления нового царства идей и отношений. благодатным низхожденнем светлых духовньх сил из высшего мира в мир человечества! 175

Die Aussage dieses Zitats entspricht der alten Legimitationsstrategie Merežkovskijs. die gesamte (idealistische oder religiöse) Kulturtradition seit der Antike als "symbolistisch" zu bezeichnen 176, was einer unkritischen Identifikation von "symbolistisch = symbolisch" gleichkommt ${ }^{177}$. Entsprechende Symbolismusdefinitionen finden sich auch bei Blok und Vjač. Ivanov zur Zeit des "Symbolistenstreits". Ėllis ist hier also nicht originell, sondern eklektisch; besonders hebt er den religiösen Ursprung der symbolistischen Bewegung hervor. Der emphatische SchluB dieses "Münchner Briefs" entspricht Ėllis' Temperament, legt aber auch nahe. daB er seinen Text wohl als Manifest verstanden wissen wollte:

Да здравствует истияное синволическое искусство, как высшая форма художественного творчества. в своих чувственно-осязательных полуземных и человеческих элементах. преломляющее и низвопящее в наш мир голоса. силы и чувства иного мира. благодать действительных небес, помощь высших духов и свято хранящее в каждом своем трепете. вздохе и дерзания - божественную печаль о высиих мирах. натежлу искупления и радость возврата. которой нет предела. ${ }^{178}$

In seinem dritten "Münchner Brief" mit dem Titel "Символизм и идея символизма. Искусство символическое, религиозное и христианское" ("Symbolismus und die Idee des Symbolismus. Symbolistische, religiöse und christliche Kunst") ${ }^{179}$ faBt Ellis seine vorhergehenden Ausführungen noch einmal zusammen: Er habe versucht, das Bestreben des zeitgenössischen Symbolismus und der symbolistischen Kunst zum "Okkultismus" zu zeigen und zu beweisen, daB das Wesen, die Hauptidee des Symbolismus als ein erlebter gegenwäriger und in die Zukunft gerichteter geistiger Aufschwung, sowohl logisch als auch psychologisch den Glauben an die Realität übersinnlicher Kräfte und die Existenz transzendenter Welten erfordere.

Ëllis unterscheidet zwei Richtungen innerhalb des gegenwärtigen Symbolismus:

1. Die sogenannte Dekadenz (декалентство), die nicht an die Realität einer geistigen Welt glaubt. sondern eine offen-subjektive Bewegung sei, die das persönliche "Ich" des solipsistischen Künstlers in den Mittelpunkt stelle180. (Hierzu zählt Ėllis zum Beispiel den Ästhetizismus eines Huysmans.)

2. Den eigentlichen Symbolismus (соб̆ственный символизм), in dem es vorwiegend um "höhere Realitäten" gehe. Baudelaire, Nietzsche und alle großen Symbolisten hätten diese beiden Richtungen verbunden, wobei jedoch die zweite überwogen habe'181.

Mit gutem Grund unterstreicht Ėllis die große Bedeutung R. Wagners für den Symbolismus, vereinnahmt ihn dann aber für sein Bestreben, den Symbolismus als religiöse Kunst auszuweisen. Wagner habe nie an der realen Existenz der Götter ge zweifelt, habe die engen Rahmen der Klassifizierung der Künste gesprengt und eine

175 Труды и лни. Nr. 6, 1912. S. $54 f$.

176 Vgl. hierzu auch W. Potthoff: Zum Begriff des "Überzeitlichen Symbolismus", a.a.O.

$177 \mathrm{Vgl}$. hierzu auch oben. S. 23 und S. $113 \mathrm{f}$. . Anm. 17.

178 Tрупы и тни. Nr. 6. 1912, S. 55f.

179 Ebd.. S. 56-62.

${ }^{180}$ Ebd.. S. 57.

181 Ebd.. S. 58

Diese Unterscheidung entspricht Vjac. Ivanovs Einteilung des Symbolismus in "realistischen" (ent spricht Ėllis" 2. Richtung. dem "собственнылй снмволизм") und "idealistischen" Symbolismus (ent spricht der 1. Richtung bei Ellis), die Ivanov in seinem Aufsatz "Две стихни в современном символизме" vomimmt und erläuten. 
"Über-Kunst" ("сверx-искусство") verkündet 182; in ihm und durch ihn sei der Symbolismus mit einem dritten Element, mit dem "Geheimen in der Religion" ("c cokpoвенным в религии") verbunden 183 .

In diesen Ausführungen tritt wieder eine Spielart von Ėllis' ambivalenter Symbolismusauffassung auf 184: Die neue, religiöse Kunst habe sich der Zukunft zugewandt und ihre Energien aus der vergessenen und mißdeuteten mythischen mittelalterlichen Vergangenheit geschöpft: das heißt, der Symbolismus mußte auf die griechische Mythologie und die christlichen Legenden des Mittelalters (in erster Linie die Gralslegende) zurückgreifen ${ }^{185}$ und konnte seine Religiosität nicht aus den dogmatisch festgelegten Lehren der Kirche schöpfen. Die gegenwärtigen Formen des kirchlichen Lebens und Kultus bezeichnet Ëllis als tot und jeglicher Kultur und Kunst fremd ${ }^{186}$.

Ėllis beschreibt abschlieBend den symbolistischer: Dichter, dem in einer Art Vision gesagt werden wird:

Иди как ты шел до сих пор! Иди до последних граней своего пути! Не бойс никаких нспьтаний и не знай никаких колебанй! Не изменяй заре будущего ради прекрасного заката прошлого! Не предавай свобощы созидания и не изменяй святому долгу дерзания! Не стань рабом мертвой формы. в которой нет уже балее жнзни! Переживи и перестрадай все образы. которые переходяин. и ты познаешь. что только одно не переходит и только одно не увядает. что лиш через жертву во имя Креста и через благодать Креста. обретешв ты силу Креста. и лишь через любовь во имя Розы и через благодать Розы. узрншъ ты красоту Розы. Только зта сила не изменяет, только эта красота не увядает! 187

182 Es wird bei Ėllis nicht klar, ob er damit Wagners Idee des Gesamtkunstwerks im Sinne der Synthese der Künste und der Verwandlung meint: Éllis' Ausführung entspricht jedenfalls Wagners Konzept.

183 Трулы и пни, Nr. 6, 1912, S. $58 f$.

$184 \mathrm{Vgl}$. oben. S. $83 \mathrm{f}$.

185. Als Beispiele führt Ellis u.a. an: Wenn Nietzsche sich nach Griechenland und Persien wenden muBte, um die Zukunft zu sehen, so habe Wagner erst dann sein christliches Mysterium geschaffen. als er die alten Vermächtnisse des Mittelalters erinnerte und verinnerlichte (damit meint Ëllis den "Parsifal", die christliche Gralslegende und das mittelalterliche Rittertum).

Christlich-religiös ist Wagner jedoch nur in seinem letzten Werk, dem "Parsifal". Was z.B. den "Ring des Nibelungen" betrifft, so ist Hebbel in seiner dreiteiligen Tragödie "Die Nibelungen" in der SchluB szene viel eher christlich-religiös als Wagner! Bei Hebbel heißt es am SchluB: "Im Namen dessen, der am Kreuz erblich!" ( $\mathrm{Vgl}$. F. Hebbel: Die Nibelungen. Ein deutsches Trauerspiel in drei Abteilungen. 1855-1860. In: Ders.: Sämtliche Werke in zwölf Bänden. 5. Band. Berlin-Leipzig (um 1925], S. 241.) Bei Wagner endet die Tetralogie mit der Götterdämmenung. also dem Weltenende.

186 Труды и дня. Nr. 6. 1912. S. 61.

Denkı man an die sogenannte Ära Konstantin P. Pobedonoscevs und die Auswirkungen ihser strengen Kontroll- und ZensurmaBnahmen auf das religiöse und kulturelle Leben RuBlands, so hat Ėllis sicher recht. Die orthodoxe Kirche ist aber auch früher bereits wiederholt als dogmatisch, tot, erstam etc. bezeichnet worden (z.B. von Friedrich Schleiermacher, später von Adolf von Hamack und dem liberalen Protestantismus Ivgl. hierzu E. Benz: Geist und Leben der Ostkirche. Hamburg 1957. S. 180f.: S. Raeder: Die russische Orthodoxie im Spiegel der Protestantischen Theologie des 19. Jahrhunderts. In: R.-D. Kluge. H. Setzer (Hrsg.): Tausend Jahre Russische Kirche. Tübingen 1989, S. 141, 150f.]). Allerdings machte sich nicht nur in RuBland um 1900 Unzufriedenheit mit den dogmatisch erstartten Formen des kirchlichen Lebens und Kultus breit, sondern auch in den Ländem Westeuropas, was in Frankreich z.B. zur Bewegung des "Renouveau catholique" (vgl. unten. S. 229. Anm. 2) oder in (deutschsprachigen) Anthroposophenkreisen 2.B. zur Gründung der Christengemeinschaft durch Rudolf Steiner (vgl. hierzu Chr. Lindenberg: Rudolf Steiner mit Selbstzeugnissen, a.a.O., S. 128-130) führe usw. Ëllis strebt jedoch weniger eine Kirchenreform im Sinne der genannten Emeuerungsbewegungen an. als vielmehr eine Rückkehr zum mittelalterlichen Katholizismus, den er positiv als enge, organische Verbindung von Religion und Kunst auffaBt: auch die Scholastik ist für ihn "lebendig" und "originell" (vgl. dazu auch unten, S. 166)!

187 Труды и дни, Nr. 6, 1912, S. 61 . 
Dieser für Ellis typische, beeindruckend formulierte, emphatische Ausbruch ist inhaltlich jedoch abstrakt und leer und bedeutet lediglich. daB der - in Ellis' Augen symbolistische Künstler unbeirn bei seiner religiösen (christlichen) Kunst bleiben soll.

In seinem Aufsatz "О задачах и целях служения культуре" ("Über die Aufgaben und Ziele des Dienstes an der Kultur") ${ }^{188}$, der gröBtenteils aus Entwürfen zu einem (nicht publizierten) Aufsatz über die Aufgaben und Ziele des "Musaget"-Verlags hervorgegangen ist ${ }^{189}$, versucht Ellis zunächst, das Wesen der Kultur zu charakterisieren: Jede Kultur habe drei "Gesichter", die als lebendige Entwicklung verstanden werden müssen: Reales, Ideales, ihre Verbindung. Ėllis führt den Gedanken der Kontinuität zwischen den einzelnen Kulturepochen aus: Jede Epoche gäbe etwas an die nächste weiter, sei zugleich Vererbender und Erbe. Jedoch allen Epochen liege ein absoluter, gemeinsamer Plan zugrunde. Dadurch seien alle Stufen miteinander verbunden und führten zum Endziel. Letztendlich werde das Ideale über das Reale siegen 190.

Das Wesen der Kultur ist für Ëllis religiös. In seinen weiteren Ausführungen über Wesen und Entwicklung der Kultur läßt sich ein offensichtlicher Reflex anthroposophischen Denkens nicht übersehen: Ellis stellt eine Analogie zwischen der Entwicklung des Individuums und derjenigen der Menschheit fest; die Menschheit mache wie auch das Individuum - verschiedene Altersstufen durch; die ganze Entwicklung der einzelnen Kulturepochen verlaufe gesetzmäBig und unterliege dem Gesetz der progressiven Spiritualisierung, auf Grund dessen man jede Kulturepoche bestimmen könne. Éllis unterscheidet drei Hauptelemente jeder Kultur: ihren Körper, ihre Seele und ihren Geist. Jede Kultur sei eine neue Synthese dieser Elemente, und jede Synthese enthalte ein Primat ${ }^{191}$.

Der Körper der Kultur (ihre äuBere, vorübergehende Hülle) sei die Gesamtheit der materiellen und utilitaristischen Mittel für die Realisierung ideeller Werte (Wissenschaft, Philosophie, Kunst $)^{192}$. Die Seele der Kultur sei der innere ganzheitliche Kem der bereits realisierten und möglichen idealen Wene. Die Seele der Kultur gibt einer Kulturepoche ein individuelles Aussehen als lebendiger Organismus im Proze B der einheitlichen Entwicklung der Kultur ${ }^{193}$. Das heißt, durch die Seele unterscheidet sich eine Kulturepoche von einer anderen. Der Geist der Kultur steht in enger Beziehung zum verborgensten Ursprung jedes idealen Seins und läßt sich nur schwer bestimmen. Der Geist jeder Kultur sei von Grund auf religiös ${ }^{194}$. Es gibt nur einen einzigen Geist der Kultur, der sozusagen über allen Kulturepochen steht ${ }^{195}$.

Bei der Charakterisierung seiner eigenen Kulturepoche richtet sich Ëllis geistesge schichtlich gegen den Positivismus und den naturwissenschaftlich geprägten Zeitgeist:

$[\ldots]$ самое суиественное устремлекие нашей эпохи - всесторонняя реакция против материализма недавного прошлого и неудержимый возврат. хотя и в новых формах. $\mathrm{K}$ вели кому н строгому иерархизму. прмзнающему центральное и верховное значенне за идеаль но-ценным. за зстетическим творчеством. философским самосознанием и особенно за

188 Труды и гни. Nr. 4-5, 1912, S. 87-96.

189 РО РГБ. Ф. 190, карт. 49, ел.хр. 6; карт. 55, ел.хр. 15.

190 Труты и тин. Nr. 4-5, 1912. S. 89. Hinter diesen Ausführungen von Ëllis verbirgt sich das alte Idealismusmodell!

191 Труды и лани. Nr. 4-5. 1912. S. 90

192 Ebd., S. 90 .

193 Ebd.. S. 91.

194 "[...] послелняя сушность и смысл каждой культуры - религиозны.". heibt es bei Ëllis. (Ebd.. S. 91.)

195 Ebd., S. $91 f$. 
венчаюиим их релитиозным созерцаннем. В наши дни осознан бесповоротный конец натурализма в искусстве. агностищизма в точном знанин. позитивизма в области философской творческой мысли и, с другой стороны. - конец схоластической метафнзики и мерт вого. бьтового, религиозного догматизма. ${ }^{196}$

Ėllis beschreibt die durchlebte Kulturkrise 197 und nennt als neue, lebendige "Losung" seiner Epoche den Symbolismus ${ }^{198}$, dessen Entwicklung und Vielfalt er folgendermaßen zusammenfaBt:

Первоначально более спекулятивный и только зстетический. он [символизм] становится все глубже и шире и, наконец. в Нишше-вагнерианской проблеме достигает универсального значения. Здесь же и возникает вопрос о самом существенном распутье.

[...] за кем же итти нам. за Нишше или за Вагнером, за самопронзвольным. всегда лишь из себя растушим творчеством. становяшимся всем, за безконечным движеннем лишь в себя верящей воли. или за строго-прекрасной и добровольно покоющейся на вере символихой искупления: за полководцем, гневно ведушим на завоевание новых стран, или за рышарем. преклоненно охраняюцим не им созданную. но ему лиш порученную свыше святыню, к сверх-человеку Нияче или к Монсальвату Р. Вагнера? 199

Obwohl Nietzsche und Wagner eine gegensätzliche Antwort auf die Frage des Ursprungs der geistigen Kultur gaben ${ }^{200}$, seien sie doch gemeinsam auf die Frage der unvermeidlichen Krise aller Kulturen und die Notwendigkeit des Auswegs aus ihr auf "überkulturellem Wege" ("сверх-культурным путем") gekommen201. Darin sieht Ėllis den Sinn der "messianischen Idee" ( мессианистическая идея) des "Übermenschen" bei Nietzsche (in "Also sprach Zarathustra") und der "Lehre von der Wiedergeburt", die auf der Gnade gründet (in Wagners "Parsifal"). Im "Parsifal" ordne Wagner der Kunst die Religion bei, die er nicht dogmatisch, sondern als Mysterium verstehe, und bewahre dabei die Hauptbedingung jeglicher Kunst: die Freiheit des Schaffens. Im "Zarathustra" habe Nietzsche in noch nie dagewesenen Formen des freien, dichterischen Schaffens eine allgemeine Darstellung der ihm vorschwebenden Synthese der ganzen Kultur der Zukunft gegeben und ihr völlig anders als Wagner, aber ebenso harmonisch, die religiöse Idee (sic!) beigeordnet, die er "messianisch" verstehe 202 .

Das Hervorbringen echter Kunstwerke bezeichnet Ėllis als "работа во имя служения духу и душе культуры" ("Arbeit im Namen des Dienstes an Geist und Seele der Kultur"); diese Tätigkeit ist für ihn religiös, eine Art "Gottesdienst", deren höchste Form das christliche Mysterium sei203.

196 Ebd.

197 Das BewuBtsein einer großen Kulturkrise um die Jahrhundertwende war allen russischen Symbolisten gemein. Vgl. hierzu auch oben. S. 89, Anm. 5.

198 Трушы и тни. Nr. 4-5. 1912, S. 92.

199 Ebd., S. $93 f$.

200 Ėllis meint hier Nietzsches Individualismus des starken Individuums. seine Idee vom "Übermenschen" als Kulturerschaffer versus Wagners religiöser Kulturauffassung. des Konzepts von Kunst als "heiligem Ritual", wie sie ihren höchsten Ausdruck im Bühnenweihfestspiel "Parsifal" gefunden habe.

201 Труды и дня. Nr. 4-5, 1912. S. 94. Gemeint ist, daB sich die Krise nur überwinden lasse, wenn man über die Grenzen der reinen Kultur hinausgeht und den Bereich der Religion hinzunimmt.

202 Ebd.. S. $94 f$.

203 Ebd.. S. $95 f$.

Auch Ellis' Zeitgenossen lebten im BewuBtsein einer Kulturkrise. Um diese zu überwinden, versuchten sie alte, vergessene Kulturen zu emeuem, wiederzubeleben, jedoch nicht in einer derartig einseitigen Weise wie Ëllis, der - von seinem Temperament ergriffen - völlig die Übersicht über Verdienste und Entwicklung der abendländischen Kultur seit der Renaissance zu verlieren scheint. 
Betrachtet man Ellis' Beiträge zum Thema Symbolismus in der Zeitschrift "Труды и дни" (seine drei "Münchner Briefe" und den Aufsatz "О задачах и целях служения культуре") insgesamt, wird man sich fragen, was Ëllis nun eigentlich unter Symbolismus versteht? Dies spricht er in einem Brief an Metner (Juni 1913) ganz deutlich aus:

Символизм. особенно русский. может и должен перевалить к области религиозного искусства. свободного от церковшины. догматики. аллегоризма. но и свободното от эроти ки и крайнего субъективизма. У Тктчева. Лермонтова. Вл. Соловьева - есть попытки значительые! Не правда ли? Французское влияние [...] многое испортило. Теперь я навсегла ушел от французского всего! Barнер в 1/2 года меня нзлечил!

Но "святые святых" цля меня срел[ние] века. 204

Éllis' Symbolismusverständnis trägt hier also starke neoromantische Züge; in zunehmendem Maße überwiegen bei ihm die Sehnsucht nach Harmonie und Einheit sowie die Rückwendung zu Traditionellem gegenüber der Auffassung von Symbolismus als antimimetischer Bewegung. Die Ar. wie Ėllis den symbolistischen Dichter charakte risiert und darstellt, erinnert stark an das Bild des romantischen Dichters als Propheten und Seher. Echter Symbolismus bedeutet nun für ihn romantisch verklärte mittelalterliche religiöse Kunst! Symbolismus, verstanden als Bruch mit allen Traditionen, bzw. die Seite des Symbolismus, die die Avantgarde vorbereitet hat, lehnt Ėllis ab (zumindest zur Zeit seiner "Труды и дни"-Beiträge). In Briefen an Metner (1913) spricht er sich wiederholt gegen die Futuristen und Modernisten aus ${ }^{205}$. In einigen Briefen verkündet er überhaupt das Ende bzw. den Untergang des Symbolismus ${ }^{206}$. während er an anderer Stelle betont, daB der wahre, echte Symbolismus erst noch beginnen werde. Lediglich die Epoche der Vorahnungen sei nun zuende 207. Eine derartige Sprunghaftigkeit belegt auch den Mangel einer eigenen. gesicherten Position.

Aus Ėllis' Arbeiten zum Thema Symbolismus, vor allem aus seinem Aufsatz "O задачах и целях служения культуре". geht deutlich hervor, daß ihm bewußt geworden ist, daB die Zeit, in der er lebt, seine Kulturepoche, nicht mehr eine einheitliche Strömung ist, und zugleich mehrere Stilformationen parallel existieren. Das Nebeneinander verschiedener Strömungen, die zum Beispiel als (Spät-)Realismus, Symbolismus. Neoromantik. Décadence. Ästhetizismus, L'ant pour l'art usw. bezeichnet werden, brachte unterschiedliche und widersprüchliche Kunsttheorien und -auffassungen mit sich, die jeweils nur die eigene Position zu begründen und durchzusetzen versuchten und an einem Verständnis der konkurrierenden Theorien nicht interessient waren. Das führe zu wechselseitigen MiBverständnissen. Symbolistische antimimetische Kunst etwa wurde von den Realisten als Spielerei aufgefaBt und nicht ernst genommen. Das Wahmehmen dieses Pluralismus von Positionen löste bei den unmittelbar davon betroffenen Symbolisten das Krisenbewußtsein der Zeit aus, wie es wiederholt in Ellis' Arbeiten anklingt.

Im russischen Symbolismus lassen sich deutlich zwei Affinitäten erkennen:

1. Symbolismus hat Affinität zum Geistigen und zum Religiösen. Diese Affinität herrscht deutlich in Ellis' Symbolismusverständnis vor. Wiederholt betont er, daB das Wesen der Kunst religiös sei. Aber auch bei einem so bedeutenden Vertreter des Symbolismus wie Vjač. Ivanov begegnet diese Affinität. Bezüglich des religiösen

204 РО РГБ. Ф. 167, карт. 8. ед.xp. 12, BI. 2.

205 Z.B. im Mai 1913 (РО РГБ. Ф. 167. карт. 8, en.xp. 10). Er verwendet darin die Begriffe "футурнсты". "модернисты" und "модернизм".

206 Z.В. Ф. 167. карт. 7. ед.xp. 40f: Ф. 167. карт. 8. ед.хр. 27

207 Ф. 167. карт. 8. ед.xp. 28. 
Wesens der Kunst finden sich in zunehmendem Maße Ähnlichkeiten und Parallelen bei Ivanov und Ėllis, und zwar nicht nur in ihrem Kunst- und Literaturverständnis, sondem auch in ihrer Biographie (Emigration, Konversion zum Katholizismus), wobei Vjač. Ivanov in seinen Arbeiten jedoch theoretisch weitaus fundierter argumentiert als Ëllis, der eher spekuliert oder gar phantasiert.

2. Symbolistische Kunst- und Stilpraxis verfügt über Affinität zur religiösen Praxis. Das heißt, der symbolistische Kunstproduzent entspricht dem Priester und der Rezipient dem Teilnehmer am Abendmahl, der durch das Geschehen der Eucharistie geläutert und verwandelt wird. Diese Affinität klingt beispielsweise in Brjusovs Aufsatz "Священная жертва"208 an. A. Belyj spricht von "преображение личности"209, wobei er diesen Vorgang jedoch nicht direkt mit dem "причастие" (Kommunion) vergleicht; auch ist der Rezipient bei Belyj aktiver als der Teilnehmer der Eucharistie. der den Leib des Herm rein und unverändert aufnimmt und dadurch gewandelt wird, während der Rezipient eines symbolistischen Kunstwerks dieses be reits in der Aufnahme umgestaltet und sich selbst in diesem Vorgang der Umgestaltung geistig verwandelt.

\section{b) Ellis' Beschäftigung mit Richard Wagner}

Richard Wagner und vor allem seine Idee vom "Gesamtkunstwerk" sowie sein Begriff des "Künstlermenschen der Zukunft" übten großen Einfluß auf die russischen Symbolisten und auf die Entwicklung der symbolistischen Theaterkunst aus. Wagner war bestrebt. Dichtung und Musik in seinen Musikdramen mit schauspielerischer Darstellung und Bühnenbild zum Gesamtkunstwerk zu vereinen, wobei das Orchester die Rolle des griechischen Chores übernehmen und das in Worten Unaussprechliche ausdrücken sollte. Das Orchester wurde bei Wagner erstmals in den Orchestergraben versenkt. Dadurch wollte Wagner die Vereinigung von Bühne und Zuschauerraum schaffen. Durch das Verschmelzen aller Künste zum Gesamtkunstwerk erstrebte Wagner eine kultische Veranstaltung, in der das Kunstgeschehen aktiv auf die Zuschauer übergehen, den Menschen aktivieren und ihn geistig und seelisch zum neuen schöpferischen "Künstlermenschen der Zukunft" verwandeln sollte. Mit "Künstlermensch der Zukunft" meint Wagner den neuen Menschen, der anders lebt, nicht mehr Spießer und Bürger ist mit Sekuritätsdruck, sondem der sich dem ästhetischen GenieBen und Erleben hingibt und in diesem GenieBen selbst umgestaltend tätig ist, das heißt, sich selbst und seine Umwelt veränder ${ }^{210}$.

Durch eine eigenwillige Interpretation des antiken Dramas kam Wagner zu seinen Begriffen des "Gesamtkunstwerks" und des "Künstlermenschen der Zukunft". Seine wichtigsten theoretischen Schriften hierzu sind: "Die Kunst und die Revolution" (1849). "Das Kunstwerk der Zukunft" (1850) und "Oper und Drama" (1851). Wagner hat den "Künstlermenschen der Zukunft" zugleich auch politisch verstanden. Revolution bedeutete für ihn die Verwandlung des Menschen zu einem höheren lebensfähigen Typus, zu einem demokratischen Künstlermenschen (im Gegensatz zu Nietzsches Ubermensch, der Individualist ist). Theater war für Wagner eine weihe-

\footnotetext{
208 In: Becы, Nr. 1, 1905.

${ }^{209} \mathrm{Vgl}$. hierzu M. Deppermann: Andrej Belyjs ästhetische Theorie des schöpferischen BewuBtseins, a.a.O., vor allem S. $172-188$.

$210 \mathrm{Vgl}$. R.-D. Kluge: Westeuropa und RuBland im Weltbild A. Bloks, a.a.O.. S. 89f., 110-115 sowie seine Vorlesung: "Symbolismus und Avantgarde in der russischen Literatur" (Universität Tübingen. WS 1992/93).
} 
volle Handlung (seinen "Parsifal" nennt er "Bühnenweihfestspiel"!), in der die Wiedergeburt des Menschen stattfindet. Ihm schwebte auch die Idee vor, die Zuschauer als eine Art Chor in das Geschehen mit einzubeziehen, wie es später dann im symbolistischen und avantgardistischen Theater praktizien wurde.

Wagner steht mit diesen Ideen gewissermaßen auslösend am Anfang. Sie wurden von den sogenannten "jüngeren" russischen Symbolisten, die sich vorwiegend auf Wagners obengenannte frühe theoretische Schriften stützten, aufgegriffen, insbesondere die Idee der Aktivierung und Einbeziehung des Rezipienten. Der Zuschauer, Leser, Rezipient soll am künstlerischen Geschehen beteiligt werden und sich dadurch innerlich verändem. A. Blok erwartete von der Dichtung eine solche verwandelnde, reinigende, ändernde Kraft im Rezipienten und spricht, in Anlehnung an die Terminologie R. Wagners, vom "человек-артист булуието"211. A. Belyj spricht von "преображение личности" 212 .

Stark beeinfluBt von Metner begann Ëllis sich gegen Ende der ersten Dekade dieses Jahrhunderts immer mehr mit der deutschen Literatur und Kultur zu beschäftigen. besonders auch mit Richard Wagner ${ }^{213}$. Wiederholt äuBert er in Briefen, daB Metner ihn angeregt habe, sich mit Wagner auseinanderzusetzen; dadurch habe er sich endgültig von den französischen Symbolisten abgewandt. Auch erwähnt er häufig Wagner und dessen Werk in seinen Aufsätzen über das Wesen des Symbolismus und über symbolistische Kunst und Literatur. In seinem dritten "Münchner Brief" etwa begründet Ellis die Nähe Wagners zum Symbolismus folgendermaßen:

И теоретически Вагнер близок символистам безконечно! Поскольку он определенно разрушал все условные рамкн классификацин искусств н проповедывал единое сверхискусство. он близок кажлому из нас в самом послепнем; поскольку он более всех других верил в высший мир и высшему миру, поскольку он полчеркнул с небывалой смелостьк) религиознук) основу всякого искусства и в «ІІарсивале» полошел вплоть К вопросу о сокровеннй суиности мистерии. он близок всем нам именяо теперћ. 214

Hier wie auch an anderer Stelle ist Ellis jedoch recht einseitig auf den späten Wagner und sein letztes Bühnenwerk, den "Parsifal", fixien, während er den ganzen "welt lich-heidnischen" Wagner ("Der fliegende Holländer", "Lohengrin". "Der Ring des

211 Vgl. A. Blok: Sobranie soxinenij. Tom 6. S. 21-25. 114, 126

212 Vgl. oben. S. $22 f$. und S. 141, Anm. 209.

Bis in die 60er Jahre dieses Jahrhunderts finden sich in der Forschung kaum Arbeiten zum Themenkomplex "Wagner in RuBland". abgesehen von einigen Teiluntersuchungen war dieses Gebiet his vor kurzem nicht systematisch aufgearteitet und nur wenig erforscht. Frühe Untersuchungen zu diesem Thema: R.-D. Kluge: Westeuropa und RuBland im Weltbild A. Bloks, a.a.O., S. 84-91, 310 314. 320f.: A.F. Losev: Problemy Richarda Vagnera v prošlom i nastojaščem. (V svjazi s analizom ego tragedii "Kol'co Nibelunga"). In: Voprosy éstetiki, Nr. 8. Moskva 1968, S. 107-113. Seit Ende der 1970er und vor allem in den 1980er/1990er Jahren sind mehrere Arbeiten zu Wagner und Blok, aber auch einzelne zu Wagner und Belyj sowie zu Wagner und Vjač. Ivanov erschienen (vgl. "Literaturverzeichnis" der vorliegenden Arbeit). Einen guten Überblick über Wagner im russischen Symbolismus bietet D. Ricci |Rizzi|: Richard Vagner v russkom simvolizme. In: Serebrjanyj vek v Rossii. Izbrannye stranicy. Moskva 1993. S. 117-136. Wichtig sind auch die beiden neueren Monographien: A. Gozenpud: Richard Vagner i russkaja kul'tura. Leningrad 1990: R. Bartlett: Wagner and Russia. Cambridge 1995: diese letztgenannte Arbeit von Bartelt dokumentiert sehr sorgfältig 150 Jahre Wagner-Rezeption in RuBland (1841-1991). für die vorliegende Untersuchung ist besonders der umfangreiche zweite Teil von Bartetts Arbeit: "Wagner and Russian Modernism" (S. 57-217) von Bedeutung.

213 Belege für Ėllis' Beschäftigung mit R. Wagner können u.a. den Briefen und Postkarten vorm Juni 1911 von V.I. Astrov an Ëllis entnommen werden (РГАЛИ. Ф. 575. on. І. ед.xp. 25).

214 Труды и дин. Nr. 6, 1912. S. 59. 
Nibelungen", "Tristan und Isolde", "Die Meistersinger" etc.) ignoriert bzw. auf sehr eigenwillige Art als Vorbereitung auf das späte christlich-religiöse Werk interpretiert. In Wagners Werken sieht Ėllis die allgemeine Idee des Symbolismus ausgedrückt:

Единая общая идея символизма - переживание и осознание наступления новой आохи. как следствия импульса, идущего из высиях миров. реаљыых и действеныых. обший мессианнстический и пророческий смысл н пафос симвонческого двикения находит полное и прекрасное выражекие в творчестве Вагнера. 215

Auch in seinem Aufsatz "О задачах и целях служения культуре" weist Ellis darauf hin, daB sich in Wagners Werk das "Hauptbestreben des Symbolismus", so wie er es ab ungefähr 1910 versteht, zeige:

[...] в творчестве $P$. Вагнера всего более выразнлось основное стремление символизма к безконечному самоуглублению. превращающему ксимволическое искусство" в сокровенный ритуал, образ-снмвол - в саморазвиваюинйся миф. а миф - в предельную форму доступного нам в творчестве. в христианскуко мистерию. 216

In seinem Briefwechsel mit Metner taucht ab 1909 Wagners Name ebenfalls immer häufiger auf. Nachdem sich Ellis zuvor ja überwiegend mit französischen und belgischen Symbolisten befaBt hatte, vor allem mit Baudelaire, wird er nun zum "fanatischen Wagnerianer"217. In einem Brief an Metner im Sommer 1909 schreibt er u.a.:
Жду текста "Парсифаля". Вчера всю ночь провел у одного друга, итравшего мне исклю- чительно Вагнера.
Да. только Вагнер мог меня спасти от Боллэра! Вагнер понял раньше А. Белого ужас от- решенной. стихийной небесной музыхн. Тогда он прявязал ее словом х планете-земле. 218

In einem anderen Brief an Metner (vom Juli 1910) heiBt es:
Моя борьба с вами в результате заставляет меня прнзнать себя побежденным
1) в признании первенства германства нал французским
2) в безусловном признанни переенства Р. Вагнера нал всем символизмом с Бодлзром во rлаве. $^{219}$

Im Juni 1912 schreibt Ėllis dann: "Вагнер сейчас в России необходим. Неужели Степпун [sic!] нужнее?"220

Ellis befaBt sich nunmehr intensiv mit Wagners Leben und Werk und bietet "Tpyды и дни" 11 Arbeiten über Wagner an (1912):

1. Wagners Pessimismus (Wagner und Schopenhauer)

2. Die Quellen zu Wagners "Parsifal"

215 Ebd.

216 Труды и пня, Nr. 4-5, 1912, S. 94.

217 Vgl. hierzu auch R. Bartlett: Wagner and Russia. a.a.O., S. 171, sowie Bartletts weitere Ausführungen (ebd.. S. 172-186). Bartlett bemüht sich. Ėllis' Auseinandersetzung mit und sein Ringen um Wagner - auch im Zusammenhang mit seiner Steiner- und Anthroposophiebegeisterung - deutlich nachzuzeichnen. Auf eine Ungenauigkeit sei in diesem Zusammenhang hingewiesen: Ėllis war im Juli 1910 nichr in Deutschland (vgl. Bartlett. S. 172), sondem setzte sich zu der Zeit in Rußland mit Steiner und Wagner auseinander; nach Deutschland ging er erst (und endgültig) im Sept./Okt. 1911.

218 РО РГБ, Ф. 167, карт. 7, ед.хр. 13.

219 Ebd., eд.xp. 24.

220 Ebd.. en.xp. 62.

Aus all diesen Äußerungen wird Ėllis' Hang zu Extremen, zur "Schwarz-Weiß-Malerei" wieder sehr deutlich: es gibt für ihn keine Kompromisse. Erst bedeutete für ihn Baudelaire und der französische Symbolismus alles. Nun ist an diese Stelle Wagner und die deutsche Kultur getreten! Dieser Übergang vom französischen Symbolismus zur deutschen Kultur stellt eine der extremen Kehrtwendungen in Ellis' Leben dar, derer es mehrere gibt und die A. Belyj so anschaulich beschrieben hat (vgl. oben, S. 36 und 123). 
3. Wagners Symbolik und Ästhetik

4. Wagners Lehre vom musikalischen Drama

5. Über Bayreuth

6. Wagners Jugendwerk

7. Wagner und Nietzsche

8. Erotische Motive bei Wagner

9. Die Idee der Mutterliebe bei Wagner

10. Baudelaire und Wagner

11. Wagner und der Symbolismus.

Außerdem plant er eine umfassende Monographie über Wagner ${ }^{22 !}$.

Zudem beginnt Ėllis 1911, Wagners Opem ins Russische zu übersetzen. Er beabsichtigt, alle Musikdramen Wagners zu übertragen und so den "russischen Wagner" zu schaffen 222 . Er beginnt mit dem "Parsifal". Es folgt der "Ring des Nibelungen" ("Rheingold", "Die Walküre", "Siegfried" und "Götterdämmerung"), dann "Lohengrin" und "Tannhäuser". Elllis hält Metner brieflich über den Fortschritt seiner Übersetzungen auf dem laufenden. Er wollte sie im "Musaget"-Verlag publizieren ${ }^{223}$. Im Dezember 1911 schreibt Ėllis an Metner, daB Steiner ihm geraten habe, sich auf Wagner zu konzentrieren:

Мне он [Steiner] советовал сосредоточиться на Вазнере. Ero совет лал мне силы перевести "Гибель богов" так, как я никогда ничего не переводил. [...] Я думаю над Вагнером силеть 10 лет minimum и дать его Россин. переводы и комментарни. Именно Вагнер - есть единственньй мост от символизма $\mathrm{x}$ теософин. от язычества к христианству. от инливилуализма $x$ рьпцарству, от безумия $x$ мулрости. от слалострастия $x$ целомулрию. от пессимизма $x$ "возрождению". от искупления $x$ мессианизму, от искусств $\mathrm{x}$ Искусству, от сцены х мистернн, от куљь та женственного $x$ мужественно-рьпарскому убежленик. от хаоса дремучей наролности $x$ формирующему индивнлуальному "я". от фантастики $x$ realiora. or болезненности к исцелению. от лемоннзма х серафимизму. от все-человеческого к сверх-человеческому. 224

Etwas später, im Januar 1912, schreibt Ėllis an Metner:

Формула мжей теперешней июзицин такова:

"В наухе - строгий. схромный эмпнризм. В литературе - Вагнернзм. В оккультизме Ш тейнеритм. в философин - Лейбниц. к[ото]рым не скоро. но займусь!"

221 Brief von Ëllis an Metner vom 5.2.1912 (РО РГБ. Ф. 167. карт. 7. eд.xp. 51) sowie seine Briefe vom Dezember 1911 (Ф. 167. кapr. 7. en.xp. 42f.). Im März 1912 schreibt er an Metner, daB er zwei Wagner-Aufsätze für "Трулы и лни" schreibe, nämlich "Wagner und sein Lohengrin" und "Der Dämonismus bei Wagner" (ebd.. en.xp. 58 ).

222 Ėllis' Bemühungen um den "russischen Wagner". seine Ühersetzungsversuche der Opem und Musikdramen Wagners sowie seine inhaltliche Auseinandersetzung mit Wagner und dessen Werk werden ausfuitrlich von $R$. Bartett: Wagner and Russia dargestellt, sie zieht dafur auch zahlreiche Archivmaterialien heran und wertet diese aus. überwiegend Ëllis' Briefe an Metner (vgl. ebd.. S. 178-186).

223 РО РГБ. Ф. 167. карт. 7. ед.xp. 30, 34. 37-39, 43f., 48f., 62. Ëllis' Übersetzungen von Wagners Musikdramen wurden jedoch nie gedruckt: vermutlich hat er sie nicht alle beendet bzw. endgültig redigiert. Aus Metners brieflichen Reaktionen geht hervor, daB Ëllis' Übertragungen gravierende Mängel aufwiesen. Im Archiv der Russischen Staatsbibliothek (im Fond des "Musaget"Verlags) und im РГАЛИ befinden sich vermutlich noch Materialien, die die Verfasserin jedoch nicht einsehen konnte.

224 Ebd., en.xp. 42.

Aus dieser übertriebenen. langen Aufzählung läBt sich deutlich das Programm der "jüngeren" Symbolisten herauslesen: die Entwicklung vorm Symbolismus als Kunst und Literatur zum Symbolismus als (religiöser) Weltanschauung und Lebensgestaltung. In seinen späteren Arbeiten zum Symbolismus betont Ëllis immer wieder, daB wahre symbolistische Kunst zugleich christlich-religiös sein müsse. In Wagners Werk sieht er eine Entwicklung zur christlichen Kunst. So lassen sich seine Fixierung auf den späten Wagner und seine intensive Beschäftigung mit dem "Parsifal" erklären. 
|...|В Вагнере (кроме хонца его жнзни) непочатъп угол символнзма. чистого искусства. хаотизма. песснмизма. теургизма. эротики. мнфотворчества и воббще чего утодно. 225

Nachdem Ëllis alle Musikdramen Wagners übersetzt und kommentiert hat. möchte er die Werke Goethes und Dantes ins Russische übertragen226.

"Musaget" druckte jedoch Ėllis' Wagner-Übersetzungen nicht, da sie zu schlecht waren 227. Ëllis versprach Metner, seine Übersetzungen zu überarbeiten, vor allem die "Parsifal"-Übertragung und bat, wenigstens "Parsifal" und "Lohengrin" zu drukken 228. Nach der Publikation von Wagners Musikdramen in Éllis' Übersetzung müsse "Musaget" dann eine russische Ausgabe von Steiners Mysteriendramen herausbringen 229

All dies bleiben aber Pläne und Wünsche von Ëllis. Tatsächlich erschienen ist lediglich sein recht umfassender Aufsatz über Wagners "Parsifal"230, der wohl in der ersten Jahreshälfte 1912 entstanden ist ${ }^{231}$.

Éllis' "Parsifal"-Aufsatz in "Труды и дни" erschien im Teil "Wagneriana", der in der zweiten Zeitschriftnummer 1912 durch eine russische Übersetzung eines Artikels von H. St. Chamberlain über Wagners Autobiographie eröffnet worden war ${ }^{232}$. In den folgenden "Wagneriana"-Teilen finden sich vorwiegend Beiträge von Metner, seine "Kommentarent würfe" ("Наброски к комментарию") zu Wagners Musikdramen, in denen er über die Wagner-Forschung allgemein und über Nietzsches Arbeiten zu

225 Ebd., en.xp. 50.

226 Ebd.. ea.xp. 53.

Ëllis folgt hier Metner, der in Dante, Goethe und Wagner die drei bedeutendsten Kulturbegründer und -träger sah. (Vgl. oben. S. 114, 116.)

227 Ф. 167. карт. 13. ед.xp. 6.

Man muB sich dabei klarmachen. daB Ëllis begann. Wagner zu übersetzen. ehe er überhaupt richtig Deutsch gelernt hatte! Als er 1911 nach Deutschland kam. beherrschte er die deutsche Sprache kaum (das gehi deutlich aus seinem Briefwechsel mit Metner hervor sowie auch aus Erinnerungen von Zeitgenossen. die Ellis in (Deutschland erlebt haben). |VgI hierzu auch oben. S. 123.| Ungeachtet dessen begann er gleich zu übersetzen!

228 Ф. 167. карт. 7. ел.xp. 65, 76-78.

Mether ermuntert Ėllis zur Überarbeitung seiner Übersetzungen, die er teilweise direkt und heftig kritisier hat. 1913 schreibt er 2.B. an Ellis: "Видите. как хорошо, что мы не успели напечатать перевод Парсифаля. Теперь Вы знаете язьк лучше и Вам яснее Ваши промахи." (РО РГБ, Ф. 167. карт. 13, en.xp. 7, Blatt 69: Brief von Metner an Ëllis vom 20.3.2.4.1913.)

229 Ф. 167, карт. 7. ел.хр. 68.

230 Труды и лня, 1913, S. 24-53.

231 Ф. 167. карт. 7. ед.хр. 62.

Im Briefwechsel mit Metner 1912 bittet Ėllis immer wieder, seinen "Parsifal"-Aufsatz. zu drucken ( $\Phi$. 167. кapr. 7. en.xp. 78. 80f.). Einige weitere Notizen von Ëllis zu Wagner allgemein und dessen Werken finden sich in der Handschriftenabteilung der Russischen Staatsbibliothek ( $\Phi$. 167. kapt. 10. eд.xp. 6). Ėllis' ungedruckte Übersetzung von Wagners "Parsifal" befindet sich im РГАЛИ (Ф. 575. on. 1. en.xp. 8). Sie war 1912 in der ersten Nummer der Zeitschrift "Труды и дия" bereits folgendermaBen angekündigt worden (auf S. 15 des Katalogs des "Musaget"-Verlags): "Рихард Вагнер. Парснфаль. Перевол Эликса. (Печатается) Настояший перевод значнтельнейиего из пронзведений Р. Вагнера представляет собой первую попьтку дать на русском языке. в сравнительно-близком переложенин (из либретто музькальной драмы-мистерин в самостоятельное словесное пронзведение). Стремясь прнблизительно передать рнтм Вагнеровского орнтинального стиха. русския перевод. однако. всклу пинегает к рнфме. оставляя без внимания случайное пользование рифмой подлиннкка. [...]" (Weitertin folgen Ausführungen über die grobe Bedeutung von Wagners "Parsifal": R. Barlelt |Wagner and Russia, a.a.O., S. 1821 mutmaBt, daB Ėllis diese Ankündigung selbst verfaßt hat.)

232 Труды и пюи. Nr. 2, 1912, S. 74-78. 
Wagner schreibt ${ }^{233}$, über Mythos. Mysterium, Symbol und Mystik allgemein ${ }^{234}$, über Wagner und seinen Mythos ${ }^{235}$ sowie über die Götter und Göttinnen der germanischen Mythologie in ihrer speziellen Ausprägung und Bedeutung in Wagners Werken ${ }^{236}$. Außerdem enthält der "Wagneriana"-Teil von "Труды и дни" 1914 Beiträge von Marietta Saginjan (über die Begriffe "Ende"/"конец" und "Vollendung"/"окончаиие" in Wagners "Ring des Nibelungen")237 und von Arthur Luther (über "Parsifal" im Mittelalter; dieser Beitrag stellt eine Ergänzung zu den mittelalterlichen Versionen der Grals- und Parsifalslegenden dar, die Ėllis in seinem Aufsatz genannt und kurz erörtert hat $)^{238}$.

Seinem Aufsatz über R. Wagners "Parsifal" stellt Ėllis ein Motto von Wagner voran: "«Произведение изкусства должно быть религией в образах». Р. Вагнер"239. Еr beabsichtigt, in dieser Arbeit die Gestalt des Parsifal in Wagners spezieller Fassung zu untersuchen.

Wagners Werk "Parsifal" verbinde Kunst und Religion, sei die neue Kunst der Zukunft: in Analogie zu Wagner, der den "Parsifal" ja "Bühnenweihfestspiel" nennt, bezeichnet Ellis dieses Werk als religiöses oder szenisches Mysterium ("сценическая мистерия" "240. Wagners Weg habe von der Oper zum musikalischen Drama geführ und dann im "Parsifal" weiter zum "szenischen Mysterium". Zwei Themen seien im "Parsifal" verbunden: das persönliche und das überpersönliche, das symbolische und das religiöse, das allgemein-menschliche und das heldenhafte, das fühlbar-wahmehmbare und das real-übersinnliche. "Parsifal" sei Wagners vollendetstes Drama und seine vollendetste Gestalt, sei wahre Mysterienkunst, Merkmal des Herannahens einer groBen Kulturkrise. In diesem Zusammenhang verweist Ellis auf das - seiner Meinung nach - größte Werk der christlichen Kultur, nämlich auf Dantes "Göttliche Komödie". die das Höchste in der Kunst sei24l. Daneben nennt er den Epilog des zweiten Teils von Goethes Faust. Diese Art von "christlichem Mysterium", wie man sie bei Dante, Goethe und Wagner finde, sei die wahre "Kunst der Zukunft"242.

Dann geht Ėllis auf Wagners Entwicklung ein. Die beiden Hauptideen Wagners seien die "Symbolik der Erlösung" ("символика искупления243") und die "Symbolik des Messianismus" ("символика мессианизма"). Wagner habe sich zwischen zwei entgegengesetzten Polen bewegt: dem Verlangen nach "Nichtsein" (небьтие) und Zerstörung einerseits und der Suche nach Martyrium und Heldentaten andererseits. In

233 Труды и лни, Nr. 4-5, 1912, S. 23-29.

234 Ebd., S. 29-37.

235 Труды и пни. Nr. 6. 1912, S. 27-34.

236 Ebd., Nr. 6, 1912. S. 34-48; 1913, S. 19-23; 1914. S. 49-52.

237 "О «конщеш и кокончанкя»". Трушы и лкя. 1914. S. 53-57.

238 " "Парсифаль" в срелние века". еbd.. S. 58-62.

239 Труды и дни. 1913, S. 24. Dieses Motto entspricht Wagners Aussage: "Das Kunstwerk ist die lebendig dargestellte Religion" in seiner Schrift "Das Kunstwerk der Zukunft" (1849; vgl. R. Wagner: Dichtungen und Schriften. Jubiläumsausgabe in 10 Bänden. Band 6. Frank furt/M. 1983, S. 31).

Beim späten Wagner wird die Kunst von einem Phänomen der Erkenntnis zu einem Phänomen des Glaubens. Zum Thema "Wagner und Religion" vgl. auch Wagners späte Schrift "Religion und Kunst" (1880; in: R. Wagner: Dichtungen und Schriften, a.a.O.. Band 10. S. 117-163) sowie die Ausführungen von H. St. Chamberlain (in: H. St. Chamberlain: R. Wagner. München 1933. S. 243-247; Ders.: Das Drama Richard Wagners. Eine Anregung. Leipzig ${ }^{2}$ 1906, S. 137f.)

240 Труды и дня. 1913, S. 26.

241 Ebd., S. $26 f$.

242 Ebd.. S. $27 f$.

243 "Искупленне" hat in den letzten Jahren einen Bedeutungswandel erfahren, wie ein Blick in Wör terbücher zu Beginn des Jhds. (z.B. I. Pawlowsky: Russisch-Deutsches Wörterbuch. ${ }^{3}$ 1911) zeigt: damals wurde "искупление" mit "Loskaufung", "Erlösung" übersetzt, heute bedeutet es "Buße". "Sühne". 
der "Symbolik der Erlösung" habe er eine erste harmonische Lösung dieses Gegensatzes gefunden; im Zusammenhang mit der Gestalt des Ritters Lohengrin sei er zur zweiten Hauptidee, der "Symbolik des Messianismus" gelangt ${ }^{244}$. Ėllis folgt dem Wagnerforscher Chamberlain bei dessen Einteilung von Wagners Leben in zwei Abschnitte: von 1813 bis 1848 und von 1848 bis 1883. Das für ganz Europa schicksalhafte Jahr 1848 bilde die Grenze zwischen diesen beiden Phasen ${ }^{245}$. In der ersten Periode gelange Wagner zum Thema der Erlösung (искупление); in der zweiten komme der Messianismus hinzu. Diese beiden Hauptideen ("символика искупления" und "символика мессианизма") habe Wagner in seinen Werken nach und nach immer weiter entwickelt und ausgearbeitet. (Ellis charakterisiert Wagners Werke chronologisch bis hin zum "Parsifal" 246.) In der Gestalt des Parsifal vereinige Wagner zum ersten Mal die drei Elemente: Mensch. Held, Ritter, die den ganzen Entwicklungsgang in Wagners Schaffen ausmachen ${ }^{247}$. Davor seien diese Elemente unverbunden aufgetreten: Siegfried sei ein Held, aber noch kein Ritter gewesen. Tristan sei Ritter, aber schon kein Held mehr gewesen. Lohengrin sei Held und Ritter, aber kein Mensch gewesen. Tannhäuser sei vor allem Mensch gewesen. Parsifal mache die Entwicklung vom Menschen über den Helden zum Ritter durch: Im ersten Akt, der vorbereitenden Charakter habe und reine Betrachtung sei, erscheine Parsifal als Mensch. charakterisiert durch Unvollkommenheit. Im zweiten und - wie Ėllis meint - be deutendsten Akt trete Parsifal als Held auf und widerstehe den Versuchungen der Sinnlichkeit. Am Ende dieses Aktes, der ganz Handlung sei, gehe die Tragödie ins Mysterium über. Im dritten Akt erscheine Parsifal als Ritter, durchdrungen von menschlıchem Mitleid, und vollbringe die Heldentat. Die Kraft werde Parsifal jedoch von oben gegeben. durch eine direkte Verbindung mit der göttlichen Gnade. Er handele als Vermittler einer höheren Welt, vermittle zwischen der Gralsbruderschaft und Christus. Dieser Akt stelle die Vollendung sowohl der Betrachtung als auch der Handlung dar, sei die Grenzlinie vom Mysteriendrama zum reinen Mysterium, verwandelt durch eine Realität, die der Bühne nicht zugänglich sei248.

Parsifals Kraft wurzele in Christus. denn ohne Christus gäbe es kein wahres Rittertum. Parsifal sei unverwundbar, weil sein Kraftquell der unsterbliche und auferstandene Christus sei (im Gegensatz etwa zu Siegfried, der ja verwundbar ist). Der Übergang von "Siegfried" zu "Parsifal" in Wagners Werk bedeute den Übergang von der Welt der Götter zur Welt des einzigen Gottes. Im "Parsifal" habe Wagner die tiefsten Tiefen religiöser Esoterik berühr:

244 Ebd., S. $28 f$.

Was Ëllis mit diesen beiden Begriffen "символика искуиления" und " символика мессианязма" eigentlich meint. definiert er nie ganz explizit. Aus seinen Ausführungen wird jedoch deutlich, daB er damit die Entwicklung vom "heidnischen" zum "christlichen" Wagner ausdrücken will. Er betont. daB die Idee des Messianismus bei Wagner aus der Idee der Erlösung hervorgehe und die beiden Themen in etlichen Werken verbunden seien. Den "christlichen" Wagner, auf den er vor allem abhebt. sieht er bereits im "Lohengrin" angelegt.

245 Ebd.. S. 29.

Vgl. hierzu auch H. St. Chamberlains Wagner-Biographie (1. Aufl. 1896, seitdem viele Neuauflagen), die Ëllis kannte und als Quelle verwendete, wie aus seinem Briefwechsel mit Metner (1911-1912) deutlich wird. (Vermutlich kannte er auch $\mathbf{H}$. St. Chamberlains Arbeit "Das Drama Richard Wagners. Eine Anregung. Leipzig ${ }^{2} 1906$.) Inhaltlich (besonders was seine religiöse "Parsifal"-Interpretation anbelangt) hat Ellis jedoch nicht viel von Chamberlain übernommen. Er kritisierte dessen Arbeiten über WagIxer (z.B. in seinem Brief an Metner vom Januar 1912. PO PГБ. Ф. 167. кapт. 7. eд.xp. 50) und plante ja selbst eine umfassende Wagner-Biographie (vgl. oben. S. 144 dieses Kapitels).

246 Труды и дан. 1913. S. 29-33.

247 Ebd.. S. 33.

248 Ebd.. S. 33, 49-51. 
Здесь намеренное как бы более. чем символическое, отожествление Парсифаля с Христом. I Іарсифаля. мессию искупления. долго жданного. предсказанного еще до своего риждения. приходящего с заранее определенными духовными чертами. прнходящего в самый страшный. неотложный миг, несущего в руках св. копье. в знак таннственной. непосрелственной своей связи с Христом и пришедшего как бы для частичного возврата божественной жертвы. ${ }^{249}$

Ėllis interpretier die Gestalt des Parsifal also in Analogie zur Christusgestalt und sieht in Parsifals Tat (die Errettung der Gralsbruderschaft) eine Entsprechung zur Erlösung der Menschheit durch den Opfertod Christi.

In einem Schema stellt Ėllis die Entwicklung von Wagners Opernwerk dar:

Года Пронзведения. Форма. Основная идея и символика.

окончания

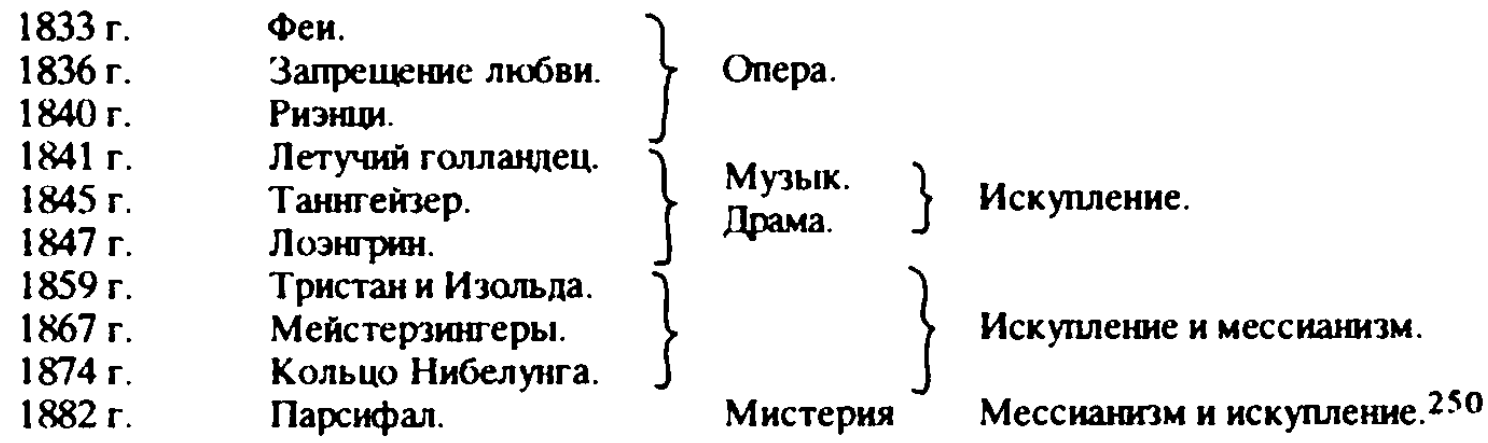

Er kommentien die in seinem Schema dargestellte Entwicklung folgendermaßen:

[...] мы получаем точную схему развнтия его [= Wagners] творчества от оперы через музьккальную драму к драме-мистерии. от трагедия обще-человеческой к тайне сверхчеловеческото. от земного к оожественному, от символизма к символике. от символики искупленяя через соединение ее с символикой мессианизма $\mathrm{k}$ строгой христианской мистерич, соелинякщей фоъективную символиху с незыблемой почвой догматнки. что имеет место в Нlapсифале.

Логика развития - изумнтельн) строга и вполне осязательна: от лемонизма и пессимкзма $\mathrm{K}$ искуплению. через искупление к возврату н возрождению. 251

Ellis geht in seiner Arbeit recht genau auf Wagners Quellen für den "Parsifal" ein. auf die Gralslegenden des Mittelalters: die Legende, wie sie in den Apokryphen des Nikodemus steht. Chrétien de Troies "Parsifal" aus dem 12. Jahrhunden (in diesem Zusammenhang behandelt er die inneren Werte des Rittertums im Mittelalter), und schlieBlich der "Parsifal" von Wolfram von Eschenbach (die deutsche Version des 16. [sic!] Jahrhunderts) ${ }^{252}$. Ausführlich diskutiert er Gemeinsamkeiten und Abweichungen zwischen Wagners "Parsifal" und seinen Quellen253.

Abschließend weist Ėllis darauf hin. daB Wagner zu Beginn der 80-er Jahre (des 19. Jahrhunderts), als er seinen "Parsifal" schuf, von seinen Mitmenschen nicht verstanden wurde, da ihnen das christliche BewuBtsein fehlte 254 :

249 Ebd., S. 52.

250 Ebd.. S. 35.

251 Ebd.

252 Vermutlich ein Druckfehler, es müBte 13. Jahrhunden heißen.

253 Труды и дин. 1913, S. 36-48.

254 Wagner war zwar zu der Zeit bereits der bekannte und gefeiene "Star" und "Meister" von Bay reuth. aber seine Wandlung und Hinwendung zu christlich-religiösen Themen, seine Auffassung von Christentum und Religion, wie sie im "Parsifal" zum Ausdruck kommt, wurde von einigen seiner Zeit genossen tatsächlich nicht oder miBverstanden (das deutlichste Beispiel dafür ist Nietzsche!). 
Если в наши дни мы явлемся свидетелями всюду возрождающегося христианского самосознання. то в пернод создания /Іарсифаяя. т.е. в начале 80-х rr. прошлого века. как одиноко, как непонтно и странно прозвучал голос Вагнера. сколько нападений и несправепливых гонений. закончившихся безумным самоубийстенным бредом Фрндрнха Ницше 255 . предстояло вынести его завету, который был (как мы старались показать) духовным итогом и окончательной победой всей его жизни. 256

Ėllis sieht die gegenwärtige Literatur und Kultur am Scheideweg stehen: Einerseits könne man zu den Formen der sogenannten "reinen Kunst" ohne philosophische und religiöse Ziele zurückkehren, andererseits müsse man jedoch den Weg wählen, der alle künstlerischen Aufgaben und Formen dem freien Geist des Christentums zuordne 257 .

Dieses Problem habe der Wagner-Nietzsche-Kontroverse zugrundegelegen, aus der Nietzsche als Sieger hervorzugehen schien. Doch nun zeige sich, daB, im Gegenteil, das christliche Thema des heiligen Grals neu erstehe. Laut Ellis ist Wagner Nietzsche überlegen.

Ëllis beendet seinen "Parsifal"-Aufsatz folgendermaßen:

Ввырастает перед нами образ совершенного рыцаря Парсифаця. одним магическим жестом которого. вычерчивакиим св. копьем знах Креста. побеждается сила древнего проклятья. гордость и сладострастие. дьпашие в современном искусстве. и звучит среди всех этих тем - прнзыв к искупленнк и ожнданию помоши свыше. звучат всего явственнее заключительные слова мнстерия:

«Являет чудо Избавителя.

«Се - искупленье Искупнтеля... 258

\section{A.V. Lavrov charakterisiert Ėllis' "Parsifal"-Aufsatz folgendermaBen:}

Что касается статьи Эллиса "«Парсифаль» Рмхарда Вагнера" [...], то она гораздо содержательнее говорила о новом повороте в илейных исканиях поэта-символнста (который быстро разочаровался в антропософин и укрепился в своем преклонения перед средне вековым религнозным искусством и идеей духовного рыцарства), чем собственно о послелней опере-мистерни немецкого композитора. 259

Dic Beschäftigung mit Wagners Werk, vor allem mit dem "Parsifal", war von großer Bedeutung für Ellis' Entwicklung. da er dadurch eine Bestätigung seines zunehmenden Interesses für das Ritterum und den Mittelalterkult fand, denen er sich immer mehr zuwandte, nachdem seine Begeisterung für die Anthroposophie und seine Verehrung R. Steiners abgeklungen war.

Durch die fortwährende Zuwendung zum mittelalterlichen Rittertum übt Ėllis wohl eher unbewuBt - die ambivalente Praxis des Symbolismus aus: die feme Ver-

255 Nietzsche wurde jedoch viel weniger verstanden und war tatsächlich einsam und alleine, im Gegensatz zu Wagner.

256 Труды и днн. 1913, S. 52.

257 Ebd.. S. 53.

258 Ebd. Bei Wagner heiBen diese zwei letzten Verse:

"Höchsten Heiles Wunder!

Erlösung dem Erlöser!"

(Vgl. R. Wagner: Parsifal. Stuttgan (Reclam|. 1976. S. 61).

Auch später, in seiner zweiten Schaffensperiode, befaBte sich Ėllis weitertin mit Wagner bzw. mit dem "Tempel des heiligen Grales" und publiziente eine Arbeit darüber (vgl. L. Kobilinsky (Ellis): Der Tempel des heiligen Grales als Dichtung und Wahrheit. In: Bayreuther Blätter, 1, 1932, S. 21-28: 2. 1932, S. 94-108).

259 A.V. Lavrov: "Trudy i dni", a.a.O.. S. 209.

M. Ljunggren (The Russian Mephisto, a.a.O., S. 68) nennt Ėllis' Parsifal-Aufsatz "a self-indulgent interpretation of Parsifal |..." 
gangenheit bot vielen russischen Symbolisten schöpferische Energien, vergessene Kulturen gelangten in ihren Werken zu völlig neuem Leben. Nicht nur Ėllis wandte sich dem Mittelalter zu, sondem zum Beispiel auch V. Brjusov (in seinem Roman "Огненный ангел") oder A. Blok (in seiner frühen Lyrik 260 und in seiner Übersetzung des "Miracle von Rutebeufe"); andere russische Symbolisten griffen auf die klassische Antike zurück (etwa Vjač. Ivanov, Nilender usw.).

Außerdem ist Ėllis' Arbeit über Wagners "Parsifal" ein guter Beleg für die breite Wirkung Wagners in RuBland zur Zeit des Symbolismus. Wagners künstlerisches und auch sein philosophisch-publizistisches Werk waren zu Beginn dieses Jahrhunderts von ähnlich großer Bedeutung in RuBland wie die literarisch-philosophischen Schriften Friedrich Nietzsches. Nicht erst im erwähnten "Wagneriana"-Teil der Zeitschrift "Труды и дни" 261 , sondern bereits früher, in den symbolistischen Publikationsorganen "Мир искусства", "Весы" und "Золотое руно", finden sich Arbeiten zu Wagner 262. Unter den russischen Symbolisten waren es vor allem A. Blok. Vjač. Ivanov, A. Belyj, S. Solov'ev und G. Čulkov, die sich mit Wagner beschäftigten ${ }^{263}$. Neben

${ }^{260} \mathrm{Vgl}$. hierzu R.-D. Kluge: Westeuropa und RuBland im Weltbild A. Bloks. a.a.O., S. 33-36.

$261 \mathrm{Vgl}$. oben. S. $145 f$.

262 In "Мир искусства" wurden z.B. Teile aus H. Lichtenbergers Werk "R. Wagner als Dichter und Denker" (1899. Nr. 7-8, 11-12) und Nietzsches Aufsatz "Wagner in Bayreuth" (1900) auf Russisch abgedruckt sowie die wichtigsten Wagner-Inszenienungen auf europäischen und russischen Bühnen diskutien (vgl. D. Ricci: Richard Vagner v russkom simvolizme, a.a.O., S. 133). "Becы" publiziente Max Hochschülers "Письма из Байрейта" ("Briefe aus Bayreuth", vgl. Весы, 1904, Nr. 9, S. 39-46: Nr. 10, S. 49-58), in denen Hochschüler seine Eindrücke über die Aufführungen des "Ring des Nibelungen" und "Parsifals" schildert. die er in Bayreuth gesehen hat: er äuBert sich in seinen "Briefen" auch allgemein zu diesen Musikdramen Wagners, zum "verborgenen", "unsichtbaren" Orchester usw. $\dot{\mathrm{E}}$. Metner veröffentlichte in "Золотое руно" (1907. Nr. 7-9, 10, 1908, Nr. 1, 2, 3-4) Arbeiten über die Wagner-Festspiele in München 1907. (Vgl. hierzu auch die Inhaltsverzeichnisse von "Becb" und "30лотое руно".)

$263 \mathrm{~A}$. Blok befabte sich hereits seit 1898 mit $R$. Wagner und dessen Werk, besuchte regelmäBig Aufführungen von Wagner-()pern (vgl R.-D. Kluge: Westeuropa und RuBland im Weltbild A Bloks. a.a.O.. S. 89f.. 313; D. Rayfield: Celtic, Wagner and Blok. In: A. McMillin (ed.): Symbolism and After. Bristol, London 1992, S. 15-38) und schrieb, neben zahlreichen Eintragungen in seinen "Запнсные книжки" (Notizhefien) und Gedichten über Themen und Motive aus Wagners Werk, u.a. 1918 eine Einleitung zur Übersetzung von Wagners Traktat "Die Kunst und die Revolution" (vgl. A. Blok: Iskusstvo i revoljucija. Po povodu Richarda Vagnera. In: A. Blok: Sobranie soxinenij. Bd. 6, S. 21-26). (Zu Blok und Wagner vgl. auch R. Bartett: Wagner and Russia. a.a.O.. S. 195-217, 232. 358-362, 364.)

Vjac. Ivanov wandte sich am 28.12.1904 mit folgendem Anliegen brieflich an Brjusov: "[... Bompoc о Вагнере должен был бы разрабатываться в "Весах" постоянно. ибо он все еще вотрос открытый и имеет чентральное значение во всем искусстве. не только в музыке". (Vgl. Vją. Ivanov: Sobranie soxinenij. Bd. Il. S. 683). In mehreren Arbeiten setzte er sich mit Wagners Synthesekonzept auseinander, z.B. in "Вагнер и Дионисово действо" ("Wagner und die Tat des Dionysos", Весы. Nr. 2, 1905), in "Прелчувствия и предвестия" ("Vorahnungen und Vorzeichen". Золотое руно. Nr. 5-6. 1906), in "Чурлянис и проблема синтеза искусств" ("Čjurlënis und das Problem der Synthese der Künste", 1914: In: Sobranie socinenij. Tom III. Brjussel" 1979, S. 147-170) sowie in "O Barнepe" ("Über Wagner": in: Vestnik teatra. 31-32. 1919.S. 2f.). (Zu Ivanov und Wagner vgl. auch R. Bartlett: Ivanov and Wagner. In: W. Potthoff (Hrsg.): Vjaceslav Ivanov, a.a.O.. S. 67-83; Dies.: Wagner and Russia, a.a.O.. S. 117-139, 228-231, 339-344, 363.)

1905 erschien in RuBland Lichtenbergers Werk: "Wagner als Dichter und Denker" in der russischen Übersetzung von S. Solovev: A. Лихтанбертер: Рихарл Вагнер как поэт и мыслитель (vgl. hierzu auch die Rezension in "Золотое руно", Nr. 5. 1906. S. 87).

A. Belyj setzte sich ebenfalls intensiv mit Wagner und dessen Werk auseinander, wie zahlreiche ÄuBerungen in seinen theoretischen Arbeiten zum Symbolismus zeigen (vgl. z.B. A. Belyj: Okno v budušcee [1904; in: Ders.: Arabeski. Moskva 1911, S. 138-146): Ders.: Pesn' żizni |1908; in: Ders.: Arabeski. Moskva 1911, S. 43-59|: Ders.: Fridrich Niçe lin: Becы. 1908. Nr. 7, S. 45-50; Nr. 8, S. 
den Brüdern Nikolaj und Emilij Metner, die Wagners Werk durch Konzerte, Diskussionsabende. Vorträge und theoretische Arbeiten propagierten. wurde Wagner in Moskau vor allem im sogenannten "Maison du Lied" im Hause der Kammersängerin M.A. Olenina-d'Al'gejm auBerordentlich verehrt ${ }^{264}$. Besonders populär in RuBland war damals der "Ring des Nibelungen" (Blok zum Beispiel verfaBte einige frühe Ge dichte auf Motive aus dem "Ring") 265 . Der Kunst- und Literaturkritiker Sergej N. Durylin publizierte 1913 eine Studie über die Rolle Wagners in RuBland²66.

Ëllis bemüht sich, in seiner Arbeit den "Parsifal" im Kontext von Wagners Musikdramen insgesamt zu betrachten. Er sieht eine Entwicklung in Wagners musikalischdramatischem Werk, innerhalb derer der "Parsifal" als letztes, vollendetstes Werk und "Bühnenweihfestspiel" den abschließenden Höhepunkt bildet. Elllis fühlte sich durch dieses Werk Wagners in seinem Bestreben, eine Verbindung zwischen Kunst und Religion zu schaffen, bestätigt. Man muB sich allerdings fragen, ob er die Religiosität bei Wagner richtig dargestellt und verstanden hat, oder vielleicht überinterpretien bzw. zu sehr für sein eigenes Anliegen vereinnahmt? In diesem Zusammenhang muB darauf hingewiesen werden, daB die Wagner-Nietzsche-Kontroverse viel komplizierter ist als Ellis sie darstellt ${ }^{267}$. Die frühen, revolutionären Schriften Wagners behandelt Ėllis gar nicht; ebenso wenig berücksichtigt er die formalen und strukturellen Elemente in Wagners Werken bzw. im "Parsifal" und geht auch nicht näher auf Wagners theoretische Arbeiten zur Konzeption des "Gesamtkunstwerks" und des "Künstlermenschen der Zukunft" ein. Im Unterschied zu anderen Beschäftigungen mit Wagner zur Zeit des russischen Symbolismus ${ }^{268}$ äußert sich Ëllis nicht über Wagners Musik. (Bei A. Blok wurde der Begriff "Geist der Musik" [theoreti scher Begriff Nietzsches] ganz mabgeblich vom Erlebnis der Wagnerschen Musik mitgetragen).

Auch wenn sich Ėllis in seinem "Parsifal"-Aufsatz bemüht. Wagners musikdramatisches Schaffen insgesamt darzustellen und die Quellen, die Wagner für den "Parsi fal" verwendete, vollständig zu erfassen, muB sein Aufsatz doch insgesamt als recht subjektiv und einseitig bewertet werden und ist weniger für die Wagner- und "Parsifal"-Forschung in RuBland von Bedcutung als daB er vielmehr deutlich die Richtung aufzeigt, die Ellis in seinen folgenden Arbeiten und seiner zweiten Schaffensphase einschlagen wird.

Hätte Ėllis sein Vorhaben ausgeführ und tatsächlich alle Musikdramen Wagners ins Russische übersetzt, wäre dies zweifellos ein großes Verdienst gewesen, denn vollständig wurden sie erst um die Mitte der zweiten Dekade dieses Jahrhunderts in RuBland bekannt. Was Wagners theoretische Arbeiten betrifft, war "Das Kunstwerk der Zukunft" bereits 1897-1898 in russischer Übersetzung in der "Русская музыкальная газета" ("Russische Musikzeitung") erschienen ${ }^{269}$. In den folgenden Jahren

55-65; Nr. 9. S. 30-39]: Ders.: Revoljucija i kul'tura. Moskva 1917). (Zu Belyj und Wagner vgl. auch

R. Barlett: Wagner and Russia, a.a.O.. S. 140-194, 231. 282-284, 344-358. 363f.. 368f.)

Auch G. Culkov war ein leidenschafilicher Verehrer Wagners (vgl. z.B. seine ÄuBerungen in G.

Culkov: Principy teatra budušcego. In: Teatr. Kniga o novom teatre. SPb. 1908, S. 199-217).

$264 \mathrm{Vgl}$. hierzu auch R. Barlett: Wagner and Russia. a.a.O.. S. $166 f$.

$265 \mathrm{Vgl}$. R.-D. Kluge: RuBland und Europa im Weltbild A. Bloks. a.a.O., S. 89.

266 Vgl. S.N. Durylin: Richard Vagner i Rossija. O Vagnere i budušxich putjach iskusstva. Moskva ("Musaget") 1913 (68 S.).

$267 \mathrm{Vgl}$. oben. S. $138 \mathrm{f}$. und S. $148 \mathrm{f}$.

$268 \mathrm{Vgl}$. etwa E.K. Metner |Vol'fingl: Modernizm i muzyka: Stat'i kritičeskie i polemiceskie. Moskva 1912: Max Hochschüler: Pis'mo iz Bajrejta: 1. In: Becы. Nr. 9, 1904 (zur Leitmotivik und zum Dionysischen und Apollinischen in Wagners Musik).

269 Die "Русская музькальная газета" (1894-1918) war die erste musikwissenschafiliche Zeit schrift in RuBland überhaupt: sie war sehr um Wagner bemüht und publiziene seit Beginn ihres Erscheinens regelmäBig Artikel über Wagner und sein Werk, Übersetzungen seiner literarischen und theoreti- 
wandte die Zeitschrift "Мир искусства" Wagner große Aufmerksamkeit zu und begann sein Werk zu propagieren und zu interpretieren. "Kunst und Revolution" sowie "Oper und Drama" wurden 1906 und ersteres noch einmal 1908 ins Russische übersetzt, 1911-1912 erschien eine russische Ausgabe von Wagners autobiographischem Werk (4 Bände). Weitere Bände mit ausgewählten Werken Wagners wurden jedoch erst in sowjetischer Zeit publiziert ${ }^{270}$.

\section{c) Ellis' Beschäftigung mit Dante}

Die große Bewunderung, die Ėllis Dante und dessen Werk zollte, ist eine seiner wenigen Leidenschaften, die keine Unterbrechung gekannt hat, sondem von 1902/03 bis mindestens 1914 anhielt (im Gegensatz zu seiner Begeisterung für Ökonomie. Baudelaire und die französischen Symbolisten, für Brjusov und Steiner; für Goethe und Wagner begann er sich erst später, ab etwa 1906/07, zu interessieren). Neben den bereits angeführten Übersetzungen aus Dantes Werk ${ }^{27 I}$ schrieb Ėllis zwei Aufsätze über ihn: "Венец Данте" 272 und "Учитель веры"273. Aber auch in seinen anderen Arbeiten geht er häufig auf Dante ein274.

Seit der Romantik haben Dante und sein Werk, vor allem die "Divina Commedia", eine wichtige Rolle in RuBland und in der russischen Literatur gespielt 275 . Wie in der Romantik, so herrschte auch im Symbolismus zunächst das Bild von Dante als Höllendichter vor (so zum Beispiel auch bei Ëllis in "Иммортели") 276. Vor allem bei den sogenannten "jüngeren" Symbolisten entstand dann jedoch das Bild von Dante als religiösem Dichter 277: der zweite und dritte Teil der "Divina Commedia" ("Purgatorio" und "Paradiso") sowie die "Vita Nuova" wurden erst durch die Symbolisten ent -

schen Arbeiten. Berichte über Wagner-Aufführungen in RuBland etc. (Vgl. R. Bartlett: Wagner and Russia. a.a.O.. S. 59-65.)

270 $\mathrm{Vgl}$. hierzu D. Ricci [Rizzi]: Richard Vagner v russkom simvolizme, a.a.O., S. 133f. sowie R.

Bartlett: Wagner and Russia. a.a.O.. S. 372-374

$271 \mathrm{Vgl}$. S $49 \mathrm{f}$. der vorliegenden Arteit

272 In "Свободная совесть I", 1906.

273 Im Teil "Danteana" in der Zeitschrift "Tруды и дин". 1914.

274 Z.B. in einigen "Becы"-Aufsätzen von 1907/08, in "Русские символисты" (1910), in seinem Aufsatz über Richard Wagners "Parsifal" ("Tрулы и пнн". 1913) und in seinem Trakıat "Vigilemus!" (1914).

Die Rolle, die Dante in RuBland, in der nussischen Literatur allgemein und im russischen Symbolismus speziell gespielt hat, wird recht austührlich in Wilfned Potthoffs erwähntem umfassenden Werk "Dante in Rubland. Zur Italienrezeption der russischen Literatur von der Romantik zum Symbolismus" (Heidelberg 1991) untersucht, wobei Potthoff darin auch detaillien auf das Thema "Dante und Éllis" eıngeht. Vera Pepitoni kommt in ihrem genannten Aufsatz "Ellıs Kobilinskij tra Dante e Marx" (in: Danusmo Russo e Cornice Europea. Firenze 1989, S. 293-314) sowie auch in ihrer Diplomarbeit ebenfalls auf Éllis' Dante-Aufsätze und seine Beschäfugung mit Dante allgemein zu sprechen.

275 Potthoff geht in seiner Arbeit von einer Kontinuität zwischen Romantik und Symbolismus aus und weist explizit darauf hın, dab der "symbolistische Dante" romantische Ursprünge habe (W. Potthoff: Dante in Rubland, a.a.O., S. 15). Die erste Berührung Rublands mit Dante sei zwar bereits für das Jahr 1757 belegt (ebd.. S. 59). aber die eıgentliche Entdeckung Dantes habe erst in der Romantik stattgefunden (ebd., S. 601). Die Romantik habe die mythenschaffende Kraft der "Divina Commedia" entdeckt. das Bild des "surovyj Dant" sei typisch gewesen (ebd.. S. 74). Die Übersetzungen Dantes zur Zeit der Komanuk zeigten die Vorliebe für den grausamen und schreckjichen Dante (ebd., S. 100). also für Dante als Höllendichter, d.h., es wird im wesentlichen aus dem "Inferno" übersetzt. Die mabgeblichen Übersetzungen Dantes seien allerdings erst in nachromantischer Zeit entstanden: "Die 50er bis 80er Jahre geben dem Symbolismus die ersten Vorbilder und Muster" (ebd.. S. 151).

$276 \mathrm{Vgl}$. hierzu auch W. Potthoff: Dante in RuBland. a.a.O., S. \$43.

277 Ebd. S. 384-457. 
deckt, von ihnen übersetzt, kommentier und nachgedichtet ${ }^{278}$. (Ein Beispiel hierfür stellt Ellis' Gedichtband "Stigmata" dar.) So wird das eigentliche Bild Dantes in RuBland also erst im Symbolismus erschlossen:

Der Schwerpunkt der Aufnahme Dantes in RuBland ist in der Literatur der Jahrhunderwende zu sehen und insbesondere mit den symbolistischen neoromantischen Tendenzen zu verknüpfen. So hat die Neigung zu neuidealistischen Konzepten, zur universalen Synthese die Entstehung des Bildes des synästhetischen und symbolischen Dante. des religiösen Dichters und des Dichters der Krise begünstigt, während zugleich der Entwurf des barbarischen Dichters der Hölle seiner Aufnahme den Weg bereitete. 279

Wie Potthoff zu Recht betont ${ }^{280}$, herrscht bei Ėllis das religiöse Verständnis Dantes im ganzen Werk vor.

In seinem Aufsatz "Венец Данте"281 (wie später auch noch in seinem Traktat "Vigilemus!", 1914) betont Ėllis die Parallele zwischen dem "Infermo" Dantes und der gegenwärtigen Zeit, d.h. der Welt, in der er lebt. Es heißt bei Ellis:

Tеперь, когда все ужасы Дантовскаго "Ада" стали действительностью. тем. чем мы дышим. с чем встречаемся каждый мит, когда разбиты все чистые сердца. жизнь становится кошмаром и над кажљым из нас склоняется призрак отчаянья и безумия; когда наша роди на. так же как некогда родина Данте превращена в одну сплошную рану, которую не перестает ни на мгновение пытать железо палачей, когда в каждое мгновенье оскорбляется всё святое. всё заветное. и нет путей спасения - именно теперь все более и более является понятным неудержимое стремление склонить колена перед тенью того. вся жизнь которого было одно страдание, одна сплошная пьтка. кго не знал никаких сделок с совестью, никаких компромиссов с жизнью, находя высший источник утешения в общения с иными мирами. и чем молитвеннее и нежнее поклонялся Вечной Розе. тем неумолимее и беспошаднее ратовал против бесчисленных полчищ врагов Истины. Добра и Красоты!. .282

$278 \mathrm{Vgl}$. Ebd., S. 151, 153, 325.

279 Ehd.. S. 601. Potthoff fuihn in seinem Werk aus, wie Dante in zunehmendem Mabe Eingang "in den Kern der symbolistischen Poetik und Ästhetik" findet (ebd., S. 601f.). Dabei sei weniger die Auf fassung vom Symbolismus als dichterischer oder literarischer "Schule" von Bedeutung. sondem vielmehr die Auffassung vom Symbolismus als Weltanschauung. vom Symbolismus, der eine Brücke zur Religion schlage (so A. Belyjs Auffassung), vom zeitlosen Symbolismus (ebd., S. 22: in diesem Zusammenhang kommt Potthoff auf den "Symbolistenstreit" in der Zeitschrift "Apollon" zu sprechen): "Die Rezeption Dantes stellt sich in Teilen als Wirkungsgeschichte der romantischen Schule und der Hegelianischen Ästhetik dar. Sie begründen bereits das symbolische Verständnis Dantes bei den russischen Romantikem. Die Rolle Dantes im Symbolismus stellt in dieser Hinsicht ein Indiz dar, wie er sich nicht mehr als Schule, sondem zunehmend als Weltverständnis begreift und in gleichem Maße seiner 'modemen' Züge entkleidet wird." (Ebd.. S. 602. In diese Art von Symbolismus /also Symbolismus, der sich "als Weltverständnis begreift" und "seiner 'modermen' Züge entkleidet wird"] müssen Ëllis und sein Werk eingeordnet werden.) Gerade in den mystisch-religiösen Zügen des zeitlosen oder überzeitlichen Symbolismus sieht Potthoff einen weiteren Anknüpfungspunkt an die Romantik: ebenso im Bild des Dichters als Propheten oder Theurgen. Das Verständnis Dantes als religiöser Dichter passe dann natürlich gut in die Theurgievorstellungen des russischen Symbolismus. Als wichtige Vermittler hierfuir fuihn Potthoff nicht nur Schlegel und Schelling an, sondem auch Cartyle und die englischen Präraffaeliten. vor allem Arthur Symons und dessen Theorie des Symbolismus als spiritualistisch-mystischer Literatur. Symons formulien am Ende seines Vorworts zu "The Symbolist Movement" sein Credo: "literature ... becomes itself a kind of religion" (ebd.. S. 182).

Potthoffs umfassendes Werk basiert im wesentlichen auf der traditionellen Symbolismusauffassung: Symbolismus wird verstanden als Anknüpfung an die Romantik. als Höhepunkı und AbschluB der aristotelischen oder mimetischen Kunst- und Literaturperiode. als Ästhetizismus. Vor allem die neoromantischen Züge des Symbolismus sind für Potthoffs Untersuchung von grober Bedeutung

280 W. Potthoff: Dante in RuBland, a.a.O.. S. 440.

281 In: Свобопная совесть I. 1906, S. 110-138.

282 Ebd.. S. 111. 
Ėllis faBt die "Divina Commedia" als christliches Lehrgedicht (im positiven Sinne) auf283. Das Ziel aller von Dante verwendeten Symbole in den drei Teilen der "Divina Commedia" sei die Kontemplation Gottes; alles bei Dante sei bloB Mittel zur Gotterkenntnis ("богопознание") 284 $^{28}$ In diesem Zusammenhang weist Potthoff darauf hin, daB die Erkenntnis Gottes, also "богопознание", das Ziel der Bewegung des "бoroискательство" ("Gottsuchertums") war und meint, daB Ėllis an dieser Stelle Dante in einen Zusammenhang mit zeitgenössischen religiösen Bestrebungen bringe ${ }^{285}$. Diese Tatsache hebt Potthoff als neue eigene Position von Ėllis hervor ${ }^{286}$. Elllis betont, da $B$ Dante nicht an den Endsieg des Guten in dieser Welt geglaubt habe; er sei Pessimist gewesen, wurde nicht verstanden, stand verlassen und alleine da:

Данте не верил в окончательное торжество в этом мире добра. он не ждал раскаяния закоснельх грешнихов и не желал им прощения ...

В этом заключается одна из оритинальнейших и нанболее ужасных черт его мрачной. сосредоточеннюй и замкнутой от мира и людей. великой души ...

Он знал Истнну, но его не поняли: он звал. - за ннм не последовали!.. 287

Ėllis begreift die "Göttliche Komödie" als Weg zur metaphysischen Erkenntnis. Anhand von Episoden aus dem "Purgatorio" und "Paradiso", die er übersetzt, führ er den stufenweisen Erkenntniserwerb vor und geht in diesem Zusammenhang auf die Gestalt der Beatrice ein, die er symbolisch interpretient: sie sei die Verkörperung von Schönheit, Wahrheit und Weisheit, das höchste Ideal des "Ewig-Weiblichen", das Vorbild für Vl. Solov'evs "Sophia". Als Kem der "Göttlichen Komödie" hebt er Beatrices anhaltende Liebe zu Dante hervor: Sie selbst habe die Reise für Dante organisiert, um ihn vor den Irrtümem. Sehnsüchten und dem Abgrund, an dem er steht, zu bewahren 288. Ausführlich beschreibt Ëllis Dantes Weg im Paradies von einem Himmel zum nächsten und nennt das "Paradiso" den höchsten poetischen Ausdruck aller Zeiten:

Ни один поэтический геняй. ни одн мистическळе прозренне - даже в моменты высшего зкстаза - ни прежле. ни после не создали нючего равного "Раю" Данте. 289

Das Ziel der ganzen Reise sei, zu Gott zu gelangen und ihn zu schauen. Um dabei nicht zu erblinden, müsse der Mensch zuvor die nötigen Vorbereitungsstufen durchlaufen. Dies sei die Hauptidee des "Paradiso"290.

Den SchluB seines Aufsatzes widmet Ëllis den letzten Versen der "Göttlichen Komödie" (33. Gesang des "Paradiso"), die seiner Meinung nach mehr Angst und Schrecken verursachen, als die dunkelsten Bilder des "Inferno", weil der Mensch hier seine eigene Nichtigkeit begreife 291 .

Ėllis' kommt zu einer Bewertung der Künste im Zusammenhang mit den drei Teilen der "Divina Commedia": Die Architektur ist für ihn die unvollkommenste Kunst. da sie am materiellsten sei und den "Traum" ("мечта") in drei Dimensionen festlege. Die nächste Stufe sei die Malerei mit nur noch zwei Dimensionen. Lediglich die Dichtung könne uns das Zittem/Beben des Traumes selbst vermitteln und nur die

$283 \mathrm{Vgl}$. dazu auch W. Potthoff: Dante in RuBland, a.a.O., S. 440,450.

284 Cвободная совесть I. S. 113.

285 W. Pothoff: Dante in RuBland, a.a.O., S. 442.

286 Ebd., S. 440.

287 Cво6одная совесть I. S. 113.

$288 \mathrm{Vgl}$. W. Pothoff: Dante in RuBiand, a.a.O., S. 442: Своболная совесть I. S. 118, 126, 128.

289 Свободная совесть I. S. 128.

290 Vgl. V. Pepitoni: Ellis Kobylinskij tra Dante e Marx, a.a.O., S. 309.

291 Сво6огная совесть I. S. $136 f$. 
Musik sei "unbeschreiblich schön" ("и лишь музыка невыразимо-прекрасна!..")292. Weiter heiBt es bei Ellis: "Поэтому «Ад" Данте более всего скульптурен, «Чистилище» более всего живописно и только «Рай» музыкален. "293 Er bringt diese Bewertung mit dem Auftreten Beatrices in Zusammenhang:

В «Алу» нет места Беатриче. в бледном свете «Чистилнща" она лиив случайная гостья и только в «Раю» небесном Беатриче раскрывает свою всеобъемлюиию суиннсть $[. . .]^{294}$

Im Rahmen seiner Rezension von "Свободная совесть I"295 formulien A. Blok seine Meinung über Ëllis' Dante-Aufsatz folgendermaßen:

[...] статья г. Эллиса о Данте была бы интересна. если бы прежде всего не прерывалась тщетными чпражнениями в переводах из Данте и если бы сам г. Эллис не так часто впадал в кстерику. 296

Damit hat Blok auf Ellis' hyperbolischen, unkritisch preisenden Tonfall hingewiesen. Dieser verwendet häufig Begriffe, ohne sie zu reflektieren. So z.B. den Begriff "Ekstase"297. Mystik und religiöse Kunst werden im traditionellen Kunstverständnis sowie auch hier bei Ellis mit Kontemplation, d.h. einer passiven Haltung, zusammengebracht. Ekstase dahingegen bedeutet ein Heraustreten, eine aktive Haltung. Kontemplation und Ekstase müssen sich eigentlich ausschlieBen. Entweder wird Gott kontemplativ (passiv) geschaut, oder man muB ihm aktiv entgegengehen, damit auch er einem entgegenkommt, also in Ekstase geraten. Religiöse Kunst muB nicht zwingend kontemplativ sein.

In seinem 1914 im "Danteana"-Teil von "Труды и дни" abgedruckten Aufsatz über Dante mit dem Titel "У читель веры" weist Ëllis darauf hin. daB er gerade an einem großen Werk mit dem Titel "Божественная Комедия Данте как христианская мистерия" ("Die Göttliche Komödie Dantes als christliches Mysterium") arbeite (das allerdings nie publizien wurde) und im vorliegenden Aufsatz den Lesem von "Труды и дни" einige seiner Gedanken aus diesem Werk darlegen möchte.

Diese zweite Arbeit über Dante unterscheidet sich nicht wesentlich von der vorangehenden Dante-Deutung: Ellis wiederholt sich in seinen Hauptaussagen, da B die "Divina Commedia" vor allem religiös aufzufassen sei und die Entstehung des Glaubens an den lebendigen Gott und den Sohn Gottes darstelle. Dante sei "der große Lehrer des Glaubens", der "Glaubensweg" ("путь веры")298. Die Entwicklung innerhalb dieses Poems führe vom Menschlichen zum Göttlichen, vom Beschreiben persönlicher Gefühle zum lebendigen Erleben von Dogmata, vom "amo" zum "credo", vom Anblick der niedrigeren und höheren Welt zur Vision Gottes ${ }^{299}$. Dantes ganzer Weg sei der umgekehrte Weg des Sündenfalls: Durch die Qualen der Hölle zur Hoffnung des. Fegefeuers und schlieBlich zum Glauben des Paradieses. Die Ursache aller

292 Ebd., S. 126.

Das entspricht der allgemeinen Auffassung von der Musik als der höchsten aller Künste bei den Symbolisten. Ëllis ist in seiner Bewertung der Künste jedoch eklektisch; vgl. auch A. Schopenhauer: Die Welt als Wille und Vorstellung. 3. Buch: R.-D. Kluge: Zur Deutung der Musik in der Dichtungstheorie einiger russischer Romantiker und Symbolisten. In: Die Musikforschung. 1969. S. 13-22.

293 С вo6onная совесть I. S. 127.

294 Ebd.

295 In der Zeitschrift "Becы", 1906. Nr. 2.

296 Zitient aus: A. Blok: Sobranie soxinenij, a.a.O., Bd. 5. S. 609 f.

$297 \mathrm{Vgl}$. Zitat auf S. 154 der vorliegenden Arbeit.

298 Труды и днн. 1914. S. 64.

299 Entsprechend hatte Ëllis die Entwicklung innerhalb Wagners musikdramatischem Werk charakterisien (vgl. oben. S. 146f.). 
Sündenfälle und des ersten Falles von Luzifer sei der Stolz gewesen. der Glaube nur an sich selbst; deshalb könne die Heilung, die Rückkehr nur im völligen Glauben an Gott liegen.

Durch seine Auffassung der "Divina Commedia" als christliches Lehrgedicht, als dogmatisches Poem, grenzt sich Ëllis von der romantischen Auffassung, die "Divina Commedia" sei vor allem ein Poem der Liebe von Dante und Beatrice, $a b^{300}$. In diesem Zusammenhang charakterisiert er den Unterschied zwischen Symbol und Dogma: das Symbol werde durch die menschliche Betrachtung und Phantasiekraft von unten nach oben aufgebaut, das Dogma steige von oben herab, von Gott zu den Menschen, das Dogma sei immer ein "credo", aber sein Inhalt sei lebendig und real. Religion ohne Dogmen sei nicht nur sinnlos, sondern auch geschmacklos 301 .

Entsprechend hebt Ėllis den 24.-27. Gesang des "Paradiso" als Zentrum der "Divina Commedia" hervor, da hier die Prüfung des Glaubens dargestellt werde.

\section{A. Lavrov kommentien den zweiten Dante-Aufsatz von Ellis sehr treffend:}

[...] статья Эллиса *Учитель веры» [...]. Фанатически восторженная. воспеваюшая «Божественную Комедию" ках христианскую мистерию и прославляющвя релитиозный догматнзм средневековья. ${ }^{302}$

Ellis' Definition von Symbol und Dogma steht in krassem Widerspruch zu Vjač. Ivanovs Formel "a realibus ad realiora"303 ("vom Realen zum Realeren", das heiBt, die äußere Hülle der Welt [realia] verbirgt die wahre Wirklichkeit [realiora]): das Symbol steigt auf nach oben zum Transzendenten und wieder herunter, versucht, das Transzendente verständlich zu machen. Das offene, wirkende Symbol bei Ivanov ist ein ProzeB. Bei Ėllis gibt es diesen ProzeB nicht und das Auf- und Absteigen wird nicht als Einheit zusammengefaBt. Ellis hat die poetologische Position von Ivanov in eine theologische umfunktioniert (theologischer Symbol- und Dogmenbegriff).

Potthoff kommt insgesamt, was Ėllis' Beschäftigung mit Dante anbelangt. zu dem folgenden Ergebnis:

Es ist klar, daß Ėllis auf besondere Weise den Weg zum Bild des mystischen Dante markien Die Vorstellungen von Ellis sind hier von großer Einheitlichkeit, wie seine literaturkritischen Aufsätze zeigen. Sie entsprechen aber durchaus auch einer bei den Symbolisten insgesamt zu beobachtenden Tendenz zu einer gewissen Verstärkung der mystischen Züge. ${ }^{304}$

Somit reiht Potthoff Ėllis in den Kontext bzw. in die Strömung des russischen Symbolismus ein. die Symbolismus weniger als literarische Schule denn als Weltanschauung versteht. Weltanschauung bei Ellis ist immer mystisch-religiös. Diese weltanschauliche Ausrichtung wird zunehmend stärker. Für Ellis heiBt das konkret: Kunst

${ }^{300}$ Vgl. dazu auch W. Potthoff: Dante in RuBland. a.a.O., S. 450.

301 Труты и днн, 1914, S. 71.

In seinem zwei Jahre zuvor publizienten dritten "Münchner Brief" hatte sich Ëllis noch vehement ge gen die dogmatisch festgelegten Lehren und toten Formen des gegenwärigen kirchlichen Lebens ausgesprochen (vgl. oben. S. 137), während er hier nun den Inhalt des Dogmas als "lebendig" und "real" bezeichnet. Er hat sich inzwischen vom Symbolismus und allen neueren literarischen und philosophischen Strömungen abgewandı und vertritt die eigenwillige Theorie. daB die Menschheit ohne Unterwerfung unter die Dogmen des mittelalterlichen Katholizismus verloren sei. Statt Kreativität und Offenheit des symbolistischen Symbols fordert er feste Normen und strikte Verordnungen. die es nicht zu hinterfragen gilt.

302 A. Lavtov: "Trudy i dni", a.a.O., S. 209.

${ }^{303}$ Diese Formel legt VjaC. Ivanov ausführlich in seinem Aufsatz "Две стихин в современном символитме" (1908) dar.

304 W. Potthoff: Dante in RuBland, a.a.O.. S. 523. 
muß zu Religion werden bzw. die im Mittelalter existierende Verbindung von Kunst und Religion muB wieder erreicht werden. Hierin kann bereits eine Überleitung zu seinem Spätwerk, seiner zweiten Schaffensperiode, gesehen werden: er versteht "ars sacra" als einzig wahre Kunst und findet sie in den Meisterwerken Žukovskijs, Puškins und Vl. Solov'evs.

An dieser Stelle kommt unwillkürlich wieder die Frage auf: War Ėllis überhaupt Symbolist? War er nicht vielleicht ein verspäteter Romantiker? Er geht zumindest einen Weg, den vor ihm viele Romantiker gegangen sind, die auf ihrer Suche nach einer positiven Unendlichkeit enttäuscht wurden und sich schlieBlich der Religion und dem Katholizismus zuwandten. 


\section{d. "Vigilemus!"}

Ėllis' Traktat "Vigilemus!", der 1913 entstand und 1914 im "Musaget"-Verlag erschien', besteht aus drei Kapiteln ("Hora Novissima", "Tempora Pessima", "Vigilemus!") und zehn Exkursen. Im Vorwort weist Ėllis darauf hin, daB "Vigilemus!" die Fortsetzung von "Русские символисты" sei und gleichzeitig eine Art Programm seiner zukünftigen Arbeiten. Wie bereits in "Русские символисты" bringt Ellis auch hier die Kulturerscheinungen und insbesondere die Kunst in Zusammenhang mit religiösen Werten, aber in noch viel extremerer Weise. Dadurch ist diese recht wirt und konfus anmutende Schrift jedoch von wesentlich geringerer Bedeutung und viel einseitiger ausgerichtet als "Русские символисты". Da sie aber sowohl als wichtiges Produkt einer schweren persönlichen Krise von Ėllis als auch als - allerdings sehr verspäteter - Ausdruck der geistigen und Kulturkrise der Zeit zu verstehen ist, darf ihr in der vorliegenden Darstellung von Ėllis' Leben und Werk ein gewisser Stellenwert zugestanden werden. Zudem wirft es ein bezeichnendes Licht auf die damalige Zeit. daB sich ein Verleger für dieses Werk fand und es in einem so renommierten Verlag wie "Musaget" publizien werden konnte.

Fast jeden Tag, heiBt es im Vorwor, würden die grundsätzlichen Ideen von Religion und Christentum stark verschleiert und entstellt, nicht zuletzt durch den gegenwärtigen MiBbrauch von Theosophie und Okkultismus. Die Menscheit habe die wahre christliche Religion verloren und sei zur Magie und Theosophie zurückgekehr. Deshalb möchte Ëllis in seinem Traktat die elementaren, allgemeinen christlichen Wahrheiten noch einmal wiederholen. In diesem Zusammenhang hebt er hervor, daB er von allen christlichen Strömungen der Lehre Vl. Solov'evs am nächsten stehe, in dessen Wort und Tat er den Beginn der von ihm erwarteten Rückkehr der Menschen zu Gott sieht ${ }^{2}$. Sein Hauptanliegen formuliert er folgendermaßen:

\footnotetext{
Основное стремлекне автора труптировать и даже выволить явления культуры и в част ности искусства из релитнозного пути отнюль не является чем-то новым и непоследовательным в общем ходе его развнтия. Уже в "Русских символистах" автором сделана 06 шьая потытка сведения последних сожровенных устремлений соеременното символизма $k$ релнгиозным иенностям. Та же идея положена в основу ряда статей его в "Трудах и Дняx". Здесь попьтка эта носит более отределенньй и четкий характер; сама богатая событиями духовная жизнь нашего времени за последние годы служит в этом случае лучшим указателем: тот факт. что мы стонм перед релитиозным возрожленнем - бесспорен! |... "Vigilemus" отнопь не является бряшорой полемнческой; в ней сжатое credo автора - и только! ${ }^{3}$
}

Im ersten Kapitel, "Hora novissima"4, fühn Ėllis aus, daB gegenwäntig der Sinn des Symbolismus immer deutlicher werde als Ahnung und Vorgefühl einer neuen $\mathrm{Zu}$ kunf, als "neueste Stunde", die erwartet wird. Er beschreibt seine Gegenwar, in der alle Grenzen in Bewegung geraten und alle hierarchischen Verbindungen zerreißen, in der gehegte religiöse Erwartungen vollkommen umgewertet werden und auch die politischen Grenzen ins Wanken geraten ${ }^{5}$. Die erwartete neue Zeit vergleicht er ihrer Größe und Bedeutung nach mit dem Erscheinen Christi auf Erden.

I Vgl. das Unterkapitel "Éllis und R. Steiner", S. 130-133.

2 Ellis: Vigilemus! Moskva 1914, S. V-VII.

${ }^{3}$ Ebd., S. VII.

4 Ebd.. S. 4-11.

5 Diese von Ėlis beschriebene "Umwertung aller Wene" ("переоценха всех иенностей") geht auf Nietzsche zurück, dessen kulturkritische Philosophie die russischen Symbolisten bereits um die Jahrhundertwende maBgeblich beeinfluBte (vgl. oben. "Einleitung" der vorliegenden Arbeit. S. 22), ist hier in "Vigilemus!" jedoch längst nicht mehr zeitgemäB. sondem eklektisch. Ëllis schrieb seinen Traktat am 
Er charakterisien sich und seine gleichgesinnten Zeitgenossen:

Мы символисты в двух смыслах: в нас всего слышнее говорят голоса старых богов. первые мы увидели свет древних мистерий и правду мертвых культур; и мы же всего ревностнее пожелали этот свет принять, как свет от Света. понять смысл древних богов. лиш как подготовителей, смысл древних мистернй - лиш как мудрость ожидания Елиного Бога-Человека и Единой Мистерни. ${ }^{6}$

Ėllis wiederholt hier in noch extremerer Form seinen alten Gedanken vom ambivalenten Symbolismusbegriff: Der Symbolismus greife einerseits auf die "fernste Vergangenheit" zurück und sei andererseits auf die "endlose Zukunft" gerichtet ${ }^{7}$. Als Beispiele für die Synthese von Christentum und Antike fühn Ėllis - wie auch schon in früheren Arbeiten - wieder die Werke Nietzsches und Wagners an, die der westeuropäischen Symbolisten (Baudelaire, Huysmans, Rodenbach, Wilde, St. George, Rilke) und die der russischen (Merežkovskij, Ivanov, Belyj, Blok; femer charakte risien er kurz die Eigenan der Werke Brjusovs, Rozanovs, E.K. Metners, Bal'monts, Vološins, Kuzmins und A. Dobroljubovs).

In heute kaum nachvollziehbaren emphatischen und exaltierten Wendungen verkündet Ellis seine Thesen vom Symbolismus als religiöser christlicher Weltanschauung und Lebenspraxis, deren Spuren und Ansätze er bis in die vorchristliche Antike und sogar in die vorantike ägyptische Kultur zurückverfolgen zu können glaubt. Das geschieht auf abstrakt-spekulative Weise ohne konkrete Belege und ohne klare Begrifflichkeit; an ihre Stelle tritt der Enthusiasmus des von seiner Idee Besessenen:

\begin{abstract}
[...] все старые боги зовут нас [= die Symbolisten], и каждого сво бол, все лревнне культуры в нас ожили. но закон смены их нарушен. все они встали одновременно в нас, как в музее: боги наши собраны в еднный храм. в новый пантеон: говорим все мы на различных языках. но не как апостолы при сошествин Духа Святого, а как стронтели башнн вавилонской. Формула. по которой стронтся наша жизнь. не знает гармонин. едннства. нерархнзма. она разноязычна: религия наииа от Галилеи, культура наииа от старых богов:

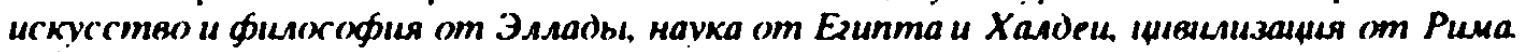
|... Эту формулу сознали мы до кониа лишв сеголня. Все старые голоса заговорили в нас в наши лни. все стародавние счеты в нас сволятся. все отложенные вопросы встакот, сроки завершактся. близится Вал девятый. Бьет hora novissima.
\end{abstract}

Nach ähnlich exaltienten und konfusen Ausführungen über den "Symbolismus der Bibel" und die große Bedeutung des Symbols des babylonischen Turms beendet Ëllis das erste Kapitel folgendermaBen:

(имволизм. как дитя современной. безбожной. лже-гуманистической культуры, повинен в построенни башни вавилонской. но он же, пламенно протестуя против нее. против всех границ материального и чувственного и "человеческого. слииком человеческото". против "человеческой мутростн" как "Последнего", купил себе право на бољшее. на возврат К путям благодатного созерцания божественного мира. к молитве Авеля - и в ковчеге Hoя ему найлется место среди современного потопа. Да не мннует его HORA NOVISSIMA. ${ }^{9}$

Vorabend des Ersten Weltkriegs. Sein Hinweis auf die ins Wanken geratenen politischen Grenzen läBt die Frage aufkommen. ob er den Kriegsausbruch gespür hat? Bereits in seinen früheren Arbeiten spricht Ellis häufig von Krisenzeiten und bevorstehenden Umbrüchen: jedenfalls scheint die Charakteristik der Unruhen der Zeit und die eschatologische Stimmung nicht aus der Lufi gegriffen zu sein.

${ }^{6}$ Ėllis: Vigilemus!, a.a.O.. S. 5.

7 Ebd.. S. 6.

8 Ebd., S. 10.

9 Ebd.. S. 11. 
Im zweiten Kapitel, "Tempora pessima"10, trifft Ėllis eine Unterscheidung zwischen Okkultismus, Mystik und heidnischen Göttem einerseits und dem echten Christentum andererseits. Er führt zahlreiche Beispiele an, welche zeigen, wie weit sich die Menschheit vom Ideal der streng religiösen Kunst entfernt und sie fast vollständig durch mystische, idealistische, romantische, mysteriöse und magische Kunst ersetzt habe; die Wahrheit der religiösen Symbolik sei den Menschen verlorengegangen. Novalis' "Marienlieder" bezeichnet Ėllis beispielsweise als "lügenhafte Gotik in der Romantik" 11, und R. Steiners Mysteriendramen 12 spricht er zwar eine einzigartige und unerreichbare okkult-symbolische Bedeutung zu, dafür aber keine religiöse und ewigchristliche ${ }^{13}$.

Weiterhin entwickelt Ėllis eine sehr eigenwillige Mythen- und Legendentheorie: Der Mythos sei in der heidnischen Götterwelt entstanden, aus der Verehrung von Halbgöttem und Helden erwachsen und stelle eine spezielle Form volkstümlicher Weltbetrachtung dar. Die germanische heidnische Mythologie bezeichnet Ellis in diesem Zusammenhang als schönste Erscheinung des volkstümlichen geistigen Lebens in der ganzen Geschichte der Menschheit ${ }^{14}$. Nach Christi Geburt habe der Mythos, der immer mystisch, aber nicht religiös sei ${ }^{15}$, seinen Platz der Legende abgetreten, die Ellis als "rein christliche neue Form der Kunst" bezeichnet und als "halbphantastische Erzählung von einem femen, aber völlig realen Ereignis" definien ${ }^{16}$.

Er preist das Werk Dantes, den "Armen Heinrich" von Hartmann von Aue und die gotische Architektur (als Beispiele führt er die Dome in Köln und Mailand sowie Westminster Abbey an) als gelungene Verbindung religiöser Dogmatik und freier schöpferischer Phantasie. Seine Gegenwart kann er jedoch nur als "tempora pessima" charakterisieren, denn die Menschheit habe sich wieder weit von Gott entfernt, seit dem 13. Jahrhundert habe sich eine tiefe Kluft zwischen Kultur und Religion aufge$\tan 17$ :

C палением культуры XIII века. которая была последням расцветом релитиозноһ куль туры. человечество начинает жить без релитин. оно попадает в порочньй крут без выхода. врашаясь между невозможностью иельно отдаться служению старым богам. отмену хоторых оно трагически пережило. и сомнением в жизнеспосионости и применимсхти хрмстианства. в котором именж) на рожовом повороте XIV веха оно

10 Ebd.. S. 12-48.

11 Ebd., S. 19.

Diese Verunteilung der "Marienlieder" mutet recht sonderbar an, da Novalis im Grunde in Ëllis' Konzepł passen müBte durch sein Plädoyer, die alte religiöse Einheit des Mittelalters in Europa wiederherzustellen (vgl. Novalis' Aufsatz: "Die Christenheit oder Europa", 1799). Unter den russischen Symbolisten war es vor allem Vjač. Ivanov, der Novalis und sein Werk in RuBland bekanntmachte: er hat Novalis sehr verehrt und ins Russische übersetzt.

12 "Die Pforte der Einweihung" (1910). "Die Prüfung der Seele" (1911). "Der Hüter der Schwelle" (1912) und "Der Seelen Erwachen" (1913).

13 Ellis: Vigilemus!, a.a.O., S. 19.

14 Ebd., S. 20f.

15 "Есть непереходимая черта между мифологией и религией [...]" (Ebd.. S. 21).

Ėllis verwendet die Bezeichnungen "religiös" und "Religion" in diesem Traktat im Sinne von "christlich religiös" und "christlicher Religion", identifizient also "religiös" mit "christlich" und "Religion" mit "Christentum"!

16 Ëllis: Vigilemus!, a.a.O., S. 20.

Ėllis ignorien bei seinen Ausfühnungen, daB es neben dem Christentum auch andere Religionen gibt und negiert überdies die Existenz buddhistischer, indischer, islamischer usw. Legenden.

17 Ellis: Vigilemus!, a.a.O., S. 22f.

Die grobe Bedeutung. die Ëllis dem 13. Jahrhunden beimiBt. wurde bereits mehrfach erwähnt: er selbst nannte sich immer wieder einen Menschen des 13. Jahrhundens bzw. des Mittelalters, der 600 Jahre zu spät geboren worden sei. 
увидело раны. показавииеся ему нексиелимыми. Пережить духовное паление папства. полную неудачу хрестовых походов. увидеть первые ужасы разлившнхся повсюду ведовства и еретичества. рост отравляющей арабской и магометанской культуры. испытать первые пароксизмы фанатизма как самой церкви. так и ее врагов. увидеть разложение рыщарства и нскаженне монашества. наконец. повсеместные и бесцельные политические распри и пережить все это сразу - для средневекового человека. с абсолютизмом всех его устремлений и оценок. означало духовно потибнуть. ${ }^{18}$

Ellis nimmt hier die Position eines starren Dogmatikers ein, der außer einem idealisierten Mittelalter nichts gelten läßt und die natürlichen Entwicklungsprozesse der Menschheitsgeschichte negativ bewertet. In seiner einseitigen Haltung, die ganz auf das 13. Jahrhundert des katholischen europäischen Mittelalters fixien ist ${ }^{19}$, ignorien er jegliche späteren religiösen Erneuerungsbewegungen, ganz zu schweigen von der Reformation, die er als häretisch verwirft.

Er betont, daB es nach dem 13. Jahrhundert nur wenige Führer gegeben habe, nur wenige, die gerettet werden konnten von Glaubenslosigkeit und geistigem Untergang. Er nennt Franziskus von Assisi, Dominikus (den Stifter des Dominikanerordens) und Dante; sie alle hätten. als letzte Hoffnung, in Abgeschiedenheit und Einsamkeit den Kontakt mit Gott gesucht und die Gegenwart vemeint. (Das trifft allerdings auf Dante gewiB nicht zu!) Doch auch diese letzte Hoffnung sei bald verlorengegangen:

[...] вслед за небывалым релитиозным пароксизмом наступила пора еще более ужасного отиаяння: это была пора спокоһного безверня. а затем уже веселый возврат $\mathbf{x}$ полужнвым старым богам"20 стал явленнем почти обинм. Наступила пора "Возрохдения", т.е. өсзрохдения языческой куяьтуры. Вся дальнейшая духовная история человечества сложнлась из борьбы этих двух начал: удаления от христианства и водворения старьх богов. что в результате и привело последовательно к гуманизму. рационализму, матернализму и великому кризясу нашюх люей.

Исторня нашей культуры после разрыва с религией на исходе XIII века может быть фозначена. как неухлонное следованне по пути "удаяения от бога". и сообразно развнтию этого начала должна стронться точная классифнкация самих ступеней этого великого палення культуры. Собразно с этим постепенно вырождалась сама илея реливца, заменяясь послеловательно теояогией, мистерией (гноснсом), мистиинамом, магией, оккульмизиом. тесософией и наконси антропософией. 21

Ėllis verwirft also jegliche Aufklärung und damit die gesamte Entwicklung der Menschheit sowie der europäischen Kultur und Literatur seit dem 13. Jahrhundert.

In seinen folgenden Ausführungen charakterisien er recht ausführlich, wie sich die Kultur immer weiter von Gott entfernt habe und die (christliche) Religion durch Theologie, Mysterium (Gnostizismus), Mystizismus, Magie, Okkultismus, Theosophie und schlieBlich Anthroposophie ersetzt worden sei.

1. Wesen und Inhalt der Religion definiert Ellis als unmittelbare Verbindung der freien und bewußten Geschöpfe mit dem Schöpfer, als Selbstbestimmung in Gott durch den Glauben. Er kann sich Freiheit nur als freiwillige Unterordnung unter et was Höheres vorstellen 22 .

${ }^{18}$ Ėllis: Vigilemus!, a.a.O., S. 23.

19 Auffallig ist. daB Ellis überhaupt nicht auf die Orthodoxie in Südosteuropa und RuBland zur Zeit des 13. Jahrhunderts zu sprechen kommt!

${ }^{20}$ Damit meint Ëllis die heidnischen Götter der griechischen Antike, der germanischen Mythologie etc.

21 Ëllis: Vigilemus!, a.a.O., S. 24.

22 Ebd., S. $25 f$.

Ėllis vertritt hier die gängige Position von Freiheit als Selbsteinschränkung, als freiwillige Unterwerfung unter ein Gesetz und geht nicht auf das Problem der Freiheit als völlige Selbstbestimmung ein. 
2. Die mittelalterliche Theologie und die Scholastik, die Ellis als "klassische Periode der Theologie" definien, stellt er direkt neben die echte christliche Religion. Den wahren Geist der Scholastik sieht er gegenwärtig in der Theologie Vl. Solov'evs wiederauferstanden, woher dessen führende Bedeutung in der derzeitigen religiösen Wiedergeburt rühre 23 .

3. Nach dem Verlust der (christlichen) Religion und Theologie beginne die Menschheit nach Mysterien (Gnostizismus) zu suchen, also nach einer realen Art der Verbindung mit einer höheren Welt. Anhand von Beispielen zeigt Ėllis, daB jede "Religion" (hier gebraucht er den Begriff Religion uneingeschränkt) ihre Mysterien habe, stellt jedoch das Mysterium der Menschwerdung Christi über die alten heidnischen Mysterien und verweist in diesem Zusammenhang auf die große Bedeutung der mittelalterlichen Mysterien des Gral, wodurch er wieder die - seiner Meinung nach überragende Bedeutung der christlichen Religion hervorhebt ${ }^{24}$.

4. Den Mystizismus definient Ėllis als "хаотическое чувство тоски осмутно-религиозном" ("chaotisches Gefühl der Sehnsucht nach etwas Vage-Religiösem"), als Rückkehr zum Alten und Formlosen. Er bezeichnet den Mystizismus seiner Tage als das "Kind des Protestantismus" und bestimmt in diesem Zusammenhang Katholizismus als "Nachahmung Christi", wohingegen Protestantismus die "Nachahmung Luthers" sei25. Hier handelt es sich nicht nur um eine falsche Definition von Mystizismus, sondem auch Ellis' Bestimmungen von Katholizismus und Protestantismus treffen das Wesen der Sache in keiner Weise und wirken in ihren subjektiv verabsolutierten Formulienungen übertrieben. Mit dem Protestantismus und Luther macht Ëllis es sich sehr einfach, indem er die ganzen Reformations- und Emeuerungsbestrebungen dieser Bewegung gleich im voraus verwirft und nur den idealisien aufgefaBten mittelalterlichen Katholizismus als einzig wahre Religion gelten läßt.

Ebenfalls in Verkennung der Tatsachen bezeichnet Ellis die Magie (Theurgie) als Anti-Religion "in der ganzen schrecklichen Bedeutung des Wortes": das heiBt, der Mensch stehe nicht mit Gott in Verbindung, sondern mit dem Teufel oder vielmehr mit dem gefallenen Engel Luzifer ${ }^{26}$. Ellis übersieht die enge Verbindung zwischen Magie und Religion in den kultisch-rituellen Akten nicht nur primitiver Religionen. da sie nicht in sein Konzept des idealisierten mittelalterlichen Katholizismus zu passen scheint, und negien die grobe Bedeutung der Theurgie für die "jüngeren" russischen Symbolisten völlig. (Vjač. Ivanov etwa identifizierte Symbolismus mit Theurgie [in seinem Aufsatz "Заветы символизма", 1910] und auch A. Belyj vertrat eine ähnliehe Haltung.)

6. Den wissenschaftlichen Okkultismus charakterisien Ellis als weit entfernt von der Religion, da er versuche, die Kräfte, Prozesse und Geschöpfe der Welt rein experimentell zu analysieren; er erweise sich jedoch als kraftlos vor dem wesentlichen metaphysischen Problem vom Primat des Geistes über die Materie und vor allen Problemen der Theologie: Unsterblichkeit der Seele. Sündenfall, Buße, Erschaffung der Seelen. Theophanie und Inkarnation des Wortes, da sich diese Erscheinungen nicht auf naturwissenschaftliche Weise erklären lieBen. Ellis hebt in diesem Zusammenhang R. Steiners Werk "Die Geheimwissenschaft im UmriB" (1910) und überhaupt Steiners Arbeiten als Musterbeispiele des wissenschaftlichen Okkultismus hervor, durch die er sich methodologisch klar von Religion, Mystik. Metaphysik und Magie abgrenze27.

${ }^{23}$ Ėllis: Vigilemus!, a.a.O., S. 27-29.

24 Ebd. S. $29-32$.

25 Ebd., S. 32-34.

26 Ebd. S. 34-38.

27 Ebd., S. 38-40. 
7. Ėllis weist auf die vielen Bedeutungen des Begriffes Theosophie hin. von denen nur zwei genau seien: Theosophie könne verstanden werden als Gotteserkenntnis, die in ein System gebracht worden sei; so gesehen sei Theosophie eine christliche Theologie (zum Beispiel die Theosophie Vl. Solov'evs, Thomas von Aquins, Dantes etc.). Die zweite Bedeutung von Theosophie sei antichristlich und bedeute die Wiederherstellung von Brahmanismus und Buddhismus (in der westlichen Welt) unter der Maske der gesamtreligiösen Wahrheit durch die von E.P. Blavackaja gegründete Theosophische Gesellschaft. was eine Emiedrigung und sogar Abschaffung des Christentums zur Folge habe 28 . In deutlich polemischem Tonfall weist Ellis darauf hin. daB sich in der sogenannten "synthetischen" und "brüderlichen" Theosophischen Gesellschaft" die gesamte Esoterik emeuent habe; nur die christliche Religion habe man dabei verges$\operatorname{sen}^{29}$.

8. Anthroposophie definien Ėllis als ein unvoreingenommenes wissenschaftliches Erforschen des geistigen Menschen. das allerdings mit Religion so gut wie gar nichts mehr zu tun habe ${ }^{30}$ :

Антропософия по идее является завершаюинм звеном всей системы наук о человеке.

Этим она оставляет свободным друтие области культуры и область релитин. как преимущественно область веры. ${ }^{31}$

Damit hat Ėllis das Wesen der Anthroposophie als Wissenschaft über den Menschen zwar richtig definiert. Auch läßt die Anthroposophie jeden einzelnen Menschen frei in seiner Entscheidung, wie weit er sich in diese Art der "Geisteswissenschaft" vertiefen will. Hat man sich jedoch für sie entschieden, ist daran eine bestimmte Welthaltung und Kulturauffassung gebunden und Ėllis' obige Aussage somit nicht mehr ganz richtig. Außerdem liegt der Anthroposophie eine christliche Haltung zugrunde, die allerdings an keine bestimmte Konfessionszugehörigkeit gebunden ist.

9. In der Romantik und im Symbolismus sicht Ellis die Suche nach dem verlorenen Paradies des Glaubens emeuer, die Sehnsucht nach Religion und die Rückkehr zum Christentum. In der gegenwärtigen Zeit scien die Vermächtnisse der Romantik die neuen Gelöbnisse des Symbolismus geworden:

\begin{abstract}
Это одинаково сказалось в "Лоэнтрине" и еще ранее в "Моряке-скитальце" Вагнера 32 . в "театре" Матерлюха. в "сказках" Уайльда. в лирнке Александра Блока. в первых стихах Бальмонта. в Эдаре По. в Верлже. В последнем он [= символизм] нашел тот синтез с католкчеством. о котором мечтал нсконн.

"Голубой цветок" Новалиса увял. он стал "Мнстической Розой" символнстов ("Rosarium" Вячеслава Иванова). ${ }^{33}$
\end{abstract}

Hier muB man sich die Frage stellen, wozu Begriff und Stil des Symbolismus eigentlich noch gebraucht werden, wenn er - wie Ëllis es tut - in dieser Weise mit Romantik identifizien wird. Alle innovatorischen und modemistischen Elemente des Symbolismus werden von Ėllis abgelehnt oder ignorien, der Begriff Symbolismus wird also in zunehmendem Maße entbehrlich; man könnte allenfalls von Neoromantik

${ }^{28}$ Ėllis spricht sich nun also entschieden gegen die Theosophische Gesellschaft aus, deren Anhänger er noch kurze Zeit zuvor gewesen war! Er differenziert hier in "Vigilemus!" deutlich zwischen Theosophie und Anthroposophie.

29 Ėllis: Vigilemus!, a.a.O., S. 40-43.

30 Ebd., S. 43-46.

31 Ebd.. S. 46.

32 Gemeint ist Wagners "Flegender Holländer", auf Russisch üblicherweise "Летучй голландец". in frühen Übersetzungen ins Russische allerdings mit "Mopяk-Cxurareu" betitelt (vgl. R. Bartlett: Wagner and Russia, a.a.O., S. 372).

${ }^{33}$ Ėllis: Vigilemus!, a.a.O., S. 47. 
sprechen. "Vigilemus!" als Programm seiner zukünftigen Arbeiten ${ }^{34}$ deutet bereits darauf hin, daB sich Ėllis vom zeitgenössischen Symbolismus abwenden und der Epoche der Romantik zuwenden wird, was ja auch tatsächlich eintritt ${ }^{35}$.

In der Entwicklung des Symbolismus sieht Ėlis die Rückkehr zur Religion in um gekehrter Reihenfolge angedeutet (8.-1.): Der französische Symbolismus sei die Rückkehr zum Mystizismus gewesen, der deutsche vorwiegend zum symbolischen Mysterium und der russische zur religiösen Suche. Ohne auch nur eine Spur wissenschaftlicher Beweisführung beruft sich Ëllis auf verschiedene symbolistische Dichter, aber auch auf so verschiedene und zeitlich weit auseinanderliegende Denker wie Franz von Assisi und Nietzsche, dem er absurderweise slavischen Messianismus unterschiebt (sic!), um die eigene fixe Idee christlich-religiöser Emeuerung des Zeitgeistes zu legitimieren:

\begin{abstract}
Избегая мертвого аллегорнзма современно внешпей церковности. от лирики Владимнра Соловьева. через "Залото в лазурн" Андрея Белого. "Стихн о Прекрасной Даме" А. Блока. "Цветы и ладань" 36 С. Соловьева. и до "Cor ardens" В. Иванова. - русскин символизм в Д. Мережковском становится вопросом о релитиозном пути будуикего ${ }^{37}$ : в славянской мессианистической концетпия учения Нишие. в "Кние невилимой"38 А. Добролюбова. в все более и более растуцем интересе молодых поэтов к похе и жизни св. Франциска Ас. сизского и к русскому попвижничеству, русския символизм с кажщым днем и часом все более и более становнтся подлинньци, христианским искусстоом. горестыы песнопе ннем о паленин человеческой душн. молитвой 06 искупленин и песнью ралостной о спасенюя. Сокровенная стихня народного духа встречает хрнстианского поэта на этом пути и обручается с ним "браком духовным". Так наша культура через симвализм возврашвется к Богу. $\mathrm{k}$ "неподвнжкому Солнцу Любвн". Кончанотся TEMPORA PESSIMA. ${ }^{39}$
\end{abstract}

Anhand des kurzen dritten Kapitels, "Vigilemus!"40, kann Ėllis' Argumentationsweise deutlich vorgeführt werden: Er fragt, ob das gegenwärtige religiöse Bestreben der Kunst für die Rettung der Menschheit vor Glaubensverlust und geistigem Untergang genüge? Allein aus sich heraus könne die "neueste Stunde" ("hora novissima") keine Kunst gebären. Sic sei eine "neue Stimme" zwischen den verschiedenen "alten Stim men", eine ungeschene Erscheinung zwischen den Lügenantlitzen aller alten Götter, die danach strebten, sie zu verschlingen. In Stunden grober Versuchungen sei es nicht die Stimme der Übermenschen, Opferpriester, Magier oder Geister, es sei die Stimme des Erlösers selbst, die auf verschiedene Weise zu den Menschen spreche (streng. prophetisch, unerbittlich, tröstend, ermutigend). In diesen Stunden seelischer und weltlicher Umwälzungen scheinen alle Wege hoffnungslos abgeschnitten zu sein; doch umso deutlicher ertönen gerade dann jene Worte, in denen das einzig Unveränderliche und Unerschütterliche beschlossen liege: "Я еемь Путь и Истина и Жизнь. VIGILEMUS!"4l Man muB sich scheuen, diese Art des "Argumentierens" von Éllis als wissenschaftlich zu bezeichnen, was sowohl durch seinen übertrieben exaltierten Tonfall als auch durch die pathetischen Ausdrücke und verwendeten Bilder bedingt wird. Der Ausruf am Ende des Traktats, daB die Menschen aufwachen und auf die Stimme des Erlösers hören mögen, bringt noch einmal Ellis ganzen religiösen Extre mismus zum Ausdruck und macht deutlich, daB "Vigilemus!" den Charakter eines

\footnotetext{
$34 \mathrm{Vgl}$. Ėllis' Vorwort. S. VI.

$35 \mathrm{Vgl}$. Teil Il der vorliegenden Arbeit.

36 = eine Gedichtsammlung.

37 Merežkovskij hat diese Frage allerdings vor den meisten der genannten Titel gestellt!

38 = ein Lyrikband.

${ }^{39}$ Ėllis: Vigilemus!, a.a.O., S. 48.

40 Ebd. S. 49.

41 Ebd.
} 
Manifests oder Aufrufs hat und nicht wie eine literaturwissenschaftliche Arbeit bewertet werden kann.

Anschließend folgen zehn "Exkurse" zum Traktat, in denen sich Ëllis bemüht, faktische Auskünfte und bibliographische Daten zu den behandelten sowie eine Reihe einzelner Thesen zu spezielleren Fragen zu geben ${ }^{42}$. Er versucht also, einen wissenschaftlichen Apparat zu erstellen. der jedoch seinem Inhalt nach eher pseudowissenschaftlich ist, da seine Ausführungen weniger objektiv erläutemden Charakters sind, sondem vielmehr seine eigenen, stark subjektiv und emotional gefärbten Ansichten widergeben.

Im ersten Exkurs, "O путяx русского символизма" ("Über die Wege des russischen Symbolismus") 43 , grenzt sich Ëllis deutlich von A. Belyj ab, der im Gegensatz zu ihm Anhänger der Anthroposophie blieb. Ėllis hebt hervor, daB die Rettung des Symbolismus vor dem Religionsverlust des Zeitgeistes, den er in den modernistischen Strömungen der zeitgenössischen Literatur und Philosophie sah, nicht in einer Synthese von Symbolismus und Theosophie oder gar Anthroposophie liege, sondem in der Umbildung der symbolistischen Kunst in religiöse Kunst, in der Rückkehr zu den ewigen Quellen der christlichen Symbolik, vor allem der frühen Gotik, in der Umwandlung der mystischen Mythenbildung in die christliche Legende. (Diese Ausführungen bilden quasi das Konzept für Ėllis' folgende Arbeiten in seiner zweiten, der deutschen Schaffensperiode).

Als die zwei Blütezeiten der christlichen Kunst in der Vergangenheit nennt er a) die frühchristliche Symbolik der Katakomben und b) die Symbolik des mittelalterlichen Katholizismus. Nachdem in den auf das 13. Jahrhunder folgenden sechs Jahrhunderten die heidnische Kultur vorgeherrscht habe, sei es nun RuBlands Aufgabe, die Verbindung zur christlichen Kunst wiederherzustellen:

Русский символизм. бывилий внешне нанболее вычурным и нскусственным и одновременно наяболее искренним и тревожњым. бессознатељњо с самого начала таил в себе и искание народнои луши и цельную жажлу божеского. Не преобразившись в нскусство христианское. он погибнет [...]. ${ }^{44}$

Im zweiten Exkurs, "О единой мистерии" ("Über das einzige Mysterium"), erläutert Ellis den im Traktat formulierten Satz: "Последняя сокровенная цель символизма - живая мистерия" 45. Unter "lebendigem Mysterium" versteht Ëllis die Aneignung, das Erleben und das kulturelle Begreifen des "Gottmenschentums" ("бoroчеловечество") als wesentlichstes Geheimnis des ganzen Christentums, als Kem "aller" (sic!) Dogmen. Lehren. Symbole und Wege der christlichen Religion.

Im dritten Exkurs mit dem Titel "О двух ликах символизма" ("Über die zwei Ant litze des Symbolismus") ${ }^{46}$ kommt Ëllis, wie auch in seinen früheren theoretischen

\footnotetext{
42 Vgl. Ėllis' Vorwor zu "Vigilemus!". S. VII.

43 Ėllis: Vigilemus!, a.a.O., S. 53-55.

${ }^{44}$ Ebd.. S. 54.
}

In diesem Exkurs weist Ėllis darauf hin. daB einige Stellen in "Vigilemus!" im Widerspruch mit den Ergebnissen seiner "Мкохенские письма" stehen, in denen er die Hoffnung auf eine zukünftige Versöhnung zwischen Symbolismus und Okkultismus ausgesprochen habe. Er erläuten dazu, daB die realen Bedingungen in der Entwicklung der Theosophie seine Ansichten geändert hätten; diesbezüglich sei vor allem wesentlich: der Auseinanderfall der Theosophischen Gesellschaft, die Entstehung der Anthroposophischen Gesellschafi, die ihm von ihren Aufgaben her fremd sei. Steiners vienes Mysteriendrama ("Der Seelen Erwachen"), das entschieden den Weg der drei ersten Mysteriendramen negiere, und vieles andere.

45 Ėllis: Vigilemus!, a.a.O., S. $55 f$.

46 Ebd. S. 56-59. 
Arbeiten über den Symbolismus, auf den Dualismus innerhalb des Symbolismus zu sprechen: einerseits greife der Symbolismus Vergangenes auf, andererseits schaffe er Neues, sei in die Zukunft gerichtet. Das führt Ellis auf die ihm eigene subjektivspekulative Weise, die vor allem den heutigen Leser recht pseudowissenschaftlich anmutet. mit Hilfe von Beispielen aus dem europäischen und russischen Symbolismus aus (Nietzsche, Vl. Solov'ev, Merežkovskij, Goethe, Wagner u.a.), wobei er der "katholischen Tendenz" im französischen und belgischen Symbolismus groBe Bedeutung beimiBt (Baudelaire [sic!], Huysmans und Rodenbach). Im russischen Symbolismus unterscheidet er trotz aller Vielfalt zwei Hauptlinien: die ästhetische und die religiöse, wobei seiner Meinung nach letztere vorherrsche und siege. Diese Unterscheidung entspricht wieder der bereits mehrfach erwähnten heutigen Einteilung des russischen Symbolismus in zwei Generationen: die "älteren" und die "jüngeren" Symbolisten sowie den zwei grundsätzlichen Positionen während des "Symbolistenstreits" 19091910: Symbolismus verstanden als neue literarische Stilformation versus Symbolismus als Weltanschauung und Lebenspraxis ${ }^{47}$. Welche dieser beiden Richtungen jedoch als primär anzusehen ist, läBt sich nicht eindeutig festlegen; sie führten zu unterschiedlichen Entwicklungen innerhalb des Symbolismus und später zu verschiedenen avantgardistischen Gruppierungen.

Der vierte, ziemlich umfassende Exkurs "О вере и религия" ("Über Glauben und Religion") 48 beinhaltet recht detaillierte Ausführungen über Glaube und Religion und ihre historische Entwicklung. Ellis kommt dabei ermeut auf den vermeintlichen Bmch von Religion und Kultur nach dem 13. Jahrhundert zu sprechen. Nach diesem Bruch habe die katholische Kirche nach äuBerer Theokratie gestrebt und sich bemüht, die alten Dogmen zu bewahren. Die Kultur hingegen habe sich einem "lügenhaften Humanismus" zugewandt, sei gottlos geworden, habe nur auf ihre eigenen Kräfte vertraut und sei zum Materialismus übergegangen.

Im fünften Exkurs, "O теологии и схоластике" ("Über Theologie und Scholastik")49, betont Ėllis, daB die Theologie als "vollkommenes System völliger Wahrheit" ihre Blütezeit im 13. Jahrhunder gehabt habe. Die Scholastik bezeichnet er seltsamerweise als "lebendiges, reales Wesen", als das "himmlische Antlitz der Sophia" 50. Nach einem Blick auf die Geschichte der Scholastik versucht er, die gängige Auffassung, daB Scholastik nicht originell, sondem trocken und tot sei, zu widerlegen 51. Das Hauptprinzip der klassischen Scholastik: "Primum credere, deinde intelligere" und ihre Ziele seien denen der gegenwärtigen Philosophie entgegengesetzt. Es ist Ellis sehr sympathisch, wissenschaftliche Erkenntnis dem Glauben nachgeordnet und sogar in seinen Dienst genommen zu sehen; als Bezugspersonen oder Beweise beruft er sich auf Thomas von Aquin 52 und Dante, obwohl letzterer doch kaum mit Scholastik in Verbindung gebracht werden kann. und führt Jesus Christus als Beispiel für die vollkommene Einheit von Wort und Tat, Glaube (Gebet) und Erkenntnis. Kirche und Persönlichkeit an. Er bedauert die gegenwärtige Abwertung und Geringschätzung der Scholastik und hebe die Verdienste Vl. Solov'evs hervor, der um eine Fortsetzung der Linie der mittelalterlichen Theologie und insbesondere der Scholastik (sic!) bemüht sei, speziell durch seine Lehre von der Theokratie und seine philoso-

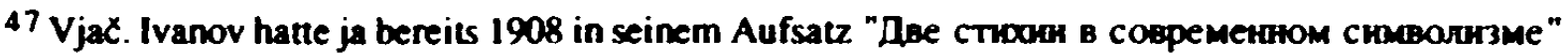
zwischen "идеалистнческнй" und "реалистический снмволизм" unterschieden.

48 Ėllis: Vigilemus!, a.a.O., S. 59-67.

49 Ebd., S. 68-78.

50 Ebd., S. 68.

51 Ebd.. S. $76 f$.

52Ëllis' Ansichten stimmen weitgehend mit dem Neuthomismus überein. 
phisch ausgeformte Lehre der Dreifaltigkeit in "Россия и вселенская иерковь" ("RuBland und die universale Kirche"). Solov'evs Theorie beruhe ganz auf dem Primat der Offenbarung, auf der schöpferischen Kraft des Glaubens.

Im sechsten Exkurs, "О религиозной мистике" ("Über die religiöse Mystik") ${ }^{53}$, differenzien Elllis zwischen Mystik und Mystizismus: Mystik sei ein Bestandteil der christlichen Religion. während Mystizismus jeglicher Bedeutung entbehre, entartete Mystik sei, den Bezug zu Gott und der transzendenten Welt verloren habe. Als Ursprung der christlichen Mystik nennt er die Mönchszelle und die Einsiedlerklause. Er behandelt weiterhin die religiöse Philosophie und Theologie Meister Eckharts sowie Jakob Böhme und Swedenborg, die im symbolistischen theoretischen Denken präsent waren.

Der siebte Exkurs trägt den Titel "О внерелигиозной магии" ("Über die nichtreligiöse Magie") ${ }^{54}$. Elllis geht darin auf die Magie und den Magier (= Vermittler zwischen der Menschheit und den Göttem) ein. Die deutlichste, künstlerischste Reminiszenz und Symbolisierung der absoluten Antinomie von Religion und Magie sei die "unsterbliche Legende" von Parsifal und Klingsor. Historisch gesehen bezeichnet er Magie als das jeweils letzte, dekadenteste Stadium einer Religion. Diese Definition ist jedoch sehr zu bezweifeln. Nach gängiger Meinung, so etwa auch bei Nietzsche55, steht Magie am Anfang religiösen Denkens als Aberglaube, als die Fähigkeit, durch das Beschwören von Geistem. Dämonen usw. Naturkräfte bändigen und beherrschen zu können.

Im achten Exkurs, "O иезуитстве и розенкрейцерстве" ("Über Jesuiten- und Rosenkreuzertum" $)^{56}$, behandelt Ëllis den Orden Jesu, das Rosenkreuzertum und Rober Fludd. während sich im neunten Exkurs. "О6 оккультной науке или тайноведения" ("Über die okkulte oder Geheimwissenschaft")57, Betrachtungen zu Theosophie, Okkultismus und Magie finden. die er - wie im siebten Exkurs - als unvereinbar mit der christlichen Religion bestimmt.

Der letzte, zehnte Exkurs, "О тео- и антропософии" ("Über Theosophie und Anthroposophie" $)^{58}, \mathrm{faBt}$ die vom (S. 163) dargestellte Abrechnung mit Theosophie und Anthroposophie noch einmal zusammen und weist auf die Vielseitigkeit von Steiners kompliziertem schöpferischen Werk hin. Die Anthroposophie sei zwar ein zentrales Element von Steiners Doktrin, erschöpfe diese aber nicht; ein weiteres wesentliches Gebiet seiner Lehre sei seine Kosmologie ${ }^{59}$. Ellis geht auf die Entwicklung in Steiners vier Mysteriendramen ${ }^{60}$ ein, die seiner Meinung nach tragisch enden: die Hauptfiguren werden von Luzifer unterworfen ${ }^{61}$. Ėllis' abschließende Ausführungen über die Anthroposophie und die Anthroposophische Gesellschaft lassen deutlich werden.

53 Ėllis: Vigilemus!, a.a.O., S. 78-85.

$\$ 4$ Ebd., S. 85-91.

\$5 Vgl. "Die Gebur der Tragödie", 1872.

S6 Ëllis: Vigilemus!, a.a.O., S. 92-99.

57 Ebd., S. 99-101.

58 Ebd., S. $101-105$

59 Steiner selbst sah zwar die Anthroposophie als sein Hauptlebenswerk an, doch ist hier von Wichtigkeit, daB Ellis die Vielseitigkeit Steiners hervorhebt, die tatsächlich dessen ganzes Leben und Werk bestimmt.

${ }^{60} \mathrm{Vgl}$. oben. S. 160 , Anm. 12

61 Ellis zitien hierzu die Rede des Benedictus am Ende des vierten Dramas "Der Seelen Erwachen" (Berlin, 1913; vgl. Ėllis: Vigilemus!, a.a.O., S. 103).

Ursprünglich hatte R. Steiner sieben Mysteriendramen geplant, doch durch den Ausbruch des Ersten Welturiegs kam es nicht dazu (1910, 1911,1912 und 1913 entstand jedes Jahr in München ein Drama und wurde dort aufgefuihrt). Das vierte Drama. "Der Seelen Erwachen", endet tatsächlich krisenhaft. was jedoch keineswegs als endgültig angesehen werden kann. 
daB "Vigilemus!" als Auseinandersetzung mit Steiner und seiner Doktrin verstanden werden muB und nicht, wie Belyj meinte 62 , eine "Schmähschrift" gegen Steiner und dessen Lehre darstellt63: Ellis bedauert, daB die Anthroposophie derzeit noch keine schöpferischen Nachfolger gefunden habe und als Schule oder Kulturbewegung noch nicht existiere 64 . Im Statut "Entwurf der Grundsätze einer Anthroposophischen Gesellschaft" seien leider weder die Ideen und Ziele der Anthroposophie noch ihr Inhalt genau bestimmt. Einen Gegensatz empfindet Ėllis als besonders störend: einerseits werde im Statut betont, daB jede religiöse Propaganda der Anthroposophischen Gesellschaft ganz fem liege, andererseits werde hervorgehoben, daB sie eine derartige Propaganda jedoch auch niemals bekämpfen werde. Nach diesen Ausführungen beendet Ëllis seinen Traktat mit dem Satz: "Будем ждать, что скажет жизн!"65.

Ėllis' Traktat "Vigilemus!" als Fortsetzung der "Русские символисты" und Programm seiner zukünftigen Arbeiten wirft unwillkürlich die Frage nach dem Bezug dieses Werks zur Stilformation des russischen Symbolismus auf. Dem Leser begegnet eine Vielzahl abstrakter Begriffe, Lexikonwissen in recht verworrener Weise. Ellis' Symbolismus stellt sich hier als Konglomerat aus romantischen und mittelalterlichreligiösen Vorstellungen dar. Die zeitgenössische russische Literatur bzw. die Weiterentwicklung des Symbolismus in RuBland wird nicht berücksichtigt, die theoretische Debatte um diese Stilformation ignorier. Während Ëllis in "Русские скмволисты" versucht, eine Geschichte des russischen Symbolismus im Kontext des europäischen zu schreiben und am Beispiel des Werks dreier typischer Vertreter die Entwicklung des russischen Symbolismus in den ersten circa 15 Jahren seines Bestehens darzustellen, bemüht er sich in "Vigilemus!" vergebens, die kulturellen und literarischen Erscheinungen seiner Zeit in ein festes System, eine hierarchische Ordnung zu pressen. 1913/1914 lebte der russische Symbolismus in seinen Hauptvertretem (Vjac. Ivanov, Sologub, Brjusov, Belyj, Blok etc.) zwar weiter, wurde aber nicht mehr von dem Bestreben bestimmt, sich durch eigene Organe, Legitimationsstrategien u.ä. als vorherrschende literarische Stilformation durchzusetzen. Die Akmeisten und die Futuristen, die ursprünglich aus dem Symbolismus hervorgegangen waren, begannen sich gegen ihn zu gruppieren. Weitere meist kleine und kurzlebige avantgardistische Gruppen und Strömungen, die ebenfalls als Abspaltungen des Symbolismus verstanden werden müssen 66 , entstanden nach dem Ersten Weltkrieg. Diese zahlreichen Gruppierungen. die den Beginn der historischen russischen literarischen Avantgarde ausmachen, müssen als Resultat der durch den Symbolismus geschaffenen Offenheit und Freiheit in Kultur und Literatur aufgefabt werden.

$62 \mathrm{Vgl}$. oben. S. $130-133$.

$63 \mathrm{Vgl}$. hierzu auch M. Ljunggren: The Russian Mephisto, a.a.O.. S. 94.

64 Das entspricht nicht ganz den Realien: am 20.9.1913 hatte die Grundsteinlegung für den Bau des Goetheanum in Dornach nach einem von Steiner entworfenen Projekt stattgefunden. Das Goetheanum war als Kulturzentrum für die anthroposophische Arbeit und die Auffuihnung von Steiners Mysteriendramen gedacht, sollte eine "Freie Hochschule für Geisteswissenschaft" werden. (Ein ursprünglich in München geplanter Bau war aus verschiedenen Gründen nicht zustandegekommen.) In den folgenden sieben Jahren beteiligten sich Anthroposophieanhänger ganz verschiedener Nationen am Bau dieses Goetheanums (danuter auch Russen, z.B. A. Belyj). Ab 1914 wurde Dornach zum neuen Zentrum der Aktivitäten Steiners. (Vgl. hierzu: Chr. Lindenberg: Rudolf Steiner mit Selbstzeugnissen und Bilddokumenten, a.a.O., S. 99ff., 150.)

65 Ėllis: Vigilemus!, a.a.O., S. 105.

66 Vgl. R.-D. Kluge: Der nussische Symbolismus, a.a.O.. S. 85f. 
Ėllis, der im Grunde zeit seines Lebens die Methode der positivistischen Beweisführung pflegte ${ }^{67}$ und zugleich als religiöser Schwärmer und glühender Verehrer des katholischen Mittelalters den traditionellen Werten und Dogmen in Kultur und Religion huldigte, muBte letztendlich alle avantgardistischen zeitgenössischen Strömungen in der Literatur und auch in der Philosophie (Theosophie. Anthroposophie) ablehnen, da sie ihm die gewünschten festen Normen und Leitfäden nicht bieten konnten. Sein Leben lang war er auf der Suche nach Führerpersönlichkeiten, nach Autoritäten, denen er sich bedingungslos hingeben könne. Er konnte sie weder in seiner Heimat RuBland noch bei R. Steiner finden. Seine persönliche Entwicklung spiegelt sich deutlich in "Vigilemus!" wider. Auffällig ist die übertriebene Pseudosystematik in diesem Traktat: Ellis versucht, alles in Systeme zu pressen, systematisch zu schematisieren ${ }^{68}$. Dadurch wird das Werk jedoch für den Leser und vor allem für den Literaturwissenschaftler keineswegs deutlicher!

Die Sprache in diesem Traktat ist - wie auch in Ellis' anderen Werken - recht exaltien und pathetisch; die Argumentationsweise ist oft durch Unstimmigkeiten und Widersprüche charakterisiert. Formulierungen, wie zum Beispiel "живая мистерия" ("lebendiges Mysterium") oder "елиная мистерия" ("einziges Mysterium") ${ }^{69}$, scheinen nicht reflektiert zu sein; ein Satz wie "Мистицизм наших дней - дитя протестантизма"70 wird in RuBland nicht verstanden; Nietzsches Zarathustra ist kein religiöser Emeuerer, wie Ëllis meint, sondem der Übermensch, der sich selbst transzen dient.

Ungeachtet all dieser Kritik stellt "Vigilemus!" dennoch einen wichtigen Bestandteil von Ellis' Euvre dar, was die vorangegangene ausführliche Diskussion dieses Traktats rechtfertigt. Im Kontext des Gesamtphänomens des russischen Symbolismus als Stilepoche und Weltanschauungslehre erhält diese Schrift eine interessante Bedeutung, denn sie spiegelt eine Position eines Vertreters des russischen Symbolismus wi der, der die auf den Symbolismus folgende avantgardistische Entwicklung nicht akzeptieren, nachvollziehen und begreifen konnte und Zuflucht vor zuviel nicht bewältigter, kreativer Freiheit und Offenheit im religiösen Mittelalter und in den Dogmen der katholischen Kirche suchte, wie es enttäuschte Romantiker im Westen (Deutschland) 100 Jahre zuvor getan hatten.

Die neugewonnene Freiheit zu Beginn dieses Jahrhunderts in Kunst und Literatur, aber auch im weltanschaulich-philosophischen Bereich, bedingt durch die Umwertung aller traditionellen Normen und Werte, rief bei Elllis in verstärktem MaBe das Gefühl der Verunsicherung und Entwurzelung hervor und als Gegenreaktion einen intensiven Drang nach festgefügten Normen. Ordnungen und Hierarchien. Überhaupt ist es interessant, die weiteren Schicksale der einzelnen Vertreter des russischen Symbolismus zur Zeit des Ersten Weltkriegs und der Oktoberrevolution zu betrachten: Die zunächst von manchen Vertretem der sogenannten "jüngeren" Symbolisten freudig und hoffnungsvoll begrüBte Revolution löste tiefe Enttäuschung aus (z.B. bei Blok und Belyj); nicht wenige Symbolisten gingen in die Emigration (z.B. Gippius, Merežkovskij, Remizov, Ivanov; letzterer konvertierte 1926 [wie Ellis] zum Katholizismus) oder kehrten sich von den avantgardistischen Strömungen ab (z.B. Brjusov, Gorodeckij u.a.).

${ }^{67} \mathrm{Vgl}$. oben. S. 31. Hier im Traktat "Vigilemus!" zeigt sich diese Herangehensweise Z.B. am angeführen Fakien- und Beweismaterial in den zehn "Exkursen".

${ }^{68}$ Ein Beispiel hierfür sind die zehn "Exkurse", bei denen stets genau die Seitenzahl angegeben ist. auf die sich die jeweiligen Ausfühnungen beziehen.

69 Ellis: Vigilemus!, a.a.O.. S. 5. 55.

${ }^{70}$ Ebd.. S. 32. 
"Vigilemus!" spiegelt also nicht nur die literarische Krise der Zeit seines Entstehens wider, sondern auch die tiefe persönliche Krise, die Ellis in diesen Jahren durchlebte und die andauerte, bis er nach dem Ersten Weltkrieg in der Schweiz ene neue Heimat fand, eine Stütze in der katholischen Kirche, in der religiösen Lehre Vl. Solov'evs und in der Literatur der - seiner Meinung nach - tief religiösen Vertreter der russischen Romantik sowie in der altrussischen Heldendichtung ${ }^{71}$.

7 Vgl. Teil II der vorliegenden Arbeit. 


\section{E. Unveröffentlichte Materialien in Archiven (PГAЛI und PO РГБ) und ge- plante Projekte}

Das in den vorangegangenen Kapiteln der vorliegenden Arbeit vorgestellte publizierte Werk enthält nicht alles, was Ellis in seiner ersten Schaffensperiode geschrieben hat. Im РГАЛИ ${ }^{1}$ und in der Handschriftenabteilung der Russischen Staatsbibliothek ${ }^{2}$ gibt es neben Briefwechseln mit verschiedenen Zeitgenossen, Tagebuchaufzeichnungen und Heften mit Vortragsmitschriften etliche Entwürfe und teilweise ausgearbeitete Manuskripte weiterer Werke, Übersetzungsentwürfe sowie eine Reihe unveröffentlichter Gedichte ${ }^{3}$. Im folgenden sollen einige dieser Archivmaterialien vorgestellt werden, die der Verfasserin wesentlich erscheinen.

Zahlreiche Notizen, die zum Teil detailliert ausgearbeitet sind, zeugen davon, daB Ëllis sich nicht nur intensiv mit der Geschichte des französischen und belgischen Symbolismus und mit Baudelaire befaBte und Vorträge über diesen Themenkomplex hielt. sondern auch ein Buch plante, in dem er die Geschichte des zeitgenössischen Symbolismus in Frankreich und Belgien darstellen und seine wichtigsten Vertreter behandeln wollte: Baudelaire, Verlaine, Rodenbach, Mallarmé und Verhaeren; auBerdem beabsichtigte er, eine Monographie über Leben und Werk Baudelaires zu verfassen ${ }^{4}$.

Weiterhin plante er ein Werk über Träume mit einem Einleitungskapitel über die Philosophie der Träume, ein Buch mit Märchen und Erzählungen, eines mit Aphorismen $^{5}$ und einen Sammelband mit verschiedenen Aufsätzen und Entwürfen ${ }^{6}$.

Interessant und erwähnenswert sind Ellis' eigene dramatische Versuche: das Drama "Канатый плясун" ("Der Seiltänzer") 7 und die Entwürfe zum "Phantasiestück" ("пьеса-фантазия") "Духи лазури" ("Geister des Himmelblaus")8.

Ungeachtet seiner Ausführungen in den vorgestellten "Весы"-Aufsätzen über die Unmöglichkeit. Symbolismus auf der Bühne darzustellen, symbolistisches Theater zu schaffen. hat sich Ëllis dennoch um diese Gattung bemüht. Der "Канатый плясун" in fünf Akten wird von Ėllis als "Символическая лрама яля интимного театра" ("Symbolisches Drama für ein intimes Theater") bezeichnet und ist Asja Cvetaeva gewidmet. Es handelt sich um ein vollständiges Manuskript von 39 Blättem, das von Thematik und Inhalt her als interessanter Versuch eines symbolistischen Stückes bezeichnet werden muB. Da es nicht publiziert wurde, soll sein Inhalt in der vorliegenden Untersuchung recht ausführlich referient werden.

Dem eigentlichen Stück sind drei Motti vorangestellt: eines von Villiers de l'IsleAdam darüber, daB Engel nur als Gedanken Gottes existieren und lediglich im $\mathrm{Zu}$ stand der Ekstase wahmehmbar seien; ein zweites aus dem vierten Gesang von Dantes

\footnotetext{
1 Фони 575 (Элгис). опись 1.66 ед.хр.

2 РО РГБ. im Фонд 167 (Э.К. Метнер) und im Фонд 190 (Мусагет).

${ }^{3} \mathrm{Vgl}$. die Auflistung der "Materialien von/über Ėllis aus Moskauer Archiven", S. 241-247 der vorliegenden Arbeit.

\ РГАЛИ. Ф. 575. on. 1. ел.хр. 12 und РО РГБ. Ф. 167. карт.10. ед.xp. 3-5: Éllis' Notizen zu Vonträgen über den (französischen)Symbolismus: PO РГБ. Ф. 167. кapr. 10. eд.xp. 7-8. 18.

"Vgl. auch Ellis' Publikation zu diesem Thema in der Zeitschrift "Весы" (1907, Nr. 9, S. 50-52) mit dem Titel: "О6 афорнзмах. Из книги «Мысли-оводы ж" ("Über Aphorismen. Aus dem Buch "Gedanken wie blutsaugende/stechende Insekten" ["овод" = "(Pferde)bremse"]).

${ }^{6}$ Dies läßt sich der Bibliographie von Ėllis' Werken entnehmen. die N.P. Kiselev angefertigt hat: PO РГБ. Ф. 19). карт. 38. ед.xp. 2 und ebd. Ф. 167. карт. 10. ед.xp. 21 . Über sein geplantes Traumbuch aubern sich Ëllis auch häufig in Briefen bzw. bittet seine Adressaten, ihm ihre Träume aufzuschreiben (vgl. hierzu vor allem den Briefwechsel mit M.I. Sizova. РГАЛИ. Ф. 575. on. 1. ед.xp. 20).

7 РО РГБ. Ф. 167. карт. 10. ед.xp. 1.

${ }^{8}$ Ebd., ed.xp. 2.
} 
"Paradiso" und ein drittes von Baudelaire: "Je sais que la Douleur est la noblesse unique!"9. An der Aufstellung der handelnden Personen sieht man bereits, daB das Drama Kinder und deren Welt oder Traumwelt zum Thema hat:

Дейтвуюине лица

1) Канатъи плясун (стройыи. очень худоя. нзяцен) 15-17 лет

2) Злой паяц (ходнт с бичем) 40 лет

3) Девушка в белом 15-17 лет

4) Маљчик-змея (с огромыым ртом) 13-15 лет

5) $1^{\text {B }}$ Антел (похожнй на K. плясуна)

6) $2^{\text {ต }}$ Авгел (похожьй на Девушху в белом)

7) Хор Добрых Духов (за сценой)

8) Утренняя звезда (с серебр. убором на голове)

9) Вечерняя звезда (с золотым убором на голове)

10) Лува (бледно-жемчужњьй головный убор)

11) Солнце (красно-золотой убор цвета заката)

12) Обезьянка (итрает ребенок 9-12 лет)

13) Титр

Публика в цирке. акробаты цирка. ${ }^{10}$

Das Drama beginnt mit einem Prolog des Theaterdirektors (in überwiegend reimlosen fünffüßigen Jamben), der darauf hinweist, daß er keine traurigere und zugleich wundervollere Geschichte kenne als die des kleinen Seiltänzers. in der es um das traurige Geheimnis der Kinderseele gehe. Das menschliche Schicksal bestehe darin. immer wieder aus dem Paradies gestoßen zu werden und auf der Erde herumirten zu müssen; nur der Tod könne den Himmel öffnen. Ellis stellt im Prolog das Bild des Seiltänzers über dem Abgrund dar. das eine Ende des Seiles werde in der Geburtsstunde mit der Erde verknüpft, das andere halte der Tod in der Hand. Über dem Seil seien Himmel, Sonne, Mond und Sterne, die Traumwelt; unter dem Seil gebe es kein Netz, nur Grausamkeit, Abgrund und Tod. Der Theaterdirektor fordert am SchluB des Prologs auf, das Stiuck aufmerksam anzuschauen; in ihm sei ein geheimer Sinn verborgen. Hier wird also an die kreativen Kräfte des Lesers oder Zuschauers appellien, er wird zum Mitdenken bzw. Mitdichten oder Weiterdichten, zum Erraten des geheimen Sinns des Stücks aufgerufen.

Der erste Akt spielt im Zirkusflur hinter den Kulissen. Während die Vorstellung auf der Arena in vollem Gange ist (im Hintergrund hört man die Schreie des Publikums), kommen der böse Bajazzo und der Seiltänzer auf die Bühne. Der Bajazzo peitscht und beschimpft den Seiltänzer, weil dieser seinen Auftritt verpaBt und statt dessen vom Mädchen in WeiB und vom weißen Engel geträumt hat, die ihn - wovon er in seiner Traumwelt fest überzeugt ist - bald in den Himmel, ins Paradies holen werden. Der Bajazzo ist außer sich über die lebensfeme Träumerei des Seiltänzers und versucht ihm klarzumachen, daB die Zirkusleute, die in Armut und Elend leben, gar nicht als Menschen gelten, sondem nur dreckige Landstreicher, eigentlich nur Tiere seien. Träume seien nur für die Kinder der Reichen bestimmt. Ohne Peitsche könne man es zu nichts bringen, auch im Zirkus nicht; das werde der Seiltänzer, wenn er heranwachse, verstehen. Als dieser nicht aufhör, seinen weißen Engel vor dem Spott des Bajazzo zu verteidigen. gerät der Bajazzo in solchen Zorn, daB er den Seiltänzer totzuprügeln droht. Der Tiger, der den Seiltänzer versteht, greift den Bajazzo an. Der Seiltänzer dankt dem Tiger für seine Rettung und bittet ihn. den Bajazzo zu verschonen. Letzterer entfemt sich, der Tiger legt sich auf seinen Platz.

${ }^{9}$ Ebd., ez.xp. 1, Bl. 2.

10 Ebd., BI. 3. 
Der zweite Akt spielt auf dem Dachboden, wo der Seiltänzer und der Schlangenjunge auf armseligen Strohlagem kauem und frieren, während ringsum die glitzemden Kostüme und Masken der Vorstellung liegen. Der Seiltänzer kann vor Schmerzen nicht schlafen; der Schlangenjunge, der ihn bislang gehaBt hat (weil er den Lügen des Bajazzo über den Seiltänzer glaubte), möchte mit ihm reden, da er zum ersten Mal unsägliches Mitleid mit dem Seiltänzer empfand, als der Bajazzo ihn wieder schlug. Der Schlangenjunge kommt zum Seiltänzer ins Bett und erzählt ihm von seiner traurigen Kindheit, seinen armen Eltern, die ihn in ihrem Elend an den Zirkus verkauft haben, und von den Qualen, die er in seiner ersten Zirkuszeit durchmachen muBte. Der Seiltänzer erzählt anschließend von sich: er komme aus dem Paradies, wo er ge meinsam mit dem weißen Engel gelebt habe, zu dem er bald zurückkehren werde. Der Schlangenjunge meint vom Bajazzo gehört zu haben, daB man den Seiltänzer seinen reichen Eltem gestohlen habe und daB er sich wohl an seine glückliche Kindheit bei diesen erinnere, aber der Seiltänzer ist sich ganz sicher, daB er im Himmel bei den Engeln gelebt habe. Um den Schlangenjungen davon zu überzeugen, daB Engel den Menschen erscheinen können, liest er diesem aus dem Evangelium vor, wie der Engel der Maria erschien. In diesem Moment taucht die dämonische Figur des bösen Bajazzo an der Türschwelle auf. Die beiden Jungen, die ihn rechtzeitig gehört haben, können schnell in ihre Betten springen und sich schlafend stellen, während der Baazzo ihr Zimmer inspiziert und teuflisch lacht.

Im dritten Akt ist auf der Zirkusarena die Vorstellung in vollem Gange: das Orchester spielt und die Akrobaten treten auf, während der Seiltänzer traurig und in Gedanken versunken dasteht und seine Blicke in die Ferne richtet. Durch dreimaliges Peitschenknallen kündigt der Bajazzo den Auftritt des Seiltänzers an, der mit in die Unendlichkeit gerichtetem schlafwandlerischen Blick auf dem Seil spaziert. Als er in der Mitte angekommen ist, tritt das weißgekleidete Mädchen ein. Der Seiltänzer meint in ihr den längst erwarteten weißen Engel zu erkennen und stürzt vom Seil. Im Publikum werden Stimmen laut; der Bajazzo und der Schlangenjunge eilen zum Seiltänzer, während das weißgekleidete Mädchen unbeweglich dasteht und traurig-still auf den Seiltänzer schaut.

Der vierte Akt zeigt den sterbenden, von Fieberphantasien geschüttelten Seiltänzer auf seinem armseligen Bett. Der Schlangenjunge ist bei ihm, weint und kümmen sich um ihn. Der Seiltänzer phantasien vom Paradies und seinem Engel und versucht zwischendurch, den schluchzenden Schlangenjungen zu trösten. Er ist überzeugt, daB ihm bei seinem Auftritt sein echter weißer Engel erschienen sei, versteht jedoch nicht, warum er fallen muBte und nun Schmerzen leidet. Er hätte wahrscheinlich das Erscheinen seines Engels nicht vor den Menschen erwähnen dürfen!

Die Bühne wird still und dunkel (wohl der Übergang zum fünften Akt, der jedoch nicht explizit bezeichnet wird). Als die Dunkelheit weicht, findet eine Verwandlung statt: Der Seiltänzer nimmt die Gestalt eines weißen Engels mit großen schwanengleichen Schwingen an; als ein ebensolcher Engel steht das weißgekleidete Mädchen neben ihm und zu ihnen gesellt sich ein unsichtbarer Chor von Kinderstimmen. Die beiden Engel (der ehemalige Seiltänzer und das ehemalige weiBgekleidete Mädchen) verlassen die Erde, fliegen immer weiter hinauf zum Himmel, lassen alle irdischen Träume hinter sich, vergessen ihre irdischen Namen. Sie werden begleitet vom Chor der unsichtbaren Geister. Der ehemalige Seiltänzer fühlt keine Schwere mehr, alles kommt ihm bekannt vor; seine Gefährtin, der andere Engel, beantwortet ihm alle Fragen und fuhrt ihn immer weiter zum Himmel, zum Paradies, wo er schon einmal gewesen ist. Als einziger Sterblicher ist Dante vor sechshundert Jahren diesen Weg ins Paradies zu seiner Beatrice gegangen, sonst keiner. Auf dem Weiterflug begegnet 
den Engeln erst der singende Morgenstern, dann der singende Abendstem und schlieBlich hören sie die Stimme des himmlischen Herolds. Dem ehemaligen Seiltänzer ist es vergönnt, ins Paradies zu gelangen, da er auch auf der Erde nie sein früheres himmlisches Dasein vergessen hat. Steme, Mond und Sonne umgeben die Engel und vemeigen sich vor ihnen; die Stimme des himmlischen Herolds kündigt das Nahen der Jungfrau Maria an. Am SchluB des Dramas singen alle "Ave Maria" und erheben ihre Hände.

AuBer dem Prolog, den Chören der unsichtbaren Geister, den Gesängen der Steme und den Worten des himmlischen Herolds und des zweiten Engels im fünften Akt ist Ëllis' Drama in Prosa geschrieben, die mitunter recht umgangssprachliche Züge trägt, vor allem, wenn der böse Bajazzo spricht. Dagegen heben sich die Verse, vor allem im fünften Akt, durch ihren hohen. pathetischen Stil und viele Archaismen ab, was die Feierlichkeit und Heiligkeit des Handlungsortes betonen soll und einen krassen Gegensatz zur Welt der armen, elenden Zirkusartisten, zum irdischen Dasein, darstellt. Inhaltlich erinnert dieses Drama einerseits stark an A. Bloks "Балаганчик" (das Jahmmarkts- und Schaubudenmilieu), andererseits an Dantes "Divina Commedia": das irdische Dasein ist zugleich als "Infemo" und "Purgatorio" zu verstehen, während im fünften Akt der Weg ins Paradies und die Glückseligkeit des Paradieses selbst the matisiert werden. Die Erinnerung an das Leben im Paradies durchzieht das ganze Werk und läBt den Seiltänzer sein hartes, elendes Dasein auf der Erde ertragen. Das Motiv des gespannten Seiles bzw. des Seiltänzers über dem Abgnund suggerien eine Nähe zu Nietzsches "Zarathustra". Im Gegensatz zu Bloks "Балаганчик", in dem ja die ganze Desillusionienung der idealen Traumwelt gestaltet wird und am Ende alles zusammenfält, zeigt Ėllis hier den Weg der Rettung für auserwählte Seelen auf, die Möglichkeit des Übergangs in eine andere Welt, auch wenn dazu die Schwelle des Todes überschritten werden muB. Ėllis konnte oder wollte Bloks "Балаганчик" nicht begreifen und fabte ihn als Beleidigung der erhabensten Ideale des Symbolismus, als Spott über das Ewig-Weibliche auf. Möglicherweise wollte er mit seinem Drama ein Gegenstück zum "Балаганчик" schaffen und darin sein Ideal vom reinen, echten Symbolismus als heilige, religiöse Kunst darstellen, die er in Dantes Werk verkörpert sah, den er ja sein ganzes Leben hindurch verehre ${ }^{\prime \prime}$.

In Ellis' Drama werden viele typisch symbolistische Themen berühr, vieles wird nur angedeutet und bleibt unausgesprochen (Themen wie Leben und Tod 2.B., die Möglichkeit eines Lebens nach dem Tode oder eines vorgeburlichen Daseins, des Zugangs in höhere überirdische Welten, die vor allem Kindern noch offenstehen etc.); trotzdem mutet es stellenweise recht konstruien an. und am SchluB findet sich wieder das für Ėllis typische übertriebene Pathos. Das sich im fünften Akt nahende Paradies ist sehr konkret gestaltet und wird vom Rezipienten schwerlich als rätselhafi und zum Weiterdichten anregend empfunden. Dennoch stellt dieses Werk einen interessanten Versuch einer künstlerischen Gestaltung dessen dar, was Ellis in seinen theoretischen Arbeiten über das Wesen des Symbolismus und dessen Entwicklung auszuführen versucht und sich auch in seinen Gedichtbänden zu gestalten bemüht.

Was Ellis' zweiten Dramenversuch betrifft mit dem Titel "Духи Лазури. Пьесафантазия для интимного театра" ("Geister des Himmelblaus. Phantasiestück für ein intimes Theater"), so scheint er Fragment geblieben zu sein ${ }^{12}$. Deutlich ist, daB es sich um eine Neugestaltung bzw. ein Aufgreifen der Faust-Thematik handelt, die Ellis am Ende des 20. Jahrhunderts spielen läßt. Der Hauptheld, "Аэронавт Люкс"

\footnotetext{
11 Vgl. oben: "Éllis' Beschäftigung mit Dante". S. 152-157.

12 Der Verfasserin war lediglich ein kurzer Auszug im PO РГБ (Ф. 167, карт.10. ед.xp. 2) zugänglich.
} 
(Aeronaut Ljuks), gestattet, dieses Werk im Kontext der Aviapoesie zu betrachten und als sehr zeitgemäB zu bewerten ${ }^{13}$. Weitere handelnde Personen sind: seine Mutter, eine ihn liebende Frau, sein Dämon, ein "Белый мar" (Weißer Magier), die "Духи лазури" (Geister des Himmelblaus), Bürger eines "Единый Город" (einer "Einzigen Stadt"), "Первые Граждане" (Erste Bürger) und Ingenieure des Himmels. Das Stück beginnt mit einem Monolog des Haupthelden, der schon seit 10 Jahren von der Welt zurückgezogen in seinem Laboratoriumsturm lebt. forscht, rechnet und arbeitet. aber trotz allen eifrigen Bemühungen das Ziel seiner Forschungen und Versuche nicht erreichen konnte. Nach diesem ausgeführten Monolog folgen nur noch kurze, stichpunktartige Notizen und fragmentarische Aufzeichnungen, die deutlich werden lassen, daB es sich um die Faust-Homunculus-Thematik handelt, daB auch Planeten (der Mars) auftreten sollen und daB der Dämon als Körper und Verstand des Haupthelden aufzufassen ist. Offensichtlich sollte wohl der gröBte Teil der Handlung in auBerirdischen Sphären spielen, ein deutlich utopischer Charakter ist nicht zu übersehen.

Ëllis machte sich auch Gedanken über Metrum und Reim dieses Dramas (der Monolog ist in fünffüBigen überwiegend reimlosen Jamben geschrieben). Dieses Werkfragment kann wohl als deutliches Zeugnis für Ellis' Abkehr von den französischen Vorbildem des russischen Symbolismus gelten und zugleich als Zuwendung zur deutschen Literatur und Kultur, nicht zuletzt durch den EinfluB E.K. Metners, der ja ein großer Goethe-Kenner und -Verehrer war. (Auch im Briefwechsel zwischen Ellis und Metner geht es wiederholt um Goethe und die Faust-Thematik). Alle weiteren Äußerungen über dieses Dramenfragment von Ellis würden jedoch nur reine Spekulationen sein und erübrigen sich somit.

Zunächst mag es als Widerspruch erscheinen, daB Ellis in seinen theoretischen Arbeiten in der Zeitschrift "Becы" Symbolismus im Theater, auf der Bühne als unmöglich ablehnt ${ }^{14}$, selbst jedoch Stücke schreibt. Es darf jedoch nicht übersehen werden. daB scine Stücke den Zusatz "для интимного театра" ("für ein intimes Theater") tragen. Symbolismus auf der Bühne ist zwar - in Ëllis' Augen - für die Massen undenkbar, für ein ausgewähltes Publikum jedoch möglich. Bezeichnend ist allerdings. daB Ellis' Stücke weder aufgefühn noch publizien wurden's.

${ }^{13}$ Seit Beginn des 20. Jahrhunderts stieB dic moderne Aviatik in ganz Europa und in starkem MaBe auch in RuBland auf grobes Interesse und wurde z.B. in den Werken der russischen Symbolisten (und später verstäkt auch bei den Futuristen) immer wieder thematisch gestaltet (etwa von A. Blok in seinen Gedichten "А зроплан" ["Aeroplan", 1910] und "Авиатор" ["Der Flieger", 1912], von V. Brjusov im Gedicht "Первым авиаторам" ["An die ersten Flieger", 1908| oder in F. Sologubs "Творимая леген19 " |"Legende im Werden": Trirodovs Raumschiff: 1907-1914|). Vgl. zu diesem Themenkomplex Felix Ph. Ingold: Literatur und Aviatik. Europäische Flugdichtung 1909-1927. Frankfur/M. 1980.

$14 \mathrm{Vgl}$. oben. S. 78.

15 Eine Lesung des "Канатъй плясун" fand am 26. Februar 1909 bei K.K. Metner statt. bei der M.I. Sizova die Rolle der "Девушка в белом" übernehmen sollte. die Ëllis unter ihrem Eindruck geschrieben hat. (Brief von Ellis an M. Sizova vom Februar 1909, РГАЛИ. Ф. 575, on. 1. eд.xp. 20.) 


\section{F. Zusammenfassung des I. Teils: Ellis' Symbolismus- und Kunstauffassung}

Nachdem Ėllis nach AbschluB seines Jurastudiums und seiner Beschäftigung mit Marxismus und Ökonomie zu Beginn dieses Jahrhunderts unvermittelt zum Symbolisten geworden war, wurden seine symbolistischen Ansichten zunächst maBgeblich durch den von ihm mitbegründeten "Argonautenkreis" geprägt: Im Vordergrund standen Bestrebungen für eine geistige Erneuerung RuBlands. Anregungen hierfür gaben die Werke und Lehren Schopenhauers. Nietzsches und VI. Solov'evs, aber auch der stark stilisierte Mittelalterkult der englischen Präraffaeliten wurde von den "Argonauten" intensiv rezipiert'. Kunst sollte Leben schaffen. Das alltägliche Dase in und die zwischenmenschlichen Beziehungen wurden mystifiziert und zu Kunstwerken stilisiert. Während Blok und auch Belyj später radikal mit der mystisch-romantischen Ausgangsposition des "Argonautenkreises" gebrochen haben ${ }^{2}$, drängt sich die Frage auf, ob Ellis die "Argonautenphase" vielleicht nie überwunden, sondern, im Gegenteil, sie später immer mehr vertieft hat?

Zunächst beschäftigte sich Ellis intensiv mit den Vertretem des französischen und belgischen Symbolismus (Übersetzungen. Vorträge, Publikationsentwürfe und Aufsätze), die einen großen EinfluB auf die russischen Symbolisten ausübten, und zugleich mit Dante. Später kam - unter dem EinfluB Metners - die deutsche Kunst und Kultur hinzu.

Ellis' Symbolismusauffassung wird zuerst stark vom Konzept frühsymbolistischer französischer Lyrik geprägt. Wie für viele russische Symbolisten war auch für ihn Baudelaires berihmtes Sonett "Correspondances" programmatisch: Symbolismus aufgrund von Synästhesien wird von den russischen Adepten nicht, wie in der Romantik. als Aufdecken geheimer Korrespondenzen, sondern als Erstellen genauer Korrespondenzen zwischen der sichtbaren und der unsichtbaren Welt verstanden. Ellis huldigte dem Individualismus und den Forderungen an die Kunst nach Freiheit und Ungebundenheit, wie sie Brjusov verrat und Nietzsche in seinen Werken darlegte (wobei man sich allerdings fragen muB. ob Ëllis Nietzsche immer richtig verstanden hat). Jedoch faBte Ëllis Brjusovs Forderung nach absoluter Freiheit in der Kunst von Anfang an dogmatisch auf: Er propagiente Freiheit wie ein Dogma und geriet dadurch allmählich immer mehr ins dogmatische Denken ${ }^{3}$.

Ėllis' Kunstauffassung trägt starke neoromantische Züge. Die parallel verlaufende Stilformation des Realismus und ihre Vertreter lehnt er radikal ab. Er versteht Symbolismus als Fortsetzung der Romantik; der "wahre" symbolistische Dichter ist für ihn ein Einsamer. Ausgestoßener, ein unverstandener Prophet, der unter der Unvollkommenheit des irdischen Daseins leidet und nur durch die Dichtung Zugang zum Absoluten erlangt. Eine rein formale Bestimmung des Symbolismus als neue literarische Schule genügt ihm folglich nicht; für ihn bedeutet Symbolismus in zunehmendem Maße mystisch-religiöse Weltanschauung, die er jedoch, trotz zahlreicher Versuche, nicht klar und eindeutig definieren kann. Unter Symbolismus versteht er einer-

\footnotetext{
1 Hierhei handelte es sich allerdings um romantisch vermitteltes westeuropäisches Mittelalter (die deutsche Romantik wurde vor allem durch die Übersetzungen und Nachdichtungen Vasilij Z̈ukovskijs vermittelt), das vor allem in den frühen Gedichten Bloks (etwa in seinen "Стихи o Прекрасно Даме"), die die "Argonauten" außerondentlich verehren. ja geradezu vergöttenten. eine wesentliche Rolle spielte. (Vgl. hierzu auch R.-D. Kluge: Westeuropa und RuBland im Weltbild A. Bloks. a.a.O.. S. 17-54.)

${ }^{2} \mathrm{Zu}$ Blok vgl. R.-D. Kluge: Westeuropa und RuBland im Weltbild A. Bloks. a.a.O., S. 59-61; zu Belyj vgl. A. Lavrov: A. Belyj v 1900-e gody, a.a.O.. S. 182ff.

$3 \mathrm{Vgl}$. hierzu auch James West (Russian Symbolism. A Study of Vyacheslav Ivanov and the Russian Symbolist aesthetic. London 1970. S. 110), der Ėllis als "perhaps the most naïvely dogmatic theorist of the Russian Symbolist movement" bezeichnet.
} 
seits den Umbau des gesamten Kulturgebäudes, das Schaffen einer neuen Kunst der Zukunft, andererseits das Aufgreifen und Fortführen alter traditioneller Kunst- und Kulturformen. Das christlich-religiöse Element in der Kunst erlangt für Ėllis eine zunehmend wichtigere Bedeutung, Symbolismus wird für ihn zur "großen Religion der Zukunft" ("великой религией будущего")4; er betont die überzeitliche Komponente des Symbolismus, der immer schon existien habe ${ }^{5}$. Immer wieder hebt Ellis hervor, daB Symbolismus mehr als Kunst sei, sich von einer neuen Stilerscheinung hin zur neuen religiösen Weltanschauung entwickelt habe.

Ėllis' Symbolismus- und Literaturauffassung ent wickelt sich immer mehr von einer rein literarisch-ästhetischen Position zu einem weltanschaulich dominierten Kunstkonzept, so daB seine Abkehr von Brjusov und seine Annäherung an Ivanov als in sich logisch und schlüssig erscheinen. Seine Symbolismusauffassung entspricht einerseits derjenigen Bloks, Ivanovs und Belyjs zur Zeit des Symbolistenstreits im "Аполлон" (gegen Brjusovs Forderung nach einer Kunst, die von jeglichen weltanschaulichen Vereinnahmungen frei sein sollte), andererseits wird sie gegen Ende der ersten und zu Beginn der zweiten Dekade dieses Jahrhunderts immer extremer, indem sie eine immer engere Verbindung zwischen Kunst und Religion fordert. Das führ schlieBlich dazu, daB letztendlich wahre Kunst, echter Symbolismus für Ëllis stets christlich-religiös sein müssen. Das "Erschaffen von Kultur" wird für Ellis zu einer Ar "Gottesdienst", deren höchste Form das christliche Mysterium ist ${ }^{6}$. In der Romantik und im Symbolismus sieht Ellis die Suche nach dem verlorenen Paradies des Glaubens emeuert, die Sehnsucht nach Religion und die Rückkehr zum Christentum. Der russische Symbolismus werde immer stärker zur echten christlichen Kunst?

Diese diffuse Vermengung romantischer und symbolistischer Theoreme zu einer retrospektiv geurteilt - eklektischen Konzeption bei Ėllis läBt sich wohl teilweise dadurch erklären, daB die theoretische Reflexion der russischen Romantik erheblich hinter der literarischen Praxis zurückgeblieben war und eigentlich erst zur Zeit des russisehen Symbolismus stattfand (vor allem durch die "jüngeren" Symbolisten) ${ }^{8}$. Die Frage nach dem Verhältnis von Romantik und Symbolismus in der russischen Literatur wird zwar diskutien ${ }^{9}$, ist aber bei weitem noch nicht gelöst ${ }^{10}$.

Ellis negien also in zunehmendem MaBe jegliche Offenheit und Unabhängigkeit. wie sie sich im Symbolismus herausbildeten, und kehn schlieBlich in seinem Traktat "Vigilemus!" nicht nur vollständig zur mimetischen Literaturtradition zurück, sondem forden zudem eine Kunst und Literatur, die sich im strengen Rahmen der Reli giosität und mittelalterlichen Frömmigkeit bewegt.

Betrachtet man das Werk seiner ersten Schaffensphase insgesamt, muB man Ëllis als Dichter und Essayisten bewerten, den zunehmend traditionelle Vorstellungen und Ideen prägten, so daB er nach anfänglichen Versuchen, sich dem Symbolismus einzu-

\footnotetext{
4 Vgl. Ëllis: Kul'tura i simvolizm. In: Becы, Nr. 10-11, 1909, S. 168.

5 Vgl. hierzu W. Pothoff: Dante in RuBland, a.a.O., S. 463, der A.W. Schlegels Aussage vom Dichten als "ewigem Symbolisieren" zitiert, und Potthoffs mehrfach erwähnten Aufsatz: Zum Begriff des "Überzeitlichen Symbolismus', a.a.O.

6 Vgl. Ellis: O zadacach i celjach služenija kul'ture. In: Труды и дни. Nr. 3-4. 1912.

7 Vgl. Ėllis' Traktat "Vigilemus!".

8 Vgl. hierzu auch R.-D. Kluge: Westeuropa und RuBland..., a.a.O., S. 66, sowie oben, "Einleitung" der vorliegenden Arbeit. S. 13.

9 Vgl. die Arbeit von Erik Egeberg: Romantizm i simvolizm, a.a.O.

$10 \mathrm{Vgl}$. zu diesem Problem auch folgenden Beitrag der Verfasserin: Lev L'vovix Kobylinskij-Ellis zapozdalyj romantik ili simvolist? (Zametki o svjazi nusskogo romantizma s simvolizmom). In: Proble my romantizma v russkoj i zasubežnoj literature (VI Guljaevskie čtenija). Tver', 15-18 maja $1996 \mathrm{~g}$. Tver' lim Druck].
} 
gliedem, immer stärker in alte romantische Denk- und Schaffensweisen zurückfiel, wozu ihm auch als Denker und Theoretiker sein eher rezeptives und weniger originelles Talent entgegenkam. Man könnte ihn als Neoromantiker im Sinne einer auf Harmonie und Religiosität festgelegten Romantik bezeichnen"1.

Ellis' Entwicklung stellt sozusagen eine Gegenreaktion auf jene innovatorischen Elemente des russischen Symbolismus dar, aus denen sich in der zweiten Dekade dieses Jahrhunderts die verschiedensten avantgardistischen Strömungen entwickelten. Folglich ist sein weiterer Lebensweg und Werdegang (Emigration in die Schweiz, Abbruch der Beziehungen zu seinen ehemaligen literarischen Mitstreitem in Moskau. Konversion zum Katholizismus und Beschäftigung mit ausschlieBlich religiösen The men) nur das konsequente Ergebnis der extremen Zuspitzung seiner Literatur- und Kunstauffassung.

$11 \mathrm{Vgl}$. hierzu auch oben. S. 157. 


\section{DIE DEUTSCHSPRACHIGE SCHAFFENSPERIODE - LEBEN UND WERK ${ }^{1}$}

\section{Leben - Biographische Angaben}

Die biographischen Zeugnisse über Ėllis als Emigrant, also über Ėllis' zweite Lebensund Schaffensperiode, sind äußerst dürftig. Die Zeit des Ersten Weltkriegs verbrachte er - zusammen mit Johanna van der Meulen ${ }^{2}$ - im wesentlichen in Basel (von Oktober 1915 bis Juni 1919) ${ }^{3}$, wobei er damals offensichtlich noch Kontakte zu seinen ehemaligen Moskauer "Musaget"-Mitarbeitem unterhielt, vor allem zu Ė. Metner, der allerdings seit 1914 in Zürich lebte ${ }^{4}$; Metner besuchte Ëllis und Johanna van der Meulen in Basel ${ }^{5}$. Einige Briefe von Ëllis aus dem Jahre $1917^{6}$ bezeugen, daB er von Basel aus die Polemik zwischen Metner und Belyj über Steiners Lehre aufmerksam verfolgte: Metner hatte 1914 sein Buch "Размышления о Гете. Разбор взглядов Р. Штейнера в связи с вопросами критицизма, символизма и оккультизма" ("Reflexionen über Goethe. Eine Beurteilung der Ansichten R. Steiners in Verbindung mit Fragen der Kritik, des Symbolismus und des Okkultismus", Moskau 1914) publizien. in dem er Steiners Goethe-Interpretation kritisierte. Darauf antwortete Andrej Belyj mit seinem Werk "Рудольф Штейнер и Гете в мировоззрении современности. Oтвет Эмилию Метнеру на его первый том «Размышлений о Гете»" ("Rudolf Stejner und Goethe in der gegenwärtigen Weltanschauung. Eine Antwort an Ėmilij Metner auf seinen ersten Band «Reflexionen über Goethe»", Moskau 1917)?

1 Vgl. hierzu auch: Ch. Villich (H. Willich), M.V. Koz'menko: Tvorteskij put' Éllisa za rubcžom. In: Izvestija Akademii Nauk. Serija literatury i jazyka. 52 (1993) 1, S. 61-69: Ch. Villich |H. Willich): L.L. Kobylinskij-Ellis kak posrednik meždu russkoj literaturoj i nemeckojazyčnymi Citateljami. In: Rossijskij literaturovedceskij zumal, 4 (1994). S. 191-195 sowie in: Kul'tumoe nasledie rossijskoj emigracii 1917-1940. Kniga vioraja. Moskva 1994, S. 258-264.

2 Ellis hatte Johanna van der Meulen bereits 1912 in anthroposophischen Kreisen um Steiner kennengelernt (unter dem Namen Po(o)lman( $n)-M o(0) y)$. (Nach ihrer Scheidung hatte sie wieder ihren Mädchennamen van der Meulen angenommen. (Diese Information entstammt dem Brief von Dr. Ulrich Barth (Stellvertreter des Staatsarchivars im Staatsarchiv Basel) vom 13.12.1994; vgl. hierzu auch oben, S. 125. Anm. 98, sowie PO РГБ, Ф. 167, картон 11. ед.xp. 1-2.1) Als zuverlässige Schülerin Rudolf Steiners war sie von ihm beauftragt worden. sich um Ellis zu kümmem. Später wandte auch sie sich von Steiner und der Anthroposophie ab. (Vgl. A. Belyj: Verwandeln des Lebens, a.a.0.. S. 72f., 211f., 506: M. Ljunggren: The Russian Mephisto, a.a.O.. S. 94.)

${ }^{3}$ Von Dr. Ulrich Barth ertielt die Verfasserin mit Brief vom 21.11.1994 folgende Information: "Der Schriftsteller «Leon [sic!| Kobilinsky» kam gemäB Einwohnerkontrolle (a 53636) als Refraktär von Weesen nach Basel und erhielt hier am 22. Oktober 1915 die Niederlassungsbewilligung. (...) Am 22. Oktober 1915 meldete er auch seine Wohnung an: Birsstrabe 86. Basel. Am 30. Juni 1919 erfolgte seine Abmeldung nach Locarno. Anhand der gängigen Findmittel lassen sich keine weiteren Hinweise oder Schriftstücke von L.K. bei uns nachweisen." Im Brief vom 13.12.1994 bestätigt Dr. Barth. daB J. van der Meulen in Basel ebenfalls in der Birsstr. 86 wohnte.

$4 \mathrm{Vgl}$. hierzu auch oben. S. 40.

5 Vgl. hierzu M. Ljunggren: The Russian Mephisto, a.a.O.. S. $101 f$.

6 PО РГБ. Ф. 167, картон 13, ед.xp. 15 und картон 14, eд.xp. 67-69. Vgl. auch M. Ljunggren: The Russian Mephisto, a.a.O., S. 128, 186, Anm. 4.

$7 \mathrm{Vgl}$. hierzu recht ausfiuhrlich M. Ljunggren: The Russian Mephisto, a.a.O., S. 63f., 83, 102-105, 108-110.119-128. 
digte Metner gegen Belyj ${ }^{8}$, dessen Buch er eine "Schmähschrift" nannte 91919 zogen Ellis und Johanna van der Meulen in die Schweiz nach Locarno-Monti und lebten dor gemeinsam bis zu Éllis' Lebensende.

Johanna van der Meulen $(1874-1959)^{10}$ stammte aus einer vornehmen, reichen holländischen Familie aus Amsterdam "'. Ihr Vater war Richter. Das kleine Haus, die Casa Fioretti, in dem sie mit Ėllis in Locamo-Monti lebte, gehörte einer Familienstiftung. Von den Geldmitteln dieser Stiftung lebten Ëllis und sie, denn beide hatten sonst kein regelmäBiges Einkommen ${ }^{12}$.

In den Jahren 1914 bis 1927 schrieb und publizierte Johanna van der Meulen unter dem Pseudonym "Intermediarius" 13 ein vierbändiges Werk mit esoterischer Thematik $^{14}$, dessen ersten Teil Ėllis ins Russische übersetzte und an den "Musaget"-Verlag nach Moskau schickte ${ }^{15}$. Diese Übersetzung wurde allerdings nicht publiziert.

Die Beziehung zwischen Johanna van der Meulen und Ėllis hatte geistigen, rein platonischen Charakter. Ellis als Mensch war - wie bereits seine Moskauer Periode gezeigt hat - unfähig, allein zu leben. Er wird als sehr liebenswürdig, aber absolut weltfremd, unpraktisch und intellektuell beschrieben, als impulsiv und gesprächig ${ }^{16}$. Im Laufe der Zeit beherrschte er die deutsche Sprache immer besser. Er verehre Deutschland und die Deutschen. Anfangs war er sogar von Hitler begeistert, da er die Hoffnung hatte, daB der Kommunismus in RuBland, der ihm sehr zuwider war, durch Hitler endgültig vemichtet werden könne, doch wandte er sich später enttäuscht von ihm und dem Nationalsozialismus ab. Johanna van der Meulen war durch und durch Christin, von grenzenloser Nächstenliebe und Altruismus beseelt. Den Sinn ihres Le bens sah sie in der Fürsorge für andere Menschen. Mit Ėllis verband sie zudem das gemeinsame Streben nach religiös-mystischen Inhalten. Sie war eher gemäBigter, zurückhaltender, bremste Ellis' Temperament und hielt ihn gewissermaBen im Zaum. Im Laufe der Jahre wuchs ihre geistige Verwandtschaft immer mehr.

Ellis wird in den $z$ wanziger Jahren von Richard Knies ${ }^{17}$ noch als "Laientheologe [...] russisch-orthodoxen Bekenntnisses" bezeichnet 18 mit romfreundlicher Gesin-

* Ellis schricb cine positive Rezension ubber Metners Gocthe-Buch mit dem Titel: "Teocoфня nepen судом культуры" ("Theosophie vor dem Kulturgericht", mit "Sagittarius" unterzeichnet), die Metner bereits im Juni 1915 an den Sekretär des "Musaget"-Verlags N. Kiselev gesandt hatte (vgl. hierzu M. Ljunggren: The Russian Mephisto, a.a.O., S. 126. 186. Anm. 42).

9 "Пасквиль" (РО РГБ. Ф. 167. картон 14. ед.хр. 69).

$10 \mathrm{Vgl}$. M. Ljunggren: The Russian Mephisto, a.a.O., S. 180, Anm. 42.

11 Diesen sowie viele Hinweise zu Ėllis' Biographie im vorliegenden Kapitel verdanke ich einem ausführlichen Gespräch mit Frau Lore Müller, die seit 1932 in Locarno lebt und durch ihren Schwiegervater persönlichen Kontakt zu Ëllis und Johanna van der Meulen hatte, an die sie sich bis heute lebhaft erinnen. AuBerdem vgl. M. Ljunggren: The Russian Mephisto, a.a.O., S. $101 \mathrm{f} ., 104$.

12 Davor, etwa bis zum Beginn des 1. Weltkriegs, wurde Ėllis ja von "Musaget" finanziell unterstïtzt und hatte don auch seine Werke publizien.

13 Intermediarius = Vermittler; J. van der Meulen hielt sich für eine Vermittlerin zwischen Himmel und Erde.

$14 \mathrm{Vgl}$. Intermediarius: Christliche Theologie und Cosmosophie nach dem Zeichen des heiligen Graal. Leipzig 1914: Dies.: Homo Coelestis. Das Urbild der Menschheit. Per Crucem ad Rosam. Basel 1918: Dies.: Universum. Der Cosmos und der cosmische Mensch. Liber mundi. Per Crucem ad Rosam. Basel 1923 und Dies.: Das große Zeichen. Arcana sapientiae. Per Crucem ad Rosam. Basel 1927.

15 Die Übersetzung befindet sich im PO РГБ. Ф. 167. картон 11. ед.xp. 1-2.

16 Diese Informationen entstammen dem Gespräch mit Lore Müller (vgl. oben. Anmerkung 11 dieses Kapitels).

17 Leiter des Matthias-Grüe wald-Vertags, Mainz.

18 So R. Knies in der "Erklärung des Verlags" in: W. Solowjew: Monarchia Sancti Petri. Die kirchliche Monarchie des heiligen Petrus als freie und universelle Theokratie im Lichte der Weisheit. Aus den Hauptwerken von Wladimir Solowjew systematisch gesammelt, übersetzt und erklär durch L. Kobi- 
nung ${ }^{19}$. Später, wohl zu Beginn der dreiBiger Jahre, konvertierte er zum Katholizismus ${ }^{20}$. Johanna van der Meulen war ursprünglich Protestantin, aber - Ellis folgend konvertierte auch sie zum Katholizismus. Gemeinsam besuchten sie regelmäßig an Sonn- und Feiertagen die Messe im katholischen Kloster "Madonna del Sasso", das auf dem Berg oberhalb von Locarno liegt.

Insgesamt lebten Ėllis und Johanna van der Meulen recht still und abgeschieden in Locarno. Wie Lore Müller ${ }^{21}$ berichtet, ging Ellis häufig schnellen Schritts mit wehender, schwarzer Pelerine auf dem Berg oberhalb Locamos spazieren. Er unterhielt keine Kontakte mehr zu seinen früheren Moskauer literarischen Mitstreitem 22; auch mit den in der Emigration lebenden russischen Literaten scheint er nicht allzu aktiv verkehrt zu haben. Jedoch erwähnt er in seinen Arbeiten aus dieser Zeit häufig die Namen der - wie er sie nennt - "Führer der russischen Emigration"23: N. Berdjaev, I.A. Il'in, V.N. Il'in, S. Bulgakov, B. Zajcev u.a., zu denen er möglicherweise Kon takt hatte. Zumindest publizierte er mitunter Beiträge in denselben Zeitschriften und Sammelbänden wie sie 24 . Nahe standen ihm wohl auch die in der Emigration lebenden D. Merežkovskij, den er für den bedeutendsten der lebenden russischen Schriftsteller hielt, und Vjač. Ivanov, den er einen der hervorragendsten russischen Symbolisten nannte 25 . Im Archiv von Dmitrij V. Ivanov in Rom befinden sich ein Brief von Ėllis an Merežkovskij (1933?) und drei undatierte Briefe an Vjač. Ivanov (vermutlich aus den dreiBiger Jahren; bei einem Brief findet sich ein Umschlag mit einem Poststempel von 1936) ${ }^{26}$. Ivanovs Antworbriefe an Ėllis, die es (wie aus Ėllis' Briefen hervorgeht) gegeben haben muB, sind leider nicht erhalten bzw. konnten bis jetzt nicht aufgefunden werden. Interessant in diesem Zusammenhang ist das indirekte Zeugnis über eine mögliche Verbindung oder Freundschaft zwischen Vją. Ivanov und Ellis, wie es in den Memoiren von Lidija V. Ivanova ausgedruickt ist: die scherzhafte Bemerkung in ihrer hauseigenen Zeitschrift über die mystische Zurückgezogenheit von Ëllis in Locamo ${ }^{27}$. Ellis jedenfalls begrüBt in seinen Briefen die neue Richtung, die Vjač. Ivanov eingeschlagen hat (damit meint er Ivanovs Konversion zum Katholizismus):

linski-F.llis. Mainz 1929. S. XIII; ganz ähnlich äußert sich Knies über Ellis in seinem "Vorwort" zu W. Solowjew: Das Lebensdrama Platons. Mit einem Nachwor über Platon und Solowjew von L. Kobilinski-Ellis. Aus dem Russischen übertr. von B. Schmitt. Mainz 1926, S. VII.

${ }^{19}$ So R. Knies im "Geleitwor" in: Christi Reich im Osten. Die geistige Bedeutung Wladimir Solowjews und die inneren Voraussetzungen zur Wiedervereinigung der nussisch-orthodoxen und der römisch-katholischen Kirche. Hrsgg. von Richard Knies. Mainz 1926, S. 1.

$20 \mathrm{Vgl}$. den Hinweis von Domkurat Dr. Karl Rudolf (Herausgeber der Zeitschrift "Theologie der Zeit") in: Theologie der Zeit, 2, Wien, 1937. S. 57.

$21 \mathrm{Vgl}$. oben, S. 180, Anm. 11.

22 E. Metner scheint Ėllis und Johanna van der Meulen im Frühjahr 1920 in Locamo-Monti besucht zu haben. konnte jedoch die katholisch inspirierte Esoterik nicht akzeptieren, während Ėllis Metners Interesse für Jung und dessen Tiefenpsychologie nicht teilte (vgl. oben. S. 40), so daB dieser Besuch ihre letzte Begegnung und das Ende ihrer Freundschaft war. $(\mathrm{Vgl}$. hierzu auch $\mathrm{M}$. Ljunggren: The Russian Mephisto, a.a.O.. S. 133f.. 188. Anm. 31-33.)

${ }^{23}$ Vgl. L. Kobilinski-Ellis: W.A. Joukowski. Seine Persönlichkeit, sein Leben und sein Werk. Paderborn 1933, S. 291.

24 Der Kontakı zu N. Berdjaev ist durch füf Briefe von Éllis an ihn (aus dem Jahre 1939) belegt, die sich in Moskau im РГАЛИ befinden (Ф. 1496. On. 1. ед.xp. 843), von der Verfasserin jedoch leider nicht eingesehen werden konnten.

$25 \mathrm{Vgl}$. Die Schildgenossen. Heft 6. Aug./Sept. 1937, S. 476.

26 Diese Informationen sowie eine Kopie der Briefe an Ivanov erhielt die Verfasserin von A. Šiskin aus Rom.

27 Vgl. L. Ivanova: Vospominanija: Kniga ob otce. Podgotovka teksta i kommentarij Dzona Mal'mstada. Moskva 1992. S. 70. 
Хорошо. что мы можем снова встретиться на новом общем пути для совместно работы во имя Хрнста! Верно. что в главном и последнем мы солндарны. Разница в предпюслелнем долкна повлечь $\mathrm{x}$ плодотворным беседам $[. ..]{ }^{28}$

Ëllis befaßte sich in seiner zweiten Lebenshälfte und Schaffensperiode weniger mit rein literarischen, als vielmehr mit philosophisch-religiösen, mystischen Fragen und Problemen. Seit den zwanziger Jahren publizierte er Arbeiten und Aufsätze auf Deutsch unter dem Namen Dr. Leo Kobilinski-Ellis. Viele seiner Werke aus dieser Schaffensperiode erschienen im Matthias-Grünewald-Verlag, Mainz, der es als erster katholischer Verlag in Deutschland unternahm, die deutschen Katholiken mit VI. Solov'ev bekannt zu machen und sowohl russisch-orthodoxe wie auch römisch-katholische Autoren zur Mitarbeit heranzog29. Zu diesem Zweck gab der Matthias-Grünewald Verlag 1926 und 1927 zwei Sammelbände heraus mit den Titeln "Christi Reich im Osten" 30 und "Ex Oriente". Der erste dieser Bände, "Christi Reich im Osten", trägt den Untertitel: "Die geistige Bedeutung Wladimir Solowjews und die inneren Voraussetzungen zur Wiedervereinigung der russisch-orthodoxen und der römischkatholischen Kirche" und ist unter aktiver Mithilfe und Mitarbeit von Ėllis entstanden 31 . In seinem "Geleitwort" charakterisiert Richard Knies die Aufgabe dieses Sammelbandes folgendermaBen:

Dieses Jahrbuch unternimmt in den Beiträgen seiner verschiedenen Mitarbeiter den Versuch, die russische Frage in ihrem religiösen Charakter zu sehen und zwar durch die Prüfung des inneren Verhältnisses zwischen der russisch-orthodoxen Kirche des Ostens und der römischkatholischen des Westens und der Möglichkeit zur Wiederherstellung der Einheit. Der Ausgang dabei wird von der lebendigen Persönlichkeit des Wladimir Solowjew genommen. [...] Dieser grobe, westlich orientierte, russische Denker steht an der Grenze von Morgen- und Abendland und richtet gewaltige Fragen nicht nur an seine Heimat RuBland, sondern auch an die Christen Westeuropas. In seinem Bekenntnis zur universellen Kirche Christi unter dem Apostel Petrus und seinen Nachfolgem als Oberhaupt liegt an RuBland die Frage um die Entscheidung über die Anerkennung des Primates Petri und damit Roms: sein philosophisch-theologisches Lebenswerk aber bedeutet an den christlichen Westen Europas die Frage um die Möglichkeit der Anerkennung jener Lehre des christlichen Ostens, die nicht nur gleichsam Kerm und Stem des Denkens seiner gläubigen Philosophen und Theologen, sondern auch der inbrünstig umfangene Glaube des einfachen Volkes ist - nämlich der Sophia-Lehre. ${ }^{32}$

Der zweite Sammelband des Matthias-Grünewald-Verlags. "Ex Oriente" (1927), widmet sich religiösen und philosophischen Problemen des Ostens und des Westens, vor allem dem Problem der Union der östlichen und der westlichen Kirchen, und wurde von Prof.Dr.theol. Ludwig Berg herausgegeben, der amtlich mit der russischen Emi granten-Fürsorge beauftragt war. In diesem Band finden sich Beiträge orthodoxer, unierter und katholischer Schriftsteller in russischer, französischer und deutscher Sprache (darunter auch Arbeiten von Ellis). Der Herausgeber Ludwig Berg äußer sich über das Anliegen des Bandes folgendermaBen:

Die Wiedervereinigung der christlichen Kirchen ist ein Werk der göttlichen Gnade, aber auch ein Werk menschlicher Mitarbeit. Nach menschlichem Ermessen wird dieses Problem der Union nicht in der nächsten Zukunft gelöst, wenn auch immer Einzelübertitte stattfinden. Hierbei darf naturgemäB weder die Liebe noch die Wahrheit verletzt werden.

28 Brief von Ëllis an V. Ivanov aus dem Archiv von D.V. Ivanov, Rom.

$29 \mathrm{Vgl}$. das Vorwort von Richard Knies in: W. Solowjew: Das Lebensdrama Platons, a.a.O., S. VI, VII.

30 "Ähren aus der Garbe. Kleines Jahrbuch des Matthias-Grünewald-Verlags für das Jahr 1926".

31 Darauf weist der Herausgeber Richard Knies in seinem "Vorwort" hin (vgl. Christi Reich im Osten, a.a.O.. S. 2).

32 Ebd., S. 1. 
Zur Wiedervereinigung drängt eine Reihe innerer Gründe, vor allem aber auch die traurige Zerrissenheit innerhalb der Millionenschar derer, die sich Christen nennen und als leidende, gemarterte Kirche einer geschlossenen, gottlosen, kampfbereiten Welt gegenüberstehen.

Dem Problem der Union der morgenländischen und abendländischen Kirchen ist das vorliegende Buch in erster Linie gewidmet, da wir in den Orthodoxen unsere "getrennten Brüder" erblicken, da die Kirchen des Morgenlandes mit denen des Abendlandes nach dem griechischen Kirchenlehrer Basilius dem Groben den einen Leib Christi bilden.

[...] Die Schwierigkeiten auf dem Wege zum hohen Ziele werden erkannt. Lösungen mit glühendem Eifer gesucht: Wege einer echten Union, d.h. einer Wiedervereinigung in Glaube, Verfassung und Gottesdienst und Wege, die sich mit der Einheit in gewissen praktischen Fragen begnügen, aber hie und da, als etwas Vorläufiges, als Durchgangsstadium zur echten, vollkommenen Union bezeichnet werden. ${ }^{33}$

Behandelt werden in den Beiträgen allgemeine Fragon zur Union, zur Geschichte und zur Dogmatik der orthodoxen und der römisch-katholischen Kirche sowie Biographisches (über Heilige, Pilger und Starzen).

Seine Aufsätze publizierte Ėllis (außer in den genannten Sammelbänden) in verschiedenen katholischen Zeitschriften, die sich ebenfalls mit Fragen und Problemen des Ostens und Westens befaBten und bestrebt waren, den deutschsprachigen Katholiken die Ostkirche und das religiöse Kulturgut RuBlands nahezubringen, wie etwa die Zeitschriften "West-östlicher Weg"34, "Theologie der Zeit"35, "Die Schildgenossen" 36 und "Das neue Reich"37.

Durch Ellis' Publikationen in den genannten katholischen Zeitschriften und Sammelbänden werden wir auf ein interessantes Phänomen gestoßen, nämlich auf das plötzliche Aufkommen eines großen Interesses an Vl. Solov'ev und seiner Unionsidee der Ost- und Westkirche unter den Katholiken im süddeutschen und österreichischen

${ }^{33}$ Ex Oriente. Religiöse und philosophische Probleme des Ostens und des Westens. Beiträge orthodoxer, unierter und katholischer Schriftsteller in russischer, französischer und deutscher Sprache. Hrsgg. von Prof. Dr. theol. Ludwig Berg. Mainz 1927, S. XIII.

34 Die Monatsschrift "West-östlicher Weg" (1928-1931. Glogau - Mainz) weist in itrem "Geleitwort" darauf hin. daB sie das Ziel verfolge. die westliche katholische Welt besser mit der Religiosität der Ostkirche bekanntzumachen. als eine Art Fortsetzung der Bestrebungen der beiden bereits erwähnten Sammelbände "Christi Reich im Osten" (1926) und "Ex Oriente" (1927) vom Matthias-GrünewaldVerlag. Das habe die Beschäftigung mit dem kulturellen Leben des Ostens und der russischen Seele zur Voraussetzung. AuBerdem müsse man das Wesen des Kommunismus und die Gründe für sein derzeitiges Aufblühen studieren. Der Name der Zeitschrift. "West-östlicher Weg", drücke bereits ihr Ziel aus. wobei Vl. Solov'ev und sein Werk einen besonderen Platz einnehmen. (Bertram Schmitt: Zum Geleit. In: West-östlicher Weg. I, 1928, S. 3-5.)

35 Die vieneljährlich erscheinende Zeitschrift "Theologie der Zeit" (1936-1939. Wien) war als Beiheft bzw. Erweiterung zum "Seelsorger" gedacht und wollte den theologischen, systematischen Unter bau zum mehr auf die seelsorgliche Praxis ausgerichteten "Seelsorger" leisten (vgl. Karl Rudolf: Zur Begründung der "Theologischen Beihefte". In: Theologie der Zeit, Heft 1, 1936, S. If.). Heft 2, 1937, mit dem Titel "Vom östlichen Christentum" und auch ein grober Teil von Heft 3-4, 1938, mit dem Titel "Ethos und Frörnmigkeit" wenden sich überwiegend Fragen des "heiligen RuBland", der Ostkirche und der Lehre VI. Solovevs zu.

36 Zwei Hefte der katholischen Zweimonatsschrift "Die Schildgenossen" (1920-1941, Burg Rothenfels - Würzburg - Mainz), nämlich Heft 6. Aug./Sept. 1937, und Heft 2, März/April 1939, sind ganz Fragen des west-östlichen Wegs, der Ostkirche und RuBlands gewidmet und werden als "Beitrag zu dem groben Werke der Wiedervereinigung der östlichen Christenheit mit der apostolischen Mutterkirche Roms" (vgl. Karlheinz Schmidthus: Vorbemerkung zu den Beiträgen dieses Heftes. In: Die Schildgenossen, 18. Jg.. Heft 2. März/April 1939. S. 89) verstanden. In beiden Heften weist die Schriftleitung dankend auf Éllis' grobe Hilfe bei der Zusammenstellung des Materials hin (vgl. Die Schildgenossen. Heft 6, 1937, S. 506 und Heft 2, 1939. S. 90).

${ }^{37}$ Die Wochenschrift für Kultur, Politik und Volkswirtschaft mit dem Titel "Das neue Reich" (Wien - Innsbruck - München) will "alle bewegenden Fragen der katholischen Welt" durcharbeiten (vgl. Das neue Reich, Nr. 52, 7. Jg., 26.Sept. 1925, S. 1219). 
Raum in den zwanziger Jahren unseres Jahrhunderts. Das Bestreben, eine Vereinigung der Christen des Ostens und Westens zu erreichen, führte nicht nur zu einer Beschäftigung mit dem Werk und der Lehre Vl. Solov'evs, sondem mit dem Kulturgut und den Traditionen der russischen orthodoxen Kirche allgemein. mit ihren Heiligen und dem Starzentum. Neben Ellis' Aufsätzen finden sich in diesen Zeitschriften und Sammelbänden Arbeiten von N. Berdjaev, V. Il'in, S. Durylin, P. Florenskij und anderen Vertretem des russischen Geisteslebens. Ein ausführliches Erforschen dieses Phänomens wäre sicher eine Untersuchung wert, würde aber in der vorliegenden Arbeit zu weit führen.

In seiner zweiten Schaffensphase war Ėllis also aktiv bestrebt, die deutschsprachi gen Katholiken mit der religiösen Kultur der Ostkirche bekannt zu machen; er setzte sich eifrig für eine mögliche Wiedervereinigung der Ost- und Westkirche ein, worunter er allerdings eher eine Rückkehr der Ostkirche in den SchoB der katholischen Kirche verstand und weniger die Vereinigung zweier gleichberechtigter Partner. (Die Angabe, daB Ëllis Jesuit wurde 38 , konnte die Verfasserin nirgends bestätigt finden.)

Bis zu seinem Tode am 17. November 1947 lebten Ellis und Johanna van der Meulen gemeinsam in der Casa Fioretti. Ellis starb in der Klinik Santa Chiara (vermutlich an Krebs) und wurde am 18. November auf dem Friedhof der St. Antonio-Kirche in Locamo beigesetzt ${ }^{39}$. Sein Grab existiert allerdings nicht mehr. (Ellis hatte ja bekanntlich keine Nachkommen, die es hätten pflegen und erhalten können). Das Haus. die Casa Fioretti, in dem Ëllis und J. van der Meulen in Locarno-Monti lebten, steht heute noch.

${ }^{38}$ Vgl. V. Fedjuschin: RuBlands Sehnsucht nach Spiritualität, a.a.O., S. 185.

$39 \mathrm{Vgl}$. die von J. van der Meulen aufgegebene Todesanzeige in der Zeitung "Giomale del popolo". Lugano. 18 novembre 1947. 


\section{Werk}

\section{A. Allgemeiner Überblick}

Auch nach seiner Abkehr von Rudolf Steiner und der Anthroposophie befaBte sich Ellis weiterhin mit mystisch-religiösen Fragen und Problemen, mit dem - nach seiner Meinung - echten, wahren Christentum. Er übersetzte nicht nur das erste Werk Johanna van der Meulens ins Russische', sondern schrieb, nach Erscheinen aller vier Werke$^{2}$, eine Art wissenschaftlichen Kommentar über die "Lehre des Intermediarius" 3 sowie eine umfassende Arbeit über die mystische Bedeutung des "heiligen Grales"4.

Ėllis verfaßte in seiner zweiten Schaffensperiode weiterhin Gedichte, allerdings auf Russisch. Hiervon zeugt das erwähnte Manuskript seines geplanten Lyrikbandes "Крест и Лира"5.

Vladimir Solov'ev, einer der geistigen Väter der "jüngeren Symbolisten", blieb auch in dieser Schaffensphase sein groBer Lehrer; Ėllis selbst betonte, daB er dem Geist seines Lehrers in allen seinen Werken treu bleibe 6 . Er übersetzte viele Werke Solov'evs ins Deutsche und publizierte in den erwähnten Sammelbänden des Matthias-Grünewald-Verlags und den genannten katholischen Zeitschriften etliche Aufsätze über den russischen Religionsphilosophen. Gleichzeitig befaBte er sich auch mit Pavel Florenskijs Sophienlehre.

Neben Vl. Solov'ev wandte sich Ellis vorwiegend der Epoche der Romantik zu. Er plante die Herausgabe einer Trilogie zur russischen Romantik mit dem Titel: "Das goldene Zeitalter der russischen Poesie". Diese Trilogie sollte aus drei eigenständigen Monographien bestehen:

1. Über Persönlichkeit, Leben und Werk V.A. Žukovskijs;

2. über Puškin und seine sogenannte "Plejade" 7 und

3. über Lermontov und die Geschichte der Kritik des "goldenen Zeitalters".

In Žukovskij. Puškin und Lermontov sah Ėllis die drei gröBten Dichter und bedeutendsten Vertreter des "goldenen Zeitalters" der russischen Literatur ${ }^{8}$. Žukovskij sei der Begründer dieser Epoche gewesen, Puškin ihr Gipfel und Lermontov ihr Vollender 9 .

Tatsächlich erschienen allerdings nur die ersten zwei Bände der geplanten Trilogie: über Žukovskij (1933) und Puškin (1948, d.h. postum, 1 Jahr nach Ëllis' Tod) ${ }^{10}$.

\footnotetext{
1 PO РГБ. Ф. 167. картон 11, ед.xp. 1-2.

$2 \mathrm{Vgl}$. vorthergehendes Kapitel, S. 180, Anm. 14

3 Vgl. L. Kobilinski-Ellis: Christliche Weisheit. Sapientia divina. Cosmologia perennis. Nach der Lehre des Intermediarius. Per Crucem ad Rosam. Basel 1929.

4 Teile dieser Arbeit wurden 1932 in den "Bayreuther Blättern" publizient (vgl. oben. S. 149. Anm. 258).

5 Vgl. oben. S. 66.

6 Vgl. L. Kobilinski-Ellis: W.A. Joukowski, a.a.O., S. 5.

7 "Die Plejade Puskkins" ist ein bis heute gängiger Begriff in der Literaturgeschichtsschreibung: vgl. etwa A. Stender-Petersen: Geschichte der russischen Literatur, a.a.O., Teil II. S. 90ff.

8 Vgl. L. Kobilinski-Ellis: W.A. Joukowski, a.a.O., S. 12.

9 Vgl. L. Kobilinski-Ellis: Alexander Puschkin. Der religiöse Genius RuBlands. Olten 1948, S. 27.

10 Der dritte Band über Lermontov ist nicht erschienen, obwohl es durchaus denkbar ist. daB Ėllis ihn nicht nur geplant hat, sondem daB unveröffentlichte Notizen oder gar ein Manuskript dazu existiert haben müssen, zumal er sich bereits in seiner ersten Schaffensperiode in Moskau mit Lermontov befaBt hat, wie die Verfasserin den Archivmaterialien (Notizbücher. Bemerkungen in Briefen u.ä.) im РГАЛИ und in der Handschriftenabteilung der Russischen Staatsbibliothek entnehmen konnte. (РГАЛИ. Ф. 575, опнсь 1, ед.xp. 10 und eд.xp. 20 [Brief Nr. 4 an M.I. Sizova vom Herbst 1908 sowie Blatt 169 auf
} 
Neben den Monographien über Žukovskij und Puškin publiziente Ėllis mehrere Aufsätze über diese beiden Dichter in den erwähnten katholischen Zeitschriften. Auch wandte er sich emeut dem Leben und Werk Gogol's zu.

In dieser zweiten, der deutschen Schaffensperiode, machte es sich Ėllis zur Hauptaufgabe, russische Literatur und Kultur in den deutschen Sprachraum zu vermitteln und die - wie er meinte - echten Verbindungen zwischen Kultur und Christentum wiederherzustellen, die seit dem Mittelalter verlorengegangen seien. In diesem $\mathrm{Zu}$ sammenhang befaßte er sich mit der russischen Literatur allgemein. der Kunst und Literatur des alten RuBland, mit der altrussischen religiösen "Heldenepik", mit dem "Heiligen RuBland"11, dem Starzentum sowie mit russischen Ikonen und Heiligenlegenden und publizierte verschiedene Arbeiten zu diesen Themen.

dem es heiBt, daB Ėllis bei P.I. Astrov über Lermontov lesen wird]; PO РГБ, Ф. 167, картон 10, ед.xp. 23. AuBerdem plante Ėllis bereits 1907 die Herausgabe eines Romantikbandes [PO РГБ. $Ф$. 167, карт. 6. ex.xp. 3 und auch Ëllis' Briefe an Metner|).

Wo sich der deutsche NachlaB von Ėllis befindet (falls dieser noch existiert), konnte ich leider trotz vieler Bemühungen bis heute nicht in Erfahrung bringen. DaB es einen NachlaB gibt oder gegeben haben muB. zeigt 2.B. das 1972 von A. Davids aus dem Ėllis-NachlaB herausgegebene Bändchen über "Heilige aus dem alten RuBland" mit Texten, die Ëllis aus dem Russischen ins Deutsche übertragen hat. Eine Kontaktaufnahme mit A. Davids ergab jedoch lediglich, das der von ihm herausgegebene Band das einzige Material aus Ėllis' NachlaB ist, das er vom damaligen Präsidenten des Intemationalen Forschungszentrums zu Salzburg, Prof. P. Dr. Thomas Michels O.S.B., erhalten hat. Leider lebt Prof. Michels nicht mehr und die Verfasserin konnte. trotz Nachfragen und Recherchen in Salzburg und der Abtei Maria Laach (in der sich ein Teil des Nachlasses von Prof. Michels befindet), nichts über den Verbleib eines möglichen weiteren Nachlasses von Ëllis in Erfahrung bringen. (In der Handschriften abteilung der PГБ und im PГAЛИ befinden sich lediglich Materialien von Ėllis (Briefe. Manuskripte. Notizbuicher, Übersetzungen etc.] bis zum Jahr 1914 [auf Russisch) sowie die erwähnten fünf Briefe an Berdjaev von 1939 (vgl. oben. S. 181, Anm. 24).) Vorn Ferdinand-Schöningh-Verlag. Paderborn. erhielt die Verfasserin Kopien der Verlags-Vertüge für die Publikation von Ëllis' Žukovskij-Monographie und seiner Solov'ev-Übersetzung "Der heilige Wladimir und der christliche Staat" sowie die Auskunf. daB das Verlagsarchiv im Frühjahr 1945 untergegangen sei und keine Korrespondenz metr existiere.

11 Der Begriff "Heiliges RuBland" entstand nach dem Untergang von Byzanz in enger Verbindung mit der Theorie von Moskau als dem "Dritten Rom" und bezeichnet das christlich-orthodoxe RuBland der Moskaver Periode (16.-17. Jahrhundert) ab etwa der Zeit der Herrschaft Ivans des Schrecklichen. Expressis verbis findet sich der Terminus zum ersten Mal in der "Geschichte des Zaren Ivans des Schrecklichen", verfaBt von seinem Gegner, Fürst Kurbskij (vgl. A.V. Solov'ev: Holy Russia: the history of a religious-social idea. 'S-Gravenhage 1959; D. Tschiževskij: Russische Geistesgeschichte. a.a.O., S. 113). Der Russische bzw. Moskauer Staat ist, nach Überzeugung Ivans des Schrecklichen. eng mit dem Himmelreich verbunden: der Zar ist zugleich Heiliger (D. Tschižewskij: a.a.O., S. 114ff.: vgl. auch H. Setzer: Moskau - das Dritte Rom. In: R.-D. Kluge/H. Setzer (Hrsg.): Tausend Jahre Russische Kirche. Tübingen 1989, S. 56).

Auf Ėllis' Verständnis dieses Terminus wird an entsprechender Stelle eingegangen werden. 


\section{B. "Christliche Weisheit" (Intermediarius)}

In den 20er Jahren wurden Ellis' Ansichten wesentlich von den esoterischen und kosmologischen Werken Johanna van der Meulens ${ }^{1}$ geprägt und beeinfluBt, mit denen er sich bereits vor dem Ersten Weltkrieg zu beschäftigen begann ${ }^{2}$. Sie regten ihn zu einer eigenen Arbeit über die "Lehre des Intermediarius" an, die "dem Intermediarius ehrfurchtsvoll gewidmet" ist ${ }^{3}$. In diesem Werk versucht Ellis, eine Darstellung der Grundsätze des synthetischen (esoterischen) Christentums zu geben. Als die beiden grundlegenden Schriften der christlichen Lehre betrachtet er das Evangelium und die "Offenbarung" des Johannes:

[...] seine beiden Schriften [besitzen] jene Vollkommenheit sowohl der inneren Tiefe wie auch der äußeren Fülle, die nur aus einer harmonischen Synthese zwischen dem Glauben an die göttlichen Geheimnisse und der Weisheit, d.h. dem Schauen der himmlischen Geheimnisse entsteht und deshalb die Fülle der gesamten christlichen Offenbarung, das esoterische Christentum bedeutet. ${ }^{4}$

Vor allem die "Offenbarung" des Johannes erlange in der gegenwärtigen Zeit eine große Bedeutung, die er - wie bereits in seinen früheren Arbeiten (etwa in "Vigilemus!") - als Zeit der Krise, der Weltenwende, als Übergangsepoche bezeichnet 5 .

Ellis' Werk besteht aus drei Teilen: Im ersten Teil, den "Prolegomena"6, versucht er, "die prinzipiellen und geschichtlichen Beziehungen zwischen der Kultur (als der irdischen Weltweisheit), der himmlischen Weisheit und der Religion zusammenzufassen"7. Wie in früheren Arbeiten, besonders in "Vigilemus!", betont er auch hier wieder den Bruch zwischen Kultur und Religion seit der Renaissance. Die moderne Kultur habe ihren eigenen "hohen Weisheitsursprung" vergessen; ohne Weisheit sei sie krank und tot ${ }^{8}$. Die neuzeitliche Philosophie und die gegenwärtige Kunst verurteilt Ëllis - mit wenigen Ausnahmen - als "verblaBte Kopie" und "abstrakte Verflachung" der alten Weisheitslehre, als "Nachklänge der Weisheit und Schönheit der Vorzeit"9. Wiederholt hebt er Dantes "Divina Commedia" als größtes dichterisches Werk der christlichen Zeitepoche hervor. Die verlorene christliche Weisheit, der wahre christliche Glaube und die echte christliche Kultur (der frühchristlichen Zeit bis hin zum Mittelalter) müBten wiedererlangt werden. "Nur die Triade: Glaube - Weisheit Kultur hat Zukunft." 10 "Der Weg durch das Kreuz des Glaubens zur Rose (rosa mystica) der Weisheit ist der christliche Weg. [...] Die alte esoterische Formel der christlichen Weisheit lautet: Per Crucem ad Rosam!"ll. Ellis formulient die Aufgabe, die er sich im vorliegenden Werk gestellt hat, wie folgt:

Sie besteht nicht in einer esoterischen Weisheitsverkündigung (die eine Meisterschaft in Weisheit. eine Hellsichtigkeit oder eine persönliche Initiation fordert), sondern in einer vielmehr exoteri-

\footnotetext{
1 Vgl. oben. S. 179f., Anm. 2. 13 und 14.

2 Vgl. Ėllis' Übersetzung des ersten Werks von Intermediarius. РО РГБ. Ф. 167. карт. 11, eд.xp. If.

${ }^{3}$ Vgl. L. Kobilinski-Ellis: Christliche Weisheit. Sapientia divina. Cosmologia perennis. Nach der Lehre des Intermediarius. Per Crucem ad Rosam. Basel 1929.

${ }^{4}$ Ebd., S.VII.

5 Vgl. z.B. ebd., S. Vul, 3, 31, 125.

Diese Aussage stellt gewissermaßen einen verspäteten Reflex der eschatologischen Disposition der "jüngeren" Symbolisten aus der Zeit der Jahrhundertwende dar.

${ }^{6}$ L. Kobilinski-Ellis: Christliche Weisheit. a.a.O., S.1-52.

7 Ebd., S.IX.

${ }^{8}$ Ebd., S. 22, 25, 29.

9 Ebd.. S. 29 .

10 Ebd., S. 29.

${ }^{11}$ Ebd., S. 38.
} 
schen Wiedergabe (gedankenmäBigen Rekonstruktion, abstrakten Interpretation und historischen Orientierung) der authentischen Fassung des Intermediarius im Zusammenhange mit der Weisheitslehre der universell-kirchlichen (apostolischen) Tradition. Er [ = der Verfasser] steht überall auf dem Boden der allgemein-zugänglichen (literarischen) Urkunden und leistet vorzugsweise Kulturarbeit. ${ }^{12}$

Im zweiten Teil: "Christliche Weisheit"13, dem Umfang nach der Hauptteil, gibt Ellis eine methodische Darstellung "der christlichen esoterischen (theologischen, kosmologischen und anthropologischen) Weisheitslehre nach den Werken von Intermediarius" 14 . In seiner "Vorbemerkung" zu diesem Teil betont er, daB sein Werk "eine Art Einführung" in die Werke des Intermediarius sei, wobei er dem "christozentrischen Charakter" der Lehre des Intermediarius eine ganz besondere Bedeutung beigemessen habe ${ }^{15}$. Im ersten, mit "Theologie" überschriebenen Unterkapitel ${ }^{16}$ schildert er die göttliche Dreieinheit (Vater, Sohn und Heiligen Geist), das Himmelreich mit seinen Hierarchien und dem himmlischen Menschen als Ebenbild und Gleichnis Gottes und abschlieBend Wesen und Wirkungsarten des Widersachers als des "persönlichen Prinzips des antigöttlichen Willens"17. Im zweiten Unterkapitel: "Kosmologie" 18 beschreibt er den Urkosmos (Archäum) mit den sieben Engelchören sowie Wesen und Entstehung des Kosmos mit den kosmischen Hierarchien, dem Stemenreich, den sie ben Planeten, dem Tierkreis, den vier Elementen und schlieBlich dem Erdenreich als "Abbild (Kleinbild) des ganzen Kosmos" 19 (Mineralreich, Pflanzenreich, Tierreich und Menschenreich). AnschlieBend geht er auf die "Anthropologie" ein20: Er unterscheidet zwischen dem "inneren (geistigen) Menschen" (Ebenbild Gottes) und dem "äußeren Menschen" ("Mikrokosmos" als Abbild des gesamten Makrokosmos) ${ }^{21}$ und schildert im folgenden den himmlischen und den kosmischen Menschen sowie die irdische Menschheit. Diesen zweiten Teil beschlieBen Ausführungen zur "Christologie"22 (Erlösung des Kosmos und Erlösung des Erdenreiches durch Christi Menschwerdung. Opfertod und Auferstehung).

Im dritten und letzten Teil23 bemüht sich Ëllis (wie bereits ansatzweise in allen Kapiteln). "eine vollständige Übereinstimmung aller Grundsätze" der Weisheitslehre des Intermediarius "mit der Weisheitssymbolik der «Genesis" [1. Buch Mose] und hauptsächlich der "Offenbarung» Johannis nachzuweisen"24. Er trifft eine Unterscheidung zwischen der "wahren christlichen Gnosis" und dem Gnostizismus (= "PseudoGnosis", "bloB-kosmische Gnosis")25. Die sogenannte "spätere Renaissance" und die Reformation (diese "Kinder der falschen Weisheit und Gnosis" [sic!]) hätten zu einer "allgemeinen Verflachung des esoterischen BewuBtseins" geführt ${ }^{26}$. Als "eine geniale, kritisch-dialektische Darstellung der Entwicklung der gesamten nachscholastischen Philosophie als eines bloB formalen, wesentlich-antinomistischen Prozesses" hebt er

\footnotetext{
12 Ebd., S. 46.

13 Ebd. S.53-154.

14 Ebd.. S. IX.

15 Ebd., S. 56.

16 Ebd.. S. 61-77.

17 Ebd., S. 73.

18 Ebd.. S. 78-119.

19 Ebd., S. 114.

20 Ebd.. S. $120-138$.

21 Ebd.. S. 122.

22 Ebd.. S. 139-154.

23 Ebd.. S.155-178.

24 Ebd., S.IX.

25 Ebd., S. $166 \mathrm{ff}$.

26 Ebd., S. 168.
} 
Vl. Solov'evs Arbeit "Die Krise der westlichen Philosophie" (1874) hervor ${ }^{27}$. Ėllis' Argumentationsweise sei exemplarisch an folgendem längeren Zitat über Philosophie. Kunst und Kultur vom 18. Jahrhundert bis in seine Gegenwart vorgeführt:

\begin{abstract}
Die Entartung der Gnosis füht zur Vorherrschaft der Reflexion und der abstrakten Philosophie, die nur die gegenseitigen Beziehungen (relationes) der Dinge erfaBt (transzendentaler Idealismus), die sich aber für eine absolute Erfassung der letzten Wesensprinzipien hält. Es beginnt eine zweite Epoche des Gnostizismus in der Form der "idealistischen" Philosophie (ohne Symbolik und kosmische Tiefe der alten Magie), die noch einmal alle vorchristlichen Richtungen der falschen Weisheit scheinbar erweckt. Zugleich verwandelt sich die Symbolik der falschen Weisheit in den Symbolismus und Allegorismus der neueuropäischen Kunst, die alle Formen der Sinnensprache der alten Mysterien in einer verflachten Form äuBerlich zu restaurieren sucht. Wenn wir den Naturalismus beiseite lassen, so müssen wir ersehen, daB alle Richtungen des ästhetischen Klassizismus von den bildenden Künsten der Spätrenaissance bis auf die neue, poetische Schule des 18. und 19. Jahrhunderts ein formativ-glänzendes, innerlich schwaches und jede wahre Religiosität entbehrendes Nachspiel der Schatten der spät-eleusinischen "Götter" und hauptsächlich "Göttinnen" bilden. indem gerade das Prinzip der inneren Einheit (der Allharmonie) der Götter [...] des alten, sehenden, orphischen Hellas verioren geht.

Die "romantische Kunst" (speziell in Deutschland) erscheint dagegen als ein ästhetisches Schattenspiel der mittelalterlichen Geister, voller Sehnsucht nach den alten, verlorenen arcana der Schönheit der verklärten (entschleienten) Weltseele 28 (der alt-hermetischen, blauen Lotosblume) und den Mysterien der Rosa mystica. Ja sogar die synthetische Kunst des gröBten Meisters, Richard Wagner, hat ihre Wurzel in der Vergangenheit, obwohl sie als "die Zukunftskunst" erlebt wurde, nämlich in der Vorweisheit der nordisch-runischen Tradition (als "Götterdämmerung") und in der Mystik und Symbolik des geistigen Rittertums (als Graal-Legende). Die sogenannte "moderne Kunst" ist sodann nur jene bunte, in die bloBe Form verliebte Formlosigkeit, die selbst die Götter und Helden nicht mehr kennt. deren Licht sie spiegelt. ${ }^{29}$
\end{abstract}

Die wahre religiöse Emeuerung könne nur aus den alten christlichen Mysterien, aus den Visionen der "Offenbarung" des Johannes und aus der Darstellung der "Lichtjungfrau" in der "Lauretanischen Litanei" geschöpft werden ${ }^{30}$.

Auffällig an Éllis' Werk sind sein recht schwer verständlicher, komplizierter Stil, häufige Wiederholungen und der Anspruch, die gesamte Kosmologie und Christologie in Grundzügen darzulegen, wodurch sich seine Arbeit recht mühsam lesen und verstehen läßt. Durch diverse Schemata versucht er seine Ausführungen zu veranschaulichen, doch bringen diese nicht immer die benötigte Klarheit. Insgesamt finden sich etliche Parallelen und Entsprechungen zum Traktat "Vigilemus!", einige Aussagen des Traktats werden hier radikalisiert (etwa das Betonen des Bruchs zwischen Religion und Kultur in der Renaissance und damit die Ablehnung der gesamten europäischen Kultur- und Geistesentwicklung seit der Neuzeit, die Hervorhebung der Gegenwart als Krisen- und Umbruchszeit. Ausführungen über Magie, Gnosis etc.).

Weder die Werke Johanna van der Meulens noch Ellis' "Christliche Weisheit", die man als Versuch eines "wissenschaftlichen Kommentars" zu Intermediarius' Arbeiten bezeichnen kann, sind zur Zeit ihres Erscheinens auf groBe Resonanz gestoßen oder haben kritische Beachtung gefunden. Ellis' Werk wurde in Basel bei Frobenius als Manuskript gedruckt. Heute sind diese Arbeiten so gut wie unbekannt. Allerdings scheint sich der damals in Rom lebende Vjač. Ivanov für die Arbeiten des Intermediarius interessiert zu haben und somit sicher auch für Ellis' Werk. Wie sich Ellis'

27 Ebd., S. 169.

28 Die Gleichsetzung von "verklären" und "entschleiem" mag dem Leser als Inkonsequenz erscheinen. Ellis möchte hiermit wohl ausdrücken, dab die wahre, leuchtende Schönheit der Weltseele aufgedeckt wird, in Erscheinung tritt.

29 L. Kobilinski-Ellis: Christliche Weisheit, a.a.O., S. 169.

${ }^{30}$ Ebd., S. 170, 171 ff., 176ff. 
Briefen an Vjač. Ivanov entnehmen läBt, befaBte sich letzterer gründlich mit diesen Werken und plante eine Publikation darüber im "Hochland"31.

Eine detailliertere Erörterung und Bewertung von Ėllis' Arbeit müBte die vier Werke des Intermediarius sowie weitere Publikationen zum Themenbereich Esoterik und Kosmologie berücksichtigen. Da dies jedoch nicht zum Aufgabengebiet der Literaturwissenschaft gehört, somit aus der Fragestellung der vorliegenden Untersiuchung herausfallt und Stoff für eine gesonderte wissenschaftliche Arbeit bietet, soll an dieser Stelle darauf verzichtet werden.

31 Vgl. Ëllis' Briefe an V. Ivanov im Archiv von D.V. Ivanov, Rom. Ivanov scheint sein Vorhaben jedoch nicht realisient zu haben. 


\title{
C. Ellis' Beschäftigung mit Vladimir Solov'ev
}

Die Beschäftigung mit Lehre und Werk Vladimir Solov'evs nimmt einen groBen Raum in Ëllis' zweiter Schaffensperiode ein. Durch Übersetzungen, die er mit Anmerkungen, Kommentaren und Abhandlungen über Solov'evs Lehre und Werk versah, versuchte er, dem deutschsprachigen Leser Wirken und Werk Solov'evs nahezubringen, wobei er dessen Sophienlehre und Unionsidee (Wiedervereinigung der Ostund Westkirche) in den Vordergrund stellte.

1925 erschien im Matthias-Grünewald-Verlag ein Band mit 31 Gedichten VI. Solov'evs, die Ëllis und Richard Knies ins Deutsche übersetzt hatten. Dazu schrieb Ėllis (im Anhangsteil) drei Abhandlungen über 1) Solov'ev als Lyriker, 2) Solov'evs Weisheits- und Schönheitslehre und 3) Weisheit und Weltseele bei Solov'ev'.

Im Vorwort zu diesem Band dankt Ėllis denen, die ihm Solov'ev erstmals nahegebracht haben: Michail Solov'ev (dem Bruder Vladimir Solov'evs), dessen Sohn, dem "priesterlichen Dichter" (Sergej M. Solov'ev), und dem bekannten Kenner und Interpreten Solov'evs, Dr. Gregor Račinskij. Ferner weist Ellis darauf hin, daB er an den Stellen, wo er in seinen Abhandlungen "Tiefpunkte" in Solov'evs Mystik berühre, stets versuche, Solov'ev wörtlich zu zitieren ${ }^{2}$.

Bei den Gedichten handelt es sich insgesamt um sehr freie Übertragungen, wobei nicht gekennzeichnet ist, welche Gedichte Ėllis und welche R. Knies übersetzt hat. Zwei Beispiele im Vergleich mit Solov'evs Original seien hier angeführt:

\author{
Heute erschien mir, leuchtend im Blauen \\ Sie, meine Königin: Ihr Angesicht \\ Kaum es erblickend in seligem Schauen. \\ leuchtet die Seele in nuhigem Licht. \\ Freut sich mit steigendem Morgen zusammen. \\ Und in der Feme (ich füchte sie nicht) \\ Langsam verrauchen die irdischen Flammen. ${ }^{3}$ \\ Вся в лазурн сеголня фвилась \\ Прело мноно царица моя. - \\ Сердие сладким востортом забилось. \\ И в лучах восходящего дня \\ Тнднм светом дуиа засветилась. \\ А вдали. дорогая. дымнлось \\ Злое пламя земного отня \\ Конец ноября 1875 \\ Канр ${ }^{4}$ \\ Als Sturmesmacht riB alles nieder. \\ Was ich erschaute und erschuf. \\ Da tönt', geheime Freundin, wieder \\ Dein fermer und dein letzter Ruf. \\ Mein Geist erwachte und erbebte: \\ Ein Adler, der voll Schrecken schreit.
}

$\mid \mathrm{Vgl}$. W. Solowjew: Gedichte. Ins Deutsche übertragen von L. Kobilinski-Ellis und R. Knies. Mainz 1925. In der Zeitschrift "Das heilige Fever" (Paderborn. 12 (1924/25). S. 462-466) waren zum 25. Todestag VI. Solov'evs einige seiner Gedichte in Ëllis' und R. Knies' Übersetzung mit kurzem erläutemden Text abgedruckt worden.

2 Ellis dankt Richard Knies, Wilhelm Ratgen und Bertram Schmitt, ohne die dieser Band (in der vorliegenden Form) nicht hätte entstehen können. (W. Solowjew: Gedichte. a.a.O.. S. IXf.)

${ }_{3}^{3}$ W. Solowjew: Gedichte, a.a.O., S.6.

4 VI. Solov'ev: Ctenija o Bogozelovecestive, a.a.O., S. 376. 
Brach er das Eisen und entschwebte

Zur unermeBlichen Herrlichkeit.

Sah Wunder ohne Zahl und Namen.

Durch Licht geheiligt und ertellt.

Und. Flamme selbst im Meer der Flammen,

Floh er die Blicke dieser Welt.5

Под чуждой властью знойной вьюги,

Виденъя прежние забыв.

Я вновь таинственно по подути

Усльшал гаснуший призыв.

И с криком ужаса и боли.

Железом схваченный орел. -

Затрепетал мой дух в неволе.

И сеть порвал. и ввысь ушел.

И на заоблачнои вершине

Пред морем пламенњх чудес

Во всесияюшей святыне

Он загорелся и исчез.

$1882^{6}$

In diesen sehr freien Übersetzungen 7 wurden im ersten Beispiel weder Metrum noch Reimschema des Originals in der Übertragung beibehalten, während dies im zweiten Beispiel immerhin der Fall ist, wodurch zumindest teilweise die inhaltliche Ungenauigkeit der Übersetzung entschuldigt werden kann.

In seiner ersten Abhandlung über Solov'ev als Lyriker bezeichnet Ėllis dessen Gedichte als poetische Schöpfungen eines russischen Dichters von höchstem Range und verweist darauf, daB Vladimir Solov'ev als Denker, Mystiker, Theologe und Sozialpolitiker im Westen zwar bekannt sei, nicht jedoch seine lyrische Dichtung. In seinen besten Gedichten sei es Solov'ev gelungen, das Heilige mit dem Schönen organisch zu vereinigen als "ars sacra". Diese Fähigkeit sei nach dem Mittelalter verlorengegangen und erst die gegenwärtige Übergangszeit habe sie sich wieder zum Ziel gesetzt ${ }^{9}$. Ellis sagt über Solov'ev:

Das, was den Mystiker Solowjew zum Poeten macht. ist seine Gabe der seelischen Spiegelung des Geistigen. Alles, was sein Geist als Übersinnliches und deshalb Unaussprechliches schaute. zeigte die reine Seele dem Geiste später wie in einem klaren, kristallenen Spiegel abgebildet: alles. was in der Wirklichkeit der Vision leuchtete, schimmerte noch einmal wie durch "blauen Duft". durch den Schleier des Traumes, und die Sinne webten die plastische und farbenreiche Form dazu. 10

Ellis teilt Solov'evs Gedichte in drei Gruppen ein:

5 W. Solowjew: Gedichte, a.a.O., S. 10.

6 VI. Solov'ev: Ctenija o Bogotelovecestve, a.a.O., S. 381.

7 Als Beispiele für den grobzügigen Umgang mit dem Original sei nur auf das "Angesicht" in der 2. Zeile und die Klammer in der sechsten Zeile des ersten Gedichts verwiesen, die nirgends im russischen Original aufureten. oder auf die "unermeBliche Herrlichkeit" in der letzten Zeile der 2. Strophe des zweiten Gedichts. die ebenfalls im russischen Original fehlt: in der dritten Strophe dieses zweiten Gedichts ist der Sinn im Deutschen ganz anders als im russischen Text. Die Interlinearübersetzung der beiden Gedichte findet sich im Anhang.

8 Vgl. W. Solowjew: Gedichte, a.a.O., S. 55-68.

9 Ebd.. S. 57.

10 Ebd., S. $61 \mathrm{f}$ : 
1) in rein romantische Dichtungen mit lyrischem Charakter, in denen die Traumbilder fast ein selbständiges Reich bilden (der EinfluB Fets sei in diesen Gedichten am meisten spürbar);

2) in eigentlich religiöse Dichtungen mit lyrisch-epischem Charakter und traditioneller Symbolik, die hauptsächlich auf dem Boden der Heiligen Schrift steht; und

3) in mystisch-symbolische Dichtungen, welche die beiden ersten Gruppen vereinigen und alle der Darstellung der Hauptgestalt, nämlich der verklärten Seele gewidmet seien. Diese Gedichte hält Elllis für die bedeutendsten, originellsten. Sie hätten häufig einen autobiographischen Ursprung.

Ėllis bestimmt Solov'evs Platz innerhalb der russischen Dichtkunst folgendermaBen: Solov'ev habe in seiner Dichtung das Beste aus der Erbschaft des sogenannten "Goldenen Zeitalters der russischen Poesie" (Žukov.skij, Puškin, Lermontov, Baratynskij) bewahrt und mit den Errungenschaften des späteren "Silbemen Zeitalters" (Fet, Tjutčev, Majkov, Polonskij) verbunden"l. Bezüglich der "inneren Form" habe Puškin Solov'ev beeinflußt und bezüglich der "äußeren Form" Fet. Im geistigen Urerlebnis seiner Dichtung sei Solov'ev jedoch ganz selbständig, sich selbst getreu und einzigartig gewesen. Sein christlich-mystischer Ausgangspunkt mache seine Poesie zur "ars sacra" 12 .

Ėllis geht ferner der Frage nach den ausländischen Einflüssen auf Solov'evs Lyrik nach: Solov'ev habe die europäische Weltliteratur gut gekannt und hoch geschätzt. Trotz gewissen Einflüssen von $\mathbf{H}$. Heine, der deutschen klassischen Schule (Schiller) und der romantischen (Jakob Böhmes "Aurora" und die deutschen romantischen Dichter $)^{13}$ sei er in seiner eigenen Lyrik selbständig ${ }^{14}$. Mitunter sei in seinen Gedichten jedoch der "Geist der urchristlichen Poetik des alten, echt religiösen Zeitalters" und auch der "Geist des Mittelalters" zu spuiren:

Wenn Solowjew in seinem Wollen der gewaltige Anti-Nietzsche und in seinem Denken der grobe Anti-Kant war und ist, so hatte er doch in seinem Fühlen mit der intimsten Sehnsucht der Romantiker eine tiefe Verwandtschaft. ${ }^{15}$

Diese philosophische Einordnung Solov'evs von seiten Ėllis' ist äuBerst bedenkJich und ein Musterbeispiel für Éllis' unkritische Panegyrik sowie seine Vorliebe für anti thetische Formulienungen. Solov'ev hat zwar gegen Nietzsche gefochten, aber nicht immer mit Erfolg und argumentativ überzeugend und kann deshalb nicht einfach als "Anti-Nietzsche" bezeichnet werden! Solov'ev und Kant trennen unterschiedliche philosophische Prämissen in der Erkenntnistheorie; sie vertreten ganz verschiedene Posi-

11 Aus heutiger Sicht scheint diese von Ėllis vorgenommene literarische Einordnung der genannten Dichter ein grober Fehler zu sein: unter dem Terminus "Silbernes Zeitalter" versteht man heute in der Literaturwissenschaft die symbolistischen Dichter, also die Zeit nach Vl. Solov'ev! Die von Ëllis' genannten Dichter reichen zeitlich an Solov'ev heran. waren Spätromantiker und zugleich Zeitgenossen von Turgenev und den groben Realisten. Ëllis verwendet den Begriff "Silbemes Zeitalter" jedoch so, wie es um die Jahrhundertwende üblich war (vgl. hierzu auch oben. "Einleitung" der vorliegenden Arbeit. S. 11f.. Anm. 4) und wie ihn etwa VI. Solov'ev selbst in seinen literaturwissenschaftlichen Arbeiten gebraucht. (Z.B. im Titel seines 1898 geplanten Buches über die russische Lyrik der zweiten Hälfte des 19. Jahr-

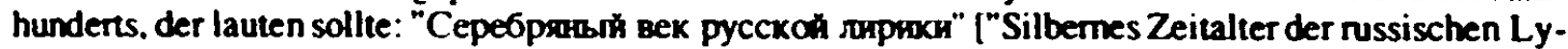
rik"l: in diesem Buch wollte Solov'ev seine Arbeiten über Fet, Tjutcev, A. Tolstoj und Polonskij publi zieren. (Vgl. S.M. Solov'ev: Žizn' i tvoræeskaja évoljucija Vladimira Solov'eva. Brjussel' 1977. S. 355].)

12 Vgl. W. Solowjew: Gedichte, a.a.O.. S. 62f.

13 Jakob Böhme hat zwar auf die deutschen Romantiker gewirkt, aber gut 200 Jahre vor ihnen gelebr, weshalb es sehr eigenwillig und gewagt von Ëllis ist, ihn bzw. seine "Aurora" nicht als Anreger. sondem als Beispiel der deutschen romantischen Schule zu nennen!

$14 \mathrm{Vgl}$. W. Solowjew: Gedichte, a.a.O., S. 63.

15 Ebd., S. 64. 
tionen. An dieser Stelle müBte auf die enge Verwandtschaft zwischen Schelling und Solov'ev verwiesen werden, was Ellis jedoch nicht tut ${ }^{16}$.

Ėlis geht näher auf die "romantische Sehnsucht" ein, die gleichzeitig der "Sehnsucht" Solov'evs entspreche: die Romantiker sehnten sich nämlich nach der Schönheit der verklärten Weltseele und nach der Weisheit (Sophia) der himmlischen All-Einheit ${ }^{17}$. Er nennt Solov'evs poetische Sendung einzigartig und zählt ihn zur auserwählten Zahl der "großen Einsamen" 18:

Wenn seine erste Aufgabe: die Verkündigung der Alleinheit [gemeint ist die "All-Einheit", H.W.] und der Welieinheir der Kirche, allmählich überall verstanden wurde, so ist doch seine zweire Aufgabe, nämlich den Weg zur inneren Einheit zwischen Glaubens- und Weisheitsprinzip zu finden. bis auf heute kaum ganz verstanden oder nachgefühlt worden. ${ }^{19}$

Wiederholt nennt Ėllis Solov'ev einen "der gröBten Einsamen", der, von der Kirche und vielen Zeitgenossen unverstanden, in seinen Gedichten nur einige seiner hellsten Visionen anklingen lasse, von denen er die meisten vor der Menschheit im Verborgenen gehalten habe.

In seiner zweiten Abhandlung 20 stellt Ellis zunächst Solov'evs Weisheitslehre (Sophienlehre) und anschlieBend seine Schönheitslehre auf eine mitunter recht verworren und widersprïchlich anmutende Weise dar und hebt Solov'evs Bestrebungen zur Schaffung einer universalen Kirche hervor. Er führt ein Schema aus Solov'evs Arbeit "Философия начала цельного знания" ("Prinzipien eines ganzheitlichen Wissens", 1877) an und versucht, daran Solov'evs "ganze Weltanschauung" in kurzgefaBter Form aufzuzeigen:

\section{I}

Das (schöpferische)

Schaffen

Subjektiver Grund:

Das Fühlen

Objektiver (irund:

Die Schönheit

1. Stufe (absolute):

Die Mystik

2. Stufe (formelle):

Die schöne Kunst

3. Stufe ${ }^{21}$ (materielle):

Die technische Kunst
II

Das Wissen

Subjektiver Ginund:

Das Denken

Objektiver Grund:

Die Wahrteit

Die Theologie

Die (abstrakte)

Philosophie

Die positive

Wissenschaft
III

Praktische Tätigkeit

Subjektiver Grund:

Das Wollen

Objektiver Grund:

Das allgem. Gute

Die Kirche

(Die geistige Gesellschaft)

Die politische

Gesellschaft (Der Staat)

Die ökonomische

Gesellschafi (Die Stande)

Semstwo 22

Er kommentiert das Schema folgendermaßen:

16 Zu Schelling und Solovev vgl. L. Müller: Solovjev und der Protestantismus. Freiburg 1951, S. 93-125.

17 W. Solowjew: Gedichte, a.a.O., S. 64.

18 Das ist möglicherweise ein unge wollter Nietzsche-Reflex.

19 W. Solowjew: Gedichte. a.a.O., S. 66.

20 Ebd., S. 69-88.

21 Diese drei Stufen in V1. Solov'evs Schema sind nicht im Sinne der Hegelschen Entwicklungsstufen zu verstehen. gemäB derer die 3. Stufe die höchste ästhetische Entwicklung darstellt, sondem als drei unterschiedliche Qualitäten.

22 W. Solowjew: Gedichte, a.a.O., S. 73. Vgl. hierzu: VI. Solov'ev: Filosofija načala cel'nogo znanija. In: Ders.: Sobranie soxinenij. Tom 1. Brjussel' 1966, S. 250-406. Schema: S. 264. 
Aus diesem Schema ist ganz klar ersichtlich, welch eine unzertrennbare Einheit die anschauliche Mystik, die konstruktive Theologie und die abstrakte Philosophie bei Solowjew bilden. Deshalb ist es unmöglich. den Mystiker Solowjew zu verstehen, ohne den Theologen und den Philosophen in ihm anzuerkennen; ebensowenig kann man die sozial-politische Frage bei ihm abtrennen von der Kirchenfrage. Die Hauptsache für uns ist aber (in diesem Schema) die enge Beziehung zwischen Mystik und Kunst, welche zwei Stufen desselben Prinzips darstellen. ${ }^{23}$

Ėllis weist also explizit auf die Einheit innerhalb Solov'evs Lehre und Werk hin.

Er betont, daB Solov'evs Lehre zu Recht als "Philosophie der All-Einheit" bezeichnet werde und charakterisien die drei Arten der Sophia, die Solov'ev unterscheidet: 1. Sophia als "eigentliche wesentliche Weisheit Gottes", die mit dem Sohne identisch sei; 2. Sophia "als göttliche Weisheit innerhalb der ganzen Welt der Kreaturen, [...] als Spiegel der Logos-Weisheit Gottes" und 3. Sopinia "in ihrer einigenden Wirkung zwischen Rein-Göttlichem und Rein-Kreatürlichem"24. Er hebt die himmlische Sophia richtig als Gegenpol der "Weltseele" hervor ${ }^{25}$, auf die er jedoch an dieser Stelle nicht näher eingeht. Die Sophia-Lehre habe auch für den Westen große Bedeutung, da sie letztendlich auf die urchristliche, orthodoxe Tradition zurückgehe, wie sie der heilige Athanasius vertreten habe 26 .

Solov'evs Schönheitslehre betrachtet Ėllis in dieser Arbeit als eine weitere Entfaltung der Weisheitslehre. Später (1937) publizierte er in der Zeitschrift "Die Schildgenossen" eine "mystisch-philosophische Studie" über Solov'evs Schönheitslehre27, deren spekulativ-visionären Charakter er hervorhebt und die zugleich eine Weiterentwicklung von Solov'evs All-Einheits-Philosophie bilde sowie die Vollendung seiner Sophienmystik. In dieser Studie referiert Ellis die zentralen Ideen Solov'evs, wie sie in den Abhandlungen "Die Schönheit in der Natur" ("Красота в природе", 1889) und "Der allgemeine Sinn der Kunst" ("Общий смысл искусства", 1890) dargelegt sind. Solov'evs eigene Poesie, und zwar seine mystisch-symbolische Lyrik, sei jedoch die beste Bestätigung und Erfüllung seiner mystischen Schönheitslehre28.

In seiner dritten Abhandlung: "Die Weisheit (Sophia) und die Weltseele (Archäa) bei Wladimir Solowjew"29 gibt Ėllis die Sophia-Lehre von Solov'ev und teilweise die von P. Florenskij ${ }^{30}$ wider. Dazu führ Ėllis zahlreiche Zitate aus Solov'evs und Florenskijs Werken an. Ėllis sieht eine vollständige Übereinstimmung zwischen der Sophia-Auffassung Florenskijs und Solov'evs und stimmt ihnen zu, wenn sie die Verehrung der Hagia-Sophia mit der Verehrung der heiligen Jungfrau Maria verbinden, in welcher sie die Trägerin und den Sitz der göttlichen Weisheit sehen. In der Mariologie des Westens findet Ellis fast alle Grundprinzipien der Sophiologie des Ostens enthalten, wenn auch unter anderen Namen ${ }^{31}$. Sophia, deren Wesen die All-Einheit ist, sei ein und dieselbe im Westen und Osten. Solov'evs Sophia-Lehre sei die Verkündigung der inneren Einheit der östlichen Sophiologie und der westlichen Mariologie. Gerade darin liege ihre einzigartige und unvergleichliche Größe. Ellis bezeichnet

23 W. Solowjew: Gedichte, a.a.O., S. 73.

24 Ebd., S. 74.

25 Ebd., S. $77 f$.

26 Ebd.. S. 79.

27 Vgl. L. Kobilinski-Ellis: Die Schönheitslehre Wladimir Solowjews. Eine mystisch-philosophische Studie. In: Die Schildgenossen. 6. Würzburg. 1937. S. 496-505.

28 Ebd.. S. 496.

29 Vgl. W. Solowjew: Gedichte, a.a.O., S. 89-99.

30 Vgl. P. Florenskij: Stolp i utverżdenie istiny. Moskva 1914.

31 Dies führt Ėllis in seinem Nachwort zu seiner Übersetzung des 11. Kapitels aus P. Florenskijs Werk "Die Säule und Grundfeste der Wahrheit" ("Столn н утверждение нстины") aus (vgl.: Christi Reich im Osten, a.a.O., S. 72-145, hier besonders S. 118-129). 
P. Florenskijs Werk 32 als "das Bedeutendste von allem. was auf dem Gebiet der russischen Mystik und Theologie, speziell der Sophiologie, nach Solowjew entstanden ist" und rühmt an seinem Stil die "unbedingte Aufrichtigkeit und Originalität" 33 . Er hebt hier richtig und wohl als erster die Bedeutung Florenskijs hervor, dessen Werk erst in den letzten Jahren intensiv rezipient und erforscht wird ${ }^{34}$.

An anderer Stelle, in der Zeitschrift "West-östlicher Weg", behandelt Elllis VI. Solov'evs sogenannte "See-Lyrik", also die Gedichte, die Solov'ev auf den Sajma-See (in NordruBland) geschrieben hat (1894; aber auch noch spätere Gedichte, bis 1898) ${ }^{35}$. In diesem Beitrag geht er auf Solov'evs metaphysische Naturlehre ein, die er in diesen Gedichten widergespiegelt sieht. Diese Gedichte seien zugleich die besten Muster von Solov'evs mystischer Poetik und die Sinnbilder seiner Ästhetik (das heiBt, seiner Schönheitslehre und Kunstphilosophie). Ëllis interpretiert sie folgendermaßen:

Rein mystisch betrachtet, ist seine [Solov'evs] See-Lyrik ein sophianisches Lied [...], weil sie (gleich dem Apostel Paulus) die verborgene Sehnsucht der ganzen Natur (Weltseele) nach der Erlösung, Befreiung und Wiedervereinigung mit dem Vater durch Christus miterlebt. Rein symbolisch genommen, bekommt dieses Lied einen kosmologischen $|\ldots|$ Sinn, weil es ein tiefsinniges. wenn auch bloB leise angedeutetes Sinnbild der Eigenschaften. Regungen und Bewegungen der Weltseele gibt, ohne das hohe Kriterium der Alleinheit Igemeint ist die "AllEinheit", H.W.] (Weisheit) zu verlieren. Vom rein ästhetischen Standpunkt aus ist dieses Lied hauptsächlich deshalb wertvoll, weil es beide rein künstlerische Momente (die innere und die äubere Form) harmonisch vereinigt und überall einen sinnenklaren Hintergrund (der Farben und der Gestaltungen) entfaltet, ohne dabei die üblichen abstracta allegorica der philosophierenden Dichter zu gebrauchen. [...] der innere Grund dieses sophianischen Liedes ist und bleibt die visionäre, und zugleich wirkliche Begegnung mit dem Wege der Welt-Seele. ${ }^{36}$

Ėllis faBt den Sajma-See als Symbol der "Weltseele" in ihren verschiedenen Stufen auf, die zugleich den vier Elementen entsprechen: Erde. Wasser, Luft und Licht. Natürlicherweise herrsche in diesen Gedichten das Element des Wassers vor. Von den zahlreichen Beispielen, die Ėllis anführt, sei eines hier zitiert:

"Es braust der See: wie bei Brandung im Meere

Steigt aus dem Abgrund hochwogender Flut.

Wirft sie voll Unruh' ihre Wellen ins Leere,

Streitet mit feindlichem Schicksal voll Wut ..."

"Grollst du, mit steinernen Ketten gebunden?

Sehnst dich nach Ruh, nach unendlichem Raum

Träumst du von Urzeit. die längst ist entschwunden?

Siehst deiner Herrschaft vergangenen Traum? ..."

Steige, zerreiße die schmählichen Bande.

Mächtige Sklavin am steinermen Zaum! ...

Nur zahmen Knechten ziemt ewige Schande.

Nur freien Wellen - unendlicher Raum! ... ${ }^{37}$

Озеро плещет валной беспокойон.

Словно как в море растуший прибой.

Рвется к чему-то стихия нестройная.

32 Stolp i utverždenie istiny.

33 Vgl. Christi Reich im Osten, a.a.O.. S. 72.

$34 \mathrm{Vgl}$. hierzu auch die Einleitung von Ulich Wemer: Pavel Florenskijs Lebensspuren. In: P. Florenskij: Die Ikonostase. Grenzerleben im revolutionären RuBland. Stuttgan 1988. S. 7f.

35 Vgl. L. Kobilinski-Ellis: W. Solowjews See-Lyrik. In: West-östlicher Weg. I. Glogau - Mainz. 1928. S. 227-233.

36 Ebd. S. 227.

37 Ebd.. S. 231. 
Спорнт о чем-то с враждебнои судьбой.

Знать. не по сертуу оковы гранытые!

Тољко в безмерном отраден покой.

Снятся бьиые века первобыттые.

Хочется снова царить над землей.

Бейся. вопнуйся. невољница пнкая!

Вечный позор добровольным рабам.

Сбудется сон твой. стихия великая.

Будет простор всем свободным волнам.

3 октября $1894^{38}$

Dazu führt Ėllis aus:

Das irdische Element des Wassers ist für Solowjew nur eine unvollkommene Form des kosmischen Urwassers und sogar des Urchaos (Tohu wa bohu) der Genesis. [...]

Die erste Strophe dieses Gedichtes spricht über das Wasser eines konkreten Sees (Ssajma) beim Sturm. Die zweite Strophe erwähnt geheimnisvoll jenen Urzustand der Welth als noch das Wasser die Erde bedeckte, was auch auf eine Hindeutung auf die Worte der Genesis (I. 6-8) über den zweiten Schöpfungstag gelten kann. Die dritte Strophe weist auf den zukünftigen Tag der Befreiung durch die Verklärung hin. 39

Ellis' Interpretation dieses Gedichts und der "See-Lyrik" Solov'evs überhaupt ist recht schwer nachvollziehbar und wenig konkret. Eine formale Lyrik-Analyse fehlt völlig. Er deutet Solov'evs See-Lyrik im Sinne seiner mystischen Philosophie und hebt zu Recht dessen Liebe zum Wasser und zu den Elementen hervor. Bei der inhaltlichen Auslegung bemüht er sich, Solov'evs Naturphilosophie zu berücksichtigen (wie sie in der Studie "Die Schönheit in der Natur" 40 dargelegt ist) und zitiert die entsprechenden Stellen aus Solov'evs Werk. Insgesamt bedient er sich jedoch einer recht verworrenen Terminologie und verwendet Ausdrücke, die Solov'ev selbst nie gebraucht hätte (vgl. etwa "kosmisches Urwasser", "Urchaos", "lebendige Urbilder der toten Natur" etc.). Immerhin hat er durch diesen Beitrag einen damals nicht sehr bekannten Themenkomplex der Lyrik Solov'evs ins BewuBtsein der deutschsprachigen Leser ge rückt.

1929 erscheint im Matthias-Grünewald-Verlag ein umfassender Band (über 600 Seiten!) ausgewählter Werke Solov'evs: "Monarchia Sancti Petri", in Ėllis' Übersetzung. von ihm kommentiert und mit Anmerkungen sowie einem Vor- und einem Nachwor versehen ${ }^{41}$.

Wie auch in seinen anderen Arbeiten über Solov'ev stellt Ëllis hier wieder dessen Sophienlehre und seine ökumenischen Bestrebungen. das heiBt seine Gedanken und Ideen zur Schaffung einer "universalen Kirche" und "freien Theokratie", in den Vordergrund; er wiederholt sich also, indem er immer wieder dieselben Aspekte von Solov'evs Werk betont. Dabei hebt er die Größe und Bedeutung Solov'evs zwar richtig hervor, verabsolutiert dessen "katholische Grundhaltung" jedoch in einseitiger Weise

38 v. Solov'ev: Čtenija o Bogočeloveřestrve, a.a.O., S. 394.

Wenn man Ëllis' Übersetzang mit dem Original vergleicht, sieht man deutlich. daB es sich hier wieder um eine sehr freie Übertragung handelt, die aber immerhin Metrum und Reimschema des Originals beibehält. Die Interlinearubersetzung dieses Gedichts findet sich im Anhang.

39 West-östlicher Weg, 1, 1928, S. 230f.

Wo allerdings in der letzten Strophe des Gedichts von "Verklänung" die Rede ist, läßt sich nicht ein deutig bestimmen.

40 "Красота в прнроде", 1889.

41 Vgl. W. Solowjew: Monarchia Sancti Petri, a.a.O. 
und geht kaum auf die unterschiedlichen Haltungen ein, die Solov'ev im Laufe seines Lebens eingenommen hat ${ }^{42}$.

In seinem Vorwor zu "Monarchia Sancti Petri" nennt Ėllis Solov'ev einen "Verkünder der Weltenwende, des Gerichts und der Wiedergeburt der universellen Kirche Christi im Lichte der Weisheit" 43 und sieht im Lebenswerk Vl. Solov'evs keine eigenwillige Neuerfindung. sondem eine organische, harmonische und traditionstreue Fortsetzung des Ursprünglichen und eine Wiederherstellung der Wahrheit der universellen Orthodoxie (вселенское православие). Immer wieder betont er, daß es Solov'ev ge lungen sei, die innere Harmonie zwischen Religion und Kultur durch den Geist der visionären Weisheit wiedemerzustellen. Seine geistige Gestalt stehe vor uns als die eines Propheten und Weisen ${ }^{44}$.

An den Anfang dieses Werks stellt Ėllis Solov'evs "Credo" und charakterisien ausführlich dessen Streben nach der Wiedervereinigung der beiden Kirchen (der orthodoxen und der römisch-katholischen). Er betont, daB nach Solov'evs Auffassung eine vollkommene, konsequente Orthodoxie von selbst ein unvermeidlicher Weg zur universellen, apostolischen Einheit der Kirchen sei ${ }^{45}$.

AnschlieBend folgen von Ellis übersetzte und erläuterte Auszüge aus einzelnen Werken Solov'evs ${ }^{46}$.

In seinem umfassenden Nachwort über Solov'ev, seine Persönlichkeit und seine Lehre kommt Ėllis zu folgendem Urteil:

Als GröBter unter den Russen war er einer der Gröbten unter den Europäem und als Echtester der Othodoxen war er einer der besten Vertreter der universellen Kirche. ${ }^{47}$

Das modeme Europa sei jedoch über die Persönlichkeit und Lehre Solov'evs ungenügend informiert, da seine Werke im Osten (d.h. in der Sowjetunion) verboten und vemichtet und im Westen bis jetzt (d.h. 1928/29) noch nicht richtig übersetzt und daher wenig bekannt seien ${ }^{48}$. In Deutschland wurde zwar 1922 eine vierbändige Aus-

42 Vgl. hierzu L. Muller: Solovjev und der Protestantismus. Nachwort vorn WI. Szylkarski. Freiburg 1951. L. Müller analysiert in dieser Arbeit die verschiedenen Perioden. die Solov'ev durchlebte, und schildert dessen wechselndes Verhälınis zur orthodoxen, römisch-katholischen und protestantischen Konfession: er nennt Solov'ev "eine der gröBten Gestalten eines ökumenischen Christentums" (ebd.. S. 9) und betont dessen Besureben, eine Einheit der Kirchen zu schaffen, in die die einzelnen Konfessionen (Orthodoxie, Katholizismus und Protestantismus) als gleichberechtigte Partner eingehen. ohne daB eine überwiegt oder eine andere vemichtet wird. Interessant ist im Vergleich dazu die Kritik WI. Szylkarskis an L. Müllers Arbeit in seinem Nachwort: "Solovjev und die Una Sancta der Zukunft" (ebd., S. 145181): Szylkarski hebt Solov'evs "katholische Grundhaltung" hervor, die dessen ganzes Leben lang vorgeherrscht habe und nennt ihn einen "katholischen Denker, der fest auf dem Boden des ökumenischen Christentums steht" (ebd., S. 175). Szylkarskis Einschätzung und Bewertung Solov'evs entspricht weit gehend derjenigen von Ellis. (In einem "Offenen Brief an Herm Szylkarski" vom 21.6.1951 antwortet L. Müller ersterem auf dessen Nachwort. das er erst nach Drucklegung zu Gesicht bekommen hat, und weist Szylkarskis Kritik als auf einem MiBverständnis beruhend zurïck.)

${ }^{43}$ W. Solowjew: Monarchia Sancti Petri, a.a.O., S. XXVIII.

44 Ebd.. S. XXIX. XXX.

45 Ebd.. S. 1-9.

46 Aus: "Die Kritik der abstrakten Prinzipien" ("Kрнтика отвлеченных начал"). "Die Vorlesungen über die Gottmenschheit" ("Чтения о Богочеловечестве", 8.-11. Vorlesung). "Der grobe Streit und die christliche Politik" ("Большоя спор н хрнстнанская политика"), "Die Geschichte und die Zukunft der Theokratie" ("Исторня и будуиность теократин") und Teile aus "La Russie et l'Eglise universelle".

47 W. Solowjew: Monarchia Sancti Petri, a.a.O.. S. 621.

${ }^{48}$ Ebd., S. $624 f$.

An anderer Stelle hatte Ėllis auf die Bekanntheit Solov'evs als Philosoph hingewiesen (vgl. oben. S. 192). jedoch meint er hier wohl das Fehlen kritischer Analysen von Solov'evs Lehre von ihm gleichge- 
gabe mit ausgewählten Werken Vl. Solov'evs im anthroposophischen Verlag "Der kommende Tag" in Stuttgart herausgegeben ${ }^{49}$, und im dritten Band dieser Ausgabe findet sich ein Aufsatz Rudolf Steiners über Solov'ev ${ }^{50}$, aber Ėllis venurteilte Steiners Lehre als antireligiös und der Lehre Solov'evs völlig entgegengesetzt; Steiner habe die Persönlichkeit und Lehre Solov'evs überhaupt nicht verstanden:

Sein Versuch, über Solowjew zu sprechen, stellt das Paradoxalste und zugleich das Banalste dar von allem. was überhaupt über Solowjew gesagt worden ist. ${ }^{51}$

Ėllis' "Monarchia Sancti Petri" endet mit einer vehementen Kritik an Steiners Solov'ev-Auslegung und einer radikalen Ablehnung der Anthroposophie. Dabei erwähnt Ellis mit keiner Silbe die Zeit seiner Begeisterung für Steiner und dessen Lehre und seine eigenen Bestrebungen, diese nach RuBland zu vermitteln. Seine Ausführungen werden zunehmend unkritischer und unwissenschaftlicher, wenn er sich bemüht, die wie er meint - Verimungen und Entstellungen Steiners gegen Solov'evs Lehre abzugrenzen:

Über den absoluten Gegensatz zwischen dem theobatischen Ideale Solowjews und dem "dreigliedrigen" Himgespinst Steiners schämen wir uns zu sprechen. (...)

Im Lichte des wahren, chrisslichen, authentischen (esoterischen) Hermetismus erscheint die Lehre Steiners wie der Trümmerhaufen des zusammengestürten babylonischen Turmes. ${ }^{52}$

Steiner kam in diese Welt, um die Sache des Manes. Solowjew aber, um die Sache des heiligen Augustinus forzusetzen. Damit aber ist alles gesagt. ${ }^{53}$

Man kann sich fragen, was diese antianthroposophische Propaganda am SchluB eines umfangreichen wissenschaftlichen Kommentars zu ausgewählten Werken Solov'evs zu bedeuten hat und muB darin Ellis' Extremismus und die "Schwarz-WeiB-Malerei" seiner ersten Schaffensphase wiedererkennen. Um so verwunderlicher mutet die recht positive Rezension an, die Bertram Schmitt im "West-östlichen Weg" zu Ėllis' Werk verfaBt hat, die jedoch verständlich wird, wenn man sich verdeutlicht, daB die Ausrichtung der Zeitschrift der einseitigen katholischen Position von Ellis weitgehend entspricht. In der Rezension heiBt es u.a.:

|... die Hervorstellung des inneren, organischen, mystisch fundienten Unionsstrebens Solowjews bildet einen Hauptvorzug des Werkes "Monarchia Sancti Petri", worin Dr. Kobilinskj-Ellis das Fundament der solowjewschen Theologie und Geschichtsphilosophie Solowjews, seine Sophia lehre durch geschickte Auswahl von Übersetzungen aus den Hauptwerken Solowjews deutlich in ither beherrschenden und grundlegenden Stellung hervorhebt. Die Übersetzung ist sorgfältig und

sinnten deutschen Theologen. Literaturwissenschaftlem und Philosophen aus dem katholischen Lager. Erste ernstzunehmende deutschsprachige Arbeiten über Solov'ev waren bereits ab 1910 erschienen (z.B. F. Stepuns Dissertation und Th. Masaryks Untersuchung; vgl. hierzu auch unten. S. 202f., Anm. 7578). In den erwähnten Sammelbänden des Matthias-Grünewald-Verlags und den katholischen Zeitschriften wurden erst in den 20er Jahren Beiträge über Solov'ev publizien und WI. Szylkarskis Arbeiten erschienen ab etwa 1930.

${ }^{49} \mathrm{Vgl}$. Wladimir Solovjeff: Ausgewählte Werke. Aus dem Russischen von Harry Köhler. 4 Bände. Stuttgar 1921-1922. Die erste Auflage des ersten und zweiten Bandes dieser Ausgabe war bereits 1914 und 1916 in Jena erschienen.

$50 \mathrm{Vgl}$. ebd., Bd. 3. S. XII-XVI.

51 W. Solowjew: Monarchia Sancti Petri. a.a.O., S. 631.

In diesem Zusammenhang kann auf Ėllis' Aufsatz "Wladimir Solowjew über die «moderne Theosophiex" (in: Christi Reich im Osten, a.a.O., S. 20-25) hingewiesen werden, worin er Solov'evs "freie Theosophie" der Doktrin der E.P. Blavackaja gegenüberstellt, die er als "Pseudo-Theosophie" bezeichnet.

52 W. Solowjew: Monarchia Sancti Petri, a.a.O., S. 630.

53 Ebd., S. 632. 
gediegen. Die Erklärungen Kobilinskis klar und sachlich. Man muB dieses Buch. das uns das wichtigste Lebenswerk Solowjews im Auszug vorstellt, als Ganzes nehmen, um es recht verstehen und würdigen zu können. [...] Für jeden, der sich mit Solowjew oder überhaupt mit dem russischen heutigen religionsphilosophischen Denken näher beschäftigt, wird dieses Buch unentbehrlich sein. [...] Die Übersetzungen und Kommentierungen der wichtigsten Stücke aus den Hauptwerken Solowjews durch Kobilinski-Ellis sind ein sicherer Führer auf dem schwierigen Weg durch das solowjewsche Lehrgebäude. ${ }^{54}$

1930 erschien im Ferdinand-Schöningh-Verlag. Paderbom, ein kleines Bändchen mit Ėllis' Übersetzung von Solov'evs "Der heilige Wladimir und der christliche Staat"55, die Ėllis mit einem kurzem Vor- und Nachwor versah. Im Vorwort nennt Ėllis dieses Werk, das Solov'ev 1888 in Frankreich, veranlaBt durch die offiziellen Festlichkeiten in Kiev zum 900jährigen Jubiläum der Taufe des heiligen Wladimir und seines Volkes verfaßt hat, eine "meisterhafte, kurze und allgemeinverständliche [...] Zusammenfassung der Hauptideen seines [Solov'evs] großen Hauptwerkes «La Russie et I'Eglise universelle»"56. Im Nachwort hebt Ellis noch einmal die Überzeugung, die seiner Meinung nach den Grund der Lehre Solov'evs bildet, hervor, nämlich, daB alle wahren Wege der christlichen Einheit (Ökumenizität), die dem Geiste und Worte Christi entsprächen, nach Rom führten 57 .

Diese Aussage zeigt wieder deutlich, daB Ėllis sich - in Übereinstimmung mit der westeuropäischen katholischen Solov'ev-Forschung - vorwiegend für "Solov'evs Weg nach Rom" interessiente ${ }^{58}$ und von der "katholischen Grundhaltung" Solov'evs überzeugt war ${ }^{59}$. Dabei ignorien Elllis die Bedeutung, die Solov'ev neben dem Katholizismus den anderen Konfessionen (Protetantismus und Orthodoxie) zugestanden hat 60 . Solov'ev ist trotz seiner Sympathien nie zum Katholizismus konvertient und hat vor seinem Tode bei einem orthodoxen Priester kommuniziert!61 Gleichzeitig drückt sich in diesen Ausführungen Ellis' Abkehr von RuBland und der Orthodoxie und seine zunehmende Hinwendung zum Katholizismus aus, denn für Orthodoxe wäre eine derartige Aussage unerträglich.

1926 erschien im Matthias-Grünewald-Verlag Bertram Schmitts Übersetzung von Solov'evs "Das Lebensdrama Platons". Dazu schrieb Ėllis eine Einführung und ein ausführliches Nachwor über "Platon und Solowjew. Die alte Philosophie und die neue Weisheit"62. Ėllis hält "Das Lebensdrama Platons" für eins der reifsten Werke Solov'evs und gibt einen ausführlichen AbriB der antiken (heidnischen) Philosophieund Kulturgeschichte und der Lehren Solov'evs von der All-Einheit und der Wiedergeburt und Verklänung. Einige Züge dieser Lehren seien schon bei Platon zu finden. Den Begriff des "Wahrhaft-Seienden", den Platon blob "vorausahnte", habe Solov'ev vollendet ${ }^{63}$. Ėllis sieht eine große Ähnlichkeit zwischen Platon und Solov'ev: Der Ausgangspunkt der Lehre Platons sei der Märtyrertod des Sokrates gewesen.

54 West-ösdicher Weg, II, 1929. S. $207 f$.

$55 \mathrm{Vgl}$. W. Solowjew: Der heilige Wladimir und der christliche Staat. Übertr. v. L. Kobilinski-Ellis. Paderborn 1930.

56 Ebd.. S. $5 f$.

57 Ebd., S. 42.

58 Vgl. L. Müller (Hrsg.): Wladimir Solowjew. Schriften zur Philosophie. Theologie und Politik. München 1991, S. 9. L. Müller zeigt in seinem Vorwort das unterschiedliche Interesse der Katholiken. Protestanten und Anthroposophen an Solov'ev und dessen Werk auf.

$59 \mathrm{Vgl}$. das Nachwort von Wl. Szylkarski in: L. Müller: Solovjev und der Protestantismus, a.a.O.. S. $145-181$.

$60 \mathrm{Vgl}$. ebd., S. 9-92.

$61 \mathrm{Vgl}$. ebd., S. $75 f$.

62 Vgl. W. Solowjew: Das Lebensdrama Platons, a.a.O., S. 95-133.

63 Ebd., S. 99. 
während Solov'ev von Christi Kreuzestod ausgegangen sei. Neben vielen Gemeinsamkeiten (beide seien zu Lebzeiten einsame Künder der Zukunft gewesen und hätten die Vergangenheit als ihren Weisheitsquell benutzt; was Platon begonnen habe, das vollendete Solov'ev) arbeitet Ellis auch Unterschiede zwischen beiden heraus. SchlieBlich kommt er zu dem für ihn typischen, hyperbolisch formulierten Ergebnis, daB Solov'evs Lehre "mit der katholischen Lehre von der «Unbefleckten Empfängnis Mariens» [...] und mit den Offenbarungen der pneumatosophischen Weisheit "des russischen Starzentums», dessen gröBte und leuchtendste Erscheinung das wunderbare Leben und die tiefgründige Lehre des prepodobni Seraphim von Sarow ist, eine harmonische Einheit" bilde64. In diesen übertriebenen Formulierungen drückt sich Ėllis' Bestreben aus, Solov'evs Lehre sowohl mit der Tradition des Katholizismus als auch mit der russischen geistlichen Tradition zu verbinden.

Weitere (kürzere) Arbeiten von Ėllis über Solov'ev sind: die Zusammenstellung "Wladimir Solowjew im Urteile seiner Zeitgenossen"65, ein Aufsatz über "Die freie Theokratie nach der Lehre von Wladimir Solowjew"66, worin Ėllis zunächst Solov'evs Auffassung vom Wesen der Freiheit und der Autorität behandelt und anschlieBend die innere und äuBere Form der "freien Theokratie" darlegt, und ein Artikel für breitere Leserkreise: "Wer war und was ist uns Wladimir Solowjew?"67. Darin wird Solov'ev als ein christlicher Weiser (Prophet) charakterisien, "der dazu berufen war, das neue Wort der Zukunft im Lichte der Ewigkeit in allen Sprachen der Gegenwart auszusprechen"68 und emeut auf seine Sophia-Lehre sowie die "freie Theosophie" eingegangen. Solov'ev lebe in den späteren Werken der bedeutendsten russischen Mystiker wie P. Florenskij, N. Berdjaev, S. Bulgakov und V.N. Il'in fort ${ }^{69}$. In Zukunft werde er auch im Westen und in Deutschland anerkannt, da seine Lehre ja eine Philosophie des Katholizismus darstelle. Sie sei für alle Zeiten, für die Ewigkeit bestimmt, Solov'ev habe für die ganze Menschheit als ein Berufener und Auserwählter gesprochen ${ }^{70}$. Ellis übersieht bzw. ignoriert (bewuBt oder unbewuBt?) völlig das Interesse der Protestanten in Deutschland an Solov'ev, die sich in den zwanziger und dreiBiger Jahren vor allem mit seiner letzten Lehensphase auseinandersetzten. Sic stellten Solov'ev neben Kierkegaard als einen der großen Vorläufer der dialektischen Theologie und interessierten sich überwiegend für die "Drei Gespräche" mit der darin enthaltenen "Kurzen Erzählung vom Antichrist"71.

Im Zusammenhang mit seiner Beschäftigung mit Vl. Solov'ev soll an dieser Stelle auf Ėllis' späteren Aufsatz: "Die Tragik der russischen Literatur"72 hingewiesen werden, der ganz von der Unionsidee geprägt ist. Die Tragik der russischen Literatur und die Tragödien der besten russischen Schriftsteller charakterisiert Ėllis als zugleich überpersönlich und überindividuell. Ihr letzter Grund liege in der russischen Volksseele und deren Geschichte. Ëllis weist auf die tiefe Zerrissenheit der russischen Volksseele hin, die er durch die Spaltung zwischen dem "heiligen" und dem "un-

64 Ebd., S. 131.

65 In: Christi Reich im Osten. a.a.O., S. 200-207.

66 In: Ex Oriente, a.a.O., S. 278-285.

67 In: West-östlicher Weg, I. 1928, S. 23-35.

${ }^{68}$ Ebd., S. 24.

$69 \mathrm{Vgl}$. hierzu auch L. Müller, der darauf hinweist, daB Solov'evs Sophienlehre aufgenommen und weiterentwickelt wurde von den russischen Philosophen P. Florenskij, S. Bulgakov, N. Losskij, S. Frank. N. Berdjaev, L. Karsavin. S. Averincev und vielen anderen. (L. Müller [Hrsg.]: Wl. Solowjew.

Schriften zur Philosophie, a.a.O., S. 241.)

70 West-östlicher Weg, I, 1928, S. 32-34.

71 Vgl. L. Müller (Hrsg.): W1. Solowjew. Schriften zur Philosophie, a.a.O., S. 9.

72 In: Die Schildgenossen, Heft 6, 1937, S. 469-476. 
heimlichen" RuBland, das heißt, zwischen dem christlichen und dem heidnischen (oder gottlosen) Reiche in RuBland bedingt sieht und die sich in den besten Werken der russischen Literatur widerspiegele (Puškin, Gogol' [Mensch-Künstler-Problematik]. Tolstoj, Dostoevskij ...). Die russische Literatur strebe nach universaler, alleuropäischer Bedeutung, nach einer Annäherung zwischen östlicher und westlicher Kultur. Diese Annäherung werde jedoch durch verschiedene Antinomien innerhalb der russischen Literatur erheblich behindert, was ihre Tragik noch vergrößere. Die groBe Sehnsucht nach einer tiefen Resignation, die sich in allen besten Werken der russischen Literatur finde, sei der einzig wahre Weg der russischen Volksseele zur Reini gung und Wiedergeburt. Doch alleine sei das christliche RuBland zu schwach gegenüber seinem schlimmsten Feinde, dem "unheimlichen", gottlosen RuBland. Es bedürfe des Beistandes seiner wahren christlichen "Brüder" und "Schwestern" im Westen. Die Kulturmissionen des Ostens und Westens müssen im Geiste des Universalismus vereinigt werden. Das erfordere aber als Vorbedingung die mystische und die sichtbar ökumenische Einheit des gesamten Reiches Christi auf Erden, also die Erfüllung der Lehre Solov'evs über "die freie und universelle Theokratie". D. Merežkovskijs und Vjač. Ivanovs Wiedervereinigung mit Rom wird von Ellis als wichtiger Schritt in die richtige Richtung hervorgehoben und auch die anwachsende Zahl der katholischen Schriftsteller, die die ganze Bedeutung VI. Solov'evs und seiner Lehre zu erfassen beginnen, sei von großer Bedeutung.

Betrachtet man Ėllis' Beschäftigung mit Vl. Solov'ev insgesamt, so fällt auf, daB er sich vorwiegend auf drei Bereiche konzentriert hat: auf die Lyrik, die Sophienlehre und die Kirchenlehre. Solov'evs Philosophie der Liebe und seine Lehre vom Gottmenschen ${ }^{73}$ klammert Ellis weitgehend (bewuBt oder unbewuBt?) aus. Folglich vermittelt er dem deutschsprachigen Leser kein vollständiges Bild von Werk und Lehre des russischen Philosophen. Dennoch ist sein Bemühen um VI. Solov'ev als positiver Versuch zu bewerten, das Werk des groBen russischen Religionsphilosophen im Westen bekannt zu machen. Obwohl in Deutschland schon zu Lebzeiten Solov'evs einzelne seiner Schriften gedruckt worden waren, setzte eine intensive Beschäftigung mit seinem Werk erst nach seinem Tode ein. Als frühe Solov'ev-Übersetzer traten vor allem Harry Köhler ${ }^{74}$. Gräfin Therese von Pestalozza, Emst Keuchel, Karl Nötzel, L. Galin und Karl Hunnius hervor, die auch theoretische Arbeiten über Solov'evs Werk verfaBten ${ }^{75}$. Erste umfassendere deutsche Darstellungen von Leben und Lehre des russischen Religionsphilosophen bieten 1910 die Dissertation von F. Stepun 76 und 1913 die Untersuchung von Thomas Masaryk 77 . Daneben sind die Arbeiten Wladimir Szylkarskis zu nennen. Frühe deutsche Untersuchungen über Solov'evs Leben und

${ }^{73}$ Hierauf weist Franz Grivec zu Recht hin in seinem Vorwort zu "Monarchia Sancti Petri", S. XV$\mathrm{XXI}$.

74 Ihre vierbändige deutsche Solov'ev-Ausgabe (vgl. oben, S. 199. Anm. 49) war ungeachtet ihrer zahlreichen Übersetzungsfehler (vgl. L. Müller: Solovjev und der Protestantismus. a.a.O., S. 132) bis zum Erscheinen der von WI. Szylkarski herausgegebenen deutschen Gesamtausgabe der Werke Solov'evs im Wewel-Verlag (ab 1953) die umfassendste deutsche Solov'ev-Ausgabe.

$75 \mathrm{Vgl}$. hierzu die "Neue Solov'ev-Bibliographie" in L. Wenzler: Die Freiheit und das Böse nach Vladimir Solov'ev. Freiburg, München 1978. S. 393-456 und L. Müller (Hrsg.): WI. Solowjew. Schriften zur Philosophie, a.a.O., S. 8f., 241.

$76 \mathrm{Vgl}$. F. Steppuhn: Wladimir Ssolowjew. Leipzig 1910.

77 Th. G. Masaryk: Vladimir Solovjev: Die Religion als Mystik. In: Ders.: RuBland und Europa. Studien über die geistigen Strömungen in RuBland. Erste Folge: Zur Russischen Geschichts- und Religionsphilosophie. Soziologische Skizzen. Bd. 1-2. Jena 1913, S. 225-277. In der Zeitschrift "Hochland. Monatsschrift für alle Gebiete des Wissens/der Literatur und Kunst" wurden seit den 1920er Jahren Arbeiten über VI. Solov'evs Lehre und Philosophie publiziert. 
Werk aus protestantischer Sicht wurden beispielsweise von Karl Nötzel und Fritz Lieb verfabt78.

Als Ėllis seine Übersetzungen. Kommentare und Aufsätze über Solov'ev publizierte (zwischen 1925 und 1930), waren dessen Lehre und Werk in Westeuropa und Deutschland jedoch noch nicht umfassend erforscht und bekannt. Ungeachtet der freien, ungenauen Übersetzungen der Gedichte Solov'evs hat Ėllis dadurch dennoch Solov'ev als Lyriker ins BewuBtsein des deutschsprachigen Lesers gerückt, was zweifellos ein großes Verdienst ist. Dabei ist zu bedauern, daB Ėllis in seinen Abhandlungen über Solov'evs Lyrik nicht auf die Form und Struktur dieser Werke eingeht und in keinerlei Weise die große Bedeutung berücksichtigt, die diese Gedichte seinerzeit für die russischen Symbolisten hatten ${ }^{79}$. Dieses Versäumnis kann Ėllis allerdings nicht zum Vorwurf gemacht werden, da sein Erkenntnisinteresse auf Solov'evs Religionsphilosophie ausgerichtet war; er schrieb philosophische und nicht literaturwissenschaftliche Arbeiten über Solov'ev und war folglich nicht an einer Strukturanalyse von dessen Lyrik interessiert. Zu kritisieren wäre jedoch abschließend noch einmal Ėlis' übertrieben pathetische Ausdrucksweise, in der er Solov'evs Lehre kommentient und wiedergibt.

$78 \mathrm{Vgl.} \mathrm{z.B.} \mathrm{Karl} \mathrm{Nötzels} \mathrm{Artikel} \mathrm{"Wladimir} \mathrm{Solowjoff"} \mathrm{in:} \mathrm{Die} \mathrm{Religion} \mathrm{in} \mathrm{Geschichte} \mathrm{und} \mathrm{Gegen-}$ wart. Handwörterbuch für Theologie und Religionswissenschaft. 5. Band. Tübingen 1931. S. 600f.; Wladimir Solowjow: Die Erzähiung vom Antichrist. Deutsch von Karl Noetzel. Luzem 1935 (mit einer Einführung von K. Noetzel); Fritz Lieb: "Der Geist der Zeit" als Antichrist. Spekulation und Offenbarung bei Wladimir Solovjev. In: Orient und Occident. 16. Heft (1934), S. 7-22.

79 Vgl. hierzu etwa R.J. Lager: Vladimir Soloviev - Symbolist Poet. Washington. D.C. 1970; A. Knigge: Die Lyrik V. Solov'evs und ihre Nachwirkung bei A. Belyj und A. Blok. Amsterdam 1973. 


\section{Monographie und Arbeiten über Vasilij Zukovskij}

In seiner Vladimir Solov'ev gewidmeten Žukovskij-Monographie bemüht sich Ėllis, Persönlichkeit, Leben und Werk dieses - wie er meint - im Westen fast unbekannten Dichters zu erschließen '. Ėllis miBt Žukovskij große Bedeutung bei. Er sieht in ihm den Vater der russischen Romantik, den Begründer der russischen Poesie 2 , ohne den die gesamte folgende russische Literatur undenkbar wäre:

Der erste wahre Dichter des neuen RuBland und der Urheber dieses "goldenen Zeitalters" war Wassilij Andrejewitsch Joukon'ski ${ }^{3}$. Alles. was vor Joukowski gedichtet wurde, war Vorbereitung: alles. was nach ihm entstand, wäre ohne Joukowski undenkbar. ${ }^{4}$

Die lyrisch-epische Romantik seiner ersten Lebensperiode wurde zur Wiege der Poesie des gröBten aller russischen Dichter, A. Puschkin, dessen Persönlichkeit und Lebenswerk den Mittelpunkt des "goldenen Zeitalters" bilden. Sie wurde zugleich zur Urquelle der russischen romantischen Bewegung überhaupt, die sich auch später während aller Zeitalter der russischen Literatur zu behaupten wuBte (von M. Lermontow bis A. Phöt lgemeint ist Fet) und von A. Phöt bis A. Blok) und einen Bestandteil der mystisch-symbolischen Lyrik W. Solowjews bildete. [...] Die

1 An dieser Stelle weist Ėllis darauf hin. dab selbst in Deutschland nur eine von Žukovskijs Dichtungen, nämlich sein "Märchen von Iwan Zarewitsch..." von Justinus Kerner übersetzt worden sei, während die deutschen Nachschlagewerke keine eigenen Schöpfungen Žukovskijs kennen würden (vgl. L. Kobilinski-Ellis: W.A. Joukowski, a.a.O.. S. 13).

Das stimmt nicht: Zukovskij war bereits zu Lebzeiten im Westen, vor allem in Deutschland, bekannt. Das von Ellis erwähnte "Märchen von Iwan Zarewitsch und dem grauen Wolf" war $z$ war von Justinus Kemer, den eine herzliche Freundschaft mit Žukovskij verband (vgl. A.N. Veselovskij: V.A. Žukovskij. S.-Peterburg 1904, S. 453f.; F.W. Neumann: Geschichte der russischen Ballade. Königsberg u. Berlin 1937. S. 53), herausgegeben und mit einer Vorrede versehen worden (1852. wenige Wochen vor Żukovskijs Tod), "übersetzt" hatte es jedoch Georg Heinrich Krieg von Hochfelden, der allerdings, wie Kerner auch, kein Russisch konnte. Krieg von Hochfelden hatte neben diesem Märchen fünf weitere lyrische Werke Żukovskijs ins Deutsche übertragen und in der "Ostergabe für das Jahr 1850" publizien. (Vgl hierzu: D. Gerhardt: Aus deutschen Erinnerungen an Žukovskij. In: Orbis scriptus. Dmitrij TschiZevskij zum 70. Geburtstag. München 1966. S. 245-313. bes. S. 245, 247-250, 263. 267-274. 2906. 313.) Kerner plante eine Übersetzung von Žukovskijs "Ahasver". die jedoch nie vollendet bzw. publi zien wurde (vgl. ebd., S. 272; H. Eichstädt: Zwölf Briefe V.A. Žukovskijs. In: Die Welt der Slaven. 14 [1969]. S. 307: D. TschiŽewskij: Russische Literaturgeschichte des 19. Jahrhunderts. I: Die Romantik. München 1977. S. 36). Auch in Anthologien u. dergl. finden sich (̈bersetzungen von Zukovskijs Werken. Karolina K. Pavlova übersetzte Žukovskijs Gedicht "Я музу кную бывало..." unter dem Titel "Weihe" (K. Pavlova: Polnoe sobranie stichotvorenij. Moskva - Leningrad 1964, S. 491f.. 595); Friedrich von Bodenstedt fertigte eine Übersetzung von Z̈ukovskijs Gedicht "Ho4b" ("Nacht") an. die im 7. Band seiner "Gesammelten Schrifien" (Berlin 1866. S. 153) publizien ist. (Vgl. zu diesem Thema auch E. Boehme. A. Luther: Frühe deutsche Übersetzungen aus dem Russischen. In: Philobiblon 6 |1933|. S. 277-286, 349-363, zu Žukovskij bes. S. 283. 353f.. 357). Zudem gab es bereits im 19. Jahrhunden deutschsprachige Monographien und Arbeiten über Žukovskij, z.B.: Carl von Seidlitz: Wasily Andrejewitsch Joukoffsky. Ein russisches Dichterleben. Mitau 1870 (21872): W. Haape: Wasily Andrejewitsch Shukowsky und seine Beziehungen zu Deutschland und Baden. Sonderdr. a. d. Beil. 2. "Allgem. Zeitung" Nr. 198f., 31.VIII.-1.IX.1899, München 1899. Daneben entstanden schon zu Lebzeiten deutsche Gedichte über Žukovskij: das erste bereits 1816 von Karl Fr. L. v. Petersen: "Wünsche? $\mathrm{lhm}$ ? dem alles Schöne..." (vgl. D. Gerhardt: op.cit.. S. 313); ein anderes von J. Kemer: "Empfangt dieB nordische Gedicht..." (Kerner stellte es seiner Vorrede in der Ausgabe von Žukovskijs "Märchen von I wan Zarewitsch..." voran: vgl. D. Gerhardt: op.cit., S. 273f.).

2 Vgl. L. Kobilinski-Ellis: W.A. Joukowski, a.a.O.. S. IIf.

${ }^{3}$ Das ist nicht ganz richtig: hier müBte man G.R. Derzavin nennen, der den strengen Kanon der klassizistischen Ästhetik erstmals auflöste. N.M. Karamzin und seine wichtige Reform der russischen Lite ratursprache werden von Ëllis vermutlich deshalb nicht erwähnt, weil es ihm hier ausschlieBlich um die Lyrik geht. (Im folgenden Zitat nennt er ja Karamzin als Begründer der modernen russischen Literatur.)

${ }^{4}$ Das ist richtig!

L. Kobilinski-Ellis: W.A. Joukowski, a.a.O., S. 11. 
russische Versifikation wurde durch Lomonossow und Derschawin geschaffen, die russische Literatur begann mit Karamsin, die russische Poesie aber erst mit Joukowski. ${ }^{5}$

Ėllis hebt also die große Bedeutung Žukovskijs und die führende Rolle, die dieser innerhalb der neuen Richtung der romantischen Literatur in RuBland und für die weitere Entwicklung der russischen Literatur überhaupt gespielt hat, hervor, während spätere Literaturgeschichten Žukovskijs bedeutende Leistung häufig nicht gebührend würdigen bzw. schmälem ${ }^{6}$. Unter den "drei Berufenen"7 der russischen Literatur jener Zeit. Karamzin. Batjuškov und Žukovskij, stand letzterer an erster Stelle und konnte zum poetischen Führer der neuen literarischen Stilformation werden, da er bei der Erfüllung seiner "Mission" die drei wesentlichen Eigenschaften besaB: "die wahre und groBe poetische Gabe, das tiefe, persönliche, seelische Leben und die harmonische Weltanschauung"8. Batjuškov besa 3 war eine große poetische Begabung, ihm fehlten jedoch "eine tiefe Persönlichkeit und eine harmonische Weltanschauung". während Karamzin die "wahre poetische Gabe" fehlte9.

Ėllis weist wiederholt auf die kulturvermittelnde Rolle und Wirkung der Übersetzungen und Nachdichtungen Žukovskijs aus der westeuropäischen und vor allem der deutschen Dichtung hin:

Die poetische Berufung Joukowskis bestand im Schlagen jener goldenen Brücke zwischen Osten und Westen, zwischen RuBland und Deutschland, die niemals später einstürzen konnte. 10

In seiner Monographie schildert Ėllis ausführlich die äußere Biographie und den inneren Werdegang Zukovskijs und charakterisiert dessen wichtigste Werke ${ }^{11}$, indem er

5 Ebd., S. 12.

$6 \mathrm{Vgl}$. etwa A. Stender-Petersen, der Žukovskij als Vorromantiker charakterisient und bewertet: Z̆ukovskij habe zwar eine grobe Rolle in der Entwicklung der russischen Literatur gespielt und dadurch den Übergang zur neven Strömung der Romantik angekündigt, sei jedoch nicht als schulebildender, ei genständiger Vertreter dieser neuen literarischen Stilformation zu betrachten (vgl. A. Stender-Petersen: (ieschichte der nussischen Literatur. Teil II, a.a.O., S. 50-58). In der von Charles A. Moser herausgegebenen Literaturgeschichte wird Zukovskij der erste Platz unter den russischen Früh-oder Vorromantikem zugewiesen (vgl. The Cambridge History of Russian Literature. Cambridge 21992, S. 123). W. Kasack behandelt in seinem Lexikon "Die Klassiker der russischen Literatur" (Düsseldorf 1986) 55 "grobe Autoren vom 18. bis zum 20. Jahrhunder", unter ihnen Derzavin, Karamzin, Krylov und Baratynskij, nicht jedoch Žukovskij! In "Kindlers Neuem Literaturlexikon" (Bd. 17, München 1992, S. 1116f.) ist Žukovskij lediglich mit einem Werk ("Певец во стане pyсскцх воннов" - "Der Sänger im Lager der nussischen Krieger") vertreten!

Żukovskijs Bedeutung für die russische Romantik, seine kulturvermittelnde Rolle (Übertragung des Geistes der westeuropäischen Dichtung nach RuBland. Umorientierung der russischen Literatur vom bisher französischen Vorbild auf die deutsche Literatur und Philosophie), muB hoch eingeschätzt werden. auch wenn die Rezeption der zeitgenössischen europäischen romantischen Literaturen und deren Strömungen in spezifisch russischer, bei Žukovskij vornehmlich in empfindsam irrationaler und religiöser Ausprägung. erfolgte. Seine Wichtigkeit für die russische Romantik war jedoch zweifellos größer als seine Bedeutung für die europäische Romantik. was deutlich wird, wenn man seine theoretischen Schriften etwa mit denjenigen seiner deutschen Zeitgenossen (z.B. Novalis, Eichendorff, Tieck, die Brüder Schlegel, Schelling. Hegel) vergleicht. Bei Žukovskij als typischem Vertreter der Romantik des Gefühls fehlt der poetologisch-transzendentalistische Ansatz.

${ }^{7}$ L. Kobilinski-Ellis: W.A. Joukowski, a.a.O., S. 37.

8 Ebd., S. 38.

${ }^{9}$ Ebd.

10 Ebd.. S. 52.

$"$ Als Quellen für seine Beschäftigung mit Žukovskij gibt Ėllis dessen Briefe sowie "die schon be stehende reiche Joukowski-Literatur" an (ebd., S. 15); im Verlaufe der Arbeit nennt er seine Quellen genaver: als wichtigste Žukovskij-Forscher zählt er K. Seidlitz und A. Veselovskij auf (ebd., S. 314), von denen er - neben dem bereits erwähnten Werk von Seidlitz (vgl. die erste Anmerkung dieses Kapitels) die folgenden Arbeiten gemeint haben dürfte: Žizn' i poezzija V.A. Žukovskogo: 1783-1852. (Po neiz- 
sich dabei der geistesgeschichtlichen Methode bedient 12. Parallel dazu schildert er die zeitgeschichtlichen, politischen und kulturellen Ereignisse und Entwicklungen, das Sprachproblem (den Streit zwischen "Beseda" und "Arzamas"), diskutien Žukovskijs Verhältnis zur Zarenfamilie, seine Auslandsreisen, seine Beziehungen zu ausländi schen, vor allem deutschen Dichtern, geht ausführlich auf den Tod Puškins ein etc. Treffend charakterisien er Žukovskij als eine tiefreligiöse Natur ${ }^{13}$, einen überzeugten Christen und einen gütigen. edlen. harmonischen Menschen, der Romantiker und Mystiker zugleich gewesen sei.

Als erste bedeutende Dichtung Žukovskijs nennt Ėllis dessen Übersetzung von Th. Grays "Elegy written in a country-churchyard", den "Dorfkirchhof" ("Сельское кладбице", 1802), "welche sowohl für seinen eigenen Weg wie auch für die Geschichte der russischen Poesie eine Epoche bedeutete"14. Weiterhin hebt er die Ballade "Ljudmila" hervor (1808; Žukovskijs erste Nachdichtung von G.A. Bürgers "Lenore") 15 , die "zur zweiten Geburt (nach dem «Dorfkirchhof») der russischen Romantik werden sollte"16. In der Zeit von 1802 bis 1812 seien Žukovskijs erste Dichtungen von unvergänglichem Wert entstanden:

Am Ende dieses Dezenniums [...] 1812 steht er [Žukovskij] in voller Blüte seiner geistigen Kräfte und schöpferischen Begabung seiner Weltanschauung nach ein strenggläubiger (orthodoxer) Christ, seiner poetischen Sendung und künstlerischen Art nach ein romantischer (vorzugsweise lyrisch-epischer) Dichter. Seine Poesie bekommt von Anfang an eine universalistische (westöstliche) Richtung, indem sie allmählich eine vorzugsweise deussche Orientierung (Schiller. Uhland) ertält. [...]

Seine Zweiwelten-Intuition, als eine Ar von "melancholischer Sehnsucht" nach der wahren Welt des Jenseits durch den Schein des Diesseits, macht Joukowski zum Romantiker. seine feste moralische Überzeugung, daB dieser Weg ein Weg "der Tugend" zur wahren jenseitigen Welt

dannym isłoxnikam i ličnym vospominanijam K.K. Zejdlica). S.-Peterburg 1883 und A.N. Veselovskij: V.A. Žukovskij. Poezija Cuvstva i "serdeCnogo voobraŽenija". S.-Peterburg 1904 (Petrograd. 21918 ). Diese Quellen und überhaupt die damalige Žukovskij-Literatur (vgl. unten. Anmerkung 48 dieses Kapitels) bilden bis heute die Grundlage der Žukovskjj-Forschung, auf ihr basieren auch die neueren Żukovskij-Monographien. wie etwa die von V. Afanas'ev: Žukovskij (Moskva 1987) mit vorwiegend dokumentarischem Charakter und von R.V. lezuitova: Żukovskij i ego vremja (Leningrad 1989), die vor allem Zukovskijs literarische Aktivitäten im Kontext des gesellschaftlich-politischen und literarischen Lebens seiner Zeit untersucht: beide genannten Monographien bieten kaum neue Ergebnisse und Einsichten.

12 L. Kobilinski-Ellis: W.A. Joukowski. a.a.O., S. 15.

$13 \mathrm{Vgl}$. hierzu auch D. Tschižewskij (Russische Literaturgeschichte des 19. Jahrhunderts. I. S. 35). der auf Zukovskijs "tiefe Religiosität, die der Frömmigkeit des deutschen Pietismus nahestand", hinweist.

${ }^{14}$ L. Kobilinski-Ellis: W.A. Joukowski, a.a.O., S. 59.

Is Žukovskij hat sich dreimal mit Bürgers "Lenore" beschäftigt und zwei Nachdichtungen ("Ljud mila", 1808. und "Svetlana", 1808-1812 entstanden) sowie eine poetische Übersetzung ("Lenora". 1831) geschaffen (vgl. F.W. Neumann: Geschichte der russischen Ballade, a.a.O.. S. 54-59, 140f.: V. Terras: A History of Russian Literature, a.a.O.. S. 199). Ellis geht zwar im Zusammenhang mit seiner Analyse der "Ljudmila" recht ausfïhrlich auf Bürgers "Lenore" und ihre Schlüsselstellung für die Ent wicklung der deutschen und westeuropäischen Ballade ein, weist aber nicht explizit darauf hin, daB sich Žukovskij insgesamt dreimal dieser Ballade zugewandt hat.

16 L. Kobilinski-Ellis: W.A. Joukowski, a.a.O., S. 71.

Die grobe Bedeutung. die Ėllis der "Ljudmila" zuspricht, wird durch die Žukovskij-Forschung bestätigt, die in dieser Ballade im allgemeinen den Beginn bzw. die Einleitung der Epoche der russischen Romantik sieht (vgl. F.W. Neumann: Geschichte der russischen Ballade, a.a.O.. S. 59; A. Stender-Petersen: Geschichte der russischen Literatur. Teil II. a.a.O.. S. 54; Istorija russkoj literatury v cetyrech tomach. T. 2. Leningrad 1981, S. 122f.: W. Diwwel. H. Grasshoff [Hrsg.]: Geschichte der russischen Literatur, Bd. 1, a.a.O., S. 261). 
sein müsse, und sein religiöser Glaube an das Mysterium der Erlösung bewirkt in ihm die besondere An des christlich romantischen Dichters. ${ }^{17}$

In dieser Charakteristik formuliert Ëllis Žukovskijs romantisch-religiöse Weltsicht, seinen weltanschaulichen Dualismus des "Hier" und "Dort" ("здесь" и "там") und hebt seinen Hang zur religiösen Mystik hervor. Kunst und Literatur sind für Žukov skij göttliche Inspiration; Dichtung ist eine andere Art von Gottesdienst; der Dichter ist ein instrumentum dei, ist Priester ${ }^{18}$.

Ėllis teilt Žukovskijs Leben und Werk in vier Perioden ein. bedient sich dabei al lerdings nicht systematisch zusammenpassender literaturwissenschaftlicher Gliede rungskriterien. Die ersten zwei Phasen von 1783-1820 und von 1821-1841 bezeichnet er als "romantische" Perioden; darauf folge dann die "epische" Periode (18411848) und abschließend die "mystische" $(1848-1852){ }^{19}$, in der sich Žukovskij schlieBlich dem Geist des Katholizismus und der katholischen Kirche annähere, ohne jedoch seiner eigenen, der orthodoxen Kirche zu entsagen 20 .

Neben der Elegie "Dorfkirchhof" und der Ballade "Ljudmila" erwähnt Elllis alle wesentlichen Werke Žukovskijs und behandelt diejenigen ausfuihrlicher, die auch heute als seine bedeutendsten Dichtungen gelten. Dabei legt er jedoch ein besonderes $\mathrm{Ge}-$ wicht auf Žukovskijs eigene Dichtungen und betont ihren Wert, während in der Žukovskij-Forschung insgesamt eher die Wichtigkeit seiner poetischen Übersetzungen und Nachdichtungen hervorgehoben wird ${ }^{21}$. Aber auch Žukovskijs Verdienste und Rolle als Übersetzer, als Vermittler fremder Kulturen und Literaturen nach RuBland, bewertet Ëllis hoch und unterstreicht dabei, daB Žukovskijs Übersetzungen ihren Vorlagen ebenbürtig oder mitunter sogar überlegen seien22.

Aus Žukovskijs "romantischen" Schaffensphasen diskutien Ėllis recht detaillien die große Doppelballade "Die zwölf schlafenden Jungfrauen" ("Двенадцать спящих дев"): "Gromoboj" (1811) und "Vadim" (1814-1817) sowie deren Vorbild, den Ro-

${ }^{17}$ L. Kobilinski-Ellis: W.A. Joukowski, a.a.O., S. 60.

18 Diese romantische Auffassung vom Dichter geht auf Schelling und Schleiermacher zurïck.

19 Diese Einteilung entspricht nicht ganz derjenigen C.v. Seidlitz', der Zukovskijs Leben in drei Abschnitte gliedert: 1783-1815, 1815-1841 und 1840|sic!)-1852 (vgl. C.v. Seidlitz: Wasily Andrejewitsch loukoffsky. Mitau 1870).

20 An mehreren Stellen seiner Arbeit weist Ėllis darauf hin, daB man Žukovskij bezüglich seiner Haltung gegenüber Kirche und Religion als Vorläufer VI. Solov'evs ansehen kann: er sei der orthodoxen Kirche treu geblieben und habe zugleich den tiefsten Sinn und Wert des katholischen Glaubens verstanden (vgl. L. Kobilinski-Ellis: W.A. Joukowski, a.a.O., S. 244, 263, 292-296, 300). Diese von Ëllis hervorgehobene Neigung Żukovskijs zum Katholizismus wird in der Forschung nicht einstimmig bestätigt. D. Gerhardt Z.B. betont. daB Žukovskij seine "mangelnden Sympathien gegen den Katholizismus" kaum verhehlt habe (vgl. D. Gerhardt: Aus deutschen Erinnerungen an Žukovskij, a.a.O., S. 281).

21 Die Literaturgeschichten betonen. daB Zukovskijs Werk überwiegend (zu drei Vierteln: vgl. F.W. Neumann: Geschichte der nussischen Ballade. a.a.O., S. 51) aus Übersetzungen und Nachdichtungen besteht, was aber Żukovskijs Bedeutung für die Entwicklung der Geschichte der russischen Literatur nicht mindere (vgl. etwa A. Stender-Petersen: Geschichte det nussischen Literatur, Teil II, a.a.O., S. 57; D.S. Mirsky: A History of Russian Literature. New York 1949, S. 75f.: D. Tschižewskij: Russische Literaturgeschichte des 19. Jahrhunderts. 1, S. 35: Istorija russkoj literatury v cetyrech tomach. T. 2. a.a.O.. S. 110: W. Dïwel, H. Grasshoff [Hirsg.]: Geschichte der russischen Literatur, Band 1. a.a.O., S. 266). Žukovskijs Originaldichtungen sind in der Tat nicht sehr zahireich und nehmen nur einen geringen Platz im Kontext seines Gesamtwerks ein. DaB sie aber durchaus wichtig und bedeutsam sind, fuihr z.B. D. Tschižewskij (Russische Literaturgeschichte des 19. Jahuhunderts, I, S. 36f.) aus.

22 Vgl. L. Kobilinski-Ellis: W.A. Joukowski, a.a.O.. S. 63, 153, 191.

Diese Meinung wird auch in etlichen Literaturgeschichten vertreten: vgl. z.B. V. Setschkareff: Geschichte der russischen Literatur. Stuttgart 1966. S. 75; W. Düwel, H. Grasshoff (Hrsg.): Geschichte der nussischen Literatur, Band 1, a.a.O., S. 266: D.S. Mirsky: A History of Russian Literature, a.a.O., S. 75f.: Istorija russkoj literatury v cetyrech tomach. T. 2, a.a.O., S. 110. 
man von Christian Heinrich SpieB23; fermer eine der bekanntesten Balladen Žukov skijs, "Svetlana" (1808-1812), die Ėllis als "Vorbild der russischen Ballade überhaupt" und als "bedeutendste aller eigenen Balladen" Žukovskijs bezeichnet ${ }^{24}$; dabei übersieht er jedoch. daB es sich bei "Svetlana" um eine zweite, recht freie Nachdichtung von Bürgers "Lenore" handelt ${ }^{25}$. AuBerdem erörtert er die Ode "Der Sänger im Lager der russischen Krieger" ("Певец во стане русских воннов", 1812), die aus Žukovskijs eigener Erfahrung (seiner Teilnahme am "Vaterländischen Krieg" 1812) entstand und seinen literarischen Ruhm begrüdete ${ }^{26}$. Weiterhin charakterisiert Ellis Žukovskijs eigene Gedichte "Theon und Eschin" ("Теон и Эсхин", 1814), "Äolsharfe" ("Эолова арфа", 1814), "Achill" (1814), "Die Nacht" ("Ночь", 1815), "Slavjanka" (1816), "An den vorbeigeflogenen, bekannten Genius" ("К мимопролетевшему знакомому гению", 1818) und "Das Unaussprechliche" ("Невыразимое", 1818), die er zu Zukovskijs besten romantischen Dichtungen zählt, da sie seine religiöse Weltanschauung und Gesinnung ausdrückten und auf dem Boden wirklich erlebter Gefühle erwachsen seien 27.

Zu Recht hebt Ėllis Žukovskijs Verdienst als Vermittler Schillers nach RuBland hervor (durch die Übersetzungen und Nachdichtungen aus Schillers Werk) und diskutiert in diesem Zusammenhang Žukovskijs Übertragung der "Jungfrau von Orleans" ("Орлеанская дева", 1824) 28 . In den Übersetzungen "Die Peri und der Engel" ("Пери и ангел", nach Th. Moore, 1821) und "Der Gefangene von Chillon" ("Шильон ский узник", Byron, 1821-1822) sei bereits Žukovskijs "epische" Schaffensperiode angelegt; durch seine Byron-Übersetzung habe er Wichtiges für den romantischen Byronkult in RuBland geleistet ${ }^{29}$. Žukovskijs Elegie "Das Meer" ("Mope", 1822), eines der bedeutendsten frühromantischen russischen Gedichte und ein Muster der Gattung, wird von Ėllis besonders hervorgehoben und neben Puškins Elegie "An das Meer" ("K морю", 1824) als "das Bedeutendste in der Meereslyrik des «goldenen Zeitalters der russischen Poesie»" bezeichnet ${ }^{30}$. Als wichtige eigene Dichtungen Żu-

${ }^{23}$ L. Kobilinski-Ellis: W.A. Joukowski, a.a.O., S. 93-113.

24 Ebd.. S. $115 f$.

$25 \mathrm{Vgl}$. oben. Anmerkung 15 dieses Kapitels. Žukovskij bemühte sich. diese Ballade, die tatsächlich einen wichtigen Platz unter den russischen Balladen einnimmt und als die "erste russische Traumballade" bezeichnet werden kann, volkstümlich-russisch zu gestalten (vgl. F.W. Neumann: Geschichte der nussischen Ballade, a.a.O., S. 58). Sie wird in der Žukovskij-Forschung allgemein als Žukovskijs bekannteste Schöpfung hervorgehoben und von einigen Literaturgeschichten Żukovskijs bestes Werk genannt (vgl. 2.B. Ch.A. Moser [Ed.]: The Cambridge History of Russian Literature, a.a.O., S. 125; W. Diwel, H. Grasshoff [Hrsg.]: Geschichte der nussischen Literatur, a.a.O.. S. 265: V. Terras dagegen wertet sie als Žukovskijs bekannteste, nicht aber beste Dichtung: vgl. A History of Russian Literature. a.a.O.. S. 199).

${ }^{26}$ L. Kobilinski-Ellis: W.A. Joukowski. a.a.O., S. 123-126.

Die Bekanntheit und Bedeutung dieser Dichtung wind in allen Literaturgeschichten und -lexika hervorgehoben (vgl. z.B. Kindlers Neues Literaturlexikon, Bd. 17, München 1992. S. $1116 \mathrm{f}$.: Istorija russkoj literatury v cetyrech tomach. T. 2. a.a.O..S. 120f.).

${ }^{27}$ L. Kobilinski-Ellis: W.A. Joukowski, a.a.O.. S. 155-160, 193.

In den Literaturgeschichten herrschen bezüglich dieser Gedichte unterschiedliche Ansichten. In W. Düwel. H. Grasshoff (Hrsg.): Geschichte der russischen Literatur, Band 1, a.a.O., S. 264f., wird Ėllis' Meinung bestätigt, während in anderen Arbeiten Žukovskijs "eindeutig rezeptive und reproduktive dichterische Veranlagung" (F.W. Neumann: Geschichte der russischen Ballade, a.a.O., S. 51) oder die Überlegenheit seiner Übersetzungen gegenüber seinen eigenen Dichtungen (A. Stender-Petersen: Geschichte der russischen Literatur. Teil II. a.a.O., S. 57f.) betont wird.

${ }^{28}$ L. Kobilinski-Ellis: W.A. Joukowski. a.a.O., S. 185-192.

29 Ebd., S. 183f., 192.

30 Ebd.. S. 195. Žukovskijs Elegie "Mope" zählt zu den bedeutendsten Schöpfungen der neueren russischen Lyrik überhaupt. Das Meer als Landschaftsmotiv vitt recht selten in der russischen Literatur 
kovskijs nennt Ėllis unter anderem dessen Märchen, vor allem diejenigen, die 1831 im poetischen Wetteifem mit Puškin entstanden sind und in der Tat bedeutsam für die Entwicklung der Gattung des Kunstmärchens in der russischen Literatur waren ${ }^{31}$. Die "geniale Umdichtung" der "Undine" von Friedrich de la Motte-Fouqué ("Ундина", 1831-1836, 1837) in klassischen Hexametem, auf die auch in den Literaturgeschichten positiv verwiesen wird ${ }^{32}$, hebt Ėllis als wichtigste Übergangsstufe zu Zukovskijs "epischer" Periode hervor ${ }^{33}$. Als AbschluB der zweiten "romantischen" Phase verweist Ėllis auf Žukovskijs "meisterhafte Übersetzung" des dramatischen Poems von Friedrich Halm (E.E. Münch-Bellinghausen) "Camoëns" ("Kамоэнс", 1839), das er als Žukovskijs poetisches Credo, seine "mystisch-romantische ars poetica" bezeichnet $^{34}$.

Žukovskijs Übertragungen bedeutender Verseper: der Weltliteratur, seine Zuwendung zum "Monumental-Epischen", behandelt Ëllis als dessen dritte Lebens- und Schaffensperiode, während derer sich die mystische Stimmung entwickelt habe, wodurch der vierte und letzte Abschnitt in Žukovskijs Werk vorbereitet worden sei. Ëllis versucht zu zeigen. daß Žukovskijs "epische" und "mystische" Phasen noch fruchtbarer waren als seine "romantischen".

Das ist ein origineller Ansatz. Allgemein wird Žukovskij in der Forschung als be deutender Vertreter der Vorromantik ${ }^{35}$ und/oder als Begründer und bis etwa 1820 wichtigster Vertreter der Romantik in RuBland, als Wegbereiter Puškins und Urheber der eigenständigen russischen Lyrik bezeichnet ${ }^{36}$, der sich dann ab den 1830 er Jahren von der neuen zeitgenössischen russischen Lyrik ab- und den alten Versepen der Weltliteratur zuwandte. Dieser späten Schaffensphase Žukovskijs wird 2 war auch große Bedeutung beigemessen ${ }^{37}$, sein Verdienst als Begründer der neueren russischen Lyrik und Führer der nussischen Romantik wird und muB allerdings noch höher bewertet werden.

Žukovskijs zunehmende Neigung zur religiösen Mystik in der dritten und vienten Schaffensperiode wird jedoch von Ellis erkannt und deshalb so sehr hervorgehoben. weil sie seiner eigenen Kunst- und Literaturauffassung entspricht. Dementsprechend charakterisien er Zukovskijs bedeutende Epen "Nalj und Damajanti" ("Наль и Дамаянти". 1837-1841, 1843), "Rustem und Sohrab" ("Рустем и Зора6", 1846-1847)

auf und wurde neben den genannten Elegien von Zukovskij und Puskin später erst von $A$. Blok wiederentdeckt. (Vgl. hierzu W. Dïwel, H. Grasshoff [Hrsg.): Geschichte der russischen Literatur, Band 1, a.a.O., S. 264 sowie die Vorlesung von R.-D. Kluge: "Klassizismus. Romantik I", Universität Tübingen. WS 1990/1991.)

31 L. Kobilinski-Ellis: W.A. Joukowski, a.a.O., S. 214-220. Vgl. hierzu auch W. Düwel, H. Grasshoff (Hrsg.): Geschichte der russischen Literatur, Band 1, a.a.O., S. 266.

32 Z.B. von D. Tschižewskij: Russische Literaturgeschichte des 19. Jahrhunderts, 1, a.a.O., S. 36.

33 L. Kobilinski-Ellis: W.A. Joukowski, a.a.O., S. 223-225.

34 Ebd.. S. 234-236.

Diese Dichtung ist tatsächlich Ausdruck von Z̈ukovskijs mystisch-romantischer Weltanschauung. seiner religiösen Kunstauffassung und drückt deutlich die romantische Vorstellung von Aufgabe und Berufung des Dichters aus. (Vgl. hierzu: W. Diwwel, H. Grasshoff [Hrsg.): Geschichte der russischen Literatur, Band 1, a.a.O., S. 267; V. Terras: A History of Russian Literature, a.a.O., S. 198; Istorija russkoj literatury v cetyrech tomach. T. 2, a.a.O., S. 132f.)

35 Vgl. z.B. M. Ehrhard: V.A. Joukovski et le Préromantisme Russe. Paris 1938; Ch.A. Moser (Ed.): The Cambridge History of Russian Literature, a.a.O., S. 123; A. Stender-Petersen: Geschichte der russischen Literatur. Teil II. a.a.O., S. 58.

$36 \mathrm{Vgl}$. 2.B. Istorija russkoj literatury v cetyrech tomach. T. 2. a.a.O., S. 104; N.L. Brodski (Hrsg.): Geschichte der russischen Literatur. Bd. 1. Berlin 1952. S. 182: W. Düwel. H. Grasshoff (Hrsg.): Geschichte der russischen Literatur, Band 1, a.a.O., S. 267; V. Setschkareff: Geschichte der russischen Literatur. S. 74f.: Kratkaja Literaturnaja Enciklopedija, Bd. 2. Moskva 1964, S. 957-959.

$37 \mathrm{Vgl}$. etwa A. Stender-Petersen: Geschichte der russischen Literatur. Teil II. a.a.O., S. 57. 
und seine Übertragung der "Odyssee" ("Одиссея", 1842-1849) als originelle Umdichtungen oder selbständige Formbildungen seiner Vorlagen ${ }^{38}$. Żukovskijs "Meisterwerk" "Ahasver" ("Странствующий жид", 1851-1852, unvollendet) aus seiner vierten (der "mystischen") Schaffensphase zählt Ëllis zu den klassischen Dichtungen der Weltliteratur ${ }^{39}$. Darin erreiche Žukovskij die Höhe jener christlichen "ars sacra", jener schönen Harmonie zwischen Religion und Kunst, die den meisten großen russischen Dichtem fehle:

Dieser Schwanengesang [gemeint ist "Ahasver"] des gelassen-geduldig in Christus sterbenden Joukowski von der furchtbaren diesseitigen Unsterblichkeit, verdient wahrhafi-unsterblich $\mathrm{zu}$ werden. Gerade unsere Zeit der tragischen Weltwende ${ }^{40}$ ist wie berufen, die ganze Tiefe der Weisheit dieser letzten Schöpfung Joukowskis mit ganzer Seele zu erleben. Sie ist nur die erste Stufe der groben Sehnsucht nach Christus und seiner Weisheit innerhalb der klassischen russischen Literatur. Das unsterbliche Wort der klassischen russischen Dichter klingt gerade heute auch im Westen immer deutlicher und bedeutungsvoller. ${ }^{41}$

In der Wochenschrift "Das neue Reich"42 hatte Ėllis bereits vor seiner Monographie einen relativ kurzen Aufsatz über Žukovskij publizien mit dem Titel "Der erste russische Romantiker", worin er auf die poetische Sendung Žukovskijs, seine große Bedeutung für die russische Romantik und russische Literatur überhaupt, "die Eröffnung des Reiches der deutschen Romantik für die Russen" durch Žukovskij33 und seine große Nachwirkung auf die folgenden russischen Dichter eingeht. Am Ende seiner Ausführungen weist Ėllis auf die "Verbindungslinie zwischen dem ersten (Schukowski) und dem letzten (Phöt) großen, russischen Romantiker" hin, wobei er Fets Lyrik als "das gröBte Ereignis der russischen Seelen- und Naturlyrik überhaupt" bezeichnet ${ }^{44}$.

${ }^{38}$ L. Kobilinski-Ellis: W.A. Joukowski, a.a.O., S. 246-282.

Diese Epen schrieb Zukovskij im wesentlichen in Deutschland, wo er nach seiner EheschlieBung (am 21.5.1841) mit der viel jüngeren Elisabeth von Reutem seinen ständigen Wohnsitz nahm (zuerst in Duisseldorf, dann in Frankfurt, später in Baden-Baden). Ëllis geht ausfuihrlich auf Žukovskijs Ehe ein.

${ }^{39}$ Diese wohl doch übertriebene, hohe Bewertung des "Ahasver" wird zumindest teilweise durch die Zukovskij-Forschung bestatigt: Bereıts Fürst Vjazemskij hielt "Ahasver" für das "beste Gedicht unter Joukoffsky's Werken. ja vielleicht der ganzen russischen Poesie" (C.v. Seidlitz: Wasily Andrejewitsch Joukoffsky, a.a.O.. S. 230; vgl. auch A.N. Veselovskij: V.A. Žukovskij. S.-Peterburg 1904, S. 451457): auch in vielen Literaturgeschichten neueren Datums wird dieses Werk als besonders künstlerische. wertvolle Arbeit hervorgehoben (vgl. etwa W. Düwel, H. Grasshoff [Hrsg.]: Geschichte der nussischen Literatur, Band 1, a.a.O., S. 267: V. Terras: A History of Russian Literature, a.a.O.. S. 197. 200); in einigen literaturgeschichtlichen Gesamtdarstellungen Zukovskijs wird es allerdings gar nicht erwähnt (z.B. bei D.S. Mirsky: A History of Russian Literature, a.a.O., und Ch.A. Moser [Ed.]: The Cambridge History of Russian Literature, a.a.O.).

40 Dieser Begriff zieht sich wie eine Ant Leitmotiv sowohl durch Ellis' erste als auch durch seine zweite Schaffensperiode

${ }^{41}$ L. Kobilinski-Ellis: W.A. Joukowski, a.a.O.. S. 315

Bereits 1930 harte Ëllis einen Teil aus dem letzten Kapitel seines Manuskripts über Žukovskijs "Ahasver" in der Monatsschrifi "West-östlicher Weg" veröffentlicht unter dem Titel: "Der Schwanengesang des ersten russischen Romantikers (Über W. Jonkowskijs [!] christliche Epopoë «Ahasver»)" (in: West-östlicher Weg. III, Mainz-Glogau, 1930, S. 247-257).

42 Nr. 32, 10. Jahrgang. 5. Mai 1928, S. 663f.

43 Žukovskij hat die deutsche Romantik jedoch ohne ihre spezifisch philosophische erkenntnistheoretische poetologische Reflektientheit (im Sinne der Brüder Schlegel, Eichendorffs, Novalis', Tiecks u.a.) nach RuBland vermittelt. (Vgl. auch D. Tschižewskij IRussische Literaturgeschichte des 19. Jahr hunderts, I. a.a.O.. S. 34), der darauf hinweist, daB sich die russischen Romantiker zuerst stilistische Aufgaben stellten und erst in zweiter Linie um die ideologischen Probleme sorgten.)

44 Das neue Reich. a.a.O.. S. 664.

Zum groben EinfluB Žukovskijs auf die nachfolgenden Dichtergenerationen vgl. auch D. Tschižw skij: Russische Literaturgeschichte des 19. Jahrhunderts, I. S. 38. 
Ėllis vermittelt dem deutschsprachigen Leser in seinem Žukovskij-Buch eine Menge wertvoller und richtiger Erkenntnisse über Leben und Werk Žukovskijs und die Rolle, die dieser für die Entwicklung der russischen Literatur gespielt hat. In seiner Monographie schafft er auf die ihm eigene Weise in einem mitunter recht preisenden Tonfall und unter Verwendung vieler Superlative ein ideales Bild von Žukovskij als harmonischem, edlen Menschen und vielseitig begabtem, tiefsinnigen Künstler, das von Žukovskijs Zeitgenossen, vor allem auch seinen deutschen Freunden, bestätigt wird ${ }^{45}$ sowie auch in den Darstellungen Žukovskijs in Literaturgeschichten und Monographien vorherrscht. Gegenüber dieser einheitlichen Darstellung Žukovskijs sind jedoch in der Forschung mitunter Vorbehalte und Zweifel geäußert worden, die nicht völlig ignorient werden dürfen ${ }^{46}$.

Ėllis ist, was die Žukovskij-Sekundärliteratur betrifft, nicht auf dem Stand seiner Zeit. 1933 gab es bereits deutschsprachige Publikationen über Žukovskij47; in RuBland waren zu Beginn dieses Jahrhunderts zahlseiche Arbeiten über ihn erschienen ${ }^{48}$. Seine empfindsam romantische Lyrik wirkte anregend auf die ersten lyrischen Versuche vieler russischer Symbolisten, zum Beispiel auf Bal'mont und vor allem auf Blok ${ }^{49}$, die sich in ihren theoretischen Arbeiten häufig über Žukovskij und sein Werk äußerten.

Bedauerlich ist, daB Ellis in seiner umfangreichen Untersuchung nur am Rande auf Zukovskijs Sprache und Stil sowie die formale Seite seiner lyrischen Werke eingeht. Insgesamt hat er jedoch eine zutreffende (wenn auch religiös übergewichtete) Darstellung Žukovskijs geboten und bereits 1933 auf dessen große Bedeutung hingewiesen, die zum Teil erst heute (und in manchen Literaturgeschichten noch gar nicht) erkannt und gewürdigt wird. In diesem Zusammenhang ist Ellis' Hinweis auf das lange Andauem der russischen romantischen Bewegung von Interesse ${ }^{50}$, die ja bekanntlich nicht mehr vollständig vom aufkommenden Realismus verdrängt werden konnte, über die späten Romantiker (Fet, Tjutčev, Majkov, Polonskij etc.) bis hin zur Lyrik Vl. Solov'evs reichte und zumindest teilweise noch in den Werken der russischen Symbolisten anklingt (z.B. in den frühen Gedichten Bal'monts oder aber in Ellis' lyrischem Werk) ${ }^{\text {s1. }}$.

$45 \mathrm{Vgl}$. D. Gerhardt: Aus deutschen Erinnerungen an Žukovskij, a.a.O.

46 Vgl. A.N. Veselovskij: V.A. Žukovskij. Poezija Cuvstva i "serdečnogo voobraženija". S. Peterburg 1904. S. Vff., 336f.: D. Gerhardt: Aus deutschen Erinnerungen an Žukovskij, a.a.O., bes. S. 282284. (In Gerhardts Arbeit wird Ėllis' Żukovskij-Monographie mehrfach erwähnt.)

$47 \mathrm{Vgl}$. oben, 1. Anmerkung dieses Kapitels.

48 Darauf weist Elllis. wie erwähnt, hin (L. Kobilinski-Ellis: W.A. Joukowski, a.a.O., S. 15; vgl. auch oben. Anmerkung 11 dieses Kapitels). Als Beispiele können angeführt werden: das genannte Werk von A. Veselovskij; N.S. Tichonravov: SoXinenija, t. 3, C. 1. Moskva 1898 ("V.A. Žukovskij"), S. 380503: Utkinskij sbornik. Pis'ma V.A. Žukovskogo. M.A. Mojer. E.A. Protasovoj. Moskva 1904 (diese Publikation nennt Ėllis als eine seiner Quellen, vgl. L. Kobilinski-Ellis: W.A. Joukowski, S. 15); 1.1 . Rezanov: Iz razyskanij o soxinenijach Zukovskogo. Vyp. 1-2. Peterturg 1906-1916.

${ }^{49} \mathrm{Zu}$ Blok und Žukovskij vgl. R.-D. Kluge: Westeuropa und RuBland im Weltbild A. Bloks, a.a.O., S. $21-24$.

$50 \mathrm{Vgl}$. oben, Zitat auf S. $204 \mathrm{f}$.

$51 \mathrm{Vgl}$. hierzu auch die "Einleitung" der vorliegenden Arbeit. S. 11-13.

Ėllis weist in seiner Monographie einige Male auf Parallelen im lyrischen Werk Žukovskijs und VI. Solov 'evs hin und betont als Verdienst Solov'evs und der russischen Symbolisten das Wiederentdecken des "goldenen Zeitalters der russischen Poesie" (vgl. L. Kobilinski-Ellis: W.A. Joukowski, a.a.O., S. 103f., 160, 194, 244). In der romantisch-religiösen Weltanschauung Žukovskijs finden sich tatsächlich viele Gedanken aus der deutschen idealistischen Philosophie Schellings bereits vorausgedacht, die der Religionsphilosoph Solov'ev später in seinem Werk reflektieren wird. ( $\mathrm{Vgl}$. hierzu die Vorlesung von R.-D. Kluge: "Klassizismus. Romantik I", Universität Tübingen. WS 1990/1991.) 


\section{E. Monographie und Arbeiten über Aleksandr Puß̌kin}

In seiner Puškin-Monographie, die den Untertitel "Der religiöse Genius Rußlands" trägt', versucht Éllis, den "religiösen Weg" Puškins zu erforschen, indem er dessen Euvre auf religiöse Elemente hin untersucht. Er möchte den Entwicklungsgang und das Reifen der tiefen, für Puškin "so charakteristischen Sehnsucht nach religiöser Wahrheit" "durch alle Perioden seines tragischen Lebens" verfolgen, da dieser "religiöse Weg" Puškins bisher am wenigsten erforscht worden sei ${ }^{2}$. Ellis weist in seiner Arbeit wiederholt darauf hin, daB Puškin zugleich Nationaldichter RuBlands und ein universaler klassischer Dichter der Weltliteratur gewesen sei, denn er habe in seinem Werk das Nationale mit dem Universalen verbunden?

Im ersten Kapitel ${ }^{4}$ charakterisien Ëllis chronologisch Puškins Leben und Werk. AnschlieBend kommt er auf Puškins "poetischen Geist" zu sprechen 5 und diskutier im dritten Kapitel "Genie und Religion bei Puschkin"6. Im letzten Kapitel untersucht er Puškins überragenden Einfluß auf die gesamte spätere russische Literatur?

Im Einleitungsteil zum ersten Kapitel schilder Ėllis die Entwicklung der russischen Kultur und Literatur von den Anfängen (Kiever Rus') bis zum "goldenen Zeitalter", das heiBt, den Gegensatz zwischen dem "heiligen" (christlich-orthodoxen) und dem "geistigen" (seit Peter dem Großen westlich orientierten, aufklärerischen) RuBland, den Puskin als nationaler und zugleich universaler Dichter in seinen Meisterwerken überwunden habe. Auch zwischendurch finden sich in Ellis' Monographie wiederholt Beschreibungen der historisch-politischen Ereignisse zu Lebzeiten Puškins.

Ėllis betont, daß Puškin als Mensch immer wieder einen tragischen Kampf gegen seine religiösen Zweifel habe führen müssen. Doch habe "sein Genie als Träger der russischen Volksseele" dabei "die wahren Inspirationen des Geistes des heiligen RuBland" erreicht ${ }^{8}$. Als bedeutsam (in diesem Zusammenhang) hebt Ėllis die Freundschaft Puškins mit Žukovskij hervor, der durch sein "religiös-poetisches Schöpfertum" großen Einfluß auf Puškin ausgeübt habe. Puškin jedoch habe sein Leben lang nicht jenen Seelenfrieden und jene innere Ausgeglichenheit gefunden, die das Wesen

I Erschienen in der "Monographienreihe Kämpfer und Gestalter", die J. David herausgegeben hat.

2 L. Kobilinski-Ellis: Alexander Puschkin, a.a.O.. S. 9.

3 Das Thema: Puskin als nationaler und internationaler Dichter erinner an Dostoevskijs Pušin-Rede (1880) und auch an das, was Vl. Solovev ("Cymb6a Пyumorka" - "Puskins Schicksal". 1897. "Oco6oe чествование Пуиикна" - "Die besondere Ehrung Puskins". 1899. "Значение поэзин в стихотворениях Пlуихина" - "Die Bedeutung der Poesie in den Gedichten Puskins", 1899) und A. Blok ("O назначении поэта" - "Über die Bestimmung des Dichters". 1921) über Puskin gesagt haben. (Vgl. hierzu auch die Ausführungen von R.-D. Kluge in seiner Puskin-Vorlesung. Universität Tübingen. SS 1992.)

4 "Die historische Gestalt" (L. Kobilinski-Ellis: Alexander Puschkin, a.a.O., S. 19-138).

5 2. Kapitel: "Der poetische Geist Puschkins" (ebd., S. 139-170).

6 Ebd.. S. 171-188.

7 4. Kapitel: "Nach Puschkin" (ebd., S. 189-196).

Am SchluB der Monographie befindet sich ein von Ėllis zusammengestellter Anhang (ebd.. S. 199227) mit "Bekenntnissen und Zeugnissen", Anmerkungen, tabellarischem Lebenslauf Puskins, einer kleinen Bibliographie, einer "Zeittafel der russischen Literatur und Geschichte zur Zeit Puschkins", einem Abbildungsverzeichnis, einem Register der behandelten Werke Puskins und einem Personenverzeichnis. Dadurch nufi diese Monographie rein äuBerlich einen wesentlich wissenschaftlicheren Eindruck hervor als Ëllis' Žukovskij-Buch, das zwar ein detailliertes Inhaltsverzeichnis, jedoch keinen An hangsteil besitzt.

${ }^{8}$ L. Kobilinski-Ellis: Alexander Puschkin, a.a.O., S. 15. Zu Ėllis' Verwendung des Terminus "Heiliges RuBland" vgl. unten. S. 221, Anm. 5. 
des "tief religiösen" Žukovskij bestimmt hätten9; bei Puškin werde alles durch seine "tragische Doppelnatur", die Ellis immer wieder betont ${ }^{10}$, bestimmt. 1824-1826 in Michajlovskoe habe der ProzeB der religiösen Vertiefung des reifenden Dichters begonnen, die ihren Höhepunkt erst während der letzten Periode seines Lebens erreicht, bis zu seinem tragischen Tode gedauert und seine besten Werke hervorgerufen habe" ${ }^{11}$. Als wichtigen Meilenstein auf Puškins religiösem Weg charakterisiert Ëllis den EinfluB P. Čaadaevs ${ }^{12}$. Puškins religiöse Erlebnisse, die er vor den Blicken der Welt verborgen habe, seien im Verlauf seines Lebens immer ernster, bewuBter und inniger geworden. Trotz seiner persönlichen Zuneigung zur östlichen Frömmigkeit habe Puškin die ganze Bedeutung und sogar manche Vorzüge des römisch-katholischen Glaubens erkannt und hervorgehoben ${ }^{13}$. Erst am Ende seines Lebens, auf seinem qualvollen Sterbebette, erreiche Puškin "die volle Klarheit und Macht seines christlichen Selbst"14. Die Tragik von Puškins Leben habe darin bestanden, daB er als Mensch "jenen erhabenen Weg der geistigen Emeuerung seines Wesens", den sein Geist verkündete (z.B. in "Der Prophet"/"Пророк"), während seines irdischen Lebensweges nicht erfüllte, sondem erst auf dem qualvollen Todeslager ${ }^{15}$. Die letzten Jahre Puškins hebt Ėllis als Blütezeit seines Schöpfertums hervor. In der Lyrik dieser Jahre erreichen, wie Ėllis meint, die religiösen Motive eine besondere Bedeutung ${ }^{16}$. Ėllis konzentrien sich vorwiegend "auf jene Verklärung und Vergeistigung des ganzen Wesens" Puškins ${ }^{17}$, das dieser angesichts des Todes erlangt habe, und schildert ausführlich Puškins letzte Tage und Stunden 18 .

Ellis sieht Puškins Leben und Werk als parallele Entwicklung:

Die intuitive Erforschung seiner Poesie der tragischen Liebe als einer tiefen Sehnsucht nach seelischer Vereinigung, wenn auch durch die Sinnesaffekte des Eros, führ unvermeidlich zu seiner Poesie des Todes, um dann im Lichte des Glaubens zu enden. Ebenso entstand auch seine

${ }^{9}$ L. Kobilinski-Ellis: Alexander Puschkin, a.a.O. S. 27-31. Ëllis fabt an dieser Stelle kurz die Ergebnisse seiner Żukovskij-Monographie zusammen: Żukovskijs zunehmende christlich-religiöse Gesinnung und seine Annäherung an die katholische Kirche.

it) Vgl. L. Kobilinski-Ellis: Alexander Puschkin, a.a.O., z.B. S. 37, 46. 53, 58, 77, 105f., 180.

11 Vgl. ebd.. S. 59.

Möglicherweise entwickelt Ėllis in seiner Monographie einen Gedanken, den er bei Vl. Solov'ev gefunden haben könnte, weiter: das religiöse BewuBtsein sei in Puskin erst später erwacht, sein christlicher Glaube habe sich allmählich immer stärker herausgebildet. (Vgl. VI. Solov'ev: Sud'ba Puskina. In: Ders.: Sobranie soxinenij. Tom IX. Brjussel' 1966. S. 33-60, hier: S. 47.)

12 Den Beziehungen zwischen Puskin und Čadaev hat Ėllis eine gesonderte Untersuchung gewidmet, die auf der Analyse des Briefwechsels dieser beiden Schriftsteller basier. (Vgl. L. Kobilinski-Ellis: A. Puschkin und P. Tschaadajew [Religionspsychologische Studie]. In: West-östlicher Weg. II. Glogau-Mainz, 1929. S. 41-52.)

13 Im "West-östlichen Weg" (1. 1928. S. 69-71) ist ein Auszug aus Puskins "Reise nach Erserum" ("Путешествие в Арзрум", 1835) in Ellis' Übersetzung abgedruckt, wobei Ėllis in seiner "Vorbemerkung" auf die grobe Bedeutung der Worte Puskins über den lebendigen. geistigen Mittelpunkt des Katholizismus hinweist (vgl. West-östlicher Weg, 1. 1928, S. 69).

14 L. Kobilinski-Ellis: Alexander Puschkin, a.a.O., S. 91.

Ėllis stüzt sich bei dieser These vorwiegend auf Aussagen aus zweiter Hand, von Freunden Puskins (P. Pletnev, A.O. Smimova, L. Sofijskij), führt aber auch Stellen aus Puskins Briefen und Werken an (ebd.. S. 91-105).

15 Ebd.. S. $108 f$.

16 Ebd.. S. $110 f$.

17 Ebd. S. 126.

18 Ebd., S. 123-138.

Schon viel früher befaBte sich Ėllis mit dem Tod Puškins. dem er eine außerordentliche Bedeutung beimaB. Er publizierte zu diesem Thema bereits 1929 eine Arbeit im "West-östlichen Weg". (Vgl. L. Kobilinski-Ellis: "Der Tod A. Puschkins". In: West-östlicher Weg, II, 1929, S. 185-196.) 
persönliche Lebenstragik: aus der unerfüllten, tragischen Sehnsucht nach wahrer Liebe auf Erden führt sie ihn in die Tragik seines grausamen und doch religiös erlösenden Todes. ${ }^{19}$

Er analysiert besonders die Werke Puškins, in denen er religiöse Elemente erkennt. Von Puškins lyrischen Werken räumt er verständlicherweise dem religiös-poetologischen Gedicht "Der Prophet" ("Пророк". 1826) einen besonderen Platz ein, zitien es vollständig. hebt es als "beste lyrische Dichtung der gesamten russischen Poesie" hervor ${ }^{20}$ und versteht es als

Folge der tiefen religiösen Krise Puschkins, seiner inneren Befreiung von der höhnischen Skepsis Voltaires und der tragisch-dämonischen Empörung Byrons. [...] [Es] bedeutete den ersten festen Schritt auf dem Wege der Rückkehr nach den Höhen des Glaubens. ${ }^{21}$

Besonders große Bedeutung mißt Ėllis auch Puškins Tragödie "Boris Godunov" (1825) bei22, die er "die erste wahre dramatische Schöpfung der russischen Literatur und das später niemals übertroffene Vorbild der russischen Dramaturgie" nennt ${ }^{23}$. Die religiöse Inspiration der russischen Volksseele selbst durchdringe, erhelle und erhebe diese Tragödie 24 . Gerade ihre volkstümliche und religiöse Grundlage sei das an sich Wichtige 25 . Den Ursprung aller Handlungen sieht Ėllis ins Jenseits verlegt: Der Chronikschreiber Pimen und das Volk seien als bewuBtes Werkzeug Gottes zu verstehen,

${ }^{19}$ L. Kobilinski-Ellis: Alexander Puschkin, a.a.O., S. 141.

DaB Puskin mitunter fröhlich und ausgelassen sein konnte und die Freuden des Lebens zu genieBen wuBte, bezeichnet Ellis als Maske, als Flucht vor Einsamkeit und Enttäuschungen (ebd., S. 148), wodurch seine Monographie der Kritik Tschižewskijs als ein Beispiel für "panegyrische biographische Darstellungen" nicht entgeht. (Vgl. D. Tschižewskij: Russische Literaturgeschichte des 19. Jahrhunderts. I, a.a.O., S. S1.)

${ }^{20}$ L. Kobilinski-Ellis: Alexander Puschkin. a.a.O., S. 73.

Dieses Werk ist tatsächlich eines der sprachgewaltigsten nussischen Gedichte überhaupt: in archaisicrend odenhaftem Stil mil Anleihen aus der Bildersprache des Alten Testaments wird die qualvolle Vorbereitung des von Golt auserwähten Propheten (= Dichters) auf scine Mission gestaltet. (Vgl. hierzu auch die Puskin-Vorlesung von R.-D. Kluge, Universität Tübingen. SS 1992.)

21 L. Kobilinski-Ellis: Alexander Puschkin. a.a.O., S. 75.

22 Ebd.. S. 60-70.

23 Ebd., S. 60.

Die Bewertung dieser Tragödie als erstes eigenständiges russisches Drama ist richtig und wird durch die Puškin-Forschung und Literaturgeschichtsschreibung bestätigt. Umstritten dagegen ist die Beurteilung des "Boris Godunov" als eines der besten Werke Puskins und der russischen Dramaturgie. Vgl. 2.B. V. Setschkareff (Alexander Puskkin. Sein Leben und sein Werk. Wiesbaden 1963. S. 151): " "Boris Godunov» gehön nicht zu den stärksten Leistungen Puskins, doch dynamische Krafi der Sprache und straffe Sicherheit der Handlungsfühung erheben ihn doch zu den besten unter den - allerdings nicht zahlreichen - guten nussischen Tragödien.": dagegen A. Stender-Petersen (Geschichte der russischen Literatur, Teil II, a.a.O.. S. 118): "Die Tragödie Boris Godunov war eins der hervorragendsten Werke Puškins"; ebd.. S. 115: "Puskin [...] schuf das erste und beste chronicle play der russischen Literatur in Shakespeares Stil"; J. Striedter (Zum Verhältnis von Geschichtsbe wuBtsein und poetischem Genre bei Puskin. In: Dargestellte Geschichte in der europäischen Literatur des 19. Jahrhunderts. Frankfurt/M. 1970. S. 108) spricht vom "bedeutendsten historischen Drama der russischen Literatur". Tatsache ist. daB dieses Drama einen radikalen Bruch mit der bisherigen Theatertradition in RuBland bedeutete, als Lesestiuck bald auBerordentliche Beliebtheit erreichte, jedoch nicht sehr bühnenwirksam war und, nicht zuletzt aus Zensurgründen, erst 1870 in gekürzter Fassung (16 Szenen) und vollständig erstmals nach der Revolution zur Aufführung gelangte. Vgl. hierzu: R. Neuhäuser: Puschkin. Boris Godunow. In: B. Zelinsky (Hrsg.|: Das russische Drama. Duisseldorf 1986. S. 51-68, 365-369; ebenfalls die Einieitung von B. Zelinsky, ebd., bes. S. 22: R.-D. Kluge: Die Komposition des "Boris Godunov". In: Serta Slavica. In memoriam Aloisi Schmaus. München 1971. S. 342-354; J. Striedter. a.a.O., hier bes. S. 83-92.)

${ }^{24}$ L. Kobilinski-Ellis: Alexander Puschkin, a.a.O., S. 61.

25 Ebd.. S. 62. 
während der falsche Mönch Grigorij von dunklen, rätselhaften Mächten zum Handeln getrieben werde 26 :

So erschuf Puskin eine gewaltige Tragödie, deren Urquellen und unsichtbare Fäden, gute und böse, von Jenseits laufen. deren Ereignisse in der geschichtlichen Wirklichkeit aus der direkten Einwirkung der himmlischen oder dunklen Mächte entstehen. Er gab einen freien Raum dem Spiele reinmenschlicher Leidenschaften und Tugenden; jedoch zeigte er, daB überall eine andere und unüberwindliche Macht und ein unfehlbarer göttlicher Wille unsichtbar wirksam sei. Diese Synthese zwischen einem neuen Drama der individuellen Charaktere im Sinne Shakespeares und einer mystischen Tragödie im Sinne der göttlichen Vorsehung (wie in der uralten sakralen Dramaturgie Indiens und Griechenlands oder in den Dramen Calderons), erhebt "Boris Godunov" Puschkins zu den gröBten Werken aller Zeiten und zum Vorbild religiösvolkstümlicher Tragödie der Zukunft. ${ }^{27}$

Ėllis hat hier einen zentralen Aspekt des "Boris Godunov" erkannt und hervorgehoben: In dieser Tragödie geht es nicht ausschlieBlich um individuelle Charaktere (Boris, Dimitrij und andere Personen), sondem das Volk als aktive, geschichtsbewegende Kraft, die die sittliche Weltordnung überwacht, tritt als wichtige handelnde Figur auf. Es führt als Medium Gottes unbewubt, spontan, einem gemeinsamen inneren dunklen Drange folgend, Gottes Willen aus, stellt als instrumentum dei die göttliche oder gottgewollte sittliche Weltordnung wieder her. So verstanden gerät die Geschichte zur Theodizee 28 . Ellis geht in seiner Interpretation sogar so weit, daB er den ermordeten Zarewitsch Dimitrij als den eigentlichen tragischen Helden bezeichnet, als heiligen engelgleichen Märtyrer ${ }^{29}$, der "als eine übernatürliche, unerforschliche und unbesiegbare Jenseitsmacht, seine beiden Widersacher, den Mörder Boris und den Usurpator (Pseudo-Dimitrij), vernichtet"30.

Auch Puškins sogenannten "kleinen Tragödien" spricht Ėllis große Bedeutung zu:

Diese vollkommenen Werke bieten eine freie Entfaltung der menschlichen Charaktere im Stile Shakespeares. Zugleich stellen sie die jenseitigen, überirdischen Mächte, nach Art der alten religiösen Tragödien und Mysterienspiele, als die entscheidenden Wirkursachen dar. ${ }^{31}$

Bei seiner Erörterung von Puškins Prosa weist Ėllis auf deren große Bedeutung für die spätere russische Literatur hin. Er betont, daB die "neue Art der Darstellung des Lebens der kleinen, durch die Macht dieser Welt besiegten Leute" (wie z.B. im "Sta tionsvorsteher"/"Станционный смотритель", 1830) in der klassischen russischen $\mathrm{Li}$ teratur Schule machte, vom "Mantel" Gogol's bis zu den "Armen Leuten" Dostoevskijs und den besten Erzählungen Tolstojs. Turgenevs und Čechovs ${ }^{32}$.

26 Ebd., S. 66-69.

27 Ebd.. S. 70.

In der Wochenschrift "Das neue Reich" (Nr. 24, 11. Jahrgang. 16. März 1929, S. 442-444) findet sich von Ellis ein Aufsatz über Puskins "Boris Godunov" mit dem Titel "Die Tragik der russischen Seele", in dem Ellis die ästhetische, formal-poetische und sprachliche Größe und Bedeutung dieser Tragödie hervorhebt und sie neben die besten Werke Shakespeares, Schillers. Hebbels und R. Wagners stellt (S. 443). Am Ende seiner Abhandlung zieht er eine Parallele zwischen der "Zeit der Wirren", in der "Boris Godunov" spielt, und der gegenwärtigen historisch-politischen Situation in RuBland bzw. der Sowjetunion (S. 444).

28 Vgl. hierzu J. Striedter: Zum Verhältnis von GeschichtsbewuBtsein und poetischem Genre bei Puskin, a.a.O., S. 85-92; R.-D. Kluge: Die Komposition des "Boris Godunov", a.a.O., bes. S. 344f., 351-353 sowie seine Puskkin-Vorlesung. Universität Tübingen, SS 1992.

29 Vgl. L. Kobilinski-Ellis: Alexander Puschkin, a.a.O., S. 62f.

${ }^{30}$ Ebd. S. 166.

31 Ebd., S. 89 .

32 Ebd., S. 101.

D. Tschižewskij (Russische Literaturgeschichte des 19. Jahrhunderts, I, a.a.O., S. 67) sieht in den "Повести покоһного Ивана Петровича Белхнна" ("Erzählungen des verstorbenen Ivan Petrovi 
Puškins unzweifelhaft bestes Prosawerk sei "Die Hauptmannstochter" ("Kamurahская дочка", 1836) als "vollendetste Darstellung des Wesens der russischen Volksseele, der Vaterlandsliebe und der Kirchentreue in einem einzigen Geschehen" 33. Diesem Werk sei eine "volkstümlich religiöse Grundlage" eigen, Maša habe sich ganz dem Willen Gottes ergeben und auch die anderen Figuren dieses Romans seien "wahrhaft russisch, vollkommen volkstümlich", was soviel wie fromm und gottergeben bedeute ${ }^{34}$. Ellis unterstreicht die Bedeutung dieses Werk als "Vorbild des späteren nussischen «psychologischen» und zugleich auch historischen Romans" 35 .

Auch den "Evgenij Onegin" (1823-1830) hebt Ėllis als bedeutendes Werk Puškins hervor und zählt die lyrischen Exkurse dieses Versromans zu dessen besten lyrischen Schöpfungen ${ }^{36}$.

Durch seine Meisterwerke "Evgenij Onegin" und "Die Hauptmannstochter" sei Puškin zum Umeber des "psychologischen Romans" in RuBland geworden ${ }^{37}$ :

Es ist doch unzweifelhaft, daB der erste jener Reihe trauriger, entwurzelter, volklich wie seelisch ungehaltener "Helden" Ewgenij Onegin ist; - ihm folgen Lermontows Petschorin. Dostojewskis Stawrogin. Turgenjews Rudin, ein Wronski L. Tolstojs und die Dämmergestalten Tschechows. Anderseits sind die "stillen" Gestalten Maschas und Tatjanas immer wieder in den russischen Meisterromanen auferstanden. ${ }^{38}$

Ėllis hat in dieser Charakteristik die Gestalt des Evgenij Onegin als erste Verkörperung des sogenannten "überflüssigen Menschen" ("лишний человек") hervorgehoben, der in seinen verschiedenen Spielarten in der nussischen Literatur des 19. (vgl. die von Ellis genannten Figuren, aber auch noch viele weitere) und auch in einigen Werken des 20. Jahrhunderts immer wieder auftritt ${ }^{39}$.

AbschlieBend untersucht Ellis das Geniale und das Religiöse bei Puškin 40 und kommt zu dem Ergebnis, daß man Puß̌kin keineswegs als sogenannten "religiösen Dichter" im Sinne der ausschlieBlichen oder hauptsächlichen Konzentration auf religiöse Motive (wie z.B. Dante, Milton u.a.) bezeichnen könne, da diese sich bei ihm frei und mannigfaltig mit vielen anderen vereinigten. Puškins Meisterwerke seien je-

Belkin"), zu denen "Станинонњый смотритель" ja gehör, den Beginn der Tradition der modemen russischen Kurzgeschichte.

${ }^{33}$ L. Kobilinski-Ellis: Alexander Puschkin, a.a.O., S. 120.

${ }^{34}$ Ebd., S. $121-123$.

35 Ebd.. S. 120.

A. Stender-Petersen (Geschichte der russischen Literatur. Teil II, a.a.O., S. 148) nennt "Die Hauptmannstochter" "einen der besten nussischen historischen Romane" und J. Striedter sieht in diesem "meisterhaften historischen Roman" (Zum Verhältnis von GeschichtsbewuBtsein und poetischem Genre bei Puškin. a.a.O.. S. 108) den "wichtigsten russischen 'Vorläufer' des bedeutendsten russischen Geschichtsromans: Tolstojs Krieg und Frieden" (ebd., S. 104). In der neusten Puskin-Forschung ist auf die vielen Unstimmigkeiten und Fehler bezüglich Personen. Zeitangaben und dergl. in diesem Roman hingewiesen worden, die von Pußkin bewuBt eingesetzt worden scien, damit der Leser zwischen Fiktion und historischer Wahtheit unterscheiden könne. (So Andreas Ebbinghaus in seinem Vortrag auf dem VI. Deutschen Slavistentag in Leipzig lam 7.10.1994) über das Thema: "Ebenen historischer Interpretation in Puskins *Hauptmannstochters".)

${ }^{36}$ L. Kobilinski-Ellis: Alexander Puschkin, a.a.O., S. 111.

37 Ebd., S. $194 f$.

38 Ebd.. S. 194.

${ }^{39} \mathrm{Vgl}$. hierzu auch R.-D. Kluge: Zum Wandel des Menschenbildes in der russischen Literatur des 19. und 20. Jahrhunderts (in: Festschrift fuir Wilhelm Lettenbauer zum 75. Geburtstag. Freiburg i.Br. 1982. S. 81-94, hier bes. S. 83-87), dessen Konzeption derjenigen von Ëllis ähnelt.

40 Vgl. L. Kobilinski-Ellis: Alexander Puschkin, a.a.O., S. 173-188. 
doch vorwiegend religiös, "die bedeutendsten Momente seiner besten Dichtungen of fenbaren stets sein nach der Ewigkeit gerichtetes, geistiges Antlitz"41.

Nach einem Hinweis auf den überragenden Einfluß Puškins auf die gesamte spätere russische Literatur ${ }^{42}$ beendet Ëllis seine Puškin-Monographie folgendermaßen:

Ebenso wie der größte Nationaldichter Puschkin den Geist der Universalität der russischen Literatur einpflanzte, impfte der gröBte russische Denker W. Solowjew uns den Geist der Ökumenizitä̉ ein. Das sind aber zwei Pfeiler unserer Einheit mit Westeuropa, die sicheren Grundlagen unseres eigenen Osteuropäertums. ${ }^{43}$

In dieser Aussage formuliert Ellis eine sehr eigenwillige Westlerposition, die religiös (und nicht - wie üblich - rationalistisch oder ökonomisch) begründet ist: Nur durch eine kulturelle und kirchliche Union mit Westeuropa könne sich ein eigenständiges Osteuropäertum herausbilden.

In der in Zürich herausgegebenen "Weltwoche" vom 25. März 1949 erschien eine Rezension, die Ëllis' Puškin-Monographie angemessen kritisch beurteilt; in ihr heißt es u.a.:

Puschkins köstliche Unverdorbenheit hat der vor einem Jahr in Locamo verstorbene russische Literaturhistoriker Leo Kobilinski mit einer besonderen Religiosität des Dichters in Zusammenhang bringen wollen (Oto Walter-Verlag. Olten). Er tut dies sehr behutsam und grenzt seine These sorgfaltig ein. Er gibt zu, daB die "religiöse Natur des Menschen Puschkin in ihrer vollen Tiefe erst auf dem Sterbebette, nicht während seines Lebens" sich offenbart habe, und er meint, daB nur in einem sehr bestimmten Sinne Puschkin als religiöser Dichter angesprochen werden könne: "Auf den höchsten Höhen des Schöpfenums Puschkins finden sich wahrhaftig stets Genialität und Religiosität". Und dies trifft zu, wenn auch die Formulierung nicht glücklich ist. [...]

Kobilinskis Buch über Puschkin gibt uns, in guten bis mäBigen Übersetzungen, viele Proben von Puschkins Versdichtung, die zwar im Interesse seiner These etwas einseitig ausgewählt wurden, aber doch einen gewissen Einblick in Puschkins Poeterei gewăhren. Man darf es als ein gutgemeintes, interessantes Buch kennzeichnen.

R.J. Humm $m^{4}$

Ėllis' Monographie und auch seine Aufsätze über Puškin müssen insgesamt als recht einseitig beurteilt werden, da er die religiösen Elemente, die sich zweifellos in Puškins CEuvre finden lassen ${ }^{45}$, überbewertet und dafür die formalen Kriterien (Struktur, Komposition, Sprache, Stil etc.) uberhaupt nicht beachtet. Er weist zwar auf viele wichtige Aspekte in Puškins Werken hin, bei seinen Interpretationen handelt es sich jedoch mitunter eindeutig um "Verzeichnungen". So beispielsweise bei "Boris Godu-

41 Ebd., S. 183.

42 Ebd., S. 191 ff. In diesem Zusammenhang bezeichnet Ëllis - in Übereinstimmung mit A. Stender Petersen (Geschichte der russischen Literatur, Teil Il, a.a.O., S. 89ff.) - Puskins jüngere Zeitgenossen (Del'vig, Baratynskij, Jazykov, Venevitinov, Kozlov u.a.) als "Puschkin-Plejade" (L. Kobilinski-Ellis: Alexander Puschkin, a.a.O.. S. 191), ein Begriff, der äuBerst bedenklich ist: Puskin hat keine eigentliche Schule gebildet; er hatte zwar viele Freunde und Nachahmer des einen oder anderen Stilzuges seiner Werke, aber keine eigentlichen Fortsetzer. Sein Werk muB als Gipfel, als unübertroffener Höhepunkt im literarischen ProzeB bewertet werden. (Vgl. hierzu D. Tschižewskij: Russische Literaturgeschichte, a.a.O., Band I, S. 72 und die Pußkin-Vorlesung von R.-D. Kluge. Universität Tübingen. SS 1992.)

${ }^{43}$ L. Kobilinski-Ellis: Alexander Puschkin, a.a.O.. S. 196.

44 Die Weltwoche, Zürich, 17.1949, 25. März 1949, S. 5.

$45 \mathrm{Vgl}$. hierzu z.B. A. Stender-Petersen (Geschichte der nussischen Literatur, Teil II, a.a.O., S. 144), der hervorhebt, dab es einige Gedichte von Puskin gibt, "die so sakral wirken, als wären sie in Verse umgeformte Gebete oder Glaubensbekenntnisse".

VI. Solov'ev fütrt in seiner Arbeit "Значенне поэзни в стнхотворевнях Пушкина" (in: Ders.: Sobranie soxinenij. Tom IX. Brjussel' 1966, S. 294-347, hier: S. 296-300) den Gedanken aus, daB man bei Pułkin jede beliebige Tendenz finden könne, wenn man nur einen entsprechenden Teil seines Werks aus dem Zusammenhang herausnimmt, darunter auch die religiöse. 
nov": Der Theodizee-Gedanke ist zwar in dieser Tragödie enthalten, doch ist es kaum möglich, den religiösen Gehalt, wie Ellis ihn herausarbeitet, nachzuvollziehen. Ëllis geht bei seiner Analyse des "Boris Godunov" überhaupt nicht auf die rein literarische Seite dieses Werks ein, auf die Strukturprobleme und Mängel, die Puškin selbst teil weise eingesehen hat. Dieses Drama wurde von den meisten zeitgenössischen Kritikem abgelehnt und ist bis heute auf der Bühne kein Erfolg. Die mangelnde Bühnenwirksamkeit wird wohl vor allem durch die Komposition der Tragödie bedingt: Es gibt zwar eine steigende Handlung im klassischen Sinne, jedoch fehlt der Höhepunkt: eine Konfrontation der Protagonisten findet nicht statt, Boris und Dimitrij treffen nie direkt zusammen. Puškins Vorstellung, daB die handelnden Personen von einer höheren, göttlichen Macht gelenkt werden, verlieh der Dichtung zwar gedankliche Tiefe und Problematik, jedoch keinen Theatererfolg. (Puškins "kleine Tragödien" waren wesentlich bühnenwirksamer) ${ }^{46}$.

Ėllis hat jedoch die große Bedeutung von Puškins "Evgenij Onegin" und seiner Prosa für die Entwicklung der russischen Prosagattungen im 19. Jahrhundert, vor allem auch für die Entwicklung des russischen Romans, erkannt und hervorgehoben.

Da aber Puskin und sein Werk 1948, als Ėllis' Monographie erschien, nicht nur in RuBland, sondem auch in Westeuropa und Deutschland bereits recht gut erforscht und bekannt waren ${ }^{47}$, muB Ėllis' einseitiger Interpretation von Puškin als "religiösem Genius RuBlands" innerhalb der Puškin-Forschung insgesamt geringere Bedeutung beigemessen werden als seiner Monographie über Leben und Werk Žukovskijs innerhalb der (deutschen) Żukovskij-Forschung. Als Gegenposition zu einseitig formali stisch-ästhetisierenden Puškin-Deutungen kann Ėllis' Beschäftigung mit Puškin jedoch bis heute Interesse erwecken.

${ }^{46} \mathrm{Vgl}$. hierzu J. Striedter: Zum Verhältnis von GeschichtsbewuBtsein und poetischem Genre bei Puskin. a.a.O., S. 83-92: R.-D. Kluge: Die Komposition des "Boris Godunov", a.a.O., und seine Pus kin-Vorlesung. Universität Tübingen. SS 1992; R. Neuhäuser: Puschkin. Boris Godunow, a a.O.

47 In deutschsprachigen "Russischen Literaturgeschichten" wurde Puškin ausführlich behandelt, z.B. in: A. Brückner: Geschichte der russischen Litteratur (Leipzig 21909) oder in: A. Luther: Geschichte der Russischen Literatur (Leipzig 1924). Als Beispiele früher a) westeuropäischer und b) deutschsprachiger Monographien und Arbeiten über Puskins Leben und Werk seien genannt: a) D. Mirsky: Pushkin. London/New York 1926; M. Hofmann: Pouchkine. Paris 1931: Pouchkine 1799-1837. Revue de liuerature comparke 16 (1937); E.J. Simmons: Pushkin. Cambridge/Mass. 1937: H. Troyat: Pouchkine. Paris 1946; b) D. Mereschkowski: Puschkin. In: Ders.: Ewige Gefährten. München 1915; H.v. Heiseler: A.S. Puschkin als dramatischer Dichter. München 1935: D. Tschiževskij: Pułkin und die Romantik. In: Germanoslavica V (1937), 1-2; eine deutsche Kurzfassung von V. Żirmunskijs Arbeit "Puschkin und Byron" erschien bereits 1926 (3) und 1927 (4) in der Zeitschrifi für Slavische Philologie. Zur Puskin-Re zeption in Deutschland vgl.: H. Raab: Die Lyrik Puskins in Deutschland (1820-1870). Berlin 1964, bes. auch Raabs Einleitung: "Die Rezeption Puskins in Deutschland und ihre Problematik" (ebd., S. 7-15). Vor allem in den Jubiläumsjahren Puskins (1899 und 1937) waren u.a. auch in Deutschland zahlreiche Arbeiten über den groben nussischen Dichter publizien worden. Der bedeutende Jubiläumsband: Solange Dichter leben. Puschkin-Studien. Zum 150. Geburtstag des Dichters. (Hrsgg. v. A. Luther). Krefeld 1949 sowie weitere wichtige Publikationen zu Puskins Leben und Werk erschienen allerdings erst nach der Veröffendichung von Ellis' Monographie. 


\section{F. Sonstige Arbeiten}

\section{a. Aufsätze über Nikolaj Gogol'}

Auch in seiner zweiten Lebenshälfte befaßte sich Ëllis wieder mit Gogol's Leben und Werk: Er schrieb ein Nachwort zur deutschen Übersetzung von Gogol's "Betrachtun gen über die göttliche Liturgie" mit dem Titel: "Die Macht des Weinens und des Lachens. Zur Seelengeschichte Nikolaus Gogols"1. Ellis bezeichnet darin Gogol' als den "bedeutendsten Vertreter der klassischen Periode ${ }^{2}$ der russischen Literatur" und nennt ihn eine "der originellsten Persönlichkeiten seiner Zeit"3. Gogol' sei einer der größten Realisten und zugleich einer der "grenzenlosesten" Phantasten gewesen. Gemäß der Art des "Lachens" bei Gogol' charakterisient Ëllis dessen Lebensgang und künstlerische Entwicklung in drei aufeinanderfolgenden Perioden als Übergang vom Urbild zum Abbild (heiteres, reinigendes, echt menschliches Lachen) und weiter zum Zerrbild (tragisches, furchtbares, dämonisches Lachen). Der Geist Gogol's trenne sich allmählich immer mehr von seiner Seele und entfalte sein eigenes, selbständiges Leben, während das seelische Leben verkümmere und sein physisch-leibliches Leben sich in eine lange, beispiellose Agonie verwandele (damit meint Ëllis Gogol's schrecklichen Todeskampf). Das Lachen werde zum Weinen des Menschen Gogol' über den zauberisch lachenden Künstler Gogol' (als er im Februar 1852 zum zweiten Mal den zweiten Teil der "Toten Seelen" verbrannte). Eine lebenslange und sein ganzes Wesen verzehrende Sehnsucht nach der christlichen "ars sacra", die keine angemessene künstlerische Erfüllung finden konnte, mache den Kern seiner persönlichen Tragödie aus; aus ihr komme die Verurteilung seines eigenen Künstlertums ${ }^{4}$. Nur in zwei Werken offenbare sich der religiöse Gogol': Im "Ausgewählten Briefwechsel mit Freunden" ("Выбранные места из переписки с друзьями", 1847) zeige sich das dritte, geistige Antlitz Gogol's, nicht sein lachendes oder weinendes, sondern sein betendes Antlitz und aus seiner letzten und reifsten religiösen Schrift "Die Betrachtungen über die göttliche Liturgie" ("Размышления о Божественной литургии". 1845 in Paris begonnen) schaue das geistige Antlitz des betenden Gogol' ganz deutlich und ruhig hervor, weil hier sein Geist mit dem Geiste der Kirche völlig einig sei 5 .

Ėllis' Beschäftigung mit Gogol' war - ungeachtet der damals schon recht großen Anzahl deutscher und ins Deutsche übersetzter Arbeiten über Gogol's Leben und Werk ${ }^{6}$ - von Interesse und Bedeutung für den deutschsprachigen Leser, vor allem seine Ausführungen über die tragische Diskrepanz zwischen Gogol' als religiösem Menschen und als Künstler. Diese Ausführungen erlauben es, Ellis' Arbeit in eine be-

I In: N. Gogol: Betrachtungen über die göttliche Liturgie. Freiburg 1938, S. 80-100.

2 Diesen Terminus verwendet Ëllis nicht im Sinne von Klassizismus, sondem von "Klassiker der russischen Literatur" und meint damit die nussische Literatur des 19. Jahthunderts; er gebraucht das Adjektiv "klassisch" also als Gegensatz zu "zeitgenössisch", "neu", "modem".

${ }^{3}$ L. Kobilinski-Ellis: Die Macht des Weinens und des Lachens, a.a.O., S. 80.

4 Ebd., S. 87.

S Ebd., S. 99 f.

Ein kürzerer Artikel über Gogol' mit fast dem gleichen Titel und entsprechendem Inhalt wie dieses Nachwort wurde von Ëllis 1937 in den "Schildgenossen" publizient (vgl. L. Kobilinski-Ellis: Die Macht des Lachens und des Weinens. Zur Seelengeschichte N. Gogols. In: Die Schildgenossen. Heft 6, 1937. S. 477-482).

6 Z.B. D. Merežkovskijs Arbeit "Gogol - sein Werk, sein Leben und seine Religion" war bereits 1914 auf Deutsch erschienen: A. Stender-Petersen und V. Zen'kovskij publizienten in den zwanziger und dreiBiger Jahren eine Reihe Arbeiten über Gogol'. Für weitere deutsche Gogol'-Sekundärliteratur vgl.: Gogol. A Bibliography. Compiled and edited by Philip E. Frantz. Ann Arbor 1989, S. 255-258. 
stimmte Diskussionstradition innerhalb der Gogol'-Forschung einzuordnen, die hervorhebt. daB man Gogol' nur dann richtig verstehen könne, wenn man ihn als reli giösen Menschen emst nehme, und folglich vorwiegend religiöse und weltanschauliche Motive bei Gogol' untersucht?.

Gogol', der eine religiöse Kunstauffassung vertrat ${ }^{8}$, strebte vergebens nach der Harmonie des Schönen, Wahren und Guten. Seine frühromantische Idealvorstellung zerbrach endgültig in den "Petersburger Erzählungen", woraufhin er sich zunehmend in einen asketischen Mystizismus hineinsteigerte, der ihn letztendlich in eine Art freiwilligen Tod trieb. Es gelang ihm nicht, die Grundanliegen seines religiösen Weltbilds in seinen künstlerischen Werken befriedigend zu gestalten, was ihn immer mehr enttäuschte und seine eigene Künstlerexistenz verwerfen lieB. Wäre es Gogol' gelungen, in seinen Werken die Diskrepanz zwischen dem Schönen und dem Wahren/Guten zu überwinden (im Sinne der Kalokagathie), dann wäre er als religiöser Mensch und Autor des "Ausgewählten Briefwechsels mit Freunden" und der "Betrachtungen über die göttliche Liturgie" so hervorgetreten, wie Ėllis ihn in seinen Arbeiten charakterisiert hat.

7 Dieser Ansatz in der Gogol'-Forschung steht in krassem Kontrast zur sowjetischen Gogol'Diskussion und wurde vor allem von russischen Emigranten verfolgt, vgl. z.B. die Arbeiten von V. Zenkovskij: Gogol als Denker (in: Zeitschrift für Slavische Philologie. IX, 1932. S. 104-130); Ders.: Die ästhetische Utopie Gogols (in: Zeitschrift für Slavische Philologie, XIII. 1936, S. 1-34); Ders.: N.V. Gogol' (Pariz |1961)); Ders.: Istorija russkoj filosofii. Tom 1. Cast' 1 (Leningrad 1991 [1. Auflage: Paris 1948], S. 186-194); K. MoXul'skij: Duchovnyj put' Gogolja. Paris 1934: D. Tschižewskij: Gogol'Studien. I. Der unbekannte Gogol', II. Gogol': Artist and Thinker, Ill. Zur Komposition von Gogol's "Mantel" (in: U. Busch u.a.: Gogol' - Turgenev - Dostoevskij - Tolstoj. München 1966. S. 57-126); P. Evdokimov: Der Abstieg in die Hölle. Gogol und Dostojewskij (Salzburg 1965, S. 11-165). Der Diskrepanz zwischen Gogol' als religiösem Menschen und als Künstler sowie der Erforschung religiöser und weltanschaulicher Motive in seinem Werk sind auch in neuerer Zeit Untersuchungen gewidmet worden. vgl. etwa H. Schreier: Gogol's religiöses Weltbild und sein literarisches Werk. Zur Antagonie zwischen Kunst und Tendenz (München 1977) und L. Amberg: Kirche, Liturgie und Frömmigkeit im Schaffen N.V. Gogol's (Bem (u.a.| 1986). In dieser letzten Arbeit wird Ėllis' "Nachwort" im Literatur verzeichnis genannt.

${ }^{8}$ Hierin konnte er sich durch die deutsche Romantik (z.B. Wackenroder) bestätigt fühlen. 


\section{b. Beiträge zur russischen Kulturgeschichte}

$\mathrm{Zu}$ erwähnen bleiben abschließend noch Ëllis' Arbeiten, in denen es allgemein um (alt)russische Literatur und Kultur geht.

Neben seiner Beschäftigung mit der russischen Romantik und dem Werk und der Lehre Vl. Solov'evs befaBte sich Ėllis mit der altrussischen religiösen "Heldenepik" und widmete diesem Thema eine Reihe von Beiträgen im "West-östlichen Weg"1. In den altrussischen Epen und Sagen ertöne die wahre Stimme der russischen Volksseele. Unter den verschiedenen Formen unterscheidet Ellis: 1. die Bylinen, die er als "lebendige Geschichtsschreibung des Volkes selbst" definiert ${ }^{2}$, 2. die Märchen, 3. geschichtliche, zeremonielle und das Volksleben betreffende Gesänge (damit meint er wahrscheinlich "stariny") und 4. geistliche Dichtungen ${ }^{3}$. Er geht vorwiegend auf die russischen Bylinen ein, die in den Bereich der Folklore gehören, allenfalls als gesunkenes Kulturgut bezeichnet werden können, als "Heldenlieder mit epischem Charakter" ("героические песни эпического характера")4, und nicht - wie Ellis es tut - als "altrussische Heldenepik"! Die Bylinen des "Kiewer Kreises", die die erste Epoche des russischen Christentums darstellen (zur Zeit des Fürsten Vladimir des Heiligen von Kiev), betrachtet Ėllis als religiös-poetische Urquelle der russischen volksepischen Schöpfung und miBt ihnen besondere Bedeutung bei, da sie als die Stimme der russischen Volksseele des "heiligen RuBland" angesehen werden können ${ }^{5}$. Er versucht, in seinen Beiträgen einige der bedeutendsten Gestalten und Ereignisse des alt russischen "Bylinenepos" zu deuten und den tiefen, mystischen, verborgen-symbolischen, geistigen Gehalt der Bylinen (vor allem aus der Zeit der Kiever Rus') zu erforschen, der sich nur im Lichte der Weisheit enthüllen könne ${ }^{6}$. In den Bylinen sieht er "das bedeutendste religiös-epische Denkmal des altchristlichen RuBland", eine Verbindung heidnischer (vorchristlicher) und christlicher Weisheitstraditionen, westlicher (urchristlich universeller) und östlicher Weisheitsüberlieferungen?. Er charakterisiert die wichtigsten Bylinenhelden der Kiever und Novgoroder Zeit (Il'ja Muromec, Dobrynja Nikitič, Aleša Popovič, Mikula Seljaninoviž, Svjatogor, Sadko, Vas'ka Buslaev u.a.). Der wesentliche Unterschied zwischen den Bylinen von Novgorod und Kiev bestehe darin, daB in den Taten der Kiever Helden das Element der überirdischen geistigen Weisheit noch deutlich zum Ausdruck komme, während die Novgoroder Helden vor allem persönliche Kraft und Kühnheit zeigten. AbschlieBend schilder Ė-

I Vgl. L. Kobilinski-Ellis: Von dem altrussischen religiösen Epos (Russische Epen und Sagen. Versuch einer kurzen Charakteristik). In: West-östlicher Weg, II, 1929, S. 248-261 und L. Kobilinski-Ellis: Über die altrussische Heldenepik: Zweite Studie. In: West-östlicher Weg, III, 1930, S. 121-127 (Teil I), S. 163-171 (Teil 11), S. 217-225 (SchluB).

2 West-östlicher Weg, II, 1929, S. 251.

$3 \mathrm{Vgl}$. ebd., S. 251-253.

$4 \mathrm{Vgl}$. hierzu den Artikel "Бbutublo" in: Literatumyj ènciklopediceskij slovar'. Moskva 1987, S. 59f.

5 Als "heiliges RuBland" bezeichnet Ėllis das alte christlich-orthodoxe RuBland (vor allem die Kiever Rus' seit der Christianisierung und in der Folge das RuBland der Moskauer Periode), obwohl der Terminus "Heiliges RuBland" expressis verbis erst seit dem 16. Jahthunden verwendet worden war (vgl. oben. S. 186. Anmerkung 11). Ellis' Gebrauch dieses Terminus entspricht somit demjenigen D. Tschi Zewskijs in der ersten Auflage seiner "Russischen Geistesgeschichte", deren erster Band folgenden Titel trägt: "Das heilige RuBland: 10.-17. Jahrhundert" (Hamburg 1959). Auffällig ist die Kleinschreibung dieses Begriffs bei Ėllis, die in den folgenden Ausführungen, in denen es ja um Ëllis' Arbeiten geht, beibehalten wurde, gegenüber der üblichen GroBschreibung: "Heiliges RuBland" als Eigenname verstanden (im Sinne der auf $S$. 186. Anmerkung 11 dargelegten Bedeutung).

6 Vgl. West-östlicher Weg. III, 1930, S. 121-127, 163-171, 217-225.

7 Vgl. ebd.. S. 123-127. 
lis seine persönlichen Eindrücke über den Bylinengesang, den er als 14jähriger Schüler im Gymnasium erlebte, und sieht in diesem Gesang eine Verkündigung des Geistes der christlichen, gottmenschlichen Weisheit und der Idee der kirchlichen Ökumenizität ${ }^{8}$.

Zu Ėllis' Beschäftigung mit religiösen, kulturphilosophischen und mystischen Themen gehört eine umfassende Abhandlung über "Das «heilige RuBland», sein Wesen und seine Sendung innerhalb der ökumenischen Kirche Christi"9. In dieser Arbeit hebt Ellis seine Gegenwan wieder als "Zeit der großen Weltkrise" hervor, die "welt historische Katastrophe unserer Zeitwende" könne nur durch eine Verbindung des westlichen und östlichen christlichen Glaubens "im Sinne der wahren kirchlichen Ökumenizität" überwunden werden ${ }^{10}$. Als Voraussetzung dafür müsse das wahre Wesen des "heiligen RuBland" erfaBt und verstanden werden, wie es die groBen russischen Heiligen, vor allem der heilige Serafim von Sarov, repräsentieren:

\begin{abstract}
Das "heilige RuBland" in diesem eigentlichen und wesentlichen Sinne ist ein mystisches, pneuma tisches Erlebnis, keine bloB empirische Wirklichkeit und keine bloB gedachte Abstraktion ("russische Idee". "christlich-östliches Prinzip" oder "östliches Christentum als bloße Lehre und Tradition"), obwohl all diese abstrakten Definitionen eine relative Hilfebedeutung besitzen können.

Jede wahre Definition des Wesens des "heiligen Rubland" muB also das pneumatische Erlebnis seines wahren Wesens sein, d.h. vorzugsweise eine direkte und mystische Erkenntnis der jenseitigen Sendung des "heiligen RuBland" und ihrer Erfüllung in diesseitiger Wirklichkeit. [...] Das "heilige Rußland" ist also die russische Volksseele selbst, die seine Erwählung zur östlichchristlichen Sendung der Verkündigung der Weisheit auf dem Boden der kirchlichen Ökumenizität erfüllt hat."
\end{abstract}

In diesem Zusammenhang behandelt Ėllis ausführlich die "Weisheitssendung des christlichen Ostens", die in der vorchristlichen Zeitepoche durch die Religion des Brahmanismus sowie die Kultur- und Religionskämpfe in Altindien, Babylonien. Persien, Ägypten und Israel vorbereitet worden sei: den Streit zwischen Religion und Magie. SchlieBlich habe die göttliche Weisheit (Logos) durch den christlichen Glau ben gesiegt ${ }^{12}$. Der Berg Athos sei das Vorbild des russisch-orthodoxen Mönchtums, des Asketentums des "heiligen RuBland" 13. Recht ausführlich schilden Ëllis die Entwicklung des christlich-orthodoxen RuBland und seiner Kunst und Kultur, beginnend mit der Taufe Vladimirs des Heiligen, betont hierbei die zunächst noch enge Verbindung zwischen Kiev und Rom, zwischen östlichem und westlichem Christentum ${ }^{14}$, und geht auf das Tatarenjoch ein. das jedoch das innere geistige Leben und den christlichen Glauben des russischen Volkes nicht zu vernichten vermochte ${ }^{15}$. Erst der Aufstieg des neuen politischen Zentrums Moskau habe eine "fatale, innere Spaltung

\footnotetext{
* Vgl. ebd., S. 223-225.

9 In: Theologie der Zeit. 2, Wien. 1937, S. 57-86.

10 Ebd.. S. $57 f$.

11 Ebd. S. 60.

$12 \mathrm{Vgl}$. ebd.. S. $60-63$.

$13 \mathrm{Vgl}$. ebd.. S. $65 f$.

14 Zur Zeit der Taufe Vladimirs des Heiligen und der Kiever Rus' hätten rege Kontakte zwischen Kiev und Rom bestanden (Austausch von Gesandten. Pilgerreisen, fürstiche Ehen zwischen russischen und westlichen Christen etc.). die erst durch das Tatarenjoch unterbrochen worden seien (ebd., S. 6668). Vgl. zu diesem Thema auch: Immo Eberl: Das erste russische Herrscherhaus - Vorfahren des christlichen Europa. Die Verwandtschaftsbeziehungen der Rurikiden zum Bereich der lateinischen Kirche vom 10.-13. Jahrhundern. In: R.-D. Kluge. H. Setzer (Hrsg.): Tausend Jahre russische Kirche. a.a.O., S. 11-21. Die Verbindung der Kiever Rus' zum lateinischen Westen (Rom) war jedoch nicht ganz so intensiv, wie von Ellis (und anderen katholischen Historikem) dargestellt.

$15 \mathrm{Vgl}$. Theologie der Zeit. 2, 1937, S 66ff.
} 
der russischen Volksseele" hervorgerufen: "Mit Moskau-RuBland brach ab sowohl die kirchlich-ökumenische wie auch die politisch-europäische Einheit des kijewschen RuBland (im Sinne der Respublica christiana)." 16 Die Herrschaft Ivans des Schrecklichen bezeichnet Ëllis als "das innere tatarische Joch" 17. Das "heilige RuBland" habe zwar im orthodoxen Mönch- und Asketentum weitergelebt, doch habe sich im Laufe der Zeit die Spaltung zwischen dem "heiligen RuBland" der heldenmütigen Asketen, Bekenner und Märyrer und dem "unheimlichen RuBland" der zuerst gleichgültigen und später phantastisch-gottfeindlichen und kirchenräuberischen Atheisten, das schlieBlich in den Führem des modernen "Bolschewismus" seine Antireligion und Antikirche gefunden habe, immer mehr vertieft. Das neue RuBland Peters des Großen habe kein neues religiöses Ideal gebracht und der fatale Widerspruch zwischen Religion und Kultur, der ganz Europa seit der Epoche der Renaissance spalte, habe im neuen RuBland sofort eine beispiellose Tiefe erreicht ${ }^{18}$. Die Tradition des asketischchristlichen "heiligen RuBland" habe jedoch im Starzentum forgelebt, während sich zugleich innerhalb der neuen russischen Kultur (vor allem auf dem Gebiet der Literatur und Philosophie) eine starke geistig-schöpferische Strömung mit religiös-christlicher Grundhaltung ent wickelt habe, die Ëllis das "geistige RuBland" nennt. In den Meisterwerken der Klassiker der russischen Literatur (Zukovskij, Puškin u.a., vor allem VI. Solov'ev) sowie in den "großartigen" Arbeiten der russischen Emigranten (V. Il'in. N. Berdjaev, N. Losskij, Vjaž. Ivanov, D. Merežkovskij u.a.) sei eine Annäherung zwischen dem "heiligen" und dem "geistigen" RuBland erreicht worden'19.

In einer anderen Arbeit mit dem Titel: "Die Tradition der Ostkirche" 20, betrachtet Ėllis die beiden großen Wege der Tradition des Ostkirchentums:

die tief verborgene, übermenschlich strenge aszetische und visionär-kontemplative Überlieferung ganzer Generationen von Einsiedlem (Abbas und Starzen) von der Urzeit des Christentums bis auf das heutige russische "Starzentum" einerseits und die Entfaltung der mystisch-theologischen Lehre von der "Weisheit" (Sophia) durch die theologischen Schulen des Ostens (...) . ${ }^{21}$

Er hebt den "pneumatischen Charakter" und das Gottmenschentum des östlichen (griechischen und byzantinischen) Christentums hervor und bezeichnet den Tempel der Hagia Sophia in Konstantinopel als "großartigstes Denkmal der christlich-östlichen Weisheit":

Die gesamte ost-kirchliche Mystik, ja die ganze religiöse Weltanschauung des christlichen Ostens in ihrer verklärten, himmlischen, urbildlichen Vollkommenheit nahm in dieser sophianischen Offenbarung ihre sichtbar-symbolischen Formen an. 22

AnschlieBend kommt er wieder auf das Starzentum zu sprechen, in dem er den "wahren Geist" und das "echte Antlitz" des "heiligen RuBland" sieht. Der gröBte und bedeutendste der russischen Starzen sei der heilige Serafim von Sarov gewesen. dessen übermenschliche Macht Ellis anhand von Beispielen charakterisien ${ }^{23}$. In ihm sieht

16 Ebd.. S. 71.

17 Ebd.. S. 72.

$18 \mathrm{Vgl}$ ebd., S. $76 f$.

$19 \mathrm{Vgl}$. ebd., S. $80 \mathrm{ff}$.

Der bereits im Kapitel "Éllis' Beschäftigung mit Vladimir Solov'ev" angeführte Aufsatz "Die Tragik der russischen Literatur" (vgl. oben. S. 201f.) behandelt eine ähnliche Thematik.

20 In: Die Schildgenossen. Heft 6, 1937, S. 411-421.

21 Ebd.. S. 411.

22 Ebd., S. 417.

23 Diese hohe Bewertung des heiligen Serafim von Sarov stimmt mit derjenigen Igor Smolitschs überein, den Ellis (neben V. Il'in und S. Cetverikov) als einen der "besten Kenner" des Starzentums be- 
Ėllis den personifizienten Vertreter des "heiligen RuBland" und den "hellsten Träger der russischen Volksseele" sowie den "heiligsten Vertreter der Ostkirche in ihrer ökumemischen Einheit", wie sie von Vl. Solov'ev erstrebt wurde 24.

Um das Starzentum geht es auch in Ellis' Beitrag in der Zeitschrift "Hochland" mit dem Titel: "Zar und Starez"25. Ėllis greift in dieser Arbeit die Legende auf, nach der der russische Zar Aleksandr 1. 1825 gar nicht wirklich gestorben sei, sondem als Starez Kuzmix bis 1864 weitergelebt und gewirkt habe. Ausführlich schildert er den vermeintlichen, jedoch nur "mystischen" Tod Aleksandrs, der "ein Übergang ins Jenseits bei Lebzeiten" gewesen sei26, und bemüht sich, die Lebensgeschichte des "Zaren und Starez" von 1825 bis 1864 zu rekonstruieren. Er beruft sich dabei auf die neuesten Forschungsergebnisse, die er als Beleg dafür ansieht, daB sich die "alte Überlieferung" vom Weiterleben des Zaren als Realität erwiesen habe. Ein derartiges Sujet entspricht in besonderem Maße Ellis' Vorliebe für mystisch-religiöse Spekulationen und paBt in den Duktus seiner Arbeiten über das "heilige RuBland". Dies wird vor allem aus dem Schluß seines Beitrags deutlich:

Das große Geheimnis des Starez Kusmitsch erfuiltte aber erst zur Zeit der Katastrophe ${ }^{27}$ ganz seinen Sinn: Der Zar hatte zum gerechten Starez werden sollen, damit zur Zeit des Sturzes des Zarenthrones das mystische Licht des Starzentums das verblutende heilige RuBland zur Reue. Sühne und wunderbaren Wiedergeburt führen könne. ${ }^{28}$

In diesem Kontext beschäftigte sich Ėllis auch mit der altrussischen Ikonenmalerei und publizierte "Eine mystisch-symbolische Betrachtung" über "Die geistige Welt der heiligen Ikonen"29, die mit einer Bibliographie über "altchristliche östliche Kunst", "christliche Ikonographie" und "russische lkonographie" beginnt ${ }^{30}$. Seine Ausführungen über "das Wesen der heiligen lkone" können zumindest teilweise (wenngleich wohl auch eher unbewuBt) als später Reflex seiner Auseinandersetzung mit R. Steiners Lehre (Theosophie/Anthroposophie) angesehen werden: Ellis geht von "drei urgründlichen Seelenkräften" aus: Wollen, Denken und Fühlen ${ }^{31}$, und arbeitet heraus, daB die russische Volksseele vorzugsweise mit der dritten Seelenkraft, dem Fühlen, verbunden ist. Das entspricht im wesentlichen der Charakterisierung der russischen Volksseele durch Steiner ${ }^{32}$. AuBerdem schafft Ellis in dieser Arbeit im Zusammenhang mit seiner Deutung der Farbsymbolik und des Regenbogens eine Verbindung zur christlichen Kosmologie des Intermediarius. Er betont, daB das ganze seelische Leben des russischen Volkes von einer tiefen imaginativ-visionären Begabung durchdrungen sei, die in der russischen Ikonenmalerei zum Ausdruck gebracht werde, sich aber auch in den Meisterwerken der russischen Literatur finde:

zeichnet (vgl. ebd., S. 418). Bei I. Smolitsch (Leben und Lehre der Starzen. Der Weg zum vollkommenen Leben. Freiburg-Basel-Wien 1988, S. 177) heiBt es: "Und bis heute bleibt Serafim die vollkommenste Gestalt in der Reihe der russischen Heiligen und die schönste Perle im reichgeschmückten Gewand der Ostkinche."

${ }^{24}$ L. Kobilinskj-Ellis: Die Tradition der Ostkirche, a.a.O., S. 421.

25 In: Hochland. 37, 1939/40. S. 59-73.

$26 \mathrm{Vgl}$. ebd.. S. 60.

27 Gemeint ist das Jahr 1917: die bolschewistische Revolution und das Ende der Zarenherrschaft in RuBland.

28 L. Kobilinski-Ellis: Zar und Starez, a.a.O., S. 73.

29 In: Theologie der Zeit, 3-4. Wien 1938. S. 202-236.

30 Ebd.. S. 202-204.

31 Ebd.. S. 204.

32 Z.B. ausgeführt in seiner Ansprache an die russischen Teilnehmer während seiner ersten Vortragsreihe in Helsingfors vom 3. bis 14. April 1912 (vgl. oben. S. 126). 
Es ist sehr bezeichnend, daB jeder grobe russische (klassische) Dichter oder Schriftsteller bei der Darstellung der spannendsten Situationen und Ereignisse immendar (und manchmal fast unabsichtlich) jene tief-russische Psychologie der imaginativ-visionären Geistigkeit darstellt, die das letzte Wesen der Mystik der hl. Ikonenmalkunst bildet und sogar die hl. Ikone selbst auf ergrei fende Weise auftreten läBt. ${ }^{33}$

In seinen folgenden Ausführungen über die Entstehung der Ikonenmalerei erinnert Éllis an die Legende vom SchweiBtuch der heiligen Veronika: der Abdruck von Christi Antlitz als "wunderbare Urikone" sei zum Urbild und Vorbild der Ikonen Jesu geworden, habe die Ikonenkunst begründet ${ }^{34}$.

Desweiteren fuihr Ėllis konkrete Beispiele aus der nussischen lkonenmalerei an, die er erläuternd schildert und bespricht (die Dreifaltigkeitsikone von A. Rublev, verschiedenartige ikonographische Darstellungen der Sophia und Christi, eine Ikone des 16. Jahrhunderts, die den Erzengel Michael darstellt, u.a.) ${ }^{35}$.

Die Grundideen Solov'evs (so wie Ëllis sie versteht und in seinen Arbeiten über Solov'ev und dessen Werk darstellt) seien zugleich der mystische Schlüssel zur russi schen Ikonographie. Das versucht Ellis in seinen Deutungen der Sophia-Ikone zu zeigen. In der russischen Ikonenmalerei spreche sich das wahre Wesen der russischen Volksseele und Frömmigkeit aus.

Wie bereits in früheren Arbeiten sowie in seinen Beiträgen zur russischen Kulturgeschichte lehnt Ėllis auch hier wieder die Aufklärung radikal ab, sie sei eine "Verdunkelung der russischen Volksseele" gewesen und habe "den Grundstein der heutigen gottlosen und menschenfeindlichen Dehumanisierung" gelegt, "deren letzte Form der rote Bolschewismus ist"36. Demgegenüber stehe die klassische russische Kultur (Literatur und Malerei) sowie die russische Philosophie; Vl. Solov'ev bleibe glaubensstark; seine Lyrik nennt Ëllis "ikonenhaft"37.

AbschlieBend betrachtet Ëllis die Mystik und Symbolik der Ikonen, die er als "die sichtbar gewordenen Antlitze und Gestalten der himmlischen Kirche"38 definiert, die die wahre Frömmigkeit und Religiosität ausdrückten. Er beendet seine Arbeit mit dem Wunsch nach kirchlicher Union, nach Wiedererlangung der "wahren Katholizität":

Die Betrachtung der altrussischen Ikonographie ist eines der besten Mittel, den Geist der östlichrussischen Frömmigkeit in seiner schöpferischen Offenbarung von Angesicht zu Angesicht zu erschauen und dadurch auf dem hl. Wege der Wiedertierstellung der ökumenischen, kirchlichen Einheit, die conditio sine qua non des weiteren Bestehens der Kirche und des Christentums überhaupt ist, einen groben Schritt weiter zu machen. Dieser Weg führ alle sicher in das Reich jener

${ }^{33}$ L. Kobilinski-Ellis: Die geistige Welt der heiligen Ikonen, a.a.O... S. $207 f$.

Zur Illustration dieser Aussage führ Ellis als Beispiele Werke bzw. Episoden oder Teile aus Werken von Žukovskij ("Die zwölf schlafenden Jungfrauen"), Puskin ("Bois Godunov", "Der Springbrunnen von Bachxisaraj"/" Baxчисараһ̆скй фонтан" [ 1822], das Sonett "Madonna" [1830]. "Die Hauptmannstochter"). Lermontov ("Das Gebet" /"Morurвa" [1837], " Der Dämon" [2.Teil, 5. u. 6. Strophe]). Gogol' ("Das Porträt"/" "loptpet"). Turgenev ("Das Adelsnest"/"Дворянское пнездо"). Dostoevskij (zahireiche Darstellungen von Ikonen sowie Formen kirchlicher Riten und Frömmigkeit). L. Tolstoj (Szenen aus "Krieg und Frieden"/"Воңна и мир"). Leskov ("Der versiegelte Engel"/"Запечатленњй антел"). Merežkovskij ("Leonardo da Vinci"), die Lyrik TjutCevs, Fets, Majkovs, Polonskijs und A.K. Tolstojs sowie Smelev als "Darsteller der Psychologie der Ikonenverehnung" an. (Vgl. ebd., S. 208-211.)

34 Ebd., S. 212-214. Ėllis' Ausführungen emsprechen hier der gängigen Auffassung über die orthodoxe lkone als Verkörperung des Archetyps oder Urbilds der heiligen Gestalten der himmlischen Welt selbst: vgl. hierzu auch E. Benz: Geist und Leben der Ostkirche. Hamburg 1957, S. 10-15.

35 L. Kobilinski-Ellis: Die geistige Welt der heiligen Ikonen, a.a.O... S. 214-230.

36 Ebd., S. 226.

37 Ebd., S. $229 f$.

38 Ebd. S. 230. 
wahren und heiligen Katholizität, deren beste Definition dem großen Führer der östlichen Christen im Sinne dieser Katholizität, dem hochwürdigen Metropoliten Graf Andrej Scheptyckij gehört: "Nichts ist mehr katholisch als die alles umfassende, wahrhaft apostolische, universelle Liebe. Sie ist auch die einzige tärige Kraft der katholischen Kirche und jeder christlichen Ak. tion. 39

Ėllis' Arbeit über die russische Ikonenkunst erschien in dem Band der Zeitschrift "Theologie der Zeit", der dem Thema "Ethos und Frömmigkeit" gewidmet war, und entspricht in besonderem Maße dem Anliegen der Zeitschrift: Das "Reich der wahren und heiligen Katholizität", die wahre kirchliche Einheit (Ökumenizität), könne nur wiederhergestellt werden, wenn man die Kultur und Religion der Ostkirche, die wahre Orthodoxie kenne, verstehe und rezipiere. Hierfür leiste Ėllis' Abhandlung einen wichtigen Beitrag, wie Oto Maurer, der verantwortiche Schriftleiter dieses Bandes, in seinem Nachwort hervorhebt:

[...] Bestaunen wir nicht täglich das unethöne Wunder jener Offenbarung der Seele des heiligen RuBland, das sich in unseren Tagen abspielt? Lehren uns die durchaus nicht militanten Kräfte des östlichen Christentums, die heute geheime, noch unterirdische Siege feiem, nicht besser, was christlicher Geist sei als so viele vielgepriesene Fortschritte und greifbare Erfolge der Kirche anderswo? Diesen Geist des sakralen, ewigen RuBland beschwör Leo Kobilinski in seinem umfangreichen Aufsatz über die Welt der heiligen Ikonen. Mögen seine ergriffenen Visionen auch manchem dunkel und unbeholfen erscheinen, mögen wir auch mit Recht den oder jenen Vorbehalt anbringen - hier atmet eine geweihte Atmosphäre, hier tut sich ein Reich auf, zu dem wir nicht alltäglich Zugang finden können; hier ist mehr als Exotik und Reiz der Fremdheit: hier spricht eine Gläubigkeit, die uns fast abhanden kam, ein heiliger Instinkt, um dessentwillen wir den Christen des Ostens fast beneiden möchten. $\left[. . .\left.\right|^{40}\right.$

Dieses lange Zitat mag zugleich als Beleg dienen für die wichtige Rolle, die Ėllis als engagienter, temperamentvoller Vermittler russischen Kulturguts an deutschsprachige Leser in deutschen katholischen Kreisen der genannten Zeitschriften und Sammelbände gespielt hat.

Im Kontext seiner Beschäftigung mit dem "heiligen RuBland" und dem östlichen Christentum befaBte sich Ellis mit russischen Heiligenlegenden, die er (aus verschiedenen Quellen) ins Deutsche übersetzte und mit kurzen Anmerkungen versah. Diese Texte aus dem Ellis-NachlaB wurden 1972 von Adelbert Davids ${ }^{41}$ in einem Bändchen zusammengefaBt ${ }^{42}$ und in der Reihe AEVUM CHRISTIANUM ${ }^{43}$ herausgegeben ${ }^{44}$. In der Einführung gibt $A$. Davids einen kurzen historischen Überblick über RuBland und seine Heiligen. da Ėllis' Übersetzungen keine Gesamtdarstellung der russischen Heiligen bieten ${ }^{45}$. Es folgen die von Ëllis übersetzten russischen Heiligenlegenden über die "ersten heiligen Metropoliten von Moskau" Petr und Aleksej, über den "Einsiedler" Sergij von Radonež, über den "Ankläger" Jurodivyj Vasja, über den "Wundertäter" Starez Serafim von Sarov und über den "Seelenführer" Starez Amvrosij von Optinat6.

39 Ebd., S. 234.

40 Ebd.. S. 237.

41 Inhaber des Lehrstuhls für Alte Kirchengeschichte und Patristik in Nijmegen.

$42 \mathrm{Vgl}$. hierzu auch oben, S. 186, 2. Teil der Anmerkung 10.

43 Salzburger Beiträge zur Religions- und Geistesgeschichte des Abendlandes.

44 Mit dem Titel: Heilige aus dem alten RuBland. Texte übertragen von L. Kobilinski-Ellis. Hrsgg. von A. Davids. Münster 1972.

$45 \mathrm{Vgl}$. ebd., S. $1-6$.

46 Éllis' Übersetzungen der russischen Heiligenlegenden müssen in der Zeit um oder nach 1927 ent standen sein, da er Werke aus dem Jahre 1927 benutzt und zitiert. 
In all diesen genannten Arbeiten vermittelt Ėllis dem deutschsprachigen Leser einen Teil der altrussischen Kultur und Literatur, allerdings in seiner eigenen, subjektiv gefärbten Interpretation. Diese Beiträge erfüllen insgesamt ein Hauptanliegen der Zeit schriften, in denen sie publiziert wurden: Die westliche katholische Welt soll besser mit der Religiosität der Ostkirche, der religiösen Kultur RuBlands bekanntgemacht werden, was eine Grundvoraussetzung für die Wiedervereinigung der östlichen Christenheit mit Rom darstellt ${ }^{47}$. Dementsprechend hebt Ėllis die Idee der kirchlichen Ökumenizität wiederholt in diesen Aufsätzen hervor, bringt aber zugleich den Kulturleistungen der Orthodoxie (Heiligenlegenden, Starzentum, Ikonenmalerei etc.) eine besondere Sensibilität und Offenheit entgegen, die sicher entscheidend durch seine Herkunft mitbedingt sind. Vor allem mit seiner hohen Bewertung der Ikonenmalerei steht Ëllis nicht isoliert da; eine in den Grundlinien vergleichbare Auffassung wurde beispielsweise von P. Florenskij, E. Trubeckoj, L. Uspenskij, V. Losskij, P. Evdokimov u.a. vertreten ${ }^{48}$, die, wie Ëllis, die gesamte westeuropäische Kultur- und Kunstentwicklung seit der Renaissance als Irrweg bzw. Décadencephänomen betrachten; trotz aller Pracht und GroBartigkeit und ungeachtet ihrer künstlerischen Emungenschaften sei die gesamte Malerei seit Beginn der Frührenaissance der gotischen Malerei des Mittelalters sowie der altrussischen Ikonenmalkunst (A. Rublev, Feofan Grek) unterlegen; lediglich in der Ikonenmalerei sei die echte christliche Kunst, wie sie bis zum Mittelalter praktiziert wurde, erhalten geblieben.

Der Einschnitt zwischen der sakralen Kunst des Mittelalters und der profanen der Renaissance wird allgemein erkannt ${ }^{49}$, was aber nicht $z$ wingend eine Herabsetzung der Renaissance und der folgenden westeuropäischen Kunst (Michelangelo, Raffael. Tizian. Cranach. Dürer und anderer großer Meister) zur Folge haben muB. Es hat jedoch immer wieder Bewegungen gegeben, die die Entwicklung der europäischen Kunst (seit der Renaissance) ablehnten oder abwerteten (man denke 2.B. an die Präraffaeliten), und auch die angeführten Namen zeigen, daB Ėllis als starrer Dogmatiker und glühender Verehrer des katholischen Mittelalterkults mit seinen extremen Ansichten keine völlig isoliente Stellung einnimmt. Florenskij etwa beurteilt die Einführung der Perspektive, die Entwicklung von der Zwei-zur Dreidimensionalität, nicht als Fortschritt. sondern als Versagen. Der Westen habe dadurch die eigentliche Spiritualität der Darstellung verloren. Die Renaissance wird folglich als Hinwendung zur Materialität abgewertet. eine Haltung, die Ėllis' Ansichten entspricht.

In seiner Einschätzung der Bedeutung der altrussischen Kultur läBt sich Ëllis in einen Zusammenhang kulturphilosophischen Denkens einordnen, der seit P. Caadaev über Vl. Solov'ev bis hin zu den russischen Religionsphilosophen der Emigration eine Traditionslinie darstellt. Caadaev hatte als erster darauf hingewiesen, daB RuBland nur durch den AnschluB an den katholischen Westen (und nicht an Byzanz!) gerettet werden könne ${ }^{50}$. Die Hinwendung nach Rom zum Katholizismus mit dem gleichzeitigen

$47 \mathrm{Vgl}$. hierzu oben. S. 183. Anmerkungen 34-37.

48 Vgl. z.B. P. Florenskij: Ikonostas (1922 geschrieben. z.B. abgedruckt in: Ders.: Sobranie soxine nij. Tom 1. Paris 1985, S. 193-316, 394f.; deutsche Übersetzung mit Einführung von Ultich Werner: P. Florenskij: Die Ikonostase. Urbild und Grenzerlebnis im revolutionären RuBland. Stuttgan 1988); E.N. Trubeckoj: Umozrenie v kraskach. Vopros o smysle żizni v drevnerusskoj religioznoj żivopisi. Moskva 1916: Ders.: Dva mira v drevnerusskoj zivopisi. Moskva 1916; E.N. Trubetzkoy: Die religiöse Weltanschauung der alturssischen Ikonenmalerei. Paderbom 1927: L. Ouspensky. W. Lossky: Der Sinn der Ikonen. Bem-Olien 1952: L. Ouspensky: La Théologie de l'icóne dans IÉglise orthodoxe. Paris 1980: P. Evdokimov: L'an de l'icône. Theologie de la beaute. Bruges 1970; außerdem: N. Thon: Ikone und Liturgie. Trier 1979.

$49 \mathrm{Vgl}$. etwa P. Bürger: Theorie der Avantgarde, a.a.O., S. 36.

$50 \mathrm{Vgl}$. hierzu auch D. Tschizewskij: Russische Geistesgeschichte, a.a.O.. S. 227-229. 
Bestreben, Elemente der Orthodoxie einzubringen, eine kirchliche Union zu schaffen, ist nicht nur für den Religionsphilosophen Vl. Solov'ev charakteristisch, sondern überhaupt für viele in der Emigration lebende russische Dichter und Denker (etwa Vjax. Ivanov, N. Berdjaev, V. Il'in). Éllis' Idealvorstellungen der römischen Papstkirche, in der sich der wahre mittelalterliche Katholizismus gehalten habe, lassen deutlich werden, daB er sich weniger vom real existierenden Westrom seiner Gegenwart als vielmehr von der westeuropäischen Mystik und dem katholischem Mittelalterkult angezogen fühlte. Vergleichbare Ideale konnte er in der orthodoxen Kirche zu Beginn des 20. Jahrhunderts (außer im Starzentum) nicht mehr finden 51 . Gleichzeitig, so paradox es zunächst klingen mag, steht Ėllis in einer gewissen Tradition des Slavophilentums, wenn er Kulturgeschichte ausschlieBlich unter dem Aspekt des Religiösen betreibt bzw. die religiöse Sphäre als eigentlichen Motor der Kulturentwicklung betrachtet und die Reformen Peters des Großen sowie die ganze nachpetrinische Entwicklung RuBlands als Fehlent wicklung abwertet ${ }^{52}$.

Man muB sich abschlieBend fragen, inwiefern Ëllis' Arbeiten für den damaligen deutschsprachigen Leser von Bedeutung waren bzw. neue Erkenntnisse über die altrussische Kultur und das russisch-orthodoxe Christentum vermittelten. In den zwanziger und dreißiger Jahren gab es nämlich bereits eine beträchtliche Anzahl deutschsprachiger Publikationen zu diesem Themenbereich ${ }^{53}$, der jedoch damals noch längst nicht erschöpfend erschlossen war. Das zeigt beispielsweise das große Interesse der genannten Sammelbände und Zeitschriften am östlichen Christentum und der russischen Kultur, Philosophie und Literatur. Ellis' Engagement und seine aktive Mitarbeit werden von ihren Herausgebem (R. Knies u.a.) immer wieder lobend hervorgehoben $^{54}$, so daB seinen Beiträgen trotz aller Subjektivität, ihrer mitunter zu pathetischen Ausdrucksweise und ihrem gelegentlichen Fanatismus Bedeutung zugestanden werden muB.

51 Vgl. hierzu auch oben. S. 137, Anm. 186).

52 Vgl. hierzu D. Tschižewskij: Russische Geistesgeschichte. a.a.O., S. 214. $216 f$.

Im Gegensatz zu Ėlis erkannten die Slavophilen jedoch die Schwierigkeiten dieser Konzeption und waren wesentlich konsequenter in ihrem Denken.

53 Ëlis selbst nennt in seiner Betrachtung über "Die geistige Welt der heiligen lkonen" Arbeiten von W. Zaloziecky, G. Ostrogorski, E. Benz, F. Heiler, M. Alpatov, F. Halle. E. Trubetzkoj, G. Wunderle u.a. (vgl. ebd., S. 202-204). Vgl. ferner z.B. Th.G. Masaryk: RuBland und Europa. Studien über die geistigen Strömungen in RuBland. Jena 1913; W. Assur: RuBland und das Christentum. Wernigerode (Harz) 1928 (darin auf S. 10 weitere Literaturangaben) sowie die Literaturangaben im Anmerkungsteil von I. Smolitsch: Leben und Lehre der Starzen, a.a.O., S. 219-231.

Ėllis' Ausführungen über das russische Starzentum entsprechen im wesentlichen denjenigen Smolitschs, den er ja auch als eine seiner Quellen nennt (vgl. oben. S. 223f., Anm. 23). Smolitschs umfassendes Werk war erstmals 1936 erschienen, stellte damals in seiner Vollständigkeit allerdings ein Novum dar; zuvor hatte Smolitsch jedoch einige Aufsätze in Zeitschriften publizier.

$54 \mathrm{Vgl}$. oben. S. 182 und S. 183, Anm. 36. Thomas Michels (= Herausgeber der Reihe AEVUM CHRISTIANUM) nennt Ëllis einen "bedeutenden russischen Religions- und Kulturphilosophen" (Heilige aus dem alten RuBland, a.a.O., S. VII). 


\section{G. Zusammenfassung des II. Teils: Ellis' Kunst- und Literaturauffassung in der Emigration}

Ėllis hat also aus seiner zweiten Schaffensperiode Arbeiten hinterlassen, die sich in keiner Weise mit dem russischen oder europäischen Symbolismus auseinandersetzen, sondem sich vor allem religiösen, kulturphilosophischen und mystischen Themen sowie der russischen Romantik (Žukovskij, Puškin) und dem Werk und der Lehre Vl. Solov'evs (Übersetzungen ins Deutsche, Kommentare, Aufsätze über Solov'evs Lehre und Lyrik) zuwenden. Er hat versucht, in seinen Beiträgen in Sammelbänden und katholischen Zeitschriften im Sinne seines groben geistigen Lehrers VI. Solov'ev weiterzuwirken und eine Vereinigung der Kirchen herbeizuführen. Sein Bestreben war es, im Osten die wahre, ursprüngliche, universelle Orthodoxie (вселенское православне) wiederherzustellen, die nicht im Widerspruch zu Rom steht, und eine Synthese zwischen Religion und Kultur zu schaffen. So weist er in seinen Arbeiten wie derholt auf die tatsächlich existierende Nähe zwischen der östlichen und westlichen Kultur, der östlichen Sophiologie und der westlichen Mariologie hin, wodurch er seine Unionsbestrebungen zu legitimieren und rechtfertigen versucht.

Seine Arbeiten aus dieser Schaffensperiode publizierte Ėllis überwiegend in deutschsprachigen katholischen Zeitschriften und Sammelbänden und im katholischen Matthias-Grünewald-Verlag (Mainz). Er verkehrte in deutschsprachigen Katholikenkreisen, die besonders um russische Emigranten bemüht warenl. Seine Werke standen jedoch - wie oben ausgeführ - in einer bestimmten Traditionslinie, die sich sowohl auf westeuropäische als auch auf russische Wurzeln zurückführen läBt ${ }^{2}$.

In seinen Arbeiten über Žukovskij, Puškin, Gogol', VI. Solov'ev sowie die russische Kulturgeschichte tritt Ellis als belesener, temperamentvoller, poetisch sensibler, aber zugleich doch auch als einseitiger, häufig unkritischer bis dogmatischer Autor auf, der dahin tendien, die meisten behandelten Themen in das Prokrustesbett der eigenen Weltanschauung zu zwingen und nur dieser gemäB zu urteilen ${ }^{3}$. Literatur ist für ihn erst dann echte Kunst, wenn sie christlich-religiös ist. Diese eigenwillige literarische Position hatte sich in seiner ersten Schaffensperiode bereits angebahnt ${ }^{4}$. GemäB diesem Kriterium bewertet er die Werke Żukovskijs. Puškins und Solov'evs sowie die alte russische Kunst und Literatur (Bylinen, Ikonen). In Žukovskijs, Puškins und Solov'evs Meisterwerken findet er eine Harmonie zwischen Religion und Kunst, eine vollständige Verbindung von Heiligem und Schönem, wie sie in der Kunst des Mittelalters, der er ja einen besonders hohen Stellenwert einräumt, bestan-

I Vgl. z.B. den "Rückblick" über die "Katholische Russen-Fürsorge in Deutschland" (in: West-östlicher Weg. I, 1928, 12, S. 275-282).

2 Ėllis' "Christliche Weisheit" läBt sich z.B. in einen gewissen Traditionszusammenhang mit der deutschen katholischen Publizistik etwa eines Johann J. von Görres bringen (vgl. dessen Schriften "Mythengeschichte der asiatischen Völker" [1810]. "Die christliche Mystik" [1836-1842] und "Athanasius" [1838]) sowie mit der um die Jahrhundertwende in Frankreich entstandenen Bewegung des "Renouveau catholique" (E. Schure, M. Barrès, P. Claudel u.a.). Éllis' überwiegend religiös ausgerichtete Arbeiten lassen sich jedoch ebenfalls mit religiösen Wiedergeburtsbestrebungen. wie sie in RuBland um 1900 aufkamen (vgl. die verschiedenen religiös-philosophischen Vereinigungen und Gesellschafien) und nach der Revolution durch russische Emigranten nach Westeuropa gelangten, in Verbindung bringen, und auberdem - wie ausgeführt - mit der nussischen Religionsphilosophie.

${ }^{3}$ Diese Einseitigkeit und Subjektivität hatte sich bereits in vielen Arbeiten seiner Moskauer Schaffensperiode gezeigt und war von E. Metner im Brief an Belyj (vom 1. April 1911) bereits hefuig kritisien worden: "[...] и в Марксе. и в Данте. и в Бољлере. и в Р. Вагнере (которого он лженстолковывает), и в Штейнере он искал и ищет толко Папу, которому надо поцеловать туфљю." (Zitient nach V. Sapov: V.I. Ivanov i E.K. Metner, a.a.O., S. 338.)

$4 \mathrm{Vgl}$. seine Beiträge in "Tруды и дын" und sein Traktat "Vigilemus!". 
den habe. Er charakterisien diese Werke als "ars sacra", was für ihn das höchste Bewertungskriterium für Kunst und Literatur ist, und kann somit diese Dichter als die gröBten, bedeutendsten bezeichnen. Vl. Solov'ev als treuer Sohn der orthodoxen Kirche, der zugleich in Verbindung mit Rom stand und in seinen Werken Religiosität und Kunst verband, nahm für Ellis den ersten Platz eins.

Auch in den Arbeiten der deutschsprachigen Schaffensperiode fallen wieder Ëllis' panegyrisch-pathetischer Stil, sein übertriebener Hang zu Superlativen und seine mitunter recht krasse "Schwarz-WeiB-Malerei" auf. Im Grunde ist er sich selber treu geblieben, auch wenn sich sein Themenhorizont in gewisser Weise eingeengt hat bzw. er fortan alle Literatur- und Kunsterscheinungen nur unter einem streng religiös-katholischen Aspekt betrachtet und bewertet. Er setzt sich für seine Überzeugungen, die denen vieler damaliger aktiver deutscher Katholiken um die genannten Zeitschriften und den Matthias-Grünewald-Verlag entsprachen, mit dem ihm eigenen Eifer ein. Aus Ėllis als Vertreter eines dogmatisch-religiösen Symbolismus (Moskauer Periode) wurde also ein Verfechter religiöser Kunst und Literatur schlechthin und ein eifriger Kämpfer für die Unionsidee, wobei in seinen Augen der Katholizismus den unbestrittenen Vorrang einnahm ${ }^{6}$; ihm muBten sich die anderen Konfessioen (die Orthodoxie, die sich - wie Ėllis meint - fälschlicherweise unter byzantinischem Einfluß von Rom abgewandt hatte; auf den Protestantismus geht er gar nicht erst näher ein!) ${ }^{7}$ unterordnen.

SSolov'ev als einer der geistigen Väter des Symbolismus ist für Ėllis in dieser Periode nicht mehr wesendich, sondem vielmehr Solov'ev als Vermittler $\mathbf{z}$ wischen der Ostkirche und Rom, als Verkünder der Unionsidee der Ost-und Westkirche.

$6 \mathrm{Im}$ Katholizismus der römischen Papstkirche sah Ėllis die authentische Religion des Mittelalters verkörper.

7 Ëllis' Abwertung bzw. Ignorieren des Protestantismus läBt sich in die Tradition Dostoevskijs einordnen: Für Dostoevskij war der Protestantismus nur eine westlich rationalistisch übersteigene Kritik am Katholizismus, ohne eigene Glaubensbasis, und lediglich als Gegenpol zum Katholizismus lebensfähig. (Ausfihnungen Dostoevskijs zu diesem Thema finden sich in seinem "Дневник писателя" ("Таgebuch eines Schriftstellers") in dem bereits zitierten Kapitel "Германский мировой вопрос. Германия - страна протестуюulas" (vgl. oben. Seite 131, Anmerkung 151) und auch in seinem Roman "Илнот" ["Der Idiot", 1868].) 


\section{SCHLUSS}

Am Ende dieser Untersuchungen zu Leben und Werk von Ėllis soll nun der Versuch einer Gesamtbewertung seines Werks untemommen werden, um dadurch seine Bedeutung für die russische Literatur herauszuarbeiten.

Ėllis' Leben und Werk. besonders die Arbeiten seiner ersten Schaffensphase, können als wichtiger Spiegel und interessanter Reflex seiner Zeit betrachtet werden: Sowohl in seiner Biographie als auch in seinem Werk spricht sich die ganze Krisen- und Umbruchsstimmung der damaligen Zeit aus. Sein chaotisches, ungeordnetes Leben spiegelt das Offene, Unbehauste des Symbolismus wider mit all seinen Dissonanzen und seiner Kreativität, während in seinen theoretischen Arbeiten immer wieder das Bestreben zu ordnen, zu systematisieren und zu kategorisieren auffällt. Der beständige Versuch, klare Termini und Definitionen zu liefem, und die harte, häufig ungerecht fertigte Kritik an allem, was nicht in seine mühsam geschaffenen Kategorien und Systeme paBt, weisen deutlich auf die Komplexität dieser literarischen Strömung in RuBland um die Jahrhundertwende hin, wie sie im Einleitungsteil der vorliegenden Arbeit aufgezeigt wurde. Die Komplexität und Vielfalt des russischen Symbolismus drückt sich auch in den zahlreichen Unstimmigkeiten, Widersprüchen und im Eklektizismus von Ėllis' Werk aus. Er ist in seinen Arbeiten selten originell oder innovativ, sondern greift meist Gedanken oder Teilgedanken anderer (bedeutenderer) Vertreter dieser Strömung auf und versucht, sie in ein System zu pressen und dementsprechend zu ordnen und zu erläutern. Er wird zum radikalen Verfechter eines "echten", "reinen" Symbolismus, ohne genau definieren zu können, was er darunter versteht. Nicht nur in seinen Werken, auch in seinem Leben ist er ständig auf der Suche nach Bindung an Autoriäten. Diese Haltung erklärt die relativ geringe Überzeugungskraft und auch das Eklektische seines Werks, das in der vorliegenden Studie kritisch beurteilt (jedoch nicht verurteilt) worden ist. Die Objekte seiner Verehrung wechseln zwar, die Richtung seines Suchens ändert sich jedoch nicht. Eine Enttäuschung folgt der nächsten: Weder Marx noch Baudelaire, Brjusov, Steiner oder die Anthroposophie können ihm die gewünschte Orientierung geben und so führt ihn sein Weg schlieBlich. wie manche Romantiker, in den SchoB der katholischen Kirche, die mit ihrer dogmatischen Glaubenssicherheit, ihrer hierarchischen Ordnung und ihrer Tradition einen geistigen Halt bieten konnte.

Mit wachsender Entschiedenheit hat Ėllis vehement gegen die Möglichkeit der Freiheit in der Kunst gekämpft und das argonautische Modell als "überzeitlichen Symbolismus" christlich dogmatisien. Trotz all seiner "Kehrtwendungen" ist seine theoretische Grundtendenz konsequent: er wollte die argonautische Suche nach der transzendenten Wahrheit durch künstlerische Gestaltung in der harmonischen Schönheit sichtbar machen und durch Wissen (Erkenntnis) bestätigen. Dies ist das Grundanliegen seiner Individualität als Dichter und Theoretiker des Symbolismus, hierdurch erklärt sich seine Einseitigkeit, sein suggestiver und exaltierter Stil, seine Suche nach bestätigenden Autoritäten und sein Eklektizismus.

Durch ausgefallene Ideen, Phantastereien und Exaltationen hat Ėllis zu Beginn dieses Jahrhunderts inspirierend und anregend auf seine symbolistischen Zeitgenossen - be sonders auf Andrej Belyj-gewirkt ${ }^{1}$. Er war maBgeblich an der Gründung des "Argonautenkreises" beteiligt, hat Brjusovs Position in "Весы" unterstützt, wirkte aktiv bei

1 Dies beschreibe Belyj ausführlich in seinen Memoiren, vor allem in "Nacalo veka". Zum EinfluB von Ëllis auf Belyj vgl. auch M. Ljunggren: The Dream of Rebirth. A Study of Andrej Belyj's Novel Peterburg. Stockholm/Sweden 1982. 
der Organisation des Verlags "Musaget" und der Zeitschrift "Труды и дни" mit, beeindruckte seine Zeitgenossen durch seine lebendige, überzeugende Vortragsart, sein Rede- und Schauspieltalent und spielte eine wichtige Rolle bei der Vermittlung der Theosophie und Anthroposophie nach RuBland. So kann man sich bezüglich Ëllis' Bedeutung der Meinung M. Ljunggrens anschließen:

Ėllis's own poetry and publicism give the impression that he was a pale second-rate writer, but the play of his demonic personality evidently made him one of those brilliant conversationalists who. in Belyj's own words, transformed his symbolist ant into a kind of collective creation. $[\ldots]$ Peterburg seems to draw upon Ellis in an especially high degree. ${ }^{2}$

In seinen Werken aus der ersten Schaffensperiode begegnet uns Ėllis einerseits, in seiner Eigenschaft als Übersetzer, als Vermittler der überwiegend neueren westeuropäischen Literatur an den russischen Leser. Dabei ist das, was er übersetzt, nicht immer originell, sondern wurde teilweise auch von anderen Zeitgenossen übertragen (etwa Baudelaires "Les fleurs du mal"); mitunter ist es aber von relativ groBer Bedeutung (vgl. zum Beispiel Potthoffs Bewertung von Ėllis als Dante-Übersetzer oder seine Übersetzungen von Baudelaires "Petits poèmes en prose", die bis heute neu aufgelegt werden). Seine eigene Lyrik mutet zur Zeit ihrer Entstehung - gemessen an derjenigen seiner symbolistischen Zeitgenossen (z.B. Brjusov, Belyj und vor allem Blok) - insgesamt recht epigonal an; Sprache und Stil seiner Gedichte wirken häufig schwerfällig, gekünstelt und mühsam konstruiert; er bedient sich ausschlieBlich traditioneller Formen, wobei er allerdings die Sonettform meisterhaft beherrscht. Als Theoretiker und Kritiker der Literatur seiner Zeit, vor allem des französischen. belgischen und russischen Symbolismus, wirkte Ëllis auf seine Zeitgenossen vor allem durch seine mündliche Vortragsart, die fanatisch, fesselnd, überzeugend und mitreiBend gewesen sein muB (vgl. die zahlreichen Erinnerungen von Zeitgenossen), also besonders durch die Art, wie er etwas vortrug und weniger durch den Inhalt.

Ėllis' Arbeiten sind zweifellos ein wichtiges und bedeutendes Zeitzeugnis. Für den heutigen Symbolismusforscher sind sie eher von zweitrangigem Interesse mit Ausnahme des umfangreichen Werks "Русские символисты", das mit seinen verschiedenen Klassifizienungs- und Schematisienungsversuchen des europäischen und russischen Symbolismus in ihrer Vielfältigkeit und Problematik heute noch von Belang ist. Auch wenn Ellis insgesamt weder darin noch in seinen anderen theoretischen Arbeiten eine radikal neue oder originelle Symbolismustheorie geschaffen hat, findet er zu Recht in der neueren Symbolismusforschung Beachtung 3. "Русские символисты" stellt immerhin einen der frühesten Versuche dar, den russischen Symbolismus in seiner Entwicklung zu beschreiben und das Werk dreier seiner Vertreter zu cha rakterisieren zu einer Zeit, als diese literarische Strömung noch nicht ihr Ende erreicht hatte und die von Ellis' behandelten, bedeutenden Verteter des Symbolismus noch gar nicht alle ihre Meisterwerke geschaffen hatten.

ln seiner zweiten Schaffensperiode wirkt Ėllis durch seine Übersetzungen aus den Werken VI. Solov'evs, seine Kommentare dazu, seine Aufsätze über russische Kultur und Literatur und seine literarhistorischen Arbeiten über Žukovskij, Puškin und Gogol' gewissermaßen als Vermittler nussischer Kultur und Literatur an den deutschsprachigen Leser.

2 M. Ljunggren: The Dream of Rebirth, a.a.O.. S. 42.

3 Z.B. bei S. Cioran, A. Hansen-Löve. R. Peterson, W. Potthoff, A. Pyman, A. Lavrov (in der BelyjMonographie) u.a. W. Kasack führ Ėllis' "Pyсское снмволисты" im "Lexikon der russischen Literatur des 20. Jahrhunders" im Artikel "Symbolismus" bei den Literaturangaben an (vgl. ebd., S. 1269). 
Unterzieht man diese Werke einer Bewertung, so muB man eingestehen, daB sie, einschlieBlich seiner Monographien über Žukovskij und Puškin, recht einseitig und subjektiv sind, da sie vorwiegend auf die Untersuchung religiöser Elemente zielen. Dabei soll jedoch der Žukovskij-Monographie eine nicht unwesentliche Bedeutung und Wichtigkeit zugesprochen werden, da sie in recht umfassender Weise Žukovskijs gesamtes Leben und Werk schilder und in den zeitgeschichtlichen Hintergrund einbettet. Außerdem hat Ellis in diesem Werk die große Bedeutung, die Žukovskij für die russische Romantik und die russische Lyrik überhaupt hatte, deutlich erkannt und formuliern ${ }^{4}$. Die Puškin-Monographie fällt wesentlich einseitiger aus, da in ihr nur die Werke Puškins, die religiöse Elemente beinhalten, behandelt und besprochen werden und Puškins Lebensweg nur unter dem Aspekt seiner religiösen Entwicklung bis zu seinem Tode geschildert wird.

Ėllis' Übersetzungen aus Solov'evs Werk und seine Erläuterungen dazu waren zumindest zur Zeit ihres Erscheinens (zwischen 1925 und 1930) von Bedeutung, da Solov'ev und seine Lehre damals im Westen und in Deutschland noch nicht vollständig erforscht und bekannt waren (wenn man von der anthroposophischen Solov'ev-Ausgabe $^{5}$, R. Steiners Solov'ev-Auslegungen und einigen weiteren Übersetzungen aus und Arbeiten über Solov'evs Werk ${ }^{6}$ absieht). Ein Verdienst von Ėllis ist zweifellos der Hinweis auf Solov'evs Lyrik, die er dem deutschsprachigen Leser durch seine Übertragungen und Abhandlungen nahegebracht hat.

Auch Ėllis' Arbeiten über die altrussische Kultur, Kunst und Literatur dürften für die damaligen Leser von Interesse gewesen sein.

Ungeachtet etlicher Verzeichnungen, Ungenauigkeiten und Fehler sowie einer nicht zu übersehenden Einseitigkeit bei seiner Bewertung der russischen Literatur und Philosophie muB doch auf den bedeutenden Beitrag hingewiesen werden, den Ellis in den zwanziger und dreiBiger Jahren dieses Jahrthunderts durch das Werk seiner zweiten Schaffensperiode geleistet hat, durch das er dem deutschsprachigen Leser neue Seiten der russischen Kultur eröffnet hat. Viele der Probleme, die Ellis in seinen Arbeiten behandelt hat, sind auch heute noch von Aktualität: Die Beziehungen zwischen Religion und Kunst, die Rolle Vl. Solov'evs bei der Entwicklung der philosophischen und religiös-mystischen Gedanken des 20. Jahrhunderts, die Unterschiede und Gemeinsamkeiten zwischen den geistigen Missionen des Westens und Ostens.

So ergibt sich als Fazit, daB die vorliegende Untersuchung in jedem Fall notwendig war und in ihrer Ausführlichkeit gerechtfertigt ist: Ėllis muB eine Bedeutung in der Frühgeschichte des russischen Symbolismus zugebilligt werden; sein Werk leistet einen Beitrag zum Symbolismus und zum russischen religiösen Denken jener Zeit, obwohl sich seine hinterlassenen Arbeiten aus der ersten Schaffensperiode vom Rang her nicht mit denen der Hauptvertreter des russischen Symbolismus messen können und die seiner zweiten eine einseitig katholische Ausrichtung haben.

Eine genauere Betrachtung des Symbol-Begriffs läBt schnell deutlich werden, daB eine rein literarische, kunsttheoretische Bestimmung dieses Begriffs nicht ausreichend ist: er transzendiert ständig die Sphäre des rein Literarischen, mythologische, philosophische, religiöse, tiefenpsychologische etc. Elemente sind ihm stets inhärent. Folglich erscheint eine Entwicklung innerhalb des Symbolismus, von einer literarisch-

${ }^{4}$ Zur Żukovskij-Schule als "Magistrale" der russischen Romantik vgl. auch den Vorlesungszyklus von R.-D. Kluge über die russische Romantik an der Universität Tübingen im WS 1990/91 und im SS 1991.

5 Solovjeff, Wladimir: Ausgewählte Werke. Aus dem Russischen von Harry Köhler. 4 Bände. Stuttgart 1921-1922.

6 Vgl. L. Wenzler: Die Freiheit und das Böse nach VI. Solov'ev, a.a.O.. S. 393-456. 
künstlerischen Stilformation zu einer religiös-weltanschaulichen Strömung, als in sich schlüssig und berechtigt ${ }^{7}$. So gesehen hat auch Ellis' Weg - bei aller Subjektivität, allen Imtümem, Übertreibungen etc. - eine innere Logik und Berechtigung, sein kritisienter Hang zu dogmatischer Einseitigkeit wäre zu relativieren.

Eine kritische Beureilung von Ėllis' Werk im Kontext des russischen Symbolismus wird unterschiedlich ausfallen, je nachdem, welche literarhistorische Forschungsposition bei der Bewertung zugrundegelegt wird ${ }^{8}$. Vertreter der traditionellen Symbolismusauffassung, die vor allem eine Kontinuität zwischen Romantik und Symbolismus erkennen und für die der Symbolismus Höhepunkt und SchluBwort der aristotelisch-mimetischen Poetik und Ästhetik darstellt, werden Ëllis' Werk in der Regel höher bewerten (wie es zum Beispiel bei Potthoff geschieht) als Symbolismusforscher, die diese literarische Strömung als progressive Tendenz in Kunst und Literatur betrachten und vor allem nach ihren Innovationen befragen.

Die Verfasserin der vorliegenden Untersuchung schlieBt sich bei Ellis' Gesamtbewertung der Meinung Gleb Struves an, die abschlieBend zitient sei:

Пусть Эллис бьл фигурой второстепенной (а как поэт и совсем незначнтельной). в историн русского символизма ему прннадлежит свое - и немалое - место. 9

${ }^{7}$ Eine derartige Entwicklung ist sowohl für den französischen als auch für den russischen Symbolismus typisch.

8 Vgl. hierzu die Ausführungen im Einleitungsteil der vortiegenden Arbeit. S. 19-23.

9 Vgl. das Vorwort von G. Struve in N. Valentinov: Dva goda s simvolistami, a.a.O., S. XII. 


\section{QUELLEN- UND LTTERATURVERZEICHNIS}

1. Bibliographie von Ellis' Werken in chronologischer Reihenfolge

\section{Ruscischsprachige Bücher:}

Иммортели. Выпуск 1 - 2. - Москва, 1904.

Русские символисты. - Москва, 1910. [Reprint: Letchworth. 1972; Neuausgabe: Toмск, 1996]

Stigmata. - Москва, 1911.

Apro. - Москва, 1914.

Vigilemus! (Т рактат). - Москва, 1914.

\section{Übersetzungen ins Russische:}

Жорж Роденбах: Покрывало. Драма. Перевод Эллиса. - Москва, 1907.

Эмиль Верхарн: Монастырь. Перевод с французского Эллиса. С предисловием А. Белого. - Москва. 1908.

Шарль Бодлэр: Мое обнаженное сердце. Перевод Эллиса. - Москва, 1907.

Шарль Бодлэр: Цветы зла. Перевод Эллиса. - Москва, 1908.

ШІарль Бодлэр: Стихотворения в прозе. Перевод Эллиса. - Москва, 1911.

Шlарль Бодлэр: Цветы зла. - Москва, 1970. [Darin etliche Gedichte in Ellis' Ubersetzung]

Шарль Бодлер: Цветы зла и стихотворения в прозе в переводе Эллиса. - Томск, 1993.

Шарль Бодлер: Цветы зла. Стихотворения в прозе. Дневники. Жан Поль Сартр. Москва, 1993. (Darin etliche Gedichte aus "Цветы зла" sowie die gesamten "Стихотворения в прозе" in Ëllis' Übersetzung]

Übersetzungen, Gedichte und Aufsātze in russischen Sammelbänden, Anthologien, "Sborniki":

Итоги. Сборник. Изданке газеты "Курьер". - Москва, 1903:

Эллис: Из ШІ. Бодлэра: "Гармония вечера". (Стр. 223).

Альманах книгонздательства "Гриф". - Москва, 1904:

Эллис: "Вакханалия", "Мироздание", "Непокорный" (из Бодлэра), "Из Роденбаха". (CTp. 128-134).

Romanzen von I.S. Taneev nach Texten bzw'. Übersetzungen von Ėllis:

"Когда, кружась, осенние листы ...". Соч. 17, № 6. 15 февр. 1905r. Слова Л. Стекетти. Перевод Эллиса.

Десять стихотворений из сборника Эллиса "Иммортели". Соч. 26, написаны 5-17 авг. 1908г::

1. "Рождение арфы". Слова Т. Мура (из "Ирландских мелодий")

2. "Канцона XXXII". Слова Данте Алитьери (из "Новой жизни")

3. "Отцветы". Слова М. Мэтерлинка.

4. "Музыка". Слова Ш. Бодлэра.

5. "Леса дремучие". Слова ШІ. Бодлэра.

6. "Сталактиты". Слова Сюлли-Прюдома.

7. "Фонтаны". Слова Ж. Роденбаха.

8. "И дрогнули враги". Слова Ж.-М. де Эредиа.

9. "Менует". Слова Ul. д'Орнаса.

10. "Среди врагов". Слова $Ф$. Нишие.

Хризопрас. Художественно-литературный сборник издательства "Самоцвет". - Москва, 1906-1907:

Эллис: "Изранлю". (Стр. 32-34). 
Свободная совесть. Литературно-философский сборник. Книга первая. - Москва, 1906: Эллис: Из "Акхордов". Стихотворения. 1. "Полночь". 2. "Звездная симфония". 3. "Феннкс". 4. "Я спасен! Подо мной воют жадныя, адския бездны ..." 5. "Черный рыцарь". (Стр. 102-109).

"Венец Данте". (Стр. 110-138).

Свободная совесть. Книга вторая. - Москва, 1906:

Эллис: "Фаэтон". "Анатомический театр". "Золотой город". "Рай Данте". (Стр. 6386).

"В апреле". "Ниобея". "Терцины". "Голубой цветок". (Стр. 159-162).

Армянская муза. Сборник, изданный под редакцией Юрия Веселовского и проф. Г.А. Халатьянца со встутительною статьею "Несколько слов о новой армянской поззни". - Mockвa. 1907:

Darin in Ellis' Übersetzung:

Рафазл Патканъян: "Перед изображеннем Богоматерн" (стр. 39-40). Ованнес Туманьян: "Лампада Гритория Просвитителя (Народное предание)" (стр. 130-131). Аветис Исаакьян: "На крылах орлиных ..." (стр. 136), "Была душа моя мрачна" (стр. 137), "Ночной порою сон ..." (стр. 141). Малезьян: "Роковые приметы" (стр. 176), "Ночник" (стр. 177). Сибиль: "Облако" (стр. 178).

Молодая Бельгия. Сборник. Ж. Роденбах. И. Жилькен, Альбер Жиро, Андрэ Фонтэна, Ш. Ван-Лерберг, М. Метерлинк. М. Эльскамп, Валер Жилль, Ф. Северэн, Ж. Марло, М. Валлер. П. Мюш. Э. Верхарн. - Москва, 1907:

Эллис: Лебедь "Молодой Бельгин". Жорж Роденбах (Основные мотивы его личности и творчества). (Стр. 48-87).

[Außerdem viele Gedichtribersetzungen von Ėllis darin.]

Воздетые руки. Книта поэзин и философин. - Москва, 1908:

Эллис: "Мечты погибияя". "Джиакомо Леопарди". "У окна". "Донне". "Лебедь". (Стр. 148-156).

Творчество. Литературный сборник. - Казань, 1909:

Перевод Эллиса: Из Верлэна: "Над лесом бледная луна". (Стр. 115).

Антология кнкгонздательства "Мусагет". - Москва. 1911:

Эллис: "Эпитафия". "Терцины". "Сонеты". "Последнее свиданье". (Стр. 255-268).

Волны вечности в русской художественной литературс. Издание Кневского религнозно-философского общества. - Киев. 1914:

Эллис: "Золотой город" (стр. 38-40). "Stabat Mater dolorosa" (стр. 305-307). "И ты, ослепшая от слез" (стр. 418).

Русский сонет XVIII - начало XX века. - Москва, 1986:

Эллис: "Любовь и смерть (Три сонета)". "Сонеты-гобелены". "К Бодлеру". "К читателю. Сонет". Шарль Бодлер: "Экзотический аромат"; "Продажная муза"; "Дуэль"; "Совы"; "Музыка". Поль Верлен: "Женшине". Арман Сюлли-Прюдом: "Спасение в искусстве. Сонет"; "Сонет". "На *Vita Nuova» Данте (Из О. Уайльда)". (Стр. 359369).

Русская поэзия серебряного века. 1890-1917. Антология. - Москва. 1993:

Эллис: "Роза ада". "Братьям-рыцарям". "Одиночество". "Сон". "Ave Maria". (Стр. 277-280).

\section{Veröfientlichungen in ruxsischsprachigen Zeitschriften:}

Русская Мысль. Ежемесячное литературно-политическое издание. - Москва, 1904:

Книта IV.: Эллис: "Пауло и Франческа" (из Данте Аллигьери). (Стр. 180-182).

Кннга X: Эллис: Из "Божественной комедия" Данте. Песнь 28-я "Чистилища". (Стр. 134-138).

Перевал. Январь. 1907:

Эллис: "Восход". "На uххере". (Стр. 36-37). 
Перевал. Август, 1907:

Эллис: "Отвергнутый Дон-Жуан" С. Рафаловича (книгоиздательства "Шиповник") und: "О двух драмах Фр. Ведекинда". (Стр. 54-56).

\section{Bect, 1907:}

№ 5: Эллис: "Корабли. Сборних стихов и прозы. М. 1907". (Стр. 73-76).

№ 6: Эллис: "Пантеон современной пошлости. Факелы. Книга вторая. Спб. 1907". (Стр. $55-62)$.

스 7: Эллис: ШІарль Бодлэр. Цветы зла. Полный перевод А.А. Панова с французскаго. Издание Ф.И. Булгакова. 2 тома. Сп6. 1907". (Стр. 75-77).

№ 8: Эллис: "Поворот. Литературно-художественные альманахи изд. жШиповник». Книга II. Сп6. 1907". (Стр. 65-68).

"В защиту декадентства. По поводу статьи Н. Бердяева «Декадентство и общественность» (Русская Мысль, 1907, № 6)". (Стр. 69-71).

№ 9: Эллис: "Об афоризмах. Из книги «Мысли-оводыж". (Стр. 50-52).

"С.М. Степняк-Кравчинский. Собрание сочинений. Ч. I-III. Библиотека «Светоча». Cп6. 1907". (Стр. 66-68).

№ 10: Эллис: "Что такое литература?" С.А. Венгеров. Очерки по истории русской литературы. Библ. "Светоча". (Стр. 54-57).

"Эмиль Верхарн. Обезумевшия деревни. Перевод Н. Васильева. Казань 1907". (Стр. 64-67).

№ 11: Эллис: "Поэту наших дней". (Стр. 15-17).

Весы, 1908:

№ 1: Эллис: "Пути и перепутья". Валернй Брюсов. Пути и перепутья. Собрание стихов. Том I. М. 1908. (Стр. 82-86).

№ 2: Эллис: "Наши эпитоны. О стиле, Л. Андрееве, Борисе Зайцеве и многом другом". (Стр. 61-68).

ㅅ. 4: Эллис: "Что такое театр?" (Стр. 85-91).

№ 6: Эллис: "Еще одна корона". (Стр. 62-63).

№ 7: Эллис: "Еще о соколах и ужах. О последних драмах Максима Горького: «Варварыж, «Враги», «Последннеж". (Стр. 53-58).

№ 9: Эллис: "Кризис современного театра. «Кризис театра». Сборник статећ. К-во «IІроблемы искусстваж. М. 1908". (Стр. 63-66).

№ 10: Эллис: "Литературный невод". (Стр. 81-86).

№ 11: Эллис: "Иванов-Разумннх. Исторня русской общественной мысли. Индивидуализм и мещанство в русской литературе и жизни XIX в. Издание II. Cп6. 1907". (Стр. 54-57).

№ 12: Эллис: "Голубая птища. По поводу постановки Московскаго Художественнаго театра". (Стр. 95-100)

Весы, 1909:

№ 1: Эллис: "О современном символизме, о кчорте» и о ждействеж". (Стр. 75-82).

№ 3: Эллис: "Ave Maria! Посв. М.И. Сизовой". (Стр. 15-18).

"О вандализме в современной критихе". Литературный распад. Критический сборник. Кн. II. Книгонздательство *Еоs». С-П6. 1909. (Стр. 82-87).

"Ж. Роденбах. Искусство в изгнания. Перевод Мария Веселовской. Изд. В.М. Саблина. М. 1909". (Стр. 95-97).

№ 4: Эллис: "Человек, который смеется. О Страшном Суде Гоголя нал миром и нал самим собой". (Стр. 84-94).

№ 5: Эллис: "Об Альманахах". Альманахи «Веринны», «Прнбой», «Колосья», «Творчествон. (Стр. 69-75).

스 7: Эллис: "Итоги символизма". Доклад, прочитанный на заседанин жО-ва Свободной Эстетихи», в Москве. 25 февраля 1909. (Стр. 55-74).

"О книгах. «Французские лирики XIX века». Перевод В. Брюсова. Изд. «Пантеона». Cn6. 1909". (Стр. 87-93). 
"Письмо в редакцию". (Стр. 104).

№ 8: Эллис: "По звездам". Вяч. Иванов. «По звездамж. К-во «Оры». Спб. 1909. (Стр. $53-62)$.

스 9: Эллис: Из книгн "Стигматы". (Стр. 7-16).

스 10-11: Эллис: "Культура и символизм". (Стр. 153-168).

"Пнсьмо в редакиию". (Стр. 178-179).

\section{Труды н дни, 1912:}

Tетрадь IV, 스 4-5: Эллис: Мюнхенские письма. I. "Умер ли символизм?" (Стр. 46-50). "О задачах и целях служения культуре". (Стр. 87-96).

Тетрадь V, № 6: Эллис: Мюнхенские письма. II. "О грехе забвения, о долге дерзания, о первых «рыцарях символизмаж и о релитиозном искусстве". (Стр. 49-56).

III. "Символизм и идея символизма. Искусство символическое, релитиозное и христианское". (Стр. 56-62).

Труды и дни, 1913:

Tетрадь VI. 스 1-2: Эллис: "«Парсифал» Рихарда Вагнера". (Стр. 24-53).

Труды и дни, 1914:

Tетрадь VII: Эллис: "Дантеана. Учитель веры". (Стр. 63-78).

Труды и дни, 1916:

Tетрадь VIII: J. van der Meulen: О планетных сферах Дантова «Рая» в свете астрософин". (Стр. 9-22). [Vermutlich von Ëllis aus dem Holländischen ins Russische übersetzt.]

Вестник русского студенческого христианского движения. 1933:

스 9-10: Кобылинский-Эллис, Л.: Смерть Жуковского. (Стр. 9-12).

Символ, 1992 (Paris):

스 28: Гимны Орфея. (Стр. 286-294).

\section{Deutschsprachige Werke:}

Wladimir Solowjew: Gedichte. Zu seinem 25. Todestage am 12. August 1925. Übersetzt von L. Kobilinski-Ellis und R. Knies. - In: Das heilige Feuer. Paderborn, 12, 1924/1925. (S. 462466).

Solowjew, W.: Gedichte. Ins Deutsche übertragen von L. Kobilinski-Ellis und R. Knies. Mit einer Abhandlung über Solowjew als Lyriker. Solowjews Weisheits- und Schönheitslehre. Weisheit und Weltseele bei Solowjew von L. Kobilinski-Ellis. - Mainz, 1925.

Solowjew, W.: Das Lebensdrama Platons. Mit einem Nachwor über Platon und Solowjew von L. Kobilinski-Ellis. Aus dem Russischen übertr. von B. Schmitt. - Mainz, 1926.

Kobilinski-Ellis, L.: Wladimir Solowjew über die "moderne Theosophie". - In: Christi Reich im Osten. Die geistige Bedeutung Wladimir Solowjews und die inneren Voraussetzungen zur Wiedervereinigung der russisch-orthodoxen und der römisch-katholischen Kirche. Hrsgg. von Richard Knies. - Mainz (Matthias-Grinewald-Verlag), 1926. (S. 20-25).

Florenski, Paul: Sophia. Aus dem XI. Kapitel des Werkes "Die Säule und Grundfeste der Wahrheit". (Aus dem Russischen übersetzt und mit einer Vorbemerkung. Anmerkungen und einem Nachwor versehen von L. Kobilinski-Ellis). - In: Christi Reich im Osten, a.a.O. (S. 72-145).

Kobilinski-Ellis, L.: Wladimir Solowjew im Uneile seiner Zeitgenossen. - In: Christi Reich im Osten, a.a.O. (S. 200-207).

Kobilinski-Ellis, L.: Die freie Theokratie nach der Lehre von Wladimir Solowjew. - In: Ex Oriente. Religiöse und philosophische Probleme des Ostens und des Westens. Beiträge orthodoxer, unierter und katholischer Schriftsteller in russischer, französischer und deutscher Sprache. Hrsgg. von Prof.Dr. theol. Ludwig Berg. - Mainz (Matthias-GrünewaldVerlag), 1927. (S. 278-286).

HI. Bonaventura: Kreuzeshymnus. Sequenz "Recordare sanctae crucis", ins Russische übertragen von L. Kobilinski-Ellis. - In: Ex Oriente, a.a.O. (S. 356). 
Kobilinski-Ellis, L.: Der erste russische Romantiker. - In: Das neue Reich, 10. Jg., 32, 5.5 . 1928. (S. 663-664).

Kobilinski-Ellis, L.: Wer war und was ist uns Wladimir Solowjew? - In: West-östlicher Weg, I, Glogau - Mainz, 1928. (S. 23-35).

Kobilinski-Ellis. L.: A. Puschkin über das Christentum und den Katholizismus. - In: West-östlicher Weg, I, Glogau - Mainz, 1928. (S. 69-71).

Kobilinski-Ellis, L.: W. Solowjews See-Lyrik. - In: West-östlicher Weg, 1, Glogau - Mainz, 1928. (S. 227-233).

Kobilinski-Ellis, L.: Christliche Weisheit. Sapientia divina. Cosmologia perennis. Nach der Lehre des Intermediarius. Per Crucem ad Rosam. (Als Manuskript gedruckt). - Basel (Frobenius), 1929.

Solowjew, W.: Monarchia Sancti Petri. Die kirchliche Monarchie des heiligen Petrus als freie und universelle Theokratie im Lichte der Weisheit. Aus den Hauptwerken von Wladimir Solowjew systematisch gesammelt, übersetzt und erklärt durch L. Kobilinskj-Ellis. - Mainz (Matthias-Grünewald-Verlag), 1929.

Kobilinski-Ellis, L.: Die Tragik der russischen Seele. Zu A. Puschkins "Boris Godunow". - In: Das neue Reich, 11. Jg., 24, 16.3.1929. (S. 442-444).

Kobilinski-Ellis, L.: A. Puschkin und P. Tschaadejew (Religionspsychologische Studie). - In: West-östlicher Weg, II, Glogau - Mainz, 1929. (S. 41-52).

Kobilinski-Ellis, L.: Der Tod A. Puschkins. - In: West-östlicher Weg, Il, Glogau - Mainz, 1929. (S. 185-196).

Kobilinski-Ellis, L.: Von dem altrussischen religiösen Epos (Russische Epen und Sagen. Versuch einer kurzen Charakteristik). - In: West-östlicher Weg, Il, Glogau - Mainz, 1929. (S. 248-261).

Solowjew, W.: Der heilige Wladimir und der christliche Staat. Ubersetzt von L. KobilinskiEllis. - Padertom (F. Schöningh-Verlag), 1930.

Kobilinski-Ellis, L.: Über die altrussische Heldenepik. Zweite Studie. - In: West-ostlicher Weg, III, Glogau - Mainz, 1930. (S. 121-127: Teil 1, S. 163-171: Teil II, S. 217-225: SchluB).

Kobilinski-Ellis, L.: Der Schwanengesang des ersten russischen Romantikers (Über W. Joukowskijs christliche Epopöe "Ahasver"). - In: West-östlicher Weg. III, Glogau - Mainz, 1930. (S. 247-257).

Kobilinsky, L. (Ellis): Der Tempel des heiligen Grales als Dichtung und Wahrheit. - In: Bayreuther Blätter, 1, 1932 (S. 21-28): 2, 1932 (S. 94-108).

Kobilinski-Ellis, L.: W.A. Joukowski. Seine Persönlichkeit, sein Leben und sein Werk. Paderborn (F. Schöningh-Verlag), 1933. (= Das goldene Zeitalter der russischen Poesie).

Kobilinski-Ellis, L.: Die Tradition der Ostkirche. - In: Die Schildgenossen, 6. Würzburg. 1937. (S. 411-421).

Saizew, Boris K.: Der hl. Sergij von Radonjesch und die Befreiung Rußlands von den Tartaren. Übersetzt von L. Kobilinski-Ellis. - In: Die Schildgenossen, 6, 1937. (S. 448-451).

Saizew, Boris K.: Gestalten des Berges Athos. Übersetzt von L. Kobilinski-Ellis. - In: Die Schildgenossen, 6, 1937. (S. 452-459).

Licharewa, Sophia A.: Uber die "Hagia Sophia" zu Konstantinopel. Ubersetzt von L. Kobilinski-Ellis. - In: Die Schildgenossen, 6, 1937. (S. 460-468).

Kobilinski-Ellis, L.: Die Tragik der russischen Literatur. - In: Die Schildgenossen, 6, Würzburg, 1937. (S. 469-476).

Kobilinski-Ellis, L.: Die Macht des Lachens und des Weinens. Zur Seelengeschichte N. Gogols. - In: Die Schildgenossen, 6, 1937. (S. 477-482).

Kobilinski-Ellis, L.: Die Schönheitslehre Wladimir Solowjews. Eine mystisch-philosophische Studie. - In: Die Schildgenossen, 6, 1937. (S. 496-505).

Kobilinski-Ellis, L.: Das "heilige Rußland", sein Wesen und seine Sendung innerhalb der ökumenischen Kirche Christi. - In: Theologie der Zeit, 2, Wien, 1937. (S. 57-86).

Gogol. N.: Betrachtungen über die göttliche Liturgie. Deutsch von $R$. von Walter. Mit einem Nachwort von L. Kobilinski-Ellis: Die Macht des Weinens und des Lachens. Zur Seelengeschichte Nikolaus Gogols (S. 80-100). - Freiburg (Herder-Verlag), 1938. 
Kobilinski-Ellis, L.: Die geistige Welt der heiligen Ikonen. - In: Theologie der Zeit, 3-4, Wien, 1938. (S. 202-236).

Kobilinski-Ellis, L.: Alexander Puschkin und seine Erzählung "Die Hauptmannstochter". - In: Die Schildgenossen. 2, Würzburg. 1939. (S. 121-138).

Kobilinski-Ellis, L.: Zar und Starez. - In: Hochland, 37, 1939/40. (S. 59-73).

Kobilinski-Ellis, L.: Alexander Puschkin. Der religiöse Genius Rußlands. - Olten (Verlag Onto Walter AG), 1948.

Heilige aus dem alten RuBland. Texte übertragen von L. Kobilinski-Ellis. Hrsgg. von A. Davids. - Münster (Aschendorff-Verlag), 1972. 


\section{А. РГИА (Российский Государственный Исторический Архив Города Москвы):}

Ф. 418, оп. 311 (Канцелярия по студенческим делам 1897 г.):

Дела о принятин в число студентов Московского Университета:

232: Грейнера Василия (Авг. 1897 - Окт. 1901, Юр. ф-т).

444: Кобылинского Ильи (14.7.1897 - 5.9.1901, Фил. ф-т).

445: Кобылинского Льва (14.7.1897 - 27.9.1903, Юр. ф-т).

Ф. 418, оп. 314 (Канцелярия по студенческим делам 1900 г.):

Дела о принятии в число студентов Московского Университета:

377: Кобылинского Сергея (16.6.1900 - 24.6.1907, Фил. Ф-т).

\section{В. РГАЛИ (Российсхий Государственный Архив Литературы и Исхусства):}

Ф. 575, опись 1, 66 ед.хр. (Элиис Лев Львович, поэт, 1895-1914, б.д.):

\section{I. Рукописи Элииса Льва Льовича}

1. Стихотворения, статьи

ед.хр. 1: Стихотворенне Эллиса Льва Львовнча "Братьям-рыцарям". Автограф. Ohnе Datum. I Blatt.

ед.хр. 2: Цикл стихотворений Эллиса Льва Львовича "Жизнь". Рухописные копия сделаны рукой Христофоровой Клеопатрой Петровной. Ohne Datum. 18 Blätter.

ед.хр. 3: Цикл стихотворений Эллиса Льва Львовкча "Любовь". Рухописные копин сделаны рукой Христофоровой Клеопатрой Петровной. Ohne Datum. 12 Blätter.

ед.хр. 4: Цикл стихотворений Эллиса Льва Львовнча "К Ницше". Рухописные котии сделаны рукой Хрнстофоровой Клеопатрой Петровной. Ohne Datum. 12 Blătter.

ед.хp. 5: Цикл стихотворений Эллиса Льва Львовича "au de lo". Рукописные копия сделаны Хрнстофоровой Клеопатрой Петровной. Ohne Datum. 35 Blătter.

ед.хр. 6: Статья Эллиса Льва Львовнча "По поводу постановки «Сагіlloneuги в Париже". Автограф. Приложена статья Роденбах Анны "Сагіlloneur", вырезка из газеты. 1913. 7 Blätter.

eд.xp. 7: /Статъя/ Эллиса Л.Л. "Спиритнзм и символизм". Автограф. Otne Datum. 3 Blätter.

ел.хр. 8: Перевод Эллиса Льва Львовича либретто оперы Вагнера Рихарда "Парсифал". Черновой автограф. Ohne Datum. 31 Blätter.

2. Тетради Эллиса Льва Львовича со стихотворениями, конспектами лекций, запи сями

ед.хр. 9: Тетрадь Эллиса Льва Львовича со стихотворениями Полонского Я.П., Рылеева К.Ф., Баратылского Е.А., Голенищева-Кутузова Гр.А., Фета А.А. и др., с рассказами Толстого Л.Н., Горького А.М., с письмом Горького к Анатолию Францу (1906), со статьями о Тургеневе И.С., Майкове А.Н. С обратной стороны конспекты лекций о6 учения Рудольфа Штейнера о духовных иерархиях. Автограф. Ohne Datum. 155/164 Blätter.

ед.хр. 10: Тетрадь Эллиса Льва Львовича с конспектами лекций по исторни философия ("мюнхенский цикл"). С обратной стороны записи по биографии Лермонтова М.Ю. Автографы. 42 Blätter.

ед.хр. 11: Тетради Эллиса Льва Львовнча с конспектами лехинй и отдельными записями по философин. Некоторые конспекты написаны Хрнстофоровой Клеопатрой Петровной. 1906, 1908. 98 Blätter.

ед.хр. 12: Записи Эллиса Льва Львовича по историн символистической шхолы (француззкие символисты). Автограф. Ohne Datum. 21 Blätter. 
ед.хр. 13: Загиси Эллиса Льва Львовича по теософия. Автограф. Otune Datum. 6 Blätter. ед.хр. 14: Записи Эллиса Льва Львовича по философин (о происхожденин вселенной, природе сновиденй̆ и др.). Автографы. /1908/. 50 Blätter.

II. Материалы к биографии Эляиса Льва Львовича

ед.xр. 15: Устав и список членов редакционного комитета сборника "Арго". Автограф Элинса Л.Л. Ohne Datum. 7 Blätter.

ед. хр. 16: Членский билет студенческого общества искусств и изящной литературы прн Московском уняверситете, выданный Эллису Л.Л. Ohne Datum. I Blatt.

ед.хр. 17: Повестка о заседанин общества свободной эстетики, просланная Эллису Л.Л. 22. фев. 1911r. 1 Blatt.

\section{III. Письма Эллиса Льва Львовича}

ед.xp. 18: Письма Эллиса Льва Львовича Грейнеру с изложением содержания своей работы "Критиха раликальной идеи". Черновой автограф. Otne Datum. 77 Blätter.

ед.хр. 19: Форзац книти Бодлэра "Цветы жизни" в переводе Эллиса Л.Л. с дарственной надписью Мальковской Софьи Николаевне. Ohne Datum. 1 Blatt.

ед.хр. 20: Письма Эллиса Льва Львовича Сизовой Марии Ивановне. 1908-1912. 169 Blätter.

ед.хр. 21: Письмо Эллиса Льва Львовича к Сизову Миханлу Ивановичу. 1911. 2 Blätter. ед.xp. 22: Письмо Эллиса Льва Львовнча Сизовым. 1907. 1 Ansichtspostkarte.

ед.хр. 23: Письмо Эллиса Л.Л. неустановленному лицу с обращением А.Д. и его визитные карточки. 1912, ohne Datum. 2 Blätter und 2 Visitenkarten von Ëllis.

N. Письма Эллису Льву Львовичу

ед.хр. 24: Письмо Алексеева Дмитрия Викторовича Эллису Л.Л. 21 нюня 1911г. 1 Postkarte.

ед.xp. 25: Письма Астрова Владимира Ивановича Эллису Л.Л. 1910-1911. 5 Вlätter (3 Postkarten und 1 Brief).

ед.xp. 26: Письмо Астрова Павла Ивановича Эллису Л.Л. Ohne Datum. 1 Blatt.

ед.xp. 27: Письмо Бнскупского С. (Biscoupsqui S.) Эллису Л.Л. 1911. 1 Postkane.

ед.хр. 28: Письма Бобровой Нины Павловны Эллису Л.Л. Ohne Datum. 6 Blätter.

ед.хр. 29: Письма Вихентьева Владимира Мкхайловича Эллису Л.Л. Письмо от 23 августа 1910 анресовано Нилеңдеру Владимиру. 14 авг. 1910т. - 3 нкня 1911г. 3 Ansichtskarten.

ед.хр. 30: Письмо Гарри Максимилиана Алексаңдровича Эллису Льву Львовичу. 20 нюля 1911r. 1 Postkarte.

ед.хр. 31: Письма Дурылина Сергея Николаевича Эллису Л.Л. Ohne Datum. 7 Blätter.

ед.хр. 32: Письма Коваленской Александры Григорьевны Эллису Л.Л. 30 апр. - 3 сен. 1911r. 5 Blätter (1 Postkarte, 2 Briefe).

ед.хр. 33: Письма Корвин Адды Адамовны и ее портреты (открытка) с дарственными подписями Эллису Л.Л. 9 сен. 1910г. 5 Postkarten.

ед.хр. 34: Письмо Крахта Константина Федоровича Эллису Л.Л. 4 авг. 1911r. 1 Blatt.

ед.хр. 35: Письмо Куроч(кина) И. Эллису Л.Л. 10 amp. 1911r. I Ansichtskarte.

ед.xp. 36: Письмо Мальковской Софьи Александровны Эллису Л.Л. Ohne Datum. 2 Blätter.

ед.хр. 37: Письмо Метнера Карла Карловича Эллису Л.Л. 14 авг. 1911г. 1 Blatt.

ед.хр. 38: Письмо Метнера Эмилия Карловича Эллиса Л.Л. Otne Datum. 1 Ansichtskarte.

ед.xp. 39: Письмо Минцловой Анны Рудольфовны Эллису Л.Л. 16 amp. 1910r. 7 Blätter.

(Eine Ansichtspostkarte und die Aufzeichnungen eines Vortrags. London 1905).

ед.хр. 40: Письмо Никулина С. Эллису Л.Л. 4 мая 1911r. 1 Ansichtspostkarte.

ед.хр. 41: Письмо Петровского Алексея Сергеевича, Сабашникова Алексея Васильевича, Трапезникова Трнфона Георгиевича, Викентьева Владимира Михайловича Эллису Л.Л. 13 авг. 1910 г. 1 Ansichtskarte.

ед.хр. 42: Пнсьма Саңдомирского Миханла Эллису Л.Л. Кюњь 1911г. 5 Blătter. 
ед.хр. 43: Письма Сидорова Алексея Алексеевича Эллису Л.Л. 12 - 29 июня 1911г. 4 Blätter.

ед.хр. 44: Письма Сизовой Марни Ивановны Эллису Л.Л. 23 авг. - 5 сен. 1911; ohne Datum. 10 Blätter.

ед.xp. 45: Письмо Сизова Михаила Ивановича. Сизовой Марии Ивановны, Костычевой Ольгы Павловны Эллису Л.Л. Othe Datum. 1 Ansichtspostkarte.

ед.xp. 46: Письмо Тамбурер Лидин Александровны Эллису Л.Л. 10 мая 1911г. 1 Аnsichtskarte.

ед.хр. 47: Письма Христофоровой Клеопатры Петровны Эллису Л.Л. 15 апр. - 29 июля 1911r. 2 Blätter (1 Brief, 1 Ansichtskarte).

ед.хр. 48: Письма Цветаевой Марины Ивановны Эллису Л.Л. 22 июня 1909 - 2 дек. 1910r. 4 Blätter.

ед.хр. 49: Письма Цветаевой Анастасин Ивановны Эллису Л.Л. 20 ноября 1910 - 18 апр. 1911r. 3 Blätter.'

Письма разных лиц разньци лищак

ед.хр. 50: Письмо Кобылинского И.Л. (брата Эллиса) неустановленному лицу с обращением Елизавета Николаевна. На обороте затиси рукой Эллиса Л.Л. Ohne Datum. 1 Blatt. [Der Brief betrifft Ėllis]

[eд.xp. 51-55: Briefe verschiedener Adressanten an Maksimilian Aleksandrovic Garri, die jedoch Ëllis nicht betreffen]

V. Материалы Издательства "Мусавет" присланы для редактирования

l. Cтихотворения

[ед.xp. 56-60: Gedichte verschiedener, meist unbekannter Verfasser, teilweise mit Ėllis' Korrekturen, die an den "Musaget"-Verlag geschickt wurden, aber sonst keinen direkten Bezug zu Ëllis' Leben und Werk haben.]

2. Статын 06 Оскар Уайльde

[eд.xp. 61-65: Aufsătze verschiedener Autoren uber Oscar Wilde aus Éllis' Archiv]

ед.хр. 66: Письма Белого Андрея (Бугаева Борнса Нихолаевкча) Кобылинскому Льву Львовнчу на почтовых открытках. 1910-1911r. 6 Postkarten.

Die folgenden Archivalien betreffen, sofern es sich nicht um Briefe an oder Materialien und Briefe von Ellis handelt, Vorgänge und Aktivitäten, die mit Ëllis direkt verbunden sind:

Ф. 55 Блок on. 2

ед.хр. 40: Письма Кобылинского Льва Львовича (псевд. Эллис) Блоку А.А. и дарственные надписи Кобылинского Л.Л. Блоку А.А. на форзацах книт Кобылинского Л.Л. 1906 - 1910r. 12 Blätter.

Ф. 80 Becenoscux on. 1

ед.хр. 294: Письмо за подписью секретаря издательства "Мусагет" Киселева Н.П. Веселовскому Юрню Алексеевичу. 3 мая 1914r. 1 Blatt. |Betriff Ėllis' Gedichtband "Apro"]

\section{Ф. 376 Бpecos on. 1}

ед.хр. 4: Письма Брюсова Валерия Яковлевича Петровской (Соколовой) Нине Ивановне. В письмах от 18 и 21 июля 1906r. стихотворения: "Морской залив", "Снова долгий, тихй вечер". 29 авг. 1905 - 3 amp. 1909. 85 Briefe/115 Blätter. [Der Brief vom 8.21.11 1908 betrifft die Zeitschrift "Весы", ihre Mitarbeiter und Probleme. u.a. auch Ëllis]

1 Ea.xp. 48 und 49 wurden mir nicht ausgehändigt mit der Begründung. daB der Cvetaeva-Fond bis zum Jahr 2000 gespern sei. 


\section{Ф. 464 Садовскпй оn. 1}

ед.хр. 9: Эллис. Помета на стихотворении Садовского Б.А. "Заклинания стихии": "Не нужно поэма - ода". Otne Datum. 2 Blätter.

ед.хр. 71: Письмо (открытка) Кобылинского Л.Л. Садовскому Борису Александровичу. 1909r. 1 Postkarte.

Ф. 1496 Бердаев оп. 1

ед.хр. 843: Эллис. 5 писем 1939 г. Н. Бердяеву. ${ }^{2}$

Ф. 1666 ред. гоз. "Реqь" оп. 1

ед.хр. 944: Эллис. Письмо в редакцию газеты "Речь". 244 Blätter (davon 1 Brief von Ėllis; ohne Datum).

Ф. 1720 3вегинцева оn. 1

ед.хр. 399: Л.Л. Эллис. "Греза" (С. Маллармэ), "Пастух коз" и "Валторна" (П. Рей). Переводы стихотворений и отрывка из поэмы в прозе с французского языка. Автограф переводчика. 1910-е годы. 3 Blätter.

Ф. 2085 Глизр оп. 1

ед.хр. 1067: Письмо Эллиса (?) Глиэру Р.М. 5 дек. 1911r. 3 Blätter.

Ф. 2530 Гольнев оn. 2

ед.хр. 239: Письма Блока Александра Александровича Кобылкнскому Льву Львовичу. Копин рукой В.В. Гольцева. 5 марта - 1 aпр. 1907r. 2 Blätter.

Ф. 2554 Бобров оn. 1

ед.хр. 49: Письма Метнера Эмилия Карловнча Боброву С.П. 18 июня - 1 сен. 1915 r. 3 Blätter (2 Briefe). [Betrifft u.a. Ellis, die Anthroposophen, Domach]

\section{Ф. 2743 Ламм оn. 1}

ед.хр. 36: П.А. Ламм. Редакция романсов С.И. Танеева "Островок", "Мечты в одиночестве гаснут", "Пусть отзвучит". "Блаженных снов ушла звезда", "Не ветер вея с высоты", "В дымке невияимке", "Бьется сердце беспокойое", "Рожденне арфы", "Люди спят", "Отсветы" и др. Соч. 17 и 26. Автограф П.А. Ламма. 1940-е годы. 69 Bläıter. [Darin Romanzen auf Übersetzungen von Ėllis]

ед.хр. 38: II.A. Ламм. Редакиия романсов, трио, дуетов, музыкальных шуток С.И. Танеева "Канщона", "Мой тяжкий грех", "Из средневековой жнзни", "Близость весны", "Сосна", "Играй, Алель". "Да в три часа сегодня ровно ...". "Вы Фросю азбуке желали обучать ..." и др. Автограф П.А. Ламма. Тетрадь. 1940-е годы. 51 Blätter. (Darin Romanzen auf Übersetzungen von Ėllis]

\section{С. РО РГБ (Рукоппсный отдел Российсхой Государетвениой Бпблиотеки):}

Die folgenden Briefe betreffen, sofern sie nicht von Ellis oder an ihn gerichtet sind. Aktivitäten und Vorgänge, die mit Ellis direkt verbunden sind:

Ф. 167 Metnep, Э.K. картон № 1

ea.xp. 12: Brief von Belyj an Metner, 26. März 1903. [Betrifft: Gründung des "Argonautenkreises"]

\section{Ф. 167 Metmep, 3.K. картон Ne 2}

eд.xp. 4: Brief von Belyj an Metner (Ende Aug./Anfang Sept. 1909). (Betrifft: Éllis-"Skandal", Grüdung von "Tруды и дни"]

ед.xp. 70: Brief von Belyj an Petrovskij (17.0kt. 1912). [Betrifft: "Musaget". "Труды и дки"]

2 Diese Briefe konnten von der Verfasserin nicht eingesehen werden. 


\section{Ф. 167 Метнер, Э.K. картон № 3}

ed.xp. 18: Brief von Belyj an Metner (20. Okt. 1913).

eд.xp. 19: Telegramm von Belyj an Metner (8. Okt. 1913).

ed.xp. 20: Brief von Belyj an Metner (14. Nov. 1913).

eд.xp. 28: Brief von A. Turgeneva an Metner (Okt. 1914).

[Eд.xp. 18-20 und 28 betreffen "Vigilemus!"]

\section{Ф. 167 Meтнер, Э.K. картон N6 5}

ea.xp. 33: Brief von Metner an Belyj (12./25. April 1914). [Betrifft: "Musaget"]

eд.xp. 37: Brief von Metner an A. Turgeneva (6./19. Okt. 1912). (Betrifft: "Musaget" und

"Труды и дни"]

\section{Ф. 167 Meтнер, 3.K. картон № 6}

ед.xp. 1-27: Briefe von Metner an Ellis (Jan. 1907 - Okt. 1914).

eд.xp. 28: Brief von Metner an seine Eltern (31. Jan. 1907). [Betrifft u.a. Ėllis]

Ф. 167 Meтнер, Э.K. картон № 7

ed.xp. 1-71: Briefe von Ellis an Metner (Jan. 1907 - Sept. 1912).

ea.xp. 72: Brief von Ėllis an Kiselev (29. Sept. 1912).

ed.xp. 73: Brief von Éllis an die Redaktion "Musaget" (1.Okt. 1912).

ed.xp. 74-88: Briefe von Ėllis an Metner (Okt. - Dez. 1912).

\section{Ф. 167 Метиер, Э.К. картон 스 8}

ed.xp. 1-28: Briefe von Éllis an Metner (Jan. 1913 - Febr. 1914).

eд.xp. 29: Brief von Ėllis an Sizov (23. Nov. 1911).

eд.xp. 30: Brief von Ėllis an den Verlag "Сфинкс" (1. Febr. 1912).

eд.xp. 31: Brief von Ellis an eine unbekannte Adressatin [1908-1911].

\section{Ф. 167 Метнер, Э.К. картон $\mathcal{N} 9$}

eд.xp. 8: Telegramm von Ellis an den Verlag "Musaget" (10. Okt. 1913).

ea.xp. 11: Dossier von Metner über "Vigilemus!" (Dez. 1913).

\section{Ф. 167 Метнер, Э.К. картон 스 10}

eд.xp. 1: Ėllis: Symbolistisches Drama "Канатый плясун".

eд.xp. 2: Ellis: Phantasiestück "Духн Лазурн".

ed.xp. 3: Ellis zum Symbolismus in Frankreich und Belgien.

eд.xp. 4: Ellis über Baudelaire.

ed.xp. 5: Ellis: Notizen zum Symbolismus in Frankreich und Belgien.

eд.xp. 6: Ellis: Notizen zu Wagner.

ed.xp. 7: Ellis: Notizen zum Vortrag über Symbolismus in Frankreich.

ed.xp. 8: Ellis: Notizen zur Arbeit über den Symbolismus.

ed.xp. 12: Ellis: Übersetzung "Dante theosophicus" (1913).

ed.xp. 13: Ellis: Gedichte (K.B.R. gewidmet).

ед.xp. 15: Ellis: Gedichte "Цветок", "Ручей", "Заря".

ed.xp. 16: Ellis: Tagebuch 1905.

ed.xp. 17: Ellis: "Meine Ästhetik" (Notizbuch) [1905-1908?].

eд.xp. 18: Ëllis: Notizbuch (1909-1910).

ed.xp. 19-20: Ellis: Notizbuch ...

eд.xp. 21: Elllis: Notizbuch (Materialien zum Märchenbuch ...).

ea.xp. 22: Ellis: Notizbuch.

ea.xp. 23: Ëllis: Notizbuch "Lermontov".

ed.xp. 24: Ellis: Notizen ...

Ф. 167 Metwep, 3.K. картон № 11

ed.xp. 1-2: Ėllis: "Intermediarius" (Übersetzung aus dem Deutschen). 
Ф. 167 Metwep, Э.K. картон N 13

ea.xp. 6-7: Metner: Briefe an verschiedene Adressaten, danunter etliche an Ëllis (Okt. 1912 Dez. 1913).

ea.xp. 8: Metner: Brief an Belyj (10. April 1915). [Betriffi u.a. die Polemik Metner-Belyj anläßlich R. Steiners Lehre]

ed.xp. 15: Metner: Brief an Ellis (17. Juli 1917).

\section{Ф. 167 Метнер, Э.К. картон $\mathcal{N} 14$}

ed.xp. 67: Brief von Ėllis an I.A. Il'in (17. April 1917).

ed.xp. 68: Brief von Ėllis an Pašukanis (7. April 1917).

ed.xp. 69: Brief von Ëllis an alle "Musaget"-Mitarbeiter (7. April 1917).

Ф. 167 Метнер, Э.К. картон N6 26

ed.xp. 18: Brief von Ëllis an das Redaktionskomitée des Verlags "Musaget" (1910-e gg.)

Ф. 190 "MycareT", Кн-во хартон $\mathbf{N 2} 34$

ed.xp. 6: Éllis: Gedichte aus "Apro" und Anmerkungen [1913].

\section{Ф. 190 "Mусагет" хартон No 36}

ea.xp. 16: Kostenvoranschlag zum Druck von "Vigilemus!" (Sept. 1913).

eд.xp. 19: Kiselev: Aufzeichnungen für seine Rede anläßlich des Drucks von Ëllis' "Vigilemus!" [1914].

Ф. 190 "Mycaret" картон № 37

ex.xp. 6: Ellis: Gedichte aus "Stigmata", die nicht in den Band eingegangen sind.

Ф. 190 "Mycaret" картон 1338

eд.xp. 2: Bibliographie von Elllis' Aufsätzen und Arbeiten, zusammengestellt von Kiselev [1910-e gg.].

Ф. 190 "Mycaret" картон 스 49

ea.xp. 6: Ëllis: Über die Aufgaben und Ziele des Verlags "Musaget" (1912).

Ф. 190 "Mycaret" картон № 55

ед.xp. 15: Ëllis: Über die Aufgaben des Verlags "Musaget" [1910].

\section{Ф. 190 "Mycaret" картон № 71}

ed.xp. 10: Brief von A. Luther an Metner (27. Okt. 1913). [Betrifft: Anmerkungen Luthers anläßlich eines Ëllis-Aufsatzes]

\section{Ф. 219 Орловы-Давыдовы картон 스 69}

eд.xp. 23: Brief von Ëllis an Orlov-Davydov auf Franzäsisch.

\section{Ф. 386 А рхив Брносова В.Я. картон Ne 18}

eд.xp. 1: Úbersetzung der Werke von Av. Isaakjan (1915-1916) [darunter eine Übersetzung von Ëllis].

Ф. 386 B.Я. Брносов картон Ne 77

ea.xp. 40: 2 Briefe von Blok an Ellis (1907).

Ф. 386 В.Я. Брносов картон $N 80$

ed.xp. 35: Brief von M. Vološin an Ëllis (4. Jan. 1908).

Ф. 386 В.Я. Брнсов картон $N 2109$

ea.xp. 44: Briefe von Éllis an Brjusov (1907-1910).

\section{Ф. 386 В.Я. Брюсов картон N2 122}

eд.xp. 8: 4 Eintrittskanten zu Vorträgen von Brjusov und Ėllis (1907). 
3. Materialien von Ellis aus Archiven in Rom:

\section{A. Archiv von Dmitrij V. Ivanov:}

Brief von Ėllis an D.S. Merežkovskij (1933[?] $)^{3}$.

3 Briefe von Ëllis an Vjac. Ivanov $(1936[?])^{4}$.

B. Bibliothek des Pontificium Collegium Russicum:

Manuskript von Ellis' unpubliziertem Lyrikband "Крест и Лира" (1920-1938): Пролог. Молитвы. Святые легенды. Рыцарскке баллады. Переводы из Данте, Петрарки, Микеланджело и др. 5

${ }^{3}$ Brief konnte von der Verfasserin nicht eingesehen werden.

${ }^{4}$ Die 3 Briefe an Ivanov wurden von A. Siskin zum Druck vorbereitet; die Verfasserin erhielt eine Kopie.

${ }^{5}$ Die Information über dieses Manuskript entnahm die Verfasserin dem Artikel von F. Poljakov: Neizvestnyj sbornik stichotvorenij i perevodov Ėllisa, a.a.O. 
4 G I P

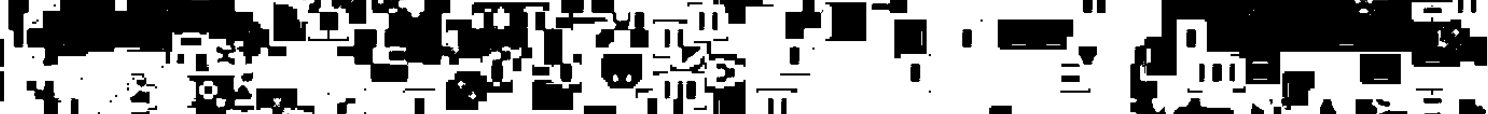

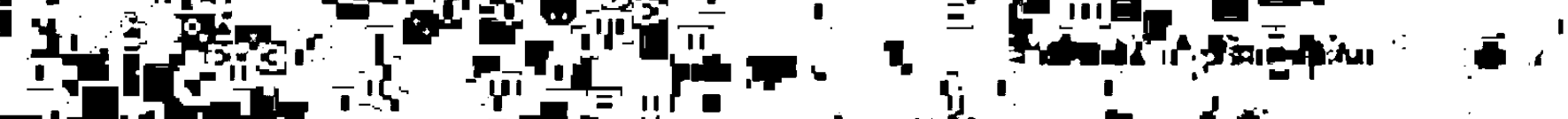
IA 然

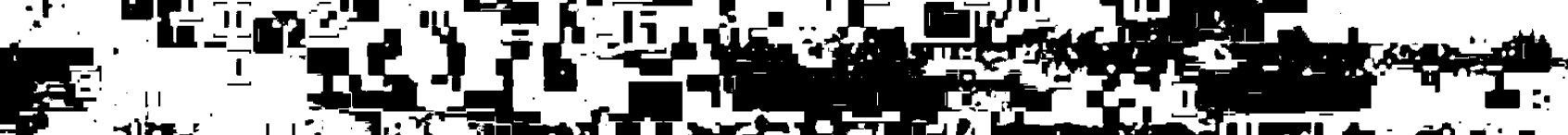
11

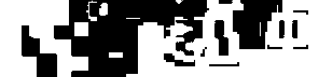

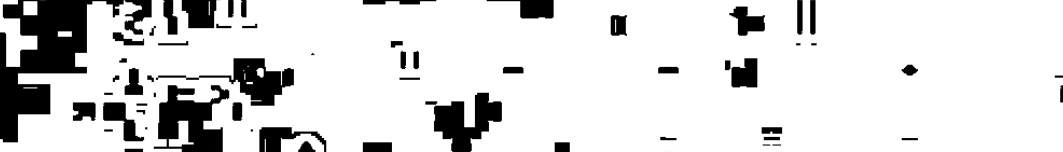

12

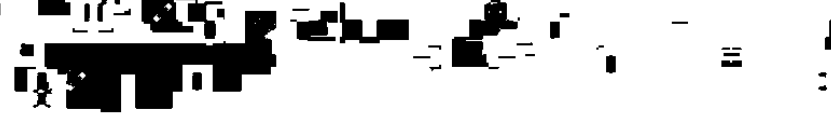

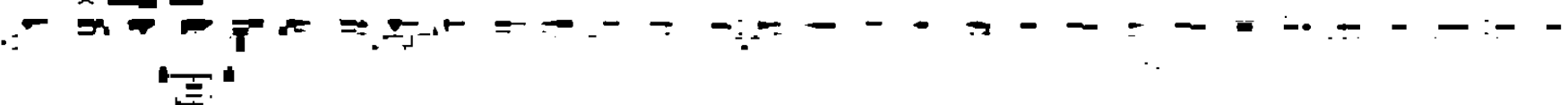
-...

$-\quad-{ }_{-}$

inivg

1آندي

1.2

$\therefore \mathbf{1}^{-0^{-}}$

$\stackrel{ \pm}{*}=$

$-\quad=$

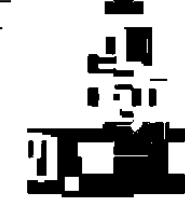

atrat

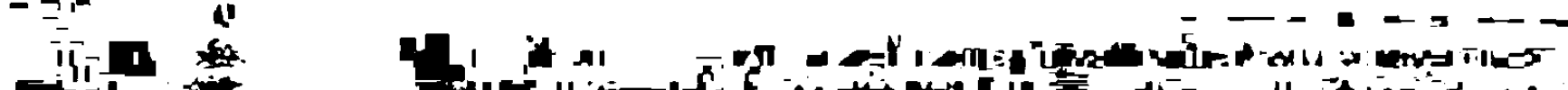

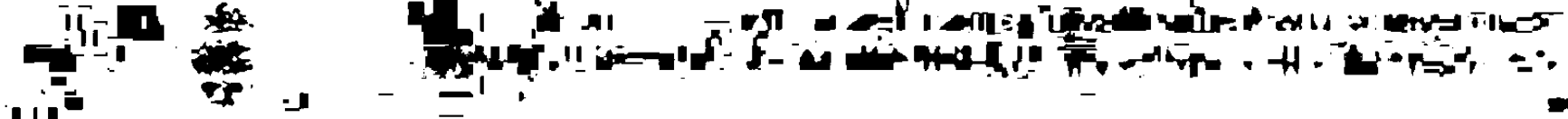

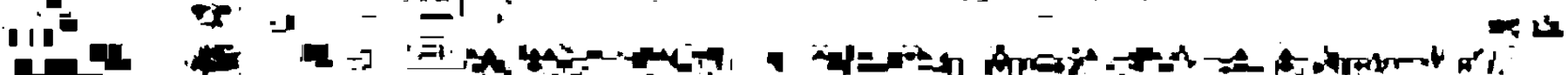

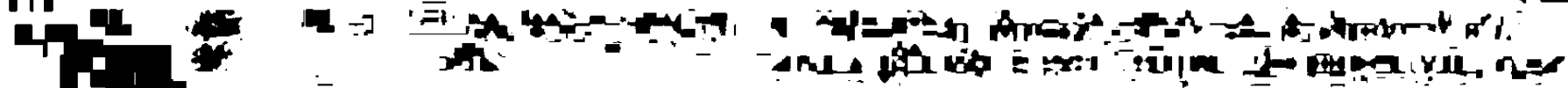
2. 10 Togl 


\section{Literaturverzeichnis}

\section{A. Werkausgaben}

\section{a. Russische Symbolisten; VI. Solov'ev}

BAL'MONT, Konstantin: Lzbrannoe. Stichotvorenija, perevody, stati. - Moskva. 1983.

BELYJ, Andrej: Kotik Letaev. - München, 1964 (= Nachdruck der Ausgabe: Petrograd, 1922).

BELYJ, Andrej: Lug Zelenyj. - New York, London, 1967. (= Slavic Series, 5).

BELYJ, Andrej: Arabeski. - München, 1969.

BELYJ, Andrej: Simvolizm. - München, 1969.

BELYJ, Andrej: Počemu ja stal simvolistom i počemu ja ne perestal im byt' vo vsech fazach moego idejnogo i chudožestvennogo razvitija. - Ann Arbor, 1982.

(Deutsche Übersetzung von Sigrun Bielfeldt: A. Belyj: Ich, ein Symbolist. Eine Selbstbiographie. - Frankfur/M., 1987).

BELYJ, Andrej: Kritika, éstetika, teorija simvolizma v dvuch tomach. - Moskva. 1994.

BELYJ, Andrej: Simvolizm kak miroponimanie. - Moskva, 1994.

BEL YJ, Andrej: Sobranie soðinenij. T. 1: Stichotvorenija i poemy. T. 2: Peterburg. - Moskva, 1994. T. 3: Serebrjanyj golub'. T. 4: Vospominanija o Bloke. - Moskva, 1995.

BLOK, Aleksandr A.: Sobranie soxinenij v vos'mi tomach. - Moskva, 1960-1963.

BRJUSOV, Valerij Ja.: Sobranie sox̌inenij v semi tomach. - Moskva, 1973-1975.

BRJUSOV, Valerij Ja.: Sredi stichov. 1894-1924. Manifesty - stat'i - recenzii. - Moskva, 1990.

CULKOV, Georgij I.: O mističeskom anarchizme. - St.-Peterburg, 1906 (Nachdruck: Letchworth, 1971).

CVETAEVA. Marina: Stichotvorenija i poemy v pjati tomach. Tom I. Stichotvorenija 19081916. - New York. 1980.

IVANOV. Vjačeslav: Sobranie sočinenij. Tom I-IV. - Brjussel', 1971-1987.

MEREŽKOVSKIJ, Dmitrij S.: Veznye sputniki. Portrety iz vsemimoj literatury. - S.-Peterburg. ${ }^{3} 1910$.

MEREZKOVSKL, Dmitrij S.: O pričinach upadka i o novych teðenijach sovremennoj russkoj literatury. - In: Ders.: lzbrannye stat'i. Somvolizm. Gogol'. Lermontov. - München, 1972 (= Nachdruck der Bände 10 u. 15 der Werkausgabe: S.-Peterburg - Moskva, 1911/1912), S. 209-305).

MÜLLER, L., WILLE. I. (Hrsg.): Solowjews Leben in Briefen und Gedichten. - München. 1977.

SOLOGUB, Fedor: Stichotvorenija. - Leningrad. 1978.

SOLOVJEFF, Wladimir: Ausgewählte Werke. Aus dem Russischen von Harry Köhler. 4 Bände. - Stuttgart, 1921-1922.

SOLOVEV, Vladimir S.: Sobranie sočinenij. Tom 1-12. - Brjussel', 1966-1970.

SOLOVEV, Vladimir S.: Čtenija o Bogozelovečestve. Stat'i. Stichotvorenija i poéma. Iz "Trech razgovorov". - Sankt-Peterburg, 1994.

SOLOWJEW, Wladimir. Deutsche Gesamtausgabe. Bd. 1-8 und Ergänzungsband (gezählt als Bd. 9). - Freiburg i.Br., München, 1953-1980.

SOLOWJEW. Wladimir: Schriften zur Philosophie, Theologie und Politik. Werkausgabe. Mit einer biographischen Einleitung und Erläutenungen von Ludolf Müller. - München. 1991.

\section{b. Nichtrussische Autoren}

INTERMEDIARIUS: Christliche Theologie und Cosmosophie nach dem Zeichen des heiligen Graal. - Leipzig, 1914.

INTERMEDIARIUS: Homo Coelestis. Das Urbild der Menschheit. Per Crucem ad Rosam. Basel, 1918. 
INTERMEDIARIUS: Universum. Der Cosmos und der cosmische Mensch. Liber mundi. Per Crucem ad Rosam. - Basel, 1923.

INTERMEDIARIUS: Das große Zeichen. Arcana sapientiae. Per Crucem ad Rosam. - Basel, 1927.

NIETZSCHE. Friedrich: Das Hauptwerk. Bd. 1-4. - München. 1990.

SCHOPENHAUER, Arthur: Werke in einem Band. - München, Wien, 1982.

STEINER, Rudolf: Philosophie und Anthroposophie. Gesammelte Aufsätze 1904-1918. Domach/Schweiz, 1965.

STEINER, Rudolf: Der Zusammenhang des Menschen mit der elementarischen Welt. Kalewala - Olaf Asteson - Das russische Volkstum. Die Welt als Ergebnis von Gleichgewichtswirkungen. - Domach/Schweiz, 1968.

STEINER, Rudolf: Anthroposophische Leitsätze. Der Enkenntnisweg der Anthroposophie. Das Michael-Mysterium. - Domach/Schweiz. 1976.

STEINER, Rudolf: Reinkamation und Karma. Wie Karma wirkt. - Domach/ Schweiz, 1978.

STEINER. Rudolf: Theosophie. Einfuihrung in übersinnliche Welterkenntnis und Menschenbestimmung. - Domach/Schweiz. 1980.

STEINER, Rudolf: Die Philosophie der Freiheit. Grundzüge einer modemen Weltanschauung. Seelische Beobachtungsresultate nach naturwissenschaftlicher Methode. - Domach/ Schweiz, 1981.

STEINER, Rudolf: Mein Lebensgang. Eine nicht vollendete Autobiographie, mit einem Nachwort herausgegeben von Marie Steiner 1925. - Dornach/Schweiz, 1986.

WAGNER. Richard: Dichtungen und Schriften. Jubiläumsausgabe in zehn Bänden. Herausgegeben von Dieter Borchmeyer. - Frankfur/M., 1983.

\section{B. Bibliographien, Literaturgeschichten, Nachschlage- und Sammelwerke}

BJALIK, B.A. (Hrsg.): Russkaja literatura konca XIX - načala XX veka. I. Devjanostye gody. II. 1901-1907. III. 1908-1917. - Moskva, 1968-1973.

CEREPACHOV, M.S., FINGERIT, E.M. (Hrsg.): Russkaja periodičeskaja pecat' (1895 oktjabr' 1917). Spravočnik. - Moskva, 1957.

DOLGOPOLOV, L.: Na rubeže vekov. O russkoj literature konca XIX-ogo - načala XX-ogo veka. - Leningrad, 1985.

DÜWEL, W., GRASSHOFF, H. (Hrsg.): Geschichte der nussischen Literatur von den Anfängen bis 1917. Band 1-2. - Berlin (O), 1986.

Istorija dorevoljucionnoj Rossii v dnevnikach i vospominanijach. Annotirovannyj ukazatel' knig i publikacij v žumalax. Tom 4, Cast' 4, 1895-1917. - Moskva, 1986.

Istorija russkoj dramaturgii. Vtoraja polovina XIX - načala XX veka (do 1917 g.). - Leningrad, 1987.

Istorija russkoj literatury $\mathbf{v}$ ¿etyrech tomach. Tom 2: $O$ t sentimentalizma $\mathbf{k}$ romantizmu $\mathrm{i}$ realizmu. Tom 4: Literatura konca XIX - načala XX veka (1881-1917). - Leningrad, 19811983.

KASACK, Wolfgang: Lexikon der russischen Literatur des 20. Jahrhunderts. Vom Beginn des Jahthunderts bis zum Ende der Sowjetära. - München, ${ }^{2} 1992$.

KELDYS, V.A. (Hrsg.): Svjaz' vremen. Problemy preemstvennosti v russkoj literature konca XIX - načala XX v. - Moskva, 1992.

KLE் (Kratkaja Literatumaja Ėncyklopedija). Tom 1-9. - Moskva, 1962-1978.

KOZMIN, B.P. (Hrsg.): Pisateli sovremennoj épochi. Bio-bibliografičeskij slovar' russkich pisatelej XX veka. - Moskva, 1992 (nach der Ausgabe von 1928).

Literatumo-chudožestvennye al'manachi i sbomiki. Bibliografið̌eskij ukazatel'. T. $1:$ 1900-1911. T. 2: 1912-1917. T. 3: 1918-1927. T. 4: 1928-1937. - Moskva. 1957-1960.

Literatumyjprocess i usskaja žumalistika konca XIX - načala XX veka. 1890-1904. Socialdemokratičeskie i obščedemokratið̌eskie izdanija. - Moskva, 1981. 
Literatumyj process i russkaja žumalistika konca XIX - načala XX veka. 1890-1904. Buržuazno-liberal'nye i modemistskie izdanija. - Moskva, 1982.

MOSER, Ch.A. (Ed.): The Cambridge History of Russian Literature. - Cambridge, ${ }^{2} 1992$.

MURATOVA, K.D. (Hrsg.): Istorija russkoj literatury konca XIX - načala XX veka. Bibliograficeskij ukazatel'. - Moskva - Leningrad, 1963.

MURATOVA, K.D. (Hrsg.): Istorija russkoj literatury XIX - načala XX veka. Bibliografizeskij ukazatel'. Obš̌̉aja Cast'. - S.-Peterburg, 1993.

Russkaja filosofija. Slovar'. Pod obక̌xej redakciej M.A. Maslina. - Moskva, 1995.

Russkaja literatura i žumalistika načala XX veka. 1905-1917. Bol'ševistskie i ob̌̌čedemokraticeskie izdanija. (Red.: B.A. Bjalik). - Moskva, 1984.

Russkaja literatura i žumalistika načala XX veka. 1905-1917. Buržuazno-liberal'nye i modernistskie izdanija. (Red.: B.A. Bjalik). - Moskva, 1984.

Russkie pisateli. 1800-1917. Biograficeskij slovar'. Tom i: A-G. Tom 2: G-K. Tom 3: K M. - Moskva, 1989-1994.

Russkie sovetskie pisateli. Poèty. Bibliograficeskij ukazatel'. Tom 1-14. - Moskva, 1977-1991 (wird fortgesetzt).

SOKOLOV, A.G.: Istorija russkoj literatury konca XIX - načala XX veka. - Moskva, ${ }^{3} 1988$.

STENDER-PETERSEN, Adolf: Geschichte der russischen Literatur. - München, ${ }^{3} 1978$.

TERRAS, Victor (Hrsg.): Handbook of Russian Literature. - New Haven and London, 1985.

TERRAS, Victor: A History of Russian Literature. - New Haven and London, 1991.

TSCHIŻEWSKIJ, Dmitrij: Russische Literaturgeschichte des 19. Jahrhunderts. I: Die Romantik. - München, 1977.

C. Sozio-ökonomischer, historischer, politischer, religions-, kultur- und geistesgeschichtlicher Hintergrund

BAER, Joachim T.: Arthur Schopenhauer und die nussische Literatur des späten 19. und frühen 20. Jahrhundens. - München, 1980 (= Slavistische Beiträge, Bd. 140).

IRezension dazu von Peter Thiergen: In: Kritikon litteranm. Intemationale Rezensionszeitschrift für Romanistik, Slavistik, Anglistik und Amerikanistik und für Linguistik, Heft 1-4, 12. Jg. 1983, S. 42-45.]

BARTLETT, Rosamund: Wagner and Russia. - Cambridge, 1995.

CARLSON, Maria: "No Religion higher than Truth". A History of the Theosophical Movement in Russia. 1875-1922. - Princeton. New Jersey, 1993. [Rezension dazu von R.v. Maydell in: Zeitschrift für Slawistik, Bd. 40, 1995, 1, S. 103-107.]

CLOWES, Edith Whitehill: A Philosophy "For All and None": The early Reception of Friedrich Nietzsche's Thought in Russian Literature, 1892-1912. - Yale University, 1981 (Ph.D.).

CLOWES, Edith Whitehill: The Revolution of Moral Consciousness. Nietzsche in Russian Literature, 1890-1914. - Illinois, 1988.

DEPPERMANN, Maria: Rußland um 1900: Reichtum und Krise einer Epoche im Umbruch. In: Musik-Konzepte 37/38. Aleksandr Skrjabin und die Skrjabinisten II. - München, Juli 1984, S. 61-106.

DEPPERMANN, Maria: Protest und VerheiBung. Zur Bedeutung Friedrich Nietzsches für die Kultur des Fin de siècle in RuBland. - In: Colloquium Helveticum. Schweizer Hefte für allgemeine und vergleichende Literaturwissenschaft 10, 1989, S. 61-88.

DEPPERMANN. Maria: Nietzsche in RuBland. - In: Nietzsche-Studien. Intemationales Jahrbuch für die Nietzsche-Forschung, Bd. 21. - Berlin - New York, 1992, S. 211-252.

DURYLIN, Sergej: Richard Vagner i Rossija. O Vagnere i buduščich putjach iskusstva. Moskva, 1913.

ESIN, B.I. (Hrsg.): Iz istorii russkoj žumalistiki načala XX veka. - Moskva, 1984.

FRENZEL, Ivo: Friedrich Nietzsche mit Selbstzeugnissen und Bilddokumenten. - Reinbek bei Hamburg, 1994. 
GOZENPUD, A.: Richard Vagner i russkaja kul'tura. Issledovanie. - Leningrad, 1990.

GOERDT, Wilhelm: Russische Philosophie. Zugänge und Durchblicke. - Freiburg, München. 1984.

GUENTHER. Johannes von: Ein Leben im Ostwind. Zwischen Petersburg und München. Erinnerungen. - München. 1969.

HAHL-KOCH, Jelena: Marianne Werefkin und der russische Symbolismus. Studien zur Ästhetik und Kunsttheorie. - München. 1967 (= Slavistische Beiträge, 24).

KLEBERG, Lars, NILSSON, Nils A. (Hrsg.): Theater and Literature in Russia 1900-1930. A Collection of Essays. - Stockholm, 1984.

KLUGE. Rolf-Dieter: Der russische Spätrealismus (1880-1920). Überblick - Bibliographie Kommentar. Eine Arbeitshilfe für Studium und Lehre. - Tübingen, 1993 (= Skripten des Slavischen Seminars der Universität Tübingen, Nr. 29).

KLUGE, Rolf-Dieter, SETZER, Heinz (Hrsg.): Tausend Jahre Russische Kirche. 988-1988. Geschichte, Wirkungen, Perspektiven. - Tübingen, 1989.

KREJD, Vadim (Hrsg.): Vospominanija o serebrjanom veke. - Moskva, 1993.

LAUER. Hans E.: Der Kulturimpuls der deutschen Klassik. Urbild und Erdengestalt - zugleich ein Beitrag zu den Zukunftsaufgaben der europäischen Mitte. - Schaffhausen. 1974.

LINDENBERG. Christoph: Rudolf Steiner. Eine Chronik 1861-1925. - Stuttgart. 1988.

LINDENBERG, Christoph: Rudolf Steiner mit Selbstzeugnissen und Bilddokumenten. Reinbek. 1992.

L.OSSKU, N.O.: Istorija russkoj filosofii. - Moskva. 1991.

MacLAUGHLIN, Sigrid: Schopenhauer in Rußland. Zur literarischen Rezeption bei Turgenev. - Wiesbaden. 1984 (= Opera Slavica, NF Bd. 3).

MASARYK. Th.G.: Russische Geistes- und Religionsgeschichte. Bd. 1-2. (Neuaufl. des 1913 erstmals erschienenen Werks. Nachwor von K. Schlögel). - Frankfun, 1992.

MAYDELL, Renata von: Dornach als Pilgerstätte der russischen Anthroposophen. - In: K. Schlögel (Hrsg.): Russische Emigration in Deutschland 1918-1941. Leben im europäischen Bürgerkrieg. - Berlin. 1995, S. 295-303.

MAYER, Hans: Richard Wagner mit Selbstzeugnissen und Bilddokumenten. - Hamburg, 1992.

METNER. E.K. $\rightarrow$ VOL'FING

MÜLLER, Ludolf: Nietzsche und Solovjev. - In: Zeitschrift für Philosophische Forschung. Hg. Georgi Schischkoff, 1946, Bd. 1, S. 499-520.

MÜLLER, Ludolf: Solovjev und der Protestantismus. Nachwon von WI. Szylkarski. - Freiburg. 1951.

OBERLÄNDER. E. u.a. (Hrsg.): Rußlands Aufbruch ins 20. Jahthundert. Politik - Gesellschaft - Kultur. 1894-1917. - Olten. Freiburg/Breisgau. 1970.

ROSENTHAL. Bemice Glatzer (Hrsg.): Nietzsche in Russia. - Princeton/NJ, 1986.

SCHERRER. Jutta: Die Petersburger religiös-philosophischen Vereinigungen. Die Entwicklung des religiösen Selbstverständnisses ihrer Intelligencija-Mitglieder (1901-1917). - Berlin. 1973 (= Forschungen zur osteuropäischen Geschichte, 19).

SCHRAMM, G., HELLMANN, M., ZERNACK. K.: Handbuch der Geschichte Rußlands. Bd. 3: 1856-1945. Von den autokratischen Reformen zum Sowjetstaat. - Stuttgart, 1983.

Serebrjanyj vek. Memuary. - Moskva. 1990.

SOLOVIEV, Alexander V.: Holy Russia. The History of a religious-social Idea. - S'Gravenhage, 1959.

STERNIN, G.Ju.: Das Kunstleben Rußlands an der Jahrhundertwende. - Dresden, 1976.

STERNIN, G.Ju.: Das Kunstleben Rußlands zu Beginn des 20. Jahrhundens. - Dresden. 1980.

STERNIN, G.Ju.: Russkaja chudožestvennaja kul'tura vtoroj poloviny XIX - načala XX veka. - Moskva. 1984.

STERNIN, G.Ju.: Chudožestvennaja žizn' Rossii 1900-1910-ch godov. - Moskva. 1988.

STÖKL. G.: Russische Geschichte von den Anfängen bis zur Gegenwant. - Sturtgart, 21965 ( $\left.{ }^{5} 1990\right)$. 
TSCHIŽEWSKIJ, D.: Russische Geistesgeschichte. -2. erw. Aufl. München. 1974.

VOLFING (Ė.K. Metner]: Modemizm i muzyka. Stat'i kritičeskie i polemið̌eskie (1907-1910). Priloženija (1911). - Moskva, 1912.

WACHSMUTH, Guenther: Rudolf Steiners Erdenleben und Wirken. Von der Jahrhundenwende bis zum Tode. Die Geburt der Geisteswissenschaft. Eine Biographie. - Dornach/ Schweiz, ${ }^{2} 1951$.

Wir erlebten Rudolf Steiner. Erinnerungen seiner Schüler. - Stuttgant. ${ }^{7} 1988$.

ZEN'KOVSKUJ, V.V.: Istorija russkoj filosofii v dvuch tomach. - Leningrad. 1991.

D. (Russischer) Symbolismus (Modernismus): Gesamtdarstellungen und Spezialuntersuchungen zu Theorie, Geschichte und ausgewählten Problemen

ALTHAUS-SCHÖNBUCHER, S.: Konstantin D. Bal'mont. Parallelen zu Afanasij A. Fet. Symbolismus und Impressionismus. - Bem, Frankfurt/M., 1975.

AVERIN, B., BAZANOVA, D. (Hrsg.): Kniga o Vladimire Solov'eve. - Moskva, 1991.

BARTLETT, Rosamund: Ivanov and Wagner. - In: W. Potthoff (Hrsg.): Vjaceslav Ivanov Russischer Dichter und europäischer Kulturphilosoph. - Heidelberg, 1993, S. 67-83.

BÜRGER, Peter. Theorie der Avantgarde. - Frankfur/M., 1974.

BURAGO, S.B.: Blok i Vagner. (Koncepcija Celoveka i éstetičeskaja pozicija). - In: lzvestija AN SSSR. Serija literatury i jazyka, 43, 1984, 6. S. 522-536.

CARLSON, M.: Ivanov - Belyj - Minclova: the Mystical Triangle. - In: Cultura e memoria. Atti del Terzo Simposio Intemationale dedicato a Vjaceslav Ivanov. Vol. I, a cura di F. Malcovati. - Firenze, 1988, S. 63-79.

CIORAN, Samuel D.: The Apocalyptic Symbolism of Andrej Belyj. - The Hague, 1973 [= Slavistic printings and reprintings, 274].

CIORAN, Samuel D.: Vladimir Solov'ev and the Knighthood of the Divine Sophia. - Waterloo, Ontario, Canada, 1977.

DEPPERMANN, Maria: Andrej Belyjs ästhetische Theorie des schöpferischen BewuBtseins. Symbolisienung und Krise der Kultur um die Jahrhunden wende. - München, 1982 (= Slavistische Beiträge, 150).

DONCHIN, Georgette: The Influence of French Symbolism on Russian Poetry. - S'Gravenhage, 1958.

EBERT, Christa: Symbolismus in Rußland. Zur Romanprosa Sologubs, Remisows, Belys. Berlin. 1988.

EGEBERG, Erik: Romantizm i simvolizm. - In: Russian Literature, XXXVIII-II, 1995, S. $149-156$.

ERMILOVA. E.V.: Teorija i obraznyj mir russkogo simvolizma. - Moskva. 1989.

FLAKER, Aleksandar: Die slavischen "Modemen". - In: Klaus von See (Hrsg.): Neues Handbuch der Literaturwissenschaft. Band 18: Jahrthundertende - Jahshundertwende (I. Teil). Wiesbaden. 1976, S. 331-358.

FLAKER, Aleksandar. Die slavischen Literaturen zur Zeit des Modernismus. Das Auftreten der Avantgarde und des Expressionismus. - In: Klaus von See (Hrsg.): Neues Handbuch der Literaturwissenschaft. Band 19: Jahrhundentende - Jahrhundertwende (II. Teil). - Wiesbaden. 1976. S. $391-428$.

FLAKER, A., UGREŠČ D. (Hrsg.): Pojmovnik ruske avangarde 1-6. - Zagreb, 1984-1989.

FLAKER, Aleksandar: Die russische Avantgarde. - In: Ders. (Hrsg.): Glossarium der russischen Avantgarde. Graz - Wien, 1989, S. 11-47.

FRIEDRICH, Hugo: Die Struktur der modernen Lyrik. Von der Mitte des neunzetnten bis zur Mitte des zwanzigsten Jahrhunderts. - Reinbek bei Hamburg. 1992.

GOFMAN, M.: Poety simvolizma. Kniga o russkich poetach poslednego desjatiletija. München, 1970 (= Nachdruck der Ausgabe: S.-Peterburg - Moskva, 1908). 
GROSSMAN, Joan D.: Briusov's Defense of Poetry And the Crisis of Symbolism. - In: J. Douglas Clayton (Ed.): Issues in Russian Literature before 1917. - Columbus/Ohio, 1989, S. 196-204.

HANSEN-LÖVE, Aage A.: Zum ästhetischen Programm des russischen Friihsymbolismus. In: Sprachkunst, XV, 1984, 2, S. 239-329.

HANSEN-LÖVE, Aage A.: Der russische Symbolismus. System und Entfaltung der poetischen Motive. Bd. 1: Diabolischer Symbolismus. - Wien, 1989.

HANSEN-LÖVE, Aage A.: Weg und Ziel. Zum System der Bewegung im russischen Symbolismus der Jahhundertwende. - In: Wiener Slawistischer Almanach, 23, 1989, S. 151-174.

HESSE, Petra: Mythologie in modemer Lyrik: Osip E. Mandel s̃tam vor dem Hintergrund des "Silbernen Zeitalters". - Bem, Frankfurt/M., New York, Paris, 1988.

HINTERHÄUSER, Hans: Fin de siècle. Gestalten und Mythen. - München, 1977.

HÖNNIGHAUSEN, Lothar: Präraphaeliten und Fin de Siècle. - München, 1971.

HOFFMANN, Paul: Symbolismus. - München, 1987.

HOLTHUSEN, Johannes: Studien zur Ästhetik und Poetik des russischen Symbolismus. Göttingen, 1957.

JACKSON, Robert Louis, NELSON, Lowry, Jr. (Hrsg.): Vyacheslav Ivanov: Poet. Critic and Philosopher. - New Haven. 1986 (= Yale Russian and East European Publications).

KLEBERG. Lars: Vjaceslav Ivanov and the Idea of Theater. - In: L. Kleberg, N. $\AA$. Nilsson (Hrsg.): Theater and Literature in Russia 1900-1930. A Collection of Essays. - Stockholm, 1984, S. 57-70.

KLUGE, Rolf-Dieter: Westeuropa und Rußland im Weltbild Aleksandr Bloks. - München, 1967 (= Slavistische Beiträge, 27).

KLUGE, Rolf-Dieter: Zur Deutung der Musik in der Dichtungstheorie einiger russischer Romantiker und Symbolisten. - In: Die Musikforschung. - Kassel und Basel, 1969, S. 13-22.

KLUGE, Rolf-Dieter: Wie funktionien ein symbolistisches Gedicht? Zu Aleksandr Bloks "Schneemaske". - In: Zeitschrift für slavische Philologie, XIII, Heft 2, 1981, S. 261-273.

KLUGE, Rolf-Dieter: Zur Theorie des russischen Symbolismus: A. Blok und F. Nietzsche. Zum Stand der Diskussion. - In: Literatur und Sprachentwicklung in Osteuropa im 20. Jahrhunden. Hrsgg. von Ebertard Reißner. - Berlin, 1982, S. $79-88$ (= Osteuropaforschung. 4).

KLUGE. Rolf-Dieter: Symbolismus und Avantgarde in der russischen Literatur. - In: Obdobje simbolizma v slovenskom jeziku, književnosti in kulturi (tipolołka problematika ob jugoslovanskem in šiř̌em evropskem kontekstu). Prvi del. - Ljubljana, 1983, S. 229-239.

KLUGE. Rolf-Dieter: Majakowskij. Mysterium buffo. - In: B. Zelinsky (Hrsg.): Das russische Drama. - Diisseldorf, 1986, S. 252-263, 396f.

KLUGE. Rolf-Dieter: Balagancik and Misterija-Buff: A Structural Comparison of Russian Symbolist and Avant-Garde Drama. - In: Donskov, Andrew and Richard Sokoloskj (ed.): Slavic Drama. The Question of Innovation. - Ottawa, 1991, S. 157-164.

KLUGE, Rolf-Dieter: "Der russische Symbolismus". Bibliographie - Kommentar - Texte. Eine Arbeitshilfe für Studium und Lehre. - Tübingen, ${ }^{3} 1992$ (= Skripten des Slavischen Seminars der Universität Tübingen. Nr. 24).

KLUGE, Rolf-Dieter: Simvolizm i avangard v russkoj literature - Perelom ili preemstvennost'? - In: Litteraria humanitas II. Genologické studie. - Bmo, 1993, S. 151-160.

Ergänzte und erweiterte Fassung mit demselben Titel in: Literatumyj avangard. Osobennosti razvitija. - Moskva. 1993, S. 53-69.

KLUGE, Rolf-Dieter: Vjačeslav Ivanovs Beitrag zu einer symbolistischen Theorie der Literatur und Kunst als Schlüssel zum Verständnis seiner Aufsätze über Aleksandr Skrjabin. - In: Potthoff, W. (Hrsg.): Vjačeslav Ivanov - Russischer Dichter und europäischer Kulturphilosoph. - Heidelberg, 1993, S. 240-249.

KNIGGE, Armin: Die Lyrik VI. Solov'evs und ihre Nachwirkung bei A. Belyj und A. Blok. Amsterdam. 1973 (= Bibliotheca Slavonica. 12).

KOPPEN, Erwin: Dekadenter Wagnerismus. Studien zur europäischen Literatur des Fin de Siècle. - Berlin und New York, 1973.

LAGER, Roben John: Vladimir Soloviev - Symbolist Poet. - Washington, D.C., 1970. 
LANGER, Gudrun: Blok. Die Schaubude. - In: B. Zelinsky (Hrsg.): Das russische Drama. Duisseldorf, 1986, S. 224-238, 392-394.

LANGER, Gudrun: Kunst - Wissenschaft - Utopie. Die "Überwindung der Kulturkrise" bei V. Ivanov, A. Blok, A. Belyj und V. Chlebnikov. - Frankfurt/M., 1990.

Lica. Biograficeskij al'manach. - Moskva - S.-Peterburg, 1: 1992, 3: 1993, 5: 1994.

Literatumoe Nasledstvo. Tom 27/28. - Moskva, 1937.

MAKSIMOV, Dmitrij Evg.: Russkie poéty načala veka. - Leningrad, 1986.

MARKOV, VI.: Balmont. A Reappraisal. - In: Slavic Review, 28, 1969, 2, S. 221-264.

MASING-DELIC, Irene: The Symbolist Crisis Revisited: Blok's View. - In: J. Douglas Clayton (Ed.): Issues in Russian Literature before 1917. - Columbus/Ohio, 1989, S. 216-227.

MASLENIKOV, Oleg A.: The Frenzied Poets. Andrey Biely and the Russian Symbolists. Berkeley and Los Angeles, 1952.

Minuv̌̌ee. Istoričeskij al'manach. - Moskva, 3: 1991, 5: 1991, 6: 1992, 8: 1992, 9: 1992; Moskva - S.-Peterburg. 13: 1993, 14: 1994, 15: 1994.

MÚLLER-SCHOLLE, Christine: Das russische Drama der Modeme. Eine Einführung. Frankfurt/M. u.a., 1992.

PAPERNO, I., GROSSMAN, J.D. (Eds.): Creating Life. The Aesthetic Utopia of Russian Modernism. - Stanford/Calif., 1994.

PETERSON, Ronald E.: A History of Russian Symbolism. - Amsterdam/Philadelphia, 1993.

POTTHOFF, Wilfried: Zum Begriff des 'Überzeitlichen Symbolismus'. Am Beispiel der russischen Literatur. - In: Obdobje simbolizma v slovenskem jeziku, književnosti in kulturi. (Tipološka problematika ob jugoslovanskem in క̌iřem evropskem kontekstu). Drugi del. Ljubljana. 1983, S. 185-196.

POTTHOFF, Wilfried: Dante in RuBland. Zur Italienrezeption der russischen Literatur von der Romantik zum Symbolismus. - Heidelberg, 1991.

POTTHOFF, Wilfried (Hrsg.): Vjaceslav Ivanov - Russischer Dichter und europäischer Kulturphilosoph. - Heidelberg, 1993.

PYMAN, Avril: A History of Russian Symbolism. - Cambridge, 1994.

RASCH, Wolfdietrich: Die literarische Decadence um 1900. - München, 1986.

RAYFIELD, Donald: Celtic, Wagner and Blok. - In: A. McMillin (Ed.): Symbolism and After. Essays on Russian Poetry in Honour of Georgette Donchin. - Bristol, London, 1992, S. 1538.

REIBNER, Eberhard: A. Blok und R. Wagner. - In: Slavistische Studien zum VIII. Internationalen SlavistenkongreB in Zagreb 1978. - Köln. Wien, 1978, S. 417-426.

REIBNER, Eberhard: Andrejew. Das Leben des Menschen. - In: B. Zelinsky (Hrsg.): Das nussische Drama. - Düsseldorf, 1986, S. 213-223, 390f.

RICCI [Rizzi], Daniela: Richard Vagner v russkom simvolizme. - In: Serebrjanyj vek v Rossii. Izbrannye stranicy. - Moskva, 1993, S. 117-136.

RICE, M.P.: Valery Brjusov and the Rise of Russian Symbolism. - Ann Arbor, 1975.

RICHARDSON, William: "Zolotoe runo" and Russian Modernism: 1905-1910. - Ann Arbor, Michigan, 1986.

SCHMIDT, Alexander: Valerij Brjusovs Beitrag zur Literaturtheorie. Aus der Geschichte des nussischen Symbolismus. - München, 1963.

Serebrjanyj vek v Rossii. Izbrannye stranicy. - Moskva, 1993.

SMIRNOV, Igor' P.: Avangard i simvolizm. (Ėlementy postsimvolizma v simvolizme) - In: Russian Literature, North Holland, 23, 1988, S. 147-168.

SMIRNOV, Igor' P.: Simvolizm, ili isterija. - In: Russian Literature, North Holland, 36, 1994. S. $403-426$.

SOLOVEV, S.M.: Žjizn i tvořeskaja évoljucija Vladimira Solov'eva. - Brjussel', 1977.

STEINBERG, Ada: The Influence of Wagner on the Symbolists. A new Evaluation of the 'Word'. - In: Dies.: Word and Music in the Novels of Andrey Bely. - Cambridge u.a., 1982. S. 24-31.

STEPHAN, V.: Studien zum Drama des russischen Symbolismus. - Frankfurt/M., Bem. 1980. 
STEPUN, F.: Vjačeslav Ivanovs Lehre vom realistischen (religiösen) und idealistischen Symbolismus. - In: Welt der Slaven. Jg. VIII, 1963, S. 225-233.

STEPUN, F.: Mystische Weltschau. Fünf Gestalten des russischen Symbolismus. - München. 1964.

STRIEDTER, Jurij: Transparenz und Verfremdung. Zur Theorie des poetischen Bildes in der nussischen Modeme. - In: Iser, W. (Hrsg.): Immanente Ästhetik. - München, 1966, S. 263296.

TSCHÖPL, Carin: Vjačeslav Ivanov. Dichtung und Dichtungstheorie. - München, 1968 (= Slavistische Beiträge. Bd. 30).

VENCLOVA. Tomas: Viacheslav Ivanov and the Crisis of Russian Symbolism. - In: J. Douglas Clayton (Ed.): Issues in Russian Literature before 1917. - Columbus/Ohio, 1989. S. 205-215.

WAAGE, Peter Normann: Der unsichtbare Kontinent. Wladimir Solowjow - der Denker Europas. - Stuttgan, 1988.

WELLEK, René: Das Wort und der Begriff Symbolismus in der Literaturgeschichte. - In: Ders.: Grenzziehungen. Beiträge zur Literaturkritik. (Deutsche Übersetzung). - Stuttgart, Berlin, Köln, Mainz, 1972, S. 64-83.

WENZLER, Ludwig: Die Freiheit und das Böse nach Vladimir Solov'ev. - Freiburg, München, 1978. [Rezension dazu von M. Deppermann in: Zeitschrift für Slavische Philologie, Bd. 47. 1987, S. 414-421.1

WEST, James: Russian Symbolism. A study of Vyacheslav Ivanov and the Russian symbolist aesthetic. - London, 1970.

\section{E. Literatur zu Ellis (Leben, Werk, Wirken, Umkreis)}

BELYJ, Andrej: Na rubeže dvuch stoletij. (Vstupitel'naja stat'ja, podgotovka teksta i kommentarii A.V. Lavrova). - Moskva, 1989.

BELYJ. Andrej: Načalo veka. (Podgotovka teksta i kommentarii A.V. Lavrova). - Moskva. 1990.

BELYJ. Andrej: Meždu dvuch revoljucii. (Podgotovka teksta i kommentarii A.V. Lavrova). Moskva. 1990.

BELYJ, Andrej: Vospominanija o A.A. Bloke. - München, 1969.

(Deutsche Übersetzung von Swetlana Geier: A. BELYJ: Im Zeichen der Morgenröte. Erinnenungen an Aleksandr Blok. - Basel. 1974).

BELYJ, Andrej: Vospominanija o Stejnere. - Paris, 1982.

(Deutsche Übersetzung von Swetlana Geier: A. BELYJ: Verwandeln des Lebens. Erinnerungen an Rudolf Steiner. - Basel, ${ }^{3} 1990$ ).

BEZRODNYJ, Michail V.: Zur Geschichte des russischen Neukantianismus. Die Zeitschrift "Logos" und ihre Redakteure. - In: Zeitschrift fuir Slawistik, 37, 1992/4, S. 489-511.

BLOK. Aleksandr i Andrej BELYJ: Perepiska. - Moskva, 1940.

A. Blok v vospominanijach sovremennikov. V dvuch tomach. - Moskva, 1980 (= Serija literatumych memuarov).

BRJUSOV, V.: Drevniki 1892-1910. - Moskva. 1927.

CVETAEVA, A.: Vospominanija. - Moskva, 1984.

(Deutsche Übersetzung von A. Kaempfe: ZWETAJEWA. Anastassja: Kindheit mit Marina. Roman einer Jugend. - Frankfurt/M., Berlin, 1992).

CVETAEVA. M.: Neizdannye pis'ma. (Red. G. und N. Struve). - Paris, 1972.

CVETAEVA, M.: Plennyj duch. (Moja vstreða s Andreem Belym). - In: Cvetaeva, M.: Socinenija v dvuch tomach. - Moskva, 1984; tom 2. S. 235-289.

ELSWORTH. J.D.: Andrey Bely. - Letchworth/Hentfordshire (England), 1972.

FEDJUSCHIN, Victor B.: Rußlands Sehnsucht nach Spiritualität. Theosophie. Anthroposophie, Rudolf Steiner und die Russen. Eine geistige Wanderschaft. - Schaffhausen (Schweiz). 1988. 
FEINSTEN, Elaine: Marina Zwetajewa. Eine Biographie. - Frankfun/M., 1993.

FRUMKINA, N.A., FLEJSMAN, L.S.: A.A. Blok meždu "Musagetom" i "Sirinom". - In: Blokovskij sbomik II. - Tartu, 1972, S. 385-397.

GARETTO, E. (Hrsg.): Żizn' i smert' Niny Petrovskoj. - Minuvšee. Istoričeskij al'manach, 8. Moskva, 1992, S. 7-138.

GRECISKIN, S.S., LAVROV, A.V.: Ėllis - poet-simvolist, teoretik i kritik (1900 - 1910-e gody). - In: XXV Gercenovskie čtenija (9). - Leningrad, 1972, S. 59-62.

IVANOVA. Lidija: Vospominanija: Kniga ob otce. (Podgotovka teksta i kommentarij Džona Mal'mstada). - Moskva, 1992.

KARLINSKY, Simon: Marina Tsvetaeva. The Woman, her World, and her Poetry. - Cambridge, 1985.

KLING, O.A.: Brjusov v "Vesach" ( $k$ voprosu o roli Brjusova v organizacii $i$ izdanii žumala). - In: Iz istorii russkoj žumalistiki načala XX veka. (Pod red. B.I. Esina). - Moskva, 1984.

LAVROV, A.V.: Brjusov i Ėllis. - In: Brjusovskie Čtenija 1973 goda. Erevan, 1976, S. 217236.

LAVROV, A.V.: Mifotvorčestvo "Argonavtov". - In: Mif - Fol'klor - Literatura (Red. V.G. Bazanov). - Leningrad. 1978, S. 137-170.

LA VROV, A.V.: Pis'ma Éllisa k Bloku (1907). - In: Literatumoe Nasledstvo, tom 92, kn. 2. Moskva, 1981, S. 273-291.

LAVROV, A.V.: "Trudy i dni". - In: Russkaja literatura i žumalistika načala XX veka. 19051917. - Moskva. 1984, S. 191-211.

LAVROV, A.V.: Pis'mo Andreja Belogo k Ėllisu. - In: Lica. Biografičeskij al'manach, 5. 1994, S. 386-398.

LAVROV, A.V.: Andrei Bely and the Argonauts' Mythmaking. - In: I. Paperno, J.D. Grossman (Eds.): Creating Life. The Aesthetic Utopia of Russian Modemism. - Stanford/Calif., 1994, S. 83-121.

LAVROV, A.V.: Andrej Belyj v 1900-e gody. Žizn' i literatumaja dejatel'nost'. - Moskva, 1995.

LAVROV, A.V., MAKSIMOV, D.E.: "Vesy". - In: Russkaja literatura u Žumalistika naðala XX veka. 1905-1917. - Moskva, 1984, S. 65-136.

Literatumoe Nasledstvo. Valerij Brjusov. Tom 85. - Moskva, 1976.

Literatumoe Nasledstvo. Valerij Brjusov i ego korrespondenty. Tom $98 \mathrm{v}$ dvuch knigach. Kniga 1: Moskva. 1991; kniga 2: Moskva. 1994.

Literatumoe Nasledstvo. Aleksandr Blok. Tom 92 v pjati knigach. Kniga 1: Moskva, 1980; kniga 2: Moskva, 1981; kniga 3: Moskva. 1982: kniga 4: Moskva, 1987; kniga 5: Moskva. 1993.

LJUNGGREN. Magnus: The Dream of Rebirth. A Study of Andrey Bely's Novel "Peterburg". - Stockholm (Sweden). 1982.

LJUNGGREN, Magnus: The Russian Mephisto. A Study of the Life and Work of Emilii Mediner. - Stockholm, 1994. [Rezensionen dazu: von K.Ju. Postoutenko in: Die Welt der Slaven, Jg. Xl, 1995, 2, S. 380-382; von R.v. Maydell u. M. Bezrodnyj in: Wiener Slawistischer Almanach. Bd. 36. 1995, S. 291-301.]

MAKSIMOV. D.E.: Brjusov. Poézija i pozicija. - Leningrad. 1969.

MALMSTAD, John E. (Hrsg.): Andrej Belyj i antroposofija. - In: Minuvšee. Istoriðeskij al'manach. Band 6: Moskva. 1992, S. 337-448; Band 8: Moskva, 1992, S. 409-471; Band 9: Moskva, 1992. S. 409-488.

(Deutsche Übersetzung von Christoph Hellmundt: A. BELYJ: Geheime Aufzeichnungen. Erinnerungen an das Leben im Umkreis Rudolf Steiners (1911-1915). - Domach. 1992.)

MAYDELL. R.v., BEZRODNYJ, M.: Neue Materialien über Ėmilij Metner. - In: Wiener Slawistischer Almanach. Bd. 36. 1995, S. 291-301.

METNER. N.K.: Pis'ma. (Sostavlenie i redakcija Z.A. Apetjan). - Moskva, 1973.

ORLOV, VI.: Puti i sudby. Literatumye očrki. - Leningrad, 1971.

PASTERNAK, L.O.: Zapisi raznych let. - Moskva. 1975. 
PEPITONI, Vera: Ellis-Kobylinskij L.L., poeta simbolisła. - Milano, 1987-1988 (unveröffentlichte Diplomarbeit].

PEPITONI, Vera: Ellis Kobilinskij tra Dante e Marx. - In: Dantismo Russo e comice Europea. Atti dei convegni di Alghero-Gressoney (1987). Il. - Firenze, 1989, S. 293-314.

PISKUNOV, V.M. (red.): Vospominanija ob Andree Belom. - Moskva, 1995.

Pis'ma Éllisa k Brjusovu i k Metneru. - In: Literatumoe Nasledstvo, tom 92, kn. 3. - Moskva, 1982, S. 291-292, S. 305-306, S. 316-317, S. 387-388, S. 559.

POLJAKOV, F.: Neizvestnyj sbomik stichotvorenij i perevodov Ėllisa (L. Kobylinskogo). In: Simvol, Nr. 28, (Paris) 1992, S. 279-294.

POSTOUTENKO, K.Ju.: Pis'ma S.P. Bobrova k Andreju Belomu 1909-1912. - In: Lica. Biograficeskij al'manach, 1, 1992, S. 113-169.

RAZUMOVSKY, Maria: Marina Zwetajewa. Eine Biographie. - Frankfun, 1989.

RIZZI, Daniela: Ėllis i Štejner. - In: Europa Orientalis, 14, 1995, 2, S. 281-294.

RIZZI, Daniela: Iz archiva V.A. Turgenevoj. Pis'ma Ėllisa, A. Belogo i A.A. Turgenevoj. - In: Europa Orientalis, 14, 1995, 2, S. 295-340.

SAAKJANC. Anna: Marina Cvetaeva. Stranicy žizni i tvoř̌estva. (1910-1922). - Moskva, 1986.

SAPOV, V. (Vstupitel'naja stat'ja, publikacija i kommentarii): V.I. Ivanov i Ė.K. Metner. Perepiska iz dvuch mirov. - In: Voprosy literatury, 2, 1994, S. 307-346; 3, 1994, S. 281-317. [Rezension dazu von R.v. Maydell u. M. Bezrodnyj in: Wiener Slawistischer Almanach, Bd. 36, 1995, S. 291-301.]

SOLOVEV, Boris: "Vesy" ili "Koran moskovskich upadoxnikov". - In: Ders.: Ot istorii k sovremennosti. Stat'i, ocerki, polemika. - Moskva, 1976, S. 140-185.

SPROGE, L.V.: Motiv "Rycarja Bednogo" v poézii simvolistov. (Organizacija chudožestvennogo edinstva knigi stichov Ėllisa "Argo"). - In: Puškin i russkaja literatura. Sbomik statej. - Riga, 1986. S. 102-109.

STEPUN, Fedor: Vergangenes und Unvergängliches. Aus meinem Leben. Erster Teil 1884 1914. - München. 1947.

(Russische Übersetzung: F. STEPUN: Byvšee i nesbyvšeesja. Tom I. - New York, 1956.)

SVEJCER. Viktorija: Byt i bytie Mariny Cvetaevoj. - Moskva, 1992.

TANEEV, S.I.: Materialy i dokumenty. Tom I: Perepiska i vospominanija. - Moskva. 1952.

TANEEV, S.I.: Dnevniki v trech knigach 1894-1909. - Moskva. 1981-1985.

TURGENIEFF. Assja: Erinnerungen an Rudolf Steiner und die Arbeit am ersten Goetheanum. - Stuttgan, 1972.

VALENTINOV N. (Vol'skij): Dva goda s simvolistami. - Stanford/Califomia. 1969.

VILLICH. Ch. [Willich, H.]: Ellis i Stejner. - In: Novoe literaturnoe obozrenie, 9, 1994, S. 182-191.

VILLICH. Ch. [Willich. H.]: L.L. Kobylinskij-Ëllis kak posrednik meždu russkoj literaturoj i nemeckojazyčnymi čitateljami. - In: Rossijskij literaturoveď̌eskij Žumal, 4, 1994, S. 191195 sowie in: Kul'tumoe nasledie rossijskoj èmigracii 1917-1940. Kniga vtoraja. - Moskva. 1994, S. 258-264.

VILLICH, Ch. [Willich. H.]: L.L. Kobylinskij-Ëllis i antroposofskoe učenie Rudol'fa Stejnera. (K postanovke problemy) - In: Serebrjanyj vek russkoj literatury: Problemy, dokumenty. Moskva. 1996. S. 134-146.

VILLICH, Ch. [Willich, H.]: Lev L'vovič Kobylinskij-Ėllis - zapozdalyj romantik ili simvolist? (Zametki o svjazi russkogo romantizma s simvolizmom). - In: Problemy romantizma v russkoj i zarubežnoj literature. (VI Guljaevskie čtenija). Tver' 15-18 maja $1996 \mathrm{~g}$. - Tver' [im Druck].

VILLICH. Ch. [Willich. H.], KOZMENKO. M.V.: Tvoř̌eskij put' Ėllisa za rubežom. - In: Izvestija RAN. Serija literatury i jazyka. 52, 1993, 1, S. 61-69.

WOLOSCHIN. Margarita: Die grüe Schlange. Lebenserinnerungen einer Malerin. - Hamburg, 1982.

(Übersetzung ins Russische von M.N. Zemčužnikova: M. Vološina: ZelenajaZmeja. Istorija odnoj Żizni. - Moskva, 1993). 


\section{F. Verschiedenes}

\section{a. Primärtexte}

BODENSTEDT, Friedrich: Gesammelte Schriften. Gesammt-Ausgabe in zwölf Bänden. 7. Band. - Berlin. 1866.

ČECHOV, Anton P.: Smert '̌inovnika. - In: Ders.: Polnoe sobranie sočinenij i pisem v 30-i tt. Tom 2. - Moskva, 1975, S. 164-166.

DANTE ALIGHIERI: Die göttliche Komödie, italienisch und deutsch. Übertragung und Erläuterung von August Vezin; Einfuihrung von Manfred Hardt. - Basel, Rom, 1989.

DOSTOEVSKIJ, Fedor M.: Germanskij mirovoj vopros. Germanija - strana protestujuščaja. (Dnevnik pisatelja za 1877 god). - In: Ders.: Polnoe sobranie sočinenij v 30-i tt. Tom 25. Leningrad, 1983, S. 151-154.

GOETHE, Johann Wolfgang: Maximen und Reflexionen. - Frankfur/M., 1980.

HEBBEL. Friedrich: Die Nibelungen, ein deutsches Trauerspiel in drei Abteilungen. - In:

Ders.: Sämtliche Werke in zwölf Bänden. 5. Band. - Berlin - Leipzig [um 1925], S. 1-241.

NEKRASOV, N.A.: "Zamolkni, Muza mesti i pečali!" - In: Ders.: Sobranie sočinenij v trech tomach. Tom 1. - Moskva, 1971, S. 228, 371f.

PAVLOVA. Karolina: Polnoe sobranie stichotvorenij. - Moskva - Leningrad, 1964.

PUŠKIN, Aleksandr S.: Polnoe sobranie soxinenij v 10-i tt. - Leningrad, 1977-1979.

SCHILLER. Friedrich: Resignation. - In: Ders.: Werke. Nationalausgabe. Band 1: Weimar, 1943, S. 166-169; Band 2. Teil 1: Weimar, 1983, S. 401-403.

TURGENEV, Ivan S.: Jakov Pasynkov. - In: Ders.: Polnoe sobranie soxinenij i pisem v 30-i tt. Sox̌inenija v 12-i tI. Tom 5. - Moskva, 1980, S. 49-89, 401-412.

ŽUKOVSKIJ, Vasilij A.: Izbrannye sočinenija. - Moskva. 1982.

\section{b. Untersuchungen und Abhandlungen}

AFANAS'EV, Viktor: Žukovskij. - Moskva. 1987.

BENZ, Emst: Geist und Leben der Ostkirche. - Hamburg. 1957.

BOEHME, E., LUTHER. A.: Frühe deutsche Übersetzungen aus dem Russischen. - In: Philobiblon. Wien, 6, 1933. S. 277-286, 349-363.

EHRHARD, Marcelle: V.A. Joukovski et le Préromantisme Russe. - Paris, 1938.

EICHSTÄDT, Hildegard: Zwölf Briefe V.A. Žukovskijs. - In: Die Welt der Slaven, 14, 1969. S. 294-311.

Fl.ORENSKIJ, Pavel: Die lkonostase. Urbild und Grenzertebnis im revolutionären Rußland. (Übersetzung und Einleitung von U. Wemer). - Stuttgart, 1988.

GERHARDT, Dietrich: Aus deutschen Erinnerungen an Zukovskij, mit einigen Exkursen. - In: Orbis scriptus. Dmitrij Tschižewskij zum 70. Geburtstag. Hrsgg. v. D. Gerhardt, W. Weintraub. H.-J. z. Winkel. - München, 1966, S. 245-313.

IEZUTTOVA. R.V.: Žukovskij i ego vremja. - Leningrad. 1989.

INGOLD, Felix Ph.: Literatur und Aviatik. Europäische Flugdichtung 1909-1927. - Frankfurt/M., 1980.

KLUGE. Rolf-Dieter: Die Komposition des "Boris Godunov". - In: Serta Slavica. In memoriam Aloisii Schmaus. - München. 1971, S. 342-354.

KLUGE, Rolf-Dieter. Zum Wandel des Menschenbildes in der russischen Literatur des 19. und 20. Jahrhunderts. - In: Festschrift für Wilhelm Lettenbauer zum 75. Geburtstag. (Hrsgg. v. A. Meštan und E. Weiher) - Freiburg i.Br., 1982, S. 81-94.

NEUMANN, Friedrich W.: Geschichte der russischen Ballade. - Königsberg und Berlin. 1937.

RAAB, Harald: Die Lyrik Puškins in Deutschland (1820-1870). - Berlin, 1964.

Romantik-Handbuch. Zeit. Literarische Formen. Künste und Wissenschaften. Romantische Lebensläufe. Hsrg. von Helmut Schanze. - Sturtgan, 1994.

SEIDLITZ. Carl von: Wasily Andrejewitsch Joukoffsky. Ein russisches Dichterleben. - Mitau. 1870. 
SMOLITSCH. Igor: Leben und Lehre der Starzen. Der Weg zum vollkommenen Leben. Mit einem Nachwort neu herausgegeben von Emmanuel Jungclaussen. - Freiburg - Basel Wien, 1988.

STRIEDTER, Jurij: Zum Verhältnis von GeschichtsbewuBtsein und poetischem Genre bei Puškin. - In: W. Iser, F. Schalk (Hrsg.): Dargestellte Geschichte in der europäischen Literatur des 19. Jahrhunderts. - Frankfurt/M., 1970, S. 75-115.

VESELOVSKIJ, A.N.: V.A. Žukovskij. Poèzija Zuuvstva i "serdežnogo voobraženija". - S.-Peterburg. 1904.

ZELINSKY, Bodo: Russische Romantik. - Köln, Wien, 1975. 


\section{NAMENREGISTER}

[Bei den angegebenen Seitenzahlen wird nur die eigentliche Studie berücksichtigt, nicht das Quellen- und Literaturverzeichnis sowie der Anhang.]

Adam von Sankt Viktor (Adam de Saint-Victor, um 1112-1192), mittellateinischer Schriftsteller, erzogen im Augustinerstift Saint-Victor (Paris); verfaßte theologische Prosaschriften sowie Sequenzen, gilt als Meister der jüngeren Periode der Sequenzentwicklung. S. 65.

Alacoque, Margarete Maria (Marguerite-Marie, 1647-1690), französische Salesianerin; ihre Visionen führten zur kirchlichen Billigung der Herz-Jesu-Verehrung (= besonderer Typ der katholischen Jesusmystik und -verehrung, die das Herz Jesu als Symbol des ganzen Menschen Jesus, v.a. seiner aufopfemden Liebe, versteht). S. 55.

Aleksandrl. Pavlovič (1777-1825), 1801-1825 russischer Zar, nahm 1805 an der dritten Koalition gegen Frankreich teil, kämpfte 1806/07 im Bund mit Preußen, schloß 1807 mit Napoleon Frieden und 1808 auf dem Erfurter KongreB ein Bündnis. Nach Napoleons Feldzug gegen Moskau (1812) verbündete er sich mit Österreich und Preußen. Nach seinem Tod entstand die Legende, daß er nicht gestorben, sondem Starez (Fedor Kuzmic) geworden sei. S. 224.

Aleksej (90er Jahre des 13. Jhds.-1378), russischer Metropolit seit 1354, unterstützte die Vereinigungspolitik der Moskauer Großfürsten. S. 226.

d'Alheim. Pierre, Baron (Pëtr Ivanovix d'Al'gejm, 1862-1922), französischer Joumalist, Romanist und Musikwissenschaftler; schrieb 1896 eine Monographie über Mussorgskij und übersetzte das Opemlibretto "Boris Godunov" ins Französische; Ehemann von M.A. Oleninad'Al'gejm.S. 33.

Amvrosij (1812-1891), Starez von Optina (= russisch-orthodoxe Einsiedelei südwestlich von Moskau). S. 226.

Andreev, Leonid Nikolaevic (1871-1919), nussischer Prosaiker und (ab 1906) Dramatiker; Vertreter eines psychologischen Realismus; in seinem dramatischen Werk vollzog er den Übergang zum Symbolismus. S. 72f., 77-79, 81f., 87.

Annenskij, Innokentij Fëdorovič (1855/56(?)-1909), russischer Lyriker, Dramatiker, Theoretiker und Literaturkritiker, Vertreter des Symbolismus. S. 9, I5, 23.

Astrov, Pavel Ivanovic (1866-?(nach 1930)), russischer Jurist und Publizist; Leiter eines literarisch-philosophischen Zirkels in Moskau, an dem viele Symbolisten teilnahmen. S. 28f., 31 . 186.

Astrov, Vladimir Ivanovič (1871-?), nussischer Publizist; emignierte nach der Oktoberrevolution. Bruder von P.I. Astrov. S. 142.

Athanasius (um 293-373), griechischer Kirchenlehrer, seit 328 Bischof von Alexandria; Heiliger. S. 195, 229.

Auslender, Sergej Abramovič (1886-1943), russischer Prosaiker, Dramatiker, Kritiker; dem Kreis der Petersburger Symbolisten zuzurechnen. S. 9.

Bakunin. Michail Aleksandrovič (1814-1876), russischer Revolutionär und Anarchist. S. 32.

Bal'mont, Konstantin Dmitrievic (1867-1942), erster großer Lyriker des russischen Symbolismus (vor allem durch seine friihen Lyrikbände 1898-1903), auch als Übersetzer und symbolistischer Theoretiker von Bedeutung: 1905-1917 verbrachte er viele Jahre im Ausland, u.a. in Paris, untemahm mehrere Reisen in alle Erdteile; begrüBte die Februarrevolution 1917, den bolschewistischen Umsturz lehnte er ab; 1920 legale Ausreise, blieb als Emigrant in Paris; seit 1927 lebte er in Capbreton am Atlantischen Ozean; ab 1932 litt er an Geisteskrankheit. S. 9. 15, 23, 28, 31, 42, 45, 50, 68, 88-90, 92-97, 99f., 104-106, 108-110, 159. 163,211

Baltrušajtis. Jurgis Kazimirovič (1873-1944), nussischer und litauischer symbolistischer Lyriker, Übersetzer und Diplomat; 1920-1939 Gesandter der Republik Litauen in Moskau; 1939-1944 vertrat er als Diplomat Litauen in Paris. S. 28.

Baratynskij, Evgenij Abramovič (1800-1844), russischer romantischer Lyriker. S. 193, 205. 217. 
Barrès, Maurice (1862-1923), französischer Schriftsteller, Vertreter zunächst der modemen Décadence, später des Nationalismus und Chauvinismus. S. 229.

Batjušov, Konstantin Nikolaevič (1787-1855), russischer romantischer Lyriker. S. 205.

Batjuškov, Pavel Nikolaevič (1864-ca.1930), russischer Literaturwissenschaftler und Übersetzer, Indologe. Theosoph; nahm am "Argonautenkreis" teil; Enkel des Dichters K.N. Batjuškov. S. $28 f$.

Baudelaire, Charles (1821-1867), Dichter, Kunst- und Literaturtheoretiker, gilt als Begründer symbolistischer Lyrik in Frankreich. $S .12,15,25,29 f ., 32,35-38,42 f ., 45,47 f ., 50,52 f$., $57,66-68,76,80-82,84,90,92,94,101,111,123,136,143 f, 152,159,166,171,176$. $229,231 f$.

Belinskij, Vissarion Grigor'evič (1811-1848), nussischer Kritiker und Publizist. S. 91.

Belyj,Andrej (eig. Boris Nikolaevið Bugaev, 1880-1934), russischer Lyriker, wichtigster Prosaiker und bedeutendster Theoretiker des russischen Symbolismus, Verfasser einer umfangreichen Memoirenliteratur. Bereits zu Schulzeiten große Begeisterung für deutsche Kultur, Beschäftigung mit Dostoevskij, Ibsen, modemer französischer und belgischer Dichtung, ab 1899 mit Vl. Solov'ev, Nietzsche und Wagner; 1899-1903 Mathematikstudium an der Moskauer Universität, anschließend (bis 1906) Philologiestudium; ab 1902 literarische Aktivitäten; 1910-1911 Reise nach Italien. Tunis, Ägypten, Palästina; 1912-1916 verbrachte er in Westeuropa. wurde stark beeinflußt von $\mathbf{R}$. Steiners Anthroposophie, lebte eine zeitlang bei Steiner in Domach; den Umsturz 1917 faßte er als Möglichkeit für eine religiöse und geistige Emeuerung Rußlands auf; 1921-1923 lebte er in Berlin; 1923 Rückkehr nach Rußland. S. 9f., 13, 15-19, 2I-23, 25-40, 42f., 45, 47f., 57f., 61, 63, 66, 68f., 72-75, 77f., 80f.. 86$92,97,99-118,122-124,126,128-132,141-143,150,153,159,162,164 f ., 168 f ., 176 f$. . $179 f . .203 .231 f$.

Berdjaev, Nikolaj Aleksandrovič (1874-1948), russischer Philosoph, Publizist, Kritiker. Seit 1894 Marxist, Agitationsarbeit in Kiev; seit 1897 mehrfach inhaftien und verbannt; seit 1904 vielseitige literarische, publizistische und gesellschaftliche Aktivitäten; stand in ständiger Verbindung mit den russischen Symbolisten; seit 1920 Professor an der Moskauer Universität: 1922 Verhaftung und Ausweisung aus Rußland. S. 75, 181, 184, 186, 201, 223, 228.

Bergson, Henri (1859-1941), franz.ösischer Philosoph; Nobelpreisträger 1927. S. 12.

Besant, Annie (geb. Wood, 1847-1933), englische Theosophin, seit 1907 Präsidentin der Theosophischen Gesellschaft in Indien. S. I/ $8 f$

Blavatskaja, Elena Petrovna (Pseud.: Radda-Bai, 1831-1891), Schriftstellerin, gebünige Russin (Ekaterinoslavl'), 1849-1859 Reisen in den Fernen Osten und nach Amerika: 1864 verläßt sie für immer Rußland, rastlose Reisen, u.a. nach Tibet; 1873 Annahme der amerikanjschen Staatsangehörigkeit, Wohnort New York; 1875 mit H.St. Olcott in New York Gründung der Theosophischen Gesellschaft; 1879 Gründung des Hauptquartiers der Theosophischen Gesellschaft in Bombay; 1882 Verlegung des Hauptquariers der Theosophen nach Adyar bei Madras: 1883 Rückkehr nach Europa; seit 1886 ständiger Wohnsitz in London. S. II8f., 122. 126f.. 163. 199 .

Blok. Aleksandr Aleksandrovič (1880-1921), bedeutendster Lyriker, Dramatiker und wichtiger Theoretiker des russischen Symbolismus. 1898-1901 Jurastudium an der Petersburger Universität, anschließend Philologiestudium (bis 1906); ab 1902 im Kreis der Petersburger Symbolisten aktiv; mehrere Reisen nach Westeuropa: erlebte die Machtergreifung der Bolschewiken mystisch verklän als kosmische Revolution: übermahm Tätigkeiten in kulturellen Organisationen des neuen Sowjetregimes. S. 9f., 12-16, $18 f ., 22 f ., 28 f ., 31 f ., 36-39.43 .4 .5$. $48 f ., 56-60,63,67-69,72,74,77-80,87,89,91,93,97,102 f ., 105,108-111,113 f ., 117$. I36. I4lf., I50f.. I55, I59, I63f., I68f., I74-177. 203f., 209, $211 f ., 232$.

Blok. Ljuhnv' Dmitrievna (geb. Mendeleeva. 1881-1939), Frau von A.A. Blok. Schauspielerin. S. 30.37.

Bobrov. Sergej Pavlovič (1889-1971), nussischer Lyriker, Prosaiker, Übersetzer, Publizist, Literaturwissenschaftler, nahm an Aktivitäten und Arbeitskreisen des "Musaget"-Verlags teil. S. 33, 47, 88, $113,117,122$. 
Bobrova, Nina Pavlovna, Schwester von S.P. Bobrov, befaBte sich, wie ihr Bruder, mit russischer Verslehre und -theorie. S. 267.

Bodenstedt, Friedrich von (1819-1892), deutscher Dichter und Übersetzer: 1854-1866 Professor für slavische Sprachen in München. S. 204.

Böhme, Jakob (1575-1624), deutscher Mystiker; hat anregend auf die deutsche Romantik (Schleiermacher, Novalis, Schelling u.a.) gewirkt sowie auf die russischen Symbolisten und religiös-philosophischen Gesellschaften. S. 167, 193.

Brjusov, Valerij Jakovlevič (1973-1924), Lyriker, Prosaiker, Dramatiker, Übersetzer, Kritiker und Literaturwissenschaftler, einer der wichtigsten und vielseitigsten Repräsentanten des russischen Symbolismus. 1892-1899 Studium der Geschichte an der Moskauer Universität; sein ganzes Leben lang blieb er als Wissenschaftler tätig; die moderne französische Dichtung beeindruckte und beeinflußte Brjusov als Student besonders; ab 1894 Publikation eigener Gedichtbände; 1904-1909 Leitung der symbolistischen Zeitschrift "Becы"; führende Persönlichkeit der Moskauer Symbolisten; zahlreiche Reisen nach Westeuropa; im 1. Weltkrieg Tätigkeit als Übersetzer aus dem Armenischen; nach 1917 AnschluB ans kommunistische Regime, 1920 Eintritt in die KP (als einziger der nichtemigrienten symbolistischen Dichter), crivielt Posten in kulturellen Institutionen. S. 9f., 14f., 18, 2l-23, 25, 28, 31-33, 36-39, 42. $45,47 f .50,55,57,66-69.71-73,75-78,80 f . .86 f ., 89 f ., 92 f ., 96-102,104-110,117,141$, 150, 152, 159, 168f.. 175-177.231f.

Bugaev, Boris Nikolaevič $\rightarrow$ A. Belyj

Bugaev, Nikolaj Vasil'evic (1837-1903), russischer Mathematiker, Professor und Dekan an der Physikalisch-Mathematischen Fakultät der Moskauer Universität; Vater A. Belyjs. S. 26.

Bugaeva, Aleksandra Dmitrievna (geb. Egorova, 1858-1922), Mutter A. Belyjs. S. 38.

Bulgakov, Sergej Nikolaevič (1871-1944), russischer Religionsphilosoph, Publizist, Kritiker, Nationalökonom. S. 181, 201.

Bunin. Ivan Alekseevic (1870-1953), russischer Lyriker und bedeutender Prosaiker des Spätrealismus: Nobelpreisträger 1933. S. 72.

Bürger, Gottfried August (1747-1794), deutscher Dichter und Übersetzer: großes Verdienst auf dem Gebiet der Balladendichtung. S. 206, 208.

Byron. George Gordon Noel, Lord (1788-1824), einer der hervorragendsten Dichter der englischen Romantik. S. 30, 47. 208, 214, 218.

Caadaev.Pëtr Jakovlevič (1794-1856), russischer Philosoph und Publizist. S. 213. 227.

Calderon de la Barca. Pedro (1600-1681), spanischer Dichter (Dramatiker). S. 215.

Carlyle. Thomas (1795-1881), englischer Schrifisteller. S. 153.

Cechov. Anton Pavlovic (1860-1904). S. 54, 77, 81f. 87, 107, 215f.

Chamberlain, Houston Stewart (1855-1927), philosophischer Schriftsteller: heiratete 1908 R. Wagners Tochter Eva: seit 1916 deutscher Staatsangehöriger, begeisterter Anhänger der Wagnerschen Kunst und Weltanschauung. S. 145-147.

Chaplin. Charles (Charlie) Spencer (1889-1977). Filmkomiker, Schriftsteller, Regisseur, Produzent. S. 36.

Chrétien de Troyes (vor 1150-vor 1190), altfranzösischer Dichter, bedeutendster französischer Vertreter des höfischen Versepos. S. 148.

Christoforova, Kleopatra Petrovna (?-1934), Moskauer Kaufmannsfrau, die den Symbolisten nahestand; russische Theosophin. später Anthroposophin: Leiterin eines Theosophischen Kreises in Moskau, an dem viele Symbolisten teilnahmen. S. 34, 51, 122.

Cimabue (um 1240-1302), italienischer Maler. S. 64.

Cirikov. EvgenijNikolaevix (1864-1932), Prosaiker und Dramatiker des russischen Spätrealismus. $S .72$.

Cjurlënis, Mikalajus Konstantinas (1875-1911), litauischer symbolistischer Maler und Komponist. S. 150.

Claudel. Paul (1868-1955), französischer Lyriker. Dramatiker und Prosaiker. Anhänger des "Renouveau catholique"; Botschafter in Tokio, Washington. Brüssel. S. 229.

Cranach. Lukas $d . \vec{A}$. (1472-1553), bedeutender deutscher Maler und Graphiker. S. 227. 
Cukovskij, Kornej lvanovič (eig. Nikolaj Vasil'evič Kornejčukov, 1882-1969), russischer Lyriker, Literaturwissenschaftler und -kritiker, Dichter und Theoretiker der Kinderliteratur, Übersetzer. S. 82.

Culkov, Georgij Ivanovič (eig. Jurij Obida IVgl. J.v. Guenther: Ein Leben im Ostwind. München 1969, S. 118 J, 1879-1939), symbolistischer Lyriker, Prosaiker und Kritiker: gilt als einer der "poetae minores" des russischen Symbolismus, dessen Werk und Beitrag zum russischen Symbolismus bis heute noch nicht befriedigend erforscht und ausgewertet sind. 1906 ent wickelte er den sog. "mystischen Anarchismus" (мистический анархнзм), ein Versuch. den Symbolismus mit politischem Radikalismus zu vereinen (vgl. seine Abhandlung "О мистическом анархизме" (СT16., 1906), zu der Vjač. Ivanov das Vorwort geschrieben hat). Herausgeber der drei Almanache "Факелы" (1906-1908), des Organs der "mystischen Anarchisten".S. 9.32f.. 37f.. 7/f.. 74.77. 150f.

Cvetaev. Ivan Vladimirovič (1847-1913), Geschichtsprofessor für antike Kulturen an der Moskauer Universität. Begründer und erster Direktor des Puškin-Museums der Schönen Künste in Moskau; Vater von M.I. und A.I. Cvetaev. S. 88.

Crefaeva. Anastasija Ivanovna (1894-1993), russische Prosaikerin; Schwester von M.I. Cvetaeva. Tochter von I.V. Cvetaev. S. 25f., 33, 40-42. 59f., 171.

Cvetaeva. Marina Ivanovna (1892-1941), bedeutende russische Lyrikerin, Dramatikerin. Prosaikerin: Tochter von I.V. Cvetaev. Während der Gymnasialzeit gemeinsam mit ihrer Schwester Anastasija mehrere Aufenthalte in Italien, Schweiz, Deutschland, Frankreich; ab Ende der ersten Dekade dieses Jahrhunderts Bekanntschaft mit führenden Vertretem der Moskauer Symbolisten. Akmeisten, Futuristen, gehörte jedoch keiner der literarischen Gruppienungen an: lehnte den bolschewistischen Umsturz ab; 1922 Emigration mit ihrem Mann Sergej Efron nach Prag: 1925 Übersiedlung nach Paris; 1939 Rückkehr in die Sowjetunion; setzte inrem tragischen Leben selbst ein Ende. S. 9f., 25f., 33. 35, 40f., 51. 59.

Dante Alighieri (1265-1321). S. 7. 10. 16, 18, 20, 25, 27, 29f., 35-37, 42, 45, 47-53, 55-57. 63. 66. 68. 83. 91. I16f.. 123. 127. 129f.. 132, 134. 145f.. I52-156. 160, 163. 166. I7I. 174. 176f.. 187. 216.229. 232.

Dejక̌a-Sionickaja, Marja Adrianovna (1859-1932), nussische Sängerin (dramatischer Sopran) und Pàdagogin. S. 29.

Del'vig. Anton Antonovič. Baron (1798-1831), nussischer romantischer Lyriker. S. 217.

Deržavin. Gavrila Romanovic (1743-1816), Lyriker, bedeutender Vertreter und augleich Überwinder des russischen Klassizismus. Wegbereiter der nussischen Romantik. S. $204 f$.

Dobroljubov. Aleksandr Michajlovič (1876-1944?), russischer Lyriker (Symbolismus), religiöser Prediger. S. 9. 58. 90. 159. 164.

Dominik(us) (1170-1221). Stifter des Dominikanerordens, fruchtbarer Emeuerer des kirchlichen Lebens im geistig aufgewühlten 13. Jahshundert: 1234 heiliggesprochen. S. 64, 161 .

Dosioevskij. Fëdor Michajlovič (1821-1881). S. 80.93. 131, 202, 212. 215f., 220, 225. 230.

Dïrer. Alhrecht (1472-1528). S. 227.

Durvlin. Sergej Nikolaevič (1877-1954), nussischer Schriftsteller, Literatur-, Kunst- und Theaterkritiker, verkehrte in den symbolistischen Kreisen des "Musaget"-Verlags, war aktiver Mitarbeiter der Zeitschrift "Труды и лни". S. 80, 117. 151. 184.

Eckart (Meister Eckhart. Eckehart. 1260-1327), bedeutender deutscher Mystiker, Mitglied des Dominikanerordens. S. 167.

Eichendorff. Joseph Freiherr von (1788-1857). S. 205. 210.

Étel'. Michail Aleksandrovič (?-Beginn der 1920er Jahre), Sohn des Narodniki-Schriftstellers A.I. Enel', russischer Historiker, Mitglied des "Argonautenkreises". S. $28 f$.

Fet. Afanasij Afanas'evič (eig. Senšin, 1820-1892), russischer Lyriker (Spätromantik), Übersetzer, Memoirenschreiber. S. 11.93-95, 109. 193. 204. 210f., 225.

Fichte.Johann Gottlieh (1762-1814). S. I20f.

Flaubert. Gustave (1821-1880). S. 5. 30. 72.

Florenskij. Pavel Aleksandrovič (1882-1937), russischer Lyriker und Prosaiker (christlich-realistische Werke) sowie herausragender Theologe, Kunsthistoriker. Techniker und Naturwissenschaftler. S. 184f., 195f.. 201, 227. 
Fludd, Roben (1574-1637), englischer Art und Rosenkreuzer. S. 167.

Franz von Assisi, Franziskus (eig. Giovanni Bemardone, 1181/82-1226), Stifter des Franziskanerordens; 1228 heiliggesprochen. S. 130, 132, 161, 164.

Franz Xaver (eig. Francisco de Gassu y Xavier [Javier], 1506-1552), spanischer katholischer Theologe und Jesuit; schloß sich 1533 Ignatius von Loyola in Paris an und wurde Mitbegründer des Jesuitenordens; unternahm u.a. Missionsreisen nach Indien. Ceylon, Molakka und Japan: Heiliger. S. 64.

Freud, Sigmund (1856-1939). S. 40.

George, Stefan (1868-1933), Lyriker, Prosaiker und Übersetzer, wichtiger Venteter des deutschen Symbolismus. S. 159.

Gessen, Sergej Iosifoviz/Osipovix (1887-1950), nussischer Philosoph, Literarhistoriker. S. IIS.

Ghil, René (eig. Guilbert, 1862-1925), französischer Dichter, Schüler Mallarmés. S. 90.

Gippius, Zinaida Nikolaevna (Hippius, 1869-1945), Frau von D. Merežkovskij, Lyrikerin, Dramatikerin und Prosaikerin des russischen Symbolismus; unter dem Pseudonym Anton Krajnij Literaturkritik und Essays. Ab 1888 publiziente sie Lyrik, bald darauf ihre erste Erzählung; ihr literarischer Salon in Petersburg (1905-1917) wurde Treffpunkt der Symbolisten; verurteilte den bolschewistischen Umsturz: 1919 mit Merežkovskij Ausreise über Warschau nach Paris; wurde eine bedeutende Lyrikerin und Publizistin der Emigration. S. 9. 15 , $68,81,87,97,102,108,169$.

Glièr, Rejngol'd Moricevic (Glière, 1874/75-1956), russischer Komponist belgischer Abstammung. Lehrer von Prokov'ev und Chat Zaturjan. S. 122.

Goethe, Johann Wolfgang von (1749-1832). S. 5, 12, 19, 34, 40, 56, 91f., 114, 116, 121, 129. $132,134,145 f ., 152,166,175,179 f$.

Gofman, Modest Ljudvigovič (1887-1959), nussischer Dichter, Literarhistoriker, Puškinforscher. S. 110.218.

Gogol', Nikolaj Vasil'evič (1809-1852). S. 8, 14, 73, 80f., 85, 103, 186, 202, 215, 219f., 225. 229. 232.

Gončarova. Anna Sergeevna (1855-?), nussische Philosophin. Theosophin. S. 122.

Gor'kij, Maksim (eig. Aleksej Maksimovið Peškov, 1868-1936), bedeutender russischer Schrifisteller des Spätrealismus, einer der Begründer der russischen Sowjetliteratur (sozialistischer Realismus). S. 72, 77. 81-83.

Gorodeckij. Sergej Mitrofanovic (1884-1967), russischer Lyriker, Prosaiker, Opemlibrettist. Ubersetzer, Kritiker. begrindete 1912 zusammen mit N. Gumilëv die literarische Gruppe der "Akmeisten". S. 169.

Görres, Johann J. von (1776-1848), deutscher Schriftsteller und Publizist; Teilnehmer des Heidelberger Romantikerkreises; ab 1827 Professor für Geschichte in München; in seiner Publizistik Vorkämpfer einer ausgesprochen katholisierenden Richtung. S. 229.

Gray. Thomas (1716-1771), englischer Lyriker. Wegbereiter der Romantik. S. 206.

Grejner, Vasilij Vladimirovič (1876-?), nussischer Jurist, Kommilitone und Studienfreund von Ellis, mit dem er gemeinsam von 1897-1901 an der Juristischen Fakultät der Moskauer Universität studierte. $S$. 25,45 .

Grek. Feofan (um 1340 - nach 1405), Fresken- und Ikonenmaler, stammte aus Byzanz, lebte und arbeitete in Rußland. S. 227.

Grigorov. Boris Pavlovič (1883-1945), russischer Theosoph, Anthroposoph; seiner Ausbildung nach Jurist: Leiter eines Arbeitskreises zum Studium der Werke R. Steiners (die er ins Russische übersetzte) im "Musaget"-Verlag. S. 122.

Gumilēv, Nikolaj Stepanovič (1886-1921), nussischer Lyriker, Prosaiker, Dramatiker, Übersetzer, bedeutendster Theoretiker des "Akmeismus", Literaturkritiker. Erster Ehemann der A. Achmatova.S. 67.

Halm. Friedrich (eig. Eligius Freihert von Münch-Bellinghausen, 1806-1871), deutscher Lyriker und Dramatiker. S. 209.

Hamsun. Knut (eig. Pedersen, 1859-1952), norwegischer Prosaiker, Dramatiker. S. 72.

Harnack. Adolf von (1851-1930), bedeutender deutscher evangelischer Theologe. S. 137. 
Hartmann von Aue (gest. zw. 1210 u. 1220), erster der drei großen höfischen Epiker der Stauferzeit.S. 160.

Hauptmann, Gerhart (1862-1946). S. 72.

Hebbel, Friedrich (1813-1863). S. 137, 215.

Hegel, Georg Wilhelm Friedrich (1770-1831). S. 91, 120f., 194, 205.

Heine, Heinrich (1797-1856). S. 193.

Hérédia, José Maria de (1842-1905), französischer Dichter, bedeutender Vertreter der Pamassiens. S. 55.

Hesiod (Hesiodos aus Askra in Böotien, Wende vom 8. zum 7. Jh.v.Chr.), griechischer Dichter. S. 113 .

Hoffmann, E.T.A. (Emst Theodor Amadeus, eig.: Emst Theodor Wilhelm, 1776-1822). S. 12.

Hofmannsthal, Hugo von (1874-1929), symbolistischer Lyriker, Dramatiker, Prosaiker und Literaturkritiker.S. 81 .

Homer (lebte Ende des 8. Jahrhunderts v.Chr.). S. 83. 210.

Hunt, William Holman (1827-1910), englischer Maler, gründete 1848 gemeinsam mit D.G. Rossetti und J.E. Millais die Schule der Präraffaeliten. S. 12, 52.

Huysmans, Joris-Karl (1848-1907), französischer Prosaiker, Hauptvertreter des literarischen Impressionismus. S. 12, 51, 82, 90, 92, 159. 166.

Ibsen. Henrik (1828-1906), bedeutender norwegischer Dramatiker, dessen Schauspiele in Skandinavien und Deutschland bahnbrechend für den Naturalismus waren. S. 12, 79f., 90.

Ilarion (1. Hälfte 11. Jahthundert), christlicher Asket und Schrifisteller; war 1051-1054 erster Metropolit von Kiev. S. 54.

I'in, Ivan Aleksandrovič (1882-1954), russischer Religionsphilosoph (Vertreter des Neuhegelianismus), Kulturhistoriker, Publizist; Dozent an der Moskauer Universität für Rechtsphilosophie; 1922 Ausweisung aus Rußland, 1923-1934 Professor am Russischen Wissenschaftlichen Institut in Berlin, nahm aktiv am politischen Leben der russischen Emigration teil; 1934 nach Machtergreifung der Nationalsozialisten: Lehrverbot, Emigration nach Zïrich. S. 181 .

Il'in. Vladimir Nikolaevič (1891-1974), russischer Theologe und Philosoph, Literatur- und Musikkritiker. Komponist: lebte in Kiev. 1919 verlieB er Rußland, ging nach Konstantinopel; 1923 siedelte er nach Berlin um und 1925 nach Paris. war dor Mitinitiator der Gründung des "Rechtgläubigen Theologischen Instituts". S. 181, 184. 201, 223, 228.

Intermediarius $\rightarrow$ J.v.d. Meulen.

Ivan IV. Vasil'evic (Ivan Groznyj. Ivan der Schreckliche, 1530-1584); seit 1533 Großfüst von "ganz Rußland": 1547-1584 erster russischer Zar. S. 223.

Ivanov, Dimitrij Vjačeslavovič (geb. 1912), Sohn von Vjač. Ivanov, Schriftsteller. S. 8. 40. I8If., 190.

Ivanov, Vjačeslav Ivanovic (1866-1949), hervorragender Lyriker, Dramatiker und Theoretiker des russischen Symbolismus. Philosoph, Historiker und klassischer Philologe. Ab 1884 Studium der Geschichte an der Moskauer Universität, ab 1886 römische Geschichte und klassische Philologie an der Universität Berlin: 1891 ging er nach Paris. befaßte sich insbesondere mit griechischen Mysterien. Nietzsche und dem Dionysoskult; 1902 Reise nach Griechenland. Ägypten und Palästina; ab 1905 lebte er in Petersburg; seine Wohnung im "Turm" (6аuня) wurde (bis etwa 1910) zum Treffpunkt von Dichtem. Künstlem und Wissenschaftlem: 1912/13 emeuter Auslandsaufenthalt, danach lebte er in Moskau: 1920-1924 Hochschullehrer in Baku; 1921 Verteidigung seiner Dissertation über den Dionysoskult: 1924 Ausreise nach Rom; 1926 Konversion zum Katholizismus; 1926-1934 Lehrauftrag für russische Sprache und Literatur an der Universität Pavia, 1934-1943 am Päpstlichen Ostinstitut in Rom. S. 9. 16-19. 22f., 28. 31-33. 39f., 45. 57f.. 71-78. 80f., 86f., 89-91. 97. 102f., 105f., I08-110.113-116. 132, 136. 140-142. 150. 156, 159f.. 162-164. 166, I68f.. I76f.. I8If., I89f.. 202.223, 228f.

Ivanova, Lidija Vjačeslavovna (1896-1985), Tochter von Vjač. Ivanov. S. 181

Ivanov-Razumnik (eig. Razumnik Vasil'evið̌ Ivanov, 1878-1946), nussischer Kritiker, Publizist, Literartistoriker und Gesellschaftswissenschaftler. S. 75. 
Jakovenko, Boris Valentinovič (1884-1948), nussischer Philosoph, stand dem Neukantianismus nahe; einer der Redakteure der Zeitschrift "Logos". S. 115.

Jakubovič, PëtrFilippovič (Pseud.: P.Ja., L. Mel'̌in u.a., 1860-1911), nussischer revolutionärer Volkstümler, Lyriker, Prosaiker und Joumalist. S. 47.

Jazykov, Nikolaj Michajlovič (1803-1847), russischer romantischer Lyriker. S. 217.

Jung, Carl Gustav (1875-1961). S. 40. 181.

Juškevič, Semën Solomonovič (1868-1927), russischer Prosaiker, Dramatiker. S. 72.

Kamenskaja, Anna Alekseevna (?-1952), russische Theosophin: Gründerin der theosophischen Bewegung in Rußland: Präsidentin der Theosophischen Gesellschaft in Rußland. S. 122.

Kankrin. Egor Francevič, Graf (1774-1845), russischer Finanz- und Wirtschaftsminister. S. 25.

Kant, Immanuel (1724-1804). S. 21,84f., 88, 115, 121,129, 193.

Karamzin, Nikolaj Michajlovič (1766-1826), Lyriker, Prosaiker, Historiker, Kritiker und Journalist; einer der Begründer der romantischen russischen Literatur, Schöpfer und Hauptvertreter des nussischen Sentimentalismus. S. $204 f$.

Kerner, Justinus (1786-1862), deutscher romantischer Dichter und Art (Balneologe), gehörte zur sog. "Schwäbischen Dichterschule". S. 204.

Kierkegaard. Sören Aabye (1813-1855), dänischer Theologe und Philosoph. S. 201.

Kiselëv. Nikolaj Petrovič (1884-1965), russischer Philologe, Studienkollege von A. Belyj; nahm am "Argonautenkreis" teil; von 1913-1915 Sekretär des "Musaget"-Verlags. S. II7. 171,180 .

Knies, Richard (1886-1957), deutscher katholischer Dichter, Leiter des Matthias-GrünewaldVerlags (Mainz). S. 180-182, 191.

Kohylinskaja, Varvara Petrovna (?-1907), Mutter von Ellis, Il'ja und Sergej Kobylinskij. S. $25 f$.

Kobylinskij, Il'ja L'vovič (1876-?), Ėllis' älterer Bruder, studierte 1897-1901 an der HistorischPhilologischen Fakultät der Moskauer Universität, anschließend keine genauen Informationen mehr über ihn bzw. seine Tätigkeiten (außer einem Brief von ihm an eine unbekannte Adressatin im РГАЛИ. Ф. 575, on. 1, ед.хp. 50); wahrscheinlich recht frih gestorben. wohl zwischen 1905 und 1910 (in seinem "Tagebuch" von 1905 erwähnt Ellis noch einen Brief seines Bruders). S. 25.

Kohylinskij. Sergej L.'vovič (1882-?), Éllis' jüngerer Bruder, studierte 1900-1904 an der Historisch-Philologischen Fakultät der Moskauer Universität, nahm gemeinsam mit Ėllis an den "Argonauten"-Treffen teil, befaßte sich mit Philosophie und war begeisterter Anhänger R.H. Lotzes, über den er eine Arbeit schrieb (vgl. A. Belyj: Načalo veka, a.a.O., S.294); später, wohl 1907, ging er als Lehrer ans Frauengymnasium nach Vyborg (nördlich von Petersburg) (РГИА, Ф. 418, on. 314, ед.xp. 377); er starb wohl recht frih, vermutlich um 1910. (In einem Brief von Nina Pavlovna Bobrova an Ėllis IPГАЛИ. Ф. 575, on. 1, ед.xp. 28. ohne Datum, wahrscheinlich gegen Ende der ersten Dekade dieses Jahrhunderts geschrieben] wird erwähnt. daß schon wieder einer seiner Brüder gestorben sei). S. 25f., $28 f$., 38.

Kozlov, Ivan Ivanovic (1779-1840), russischer romantischer Lyriker, Übersetzer. S. 217.

Kracht, Konstantin Fëdorovič (1868-1919), Bildhauer; nahm am "Argonautenkreis" teil; Leiter einer der Arbeitsgemeinschaften um den "Musaget"-Verlag. S. 117.

Krieg von Hochfelden, Georg Heinrich (1798-1860), badischer Generalmajor, betätigte sich auch als literarischer Übersetzer; persönliche Begegnung mit V.A. Żukovskij in Baden-Baden. S. 204.

Krishnamurti, Jiddu (1895/1897-1986), südindischer Brahmane, religiöser Denker und Dichter; wurde 1910 von A. Besant als neuer Weltlehrer ausgerufen, wandte sich jedoch 1929 von der Theosophie $a b$. Seine Lehre, aus indischen und europäischen Quellen gespeist, betont, daß der Seelenfrieden und die Wahrheit nur intuitiv erfahren werden können, durch freie "Ergüsse" der einzelnen Persönlichkeit; diesbezüglich sei jedes vollendete philosophische und religiöse System ein Hindemis. S. 119.

Kropotkin. Pëtr Alekseevič. Fürst (1842-1921), russischer Schriftsteller, Revolutionär und Anarchist. S. 32. 
Krylov, Ivan Andreevič (1769-1844), bedeutendster russischer Fabeldichter. S. 205.

Kuprin, Aleksandr Ivanovič (1870-1938), bedeutender Prosaiker des nussischen Spätrealismus. S. 72.

Kuzmin, Michail Alekseevič (1872-1936), russischer Lyriker, Prosaiker, Dramatiker, Übersetzer, Kritiker und Komponist (Schüler von Rimskij-Korsakov); wichtiger Vertreter des Akmeismus; aktiver Mitarbeiter der Zeitschriften "Весы" und "Аполлон". S. 77, 159.

Leopardi, Giacomo, Graf (1798-1837), bedeutender italienischer Lyriker. S. 47, 66.

Lermontov, Michail Jur'evič (1814-1841), einer der bedeutendsten Lyriker und Prosaiker der russischen Romantik. S. 14, 83, 134, 140, 185f., 193, 204, 216. 225.

Leskov, Nikolaj Semënovič (1831-1895), bedeutender russischer Prosaiker. S. 225.

Lomonosov, Michail Vasil'evič (1711-1765), bedeutender russischer Universalgelehrter; Dichter, Dramatiker, Philologe und Naturwissenschaftler, Gründer der Moskauer Universität (1755). S. 205.

Losskij. Nikolaj Onufrievic (1870-1965), nussischer Philosoph: 1922 aus Rußland ausgewiesen. S. 201, 223.

Lotze, Rudolf Hermann (1817-1881), deutscher Philosoph. Arzt und Naturwissenschaftler. S. 28.

Loyola, Ignatius von (span. Iñigo Lopez de Loyola, 1491-1556), stiftete 1534 in Paris den Jesuitenorden: 1537 wurde er Priester. Heiliggesprochen 1622. S. 36, 132.

Luigi (Ludovico) I. Gonzaga (1267-1360), entstammte dem nach der Burg Gonzaga bei Mantua benannten oberitalienischen Fürstengeschlecht, gewann 1328 die Signorie Mantua, wurde 1329 von Kaiser Ludwig IV., dem Bayem, mit dem Reichsvikariat über Mantua belehnt. S. 55.

Luther, Arthur (Artur Fèdorovič Ljuter, 1876-1955), Rußlanddeutscher, gelehrter Philologe. Russist, Literarhistoriker und Ubersetzer, 1903-1914 Lektor an der Moskauer Universität. Spăter lebte er in Deutschland, war Bibliothekar der "Deutschen Bücherei" in Leipzig und hat viel über die russische Literatur geschrieben, danunter 1924 seine positivistisch ausgerichtete "Geschichte der nussischen Literatur", femer Übersetzungen. S. 5. 146. 204, 218.

Luther, Martin (1483-1546). S. 162.

Maeterlinck, Maurice (1862-1949), französisch-belgischer Lyriker, Dramatiker, Prosaiker, einer der bedeutendsten Vertreter des Symbolismus. S. 12. 47, 79f., 90, 163

Majakovskij, Vladimir Vladimirovic (1893-1930), russischer futuristischer Lyriker und Dramatiker. S. 23, 78.

Majkov. Apollon Nikolaevič (1821-1897), russischer Lyriker (Spätromantik) und Übersetzer. S. $11,193,211,225$.

Makovskij, Sergej Konstantinovič (1877-1962), russischer Dichter, Kunsthistoriker und -kritiker, Redakteur der Zeitschrift "Аполлон". S. 72.

Mallarmé, Stéphane (1842-1898), Lyriker, Prosaiker, Kritiker und Theoretiker des französischen Symbolismus. S. 12, 85, 90, 92, 171 .

Mandel '̌stam, Osip Émil'evic (1891-1938), russischer Lyriker und Prosaiker. Ab 1911 häufiger Gast bei Vjac. Ivanov in Petersburg; ab 1912 Mitglied der Akmeisten-Vereinigung "Цlex поэтов" ("Dichter-Innung"). Ab 1928 hatte die politische Hetze gegen ihn zugenommen; 1934 wurde er erstmals verhaftet und zu drei Jahren Verbannung venuneilt: 1938 erfolgte die zweite Verhaftung und Deportation in ein Lager. S. 2 lf.

Manes (Mani, Manichäus, 215/16-276/77), Stifter des Manichäismus (= eine gnostische Weltreligion), predigte im persischen Reich und in Indien. S. 132.

Marx, Karl Heinrich (1818-1883). S. 25, 37, 42, 49, 75, 123, 152, 154, 176, 229, 231.

Maupassant, Guy de (1850-1893). S. 30.

Mejerhol'd. Vsevolod Ėmil'evič (1874-1940), nussischer Regisseur, Schauspieler und Theaterwissenschaftler, bedeutender Vertreter des russischen experimentellen Theaters. S. 77, 79. 87.

Merežkovskij, Dmitrij Sergeevič (1865-1941), bedeutender Lyriker, Prosaiker, Theoretiker und Kritiker des nussischen Symbolismus, Übersetzer und Philosoph. 1884-1889 Studium der Geschichte an den Universitäten Moskau und Petersburg: 1888-1904 Publikation seiner 
Lyrikbände; 1889 Eheschließung mit Z. Gippius; in den 90er Jahren Übersetzung griechischer Tragödien, Reise nach Griechenland: ab 1896 Beginn seines reichen religionsphilosophischen Werks in Romanform; 1905-1912 lebte er in Paris; entschiedener Gegner des bolschewistischen Umsturzes; 1919 Ausreise über Warschau nach Paris; in der Emigration wurde er publizistisch gegen die Sowjetmacht aktiv. S. 9, 12, 14-16, 23, 50, 76, 80f., $85 f$., 90f.. 96. 102, 107f.. 136, 159. 164, 166, 169, 181, 202, 218f., 223. 225.

Merner, Emilij Karlovič (Medtner [Familie deutscher Herkunft], 1872-1936), Theoretiker und Kritiker des russischen Symbolismus, Journalist und Philosoph. Verfasser zahlreicher musikwissenschaftlicher Arbeiten (meist unter dem Pseudonym Vol'fing). Er weilte häufig in Deutschland. höre Vorlesungen an Deutschen Universitäten (z.B. 1907 in Leipzig). In der ersten Dekade des 20. Jahrhundens spielte er eine wichtige Rolle als Vermittler der deutschen Literatur (Goethe!) und Kultur nach Rußland und Moskau, war zu seiner Zeit eine wichtige Persönlichkeit (vor allem in den Moskauer Symbolistenkreisen), auch was die Vermittlung Wagners nach Rußland betriff. Gemeinsam mit dem Ehepaar d'Alheim gründete er 1908 in Moskau das sogenannte "Maison du Lied". Seit Beginn des Ersten Weltkriegs lebte er in der Schweiz (Zürich) und geriet zusehends unter den Einfluß C.G. Jungs. S. 5. 10,26f.. 33f.. 36, 39f., 46, 73, 109, III-II7, I22-132, I35, 140, 142-145, 147. I5I. 159.171. $175 f . . .179 f ., 229$.

Metner, Karl Karlovic (Mediner, 1874-1919), Prokurist des Vorstands einer Moskauer Aktiengesellschaft; Bruder von E.K. und N.K. Metner. S. 175.

Metner, Nikolaj Karlovič (Medtner, 1879-1951), Bruder von Ė.K. Metner, nussischer Komponist und Pianist, neben Skrjabin bedeutender Vertreter des Symbolismus in der Musik. 1921 emigriente er, seit 1936 lebte er in Grobbritannien. S. 28, 3I, 151 .

Meulen, Johanna van der (Po(o)Iman(n)-Mo(o)y, 1874-1959), Lebensgefährtin von Éllis seit 1912/13: bis 1913 Anhängerin der Anthroposophie und zuverlässige Schülerin R. Steiners: 1913 Abkehr von Steiner und der Anthroposophie; unter dem Pseudonym Intermediarius publiziente sie vier esoterische und kosmologische Werke. S. 7, 117, 125, 129, 179-181. 184f.. 187-190.

Michelangelo (eig. Michelagnjolo di Ludovico Buonarroti-Simoni, 1475-1564). S. 66, 227.

Millais, John Everell (1829-1896), englischer Maler, gehöne der Bruderschafi der Präraffaeliten an. S. 12,52

Milton. John (1608-1674), bedeutender englischer Lyriker und Prosaiker. S. 30, 216.

Minclova. Anno Kudol'fovna (ca.1860-1910??]), Theosophin. Ubersetzenn, später Anthroposophin. Mittlerin sowohl zwischen den verschiedenen russischen Theosophen als auch zwischen den Theosophen im Westen und in Rubland: hielt sich für eine persönliche Schülerin R. Steiners, mit dem sie seit 1906 im Briefwechsel stand. 1908 versuchte sie, eine Reise Steiners nach RuBland zu organisieren. die jedoch nicht zustande kam. Sie übersetzte Steiners Werke ins Russische (1910 erschien in Petersburg Z.B. ihre vollständige russische Übersetzung von Steiners "Theosophie") und übte in Arbeitskreisen der Symbolisten. an denen u.a. Ellis und Belyj teilnahmen. großen Einfluß aus. Später meinte sie, die gleiche "Einweihungsstufe" wie Steiner erreicht zu haben. trat aus den Reihen seiner Schüler aus, ging ihren eigenen okkulten Weg und verschwand im Jahre 1910 plötzlich spurlos. (Vgl. V. Fedjuschin: Rußlands Sehnsucht, a.a.O.. S. 93ff; M. Carlson: Ivanov - Belyj - Minclova: the Mystical Triangle. In: Culturá e memoria. Atti del Terzo Simposio Intemationale dedicato a Vjaceslav Ivanov. Vol. I. a cura di F. Malcovati. Firenze 1988. S. 63-79.). S. 34, 122

Minskij. Nikolaj Maksimovic (eig. Vilenkin. 1855-1937), nussischer Lyriker, Dramatiker, Philosoph. Übersetzer, Theoretiker und Kritiker des frühen Symbolismus. S. 12.

Miropol'skij, A L. (eig. Aleksandr Aleksandrovič Lang. 1872-1917), russischer Lyriker, wirkte 1894/95 an Brjusovs Bänden "Рyсские скмволисты" mit. S. 14.

Moore. Thomas (1779-1852), englisch-irischer Lyriker. S. 47. 208.

Moréas, Jean de (eig. Joannis Papadiamantopoulus, 1856-1910), französischer Lyriker, Dramatiker und Theoretiker des Symbolismus (griechischer Abstammung, lebte seit 1882 in Paris); 1886 publiziente er in der Zeitung "Le Figaro" sein "Manifest des Symbolismus". S. 12 . 
Morozova, Margarita Kirillovna (geb. Mamontova, 1873-1958), Gründerin des Verlags "Put"' und der Moskauer Religionsphilosophischen Gesellschaft: Ehefrau des Moskauer Fabrikanten, Literarhistorikers und Kunstkritikers Michail Abramovið Morozov (1870-1903). S. 30.

Morris, William (1834-1896), englischer Lyriker, Dramatiker, Prosaiker und Kunsthandwerker, dem - wie auch den Präraffaeliten - die romantisch gesehene Gotik als Vorbild diente. S. 12.

Motte-Fouqué, Friedrich Heinrich Karl, Freiherr de la (1777-1843), deutscher romantischer Dichter (entstammte einer altadeligen französischen Hugenottenfamilie). S. 209.

Nadeždin. Nikolaj lvanovič (1804-1856), russischer Kritiker, Philosoph, Gelehrter und Journalist. S. 108.

Nekrasov, Nikolaj Alekseevič (1821-1877/78), bedeutender Lyriker, Dramatiker, Prosaiker und Kritiker des russischen Realismus. S. 102.

Nietzsche, Friedrich Wilhelm (1844-1900). S. 12, 16, 18, 21f., 26, 29, 47, 66, 76f., 80, 90, 92. 97, 100f., 121, 134, 136f., 139. 144f., 148-151. 158f., 164. 166f., 169, 174, 176, 193f.

Nikitenko, Aleksandr Vasil'evič (1804-1877), nussischer Kritiker und Literaturwissenschaftler.

Nilender, Vladimir Ottonovič (1883-1965), russischer Lyriker, Altphilologe und Übersetzer aus dem Griechischen, lebte eine zeitlang (ca.1909-1911) wie Ėllis im Gasthaus "Don" in Moskau, kümmerte sich um Ėllis und sorgte dafür, daß dieser sich regelmäßig emährte und äußerlich pflegte. S. 28, 4lf., 150.

Novalis (eig. Freihert Friedrich von Hardenberg. 1772-1801). S. 12, 60, 79, 97, 132, 160, 163. 205,210 .

Olcon. Henry Steel (1832-1907), amerikanischer Theosoph, mit E.P. Blavatskaja 1875 Mitbegründer der Theosophischen Gesellschaft in New York. S. 118.

Olenina-d'Al'gejm, Marija Alekseevna (Marie, 1869-1970), Kammersängerin (Mezzosopran); Frau von Pierre d'Alheim. S. 33, 151.

Ovid (lat. Publius Ovidius Naso, 43 v.Chr. - etwa 17 n.Chr.), bedeutender römischer Dichter. S. 53.

Ozerov, Ivan Christoforovič (1869-1942), Nationalökonom, Professor für Finanzrecht an der Moskauer Universität, Mitglied des Staatsrates. S. 25, 36.

Panov', A.A., nussischer Übersetzer. S. 76.

Pasternak, Boris Leonidovic (1890-1960), russischer Lyriker, Prosaiker, Übersetzer; gehörte anfangs der symbolistischen und futuristischen Richtung an. Den Nobelpreis (1958) mußte er auf politischen Druck Chrušcëvs ablehnen. S. I/3.

Pasternak, Leonid Osipovic (1862-1945), nussischer Maler; Vater von B.L. Pastemak. S. 31 . 35.

Pašukanis, VikentijVikent'evič (?-1919), Mitarteiter des "Musaget"-Verlags, Inhaber des Verlags "V.V. Pašukanis" in Moskau. S. 117.

Pavlova, Karolina Karlovna (geb. Karoline Jon Jaenisch, 1807-1893), russische Dichterin und Übersetzerin; Tochter eines russifizienten deutschen Professors der Moskauer Universität. S. 204

Pečkovskij. Aleksandr Petrovič, Chemiestudent, Übersetzer aus dem Deutschen: Studienkollege von A. Belyj; nahm am "Argonautenkreis" teil. S. 48.

Petersen. Karl Fr.L. von (1775-1822), Baltendeutscher, Freund V.A. Zuukovskijs. Gelegenheitsdichter. S. 204.

Pëtr (?-1326), russischer Metropolit seit 1308, verlegte den Metropolitensitz von Vladimir nach Moskau. S. 226.

Pëtrl. Velikij (Peter der Große, 1672-1725), 1682/89-1725 russischer Zar. S. 212, 223, 228.

Petrarca, Francesco (1304-1374). S. 55.66.

Petrovskaja. Nina Ivanovna (verh.: Sokolova. Pseud.: $H^{*} * *, N, 1884-1928$ ), Prosaikerin und Kritikerin des russischen Symbolismus. Ubbersetzerin; erste Frau von S.A. Sokolov; spielte eine wichtige Rolle im Kreis der Moskauer Symbolisten, nahm am "Argonautenkreis" teil; durch ihre Beziehung zu Belyj und Brjusov wurden die Spannungen zwischen diesen verstärkt und gipfelten schließlich in Brjusovs Fordenung zum Duell: diente Brjusov als Modell für die Renata in seinem Roman "Ognennyj angel". 1911 verließ sie Rußland, lebte zunächst 
in Rom, seit 1922 in Berlin; 1928 setzte sie ihrem schweren Leben in Paris selbst ein Ende. S. 9.28.

Petrovskij. Aleksej Sergeevič (1881-1958), nussischer Übersetzer, Mitarbeiter der Bibliothek des Rumjancev-Museums in Moskau: enger Freund A. Belyjs: Mitglied des "Argonautenkreises". S. 27.

Pjast, Vladimir Alekseevič (eig. Pestovskij, 1886-1940), Lyriker und Prosaiker des russischen Symbolismus, Übersetzer, befaßte sich mit Verslehre und -theorie. S. 9, 113.

Pjatnickij, Konstantin Petrovič (1864-1938), gründete 1898 in Petersburg den "Znanie"-Verlag, war Mitherausgeber der "Znanie"-Bände und nahm aktiv am literarischen Leben Rußlands teil. S. 72.

Plato (griech. Platon, 427-347 v.Chr.). S. 200f.

Pobedonoscev. Konstantin Petrovič (1827-1907), russischer Staatsmann, Jurist: 1880-1905 Oberprokuror des Heiligen Synods; übte großen politischen Einfluß auf die Zaren Aleksandr III. und Nikolaj II. aus. S. 137.

Pocco, Aleksandr Michajlovic (Pozzo, 1882-1941), Mann von N.A. Turgeneva, russischer Rechtsanwalt, Redakteur der Moskauer Zeitschrift "Северное сияние" ("Das Nordlicht"); seit 1913 persönlicher Kontakt mit R. Steiner, Mitbegründer und Herausgeber des russischen anthroposophischen Verlags "Tropa".

Poe, Edgar Allan (1809-1849), Lyriker und Prosaiker, bedeutendster Vertreter der amerikanischen Romantik. S. 12, 80f., 85, 90, 92, 94, 163.

Polivanov, Lev Ivanovic (Pseud. P. Zagarin, 1838-1899), Éllis' Vater, bedeutender nussischer Pädagoge, Literaturwissenschaftler, Verfasser mehrerer literarischer Arbeiten. 1861 beendete er sein Studium an der Historisch-Philologischen Fakultät der Moskauer Universität; 1868 gründete er in Moskau das sogenannte "Polivanovskaja Gimnazija", das als eines der besten vorrevolutionären Gymnasien galt; bis zu seinem Lebensende war er Direktor dieses Gymnasiums. Als humaner und talentienter Pädagoge übte er großen Einfluß auf seine Zöglinge aus, zu denen u.a. Brjusov und Belyj gehörten. S. 25.

Poljakov, Sergej Aleksandrovic (1874-1942), Moskauer Industrieller, Übersetzer und Literat, aktiver Anhänger des Symbolismus; gründete 1899 in Moskau den Verlag "Skorpion": schrieb in "Becы" unter dem Pseudonym S. Ešxboev. S. 32, 71.

Polonskij,Jakov. Petrovič (1819-1898), nussischer Lyriker (Spätromantik) und Prosaiker. S. II, 193.211.225

Portmann, Adolf (1897-1984), Schweizer Biologe: publiziente Abeiten zur vergleichenden Morphologie, allgemeinen Biologie und Entwicklungsgeschichte; war um Zusammenarbeit von Okologie, Verhaltensforschung, Soziologie und Philosophie bemüht. S. 121 .

Prudhomme, René-François-Armand (Sully Prudhomme, 1839-1907), französischer Lyriker, Übersetzer, einer der Hauptventreter der "Parnassiens"; Nobelpreisträger 1901. S. 47.

Puškin. Aleksandr Sergeevic (1799-1837). S. 7, 47, 58, 65, 81, 83, 108. 157, 185f., 193, 202. 204. 206, 208f.. 212-218, 223, 225, 229, 232f.

Račinskij, Grigorij Alekseevic (1859-1939), nussischer Schriftsteller, Übersetzer, Philosoph; Vorsitzender der Moskauer Religionsphilosophischen Gesellschaft; Anhänger Kants; bis 1901 Mitglied des Redaktionskomitees der Zeitschrift "Bompосы философин" ("Fragen der Philosophie"). S. 132, 191.

Raffael (Raphael, eig. Raffaello Santi, 1483-1520). S. 52, 227.

Remizov, Aleksej Michajlovič (1877-1957), Prosaiker, Theoretiker und Kritiker des russischen Symbolismus, Übersetzer. Den bolschewistischen Umsturz betrachtete er als tragisches Ende des alten religiösen Rußlands; 1921 Emigration nach Berlin; ab 1923 lebte er in Paris. S. 9.78, 169.

Reutern. Elisabeth von (1821/22-1856), Ehefrau V. Zukovskijs. S. 210.

Rilke, Rainer(René) Maria (1875-1926). S. 51, 81f., 113,159.

Rimbaud, Jean-Arthur (1854-1891), Lyriker des französischen Symbolismus. S. 12, 104.

Rjabušinskij. Nikolaj Pavlovič (1876-1851), nussischer Bankier, Industrieller und Kunstmäzenat: Herausgeber der aufwendigen Zeitschrift "Золотое руно", die er auch finanzierte. S.72. 
Rodenbach, Georges (1855-1898), Lyriker, Dramatiker, Prosaiker, wichtiger Vertreter des französisch-belgischen Symbolismus. S. 12, 45, 47f., 50f., 76, 80-82, 90, 92, 159, 166, 171 .

Rosenkreutz, Christian (14. Jahrhundert), legendärer Begrïnder der mönchsähnlichen Rosenkreu(t)zer-Bruderschaft Ende des 14. Jahthunderts mit mystisch-reformatorischen Zielen. (Im 16.-18. Jahrhunden Gründung verschiedener Rosenkreutzer-Bruderschaften mit dem Ziel, die religiösen, kulturellen und politischen Verhältnisse zu reformieren. Im 19. Jahrhunden Wiederaufleben rosenkreutzerischen Gedankenguts in neugnostischen Gruppen mit pansophischer und okkulter Ausrichtung.) S. 123, 127, 167.

Rossetti, Gabriel Charles, genannt Dante Gabriel (1828-1882), englischer Maler und Dichter, Mitbegriinder der Gemeinschaft der Präraffaeliten. S. 12, 52.

Rozanov, Vasilij Vasil'evic (1856-1919), russischer Philosoph, Schriftsteller, Kritiker, Publizist. S. 159.

Rublëv, Andrej (um 1360/70-1427/30), russischer Fresken- und Ikonenmaler, bedeutendster Vertreter der Moskauer Schule der (lkonen)Malerei; als Mönch in und um Moskau tätig. S. 225. 227.

Ruskin. John (1819-1900), englischer Schriftsteller und Sozialreformer, 1870-1884 Professor für Kunstgeschichte in Oxford; setzte sich für die junge Generation der Präraffaeliten ein. S. 12.

Sadovskoj. Boris Aleksandrovic (eig. Sadovskij, 1881-1952), Lyriker, Prosaiker, Kritiker und Literarhistoriker des russischen Symbolismus. S. 80.

Saginjan, Marietta Sergeevna (1888-1982), Lyrikerin, Prosaikerin und Kritikerin, stand zunächst den Symbolisten nahe; seit den 30er Jahren erfolgreiche Autorin des Sozialistischen Realismus und der Aufbau- und Produktionsliteratur. S. 146.

Schelling, Friedrich Wilhelm Joseph von (1775-1854). S. 12, 20, 91, 120f., 153, 194, 205, 207, 211 .

Schiller, Friedrich von (1759-1805). S. 5, 60, 193, 206, 208, 215.

Schlegel. August Wilhelm von (1767-1845), deutscher Dichter, Kritiker, Literarhistoriker, Ubersetzer; zusammen mit seinem Bruder Friedrich legte er die Grundlagen der romantischen Kunstlehre. S. 12, 20, 23,91, 97, 153, 177, 205, 210.

Schleiermacher, Friedrich Ernst Daniel (1768-1834), deutscher evangelischer Theologe und Philosoph; gehörte dem Kreis der Romantiker an. S. 137, 207.

Schnitzler, Arthur (1862-1931), österreichischer Dramatiker und Prosaiker, ursprünglich Arzt. S. 79.

Schopenhauer, Arthur (1788-1860). S. 12, 26, 28, 91, 143, 155, 176.

Schuré, Edouard (1841-1929), französischer Schriftsteller, Vertreter der Bewegung "Renouveau catholique"; stand der Theosophie nahe. S. 229.

Serafim von Sarov (Serafim Sarovskij, eig. Prochor Mošnin, 1759-1833), nussischer Mönch. Asket und Starez: 1903 von der russisch orthodoxen Kirche heiliggesprochen. S. 201, 222224, 226.

Serafimovič, Aleksandr (eig. Aleksandr Serafimovič Popov, 1863-1949), russischer Prosaiker, Vertreter des Sozialistischen Realismus. S. 72.

Sergius von Radonež (Sergij Radonežskij, eig. Varfolomej, ca.1321-1391/92), Gründer des Dreifaltigkeitsklosters (Т ронце-Сергиева Лавра) in Sergiev Posad bei Moskau, das Vorbild für viele nordrussische Klöster wurde. S. 226.

Šstov, Lev (eig. Lev Isaakovið Švarcman, 1866-1938), russischer Philosoph (Existentialismus) und Literaturkritiker; lebte seit 1920 in Paris. S. 74.

Seuse, Heinrich (latinisien Suso, um 1295-1366), hervorragender Mystiker, Mitglied des Dominikanerordens; Schüler von Meister Eckehart; führte ein streng asketisches Leben. hatte viele Leiden zu erdulden: Heiliger. S. 55.

Shakespeare, William (1564-1616). S. 5.30,78,87.215.

Shelley.Percy Bysshe (1792-1822), Lyriker, Dramatiker und Theoretiker, bedeutender Vertreter der 2. Generation der englischen Romantiker. S. 94.

Sidorov, Aleksej Alekseevič (1891-1978), Lyriker, Übersetzer, Kunsthistoriker und Kritiker; Mitarbeiter der Zeitschrift "Т руды и дня". S. II7. 
Sizov, Michail Ivanovič (Pseud.: M. Sedlov, Mich. Gorskij, 1884-1956), Physiologe, Pädagoge, Kritiker, Übersetzer, Mitglied des "Argonautenkreises", Freund von A. Belyj.

Sizova, Marija (Magdalina) Ivanovna (1889(?)-1969), Schriftstellerin. Regisseurin, Theaterpädagogin: Schwester von M.I. Sizov; Anhängerin der Philosophie VI. Solov'evs; beschäftigte sich mit verschiedenen Vortragszyklen R. Steiners; 1912 gründete sie in Moskau einen Arbeitskreis zur Theosophie/Anthroposophie. Mit Ėllis, der sie wiederholt als seine "geistige Schwester" bezeichnet (РГАЛИ, Ф. 575, on. 1, ед.xp. 20, Blatt 67 und 71; ebd., ed.xp. 44) vertand sie seit mindestens 1908 (Beginn des im РГАЛИ archivierten Briefwechsels) eine innige Freundschaft. S. 30, 45, 123-126, 171, 175, 185 .

Skitalec (eig. Stepan Gavrilovic Petrov, 1869-1941), Lyriker, Dramatiker und Prosaiker des nussischen Spätrealismus; 1922-1934 lebte er in Harbin (China); später. Vertreter des Sozialistischen Realismus. S. 72.

Skrjabin, Aleksandr Nikolaevic (1871/72-1915), russischer Komponist und Pianist, Hauptvertreter des Symbolismus in der Musik. S. 18, 32, 89.

Šmelëv, Ivan Sergeevič (1875-1950), nussischer Prosaiker; emigrierte 1922 nach Paris, wurde einer der beliebtesten Autoren der russischen Emigration. S. 225.

Sokolov, Sergej Alekseevič (Pseud.: Sergej Krečetov, 1878-1936), russischer Rechtsanwalt, Lyriker, Inhaber des Verlags "Grif", Redakteur der Zeitschrift "Перевал". S. 270.

Sologub, Fëdor (eig. Fëdor Kuz'mið Tetemikov, 1863-1927), bedeutender Lyriker, Prosaiker, Dramatiker und Übersetzer des russischen Symbolismus. Beendete 1882 seine Lehrerausbildung in Petersburg; arbeitete bis 1907 als Mathematiklehrer (bis 1892 in der Provinz); publiziente ab 1884 Gedichte, seit 1896 auch Prosawerke; 1921 wurde ihm die erbetene Ausreisegenehmigung verweigert. S. 9, 15, 53, 77f., 81, 102, 105, 108, 168, 175.

Solov'ëv. Michail Sergeevič (1862-1903), russischer Pädagoge, Übersetzer, Herausgeber der Werke seines Bruders VI. Solov'ev. S. 191 .

Solov'ēv. Sergej Michajlovič (1885-1942), nussischer Lyriker, Prosaiker, Übersetzer, Philologe, Theologe; Sohn von M.S. Solov'ev; enger Freund A. Belyjs; Mitglied des "Argonautenkreises". 1917 Priesterweihe; 1918 Konversion zum Katholizismus. S. 26, 28-30, 49, 150 , 164, 191, 193.

Solov'ëv. Vladimir Sergeevix (1853-1900), russischer Lyriker, bedeutender Religionsphilosoph. Kritiker. Publizist. S. 7f., 10f., 13f., 16, 18, 30f., 56-58, 100f., 122, 124, I31f., 140. 154, 157f., 162-164, 166f.. 170, 176, 180-186, 189, 191-204, 207, 211-213, 217, 221, 223-225, 227-230, 232f.

Spieß. Christian Heinrich (1755-1799), deutscher Schriftsteller, Vertreter des abenteuerlichen Ritterromans und Ritterstücks. S. 208.

Stecchetti, Lorenzo (eig. Olindo Guerrini, 1845-1916), italienischer Lyriker (stark von Baudelaire beeinflußt). S. 29, 36, 47.

Steiner, Rudolf Joseph Lorenz (1861-1925), Begriinder der Anthroposophie; 1889-1896 Mitarteiter an der Weimarer Goethe-Ausgabe (Naturwissenschaftliche Schriften); 1891 Promotion zum Doktor der Philosophie; 1902-1912 Generalsekretär der deutschen Sektion der Theosophischen Gesellschaft; 1912/1913 Gründung und Konstituierung der Anthroposophischen Gesellschaft; ausgedehnte Lehr- und Vortragstätigkeit; Errichtung der "Hochschule für Geisteswissenschaften" (= Goetheanum) in Dornach/Schweiz: 1919 Begründung der Freien Waldorfschule in Stuttgart; 1922 Mitwirkung bei der Begründung der Christengemeinschaft. S. 7, 10, 34-36, 38-40, 42, 45, 115, 117-134, 137, 144, 149, 152, 158, 160 , 162, 165, 167-169, 179, 185, 199, 224, 229, 231, 233.

Stepnjak-Kravčinskij, Sergej Michajlovič (1851-1895), nussischer Prosaiker, Übersetzer, Theoretiker und Publizist; gehörte zum terroristischen Flügel des Narodničestvo (Земля и воля). S. 74

Stepun. Fëdor Avgustovič (Steppun, 1884-1965), russischer Philosoph, Kulturhistoriker und -soziologe, Prosaiker, Literaturkritiker und Essayist. 1903-1907 Studium der Philosophie an der Universität Heidelberg; deutsche Philosophie und Kultur spielten fortan in seinem Leben eine groBe Rolle. 1910 Promotion zum Dr.phil. mit einer Arbeit über die Philosophie Vl. Solovevs. 1910 Griindung der intemationalen philosophischen Zeitschrift "Logos"; Heraus- 
gabe der nussischen Ausgabe in Moskau. Rege Vortragstätigkeit im Bereich der Religionsphilosophie. Nach der Februarrevolution aktive Tätigkeit gegen die Bolschewiken für den Aufbau demokratischer Freiheit. 1922 Ausweisung aus der Sowjetunion gemeinsam mit den Philosophen N. Berdjaev, S. Frank, I. ll'in, N. Losskij u.a. Ab 1926 Professur für Soziologie an der TH Dresden. 1937 Zwangspensionierung durch die nationalsozialistische Regierung: bis 1945 Publikationsverbot. 1946 Emennung zum Honorarprofessor für russische Geistesgeschichte an der Universität München. Bis an sein Lebensende Ausübung wissenschaftlicher, schriftstellerischer und publizistischer Tätigkeiten. S. 5, 42, 78, $113,115,143$, 199, 202.

Strindberg, August (1849-1912), bedeutender schwedischer Dramatiker und Prosaiker. S. 79.

Swedenborg. Emanuel von (1688-1772), schwedischer Naturforscher, Naturphilosoph und Theosoph. S. 167.

Symons, Arthur (1865-1945), Schriftsteller und Kritiker, in seiner Jugend einer der führenden symbolistischen Dichter Englands. S. 153.

Tamburer, Lidija Aleksandrovna (1870-ca.1940), nussische Zahnärztin, Freundin der Familie Cvetaev.S. 33.

Taneev, Sergej Ivanovic (1856-1915), nussischer Komponist, Pianist; von 1878-1906 Professor am Moskauer Konservatorium. S. 26, $28 f ., 48$.

Taneev, Vladimir Ivanovic (1840-1921), russischer Jurist, Philosoph, Soziologe; Bruder von S.I. Taneev.

Telešov. Nikolaj Dmitrievič (1867-1957), russischer Prosaiker des Spätrealismus: organisiente 1899 die Schriftstellervereinigung "Sreda"; war an den Sammelbänden des Verlags "Znanie" beteiligt. S. 72.

Theresia von Jesus (Teresa de Jesús. 1515-1582), spanische Mystikerin; Förderin der katholischen Reform; reformiente den Orden der Karmeliterinnen. Heilige. S. 55.

Thomas von Aquin (1225 od.1226-1274), bedeutendster Philosoph und Theologe des Mittelalters; 1322 heiliggesprochen: 1567 zum Kirchenlehrer erhoben. S. 131, 163, 166.

Tieck, Ludwig (1773-1853), Lyriker, Prosaiker und Dramatiker der deutschen Romantik. Übersetzer. S. 205, 210.

Tizian (eig. Tiziani Vecelli(o), 1476/77 od.1489/90-1576). S. 227.

Tjutčev, Fëdor Ivanovič (1803-1873), bedeutender russischer Lyriker der Spätromantik, Publizist, Diplomat. S. 11, 14, 140. 193.211, 225.

Tolstoj, Aleksej Konstantinovic (1817-1875), nussischer Lyriker (Spätromantik), Dramatiker, Prosaiker, Übersetzer, Diplomat. S. 193, 225.

Tolstoj, Lev Nikolaevic, Graf (1828-1910). S. 77, 81f., 85, 202, 215f., 220, 225.

Troll, Wilhelm (1897-1978), deutscher Biologe; befaßte sich vor allem mit der Systematik und Morphologie der Phlanzen. S. 121.

Turgenev, Ivan Sergeevic (1818-1883). S. 60, 81, 193, 215f., 220, 225.

Turgeneva, Anna Alekseevna (Asja, A.A.T., 1890-1966), nussische Graphikerin und Malerin; erste Frau von A. Belyj; Schnitzerin am ersten Goetheanum, Bühneneurythmistin. S. 36, 51 , $118,124.126-129,132 f$.

Turgeneva, Natalija Alekseevna (1886-1942), Schwester von A.A. Turgeneva. Frau von A.M. Pozzo, Eurythmistin; übersetzte R. Steiners Werke ins Russische für den Verlag "Tropa". S. $123-125,127$.

Uhland, Ludwig (1787-1862), deutscher romantischer Dichter, bedeutendster Vertreter der schwäbischen Spätromantik. S. 206.

Unger, Carl (1878-1929), bedeutender Untemehmer aus Süd-Württemberg, einer der (zeitlich) frühesten Anhänger Steiners; übte eine aktive Vortragstătigkeit über theosophische und anthroposophische Themen aus; war ab 1912 Vorsitzender der Anthroposophischen Gesellschaft; leitete die gesamte Finanzverwaltung beim Bau des ersten Goetheanums. S. 127.

Uspenskij, Gleb Ivanovič (1842-1902), russischer Prosaiker, bedeutendster Repräsentant des Narodnixestvo.S. 82.

Valentinov. N. (eig. Nikolaj Vladislavovič Vol'skij, 1879-1964), russischer Publizist, Philosoph, Sozialdemokrat; verfaBte Bücher über nolitische und wirtschaftliche Themen. Während 
seiner Studienjahre an den Technischen Hochschulen zuerst in Petersburg und dann in Kiev wurde er mehrfach verbannt bzw. ins Gefängnis geworfen wegen seiner Mitgliedschaft in der Sozialdemokratischen Panei und seiner Teilnahme an politischen revolutionären Aktivitäten. Er floh nach Genf, wo er Lenin kennenlemte und unter dessen Einfluß geriet. 1905 kam er nach Moskau, allerdings bereits als Menschewik. Neben zahlreichen Buchpublikationen schrieb er für verschiedene Zeitungen und Zeitschriften, wobei er sich mehrerer Pseudonyme bediente. Nach der Oktoberrevolution blieb er zunächst in Rußland. Später (1930) emigrierte er und verbrachte seine letzten Lebensjahre in Paris und New York. S. 35. 39. 43. 50.234.

Vasil'ev. N., russischer Übersetzer. S. 76.

Venevitinov, Dmitrij Vladimirovič (1805-1827), russischer romantischer Lyriker, erster russischer Theoretiker der philosophischen Romantik. S. 217.

Vengerov. Semen Afanas'evic (1855-1920), nussischer Literarhistoriker und Bibliograph. S. 74.

Veresaev, Vikentij Vikent'evič (eig. Smidovix, 1867-1945), nussischer Prosaiker des Spätrealismus: Arzt; nach der Oktoberrevolution auch als Übersetzer und Literarhistoriker hervorgetreten.S. 73.

Verhaeren, Émile (1855-1916), Lyriker des französisch-belgischen Symbolismus; Mitbegründer der literarischen Bewegung "La jeune Belgique". S. 12, 38, 45, 48, 76, 83, 90, 97, 171.

Verlaine, Paul (1844-1896), bedeutender französischer Lyriker, Prosaiker; Wegbereiter des Symbolismus. S. 12, 47, 51, 90, 92, 97, 163, 171 .

Veselovskaja, Manja Vasil'evna (1877-1937), Kritikerin des russischen Symbolismus. Übersetzerin; Frau des Übersetzers und Literaturwissenschaftlers Ju.A. Veselovskij (18721919). S. 76.

Villiers de I'Isle-Adam. Jean-Marie Mathias Philippe-Auguste, Comte de (1838-1889), französischer Schriftsteller, Prosaiker, Dramatiker, literarischer Neo-Katholik im Sinne der französischen Décadence; befaßte sich mit Okkultismus, Freimaurerei und Theosophie. S. 171 .

Vjazemskij, Pëtr Andreevič, Fürst (1792-1878), russischer romantischer Lyriker, Literarhistoriker und Literaturkritiker. S. 210.

Vladimir l., der Heilige (?-1015), Großfürst von Kiev, regierte 980-1015; vermählte sich mit der byzantinischen Kaisertochter Anna. führe 988 das Christentum als Staatsreligion ein (Christianisienung Rußlands). S. 200, 219, 222.

Vladimirov, Vasilij Vasil'evił (1880-1931), russischer Künstler und Ikonenmaler; gestaltete Buchumschläge für die Symbolisten im Verlag "Grif"; enger Freund A. Belyjs; Mitglied des "Argonautenkreises". S. 28.

Vol'fing $\rightarrow$ E.K. Metner.

Vol'kenštejn, Vladimir Michajlovič (1883-?), russischer Dramatiker und Theaterwissenschaftler. S. 57, 67.69.

Vološin, Maksimilian Aleksandrovič (eig. Kirienko-Vološin. 1877-1932), russischer Lyriker, Maler, Theoretiker, Kritiker, Übersetzer, Vermittler der romanischen Kultur und Literatur im Kreis der Symbolisten. Sein Jurastudium an der Moskauer Universität (1897-98?) mußte er wegen Beteiligung an studentischen Unruhen abbrechen; ab 1900 als Schriftsteller und Maler tätig; 1901-1917 lebte er überwiegend in Paris, reiste viel durch Europa, besuchte regelmäßig Rußland; 1917 Rückkehr nach Rußland, Ubersiedlung nach Koktebel' (Ostkrim); konsequenter Gegner des kommunistischen Systems. S. 25, 28, 31, 159.

Vološina, Margarita Vasil'evna (geb. Sabašnikova. 1882-1973), erste Frau von M.A. Vološin. russische Malerin (Schülerin I. Repins), verkehrte in (symbolistischen) Literatur- und Künstlerkreisen in Moskau, Petersburg und Koktebel'. 1905(?) erste Begegnung mit R. Steiner; davor hatte sie sich, angeregt durch A.R. Minclova, schon mit seinen Schriften befaßt. In der Folgezeit gehörte sie Steiners Schülerkreis an und versuchte, in ihren Bildem seinen künstlerischen Intentionen zu folgen. S. 42, $118,123 f ., 126,133$.

Voltaire (eig. François-Marie Arouet, 1694-1778). S. 214.

Wackenroder, Wilhelm Heinrich (Pseud. Emst Winter, 1773-1798), bedeutender Kunstschriftsteller der deutschen Frïhromantik. S. 220. 
Wagner, Richard (1813-1883). S. 5, 7, 12, 18, 23, 34, 58, 77, 92, 114, 116, 134, 136f., 139152, 155, 159, 163,166, 189, 215, 229.

Weizsäcker, Carl Friedrich Freiherr von (geb. 1912), deutscher Physiker und Philosoph. S. 121 .

Wilde, Oscar (1854-1900), Lyriker, Prosaiker und Dramatiker des englischen Symbolismus; Essayist; Vertreter eines der französischen Décadence verbundenen Ästhetentums: "l'art pour l'art" als Lebensform. S. 12, 30, 55, 79-81, 90, 159. 163.

Wolfram von Eschenbach (um 1170-ca.um 1220), bedeutender mittelhochdeutscher Dichter, Haupt werk und einziges vollendetes seiner Epen: "Parzival" (ca.1200-1210). S. 148.

Zajcev, Boris Konstantinovič (1881-1972), russischer Prosaiker, Übersetzer, Literarhistoriker, wurde durch L. Andreev in N. Telešovs Schriftstellerkreis "Sreda" eingefuihrt; stand auch symbolistischen Kreisen nahe; 1922 Verhaftung und Ausreise aus Rußland: lebte zunächst in Deutschland und Italien, ab 1924 bis zu seinem Lebensende in Paris. S. 81f., 181 .

Žemčužnikov, Aleksej Michajlovič (1821-1908), nussischer Lyriker (Realismus, der Tradition N.A. Nekrasovs verpflichtet) und Publizist. S. 11 .

Zukovskij, Vasilij Andreevič (1783-1852), russischer Dichter und Übersetzer, der von außerordentlich großer Bedeutung für die russische Romantik und die Entwicklung der russischen Lyrik überhaupt war. Lebte ab 1841 in Deutschland. S. 7. 93. 109, 157, 176, 181, $185 f$., $193,204-213,218,223,225,229,232 f$. 


\section{ANHANG: Übersetzung der Zitate}

\section{Zu Seite 9:}

Anmerkung I: "Ëllis |ist| Baudelaire-Übersetzer, einer der leidenschafilichsten frühen Symbolisten, ein zerfahrener Dichter, ein genialer Mensch."

\section{Zu Seite 13:}

Anmerkung 12: " $[.$.$\} der Begriff «Symbolismus» umfabt eine Anzahl verschiedener Bedeutungen, weil$ er nicht eine einzige, homogene Bewegung beschreibt. sondem vielmehr mehrere, parallele Strömungen."

Anmerkung 14: "eine facettenreiche Bewegung"

\section{Zu Seite 14:}

Anmerkung 18: "(...) ich hoffe eine Lyrik zu schaffen, die dem Leben gegenüber fremd ist, Stimmungen zu erzeugen, die das Leben nicht zu geben vermag."

Anmerkung 19: "Oh, bedecke Deine bleichen Beine."

Anmerkung 23: " "Der ausgesprochene Gedanke ist Lüge». In der Dichtkunst wirkt das, was nicht gesagt wird und durch die Schönheit des Symbols hindurchschimmen. stärker auf das Herz als das, was mit Worten ausgedrückt wird. Der Symbolismus vergeistigt den eigentlichen Stil, die eigentliche künstlerische Substanz der Dichtung. macht sie transparent, durchscheinend, wie die dünnen Wände einer Alabasteramphore, in der eine Flamme brennt."

\section{Zu Seite 15:}

Anmerkung 25: "|... Oh. möge das werden, was es nicht gibt. / Niemals gibt |... / Ich brauche das, was es auf der Welt nicht gibt $\mid$...."."

\section{Zu Seite 17:}

Anmerkung 35: "Das Symbol ist nur dann ein wahres Symbol, wenn es unerschöpflich und grenzenlos in seiner Bedeutung ist. wenn es in seiner geheimen (hieratischen und magischen) Sprache der Andeu tung und Suggestion etwas Nichtverbales, etwas dem äuberen Won Nichtadäquates ausspricht. Es ist vielgestaltig. vieldeutig und stets dunkel in seiner letzten Tiefe. Es ist ein organisches Gebilde, wie Kri stall. Es ist sogar eine Art Monade, - und dadurch unterscheidet es sich vom zusammengesetzten und zerlegbaren Bestand der Allegorie, der Parabel oder des Vergleichs. Die Allegorie ist eine Lehre: das Symbol - eine Sinngebung. Die Allegorie ist ein Sinnbild: das Symbol - ein Hinweis. Die Allegorie ist logisch begrenzt und innerlich unbeweglich: das Symbol hat eine Seele und eine innere Entwicklung. es lebt und verandert sich."

\section{Zu Seite I8:}

Anmerkung 36: "Der realistische Symbolismus geht vom Symbol zum Mythos: der Mythos ist bereits im Symbol enthalten. ist ihm immanent: die Betrachtung des Symbols offenbahrt im Symbol den Myt hos."

Anmerkung 42: "Der «Symbolismus» ist, wie die «Romantik», eine bestimmte historische Erscheinung. die mit bestimmten Daten und Namen verbunden ist. Nachdem die «symbolistische * Bewegung als literarische Schule Ende des 19. Jahrhunderts in Frankreich entstanden war (nicht ohne englischen EinfluB). fand sie in allen Literaturen Europas Anhänger, befruchtete mit ihren Ideen die anderen Künste und beeinflubte zwangsläufig auch die Weltanschauung der Epoche. Aber dennoch hat sie sich stets ausschlieblich auf dem Gebiet der Kunst ent wickelt. |...

Der Symbolismus ist eine Methode der Kunst. die in jener Schule klar erkannt wurde. die den Namen «symbolistische [Schule]» erhielt."

\section{Zu Site 20:}

Anmerkung 52: "Symbolismus |... Die russische Bewegung war, wie die französische. ein Wiederaufkommendes Idealismus und Ästhetizismus. Realismus und Positivismus hatten sich in Rußland lange der Vorherrschaft erfreut, bevor der Symbolismus als neoromantische Reaktion entstand."

\section{Zu Seite 20-21:}

Anmerkung 53: "In vielertei Hinsicht wiederholte der Symbolismus die Entwicklung der Romantik. Als Reaktion auf das offenbare Versäumnis der vorangegangenen Generation, die geistigen Bedürfnisse der gebildeten Klassen zu befriedigen, wandte er sich einer idealistischen Weltanschauung zu und emeute dabei die Suche nach absoluten Werten und religiöser Sensibilität. Dann. nachdem sie einen derartigen Idealismus ins Extrem getrieben hatten. vemeinten itn einige Symbolisten. wie einige Romantiker. durch eine Art romantische Ironie oder eine Hinwendung zum Mystizismus. Eskapismus, oder zu unkontrol lierter Phantasie. Die politische Erfahrung einiger russischer Symbolisten gleicht ebenfalls derjenigen der Romantiker: Sie begannen geradezu als Revolutionäre und fanden sich schlieblich in den Reihen konservativer Gegner des Sowjetregimes wieder." 
Zu Seite 21:

Anmerkung 55: "Wiederentdeckungen bekannter romantischer Klischees"

Zu Seite 22:

Anmerkung 59: "Aber die ganze moderne russische Lyrik ist aus dem gemeinsamen symbolistischen Ursprung hervorgegangen. Der Leser hat ein kurzes Gedächtnis - er will das nicht wissen."

Zu Seite 25:

Anmerkung 5: "[...] bereits seit 1903 nannte er sich selbst nicht anders als Symbolist, wobei er hinzufügte: «lch bin ehemaliger Marxist»."

Zu Seite 26:

Anmerkung 16: "Seele des Kreises - aufstachelnder Agitator, Propagandist"

Zu Seite 26-27:

Anmerkung 19: " $[$... $)$ das exoterische Ziel ist das Studium der Literatur, die Schopenhauer und Nietzsche gewidmet ist, und auch [das Studium des Werks] dieser Autoren: das esoterische Ziel ist die Reise durch Nietzsche in der Hoffnung, das Goldene Vlies zu finden [...) Emilij Karlovix, fühien Sie, was in dieser Wortverbindung klingt, die im 20. Jahrhundert von russischen Studenten ausgesprochen wird - die Argonauten durch Nielzsche zum Goldenen Vies!! [...] für andere wird sich dieses Davonschwimmen hinter die Horizontlinie, das ich unternehmen will, als Untergang erweisen, aber man muB auch wissen, daB das Segel dann, wenn es für den Blick des Küstenbewohners hinter dem Horizont versinkt, dennoch immer weiter mit den Wellen kämpft, dem unbekannten Golt ... entgegenstrebend ..."

Zu Seite 27:

Anmerkung 25: "zuerst mystische, dann psychische und schlieBlich reale"

Zu Seite 27-28:

Anmerkung 27: "Ein abscheulicheres Lebewesen als dasjenige, das ich am 25. August um 7 Uhr abends am Himmel sah. habe ich noch nie gesehen [...] Der riesengrobe, trübe, wie ein fettiges Blatt Papier. grün-gelbe (ich vermeide genauere Epitheta, die sich in meinem Kopf drehen, um ... «keine Gänse zu reizen») Mond ging zum Schrecken der Erdbewohner auf, wobei er mindestens eine der ägyptischen Qualen ankündigte, die Pest und dergleichen I...] Die klebrige, stickige Atmosphäre war mit bösartigem Nebel und drekkigen Ausdünstungen der Blumen-Allee angefüllt. Ein gelb-gesäumter Sonnenuntergang vollendete das Bild. Ich muBie bis zur Sretenka-StraBe gehen, und fühlie deutlich, daB es kein gutes Ende nehmen wird: - und ich erkrankte tatsächlich an Schlaflosigkeit und dergleichen; $[\text {... }]^{\prime \prime}$

Zu Seite 28:

Anmerkung 33: "sehr geschwätziger Philosoph. der seinen Gesprächspartner zu Tode reden konnte"

Zu Seite 29:

Anmerkung 38: "Es war am Dienstag. den 15. Februar 1905. Wir musizierten wie gewöhnlich. Wir sprachen unter anderem über verschiedene Romanzen mit gecignetem und ungeeignetem Text Kobylinskij-Ëllis sagte, dab er einen guten Text für eine Romanze habe und trug uns "Wenn, kreisend, die Herbstblätter" vor. Sergej Ivanovic gefielen diese Verse. Er fand sie leicht, klangvoll und sagte, dab man zu solchen Versen schnell Musik schreiben könne. Im Scherz fragten wir, ob er das in einigen Stunden könne, er antwortete uns: "Nicht in Stunden, sondem in Minuten. Wollen Sie, daB ich es sofort mache, in nicht mehr als 40-50 Minuten?". Uns interessierte das sehr und wir versprachen, die Romanze sofort zu singen, sobald Taneev sie geschrieben haben wïde. Sergej Ivanovix ging in sein Schlafzimmer, und nach ungefähr 25-30 Minuten brachte er uns die Romanze."

\section{Zu Seite 30:}

Anmerkung 42: "Gott! Gib mir Geduld, um die Banalität der Gespräche zu ertragen und nicht vorzeitig den Verstand zu verlieren.

Die Erinnerungen an die vergangenen Schicksalsschläge. Schrecken. Stürze. Beleidigungen und Seelenqualen sind mein Vampir, mein Schmerz ...

Aber auch darin ist etwas Gutes, denn darin liegt der eindeutige Beweis, daB es eine andere Realität, ein Reich der Träume gibt.

Meine Krankheit ist eine Krankheit der Einbildungskraft, aber das heiBt bei weitem nicht, daB es eine eingebildete Krankheit ist.

Derjenige. der wenigstens einmal aus der Zeit in die Ewigkeit geblickt hat, kehrt nicht zurück, er ist entweder alles oder nichts. hat entweder das Chaos besiegt oder geht für immer zugrunde!"

Anmerkung 44: "Ich liebe die Welt, weil sie ein Abglanz des Exigen ist. Ich liebe sie nicht, weil sie ein Abglanz des Ewigen ist."

Zu Seite 31:

Anmerkung 45: "Lieber Freund, oder siehst Du nicht, / DaB alles, was wir sehen - / Nur Abglanz, nur Schatten ist / Von dem, was man mit Augen nicht sehen kann? [...]"

Anmerkung 46: "Alles oder nichts." 
Anmerkung 47: [A. Belyj spricht vom] "stumpfsinnigsten. jämmerlichsten Sammelband «Freies Gewissens"

\section{Zu Seite 33:}

Anmerkung 54: "Wir sehen den Sinn des historischen Prozesses in der Suche der Menscheit nach neuer Freiheit. Wir begrüBen die sozialistische Bewegung, die bestrebt ist, die alte ökonomische Ordnung zu zerstören, aber der Sozialismus ist für uns nicht das einzige Ziel und die endgültige Form der gesellschaftlichen Organisation. Der freie Gedanke und das freie Schaffen der Dichter und Künstler, der Weisen und Propheten - das ist das Licht auf dem Weg der Menschheit. Wir kämpfen für die Befreiung der Persönlichkeit von den Ketten moralischer, philosophischer und religiöser Dogmatik und versöhnen uns nicht mit einer oberflächlichen Weltanschauung. die versucht, die Sphäre der inneren Erlebnisse einzuschränken. Wir erheben unsere Fackel im Namen der Bestätigung der Persönlichkeit und im Namen der freien Vereinigung der Menschen, die auf der Liebe zur zukünftigen verwandelten Welt gegründet ist. In diesem Sinne sind wir Anarchisten."

\section{Zu Seite 35:}

Anmerkung 2: "Ich schaute: im Publikum tauchte das, wie eine Gipsmaske, weiße Gesicht des Studenten auf, das von einem schwarzen Bar, wie von einem Krähenflügel, eingerahmt war; er drückte das Kinn an den hohen dunkelblauen Kragen, wobei er die weiße Glatze in den Gehrock tauchte; plötzlich schossen. mit unge wöhnlichem Glanz, seine grünen, phosphorfarbenen Augen an uns vorbei: aus engen Schlitzen; und die roten Lippen erstamen irgend wie erschlaff: $[\text {... }]^{n}$

Anmerkung 3: "Ėllis ist unvergeBlich und, wie auch A. Belyj, einmalig. Dieser seltsame Mensch [...]. der die Nacht zum Tag machte und den Tag zur Nacht, der in einem stets dunklen Zimmer mit heruntergelassenen Vorhängen und Kerzen vor einem Porträt Baudelaires und später vor einer Büste Dantes wohnte, hatte das Temperament eines rasenden Agitators, schuf ungewöhnliche Mythen und erfand Geschichten, war der Schöpfer verschiedenster Parodien und ein erstaunlicher Mimiker. [...]

Er hatte die grobe Gabe, ein Auditorium in Begeistenung zu versetzen, seine Aufmerksamkeit auf die ein oder andere Frage zu lenken. aber es war durchaus nicht ausgeschlossen. daB Ëllis mitten im Vortrag plötzlich erklärte: «Ach, soll euch alle der Teufel holen, ich habe es satt zu reden», und forging."

Anmerkung 4: "Ellis besaB die Fähigkeit die Menschen mitzureiBen, zu magnetisieren. Seine Parodien darauf, wie ein Bolschewik, ein Menschewik, ein Sozialrevolutionàr, ein Kadett, ein Junker, ein Page. ein Jude oder ein Armenier Walzer tanzt, waren so ausdrucksvoll und komisch, daB die Zuschaver sich krank lachten. Ihn selbst habe ich jedoch niemals lachen gesehen.

Zu Seite 36:

Anmerkung 7: "I... | ich wubte, daB der ungestüme Ėllis bereit war für das zu sterben. was gerade sein Ideal war: leider wechselten die Ideale: zuerst war er wissenschaftlicher Marxist und Agitator; dann Verehrer Stecchettis: 1901 propagiene er Professor Onerov; 1902-1907 war er Baudelaireaner, 1908 Brjusovanhänger: 1909 - "Dantejünger": 1910 - Sucher eines Einweihungsweges; von 1911 bis 1913 war er Steinerianer, von 1915 bis 1916 ein trever Verehrer Loyolas $[. . .]^{\prime \prime}$

"Ökonom - Pessimist - Baudelaireaner - Brjusovanhänger - Dantejünger - Okkultist - Steinerianer Katholik"

Anmerkung 9: "[...] er war niemals der, als der er sich und uns erschien; er war blob Mimiker, sein Talent wurde von genialen Funken überlagert: $[\ldots]^{"}$

Anmerkung 10: "Kobylinskij war gebildet. besaB eine Rede- und Schauspielbegabung: er konnte die eine oder andere Rolle spielen und dabei glauben, daB die Rolle Überzeugung ist: $\mid$..."

Anmerkung 1I: "Seine ganze Begabung legte er auf seine Zungenspitze; die Talentlosigkeit floB in seine Feder."

Zu Seite 37:

Anmerkung 12: "[...] er wäre ein bedeutender Schauspieler gewesen. und wurde - ein schlechter Übersetzer, ein unbegabter Dichter, ein mittelmäBiger Publizist und ein Ex (Ex-Symbolist. Ex-Marxist usw.): $($...."

Anmerkung 13: "Er verursachte einen Skandal nach dem nächsten; der fallige Skandal endete in Hysterie; die Hysterie nahm derartige Formen an, daB wir sagten: «Das ist nun auch sein Ende!»

Aber Kobylinskijs «Leiche* erhob sich und begann eine neue Lebensphase $[. . .]^{\prime \prime}$

Anmerkung 15: "Ëllis, blaB, mit blutroten Lippen, wie bei einem Vampir, [...] mit einem Gesicht, das immer näher rückte und den Gesprächspartner mit Speichel übergoB - quälte A.A. I= Blok I, zuckte nervös mit den Schultem und zwirbelte ständig seinen Schnurrbart: und - schüttete seine Wortarabesken aus: alle wollten in der Stille verweilen. die man von den Gräbern mitgebracht hatte, aber nein: mit leidenschafulicher, unersättlicher, fanatischer Herzlosigkeit zog Ëllis A.A. hinter sich her von den Gestalten Dantes, den Chimären der Kathedralen, zu ... Baudelaire, der A.A. so fremd war; $[\ldots]$ ich sah, wie A.A. unter dem Wortschwall grün wurde; unerträglich war ihm diese Überspanntheit von Ëllis auf den 
Spiralen der Scholastik: [...] ich erinnere mich folgendermaßen: das kahle, totenăhnliche Gesicht, das Grün der Augen und die blutroten, feuchten Lippen; dahinter der beiseite geschobene, entkräftete Blok. der unter dem Schwall der Pardoxa längst erstam ist; die strahlende Sonnenbräune war erloschen, graugelbe Schatten überzogen das magere Gesicht, und die zittemden Lippen flehten um Hilfe: «Befreit mich doch schnell von diesem trockenen Wirbelsturm!* $|\ldots|$

Später sagte Blok: «Nein, wissen Sie, nein: ich kann Lev L'vovix l= Ėllis| dennoch nicht ertragen, nein wirklich, neinu!"

Anmerkung 19: "Leben Sie für immer und unwiderruflich wohl."

Zu Seite 38:

Anmerkung 25: "Ich entschuldige mich vielmals bei lhnen und besonders bei Aleksandra Dmitrievna I= Belyjs Mutter] für meine übermäBig bösen Worte zu den Brüdern Kobylinskij. Aber es ist auch wahr. daB diese Brüder (obwohl Sie sie lieben und schätzen) zu den hohlköpfigsten. streitsüchtigsten und unertuäglichsten Schwätzem in Moskau gehören."

Zu Seite 39:

Anmerkung 27: "An Ėllis"

"Nein! Zum Abgnund, durch Strahlen erleuchtet, / Rufe mein Herz nicht! / Die Jahre vergehen. und dem Traum sind immer lieber / Die sündigen Lieder der Liebe.

WeiBe Ritter ... die Zufluchtsstätte Palestinas ... / Ewige Rose und Kreuz ... / Ach, ein einziger KuB ersetzt / Mir alle himmlischen Bräute!

Ach! Für einen Augenblick unter frischem Flieder / Mit der Geliebten - gebe ich für immer / Die viel zu sehr an den nicht von dieser Welt stammenden Gesang gewöhnten / Obengenannten mystischen Damen her.

Sie in Liedern zu preisen vermag ich nicht ... / Herz! Preise wieder ewig in Lobeshymnen. / Die mit den Jahren immer gerührter und wunderbarer werdende / Irdische Liebe!"

\section{Zu Seite 40:}

Anmerkung 31: "Die Sache ist die, daB zwischen meiner geistigen Persönlichkeit und seiner |= Metners| niemals irgendein Bruch war, aber es hat einen Bruch zwischen seiner eigentlichen Persönlichkeit und seiner äußeren Hülle gegeben, die unter die elementar-magnetische Suggestion der äußerst gefährlichen türkisch-arabischen Magie durch Doktor Jung geraten ist. Den äuBeren Umgang konnte man damals de facto unmöglich beibehalten, helfen konnte man auch nicht. Wenn Ė.K. I= Metner| diesen gefährlichen EinfluB überwunden hat. denn Doktor Jung selbst hat (sehr bald nach meiner äuBeren Trennung von E.K.) eine Katastrophe erlitten und ist kaum in der Lage wie früher einen magischen Strom zu vermitteln (die letzten Arbeiten Doktor Jungs sind philosophisch belanglos und ungefährlich. Er ist ein Durchschnittspsychologe geworden. Prof.Dr. Freud dagegen stinkt noch immer und vergiftet die Umwelt), dann kann unser äuberer Umgang leicht wiederhergestellı werden."

"|...| ich verneine das eigentliche Faktum meines Bruchs mit E.K., mit seinem Geist, seiner Seele, seiner echten Persönlichkeit und seinem Weg. Es hat kein Bruch zwischen meiner Persönlichkeit und der Persönlichkeit von E.K. stattgefunden, sondern ein Bruch zwischen seiner Persönlichkeit und seiner äußeren Hülle durch die sexuelle Magie und durch die psychoanalytische Methode der Suggestion (sogar mechanisch - während des Schlafens in einem gemeinsamen Zimmer) des Herm Jung selbst."

\section{Zu Seite 41:}

Anmerkung 35: "An den Zauberer"

"Der Mund wie Blut, und die Augen sind grün. / Und das Lächeln ist gequält-böse ... / Oh, Du verbirgst es nicht. jetzt habe ich verstanden: / Du bist der Geliebte der bleichen Mondfrau.

Über Dir werden auch am Tage nicht schwächer / Die Sagen der Nächte in der femen Kindheit. / Deshalb hast Du von Geburt an niemandem gehört. / Deshalb liebtest Du von der Wiege an.

Oh. wie viele hast Du geliebt. Dichter: / Schwarzäugige. Hellblonde. / Und Hochmütige, und Zärtiche. und Finstere, / Hast ihnen Deine eigene Phantasie vertiehen.

Aber das Vergessen, ach, ist es in der Brust? / Gibt es Zauber in irdischen Stimmen? / Verschwindend. wie Rauch im Himmel. / Gingen sie fort, gingen fort.

Als ewiger Gast am fremden Ufer, / Bist Du gepeinigt vom silbernen Horn ... / Oh, ich weiB viel, sehr viel, / Aber woher, kann ich nicht sagen.

Deshalb gebüren Dir die bleichen Funken des Pokals / Und das Betäubungsmittel der Genüsse: / Du bist der Geliebte der Mondjungfrau. / Du gehörst zu denen. die die Mondfrau liebkost hat."

Zu Seite 41-42:

Anmerkung 37: "I... Lev L'vovic Ėllis trat ein.

Mager, im schwarzen Gehrock. (...) ein «Doktor», ein Magier aus einem mittelalterlichen Roman.

Ëllis lebte in Armut. ohne festes Einkommen. von Gedichten und Aufsätzen. fertigte Übersetzungen an. hatte kein häusliches Leben. Er hatte ein Zimmer im Gasthof «Don» am Smolenskij Marktplatz und hielt 
sich tagsüber in Redaktionen auf. abends - in den Häusem von Freunden. wo man itn freudig begrübte. wie einen willkommenen Gast. die neusten Gedichte hörte und gemeinsam mit ihm ins Dickicht der Träume und der Streitereien über die Rolle von Symbolismus und Romantik enteilte. Er war häufig hungrig, war unpraktisch, hatte jedoch einen scharfen Verstand und eine glänzende Redebegabung. die die verschiedenartigsten Menschen bezauberte. Und er besaB noch ein Talent. mit dem er die Menschen ebenso wie mit seinen melodischen Versen eroberte: das Talent, alles, woriber er sprach, anschaulich darzustellen, - vielmehr: das Talent, etwas zu verwandeln, mit einer derartigen Kraft und Augenblicklichkeit zu verkörpem, wie es nicht einmal der geschickteste Schauspieler vermag, der stets an eine bestimmte Rolle und an die Unfreiheit der Wahl gebunden ist.

Ėllis war, trotz seiner völlig unsicheren materiellen Lage, spöttisch, äußerst undankbar, hochmütig gegenüber demjenigen, der ihm zu Essen gab, gebieterisch zu demjenigen, von dem er abhing."

\section{Zu Seite 47:}

Anmerkung 2: "le libertin" = "der Wüstling"; "cвободньй" = "der Freie"; "pacnутник" = "der Wüstling"

"mensonge" = "ложь" = "Lüge": "невннная простота" = "unschuldige Einfalt"

"Vous sentez tous la mort" = "вы все пахнете смертью"/"от вас исходит запах труnа" = "ihr riecht alle nach Tod"; "вы все подобны скелетам" = "ihr gleicht alle Skeletten"

Anmerkung 3: "I...! Ellis erählt blob in welken Versen den Inhalt der französischen Grdichte nach [..."

Anmerkung 4: "Auf jeden Fall hat Ėllis' [Werk] «Immonteli weine Existenzberechtigung. und es ist sehr zu bedauem, daB er verspricht, in Zukunft auf ähnliche Weise wie mit Baudelaire auch noch mit Verlaine. Prudhomme, Rodenbach. Nietzsche, Dante und anderen abzurechnen."

Zu Seite 48:

Anmerkung 13: "Die Gerechtigkeit verlangt jedoch, auf die wenigen Gedichte zu verweisen, deren Übersetzung Herm Ėllis nicht schlecht gelungen ist. So etwa die Übertragung des berühmten *Albatros». «Die Abendharmonie», *Die Katze* (1. Stück) und *Die Verblendeten*."

Anmerkung 21: "[...] Auf S. 73 verwechselt Ėllis das Wort hanche (Hüfte) mit dem Wort hache (Axt) (....): ständig triff man auf Prosaismen: «möge mir der Speer die Seite durchbohren» (S. 29); «möge sich mein ganzer Geist plötzlich entzünden» (S. 31); es gibt riskante oder nicht ganz russische Ausdrücke: «der Boden des Alkovens» (S. 46), «vom Altar entfremdet leben» (S. 53); falsche Betonungen: «betrunken», *Versteigenung», «drohénder $*$ in den Gedichten werden auf Schritt und Tritt folgende Worte verwendet: Ekstase. Energie, Kult. monoton. Autorität: und letztendlich sind folgende Verse einfach nicht künstlerisch: alch dürste nach Wunden, ich dürste. damit / Man mir mit den Füßen die Stirne beschmutze.w $|. . .|^{\prime \prime}$

Zu S. 49:

Anmerkung 22: "Ach, wäre sie $\mid=$ die Übersetzung] doch an einem * geheimen Ont* geblieben [... I, ohne Vorwort von Herm Belyj. der Wache über die russische Literatur hält!"

Anmerkung 25: "Nicht übel sind wohl die Übersetzungen aus Dante. Hern Ėllis beherrscht die Terzine. und nur in seltenen Fällen stockt dieses VersmaB bei ihm ein wenig. Die Übertragungen von Auszügen aus der «Götulichen Komödie» und seine Nachahmungen machen einigen Eindruck."

Zu Seite 50:

Anmerkung 33: "[...] Einzelne Werke Baudelaires haben viele übersetzt: sowohl Brjusov als auch Bal'mont und Merezkovskij, aber es hat wohl keiner von ihnen so gut wie Ëllis Baudelaire gekannt und, was man schon mit GewiBheit sagen kann. keiner von ihnen, und von den Symbolisten überhaupt, war ein derartiger Baudelaire-Verehrer."

\section{Zu Seite 51:}

Anmerkung 4: "Diese Hinwendung vom ästhetischen Illusionismus zum Mystizismus, um es ganz ge nau zu sagen. - zum Christentum, ist innerhalb des «zeitgenössischen Symbolismus» vielleicht das wesentlichste Symptom seiner EntwickJung. von Verlaine und Huysmans bis hin zu Rodenbach und Rilke. Auf diesem Weg kommt der Symbolismus unausweichlich in enge Berührung mit der heiligen Symbolik des Katholizismus, über die sich der helle Schatten des bedeutendsten aller Dichter mit seinem ergreifenden Segen, der Schatten Dantes neigt."

Anmerkung 6: "Zu denen dann, die froh das Herz sich wahren. / Wie brennend auch das Leid ist. dem sie eigen, / Da einst sie doch zum seligen Volke fahren.

Und darfst zu ihm dann selbst du aufwärts steigen. / Wird weiter dir, wenn ich hinweggegangen. / Sich eine Seele zum Geleite zeigen."

IÜbersetzung von August Vezin: in: Dante Alighieri: Die göttliche Komödie, italienisch und deutsch. a.a.O..S. 131 


\section{Zu Seite 52:}

Anmerkung 9: "Im Land des Wahnsinns"

"Der Wahnsinn. wie ein schwarzer Monolith. / fiel vom Himmel und erhob sich als Sarkophag: / die Gestalt der Bäume gleicht schlafenden Magiem / und ist mit Zittern und Beben des beschädigten Mondes übergossen.

Hier ist ewige Finstemis mit ewigem Schweigen verschmolzen: / mit heruntergeschlagenem Visier und schwarzem Banner/ wandert hier der Tod mit unerbittlichem Schritt umher, / wie eine Schildwache auf lautlosen Fliesen.

Hier sind die Schatten derer, die den Himmel beleidigt haben / durch Gotteslästerung maBloser Absichten. / die, fern der vergänglichen Erscheinungen der Erde.

Makellose Würdenträger des Bösen waren; / hier sind die Seelen derer, die / das wahnsinnige Antlitz des gestürzten Gottes streng bewahr haben."

Zu Seite 53:

Anmerkung 11: "Und sich zum andem Reich mein Sang erheben./ Wo rein die Seele wird vom RuB der Sünde / Und wert, empor zum Paradies zu schweben."

[Übersetzung von August Vezin: in: Dante Alighieri: Die göttliche Komödie, italienisch und deutsch. a.a.O., S. 381]

Anmerkung 15: "Und still verging der Tag, und der Sonnenuntergang verlosch ... / ich spürte den heiligen Hauch des Todes. / und ich richtete den Blick hoffnungsvoll hinter den Horizont / und erwartete etwas ... und eine Vision zeigte sich."

Zu Seite 54:

Anmerkung 18: "Nächtliche Stigmata"

"Als junge Nonne im schwarzen Leichengewand, / die bleichen Hände auf die Brust gelegt. / mit trübem. gesenktem, ergebenem Blick. / geht die Nacht ihren traurigen Weg.

Unter ihrem Blick erlöschen, ersterbend, / die Farben und Flügel, die Augen und Strahlen, / nur hinter der Mauer des femen Paradieses / erklingen die goldenen Schlüssel immer hörbarer.

Ihre strengen Konturen sind verwischt: / ein weites Leichengewand, eine hohe Mönchskappe. / bittere Seufzer. dumpfes Schluchzen / breitet sich hinter ihr aus ... aber plötzlich

sind alle ihre Augen zum Himmel erhoben, / alle Myriaden von brennenden Augen. / ihre goldenen Stigmata strahlen / im süßen Feuer der herabsteigenden Schwerter.

Ajs BlutfluB, wie eine purpurfarbene Wunde, / schimmert der Mond rot auf der weitgeöffneten Lende. / Dont im Himmel auf Nebelstufen / steigen Engel hemieder und hinauf auf den Berg.

Gott! Zu Dir strecke ich meine Hände aus, / oh, senke das brennende Schwern herab, / damit ich im Feuer des unerüäglichen Glühens / die nächtlichen Stigmata entzünden kann!"

Anmerkung 19: "An einem schönen Abend saB der nicht minder schöne Exekutor Ivan Imitric Červjakov in der zweiten Sesselreihe und sah sich durchs Opernglas die «Glocken von Comeville» an. Er schaute und fühte sich auf dem Gipfel der Glückseligkeit. Aber plötzlich ... In Erzählungen stöBt man hăufig auf dieses «aber plöłzlich». Die Schriftsteller haben recht: das Leben ist voller Überraschungen!" Zu Seite 55:

Anmerkung 21: "Da ward mir's klar: in jedem Himmelskreise / lst Paradies, tränkt auch der Gnadenregen / Des Höchsten Guts sie nicht in gleicher Weise."

[Übersetzung von August Vezin; in: Dante Alighieri: Die göttliche Komödie, italienisch und deutsch. a.a.O., S. 7891

Zu Seite 56:

Anmerkung 25: "Der Traum"

"Ich schlummerte, die Kerze dunstete. / über dem geneigten Haupt / ging drohend der Schatten von irgendjemand hin und her. / wie ein finsterer Wachtposten.

Aber nur dreimal, beim Einschlafen. / hatte ich den Namen der Geliebren ausgesprochen, / ein weiBer Engel, ein Engel aus dem Paradies. / trug mein Herz in den Himmel hinüber.

Das Licht ist feierlich und hell, / das Herz atmet das weibe [Licht], / und gotische Bögen / ziehen über mir vorüber.

Und als Majestät der Majestäten / auf dem buntgemusterten Glasfenster / neigt Beatrice / mir ihre zärtichen Blicke zu!

Zu Seite 57:

Anmerkung 26: "Ganz zu schweigen von der einseitigen, übertriebenen, offensichtlich leblosen Tendenz des Autors, kann der Gedichtband kein deutlicher und überzeugender Ausdruck eines «ganzheitlichen mystischen Weges» sein; vergebens vernachlässigt der Autor die künstlerischen Aufgaben. [...] Die Verse des Herm Ellis sind, als «lyrische Ertebnisse» (es sind doch immerhin Verse!), viel zu rhetorisch $[\ldots]^{\prime \prime}$ 


\section{Zu Seite 58:}

Anmerkung 32: "Indem wir an keine anderen Wege glauben, warten wir ergeben auf den Armen Ritter." Zu Seite 58-59:

Anmerkung 33: "Argo"

"Auf den Wellen spiegelt sich der Sonnenschild. / vom ewigen Schwimmen sind wir längst ermüdet: / die schnelle Argo schaukelt in voller Fahn, / dann jagt Boreas unser Schiff. / Auf den Wellen spiegelt sich der Sonnenschild...

Irgendjemandes Tränen haben die elastischen Taue benetzt, / hinter dem Heck sind Silberstrahlen... / «Ach. Freunde, werde ich emeut die Morgenröte sehen, / oder ist es Zeit für uns. den Anker zu werfen?» / Irgendjemandes Tränen haben die elastischen Taue benetzt...

Der Wind stöhnt ... Schweigend versammelte sich auf dem Deck / die Familie der traurigen Argonauten... / Der Wind stöhnt, es gibt keine Äußerung zur kummervollen Klage... / *Wo seid ihr, wo seid ihr, andere Länder?!» / Es gibt keine Antwort auf ihre kummervolle, kummervolle Klage...

Was? Stehen wir? Dann hält Neptun mit seiner mächtigen Hand / unser schwankendes Schiff... / Gleichsam wie mit einer Toga, wurde der Himmel von einer Wolke eingehüllt. / der Sonnenschild versinkt im Grund. / Der Blick fuillt sich mit brennenden Tränen... / Wo bist Du nur. Goldenes Vlies?"

\section{Zu Seite 60-61:}

Anmerkung 43: "Ich liebe die Milde des Welkens / und das Wachs des ergebenen Antlitzes, / ich liebe das Leiden um des Leidens willen / und die endlose Hoffnungslosigkeit! [...]

Und euch, versiegende Flüsse. / Herzen, die ihr in Eis gefesselt seid. / euch, ihr Pechvögel, und euch, itr Kruppel. / besingt mein Wahnsinn!"

\section{Zu Seite 61:}

Anmerkung 44: "Aber nichts Heiligeres bleibt der ausgebrannten Seele / wenn die Ferne alles entreißt. / als Du, der ungeteilten Liebe / unausgesprochene Trauer!"

Anmerkung 48: "Lindere meinen Kummer"

Anmerkung 49: "Für die Untergegangenen gibt es kein Wiedersehen. / für die Wahnsinnigen keine Trennung. / ich werde. das Schluchzen verbergend, / die Hände ringend, ein Jahrhundert herumjagen!

Mein Doppelgänger nickt mir aus der Finstemis des Fensters / höhnisch zu. / *Wir fliegen in ein Land ohne Sonne", / und nickend entschwindet er.

Aber mit mir ist mein Rätsel, / Trugbilder wiegen das Herz ein, / Weine. grünes Lämpchen / «Lindere meinen Kummen."

Zu Seite 62:

Anmerkung 52: "Durch den toten Atem des Frühlings im Zimmer / ist mein winterlicher Geist wundersam benebelt. / durch die schrägen Strahlen des rosafarbenen Mondes / ist hier sogar die bleiche Luft gerüxet:

gestickte, künstliche Träume. / eure bunte Welt ist für das Herz seltsam-süB; / ich kann nicht aus dem seidenen Land forgehen - / mein Geist ist durch unerfüllbare Träumereien verletzt.

Im Wohnzimmer herrscht, die Ruhe genieBend, der Frühling. / leuchtend blühen und atmen die Lampenschirme. / Papageien und Amorknaben fliegen umber.

während die Schneeflocken am Fenster tanzen... / Und, gleich Liebkosungen einer aromatischen $W$ anne. / ist hier das Lächeln des Frühlings wohlriechend."

\section{Zu Seite 63:}

Anmerkung 55: "Vergessene Gelübde"

"Am Tag der Vertreibung, in der Stunde der Verzagtheit. / verschmachtend, verurteilt, / lobpreise die drei ewigen Rosen. / die drei vergessenen Gelübde.

Die erste Rose ist die Demut. / das Herz des armen (Mannes) Christus, / die Rose des Grams, die Verlobung / mit der heiligen Armut!

Lobpreise die zweite Rose - / die heilige Keuschheit. / das sanftmütige Herz Mariens. / die am Kreuze steht.

Die dritte Rose ist das Herz des Lammes. / die Rose des bangen Gehorsams. / die weiße Rose des Grals. / die das Paradies aufschlieBt!"

Zu Seite 64:

Anmerkung 61: "Der Wanderer/Pilger"

"Mir entgegen geht ein Pilger, / von hohem Wuchs, majestätisch und streng. / *Wer bist Du, Gottesgesandter?»/Er antwortet still: «Ich bin Gott! »"

\section{Zu Seite 66:}

Anmerkung 70: "Empfange die Begeistenung meiner Grübe, / Du Zauberer, der die Zauberei nicht kennt. / Du Glücklichster unter den Dichtern. / Du Unglücklichster unter den Menschen." 


\section{Zu Seite 67:}

Anmerkung 72: "I... An zweiter Stelle stehen Ellis' Gedichte, stark in die Länge gezogen, aber im allgemeinen. soweit ich weiß, die besten, die dieser Dichter geschrieben hat. Im «Phaëton», "Anatomischen Theater und in der «Goldenen Stadtw ist der Geist wahrer und lebendiger Dichtkunst zu spüren."

Anmerkung 73: "Ëllis |... | war nie ein Dichter und wird nie einer sein. Baudelaire versteht er überhaupt nicht [...]"

Anmerkung 74: "Herm Ellis" Vers ist welk und schlaff [ohne Knochen]: [... Die Themen seiner (iedichte sind interessant. die inneren Erlebnisse tief, aber, um sie zu bewältigen. braucht man grobe Begabung. Hert Ellis jedoch hat sie nicht."

Anmerkung 75: "[...] Auch den abbildenden Gedichten, den vermittelnden Gedichten, mangelt es an innerer Selbstrecht fertigung. an freudiger Glut und an der Begeisterung des Gedichts als Selbstzweck. Vielleicht könnte Herr Ëllis über seinen wahrthaft erlebten und wertvollen mystischen Weg ein wunderbares Buch mit Reflexionen und Schilderungen schreiben, aber was Verse damit zu tun haben. weiB ich nicht $[. .]$.

Anmerkung 76: "Ëllis schreibt langatmig. langweilig. mit Anspruch auf Auserlesenheit und mit groben Fehlgriffen."

Anmerkung 78: "Als interessanter Kritiker bleibt Hern Ellis auch im Gedichtband ein solcher. Bei ihm findet man Gedanken, die Aufmerksamkeit verdienen, schöne Vergleiche, energische Ausdrücke, aber den Geist wahrer Poesie gibt es nicht in seinen Versen (... |. Als Präparate, die manchmal künstlich. manchmal nicht ohne gravierende Fehlgriffe vorbereitet worden sind. - können die Gedichte des Herrn Ëllis von Intcresse sein. aber nicht begeistern. man kann sie lesen, möchte sie aber nicht auswendig lemen."

\section{Zu Seite 73:}

Anmerkung 12: "Was ist ein Almanach? Das ist eine Vereinigung literarischer Namen ohne jegliche Richtung, ein Geflecht aller Strömungen ohne Unterschied und Auswahl, eine Kombination jedes belie. bigen Materials, das einem in die Hande gerat, mit einem einzigen Ziel: «wenn es nur ein Buch gibt»."

Zu Seite 74:

Anmerkung 18: "|. .1 alle übrigen Aufsätze und Aufsätzchen in *Fakely" sind entschieden schlecht. unmotivien, verworren, voller schreiender Widersprüche, und, vor allem. unerträglich prätentiös und. ungeachtet dessen. - langweilig. langweilig und nochmals langweilig!.."

Anmerkung 22: "Was haben Sie denn wirklich geschaffen, auBer Büchem mit schlechten Versen, einigen Rezensionen und Aufsätzen? Aus Ihrem Mund wirkt der Ton nur komisch. in dem sich selbst Bakunin genieren wirde zu sprechen!.."

\section{Zu Seite 76:}

Anmerkung 36: "verhangnisvolke Verworrenheit von Termıni": "Unklarteit in den Termıni"

Anmerkung 37: "Ja. dieses Buch V. Ivanovs ist wahrhaftig ein Weg den Sternen entgegen."

Anmerkung 41: "1... Symbolismus, als konkret-historische literarische Schule, und Symbolismus, als neue Lehre und neue Methode des künstlerischen Schaffens, die bisher noch nirgends eine erschöpfende Realisierung gefunden hat. als Methode, die den zukünfigen Jahrhunderten zugewandt ist und unbewubt auch in der Vergangenheit ange wendet wurde."

\section{Zu Seite 77:}

Anmerkung 45: "Was unser gegenwärtiges Theater betriffi, so können wir, um die Wahutheit zu sagen. kaum noch tiefer sinken als «Die Schaubude* und *Das Leben des Menschen*; in der nahen Zukunft droht uns bereits. als letzte Stufe der Ober-Banalitat. das Marionettentheater |... |"

\section{Zu Seite 78:}

Anmerkung 50: "Genug der Theatervorstellung. wir wollen Handlung. Die Zuschauer sollen sich im Chor vereinigen, wie die mystische Gemeinschafi der antiken *Orgien* und *Mysterien*."

Anmerkung 54: "Das Wesen des Symbolismus ist die Fähigkeit. die feinsten Andeutungen der Dinge zu erhaschen und dabei nicht ihr reales Angesicht zu entstellen |...

Das Wesen des Symbolismus sind Korrespondenzen. zahllose. nicht [oder kaum] erfaBbare, kaum und nur teilweise realisierbare Korrespondenzen, die niemals mit der Welt der Erscheinungen übereinstimmen, und die einzige Art sie zu vermitteln waren immer und werden immer jene "verwirnen Worte" des lyrischen Dichters sein, als deren wichtigste Eigenschaft ihre Unzugänglichkeit für den Durchschnittsmenschen. der vom Beben des Lebens erfüllt ist, anerkannt werden muB. ihre aristokratische AusschlieBlichkeit und absolute Untauglichkeit für jedes beliebige gesellschaftliche Experiment."

\section{Zu Seite 79:}

Anmerkung 58: "Die Krise des Symbolismus liegt dann. daB er aufgehön hat, nur Wunschtraum und Gebet zu sein. sondem begonnen hat. «sich um den morgigen Tag zu sorgen», seine Schwanenflügel vertoren hat und begonnen hat, sich überall wie eine Gans zu mästen!.. |... 
Wir beguüBen die Krise des Theaters als eine Form der Krise des Symbolismus. denn das ist ein gutes Symptom, daB die Krankheit der Krankheiten (die Vulgarisierung) jeder beliebigen heiligen Idee den Höhepunkt erreicht hat. daB das folgende Stadium entweder die Genesung und Rückkehr in die Höhle Zarathustras oder der Untergang von allem ist. Aber es lebe auch ein derartiger Untergang!.. Übrigens. ist dort ein Untergang überhaupt möglich, wo die Ewigkeit selbst in der Luft liegt? Ihs, die ihs die Menschheit mehr als die Ewigkeit selbst liebt, verlaBt uns!"

Anmerkung 61: "rолубон" = "blau, hellblau, himmelblau": "синий" = "blau"

"Übrigens ist die (himmel)blaue Farbe, «bleu", die durch Maeterlincks Vogel unmittelbar von Novalis" *Blauer Blume* entlehnt ist und in direkter Verbindung mit dem azurblauen (d.h. himmelblauen) Reich der Zukunft steht, von wo auch der «blaue Vogel» gewonnen wurde, die Grundlage für den Symbolismus des ganzen Stiickes."

\section{Zu Seite 80:}

Anmerkung 62: "[...] wir wissen, daB der Symbolismus immer mehr zum lediglich methodischen Mittel für rein-religiöse (dogmatische, sogar gesellschaftlich-theokratische) Forschungen und für moralische Konstruktionen wird. Die Verwandlung des Symbolismus in nur ein Mittel zu auBer-poetischen Zielen. die zuerst mit tödlich-genialer Macht von F. Nietzsche und mit barbarischer UnbewuBtheit von H. Ibsen vollführ wurde, hat den Symbolismus für immer in zwei entgegengesetzte Bahnen gespalten.

Symbolismus als Ziel - der Symbolismus der Schule von E. Poe. Baudelaire. Wilde. Rodenbach. Maeterlinck -, und Symbolismus als Mittel in den Werken der groben Moralisten der Gegenwan (Nietzsche. Ibsen. Dostoevskij, Merežkovskij) sind zwei unterschiedliche Begriffe. Sie zu mischen ist unmöglich."

\section{Zu Seite 81:}

Anmerkung 69: "[...] der zukünftige Stilhistoriker wird nur dann das ganze AusmaB der Revolution in unserer Prosa verstehen, wenn er gründlich die besten Seiten der ehrlich-realistischen bleichen, aber nicht farblosen, zaghaften, aber graziösen, und, vor allem. weisen Prosa Cechovs, dieses letzten selbständigen Stilisten in der vorrevolutionären Periode der russischen Prosa, vergleicht mit der schonungslos-bildhafien, raffinien-ausdrucksvollen und stets symbolisch Verallgemeinerungen erreichenden klassisch-strengen Sprache in Brjusovs «Erdachsex."

Anmerkung 70: "Von Puskin zu Gogol', von Gogol' zu Turgenev und Tolstoj, und von Tolstoj zu Cechov vertäuft der Entwicklungsfaden unserer kalten» Prosa. Von Čechov zu Brjusov gibt es einen Sprung, eine Kluft: hier entsteht die «neue» Prosa."

Anmerkung 7I: "Es ist eine banale Tradition M. Gorkij aus Cechov herzuleiten, L. Andreev aus Gor'kij und B. Zajcev aus Andreev. Das Ganze ist ein entschiedenes MiBverständnis. M. Gorkij als Realist (wenn man überhaupt emsthaft über ihn als Schriftsteller sprectren kann) ist das absolute Gegenteil von Cechov in jedertei Hinsicht und Beziehung."

\section{Zu Seite 82:}

Anmerkung 72: "Der zukünftige Historiker des «neuen Stils» in RuBland wird vergeblich die neue Prosa in den unglücklichen, geschmacklosen. für den Markt bestimmten Bänden der Werke unserer zeitgenössischen Epigonen suchen, jener Halbrealisten und Halbdecadents, an deren Spitze einer der kühnsten (was die Ideen betriff) und der geschmacklosesten und hilflosesten (was die Methode betriff) Epigonen steht: Leonid Andreev."

Anmerkung 73: "Boris Zajcev ist der klassische Typ des Epigonenschrifistellers. Er ist immer und in allem Epigone und nur Epigone. Wenn L. Andreev, vom historischen Standpunkt gesehen. als ekiekti scher Epigone Čechovs und der "Decadence" erscheint, dann ist Zajcev der Epigone des Epigonentums und der Eklektiker unter den Eklektikem. Und wenn man wiederholt hört, daB Zajcev auch eine eigene Schule in der Prosa begründet hat, fragt man sich unwillkürlich. wozu man blo8 seine Nachfolger zählen soll. zu welchen Epigonen der Epigonen des Epigonentums!"

Anmerkung 75: "Der russische Symbolismus ist der Sohn der westlichen groben Emeuerung der Kunst: er braucht eine strenge Methode: wir haben viel zu sehr gelitten. um dann (bereits) bagatellisiert zu werden und zu lispeln. wenn der Kampf noch nicht beendet ist: nach Baudelaires Prosa. wo jedes Won ein feuriges Stigma ist, nach Huysmans' durch Aromen vergiftetem Stil, nach Rilkes kindlich-keuscher und, wie eine Orgel, strenger Prosa, nach dem Glockenklang von Rodenbachs Metaphem, ist es eine Schande, daB wir uns von den langen Kaftanen und Herrenmänteln der geschmacklosen und plumpen Gestalten Zajcevs hinreißen lassen! Wäre es nicht besser einfach noch einmal Gl. Uspenskij. Cechov und Tolstoj zu lesen?.."

\section{Zu Seite 83:}

Anmerkung 77: "Für den Dichter sollte es keine Parteien. Klassen. Programme und Paragraphen geben. Für den Dichter sind alles nur Mittel und Objekte um höherer nichr-menschlicher Ziele willen. Der Dichter ist überall und immer ein Ausgestobener, er muB das wissen. darin liegen sein hoher Stolz und seine höchste Würde. Was immer uns auch die schlaven oder einfältigen Menschen von der Sobornosi' 
[= Gemeinsamkeitserfahrung (einer universalen christlichen Glaubensgemeinschaft)] erzählen mögen alle Dichter von Dante bis Verhaeren. von Homer bis Lermontov waren «nicht von dieser Welt», waren Halbgötter und Verstoßene, waren Rächer und Paria. waren Henker und Opfer! Der Dichter kann überall Mitgefühl und Verständnis finden, sieht überall seine Wirkung. aber dennoch ist er immer und überall einsam! Dieser Weg des AusgestoBenseins und der Einsamkeit, d.h. der Weg des striktesten Individualismus, ist zugleich der einzig würdige Weg für einen schaffenden Künstler."

Anmerkung 79: "Der russische Symbolismus [...] hat nicht nur keine alte Schule zugunsten von etwas grenzenlos Neuem oder "Neuem, allzu Neuem" abgeschafft oder besiegt, sondern war, im Gegenteil. eine zutiefst konsequente und historisch und psychologisch unausweichliche Weiterentwicklung. Verfeinerung und Verkomplizierung aller sehnlichsten, tiefsten und daverhafiesten Strömungen und Bestrebungen der russischen Wortkunst."

Zu Seite 84:

Anmerkung 81: 1. "Symbolismus - das ist Kultur": 2. "Kultur - das ist Symbolismus"

Anmerkung 83: "Zuerst hat sich der Symbolismus als neue und einseitig ästhetische Lehre selbst der Kultur genähert, wobei er sich in alte Rüstungen kleiden wollte ... aber all diese Rüstungen erwiesen sich als rostig und schlaff, und so begann die neue Lehre unauffällig. Schritt für Schritt, alle, entschieden alle kulturellen Werte umzuprägen; so wurde der Symbolismus unwillkürlich von einem Drang nach Kultur zur Quelle, die diesen Drang befriedigt. Und dann vollzog sich ein Wunder: die neue Lehre erwies sich als alte, ursprüngliche, aber bewahrte zugleich ihre ganze bebende. feurige Jugend; indem sie alles zerstörte. schuf sie etwas, indem sie verneinte - bestätigte sie, indem sie gotteslästerte - betete sie und wurde, indem sie an allen akulturellen Werten $\approx$ zweifelte, selbst zur lebendigen Inkarnation der Kultur."

Anmerkung 86: "Der Kampf für den Symbolismus ist deshalb und wird sein ein Kampf gegen Dogmen, gegen den Empirismus des Gedankens. gegen den Realismus im künstlerischen Schaffen und gegen die Souveränität des theoretischen Verstandes (des «reinen Verstandes»)."

Zu Seite 85:

Anmerkung 88: "Der Symbolismus, und nur der Symbolismus selbst, ist die letzte und vollkommenste Form der Kunst und zugleich bereits auch etwas Umfassenderes als die Kunst, indem er selbst eine erste, neue Form eines anderen Bewußtseinszustands der Menschheit [Hervorhebung von mir, H.W.] darstellt, eine neue Erscheinungsform der zeitgenössischen komplexen und verfeinerten Gemeinschaftssecle und einen ersten Hinweis auf ein noch vollkommeneres Stadium ihrer EntwickJung in der Zukunft. Längst schon hat der Symbolismus begonnen. aus dem Drang nach einem ofreien Vers* heraus nach einer afreien Persönlichkeit " zu begehren."

Anmerkung 89: "jene [...] Konfession, die wir ohne Bedenken die "große Religion der Zukunft" uns zu nennen entschließen"

Anmerkung 92: "Merežkovskij |... sieht nicht die rettenden Oasen in der Wüste unserer zeitgenössischen Literatur."

Zu Seite 85-86:

Anmerkung 93: "Der Weg vom Symbol zum Dogma - das ist der Weg Merezkovskijs.

Der Weg von der Betrachtung zur Tat, von der Literatur zur neuen Kirche."

Zu Seite 86:

Anmerkung 95: "So wurden wir alle aus Ägypten geführt, aber keiner hat mit seinen eigenen Augen das Land Kanaan gesehen! So begann unser Umherirren durch die Wüste ... aber bei diesem Umherimen wurde uns eine führende und drohende Feversäule gegeben, und wir kennen jetzt ihren Namen. Das ist der Symbolismus! Die besten unter uns sind bereits in der Wüste umgekommen, diejenigen, die jetzt vorangehen, werden zwangsläufig untergehen, vielleicht schon morgen, aber die Säule wird niemals verlöschen ..."

\section{Zu Seite 87:}

Anmerkung 98: "Das Ziel des Symbolismus ist - durch eine Reihe einander gegenübergestellter Bilder den Leser gleichsam zu hypnotisieren, in ihm eine bestimmte Stimmung hervorzurufen."

\section{Zu Seite 88:}

Anmerkung 3: "Für die Charakteristik von Ėllis ist die Tatsache, daB er im letzten Jahr bei der Wahl der Mitglieder des literarisch-künstlerischen Kreises durchgefallen ist, nicht ohne Interesse. -

Von Ėllis sagt man doch. daß er früher einmal in der Universitätsbibliothek ein ganzes Kapitel aus einer seltenen Ausgabe von Kants Werken herausgeschnitten habe."

Zu Seite 89:

Anmerkung 7: "Gewöhnlich meint das Wort «Symbolismusw konkret und genau eine lebendige literarische und überhaupt ideelle Bewegung, die Entstehung einer neven künstlerischen Schule etwa um die 
Mitue des 19. Jahuhunderts. die sich als Wortführerin des allgemeinen kulturellen Umbruchs in der Mitte des vergangenen Jahthunderts erwiesen hat."

Zu Seite 90:

Anmerkung 10:

"A) Künstlerischer Symbolismus im eigentlichen Sinne (als Selbstzweck) - E. Poe, Baudelaire, Verlaine. Mallarmé und ihre nächsten Schüler: K. Bal'mont («LaBt uns wie die Sonne sein»), V. Brjusov. A. Belyj («Gold im Azurblau», «Die Sinfonien»).

a) Ästhetizismus - Huysmans (als Autor von *A rebours»). Wilde.

b) Neoromantik - Maeterlinck, Rodenbach, K. Bal'mont («Stille»).

B) Symbolismus (ideeller), als Mittel:

a) moralischer (lbsen).

b) metaphysischer (S. Mallarme, R. Ghil),

c) rein mystischer (Aleksandr Dobroljubov).

d) individualistischer (F. Nietzsche).

c) kollektiver («gemeinschafulicher», «das ganze Volk umfassender»),

1) mit sozialem Unterton (E. Verhaeren),

2) mit theokratischer und religiös-gesellschafulicher Ausrichtung (Huysmans. D. Merežkovskij, V. Ivanov)."

Anmerkung 12: "Erstens. Wir spuren stets unmittelbar etwas Neues, etwas Unerforschtes und früher Unbekanntes, etwas viel Vollkommeneres im eigentlichen Aufbau und besonders in der gegenseitigen Verbindung der künstierischen Gestalten und Bilder. [...]

Dieses «Gefühl des (neuen] Stils» vereint die verschiedensten Formen des Symbolismus und hält sie zusammen.

Zweirens. Die blobe Gerechtigkeit veranlaBt uns einzugestehen, daB der $*$ Symbolismus* seit den ersten Tagen seines Bestehens und bis in die Gegenwan hinein sich als jene unendlich hellhörige, komplizierte und feine Form der Offenbanung aller ideellen Bedürnisse. Nachforschungen und Bewrubtseinsrevolutionen der modermen Menschheit erwiesen hat, die wir ohne Überureibung gleichzeitig Sehvermögen. Tastsinn, Gehör und sogar Gewissen der zeitgenössischen Seele nennen können."

Zu Seite 91:

Anmerkung 13: "Dichten, künstlerische Gestalten und Bilder erschaffen - heiBt symbolisieren."

Anmerkung 15: "Das Wesen des künstlerischen Schaffens ist das gleiche, wie das Wesen aller höheren Bereiche geistiger Betätigung. es ist die Erkenntnis."

Zu Sieite 91-92:

Anmerkung 17: "Je tiefer und bewubter das künstlerische Schaffen ist, desto mehr beginnt es, alles Sichtbare. Reale nur als Gleichnis zu betrachten, nur als Zeichen, als Hülle oder Symbol von etwas grobem Unbekannten, das man nur bestimmen kann, wenn man vom Vergänglichen als entstellter und widergespiegelter Kopie des Ewigen ausgeht. Wenn wir dazu ergänzen, daB die grundlegende Lehre, die grundlegende Forderung und Überzeugung des zeitgenössischen Symbolismus gerade eben diese Auffassung vom künstlerischen Schaffen als Verwandlung aller Realia in Zeichen, das heißt in Symbole der in ihnen enthaltenen Ideen ist, dann wird völlig verständlich. warum wir gerade den zeitgenössischen Symbolismus für die bewuBteste und höchste Form der Kunst halten."

Anmerkung 18: "Betrachtung (...) des Lebens durch das Prisma der Kunst"

Anmerkung 19: "Diese zwei Gefahren sind die Rückkehr zum Realismus (in welcher Form auch immer) und der Tod im Dogmatismus."

Anmerkung 21: "Wir glauben, daB dem wahren Symbolismus alle diese tödlichen Gefahren gleich fem liegen. denn sein Wesen ist die freie schöpferische Arbeit der höchsten Erkenntnis. seine Form ist unvermeidlich und immer aristokratisch und individualistisch. [...] Dieser aristokratische Individualismus ist das brennendste und markanteste Vermächtnis aller (ohne Ausnahme) Begründer und der ersten Verfechter des Symbolismus, die ihren extremsten und vortrefflichsten Vertreter in der Person Friedrich Nietzsches gefunden haben.

Der aristokratische Individualismus ist das erste und letzte Gebot des Symbolismus. die lebendigste seiner Losungen, das neuste Wort aller von ihm gesprochenen Worte!"

Anmerkung 23: "aus der Suche nach einem «freien Versw ist der Symbolismus zur Suche nach einer «freien Persönlichkeit" geworden"

Zu Seite 94:

Anmerkung 32: "[...] die Musik der Schatten, der nichtverkörperten und halbverkörperten Erscheinungen. der rastlose Wunsch. sich, indem man betrachtet, von der Vormundschaft der Dinge freizumachen und das Unendliche auf einer anderen Ebene als der Welt der vergänglichen Erscheinungen zu begreifen, der Wunsch. das Weltall nicht so sehr zu erkennen, sondem vielmehr zu lieben, die Fähigkeit, mit einer 
fast kindlichen, rührenden Aufrichtigkeit, mit einer Weiblichkeit, dieser Musik der Zärtlichkeit.jede Blume zu berühren und dennoch traurig und betrogen zu bleiben - all diese für jeden echten Romantiker typischen Züge treffen in den vertrautesten Klängen und Zeilen der Lyrik Bal'monts und Fets zusammen."

Anmerkung 36: "|... bereits in Bal'monts erstem Buch finden wir erstaunlich korrekte Verfahren des Aufbaus von Symbolen. einen Reichtum an Bildem und Gestalten. die natürlich und eindringlich jene «Korrespondenzen» zwischen der äuberen und der inneren Welt herstellen. die $\mathrm{Ch}$. Baudelaire fuir das Wesen einer jeden Symbolisierung hielt."

Zu Seite 95:

Anmerkung 41: "[...] den Weg des ekstatischen Eindringens in die Seele der Welt, in das Wesen des Weltalls, die endgültige Rechtfertigung der ganzen Mannigfaltigkeit des Universums, das große «Ja». das er qualvoll vergebens sein ganzes Leben lang gesucht hat."

Anmerkung 42: "Der höchste Höhenflug und der tiefste Fall - das ist das Hauptthema dieses bemer kenswerten Buches."

Anmerkung 46: "I... bis heute wird [Bal'mont] von vielen für das Haupt der symbolistischen Schule in RuBland gehalten, bis jetzt verstehen es nur wenige Leser und Kritiker, sich in der Menge der von ihm geschaffenen Werke zurechtzufinden. seine zwei einander ausschließenden Antlitze zu unterscheiden. das Antlitz des unsterblichen, bedeutenden und begeisten-verwegenen Suchers neuer Bilder und Klänge, Bal'monts, des Schöpfers einer neuen Poesie in RuBland, dessen Verdienste in ihrem Wen nicht hoch genug geschätzt und bewentet werden können, und das Antlitz des ausgebrannten, gebrochenen und sich selbst verloren habenden. krafulosen und prätentiösen Verunstalters aller Stile, des bedauemswerten Parodisten aller seiner besten und ersehntesten Weisen $|. .$.

Von unseren gegenwärigen Dichtern hat vielleicht keiner besser als Bal'mont geschrieben und keiner schlechter als er, aber ewig ist nur das Schöne!"

\section{Zu Seite 96:}

Anmerkung 50: "|...] wenn Bal'mont das Geheimnis des poetischen Rhythmus beinahe von Anfang an wunderbar beherrschte und am Ende seines Wegs zur Selbstparodie gelangte, dann hat Brjusov dagegen mit scharfen Dissonanzen begonnen. die jetzt im Vergleich mit den besten Perlen seines künstlerischen Werks. die er erst am Ende geschaffen hat, als eine An Parodie erscheinen, und hat erst nach einer schwierigen Prüfung die fehlerlose Sicherheit und Genauigkeit seines Meißels erreicht."

Anmerkung 53: "Sein Autor $1=$ der Autor des Buchs «Chefs d'Euvres»] bestimmt bereits be wulbt seinen Platz und stellt diesem «letzten Buch seiner Jugend» und ersten Buch der Jugend des nussischen Symbolismus ganz. bestimmte Aufgaben. Extremer Individualismus. die Verschiebung des Zentrums auf die Persönlichkeit des Künstlers (Subjektivismus), die Konfession des Dogmas vom Selbstwert des künstlerischen Schaffens, die hervorgehobene Bedeutung der künstlerischen Form selhst - das ganze spätere kampfiüchtige Programm der neuen Schule ist bereits im *Vorwon» vorn Autor genau formu lien $|\ldots| "$

\section{Zu Seite 97:}

Anmerkung 57: "die Periode einträchtigen, breiten und offenen kamptlustigen Aufuretens"

Anmerkung 58: "Ab diesem Zeitpunkt tritt seine Ansicht der neuen Kunst (Symbolismus vor allem verstanden als «Poesie der Andeutungen», als neue Schule. die vorherrschen und zwangsläufig und kontinuierlich die zwei vorhergehenden Schulen - die klassische und die romantische - ersetzen soll) in den Hintergrund vor der Verkündigung der Hauptmission der neuen Schule - der ahsoluten Freiheit des künstlerischen Schaffens."

Anmerkung 60: "|...| Freiheit und Gleichberechtigung aller Schulen und Richtungen vor dem einzigen Antlitz der Wahrheit - innere Freiheit der Kunst und völlige Unabhängigkeit des künstlerischen Schaffens von jeglichen äuberen Bedingungen und Momenten |...]. Neue Kunst. Symbolismus, modeme Kunstrichtung - das sind alles nur Formeln für die Kunst, die sich bewubt und unwiderruflich von allen äuberen Rahmen und allen inneren Trennwänden befreit hat. für die einzige freie Kunst."

\section{$\mathrm{Zu}$ Seite 98:}

Anmerkung 62: "zum Begreifen der inneren Welt durch die äußere durch freies. kreatives Erschaffen plastisch-vollendeter Symbole"

Anmerkung 63: "Alle seine |= des Gedichtbands *Tertia Vigilia»| Teile sind genau und exakt aufeinander aufgeschichtet wie Flachreliefs in der Bildhauerkunst: sie alle haben eine organische Verbindung zu seinen zukünftigen Werken: fast in jeder Strophe spür man den Schlag des erfahrenen Meibels. zu jedem Akkord kommt eine neue, originelle und überzeugte Nore."

Anmerkung 65: "Dichterisches Schaffen ist für Brjusov kein schöner Zeitvertreib, kein göttliches Spiel. keine gesellschaftlich-nützliche Arbeit, nicht einmal eine Pflicht vor sich selbst: es ist für ihn Unvermeidlichkeit, aber auch nicht nur Unvermeidlichkeit, sondem eine heilige Mission, eine Art Kult. 
Es ist eine Pflicht nicht vor seinesgleichen. nicht vor den Menschen (umso weniger vor den Zeitgenossen), nicht vor sich selbst, sondem vor Höheren Mächten, vor der Ewigkeit selbst."

Anmerkung 67: "Der Künstler vergötten die Welt als Ganzes, als Gegebenes. denn aus ihr erlernt er die Geheimnisse aller Dinge und aus ihr schöpft er die Farben und Töne, und zur gleichen Zeit ist für ihn jedes Ding nur ein Wölkchen, ein vorübergehendes Bild des Ewigen Symbols [... "“ $^{\prime \prime}$

\section{Zu Seite 99:}

Anmerkung 69: "Brjusovs tragischer Pessimismus. sein ganzer heldenhafier Individualismus und der finstere Wahnsinn seiner ergreifenden Phantasie, die sich gegenseitig hervorheben. sind mit feurigen Buchstaben in die besten Szenen dieser bedeutenden Tragödie geprägi, deren Held die ganze Menschheit ist."

Anmerkung 70: "Vielfaltig. aber in harmonischer Kontinuität der Formen und Methoden offenban sich ein einheitliches schöpferisches «lch». Es beginnt mit seinen ersten kühnen und düster-enthobenen Be trachtungen und Vorahnungen, die unbewubt und qualvoll in die Form des grellsten Impressionismus gekleidet sind: dann fähr es fort mit einem behartichen Sucher, nach einer plastischen, wahmehmbaren. beinahe pamassistischen Form zur Festigung des Symbols und endet schlieBlich mit zwei grandiosen Werken. die eine völlige Synthese von Form und Inhalt erreicht haben, mit dem Drama «Die Erde» und dem Roman «Der feurige Engels."

Anmerkung 72: "|...) die ganze Grenzenlosigkeit des Symbolismus in all seinen vielseitigen Bestre bungen zu zeigen, alle möglichen, äuBersten Konsequenzen aus der Theorie des künstlerischen Schaffens zu ziehen. als Kontemplationen der Wesenheiten in den Erscheinungen. theoretisch und praktisch alle kompliziertesten Verbindungen des Symbolismus mit der reinen Mystik (bis hin zu Geistererscheinungen und zur Theurgie). der zeitgenössischen wissenschaftlichen Philosophie und den Hauptformen des "neuen religiösen BewuBtseins" herzustellen |...]"

\section{Zu Seite 100:}

Anmerkung 73: "Wenn die Geschichte von Bal'monts Werk eine Reihe tiefer Metamorphosen der poetischen Persönlichkeit ist, die beinahe augenblicklich ihre Form gefunden haben, wenn Brjusovs Entwicklungsgeschichte eine organische, harmonische und in ihrer Folgerichtigkeit geschlossene Entfaltung einer einzigen komplizierten und feinen Form ist, dann ist der ganze von A. Belyj zurückgelegte Weg ein rastloser und äuberlich inkonsequenter Wechsel verschiedener Formen, eine nervöse Auswahl immer neuer und neuer Formen, zur Offenbarung einer einzigen, alles vereinenden Idee, zur Bestimmung ein und desselben Wesens. zur Darstellung ein und desselben einzigen Antlizes."

Anmerkung 74: "Alles. was A. Belyj geschaffen hat. seine ganze pathetische Lyrik und die ganze Musik seiner vier «Sinfonien», ist eine einzige Vision: (...) darin besteht auch der tiefe EinfluB und dic Modernität von Belyjs Predigt, daB er in sich sownhl die freie künstlerische Betrachtung (Symbolismus) als auch das Schauen des (ceheimnisses vereint, dał er sowohl vom neuen Gott als zukünftigem erzählt als ihn in sich sieht. Diese Verbindung von Symbolismus und Messianismus macht das Wesen A. Belyjs aus. Das ist sein *Ganzes* und das *Ganze* seines Werks... |... . A. Belyjs Mission ist eine Vereinigung der neuen religiösen Offenbarung mit der künstlerischen Form des zeitgenössischen Symbolismus."

Anmerkung 75: "das grobe hoffnungslose «Nein» gegenüber allem, seinen «Glaubensvertust an allem»" Zu Seite 101:

Anmerkung 79: "Erstellen genauer Entsprechungen zwischen der sichtbaren und der unsichtbaren Welt" Anmerkung 82: "Ich nenne A. Belyjs Lyrik originell in dem Sinn. daB sie nicht nur eine neue künstlerische Form darstellt, die auf zuerst von ihm entworfene und entwickelte ästhetische Normen aufgebaut ist, sondern auch einen neuen Seeleninhalt und eine neue Konfession der Persönlichkeit. die erstmals zu Ausbrüchen. Betrachtungen und Visionen erregt wurde, die sie früher niemals gekannt hat.

A. Belyjs Lyrik ist keine Betrachtung ewiger, unveränderlicher und auBerhalb liegender Wene, keine Musik der inneren Stimmungen; mit einem Wort. sie hat nichts gemeinsam mit dem *Parnassismus», sie ist nur in Ausnahmefällen romantisch. Man kann sie nicht streng-symbolistisch nennen. wie die strengkontemplative Lyrik Brjusovs, denn sie überschreitet fast immer mit kühnen und ungestümen Ausbrüchen die Grenze des ästhetischen Verstehens. die Schwelle der reinen Betrachtung, und wird dabei. ähnlich wie die "Sinfonien», zum Pathos der Klarsichtigkeit Ivgl. hierzu auch oben, S. 104. Anmerkung 991. zum lebendigen Beben der Vorahnungen und Vorzeichen, zum weitsichtig-feinfühligen Stil des Vorgefühls von stets etwas Gröberem, als nur eine rein-künstlerische Offenbarung. Beinahe jedes Gedicht A. Belyjs strebt unvermeidlich danach, sich entweder in ein Gebet zu verwandeln oder in einen Dithyrambus, oder in ein für den Dichter viel zu intimes Bekenntnis, in eine Beichte seiner ketzten Tiefen und der letzten Gründe seines verborgenen «Ich», in eine Beichte, die als mystisch-symbolischer Charakter gefäbt ist." 
Anmerkung 83: "VI. Solov'ev und Fr. Nielasche - diese zwei Gefährten, die zu verschiedenen Seiten aufrufen, die zwei Führer, die in verschiedenen Mundarten sprechen - werden lange die nächsten, teuersten Lehrer A. Belyjs sein, wie die zwei Querbalken seines Kreuzes."

\section{Zu Seite 103:}

Anmerkung 93: "[...] wenn wir A. Belyjs Entwicklung in einem einzigen Symbol zusammenfassen, können wir mit Gewibheit sagen, daB sein erster, wahnwitzigster Flug zur Sonne nicht geglückt ist. er wurde verbrannt, wie alte ihm gleichenden Wahnsinnigen; seine zu Asche verbrannte Leiche fiel auf die Erde und wurde in alle Himmelsrichtungen geweht, dorthin. wo nur Leiden. Tod und Trauer ewig sind. Aber das Herz des Dichters ist nicht im himmlischen Fever verbrannt, es wurde in eine Marmorume gelegt und über ihm wurde der *Flammende Stern», das grobe Zeichen des Pentagramms, entzündet."

Anmerkung 94: "Die ihrem Wesen nach ekstatische, ihrer Form nach pathetische, allseitige Annahme des Weltalls und die Symbolisierung seines ursprünlichen Wesens als «Gold im Azur» führ den Dichter zu einer entschiedenen Krise, zu einer Umwertung der wichtigsten Symbole, zum «Glaubensverlust an allem». Nachdem er seinen gigantischen Flug zur Weltsonne, seinen Argonautenweg durch die Luft nicht vollendet hat. ist er zu Asche geworden, und seine Asche ist untrennbar von den Aschehaufen, in die jetzt die ganze Welt zerfallen ist, die, wie man vor kurzem noch glaubte, nur aus Gold und Azur, aus Himmelsfeuer und reinstem Äther gewebt ist. Jedoch diese Einäscherung und Zerstäubung des Dichters und seiner Welt konnte nicht absolut sein: letzteres erwies sich als ebenso unmöglich, wie die endgültige Realisierung des absoluten in die Höhe Strebens von *Gold im Azur»."

\section{Zu Seite 104:}

Anmerkung 97: "Dieses Hauptmerkmal ist ein überwältigendes, aus seinem tiefsten $\alpha$ lchn erwachsendes Streben, den Symbolismus, als Betrachtung, in die Symbolik der Geheimvision und der Geheimsärigkeit zu verwandeln, die moderne ästhetische Weltanschauung, die sich als Symbolismus versteht, in ein synthetisches System, in einen Symbolismus, der Weltanschauung geworden ist. Dieses Hauptmerkmal ist ein rein praktisches Streben: konsequenterweise und unvermeidlich führ es A. Belyj zur Notwendigkeit. die Grenzen der «symbolistischen Kunst* wesentlich zu überschreiten und die letzten Geheimnisse des Okkultismus zu berühren, mehr noch. die letzte und ungeheuerlichste Frage nach der Realisienung jenes Wegs zu berühren, dessen eine unvermeidliche Etappe die Begabung des theurgischen Handelns ist sowie die Notwendigkeit. nicht nur das betrachtende und schaffende BewuBtsein, sondern auch das ganze «Ich» in ein lebendiges, ganzheitliches und einziges symbolistisches «Ich» zu verwandeln."

Zu Seite 104-105:

Anmerkung 100:

ALLGEMEINES SCHEMA DER ENTWICKLUNG DES RUSSISCHEN SYMBOLISMUS

\begin{tabular}{|c|c|c|c|}
\hline Vertreter: & K. Bal'mont & V. Brjusm & A.Belvi \\
\hline $\begin{array}{l}\text { Form des } \\
\text { Symbolismus }\end{array}$ & $\begin{array}{l}\text { Romantischer } \\
\text { Symbolismus }\end{array}$ & $\begin{array}{l}\text { Ästhetischer Symbo- } \\
\text { lismus im engen } \\
\text { Worsinn }\end{array}$ & $\begin{array}{l}\text { Symbolismus der } \\
\text { Klarsichtigkeit }\end{array}$ \\
\hline $\begin{array}{l}\text { Ar der } \\
\text { Symbolisienung }\end{array}$ & $\begin{array}{l}\text { Entriicktes } \\
\text { Träumen }\end{array}$ & $\begin{array}{l}\text { Konzentrien- } \\
\text { kontemplatives } \\
\text { Verstehen } \\
\end{array}$ & $\begin{array}{l}\text { Ekstatische } \\
\text { Verschmelzung }\end{array}$ \\
\hline $\begin{array}{l}\text { Verwandlung der } \\
\text { Sache durch }\end{array}$ & Traum & Erleuchtung & Vision \\
\hline $\begin{array}{l}\text { Methode der } \\
\text { Symbolisierung }\end{array}$ & $\begin{array}{l}\text { Gegenüberstellung } \\
\text { von res und realiora }\end{array}$ & $\begin{array}{l}\text { Empfinden in } \\
\text { res-realiora }\end{array}$ & $\begin{array}{l}\text { Verschmelzung mit den } \\
\text { realiora und Aufstieg } \\
\text { zum Ens realissimum }\end{array}$ \\
\hline $\begin{array}{l}\text { Allgemeiner Charakter } \\
\text { des Schaffens }\end{array}$ & $\begin{array}{l}\text { Illusionistischer } \\
\text { Idealismus }\end{array}$ & \begin{tabular}{|l|} 
Ideologischer \\
Realismus \\
\end{tabular} & $\begin{array}{l}\text { Theurgische } \\
\text { Symbolik }\end{array}$ \\
\hline $\begin{array}{l}\text { Formal-künstlerische } \\
\text { Bestimmung }\end{array}$ & $\begin{array}{l}\text { Asthetik der Reflexion } \\
\text { und reine Lyrik } \\
\text { der Schanten }\end{array}$ & $\begin{array}{l}\text { Rhyrthmik der "Korre- } \\
\text { spondenzen" und Sym- } \\
\text { bolik der Polaritäten }\end{array}$ & $\begin{array}{l}\text { Mystik der } \\
\text { All-Einheit }\end{array}$ \\
\hline $\begin{array}{l}\text { Ausgangspunkt der } \\
\text { Weltanschauung }\end{array}$ & $\begin{array}{l}\text { Extremer Impressionis- } \\
\text { mus (Philosophie d. } \\
\text { Augenblicks. Immo- } \\
\text { ralismus) }\end{array}$ & $\begin{array}{l}\text { Streben nach Differen- } \\
\text { zienung. Objektivierung } \\
\text { und Spezialisierung }\end{array}$ & $\begin{array}{l}\text { Drang nach einer } \\
\text { zentralen Synthese }\end{array}$ \\
\hline $\begin{array}{l}\text { Philosophische } \\
\text { Grundprämisse }\end{array}$ & Pluralismus & Dualismus & Monismus \\
\hline
\end{tabular}




\begin{tabular}{|c|c|c|c|}
\hline $\begin{array}{l}\text { Ethische } \\
\text { Selbstbestimmung }\end{array}$ & $\begin{array}{l}\text { Ideal der schönen } \\
\text { Verliebtheit }\end{array}$ & $\begin{array}{l}\text { Idee der } \\
\text { Opferleistung }\end{array}$ & $\begin{array}{l}\text { Kult der heiligen } \\
\text { Liebe }\end{array}$ \\
\hline $\begin{array}{l}\text { Vortherrschende } \\
\text { Geisteshaltung }\end{array}$ & Gefuihl & Verstand & Wille \\
\hline $\begin{array}{l}\text { Zentrales Streben } \\
\text { des Schaffens }\end{array}$ & $\begin{array}{l}\text { Lyrik der Weiblich- } \\
\text { keit und sinnli- } \\
\text { chenZärdichkeit }\end{array}$ & $\begin{array}{l}\text { Erotik und } \\
\text { Leidenschafiskult }\end{array}$ & $\begin{array}{l}\text { Religiöses Pathos der } \\
\text { Ewigen Weiblichkeit }\end{array}$ \\
\hline Hauptziel & Enthebung & Betrachiung & $\begin{array}{l}\text { Aufruf (und } \\
\text { Tatendrang) }\end{array}$ \\
\hline $\begin{array}{l}\text { Beziehung zur } \\
\text { Öffentlichkeit }\end{array}$ & Ichsucht & Individualismus & $\begin{array}{l}\text { Sobornost } \\
\text { lGemeinsamkeitserfah- } \\
\text { rungl }\end{array}$ \\
\hline Höchstes Ideal & Schönheit & Wahtheit & Vollkommenheit \\
\hline $\begin{array}{l}\text { Entwicklungsform des } \\
\text { schöpferischen "Ich" }\end{array}$ & $\begin{array}{l}\text { Völlige Transfor- } \\
\text { mation des "Ich" }\end{array}$ & $\begin{array}{l}\text { Organische } \\
\text { EntwickJung }\end{array}$ & $\begin{array}{l}\text { Chaotische Dynamik } \\
\text { der Formen bei Unver- } \\
\text { änderlichkeit der zentra- } \\
\text { len Idee }\end{array}$ \\
\hline $\begin{array}{l}\text { Allgemeine Bestim- } \\
\text { mung des Schaffens }\end{array}$ & $\begin{array}{l}\text { AusschlieBlich } \\
\text { poetisches Schaffen }\end{array}$ & $\begin{array}{l}\text { Poesie. verschmolzen } \\
\text { mit metaphysischer } \\
\text { Selbstbestimmung und } \\
\text { wissenschafulicher } \\
\text { Methode } \\
\end{array}$ & $\begin{array}{l}\text { Allseitig-synthetisches } \\
\text { Schaffen (Poesie, } \\
\text { Philosophie. Wissen- } \\
\text { schaft. Mystik) }\end{array}$ \\
\hline $\begin{array}{l}\text { Wichtigstes } \\
\text { poetisches Mittel }\end{array}$ & Reim & Epitheton & Rhythmus \\
\hline $\begin{array}{l}\text { Historische Stellung in } \\
\text { der Entwicklung des } \\
\text { Symbolismus }\end{array}$ & $\begin{array}{l}\text { Vergangenheit } \\
\text { des Symbolismus }\end{array}$ & Gegenwan & Zukunft \\
\hline
\end{tabular}

\section{Zu Seite 106:}

Anmerkung 102: "Die Haupttendenz des Symbolismus - die grenzenlose Selbstvertiefung in den Ensnicklungsproze $\beta$, die ihn konsequent aus dem «Drang nach neuen Formen* zur *Umwertung aller Werte*, aus einer ästhetischen Schule zu einer neven, synthetischen Weltanschauung. zu einer Vorahnung ciner neuen Kulturepoche, aus dem Schaffen des afreien Verses» zur Selbstbestimmung des «freien Ceistes» gewandelt hat - trat in jedem Schritt beider Strömungen ebenso zutage, der russischen in gleichem Mabe wie der westeuropäischen."

\section{Zu Seite 107:}

Anmerkung 106: "Einerseits wurde er [ = der Symbolismus| sehr schnell zur synthetischen Weltanschauung. er erreichte jenes Stadium, wo die jenseitige Welt ihm zugänglich wurde als behartiche höhere Sphäre, als realiora. er begann bereits, sich in die strengen Formen einer einheitlichen Symbolik zu verselbständigen, er dachte bereits über eine neue Kultur und eine neue Persönlichkeit nach.

Andererseits bewahrte er weiterhin sehr lange (und tut dies teilweise auch jetzt noch) die engen Rahmen der ursprünglichen Formation, bekennt sich weiterhin zum Kanon der «reinen Kunst», zum Dogma des Immoralismus und grenzenlosen Individualismus, fürchtet dabei jegliche Dauertaftigkeit. jegliches Wirklichkeitsgefühl (und wenn auch nur ein überirdisches), und hält sich nach wie vor für einen Impressionismus par excellence."

Anmerkung 109: "Möge der Dichter nicht seine Bücher erschaffen. sondern sein Leben. (...) Auf den Altar unserer Gottheit werfen wir uns selbst. Erst das Messer des Opferpriesters, das die Brust durchschneidet. gibt das Recht auf den Namen des Dichters."

\section{Zu Seite 108:}

Anmerkung 1/3: "AbschlieBend darf nicht unerwähnt bleiben, daB wohl jene Seiten von Herm Ellis' Buch die - zugunsten der Vemunf - überzeugendsten Argumente für den Symbolismus darstellen, auf denen er über die Innovationen seiner äuBeren und inneren Verfahren spricht. über die erseaunliche Technik und über die überraschende Musikalität seiner Verse, die tatsächlich Gehör und Seele tief und berückend bezauber."

\section{Zu Seite 110:}

Anmerkung 122: "Das Buch des bedeutenden russischen symbolistischen Dichters L.L. Kobylinskij (Ëllis) ist eine der besten Untersuchungen des Schaffens von K. Bal'mont. V. Brjusov und A. Belyj. Am Beispiel seiner genialen Zeitgenossen betrachtet Ėllis die wesentlichen theoretischen Grundsätze des 
russischen Symbolismus, analysiert dessen Verbindung zu verwandten europäischen Strömungen und prophezeit dem Symbolismus eine zeitlose grobartige Zukunft. [...]."

\section{Zu Seite 112:}

Anmerkung 2: "[Die Zeitschrift| Trudy i dni setzt sich ein doppeltes Ziel:

Die erste, spezielle Bestimmung der Zeitschrift ist, das Aufdecken und Bestätigen der Prinzipien des echten Symbolismus auf dem Gebiet des künstlerischen Schaffens zu fördern.

Die zweite und allgemeinere Bestimmung ist, als Kommentator der ideellen Verbindung zu dienen, die die vielseitigen Bemühungen der Gruppe von Künstlem und Denkem vereint, die sich unter dem Banner des Musaget-Vertags zusammengeschlossen haben.

Entsprechend dieses doppelten Ziels besteht die Zeitschrift aus zwei Teilen.

In der ersten Abteilung befinden sich theoretische und kritische Aufsätze, die allgemeinen Fragen und einzelnen Erscheinungen des künsllerischen Schaffens gewidmet sind.

Im zweiten Teil werden Probleme des modemen philosophischen und religiös-sittlichen BewuBtseins sowie Themen der Ästhetik. die im allgemein philosophischen Zusammenhang erforscht wird, erarbei let."

\section{Zu Seite 113:}

Anmerkung 11: "Dieser Name betont das Apollinische (trennt es dabei jedoch keineswegs vom Dionysischen) und grenzt sich vom Ästhetentum ab. denn er bedeutet die Vereinigung aller Arten künstlerischen Schaffens im Einvernehmen, dem Ziel Kultur zu schaffen zu dienen."

\section{Zu Seite 114:}

Anmerkung 19: "RuBland kann nicht ohne Deutschland existieren und Deutschland braucht RuBland ebenfalls. Die beiden sind Vettem."

\section{Zu Seite 115:}

Anmerkung 29: "Mischung aus einem Säugling und einem alten Männlein, weder Kind noch Mann. sondern ein garstiges Bürschlein, das vor Eintritt der Geschlechtsreife kastrien wurde und sich dann wundert. daB ihm kein Bar wächst"

\section{Zu Seite 122:}

Anmerkung 70: "Steiners EinfluB auf mich ist überwältigend"

\section{Zu Seite 123:}

Anmerkung 75: "Bei Ellis, einer luziferischen Natur, vollzog sich alles im Leben mit einem einzigen Schlag: und immer überschlug er sich. niemals erreichte er das Ziel seiner Springe im Leben; sein erster "Umschw'ung *: von der Schulbank im Gymnasium zu Karl Marx [...] als Ergebnis: der aUmschw'ung" zu ... Baudelaire und zum Symbolismus: $\mid$... $\mid$ in Baudelaire vollzog sich ein |never| *Umschw'ung : : von Baudelaire ... zu Dante und zur Interpretation atheosophischer Ahgründex. das heiBt in Dante vollzog sich ein neuer "Umschw'ung " : von Dante zu Steiner, 1911 machte er sich auf den Weg: ohne (ield, ohne Sprachkenntnisse, ohne Erfahung: nachdem er bei Freunden gewohnt hatte, die ihn betreuten und "wuschen» im wörlichen Sinne, wurde dieser «viel zu lextremel Moskauer» in Berlin zum aviel zu lextremen] Deutschen - und lieB sich in der ersten Reihe des gemütlichen Vortragsraums des Berliner Zweigs [der Theosophischen Gesellschaft] in der Geisbergstrabe nieder."

Anmerkung 82: "Wir leben hier so freundschafulich und so streng. Abends ein Vortrag. danach im Cafe Gespräche über Belanglosigkeiten [das ist notwendig, sonst wird die Seele zu sehr ergriffen]. Morgens im Park wiederholen wir den Vorrag mit Hilfe von Notizen auf Russisch."

\section{Zu Seite 124:}

Anmerkung 87: "unseren Einzigen Meister. Apostel und Magier"

Anmerkung 89: "Der Doktor ist gewaltiger als alle meine Fantasieträume und Vorstellungen: er ist wirklich ein Magier. Ritter und Lehrer."

\section{Zu Seite 127:}

Anmerkung 118: "Das Geheimnis und die Tragik der Persönlichkeit Steiners sind beispiellos.

Er ist der unverstandene Ühermensch!

Ich stimme zu. daB die Realisierung Seines Impulses als theosophische Kultur nicht gelungen ist, daB der Symbolismus feiner und musikalischer ist. aber der Impuls selbst ist unersetzlich. einzigartig. ohne inn würde auch der Symbolismus umkommen, würde zur Stilisienung werden, die Kultur - zum Museum. Er ist kein Materialist, denn nach Seiner Lehre läBt sich alles auf den Urgeist zurückführen. Jedoch Seine Methode in der *Geheimwissenschaft * erinnert an die Methode der materialistischen Positivisten und ist gefährlich für naive Seelen. Sehen Sie, wie schwierig hier alles ist!"

\section{Zu Seite 128:}

Anmertung 123: "In Köln hatte ich eine langandauernde und heftige Auseinandersetzung mit dem Doktor, in der ich ihm schonungslos alle meine «Kontras» gegen die Theosophie dartegte und dabei die zwei Hauptpunke verneinte: 
1) die Möglichkeit des Okkultismus für die Masse

2) die Unmöglichkeit einer Bewegung ohne Hierarchie [...|"

Za Seite 129:

Anmerkung 128: "Überhaupt wächst meine Hingezogenheit zu «Musaget» immer mehr, mein Wunsch. etwas eigenes zu schaffen, nimmt zu: ich möchte nicht nur etwas Fremdes verkünden, denn in RuBland ist Theosophie unvorstellbar, Okkultismus gefährlich. und wir brauchen Kultur, Kultur und nochmals Kultur."

Zu Seite 131:

Anmerkung 147: "Halb-Religion, Halb-Mysterium, Halb-Freimaurerei. Halb-Wissenschaft"

Zu Seite 135:

Anmerkung 169: "Einerseits war die sogenannte «symbolistische Bewegung» in Europa und besonders in RuBland seit jeher nicht nur eine ästhetische, philosophische oder wissenschaftliche Strömung. Von Anfang an strebte sie nach einer Synthese aller Elemente der Kultur und näherte sich sogar halbbewuBt an die Primärquelle an, das heißt an den Bereich, der tiefer als der Begriff «Kultur liegt. $[\ldots \mid$

Andererseits strebt die wichtigste und lebendigste Strömung aller unzähligen überall entstehenden Schulen und Richtungen auf dem Gebiet des "Okkultismus", ich spreche hauptsächlich vom modemen deutschen «wissenschafilichen Okkultismus*, mit allen Kräften zur Symbolik und zum Symbolismus."

Anmerkung 173: "Unsere Bewegung wird immer ein neuer geistiger «Kreuzzug» sein. notwendig ist lediglich die Treue gegenüber dem letzten Symbol, das bisher noch nie von irgendjemand verraten wurde. das bisher noch von keinem, auch von uns Symbolisten nicht, eriangt wurde, und wir werden von oben geführ und unsere Aufgabe wird erfullt werden!"

Zu Seite 135-136:

Anmerkung 175: "Entweder hat es den Symbolismus als geistige Bewegung sui generis überhaupt nie gegeben, oder er war immer, ist und muB immer sein eine tief geistige Bewegung unserer ganzen Epoche, deren Wurzeln tiefer liegen als sein ganzes künstlerisches, philosophisches und wissenschafuliches Hervortreten und seine künstlerische, philosophische und wissenschaftliche Motivierung: eine geistige Strömung, die nur teilweise in der sogenannten neuen Kunst zum Ausdruck kam und in ihrem Urgrund ein tief mystischer Aufschwung der ganzen Kultur und des ganzen Lebens unserer Epoche war, das Zeichen für das Herannahen eines neuen Reichs der Ideen und Beziehungen, das segenspendende Hemiedersteigen heller geistiger Kräfte aus der höheren Welt in die Welt der Menschheit!"

Zu Seite 136:

Anmerkung 178: "Es lebe die wahre svmbolistische Kunss, als höchste Form des künstlerischen Schaffens, in ihren sinnlich-wahmehmbaren halbirdischen und menschlichen Elementen, die in unserer Welt Stimmen. Kräfte und Gefühle einer anderen Welt, die Glückseligkeit des wirklichen Himmels, die Hilfe höherer Ceister widerspiegelt und zu uns hinabversetzt, und die in jedem Zittern. Seufzen und in ihrer Kühnheit die göttliche Trauer über die höheren Welten, die Hoffnung auf Sühne und die Freude der Rückkehr, die grenzenlos ist, hoch und heilig be wahr."

Za Seite 137:

Anmerkung 187: "Gehe. wie Du bisher gegangen bist! Gehe bis ans letzte Ende Deines Wegs! Fürchte keine Versuchungen und kenne kein Schwanken! Verrate nicht die Morgenröte der Zukunft wegen eines schönen Sonnenuntergangs der Vergangenheit! Verrate nicht die Schaffensfreibeit und verletze nicht die heilige Pflicht der Kühnheit! Werde nicht Sklave toter Formen, in denen schon kein Leben mehr ist! Durchlebe und durchleide alle Bilder und Gestalten, die verändertich sind. und Du wirst erfahren. daB nur eines nicht vergeht und nur eines nicht welkt, daB Du lediglich durch das Opfer im Namen des Kreuzes und durch den Segen des Kreuzes die Krafi des Kreuzes erlangen und nur durch die Liebe der Rose und durch den Segen der Rose die Schönheit der Rose erblicken wirst. Nur diese Kraft ändert sich nicht, nur diese Schönheil welkt nicht!"

Zu Seite 138:

Anmerkung 194: "| ... d das innerste Wesen und der Sinn jeder Kultur ist religiös."

Zu Seite 138-139:

Anmerkung 196: "I... das Hauptbestreben unserer Epoche ist eine allseitige Reaktion gegen den Materialismus der jüngsten Vergangenheit und eine unaufhaltsame Rückkehr, wenn auch in neuen Formen, zur groben und strengen Hierarchie, die die zentrale und hohe Bedeutung für das Ideal-Hochwertige, für das ästhetische Schaffen, das philosophische SelbstbewuBtsein und besonders für die sie krönende religiöse Betrachtung anerkennt. In unseren Tagen wird das unwiderrufliche Ende des Naturalismus in der Kunst. des Agnostizismus in der exakten Wissenschaft, des Positivismus im Bereich des philosophischen schöpferischen Gedankens und. auf der anderen Seite, das Ende der scholastischen Metaphysik und des toten, allgernein verbreiteten, religiösen Dogmatismus begriffen." 


\section{Zu Seite 139:}

Anmerkung 199: "Ursprünglich mehr spekulativ und nur ästhetisch, wird er [= der Symbolismus] im mer tiefer und breiter und erreicht schlieBlich im Nietzsche-Wagner Problem universelle Bedeutung. Hier entsteht auch die Frage nach dem wichtigsten Scheideweg.

[...] wem sollen wir folgen. Nietzsche oder Wagner, dem spontanen, stets nur aus sich heraus erwachsenen Schaffen, das alles wird, der endlosen Bewegung des nur an sich selbst glaubenden Willens, oder der streng-schönen und freiwillig auf dem Glauben beruhenden Symbolik der BuBe/Sühne: dem Heerführer, der zornig zur Eroberung never Länder auszieht, oder dem Ritter, der das nicht von ihm geschaffene, sondern ihm nur von oben anvertraute Heiligtum verehrend bewacht, sollen wir zu Nietzsches Ubermensch oder zu $R$. Wagners Monsalvat gehen?"

\section{Zu Seite 140:}

Anmerkung 204: "Der Symbolismus, besonders der russische, kann und muB übergehen in den Bereich der religiösen Kunst, die frei von [falscher] Kirchlichkeit, Dogmatik und Allegorik ist, aber auch frei von Erotik und extremem Subjektivismus. Bei Tjuťev, Lermontov und VI. Solov'ev gibt es bedeutende Versuche! Nicht wahr? Der französische EinfluB |...) hat vieles verdorben. Jetzt bin ich für immer ganz vom Französischen fortgegangen! Wagnerhat mich in einem halben Jahr geheilt!

Aber das «Allerheiligste * ist für mich das Mittelalter."

\section{Zu Seite 142:}

Anmerkung 214: "Auch theoretisch steht Wagner den Symbolisten unendlich nahe! Da er entschieden alle konventionellen Klassifizierungsrahmen der Künste zerstön hat und eine einzige Üher-Kunst propagien hat, ist er jedem von uns im tiefsten Inneren nahe; da er mehr als alle anderen an eine höhere Welt und der höheren Welt geglaubt hat, da er mit beispielloser Kühnheit die religiöse Grundlage jeder Kunst hervorgehoben und sich im «Parsifal» bis an die Frage vom geheimen Wesen des Mysteriums angenäher hat. steht et uns allen gerade jetzt nahe."

\section{Zu Seite 143:}

Anmerkung 215: "Die eine gemeinsame Idee des Symbolismus - das Erleben und Begreifen des Herannahmens einer neuen Epoche als Folge des Impulses, der aus höheren Welten kommt. realen und wirk samen, der gemeinsame messianistische und prophetische Sinn und das Pathos der symbolistischen Bewegung - findet im Schaffen Wagners vollkommenen und schönen Ausdruck."

Anmerkung 216: "I...) im Schaffen $R$. Wagners drückte sich immer stärker das Hauptbestreben des Symbolismus nach unendlicher Selbstvertiefung aus, die die «symbolistische Kunst» in ein (tief im Innern) verborgenes Ritual verwandelt, das Symbolbild in einen sich selbst entwickelnden Mythos, und den Mythos in die höchste Form, die uns im künstlerischen Schaffen zugänglich ist, in ein chrisliche Mysterium."

Anmerkung 218: "Ich warte auf den Text des «Parsifaly. Gestem habe ich die ganze Nacht bei einem Freund vertracht, der mir ausschlieBlich Wagner vorgespielt hat.

Ja. nur Wagner konnte mich vor Baudelaire retten! Wagner hat früher als $A$. Belyj den Schrecken der enthobenen, elementaren himmlischen Musik begriffen. Dann hat er sie durch das Wort an den Planeten Erde gefesselt."

Anmerkung 219: "Mein Kampf mit thnen zwingt mich im Ergebnis mich als besiegt zu erklären

1) in der Anerkennung des Vorrangs des Germanischen vor dem Französischen

2 ) in der unbedingten Anerkennung des Vorrangs R. Wagners vor dem gesamten Symbolismus mit Baudelaire an der Spitze."

Anmerkung 220: "Wagner ist jetzt in Rubland unentbehrlich. Wäre es möglich, daB Stepun notwendiger iss?"

\section{Zu Seite 144:}

Anmerkung 224: "Er I= Steiner| hat mir geraten. mich auf Wagner zu konzentrieren. Sein Rat hat mir Kräfte gegeben, die *Götterdämmerung* so zu übersetzen, wie ich noch niemals etwas übertragen habe. [...] Ich beabsichtige, mich mindessens 10 Jahre mit Wagner zu beschäftigen und ihn Rubland zu geben. Übersetzungen und Kommentare. Gerade Wagner ist die einzige Brücke vom Symbolismus zur Theosophie, vom Heidentum zum Christentum, vom Individualismus zum Rittertum, vom Wahnsinn zur Weisheit, von der Wollust zur Keuschheit, vom Pessimismus zur «Wiedergeburt», von der Sühne zum Messianismus, von den Künssen zur Einen Kunst, von der Bühne zum Mysterium. vom Kult des Weiblichen zur männlich-ritterlichen Uberzeugung. vom Chaos des schlafenden Volkes zum entstehenden individuellen *Ich», von der Phantastik zu den Realiora, von der Krankheit zur Genesung. vom Dämonischen zum Seraphischen, vom All-Menschlichen zum Über-Menschlichen."

Zu Seite 144-145:

Anmerkung 225: "Die Formel meiner jetzigen Position ist die folgende: 
«ln der Wissenschaft - strenger, bescheidener Empirismus, in der Literatur - Wagnerismus, im Okkul tismus - Steinerismus, in der Philosophie - Leibniz, mit dem ich mich, zwar nicht bald. aber beschäfuigen werde!»

[...] In Wagner ist (auber seinem Lebensende) ein noch unberühner Winkel Symbolismus, reiner Kunst, Chaos. Pessimismus. Theurgie, Erotik. Mythenschaffen und überhaupt was man will."

\section{Zu Seite 145:}

Anmerkung 228: "Sehen Sie, wie gut, daB wir Ihre Übersetzung des Parsifal noch nicht gedruckt haben. Jetzt kennen Sie die Sprache besser und Ihre Fehler sind ihnen deutlicher."

Anmerkung 23I: "Richard Wagner. Parsifal. Ubersetzt von Ellis. (Im Druck). Die vorliegende Cibersetzung von $R$. Wagners bedeutendstem Werk ist der erste Versuch einer relativ textnahen Übertragung ins Russische (aus dem Libretto des musikalischen Mysteriendramas in ein selbständiges literarisches Werk). Während die russische Übersetzung bestrebt ist, den Rhythmus von Wagners Originalvers annähernd wiederzugeben. verwendet sie jedoch überall Reim und ignorien dabei den seltenen Gebrauch des Reimes im Original. (...)."

\section{Zu Seite 146:}

Anmerkung 239: " «Ein Kunstwerk muß Religion in Bildem sein». R. Wagner."

\section{Zu Seite 148:}

Anmerkung 249: "Hier ist wohl mehr beabsichtigt als eine symbolische Identifizierung Parsifals mit Christus. Parsifals, des Messias der Erlösung. des lang Erwarteten, der bereits vor seiner Gebun prophezeit worden war, der mit vorherbestimmten geistigen Zügen ausgestattet im schrecklichsten. dringlichsten Augenblick kommt, der in seinen Händen den heiligen Speer trägt als Zeichen seiner geheimen. unmittelbaren Verbindung mit Christus und der kommt, um gleichsam das göttliche Opfer teil weise zurückzuerstatten."

\section{Anmerkung 250:}

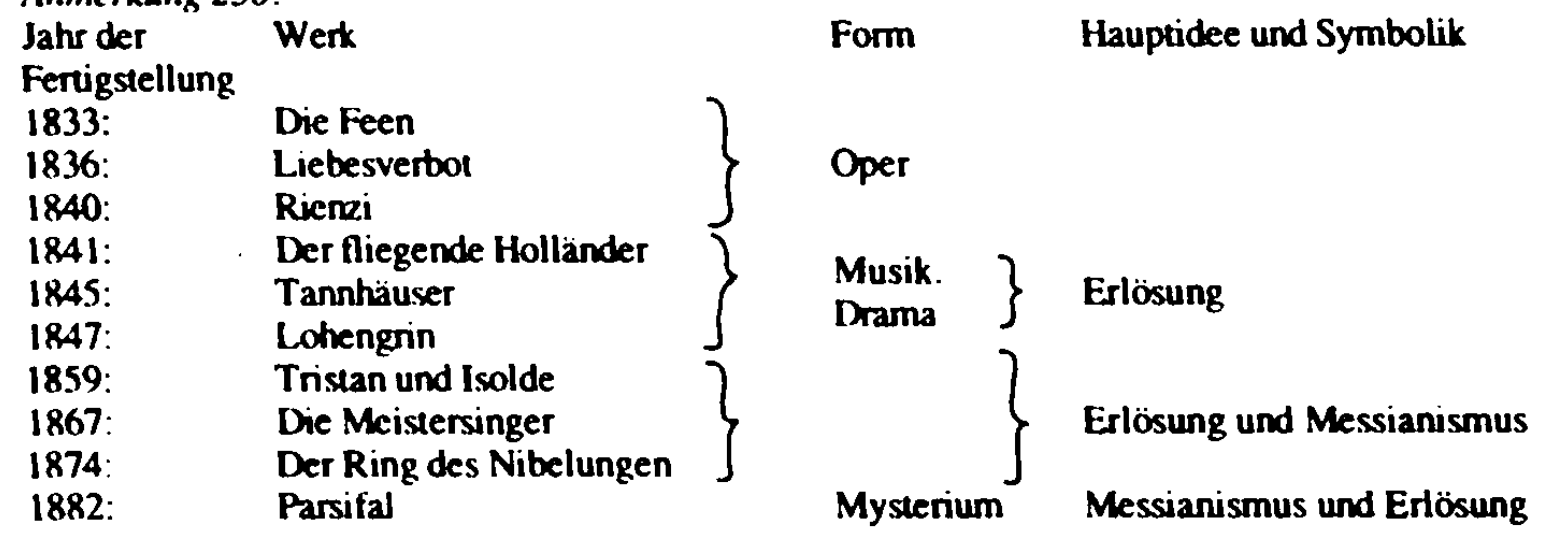

Anmerkung 25I: " [...] wir ertalten ein genaues Schema der Entwicklung seines [= Wagners] Schaffens von der Oper über das musikalische Drama zum Mysteriendrama, von der allgemein-menschlichen Tragödie zum übermenschlichen Geheimnis, vom Irdischen zum Göttlichen, vom Symbolismus zur Symbolik, von der Symbolik der Erlösung über itre Vereinigung mit der Symbolik des Messianismus zum strengen christichen Mysterium, das die objektive Symbolik mit der unerschütterlichen Grundlage der Dogmatik vereint, was im Parsifal stattfindet.

Die Logik der Entwicklung ist erstaunlich streng und deutlich wahrnehmbar: vom Dämonismus und Pessimismus zur Erlösung, über die Erlösung zur Rückkehr und Wiedergeburt."

Zu Seite 149:

Anmerkung 256: "Wenn wir in unseren Tagen Zeugen des überall wiedererstehenden chrislichen Selbstbewubtseins sind, wie einsam, wie unverstanden und fremd klang damals doch zur Zeit der Erschaffung des Parsifal, das heißt zu Beginn der 80er Jahre des vergangenen Jahrhunderts. Wagners Stimme, wie viele Angriffe und ungerechte Verfolgungen, die mit der wahnwitzigen selbstmörderischen Fieberphantasie Friedrich Nietzsches endeten. mubte sein Vermächtnis ertragen, das (wie wir zu zeigen versucht haben) das geistige Ergebnis und der endgültige Sieg seines ganzen Lebens war."

Anmerkung 258: "Es ersteht vor uns das Bild des vollkommenen Ritters Parsifal, durch dessen magische Geste, die mit dem heiligen Speer das Zeichen des Kreuzes zeichnet, die Kraft des uralten Fluchs besiegt wird. Stolz und Wollust, die in der zeitgenössischen Kunst atmen. und es ertönt inmitten all dieser Themen der Aufruf zur Erlösung und zum Warten auf Hilfe von oben. es ertönen immer deutlicher die Schlubworte des Mysteriums: «Das Wunder des Ertösers erscheint. / Es ist - die Erlösung des Erlösers...." 
Anmertung 259: "Was Ellis' Aufsatz «Richard Wagners 'Parsifal' (1913, Nr. 1-2) betriffi. so handelt er viel aufschluBreicher von der neuen Kehrtwendung im ideellen Suchen des symbolistischen Dichters (der schnell von der Anthroposophie entuäuscht wurde und in seiner Verehrung der mituelalterlichenreligiösen Kunst und der Idee des geistigen Rittertums festen FuB faBte), als von der letzten Mysterienoper des deutschen Komponisten im eigentlichen Sinne."

Anmerkung 259: "eine genieBerische Interpretation des Parsifal [...]"

\section{Zu Seite 150:}

Anmerkung 263: "[...] die Wagner-Frage muB in *Vesy* ständig behandelt werden, denn sie ist immer noch eine offene Frage und hat zentrale Bedeutung in der ganzen Kunst, nicht nur in der Musik."

\section{Zu Seite 153:}

Anmerkung 279: "die Literatur wird selbst eine Art Religion"

Anmerkung 282: "Jetzt. da alle Schrecken von Dantes «Hölle» Wirklichkeit geworden sind in dem, was wir atmen, auf was wir jeden Augenblick treffen, da alle reinen Herzen zerschlagen sind, wird das Leben zum Albtraum und über jeden von uns neigt sich das Gespenst der Verzweiflung und des Wahnsinns; da unsere Heimat, ebenso wie einst die Heimat Dantes, in eine einzige grobe Wunde verwandelt ist. die das Eisen der Henker ständig folten, da jeden Augenblick alles Heilige, Ersehnte beleidigt wird und es keine Wege der Rettung gibt. - gerade jetz wird immer verständlicher das unaufhaltsame Streben, die Knie vor dem Schatten dessen zu beugen, dessen Leben ein einziges Leiden war, eine einzige große Qual, der nie gegen sein Gewissen handeltc. keine Kompromisse mit dem Leben schloB, der den höchsten Trostquell im Umgang mit anderen Welten fand, und je andächtiger und zärticher er sich vor der Ewigen Rose verneigte. desto unerbittlicher und schonungsloser kämpfte er gegen die unzähligen Scharen von Feinden der Wahrheit. des Guten und der Schönheit!.."

Zu Seite 154:

Anmerkung 287: "Dante glaubte nicht an den endgültigen Sieg des Guten auf dieser Welt. er erwanete nicht die Reue der verstockten Sünder und wünschte ihnen keine Vergebung ...

Hierin liegt einer der originellsten und schrecklichsten Züge seiner düsteren, konzentrienen und vor der Welt und den Menschen verschlossenen, groben Seele ...

Erkannte die Wahteit, aber man verstand ihn nicht: er rief, man folgte ihm [jedoch) nicht..."

Anmerkung 289: "Kein dichterisches Genie, keine mystische Erleuchtung hat - sogar in den Augen blicken der höchsten Ekstase - weder vorher noch danach etwas geschaffen, was Dantes «Paradies» gleicht."

\section{Zu Seite 155:}

Anmerkung 293: "Deshalb ist Dantes «Hölle» vor allem plastisch. das «Fegefeuer» vor allem bildhaft und nur das «Paradies» musikalisch."

Anmerkung 294: "In der «Holle» ist kein Platz für Beatrice, im bleichen Licht des «Fegefeuers» ist sic lediglichein zufälliger Gast, und nur im himmlischen «Paradies» offenbar sie ihr allumfassendes Wesen $|\ldots|^{\prime \prime}$

Anmerkung 296: "I... der Aufsalz von Herrn Ellis über Dante wäre interessant, wenn er vor allem nicht durch vergebliche Übersetzungsübungen aus Dantels Werkl unterbrochen würde und wenn Hert Ellis selbst nicht so häufig in Hysterie verfiele."

Zu Seite 156:

Anmerkung 302: "I... Ellis' Aufsatz «Der Lehrer des Glaubens» ist fanatisch exaltien, lobpreist die «Göttliche Komödiex als christliches Mysterium und verherrlicht den religiösen Dogmatismus des Mittelalters:"

Zu Seite 158:

Anmerkung 3: "Das Hauptbestreben des Autors, die Kulturerscheinungen in Gruppen zusammenzufassen und sie und insbesondere die Kunst sogar aus dem religiösen Weg herzuleiten, ist durchaus nichts Neues und Inkonsequentes in seinem allgemeinen Entwicklungsgang. Bereits in den *Russischen Symbolisten w hat der Autor den allgemeinen Versuch unternommen, die letzten geheimen Bestrebungen des zeitgenössischen Symbolismus auf religiöse Werte zurückzufuihren. Dieselbe Idee liegt auch einer Reihe seiner Aufsäıze in *Tnudy i dni» zugrunde. Hier trägt dieser Versuch einen bestimmteren und deut icheren Charakter, das an Ereignissen reiche geistige Leben unserer Zeit in den letzten Jahren dient in diesem Falle selbst als bester Wegweiser: die Tatsache, daB wir vor einer religiösen Wiedergeburt stehen. ist unbestreitbar!

|... . Vigilemus* ist durchaus keine polemische Broschüre: in itu findet sich das komprimierte credo des Autors - und weiter nichts!"

Zu Seite 159:

Anmerkung 6: "Wir sind Symbolisten im zweifachen Sinn: in uns sprechen die Stimmen der alten Götter immer vemehmbarer, wir haben als erste das Licht der antiken Mysterien und die Wahrheit der toten 
Kulturen geschaut; und wir wollten dieses Licht immer eifriger aufnehmen, als Licht vom Licht, wollten die Bedeutung der antiken Götter lediglich als Vorbereiter, die Bedeutung der antiken Mysterien lediglich als Weisheit des Wartens auf Einen Einzigen Menschengott und Ein Einziges Mysterium verstehen."

Anmerkung 8: "[... alle alten Götter rufen uns [= die Symbolisten], und jeden [ruft] sein Gott, alle antiken Kulturen sind in uns aufgelebt, aber das Gesetz ihrer Abfolge ist zerstörn, sie sind alle gleichzeitig in uns erstanden, wie im Museum: unsere Götter sind in einem einzigen Tempel versammelt, in einem neuen Pantheon; wir alle sprechen in verschiedenen Sprachen, aber nicht wie die Apostel beim Herabsteigen des Heiligen Geistes, sondern wie die Erbauer des babylonischen Turmes. Die Formel. gemäB derer sich unser Leben aufbaut, kennt keine Harmonie. Einheit. Hierarchie, sie ist vielsprachig: unsere Religion kommt aus Galiläa, unsere Kultur von den alten Göttern: die Kunst und Philosophie aus Griechenland, die Wissenschafi aus Ägypten und Chaldäa, die Zivilisation aus Rom. [...] Dieser Formel sind wir uns erst heute völlig bewuBt geworden. Alle alten Stimmen haben in diesen Tagen in uns zu sprechen begonnen, alle überlieferen Rechnungen werd' $n$ in uns beglichen, alle beiseite gelegten Fragen stellen sich, alle Fristen laufen ab, die schwerste Prüfung naht. Es schlägt die neueste Stunde."

Anmerkung 9: "Der Symbolismus als Kind der zeitgenössischen, gottosen, lügenhafi-humanistischen Kultur ist Schuld am Bau des babylonischen Turmes, aber zugleich hat er sich, indem er feurig gegen ihn ! = den habylonischen Tumn], gegen alle materiellen und sinnlichen Grenzen und das «Menschlich. allzu Menschliche» sowie gegen die «menschliche Weisheit» als das «Höchste» protestiert, das Recht auf etwas Größeres erkauft, auf die Rückkehr zu den Wegen der segenspendenden Betrachtung der gö̈tlichen Welt, zum Gebet Abels. und in Noahs Arche findet sich ein Platz für ihn inmitten der gegenwärtigen Sintflut. Und die neueste Stunde geht nicht an ihm voriber."

\section{Zu Seite 160:}

Anmerkung 15: "Es gibt eine unüberschreitbare Trennlinie zwischen Mythologie und Religion (...)" Zu Seite 160-161:

Anmerkung 18: "Seit dem Verfall der Kultur [nach dem] 13. Jahuhunder, das die letzte Blütezeit der religiösen Kultur war, beginnt die Menschheit ohne Religion zu leben, sie gerät in einen Teufelskreis ohne Ausweg. wobei sie zwischen der Unmöglichkeit. sich ganz dem Dienst an den alten Göttem hinzugeben. deren Abschaffung sie tragisch erlebt hat, und dem Zweifel an der Lebensfahigkeit und Tauglichkeit des Christentums kreist, an dem (gemeint ist das Christentum) sie gerade an der schicksalhaften Wende zum 14. Jahrhundert Wunden entdeckt hat, die ihr unheilbar erscheinen. Den geistigen Sturz des Papsttums crleben. den völligen Mißerfolg der Kreuzzüge, als erste die Schrecken der sich überall verbreitenden Hexerei und Häresie sowie das Anwachsen der giftigen arabischen und mohammedanischen Kultur zu sehen, als erste die Paroxysmen des Fanatismus sowohl der Kirche als auch ihrer Feinde zu erfahren. den Niedergang des Rittertums und die Entstellung des Mönchtums sowie schlieblich überall die nutzlosen politischen Streitigkeiten zu sehen, und das alles zugleich zu erleben, - bedeutete fur den mittelalterlichen Menschen. mit dem Absolutismus aller seiner Bestrebungen und Unteile, geistig zugnunde zu gehen."

\section{Zu Seite 161:}

Anmerkung 21: " 1 ... nach dem beispiellosen religiösen Paroxysmus begann die Zeit einer noch schrecklicheren Verzweiflung; es war die Zeit der friedlichen Ungläubigkeit, und dann wurde die fröhliche Rückkehr zu den halblebendigen alten Göttem beinahe eine allgemeine Erscheinung. Die Zeit der $\star R e-$ naissance, brach an, das heißt, der Wiedergeburt der heidnischen Kultur. Die ganze weitere Gei stesgeschichte der Menschheit ergab sich aus dem Kampf dieser beiden Ursachen: der Entfernung vorn Christentum und der Schaffung alter Götter, was im Ergebnis folgerichtig zu Humanismus, Ratio nalismus, Materialismus und zur groben Krise unserer Tage gefühn hat.

Die Geschichte unserer Kultur nach dem Bruch mit der Religion am Ausgang des 13. Jahthunderts kann als unbeimes Verfolgen des Wegs der aEnffernung von Gotr - bezeichnet werden. und diesem Prinzip entsprechend muß eine genaue Klassifizierung der eigentlichen Stufen dieses groben Niedergangs der Kultur erstellt werden. In Úbereinstimmung damit ist die Idee der Religion selbst allmählich entantet, und wurde folgerichtig ersezt durch Theologie, Mysterium (Gnosis), Mystizismus. Magie. Okkultismus. Theosophie und schlieBlich durch Anthroposophie."

\section{Zu Seite 163:}

Anmerkung 31: "Die Anthroposophie ist der Idee nach das Endglied des gesamten Systems der Wissenschaften vom Menschen. Dadurch läBı sie die anderen Bereiche der Kultur und den Bereich der Religion, wie (auch) besonders den Bereich des Glaubens, frei."

Anmerkung 33: "Das hat sich gleichermaBen im «Lohengrin» und noch früher im «Fliegenden Hollän der* Wagners, im *Theater Maetertincks, in den * Märchen* Wildes, in der Lyrik Aleksandr Bloks, in 
den frühen Versen Bal'monts, bei Edgar Poe und bei Verlaine gezeigt. Bei letzterem fand er [= der Symbolismus] jene Synthese mit dem Katholizismus, von der er seit jeher träumte.

Novalis' «Blaue Blume» ist verwelkt, sie wurde zur «Mystischen Rose» der Symbolisten (Vjaceslav Ivanovs «Rosarium»)."

\section{Zu Seite 164:}

Anmerkung 39: "Indem er dem toten Allegorismus der zeitgenössischen oberflächlichen Kirchlichkeit entrinnt, wird der nussische Symbolismus, von der Lyrik Vladimir Solov'evs, über Andrej Belyjs «Gold im Azur», A. Bloks «Verse von der Schönen Dame». S. Solov'evs «Blumen und Weihrauch», bis hin zu V. Ivanovs «Cor ardens», bei D. Merežkovskij zur Frage nach dem religiösen Weg der Zukunfi: in der slavischen messianischen Konzeption von Nietzsches Lehre, in A. Dobroljubovs \&Unsichtbarem Buch». im immer stärker werdenden Interesse der jungen Dichter an der Epoche und am Leben des heiligen Franz von Assisi und am russischen Asketentum, wird der russische Symbolismus mit jedem Tag und jeder Stunde immer mehr zur echten christlichen Kunst, zum traurigen Gesang vom Niedergang der menschlichen Seele, zum Gebet um Buße/Sühne und zum Freudenlied von der Rettung. Das (tief im Innem) verborgene Element des Volksgeistes begegnet dem christlichen Dichter auf diesem Weg und schlieBt mit ihm eine ageistige Ehe». So kehrt unsere Kultur durch den Symbolismus zu Gott zurück. zur «unbeweglichen Sonne der Liebe». Es enden die schlechtessen Zeiten."

Anmerkung 41: "Ich bin der Weg und die Wahrheit und das Leben. Vigilemus!"

Zu Seite 165:

Anmerkung 44: "Der russische Symbolismus, der äußerlich höchst gezien und künstlich war und gleichzeitig höchst aufrichtig und rastlos, barg unbewuBt von Anfang an sowohl das Suchen der Volksseele als auch den einheitlichen Drang nach Göttlichem in sich. Wenn er sich nicht in christliche Kunst verwandelt, wird er zugrunde gehen [....."

Anmerkung 45: "Das letzte geheime Ziel des Symbolismus ist das lebendige Mysterium."

\section{Zu Seite 168:}

Anmerkung 65: "Wanen wir ab, was das Leben sagen wird."

Zu Seite 169:

Anmerkung 70: "Der Mystizismus unserer Tage ist das Kind des Protestantismus."

Zu Seite 172:

Anmerkung 9: "Ich weiß, daß der Schmerz der einzige Adel ist."

Anmerkung 10: "Handelnde Personen

1) Der Seiltänzer (gut gebaut, sehr mager. elegant) 15-17 Jahue

2) Der böse Bajazzo (geht mit einer Peitsche umher) 40 Jahre

3) Das Madchen in WeiB. 15-17 Jahre

4) Der Schlangenjunge (mit sehr grobem Mund) 13-15 Jahre

5) Der erste Engel (dem Seiltänzer ähnlich)

6) Der zweite Engel (dem Mädchen in WeiB ähnlich)

7) Chor der Guten Geister (hinter der Bühne)

8) Der Morgenstern (mit silbermem Kopfschmuck)

9) Der Abendstem (mit goldenem Kopfschmuck)

10) Der Mond (blab-perlenfarbiger Kopfschmuck)

11) Die Sonne (rot-goldener Kopfschmuck in der Farbe des Sonnenuntergangs)

12) Ein Affe (gespielt von einem 9-12jährigen Kind)

13) Ein Tiger

Das Publikum im Zirkus, Zirkusakrobaten."

Zu Seite 176:

Anmerkung 3: "vielleicht der naivste dogmatische Theoretiker der russischen symbolistischen Bewegung"

Zu Seite 182:

Anmerkung 28: "Gut. daB wir uns wieder auf dem neuen gemeinsamen Weg für gemeinsame Arteit im Namen Christi begegnen können! Es stimmt, daB wir im Wesentlichen und in den letzten Fragen solidarisch sind. Eine Differenz in weniger wichtigen Dingen muB fruchtbare Gespräche mit sich bringen $|. . .|^{\prime \prime}$

Zu Seite 191:

Anmerkung 4: "Ganz im Himmelblau erschien heute / Vor mir meine Zarin. - / Das Herz begann in süßem Entzücken zu schlagen. / Und in den Strahlen des beginnenden Tages / Begann die Seele in stillem Licht zu leuchten. / Und in der Ferne, meine Liebe, rauchte / Die böse Flamme des irdischen Feuers.

Ende November 1875, Kairo" 


\section{Zu Seite 192:}

Anmerkung 6: "Unter der fremden Macht des hitzigen Schneegestöbers, / Die früheren Visionen vergessen habend, / Hörte ich emeut der geheimnisvollen Freundin / Verlöschenden Ruf.

Und mit einem Schrei des Schreckens und Schmerzes. / Wie ein mit Eisen gefesselter Adler, - / Erbebte mein Geist in Unfreiheit, / Und zerriB das Netz, und entschwand in die Höhe.

Und in der Höhe über den Wolken / Vor einem Meer flammender Wunder / Im überall strahlenden Heiligtum / Flammte er auf und verschwand."

Zu Seite 196-197:

Anmerkung 38Der See schlägt mit unruhigen Wellen ans Ufer, / Ebenso wie im Meer die anschwellende Brandung, / Strebt die ungeordnete Elementarkraft irgendwo hin. / Streitet mit dem feindseligen Schicksal über irgendetwas.

Die granitenen Fesseln sind wohl nicht nach seinem Wunsch! / Nur im UnermeBlichen ist Ruhe erquicklich. / Er träumt von den unberührten vergangenen Jahrhundenten. / Möchte wieder über die Erde herrschen.

Tobe, woge. Du wilde Gefangene! / Ewige Schande den freiwilligen Sklaven. / Dein Traum wird in Erfüllung gehen, Du gewaltige Elementarkraft. / Allen freien Wellen wird weiter Raum gegeben werden.

3. Oktober 1894"

Zu Seite 229:

Anmerkung 3: "I...) sowohl in Marx, als auch in Dante, in Baudelaire, in R. Wagner (den er falsch auslegt) und auch in Steiner suchte und sucht er nur den Papst, dem man die Schuhe küssen müsse."

Zu Seite 232:

Anmerkung 2: "Ellis' eigene Dichtungen und seine Publizistik vermitteln den Eindruck, daB er ein blasser zweitrangiger Schriftsteller war, aber das Spiel seiner dämonischen Persönlichkeit lieB ihn zweifellos zu einem jener brillianten Gesprächspartner werden, der, in Belyjs eigenen Worten, seine symbolistische Kunst in eine Art kollektive Schöpfung verwandelte. [...] Petersburg scheint Ellis in besonders hohem Grad verpflichtet zu sein."

Zu Seite 234:

Anmerkung 9: "Mag Éllis eine zweitrangige Gestalt gewesen sein (und als Dichter auch ganz bedeu tungslos), in der Geschichte des russischen Symbolismus gebüht ihm ein eigener - und nicht unbedeutender-Platz." 


\title{
AUS OSTEUROPÄISCHEN LÄNDERN
}

\author{
BÜCHER \\ Literatur- und Sprachwissenschaft \\ ost- und südosteuropäische Geschichte \\ Humaniora \\ Neuerscheinungsdienst \\ Sortiment \\ Antiquariat
}

\section{ZEITSCHRIFTEN UND ZEITUNGEN}

\author{
Abonnements \\ Besorgung rückliegender Jahrgänge \\ Zeitschriftenantiquariat
}

\section{VERLAG OTTO SAGNER \\ Wissenschaftliche Arbeiten zur Slavistik und zur ost- und südosteuropäischen Geschichte und Geistesgeschichte}

\section{KUBON \& SAGNER}

\author{
Buchexport Import GmbH
}

(Heßstraße 39-41)

D-80328 München

Telefon: (089) 54 218-0 - Telefax: (089) 54 218-218 - Telex: 521671 kısa d

Telegr.: buchsagner muenchen · email: postmaster@kubon-sagnerje 